Andrews University

Digital Commons @ Andrews University

2016

\title{
The Two Witnesses of Revelation 11:1-13: Arguments, Issues of Interpretation, and a Way Forward
}

Ian R. Brown

Andrews University, irbrown@andrews.edu

Follow this and additional works at: https://digitalcommons.andrews.edu/dissertations

Part of the Biblical Studies Commons

\section{Recommended Citation}

Brown, Ian R., "The Two Witnesses of Revelation 11:1-13: Arguments, Issues of Interpretation, and a Way Forward" (2016). Dissertations. 1616.

https://digitalcommons.andrews.edu/dissertations/1616

https://dx.doi.org/10.32597/dissertations/1616

This Dissertation is brought to you for free and open access by the Graduate Research at Digital Commons @ Andrews University. It has been accepted for inclusion in Dissertations by an authorized administrator of Digital Commons@ Andrews University. For more information, please contact repository@andrews.edu. 


\begin{abstract}
THE TWO WITNESSES OF REVELATION 11:1-13: ARGUMENTS, ISSUES OF INTERPRETATION, AND A WAY FORWARD
\end{abstract}

by

Ian R. Brown

Adviser: Ranko Stefanović 


\title{
ABSTRACT OF GRADUATE STUDENT RESEARCH
}

\author{
Dissertation
}

\author{
Andrews University
}

Seventh-day Adventist Theological Seminary

\section{Title: THE TWO WITNESSES OF REVELATION 11:1-13: ARGUMENTS, ISSUES OF INTERPRETATION, AND A WAY FORWARD}

Name of researcher: Ian R. Brown

Name and degree of faculty adviser: Ranko Stefanović, Ph.D.

Date completed: September 2016

The narrative of Rev 11:1-13 involves two prophet-witnesses. The question of the identity of the two witnesses of Rev 11:1-13 has been answered in a variety of ways. In the history of exegetical investigation, they have been seen as two actual people, a symbol for a larger group, or even a symbol for inanimate objects. Clearly, some proposals seem more plausible than others do; however, the debate remains open. Indeed, the possibility exists that a stronger case could be made for a previous proposal or that a new one could be found that is more agreeable to scholars of Revelation. The purpose of the present study is to clarify the nature of the problem of identifying the two witnesses and to form a plan for finding a more satisfactory answer. In this way, the research illuminates the path beyond the current state of inconclusiveness. This purpose is accomplished through a survey of arguments that are representative of those used to 
support the major exegetical identifications of the two witnesses and through an examination of the broad interpretive issues that can be derived from those arguments. In short, the research aims to meet the need for a review of the literature that will more fully expose the state of the question concerning the identity of the witnesses and so offer a basis for a new investigation into that question.

The most popular identifications of the two witnesses can be divided into those that understand the witnesses literally and those that understand the witnesses symbolically. The presentations of argumentation are separated according to this division, with one chapter dealing with literal identifications and another chapter covering symbolic ones. In each chapter, the presentations begin with an extensive summary of one exposition. These summaries function as the basis for discussing other significant expositions of the witnesses that, although differing in certain ways from the main ones, still represent the same broad class of identifications. Descriptions of the broad issues of interpretation that are deducible from the presented arguments are given at various points in the presentations. Issues of interpretation shared by the commentators are identified in the conclusions to each chapter.

The thinking of Donatus Haugg forms the central exposition for the chapter on literal interpretations. The expositions of James Henthorn Todd, Isbon Thaddeus Beckwith, and Christine Joy Tan are also featured. All four commentators identify the witnesses as two individuals who appear in the future after the composition of Revelation. The work of Johannes Munck is also featured in this chapter. He identifies the two witnesses with Peter and Paul. His exposition represents those interpreters who 
identify the witnesses as two people contemporaneous to John. Munck's exposition receives an abbreviated treatment.

The thinking of Gregory Kimball Beale forms the foundational exposition for the chapter on symbolic interpretations. The expositions of Hendrik Rijk van de Kamp and Gerhard Maier are also featured. All three commentators see the two witnesses as a symbol of God's people. The work of Ekkehardt Müller is also featured in this chapter. He argues that the two witnesses symbolize the Bible. His exposition represents those interpreters who see the witnesses as a symbol for sacred writings. Müller's exposition receives an abbreviated treatment.

When one considers these chapters, thirty-five broad issues of interpretation are common to at least two of the nine featured commentators. In the penultimate chapter, these issues are evaluated. In the evaluation, fourteen issues are identified as the main issues in the debate over the identity of the two witnesses, because the majority of the nine representative commentators address them. As for the issues that are less common among the nine commentators, these issues are assessed to see whether they should join the main issues in a new investigation of the identity question. Seventeen of these are found to be relevant for further discussion of the identity question. Four issues appear to be of such low relevance that they need not be a part that discussion.

Accompanying the evaluation are small summaries of what the commentators have said in addressing the broad issues of interpretation. In a brief way, argumentation from the two preceding chapters can be seen together and is arranged first by issue, rather than by commentator.

The rest of the penultimate chapter concerns how the issues that result from the 
evaluation can be organized into a research plan to aid scholars in treating them. Although not exhaustive, the plan in theory includes the issues essential for a more intimate engagement with the debate over the identity of the witnesses. The first part of the plan consists of five issues related to the interpretative framework that may be applied to the tale of the two witnesses. These issues concern the use of the OT in Revelation, the symbolism present in Revelation, and the matter of how Revelation relates to history (an interpretive approach). The second part of the plan consists of sixteen issues related to the text of Rev 11:3-13, such as the themes of testimony and prophecy, the images of the olive trees and the lampstands, and other aspects of the passage that involves the witnesses. Seven issues that concern the history of the interpretation of the passage, such as the early interpretation of the witnesses and various traditions about significant OT and NT figures, form the third part of the plan. The issues of the immediate context before the passage and after the passage form the fourth part of the plan. The issue of historical data completes the research plan. The final chapter summarizes and concludes the study. 
Andrews University

Seventh-day Adventist Theological Seminary

THE TWO WITNESSES OF REVELATION 11:1-13: ARGUMENTS, ISSUES OF INTERPRETATION, AND A WAY FORWARD

\author{
A Dissertation \\ Presented in Partial Fulfillment \\ of the Requirements for the Degree \\ Doctor of Philosphy
}

by

Ian R. Brown

September 2016 
CCopyright by Ian R. Brown 2016 All Rights Reserved 


\title{
THE TWO WITNESSES OF REVELATION 11:1-13: ARGUMENTS, ISSUES OF INTERPRETATION, AND A WAY FORWARD
}

\author{
A dissertation \\ presented in partial fulfillment \\ of the requirements for the degree \\ Doctor of Philosphy
}

by

Ian R. Brown

APPROVAL BY THE COMMITTEE:

Faculty Adviser,

Ranko Stefanović

Professor of New Testament

Director of $\mathrm{PhD} / \mathrm{ThD}$ Religion Program Thomas Shepherd

P. Richard Choi

Professor of New Testament

Dean, SDA Theological Seminary

Jiř́ Moskala

Jacques B. Doukhan

Professor of Hebrew and Old Testament Exegesis

John Reeve

Professor of Church History

Loren L. Johns, Professor of New Testament

Anabaptist Mennonite Biblical Seminary

Date approved 
TABLE OF CONTENTS

LIST OF ILLUSTRATIONS ........................................................................ ix

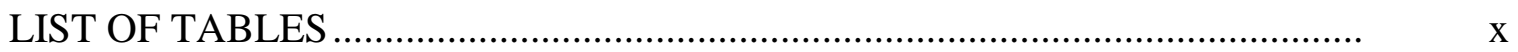

LIST OF ABBREVIATIONS .................................................................... xi

ACKNOWLEDGMENTS ……………………………............................... xiii

Chapter

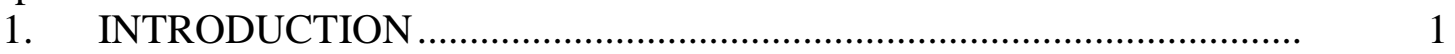

Background to the Problem ................................................................ 1

Statement of Problem ......................................................................... 3

Purpose of the Research ...................................................................... 5

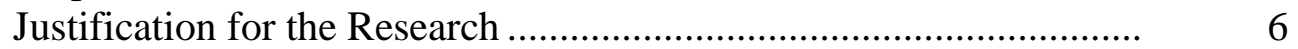

Delimitations .................................................................................. 10

Exegetical Delimitation.............................................................. 10

Delimitations on the Range of Exegetical Works Involved........ 11

Works with Argumentation................................................. 11

Works from the Eighteenth Century to the

Twenty-First Century.................................................... 11

Works Written in Several European Languages .................. 12

Delimitations on the Presentations of Commentators'

Arguments.................................................................... 12

Presentations Only for Representative Works .................... 12

Some Reasoning Presented More Succinctly ...................... 13

Some Reasoning Not Presented ........................................... 14

No Evaluation of Arguments ............................................ 14

Sketch of the Study .........................................................................

Chapter 2: Survey of Similar Literature ....................................... 15

Chapters 3 and 4: Presentations of Arguments and

Descriptions of Broad Issues of Interpretation .................... 15

Chapters 5 and 6: Discussion of Broad Issues of

Interpretation and Summary and Conclusions ..................... 17

2. SURVEY OF SIMILAR LITERATURE ................................................. 20



Works Furthest from the Present Study …………………………... 21 
Expositions of Revelation and Reviews of the

Literature on Revelation .............................................. 21

Historical Studies .................................................................. 22

Studies of Ideas and Discussions of Ancient Literature............. 23

Works Closest to the Present Study ................................................ 25

Two Works Related to Revelation as a Whole ......................... 26

Edward Bishop Elliott.................................................... 27

Le Roy Edwin Froom.................................................... 28

Ten Works with Rev 11:3-13 as a Major Concern ................... 31

Donatus Haugg.......................................................... 33

Walter E. Staten ....................................................... $\quad 34$

John Miesel ............................................................ $\quad 35$

Thomas W. Mackay .................................................... $\quad 36$

Paolo Byong-Seob Min ................................................... $\quad 38$

Rodney Lawrence Petersen............................................ 39

Kevin John O'Brien..................................................... 40

William Douglas Adamson ............................................ $\quad 42$

Seth Turner................................................................ 44

Christine Joy Tan ......................................................... 46

Summary and Conclusions ....................................................... 50

3. THE TWO WITNESSES AS TWO INDIVIDUALS .......................... 53



Content of the Chapter ..................................................... 53

Literal Identifications through Time ...................................... 54

The Futuristic View through Time .................................. 55

The Contemporary View through Time........................... 62

Influence on the Choice of Expositions Featured in

This Chapter......................................................... 65

Donatus Haugg ................................................................... 68

Introduction ...................................................................... 68

The Proper Approach to Interpreting Rev 11:1-13 .................. 71

Arguments That Involve Specifically the Identity Question....... 75

The Temporal Situation of the Two Witnesses.................. 75

Rev 11:1-2 and the Two Witnesses ................................ 81

The Scene for the Episode of the Witnesses ...................... 91

The Activity and Fate of the Two Witnesses..................... 92

Unnamed NT Era Prophets .............................................. 105

Summary and Conclusions..................................................... 108

Other Significant Expositions .................................................... 113

James Henthorn Todd .......................................................... 114

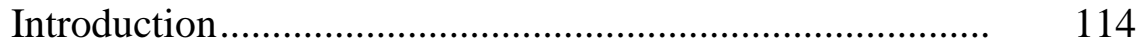

Starting Points for Todd .................................................. 116

The Two Witnesses Are Two Literal Figures ..................... 118

The Question of Greater Specificity ................................ 122

Conclusion ............................................................... 122 
Isbon Thaddeus Beckwith ............................................................ 123

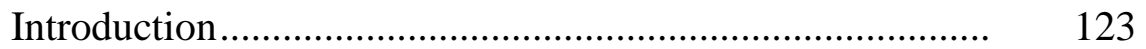

Starting Points for Beckwith ................................................ 124

Arguments concerning the Witnesses as Two Particular

Individuals ............................................................. 127

Arguments against Interpreting Rev 11:1-13

Figuratively ........................................................ 129

Conclusion ................................................................ 131

Christine Joy Tan ..................................................................... 131

Introduction.................................................................... 131

Textual Circumstances That Support the Futurist View ..... 136

The Testimony of the Early Church That Supports the

Futurist View

157

Two Discussions Related to the Futurist View ................... 157

Conclusion ....................................................................... 159

Summary and Conclusions for Other Significant Expositions ... 160

Johannes Munck .......................................................................... 160

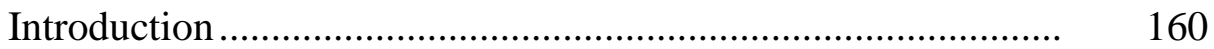

Overview of Munck's Study of the Two Witnesses .................... 161

Select Arguments and Broad Issues of Interpretation.................. 167

Arguments concerning Rev 11:3 ..................................... 168

Arguments concerning the Connection of Rev 11:3-13 to

the Passages That Follow........................................... 172

Summary and Conclusions........................................................ 180

Summary and Conclusions for the Chapter......................................... 181

The Exposition of Donatus Haugg............................................... 181

The Expositions of James Todd, Isbon Beckwith, and

Christine Tan............................................................... 182

Shared Issues of Interpretation.................................................. 182

The Exposition of Johannes Munck .......................................... 185

Summation …….................................................................... 188

4. THE TWO WITNESSES AS A SYMBOL.............................................. 189

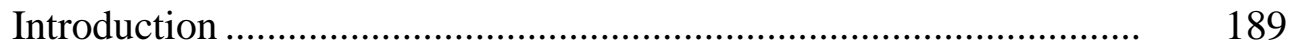

Content of the Chapter ............................................................ 189

Symbolic Identifications through Time ………………….......... 190

The View over Time That the Witnesses Indicate God's People

The View over Time That the Witnesses Indicate

Sacred Writings ......................................................... 200

Influence on the Choice of Expositions Featured in

This Chapter............................................................... 207

Gregory Kimball Beale ............................................................... 209

Introduction ........................................................................ 209

Beale's Interpretive Framework ................................................ 210

Use of the OT in Revelation ............................................. 211 
Symbolism in Revelation................................................. 212

Interpretive Approach to the Content of Revelation............ 212

Beale's Arguments Specifically concerning the

Two Witnesses

Six Main Reasons for Beale's Position on the Witnesses .... 215

Additional Arguments for Beale's Position on

the Witnesses

228

Summary and Conclusions......................................................... 246

Other Significant Expositions …………………………………..... 253

Hendrik Rijk van de Kamp ................................................... 254

Introduction ................................................................. 254

Van de Kamp's Interpretive Framework .............................. 255

Specific Promotion of van de Kamp's Identification ........... 257

Criticism of Alternative Identifications .............................. 259

The Timing of the Witnesses' Activity ................................ 267

Conclusion ................................................................... 268

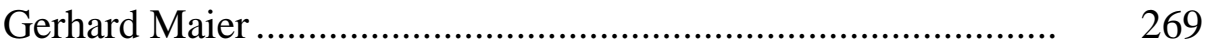

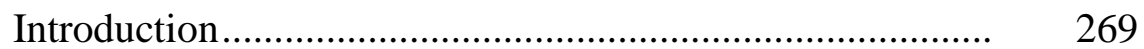

Maier's Interpretive Framework........................................... 270

Major Considerations Leading to Maier's Identification ..... 273

Material that Complements Maier's Major

Considerations

277

The Timing of the Witnesses' Activity ................................ 282

Conclusion .................................................................... 285

Summary and Conclusions for Other Significant Expositions ... 285

Ekkehardt Müller...................................................................... 286

Introduction ......................................................................... 286

An Overview of Müller's Study of the Two Witnesses .............. 286

Select Arguments and Broad Issues of Interpretation.................. 291

Arguments Involving the Key Concept of Prophecy .......... 292

Arguments Involving the Key Concept of Testimony ......... 293

Arguments Involving the Timing of the Witnesses'

Activity

294

Arguments Involving the Witnesses as Lampstands ........... 295

Thoughts concerning the Timing of the Witnesses'

Activity

297

Summary and Conclusions....................................................... 300

Summary and Conclusions for the Chapter....................................... 301

The Exposition of G. K. Beale ................................................... 302

The Expositions of H. R. van de Kamp and Gerhard Maier ....... 302

Shared Issues of Interpretation................................................... 302

The Exposition of Ekkehardt Müller ………………………....... 305

Summation ........................................................................ 307

5. DISCUSSION OF BROAD ISSUES OF INTERPRETATION ................ 309

Introduction 
The Common Broad Issues Discussed ............................................... 311

Interpretive Approach ........................................................... 311

The Degree to Which Symbolism Plays Role............................. 315

Distinguishing the Symbolic from the Literal............................. 318

The Image of the Olive Trees, the Image of the Lampstands,

Use of the OT, and How to Interpret Symbolism ............... 319

The Miraculous Powers of the Two Witnesses........................... 324

The Unity and the Duality of the Witnesses ............................... 325

Traditions about Moses, about Elijah, and about Enoch............. 326

Traditions about Peter and Traditions about Paul ...................... 329

Early Interpretation of the Witnesses......................................... 330

The Themes of Testimony and Prophecy.................................... 331

The Person-oriented Language Used to Describe the Witnesses .................................................................. 332

The Meaning of the Three-and-a-half-year Period ..................... 333

The Immediate Context before the Episode of the Witnesses

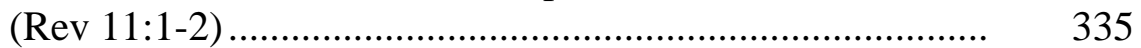

The Setting for the Events of Rev 11:3-13................................ 336

The Immediate Context after the Episode of the Witnesses (at least Rev 11:15-18) .................................................. 339

The Fate of the Witnesses ....................................................... 341

The Identity of the Beast in Rev 11:7 and the Meaning of the Great Earthquake......................................................... 342

The Audience to the Fate of the Witnesses ................................ 344

Historical Data ........................................................................ 345

The Verb Tenses of Rev 11:1-13 ........................................... 349

The Lack of Names .............................................................. 349

The Introduction of the Witnesses ............................................ 350

The Crucified Lord of Rev 11:8 .............................................. 352

Messianic Forerunners ............................................................ 352

The Sackcloth Clothing ............................................................ 353

The Theme of Warfare .............................................................. 354

A Research Plan for Identifying the Two Witnesses ........................ 355

Categorizing the Issues of Interpretation ................................... 355

The Arrangement of Argumentation in the Studied Commentators .............................................................. 356

A New Plan for Research....................................................... $\quad 360$

Conclusion................................................................................. 362

6. SUMMARY AND CONCLUSIONS ................................................... 364

Appendix

A. LITERAL, FUTURISTIC IDENTIFICATIONS OF THE TWO WITNESSES. 
B. IDENTIFICATIONS OF THE TWO WITNESSES AS

CONTEMPORARIES OF JOHN.......................................................... 385

C. IDENTIFICATIONS OF THE TWO WITNESSES AS

THE PEOPLE OF GOD ..................................................................... 391

D. IDENTIFICATIONS OF THE TWO WITNESSES AS

SACRED WRITINGS ....................................................................... 408

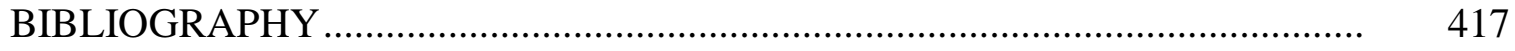

CURRICULUM VITAE ............................................................................... 495 


\section{LIST OF ILLUSTRATIONS}

1. Broad Issues of Interpretation in Haugg's Argumentation......................... 109

2. Broad Issues of Interpretation in Todd's Argumentation .............................. 117

3. Broad Issues of Interpretation in Beckwith's Argumentation ...................... 125

4. Broad Issues of Interpretation in Tan's Argumentation .............................. 137

5. Broad Issues of Interpretation in Munck's Argumentation ......................... 169

6. Broad Issues of Interpretation in Beale's Argumentation ........................... 247

7. Broad Issues of Interpretation in van de Kamp's Argumentation ................ 256

8. Broad Issues of Interpretation in Maier's Argumentation.......................... 271

9. Broad Issues of Interpretation in Müller's Argumentation ......................... 292

10. List of Main Issues of Interpretation .................................................... 355

11. List of Supplementary Issues of Interpretation .................................... 356

12. Research Plan for Identifying the Two Witnesses ................................... 361 


\section{LIST OF TABLES}

1. Broad Issues of Interpretation Shared by Haugg, Todd, Beckwith, and Tan.

2. Broad Issues of Interpretation Shared by Munck, Haugg, Todd, Beckwith, and Tan ........................................................................ 186

3. Broad Issues of Interpretation Shared by Beale, van de Kamp, and Maier .....

4. Broad Issues of Interpretation Shared by Müller, Beale, van de Kamp, and Maier

5. Broad Issues of Interpretation Shared among All Nine Examined Commentators 


\title{
LIST OF ABBREVIATIONS
}

\author{
AUSS $\quad$ Andrews University Seminary Studies \\ BBKL Biographisch-Bibliographisches Kirchenlexicon. Edited by F.-W. Bautz \\ and T. Bautz. Nordhausen, Germany, 1990- \\ Bib Biblica \\ BSac Bibliotheca Sacra \\ BT The Bible Translator \\ BZ Biblische Zeitschrift \\ CBQ Catholic Biblical Quarterly \\ CCSL Corpus Christianorum, series latina. Turnhout, 1953- \\ CCT Corpus Christianorum in Translation. Turnhour, 2009- \\ CTJ Calvin Theological Journal \\ DBSup Dictionnaire de la Bible, Supplément. Edited by L. Pirot et al. Paris, 1926- \\ DTT Dansk Teologisk Tidsskrift \\ FC Fathers of the Church. Washington, DC, 1947- \\ GCS Die griechischen christlichen Schriftsteller der ersten Jahrhunderte, Neue \\ Folge. Berlin, 1995- \\ JATS Journal of the Adventist Theological Society \\ JSNT Journal for the Study of the New Testament \\ JTS Journal of Theological Studies \\ LCL Loeb Classical Library. Cambridge, MA, 1912-
}




\begin{tabular}{|c|c|}
\hline NovT & Novum Testamentum \\
\hline NRTh & La nouvelle revue théologique \\
\hline NTApo & $\begin{array}{l}\text { New Testament Apocrypha. Edited by W. Schneelmelcher and R. McL. } \\
\text { Wilson. Rev ed. } 2 \text { vols. Louisville, KY, 1991-1992 }\end{array}$ \\
\hline NTS & New Testament Studies \\
\hline$O D N B$ & $\begin{array}{l}\text { Oxford Dictionary of National Biography. Edited by Henry Colin Gray } \\
\text { Matthew and Brian Howard Harrison. Oxford, } 2004\end{array}$ \\
\hline$O T P$ & $\begin{array}{l}\text { Old Testament Pseudepigrapha. Edited by J. H. Charlesworth. } 2 \text { vols. } \\
\text { Garden City, NY, 1983-1985 }\end{array}$ \\
\hline PL & $\begin{array}{l}\text { Patrologia latina [= Patrologiae cursus completus, series latina]. Edited by } \\
\text { J. P. Migne. } 217 \text { vols. Paris, 1844-1864 }\end{array}$ \\
\hline$R B$ & Revue biblique \\
\hline$R H P R$ & Revue d'histoire et de philosphie religieuses \\
\hline $\mathrm{SC}$ & Sources chrétiennes. Paris, 1943- \\
\hline Spec & Speculum \\
\hline$S T$ & Studia theologica \\
\hline$S T K$ & Svensk Teologisk Kvartalskrift \\
\hline$T D N T$ & $\begin{array}{l}\text { Theological Dictionary of the New Testament. Edited by G. Kittel and G. } \\
\text { Friedrich. Translated and edited by G. W. Bromiley. } 10 \text { vols. Grand } \\
\text { Rapids, MI, 1964-1976 }\end{array}$ \\
\hline$T W N T$ & $\begin{array}{l}\text { Theologisches Wörterbuch zum Neuen Testament. Edited by G. Kittel and } \\
\text { G. Friedrich. } 10 \text { vols. Stuttgart, 1933-1979 }\end{array}$ \\
\hline$Z N W$ & $\begin{array}{l}\text { Zeitschrift für die neutestamentliche Wissenschaft und die Kunde der } \\
\text { älteren Kirche }\end{array}$ \\
\hline
\end{tabular}




\section{ACKNOWLEDGMENTS}

First, I thank my Creator and Redeemer, Jesus, for bringing me through this academic endeavor. Without His wisdom and sustaining power, this dissertation would not have been possible. Second, I thank my family for their support and encouragement

through the long dissertation process. I have in mind my wife, Megan, my two children, Nathan and Christian, my parents, and my mother-in-law. They have offered words of encouragement, shown patience with me, and prayed much for me during the process. Third, I thank my initial adviser, Jon Paulien, for his supervision of the project in its initial stages. Fourth, I thank my present adviser, Ranko Stefanović, for supervising the project to its completion. Fifth, I thank my other committee members for their questions about aspects of the dissertation. Those questions have shaped the final product.

I also thank the many unknown individuals whose work has helped me to do mine. I have in mind here particularly the Interlibrary Loan Department of the James White Library. They were a tremendous help in getting copies of articles and essays. I am also thinking of the people behind the digitization of books, dissertations, theses, articles, and essays. Their work, when combined with the internet, made the literature from many libraries easily accessible.

Finally, I thank the financial donors to the $\mathrm{PhD} / \mathrm{ThD}$ in Religion Program. Their donations helped get me started in the Program and sustained my time in it. 


\section{CHAPTER 1}

\section{INTRODUCTION}

\section{Background to the Problem}

Rev 11:1-13 presents a small drama within the greater drama that is the book of Revelation. This passage mentions various locations, such as the temple, the altar, the outer court, the holy city, heaven, earth, the abyss, and the street of the great city. It contains a small host of characters, such as the prophet John, worshipers, nations, two prophet-witnesses, a beast, peoples, earth dwellers, their enemies, and a remnant. It also narrates lots of action. This passage describes measuring, trampling, prophesying, plagues, murder, disrespect for the dead, celebration, fear, resurrection, ascension, an earthquake, destruction, and glory given to God. In addition, the action is associated with specific periods, such as forty-two months, 1,260 days, and three and a half days.

Each of these elements engenders a question. What does this represent? Who are these people? Commentators have responded with a variety of suggestions about the meaning of the major locations, the key actors, and the important events in this passage.

Two key actors in this mini-drama are the prophet-witnesses. In response to the more specific question-Who or what are these two witnesses from the perspective of 
exegesis? — commentators have argued for various individuals, groups, and even

inanimate objects as the reality represented by the two witnesses of Rev $11 .^{1}$

${ }^{1}$ Thomas R. Schreiner defines exegesis as "the method by which we ascertain what authors meant when they wrote a particular piece of literature." Thomas R. Schreiner, Interpreting the Pauline Epistles, 2nd ed. (Grand Rapids, MI: Baker Academic, 2011), 7. He also notes here that this method assumes that one can figure out what an author's intended meaning was. Ibid., 7-8. Cf. Jeannine K. Brown, Scripture as Communication: Introducing Biblical Hermeneutics (Grand Rapids, MI: Baker Academic, 2007), 23; and Gordon Donald Fee, New Testament Exegesis: A Handbook for Students and Pastors, 3rd ed. (Louisville, KY: Westminster John Knox Press, 2002), 1. A more detailed defining of exegesis along these lines is available in Darrell L. Bock, "Opening Questions: Definition and Philosophy of Exegesis," in Interpreting the New Testament Text: Introduction to the Art and Science of Exegesis, ed. Darrell L. Bock and Buist Martin Fanning (Wheaton, IL: Crossway Books, 2006), 23-27. Meanwhile, Stanley E. Porter and Kent D. Clarke discuss the fact that modern interpreters can differ in their definitions of exegesis and in their conceptions of how it should be conducted. Stanley E. Porter and Kent D. Clarke, "What Is Exegesis? An Analysis of Various Definitions," in Handbook to Exegesis of the New Testament, ed. Stanley E. Porter (Boston: Brill Academic, 2002), 3-21.

The authors of at least one recent work on Revelation in fact offer a different picture of exegesis, as far as it pertains to Revelation. See Judith L. Kovacs, Christopher Charles Rowland, and Rebekah Callow, Revelation: The Apocalypse of Jesus Christ, Blackwell Bible Commentaries (Malden, MA: Blackwell, 2004), 11-14; cf. 248. Kovacs and Rowland, the main authors of this commentary, take seriously the idea that Revelation is based on one or more visionary experiences. Ibid., 12-13. One deduction from this is that readings of Revelation that some might consider "eisegesis ('reading into the text')" as opposed to exegesis, conceived similarly to what is noted above, gain a new legitimacy in scholarship, even though some of those readings may be socially problematic. Ibid., 13; cf. 247-250. Another result is that "it becomes difficult to describe any intention of the author [of Revelation], other than at most the ordering of the visions and their dissemination." Ibid., 13. Because of this proposition about authorial intention, Kovacs and Rowland see the visionary author of Revelation, John, and the readers as being in a similar position relative to the text. Therefore, in their opinion, the various responses to the text throughout history, whether exegetical, comparable with the conception above, or eisegetical, are "as important [to the exegesis of Revelation] as what the recipient of the vision and the original hearers may have understood it to mean." Ibid. In this way, the exegesis of Revelation is reconceived to include not simply what the text meant when composed, but also what it has meant to people since then. Moreover, the two facets seem to be on equal footing; one does not have priority over the other.

I agree that the visionary character of Revelation must be taken seriously and that perhaps it does cast some doubt on the notion of authorial intention in Revelation. Moreover, I too see significance in understanding what the text of Revelation has meant 
My interaction with the exegetical literature concerning the witnesses' identity has revealed that a more thorough and more extensive exegetical investigation into their identity could prove to be a fruitful enterprise. First, this literature offers many interesting observations and inferences in an attempt to answer this identity question. At times, commentators make some of the same observations and even some of the same inferences from those observations, but finally reach different conclusions.

Consequently, one may be torn in trying to decide whether one proposed answer is better than another is. Second, one occasionally discovers intriguing observations and inferences that are uncommon in the literature. The fact that others have found novel, yet significant, things to say about the witnesses suggests that further study might lead to new evidence or even a new conclusion.

\section{Statement of Problem}

A necessary step to conduct a new exegetical investigation into the identity of the two witnesses is a formal review of the previous literature concerning the question. The

to people since its composition. If I did not, I would not have carried out the present study. That history of interpretation after all includes the attempts of past exegetes, and those efforts can inform and influence later expositors. Nevertheless, the picture of exegesis that Kovacs and Rowland present has gone too far in downplaying the significance of authorial intention and in placing John and the readers in nearly the same position relative to the text. Although one might consider John and the readers as both being interpreters of the visions, they are not in the same position respective to the text. Only John has received the visions, not the readers. The readers have access to the visions only through John. Consequently, the readers receive what is essentially an interpretation of the visions, albeit one that seems to retain much of the elusive and allusive character of the original visions. John conceives this interpretation, and thus it bears his authorial intention. Exegesis along the lines of Schreiner, Fee, and others is therefore possible. 
purpose of this step is to provide a starting point and a guide for the rest of the investigation. ${ }^{2}$ The review might best accomplish this by exposing the broad issues of interpretation that commentators have raised in their quest to give an exegetical identification of the witnesses. Since these issues have been significant for past research into this topic, they could also provide a basis for a new investigation of the matter.

Given the need for such a review of the literature, I have looked to see whether one has already been conducted. Specifically, I have looked for a literature review that has four features. ${ }^{3}$ First, the work focuses its discussion upon identifications of the two witnesses from an exegetical perspective. Second, it contains exhaustive presentations of the arguments supporting proposed identities. An exhaustive presentation attempts to encapsulate the whole of an expositor's reasoning behind the choice of a particular identification. Such presentations are important, because they could benefit readers who do not necessarily wish to conduct their own review of commentators. Third, it describes the broad issues of interpretation raised by the commentators' arguments. Such issues have to do with the topics and themes that expositors debate in their argumentation. These issues are broad enough that two or more expositors can all speak to them, while

\footnotetext{
${ }^{2}$ Nancy Jean Vyhmeister, Quality Research Papers: For Students of Religion and Theology, 2nd ed. (Grand Rapids, MI: Zondervan, 2008), 209.

${ }^{3}$ The handling of previous literature in Roger Lucas's dissertation illustrates to a large degree the kind of literature review that I desired to find and that I describe in this paragraph: he clearly focuses his discussion on a wide range of exegetical works; he describes the arguments that select commentators offer in support of their views on his topic; and he identifies issues of interpretation that he has seen in his review of the literature. Roger Paul Lucas, "The Time of the Reign of Christ in 1 Corinthians 15:20-28 in Light of Early Christian Session Theology" (PhD dissertation, Andrews University, 1997), 1-122, accessed July 2, 2015, ProQuest Dissertations \& Theses Global.
} 
the details of what is said may differ among the expositors. Yet, such issues should not be so broad that they have no noticeable connection to the figure of the two witnesses. Fourth, it involves a wide range of literature. The more extensive this range, the more adequately the review can present supporting arguments and describe the interpretative issues, because these elements are ultimately based on the set of literature chosen for review. In other words, using a broad set of literature that comes from various times and that represents several languages can lead to a clearer picture of the state of the question concerning the witnesses and thereby a firmer basis from which to begin a new exegetical investigation into their identity. My search has not produced a review of the literature that has all of these features. ${ }^{4}$ The need still exists for a review of the literature that will more fully expose the state of the question concerning the identity of the witnesses and so offer a basis for a new investigation into that question. ${ }^{5}$

\section{Purpose of the Research}

Throughout the history of the interpretation of Rev 11, expositors have put forth a variety of suggestions as to the exegetical identity of the two witnesses. Clearly, some proposals seem more plausible than others do; however, the debate remains open.

${ }^{4}$ My MA thesis comes close. See Ian Robertson Brown, "The Two Witnesses (Rev 11:3-13) as Two Individuals Appearing near the End of the Age: A Selective Literature Review and Issues of Interpretation" (MA thesis, Andrews University, 1999). Arguably, it contains the four critical features. Nevertheless, the study is limited. First, it offers readers a picture of only one segment of the debate concerning the identity of the two witnesses. Second, the thesis involves a smaller set of literature, which is only partly because of the previous limitation. Besides its limitations, the thesis contains what I now consider a weakness. The issues of interpretation were defined so broadly that they really lost their distinction as being issues in the debate over the identity of the witnesses.

${ }^{5}$ See chapter 2 of the present study for substantiation and further discussion. 
Indeed, the possibility exists that a stronger case could be made for a previous proposal or that a new one could be found that is more agreeable to scholars of Revelation. The purpose of my research is to clarify the nature of the problem of identifying the two witnesses and to form a plan for finding a more satisfactory answer. In this way, my research illuminates the path beyond the current state of inconclusiveness. This purpose is accomplished through a survey of arguments that are representative of those used to support the major exegetical identifications of the two witnesses and through an examination of the broad interpretive issues that can be derived from those arguments. In short, my research aims to meet the need for a review of the literature that will more fully expose the state of the question concerning the identity of the witnesses and so offer a basis for a new investigation into that question.

\section{Justification for the Research}

The present project is significant partly because it forms the literature review needed for a new exegetical investigation into the identity of the two witnesses. This contribution can then aid researchers in achieving that ultimate goal.

Biblical scholars can improve and modify their methods, arguments, and conclusions by examining histories of interpretation and reflecting upon them. With respect to the exegesis of Revelation, this process can lead ideally to more accurate and more credible results. ${ }^{6}$ The proposed study exposes part of the history of the

\footnotetext{
${ }^{6} \mathrm{Cf}$. the words of Hans Dieter Betz concerning the study of the Sermon on the Mount (Matt 5:3-7:27) and the Sermon on the Plain (Luke 6:20-49): "It is true not only that our present problems regarding these texts have evolved in history before us, but also that past scholarship has made important discoveries that have been forgotten or misunderstood; if recovered and properly understood, these older discoveries can make
} 
interpretation of Revelation and offers some reflections upon it. Consequently, this study is also significant because it contributes to that evaluative process.

The exegetical investigation into the witnesses' identity, however, is more than a scholarly curiosity. At the end of the twentieth century and the start of the twenty-first, the question of the witnesses' identity has occasionally entered the public realm outside the academy. Here are a few examples where the matter of the witnesses has received wide dissemination because it has played a role either in a wider situation or in a larger narrative that has garnered popular attention.

One example involves Marshall Herff Applewhite, Jr., the leader of the Heaven's Gate religious group. In March 1997, thirty-nine people, including Applewhite, committed suicide to enter a higher existence. Although the group had already occasionally been a subject of interest to outsiders during its multiyear history, the mass suicide led to renewed attention from the media and researchers. One datum mentioned in this new wave of investigation has been that Applewhite and his previously deceased co-leader, Bonnie Lu Trusdale Nettles, had at one time seen themselves as the two witnesses of Revelation 11. ${ }^{7}$

important contributions even in the present. Thus, the history of exegesis and the current discussions of exegetical problems must be brought to bear on each other." Hans Dieter Betz, The Sermon on the Mount: A Commentary on the Sermon on the Mount, Including the Sermon on the Plain (Matthew 5:3-7:27 and Luke 6:20-49), ed. Adela Yarbro Collins, Hermeneia-A Critical and Historical Commentary on the Bible (Minneapolis: Fortress Press, 1995), 5.

${ }^{7}$ See among the many discussions and other pieces of literature: George D. Chryssides, "'Come on up, and I Will Show Thee': Heaven's Gate as a Postmodern Group," in Controversial New Religions, ed. James R. Lewis and Jesper Aagaard Petersen (New York: Oxford University Press, 2005), 353-370; John R. Hall, Philip Daniel Schuyler, and Sylvaine Trinh, Apocalypse Observed: Religious Movements and 
A second example is the popular comic book story, Kingdom Come, involving Superman, Wonder Woman, Batman, and various other superheroes and supervillians. Explicitly interwoven in this tale are references to the Book of Revelation, including the two witnesses. ${ }^{8}$

A third example comes from the twelve novels by Tim F. LaHaye and Jerry B. Jenkins that constitute the heart of the popular Left Behind® book series and form one long narrative. Together these books offer a fictional account of Christ's second coming and the seven years leading up to it. Nearly all the books refer to the two witnesses. ${ }^{9}$

Violence in North America, Europe and Japan (London: Routledge, 2000), 152-157, 179182, 190-191; John Gordon Melton, "Applewhite Jr., Marshall Herff," Religious Leaders of America: A Biographical Guide to Founders and Leaders of Religious Bodies, Churches, and Spiritual Groups in North America, 2nd ed. (Detroit, MI: Gale Research, 1999), 21; Christopher Partridge, "The Eschatology of Heaven's Gate," in Expecting the End: Millennialism in Social and Historical Context, ed. Kenneth G. C. Newport and Crawford Gribben (Waco, TX: Baylor University Press, 2006), 49-66, 251-257; and Benjamin Ethan Zeller, "Scaling Heaven's Gate: Individualism and Salvation in a New Religious Movement," Nova Religio 10, no. 2 (November 2006): 75-102, accessed July 3, 2015, EBSCOhost ATLA Religion Database with ATLASerials.

${ }^{8}$ The story originally appeared as a four issue miniseries from May 1996 to August 1996. The four issues were later published in a single paperback volume: Mark Waid, Alex Ross, and Todd Klein, Kingdom Come (New York: DC Comics, 1997). The many reprints of the collected work and the adaptation of the story as a novel and then as an audiobook indicate the popularity of the story. For the latter two items, see Elliot S. Maggin, Kingdom Come, Based on a story by Mark Waid and Alex Ross (New York: Warner Books, Warner Aspect, 1998); and John Whitman, Kingdom Come, based on a story by Mark Waid and Alex Ross and the novelization by Elliot S. Maggin, prod. and dir. Maja Thomas (New York: Time Warner Audiobooks, 1998), 2 audiocassettes.

${ }^{9}$ The two witnesses appear as actual characters only in the first six books. Timothy Francis LaHaye and Jerry Bruce Jenkins, Left Behind®: A Novel of the Earth's Last Days, [Left Behind ${ }^{\circledR}$ Book Series 1] (Wheaton, IL: Tyndale House, 1995); Timothy Francis LaHaye and Jerry Bruce Jenkins, Tribulation Force: The Continuing Drama of Those Left Behind, [Left Behind® Book Series 2] (Carol Stream, IL: Tyndale House, 1996); Timothy Francis LaHaye and Jerry Bruce Jenkins, Nicolae: The Rise of Antichrist, [Left Behind® Book Series 3] (Wheaton, IL: Tyndale House, 1997); Timothy Francis 
The final instance involves the science-fiction TV drama series The Dead Zone.

The show, which ran for six seasons (2002-2007), focuses on the life of Johnny Smith, a man who has gained psychic abilities after being in a coma. At least two episodes of the show refer to the two witnesses. ${ }^{10}$

LaHaye and Jerry Bruce Jenkins, Soul Harvest: The World Takes Sides, [Left Behind® Book Series 4] (Wheaton, IL: Tyndale House, 1998); Timothy Francis LaHaye and Jerry Bruce Jenkins, Apollyon: The Destroyer is Unleashed, [Left Behind® Book Series 5] (Carol Stream, IL: Tyndale House, 1999); and Timothy Francis LaHaye and Jerry Bruce Jenkins, Assassins: Assignment: Jerusalem, Target: Antichrist, [Left Behind® Book Series 6] (Wheaton, IL: Tyndale House, 1999). Most of the remaining books though still make at least one reference to them. Timothy Francis LaHaye and Jerry Bruce Jenkins, The Indwelling: The Beast Takes Possession, [Left Behind ${ }^{\circledR}$ Book Series 7] (Wheaton, IL: Tyndale House, 2000), 1, 3-4, 329; Timothy Francis LaHaye and Jerry Bruce Jenkins, Desecration: Antichrist Takes the Throne, [Left Behind ${ }^{\circ}$ Book Series 9] (Wheaton, IL: Tyndale House, 2001), 93, 108, 115; Timothy Francis LaHaye and Jerry Bruce Jenkins, The Remnant: On the Brink of Armageddon, [Left Behind® Book Series 10] (Wheaton, IL: Tyndale House, 2002), 232; Timothy Francis LaHaye and Jerry Bruce Jenkins, Armageddon: The Cosmic Battle of the Ages, [Left Behind® Book Series 11] (Wheaton, IL: Tyndale House, 2003), 307, 324; and Timothy Francis LaHaye and Jerry Bruce Jenkins, Glorious Appearing: The End of Days, [Left Behind® Book Series 12] (Wheaton, IL: Tyndale House, 2004), 382. The popularity of the book series is seen not only in the numerous books sold, but also in the expansion of the book series to include three prequels and a sequel and in the existence of various related media and merchandise. For the prequels, see Timothy Francis LaHaye and Jerry Bruce Jenkins, The Rising: Antichrist is Born: Before They Were Left Behind, [Left Behind® Book Series, Prequel, 1] (Wheaton, IL: Tyndale House, 2005); Timothy Francis LaHaye and Jerry Bruce Jenkins, The Regime: Evil Advances: Before They Were Left Behind, [Left Behind ${ }^{\circledR}$ Book Series, Prequel, 2] (Carol Stream, IL: Tyndale House, 2005); Timothy Francis LaHaye and Jerry Bruce Jenkins, The Rapture: In the Twinkling of an Eye: Countdown to the Earth's Last Days, [Left Behind ${ }^{\circledR}$ Book Series, Prequel, 3] (Carol Stream, IL: Tyndale House, 2006). For the sequel, see Timothy Francis LaHaye and Jerry Bruce Jenkins, Kingdom Come: The Final Victory, [Left Behind® Book Series Sequel] (Carol Stream, IL: Tyndale House, 2007).

${ }^{10}$ The episode "Instinct" first aired August 15, 2004. The episode "Vortex" first aired August 6, 2006. The scripts for the episodes document mention of the two witnesses and are available on-line from the USA Network, which originally aired the episodes: Erin Maher and Kay Reindl, "Instinct," script prepared for The Dead Zone, USA Network, August 2004, 2-5, 20-20A, 35-38A, 56-56B, accessed July 2, 2015, http://www2.usanetwork.com/series/thedeadzone/theshow/episodeguide/episodes 
At least those who have been directly involved in the situations just noted - the members of Heaven's Gate, the authors of Kingdom Come, the writers of the Left Behind ${ }^{\circledR}$ series, and the writers for The Dead Zone - have shown a distinct non-academic interest in the identity of the two witnesses, even if the specific nature of that interest varies according to the situation. Moreover, given that these are just examples, definitely others living at the end of the twentieth century and at the start of the twenty-first have the same general interest. Potentially, though, because of the dissemination of information, such as that concerning Heaven's Gate, or of narratives, such as Kingdom Come and Left Behind®, many others living at this time and functioning apart from the academy have or could gain an interest in the question of the witnesses. Therefore, in light of these circumstances, an exegetical investigation into the identity of the two witnesses has a potential non-academic audience and could influence how those outside the academy understand and respond to these figures. This observation in turn adds to the importance of the present research.

\section{Delimitations}

\section{Exegetical Delimitation}

As implied above, the present study exhibits four features that I consider critical for a picture of the state of the question concerning the exegetical identity of the two witnesses. Not surprisingly, one of those features is a focus on exegetical works. This then is one delimitation of this study. It means that homiletical and devotional treatises

/s3_instinct/instinct.pdf; and Michael Taylor, "Vortex," script prepared for The Dead Zone, USA Network, August 2005, 35-37A, 42-45, accessed July 2, 2015, http://www2.usanetwork.com/series/thedeadzone/theshow/episodeguide/episodes /s5_vortex/script.pdf. 
have been excluded from the set of literature that lies behind the presentations of argumentation, which form another key feature of the present study.

Delimitations on the Range of Exegetical Works Involved

Another critical feature is having breadth to the set of exegetical works. Yet, the sheer mass of the literature that deals with the identity of the witnesses, even when one focuses on exegetical works, has made using a comprehensive set of literature nearly impossible, if the project was to remain manageable. Thus, the need for further delimitations existed. These delimitations define this feature for the present study.

\section{Works with Argumentation}

First, the underlying literature set consists of works that actually have argumentation concerning the witnesses. Some interpreters simply state an identification without offering any reasons for their conclusion. Their comments cannot lead to any presentation of arguments about the witnesses' identity, and therefore these works have been excluded.

\section{Works from the Eighteenth Century to the Twenty-First Century}

Second, the body of works is mostly confined to items that were published from the eighteenth century to the start of the twenty-first century. It is during this period that modern methods of exegesis have taken hold within biblical studies. Moreover, a focus on modern works is more appropriate for viewing the current state of the debate over the witnesses' identity. 


\section{Works Written in Several European \\ Languages}

Third, the literature set is delimited almost solely to works written originally in English, German, French, Italian, Dutch, Danish, and Spanish. The order of this listing denotes a descending scale of representation in this body of works. Accordingly, English works have the greatest representation in the literature set and Spanish works the least. Although English works have the highest representation, they do not form a majority in the literature set. Rather, the majority consists of works written originally in English, German, and French. I must stress that this perspective on the delimited set of literature ignores that a work may be accessible through a translation. Again, I am looking here from the perspective of the original language of the resources.

\section{Delimitations on the Presentations of Commentators' Arguments}

Again, the present study includes exhaustive presentations of commentators' arguments about the identity of the witnesses. Having this is critical for a picture of the state of the question concerning the exegetical identity of the witnesses. Besides being informative in themselves, the arguments suggest broad issues of interpretation in the debate. Describing those issues is also critical for a picture of the status of the debate. Four other delimitations shape the presentations of argumentation.

\section{Presentations Only for Representative Works}

One delimitation addresses the following problem: Even with the previous delimitations, a large amount of material remains; offering a survey of the argumentation of each piece would have made the project unmanageable. To solve this problem, nine representative expositions have been selected to have their reasoning presented in varying 
detail. These presentations offer a generous sampling of the arguments that may be found in all the other studies that help to form the mass of remaining material.

Obviously, selecting particular works to represent whole classes might mean that some distinctive points of argumentation are omitted. Nevertheless, I am confident from my close examination of much of the literature on the two witnesses that this way of dealing with the literature still leads one to the most important broad issues of interpretation. The presentations provide sufficient material to show the major broad issues in the debate since 1700 over the identity of the two witnesses. In the end, the task of dealing with the mass of literature has been made more manageable, and the presentations as a whole are easier to work with for readers of the present study.

\section{Some Reasoning Presented More Succinctly}

Another delimitation that pertains to presenting supporting arguments is that some of the reasoning is described more concisely than how it could be. By minimizing the presentation of some argumentation, I do not wish to suggest that these arguments are unimportant and do not play a critical role in their respective expositions. Rather, this delimitation is intended to allow space for other parts of the study and to make the presentations more readable. Some of the more succinct handling of argumentation occurs with arguments that function indirectly to support an interpreter's identification of the witnesses. For instance, the intellectual frameworks that commentators use to understand Revelation may well affect their conclusions about the witnesses, even though they do not make that connection explicit. I have minimized the presentation of the argumentation behind those frameworks, going so far at times as to state simply an interpreter's opinion about a matter and to cite the pages where this expositor reasons out 
the matter. I have also made the presentation of some direct argumentation more succinct. The arguments directly bearing on the identity question are presented more briefly than they could be for five of the featured commentators. Their works are meant to offer material that could either supplement or replace what is present in the two works that form the foundation for the complete presentation of arguments.

\section{Some Reasoning Not Presented}

As is made clear below, I do not present the full complement of arguments for two expositions discussed in this study. By doing this, again, I do not wish to suggest that these arguments are unimportant and do not play a critical role in their respective expositions. Here too, the delimitation is intended to allow space for other parts of the

study. The two expositions that have received a truncated treatment represent opinions on the witnesses that have been less popular in the debate since 1700 over their identity. In each case, however, an overview of the work and a sample of the argumentation are presented to give a taste of the commentator's reasoning and to show most of the broad issues of interpretation that could be derived from the full exposition.

\section{No Evaluation of Arguments}

A final delimitation is that no attempt has been made to evaluate the arguments. This task is left for future exegetical investigation. This delimitation does not exist simply to economize space. It also exists because it seems premature to evaluate the arguments without addressing first the issues inferred from them. 


\section{Sketch of the Study}

\section{Chapter 2: Survey of Similar Literature}

The rest of the present study consists of five chapters. In the next chapter, which is the second for the whole study, other works dealing with the history of the interpretation of the two witnesses are discussed. In doing this, I demonstrate the uniqueness of this study in its handling of that history. In other words, justification is given for the claim made above that a review of the literature is still needed to see more fully the state of the debate about the witnesses. At the end of the chapter, it is observed how the present study meets this need in contrast to the other works discussed there.

Chapters 3 and 4: Presentations of Arguments and Descriptions of Broad Issues of Interpretation

The most popular opinions about the witnesses can be naturally divided into literal and symbolic identifications. Accordingly, numerous commentators have identified the witnesses as two actual individuals (literal), while many others have understood them as representing some other reality (symbolic), such as an ecclesiastical body or even parts of the Bible. Thus, one has two types of exegetical identifications. The presentations of argumentation, as delimited above, are separated according to this division, with the third chapter concerning literal identifications and the fourth chapter concerning symbolic ones.

Each chapter begins with an overview of the respective type of identification over time. This is followed by a discussion of the selection of the works to be featured in that particular chapter. The history just reviewed has influenced the selection. Then, in each chapter, the actual presentations begin with an extensive summary of one exposition. These summaries function as the bases for discussing other significant expositions of the 
witnesses that, although differing in certain ways from the main one, still represent the same broad class of identifications. Descriptions of the broad issues of interpretation that are deducible from the presented arguments are mostly given after an argument or set of arguments has been mentioned. The procedure is different for the two foundational works. For those pieces, the descriptions of the broad issues are offered in summaries of the full argumentation of the two works. Issues of interpretation shared by the studied commentators are identified in the conclusions to each chapter.

As for specifics concerning these two chapters, the thinking of Donatus Haugg forms the central exposition of chapter $3 .{ }^{11}$ He identifies the two witnesses as two unnamed end-time prophets. Three other expositions discussed in this chapter also identify the witnesses as two individuals who appear in the future after the composition of Revelation. These interpretations come from James Henthorn Todd, Isbon Thaddeus Beckwith, and Christine Joy Tan. ${ }^{12}$ The work of Johannes Munck is also featured in chapter $3 .{ }^{13}$ He identifies the two witnesses with Peter and Paul. His exposition

${ }^{11}$ Donatus Haugg, Die zwei Zeugen: Eine exegetische Studie über Apok 11, 1-13, Neutestamentliche Abhandlungen 17, issue 1 (Münster in Westphalia: Verlag der Aschendorffschen Verlagsbuchhandlung, 1936).

${ }^{12}$ Isbon Thaddeus Beckwith, The Apocalypse of John: Studies in Introduction, with a Critical and Exegetical Commentary (New York: Macmillan, 1919), accessed June 12, 2015, Google Books; Christine Joy Tan, "A Defense of a Futurist View of the Two Witnesses in Revelation 11:3-13" (PhD dissertation, Dallas Theological Seminary, 2010), accessed June 12, 2015, ProQuest Dissertations and Theses Global; and James Henthorn Todd, Six Discourses on the Prophecies Relating to Antichrist in the Apocalypse of St. John. . . . (Dublin: Hodges and Smith; London: F. and J. Rivington, 1846), accessed June 12, 2015, Google Books.

${ }^{13}$ Johannes Munck, Petrus und Paulus in der Offenbarung Johannis: Ein Beitrag zur Auslegung der Apokalypse, Det Lærde Selskabs Skrifter, Teologiske Skrifter, 1 (Copenhagen: Rosenkilde og Bagger, 1950). 
represents those interpreters who identify the witnesses as two people contemporaneous to John. Munck's exposition receives an abbreviated treatment.

The thinking of Gregory Kimball Beale forms the foundational exposition for chapter $4 .{ }^{14}$ He believes that the two witnesses represent the whole church throughout its existence before Jesus' second coming. Two other expositions discussed in this chapter offer a similar symbolic identification. These come from Hendrik Rijk van de Kamp and Gerhard Maier. ${ }^{15}$ The work of Ekkehardt Müller is also featured in chapter $4 .{ }^{16} \mathrm{He}$ argues that the two witnesses symbolize the Bible. His exposition represents those interpreters who see the witnesses as a symbol for sacred writings. Müller's exposition receives an abbreviated treatment.

Chapters 5 and 6: Discussion of Broad Issues of Interpretation and Summary and Conclusions

In the fifth chapter, several of the broad issues of interpretation that are described in the previous two chapters are evaluated. For the sake of brevity, I limit myself to those

\footnotetext{
${ }^{14}$ Gregory Kimball Beale, The Book of Revelation: A Commentary on the Greek Text, New International Greek Testament Commentary (Grand Rapids, MI: William B. Eerdmans; Carlisle, United Kingdom: Paternoster Press, 1999).

${ }^{15}$ Hendrik Rijk van de Kamp, Openbaring: Profetie vanaf Patmos, Commentaar op het Nieuwe Testament, 3rd ser., Katholieke Brieven en Openbaring sec. (Kampen, Netherlands: Uitgeverij Kok, 2000); and Gerhard Maier, Die Offenbarung des Johannes: Kapitel 1-11, Historisch-Theologische Auslegung, Neues Testament (Witten, Germany: SCM R. Brockhaus; Giessen, Germany: Brunnen Verlag, 2009). Maier covers the rest of Revelation in Gerhard Maier, Die Offenbarung des Johannes: Kapitel 12-22, HistorischTheologische Auslegung, Neues Testament (Witten, Germany: SCM R. Brockhaus; Giessen, Germany: Brunnen Verlag, 2012).

${ }^{16}$ Ekkehardt Müller, Der Erste und der Letzte: Studien zum Buch der Offenbarung, Adventistica, Forschungen zur Geschichte und Theologie der SiebentenTags-Adventisten, 11 (Frankfurt am Main: Peter Lang, 2011).
} 
issues that are a concern common to two or more of the studied commentators. In the evaluation, several issues are identified as the main issues in the debate over the identity of the two witnesses, because the majority of the nine examined commentators address them. Inasmuch as the works of the nine commentators are representative of a large set of literature on the two witnesses, the issues most discussed by them should be representative of the main issues in the debate. To engage in the debate, seeking to support a past proposal or to offer a new one, would seem to require at a minimum that one address these main issues. As for the issues that are less common among the nine commentators, these issues are assessed to see whether they should join the main issues in a new investigation of the identity question. Many of these are found to be relevant for further discussion of the identity question.

Accompanying the evaluation are small summaries of what the studied commentators have said in addressing the broad issues of interpretation. In a brief way, argumentation from the two preceding chapters can be seen together and is arranged first by issue, rather than by commentator. Arrangement by commentator still appears though in a secondary way. Briefly reviewing how the issues have been addressed offers guidance for future investigation of the issues.

The rest of chapter 5 concerns how the issues that result from the evaluation can be organized into a research plan to aid scholars in treating them. Some consideration is given here as to whether the scholars examined in the present study have used some logical order in dealing with the issues that they raise. Because of the delimitation of discussing only common issues of interpretation, however, the plan is not exhaustive. 
Nevertheless, what is included are in theory the issues essential for a more intimate engagement with the debate over the identity of the witnesses.

The final chapter summarizes and concludes the study. 


\section{CHAPTER 2}

\section{SURVEY OF SIMILAR LITERATURE}

\section{Introduction}

It was stated in the introduction that the present study has not been done before and is thus unique. It seems fitting to demonstrate this point. Again, the present study has four particular features that I consider critical for a fuller look at the state of the question of the exegetical identity of the two witnesses: (1) a focus on exegetical works as opposed to devotional or homiletical pieces; (2) the involvement of a wide range of works; (3) exhaustive presentations of the arguments that underlie particular identifications; and (4) a description of the broad issues of interpretation that may be derived from commentators' arguments. I have defined these features more closely in the previous chapter.

I now offer a closer look at the many extant works that touch upon the history of the interpretation of the two witnesses, but that do not exhibit all four of the key features found in the present investigation. ${ }^{1}$

${ }^{1}$ My MA thesis could be considered to have all four features, but it has its limits. See Brown, "The Two Witnesses (Rev 11:3-13) as Two Individuals Appearing near the End of the Age: A Selective Literature Review and Issues of Interpretation." The thesis covers only one specific class of literal identifications, whereas the present study deals more broadly with literal identifications and considers symbolic identifications. The thesis also involves a smaller set of literature, which is only partly because of the previous limitation. The present study is based not only on a set of works that exhibits a 


\section{Works Furthest from the Present Study}

Furthest from the present work are the numerous pieces that touch slightly upon the vast discussion about the two witnesses that has taken place from the time of the early church to the start of the twenty-first century.

\section{Expositions of Revelation and Reviews of the Literature on Revelation}

Many expositions of Revelation, ranging from full commentaries to quite focused studies, speak about the two witnesses and in doing so say just a little about the history of their identification. ${ }^{2}$ Some surveys of the literature on Revelation also refer only in a

broader spectrum of identifications, but also on one that covers a wider time frame and that encompasses more non-English pieces. These advances over my previous investigation allow the present study to offer a more complete picture of the debate over the exegetical identity of the two witnesses. The fuller picture in turn permits a more precise discussion of the issues of interpretation and thus a better basis for future research. Besides its limitations, the thesis contains what I now consider a weakness. The issues of interpretation were defined so broadly that they really lost their distinction as being issues in the debate over the identity of the witnesses.

${ }^{2}$ See, for example, Joseph Sylvester Considine, "The Two Witnesses: Apoc. 11:313," $C B Q$ 8, no. 4 (October 1946): 386, 390-391; Friedrich Hermann Christian Düsterdieck, Kritisch exegetisches Handbuch über die Offenbarung Johannis, 4th ed., Kritisch exegetischer Kommentar über das Neue Testament 16 (Göttingen: Vandenhoeck und Ruprecht's Verlag, 1887), 369-378, accessed July 3, 2015, Google Books; André Feuillet, "Essai d'interprétation du chapitre XI de l'Apocalypse," NTS 4, no. 3 (April 1958): 189-190, 191n3, 195n3; Hans Werner Günther, Der Nah- und Enderwartungshorizont in der Apokalypse des heiligen Johannes, Forschung zur Bibel 41 ([Würzburg, Germany?]: Echter Verlag, 1980), 248-254; Philip Lee Mayo, "Those Who Call Themselves Jews": The Church and Judaism in the Apocalypse of John, Princeton Theological Monograph Series 60 (Eugene, OR: Pickwick Publications, 2006), 132, 135; and Pierre Prigent, Commentary on the Apocalypse of St. John, trans. Wendy Pradels (Tübingen: Mohr Siebeck, 2001), 52-54, 349n31, 350-351, 357. With the last work, cf. the original French at Pierre Prigent, L'Apocalypse de Saint Jean, Rev. ed., Commentaire du Nouveau Testament, 2nd ser., 14 (Geneva: Labor et Fides, 2000), 36-38, 269-271, 275. 
minor way to previously proposed identifications of the witnesses. Among these are broad surveys that cover the history of the interpretation of Revelation as whole. ${ }^{3}$ There are also smaller literature reviews that focus on "recent" works. The newer items might pertain to a particular topic, or an author may highlight them simply to let others know what is generally happening in the field of studying Revelation. ${ }^{4}$

\section{Historical Studies}

The expositions and surveys of literature that were just noted clearly involve discussions that are in some sense "historical." There is, however, another class of works that intersect in a minor way with the debate over the two witnesses and that involve "historical" reflection. The tenor of these presentations differs from that found in the expositions on Revelation and the reviews of the literature about Revelation. This difference probably stems from a difference in the aims that the two sets of authors have

${ }^{3}$ See, for example, Beckwith, Apocalypse, 40, 321-322, 324, 326, 331-332; and Robert Henry Charles, Studies in the Apocalypse. . . (Edinburgh: T. \& T. Clark, 1913), 10, 13, accessed July 3, 2015, Internet Archive Canadian Libraries Collection. Incidentally, Beckwith also refers to the history of the interpretation of the two witnesses in his exposition of Revelation 11; see Beckwith, Apocalypse, 585-586, 595. Beckwith's work exemplifies those works in which a review of the literature on Revelation accompanies an exposition of the whole book. This is not always the case, however, as illustrated by Charles's survey. Beckwith's interpretation of the witnesses is featured in chapter 3 of the present study.

${ }^{4}$ For remarks on the history of the interpretation of the witnesses that appear in a smaller survey that is oriented toward a particular topic, see, for instance, Felise Tavo, "The Ecclesial Notions of the Apocalypse in Recent Studies," Currents in Biblical Research 1, no. 1 (October 2002): 118, 123, 130-131, accessed July 3, 2015, EBSCOhost ATLA Religion Database with ATLASerials. For such remarks that appear in a smaller survey that is more general in orientation, see, for example, André Feuillet, L'Apocalypse: État de la question, Studia neotestamentica, Subsidia, 3 (Paris: Desclée de Brouwer, 1963), 34, 50-51, 106. 
brought to their investigations. While the one class (expositions and reviews of literature) speaks of the history of interpretation more with a view towards someone expounding upon the text of Revelation, the other class speaks of the history of interpretation more for the purpose of simply clarifying and presenting a part of the record of human history. In any case, historical studies of the latter kind form another group of literary works that stand far from the present study. These investigations range in focus from remarks on a particular individual to the examination of many individuals living over a long period. ${ }^{5}$

\section{Studies of Ideas and Discussions of Ancient Literature}

Two more groups of literature that speak only slightly of the history of the interpretation of the two witnesses can also be noted. First, some pieces, unlike the various studies just noted above, are far more interested in ideas in history than the

\footnotetext{
${ }^{5}$ See, for example, Warren Johnston, "Thomas Beverley and the 'Late Great Revolution': English Apocalyptic Expectation in the Late Seventeenth Century," in Scripture and Scholarship in Early Modern England, ed. Ariel Hessayon and Nicholas Keene (Aldershot, Hampshire, UK: Ashgate, 2006), 162-163, 169; Jeffrey K. Jue, Heaven upon Earth: Joseph Mede (1586-1638) and the Legacy of Millenarianism, Archives internationales d'histoire des idées 194 (Dordrecht, Netherlands: Springer, 2006), 82-83, 103-106, 168-169, 221, 240-241; Philip D. W. Krey, "The Apocalypse Commentary of 1329: Problems in Church History," in Nicholas of Lyra: The Senses of Scripture, ed. Philip D. W. Krey and Lesley Smith, Studies in the History of Christian Thought 90 (Leiden: Brill, 2000), 269, 271, 274, 278-288; Wilhelm Kamlah, Apokalypse und Geschichtstheologie: Die mittelalterliche Auslegung der Apokalypse vor Joachim von Fiore, Historische Studien 285 (Berlin: Verlag Dr. Emil Ebering, 1935; reprint, Vaduz, Liechtenstein: Kraus Reprint, 1965), 52, 91-92, 126-127; Walter Klaassen, Living at the End of the Ages: Apocalyptic Expectation in the Radical Reformation (Lanham, MD: University Press of America; Waterloo, ON, Canada: Institute for Anabaptist and Mennonite Studies, Conrad Grebel Colloge, 1992), 2, 8, 26-28, 46, 50, 54, 79-82; and Gian Luca Potestà, Il tempo dell'Apocalisse: Vita di Gioacchino da Fiore, Collezione storica (Rome: Editori Laterza, 2004), 64-67, 182-183, 229, 311-313.
} 
historical individuals who have espoused those ideas. These works include discussions about how biblical figures, like Enoch and Elijah, have been perceived, discussions concerning the notion of the antichrist, and investigations into traditional ideas that may have influenced the beliefs of Jesus and his first followers. ${ }^{6}$ Second, some works concern ancient literature that may have a literary relationship to Rev 11, like the Coptic Apocalypse of Elijah. In these cases, the two witnesses and the history of their identification are mentioned when researchers try to relate aspects of the ancient literature to the wider historical and literary contexts of that literature. ${ }^{7}$

${ }^{6}$ For remarks on the history of the interpretation of the witnesses that appear in a discussion concerning biblical figures, see, for instance, James Claire VanderKam, "1 Enoch, Enochic Motifs, and Enoch in Early Christian Literature," in Jewish Apocalyptic Heritage in Early Christianity, ed. James C. VanderKam and William Adler, Compendia Rerum Iudaicarum ad Novum Testamentum, Sec. 3, Jewish Traditions in Early Christian Literature, 4 (Assen, Netherlands: Van Gorcum; Minneapolis: Fortress Press, 1996), 89, 91-100; and Joel Arthur Weaver, Theodoret of Cyrus on Romans 11:26: Recovering an Early Christian Elijah Redivivus Tradition, American University Studies, Ser. 7, Theology and Religion, 249 (New York: Peter Lang, 2007), 119-132, 140, 142, 149-150. For such remarks that appear in a discussion concerning the antichrist concept, see, for example, Wilhelm Bousset, The Antichrist Legend: A Chapter in Christian and Jewish Folklore, trans. Augustus Henry Keane (London: Hutchinson, 1896; reprint, American Academy of Religion, Texts and Translations Series, 24, Atlanta, GA: Scholars Press, 1999), 27-28, 58, 73-74, 81-82, 104, 203-210, 225-226, 289n12; and Richard Kenneth Emmerson, Antichrist in the Middle Ages: A Study of Medieval Apocalypticism, Art, and Literature (Seattle: University of Washington Press, 1981), 7, 39, 41, 46-47, 69, 77-78, $95-99,118,154-155,209,215,217-218,220,237$. For such remarks that occur in a discussion about influences on the thinking of Jesus and his first followers, see Klaus Berger, Die Auferstehung des Propheten und die Erhöhung des Menschensohnes: Traditionsgeschichtliche Untersuchungen zur Deutung des Geschickes Jesu in frühchristlichen Texten, Studien zur Umwelt des Neuen Testaments 13 (Göttingen: Vandenhoeck \& Ruprecht, 1976), 9-149 passim, 237-425 passim; and James Douglas Grant Dunn, Christology in the Making: A New Testament Inquiry into the Origins of the Doctrine of the Incarnation (Philadelphia: Westminster Press, 1980), 92-95, 303n137.

${ }^{7}$ See, for example, Klaus Berger, Die griechische Daniel-Diegese: Eine altkirchliche Apokalypse: Text, Übersetzung und Kommentar, Studia Post-Biblica 27 (Leiden: E. J. Brill, 1976), 39, 145, 148; and Orval Stewart Wintermute, "Apocalypse of 


\section{Works Closest to the Present Study}

Having outlined the kinds of works that stand furthest from the present study, I turn to twelve particular works that stand closest to it, but that still do not exhibit all of its key features. Various works that lie between these two sets of literature, however, are not ignored. Those works are listed in the footnotes.

What makes these twelve works very similar to the present study is that they involve a wide assortment of literature concerning the witnesses and present reasons for some of the identifications that they spotlight. Because of this similarity, they can adequately illustrate how the present study differs from other works that deal with the history of the interpretation of the two witnesses. Consequently, they merit a more detailed examination than what has already been offered here for the mass of other works.

Accordingly, what follows are some brief remarks concerning how each of these works has handled the history of the interpretation of the witnesses. Specifically, my statements for each work center on four elements: the kind of literature involved in the author's interaction with this history, the arrangement of the author's comments on this history, the nature of those comments, and the author's purpose for dealing with this history. The order of my remarks on each work, however, does not necessarily follow the order of this listing.

Two of the twelve works cover Revelation as a whole. The rest though have Rev

Elijah (First to Fourth Century A.D.): A New Translation and Introduction," in Apocalyptic Literature and Testaments, ed. James H. Charlesworth, vol. 1 of The Old Testament Pseudepigrapha (Garden City, NY: Doubleday, 1983), 721, 725, 747, note "m.". 
11:3-13 with its motif of the two witnesses as a major concern.

Two Works Related to Revelation as a Whole

Two of the twelve works that stand closest to the present study involve the interpretation of Revelation as a whole. ${ }^{8}$ The earlier of these works is Edward Bishop Elliott's commentary on Revelation. This commentary contains an appendix that outlines the history of the interpretation of Revelation. ${ }^{9}$ The other work is Le Roy Edwin Froom's

\footnotetext{
${ }^{8}$ Relative to the present study, several works stand between the two works being described in this section and the mass of literature outlined earlier. In some cases, the references to the history of the interpretation of Revelation are concentrated in a particular portion of the work; only in those cases are particular pages given, namely, the pages for the key section. The works in question are as follows: Ernest-Bernard Allo, Saint Jean: L'Apocalypse, 3rd ed., Études bibliques (Paris: Librarie Lecoffre-J. Gabalda et Cie., 1933), ccxxxv-cclxxiv; Astérios Argyriou, Les exégèses grecques de l'Apocalypse à l'époque turque (1453-1821): Esquisse d'une histoire des courants idéologiques au sein du peuple grec asservi, Epistemonikai pragmateiai, Seira philologike kai theologike, 15 (Thessalonica, Greece: Hetaireia Makedonikon Spoudon, 1982); Wilhelm Bousset, Die Offenbarung Johannis, 6th ed., Kritisch-exegetischer Kommentar über das Neue Testament 16 (Göttingen: Vandenhoeck und Ruprecht, 1906), 49-119, accessed July 3, 2015, Google Books; Alfred Jenour, Rationale Apocalypticum: Or, A Systematic Exposition of the Apocalypse; with Historical Proofs and Illustrations. . . 2 vols. (London: Thomas Hatchard, 1852), 2:399-492, accessed July 3, 2015, Internet Archive American Libraries Collection; Peder Madsen, Johannes' Aabenbaring, indledet og fortolket, 2nd ed. (Copenhagen: G. E. C. Gad, 1896), 172-251, accessed July 3, 2015, EBSCOhost American Theological Library Association (ATLA) Historical Monographs Collection, Series 2; Gerhard Maier, Die Johannesoffenbarung und die Kirche, Wissenschaftliche Untersuchungen zum Neuen Testament 25 (Tübingen: J. C. B. Mohr [Paul Siebeck], 1981); Tom McIver, The End of the World: An Annotated Bibliography (Jefferson, NC: McFarland, 1999); and Arthur William Wainwright, Mysterious Apocalypse: Interpreting the Book of Revelation (Nashville, TN: Abingdon Press, 1993). For Maier, cf. Maier, Kapitel 1-11, 454-455.

${ }^{9}$ Edward Bishop Elliott, Hora Apocalyptica; or, A Commentary on the Apocalypse, Critical and Historical. . . . 5th ed., 4 vols. (London: Seeley, Jackson, and Halliday, 1862), 4:275-563, accessed July 3, 2015, Internet Archive American Libraries Collection. As might be expected with a work as vast as this, Elliott does refer in other places to the history of the interpretation of the witnesses. See, for example, ibid., 2:207208, 210-212, 420n2; 4:577-579, 594n3, 631n1, 641, 682, 685-686.
} 
multivolume work dealing with the history of the interpretation of Daniel and

Revelation. $^{10}$

\section{Edward Bishop Elliott}

Elliott (1793-1875) covers numerous expositors of the book of Revelation, from the earliest known comments to 1862 , when the fifth edition of his commentary was published. He deals with this material chronologically. For each expositor, Elliott offers biographical and bibliographical remarks, although the length of those remarks varies. ${ }^{11}$ With many of the commentators, Elliott briefly describes what an interpreter has said concerning the major features of Revelation, especially Rev 4-22. ${ }^{12}$ For other commentators, however, Elliott's treatment is more concise. ${ }^{13}$ In any case, references to identifications of the witnesses appear throughout this account of the history of the interpretation of Revelation, although such references are not evident for every named commentator. Elliott rarely adds any of the reasons for those identifications.

${ }^{10}$ Le Roy Edwin Froom, The Prophetic Faith of Our Fathers: The Historical Development of Prophetic Interpretation, 4 vols. (Washington, DC: Review and Herald, 1946-1954), accessed July 3, 2015, General Conference of Seventh-day Adventists, Office of Archives, Statistics, and Research Online Archives, Books Section

${ }^{11}$ For example, on the shorter side are Elliott's remarks related to Hippolytus of Rome (ca. 170-ca. 236) or those related to Jacques-Bénigne Bossuet (1627-1704). Elliott, Horce Apocalyptica, 4:283, 501. Meanwhile, on the longer side, there is the example of his remarks related to Jerome of Stridon (Eusebius Sophronius Hieronymus, ca. 347-419/420) or those related to Andrew of Caesarea (late sixth century-early seventh century). Ibid., 4:316n4, 353-356.

${ }^{12}$ For instance, consider his examination of Heinrich Bullinger's (1504-1575) work at ibid., 4:443-450. 551.

${ }^{13}$ For example, consider his treatment of five British commentators at ibid., 4:543- 
Incidentally, in the transitions between blocks of material, Elliott occasionally mentions broad historical circumstances that he finds pertinent to the expositors and the expositions that he is examining.

Elliott's presentation is not strictly for the sake of an accurate historical record. He concludes his literature review by pointing out three significant approaches to interpreting Revelation that are apparent from his survey, the preterist (or contemporaryhistorical), the futurist (or eschatological), and the historicist. ${ }^{14}$ After the survey, Elliott seeks to examine and refute the former two approaches and thereby show his support for the last one. ${ }^{15}$ Therefore, Elliott's purpose for his survey also encompasses preparing the way for the criticism that follows it.

\section{Le Roy Edwin Froom}

With the assistance of many people, Froom (1890-1974) has produced a work that is quite vast in its coverage of commentators who have dealt with Daniel and Revelation, although expositional literature on these books is not the only material that he discusses. ${ }^{16}$

${ }^{14}$ Ibid., 4:562-563.

${ }^{15}$ Ibid., 4:564-664; cf. 4:563.

${ }^{16}$ Although the interpretation of the books of Daniel and Revelation are Froom's central concern, he also pays attention to the interpretation of other eschatological biblical passages, such as the so-called Synoptic Apocalypse (Matt 24, Mark 13, Luke 21) and 2 Thess 2. Froom, Prophetic Faith, 1:30. Moreover, he occasionally considers non-expositional literature, artwork, and historical situations where eschatological fervor was expressed outside the arena of literature. See, for example, ibid., 1:574-579, 586594. Notice also his remarks on this practice at ibid., 2:14; cf. 1:24-25; $2: 15$. As for his study ultimately being a collaborative work, see ibid., $1: 13 ; 2: 15$. Compare in this regard the acknowledgements at the end of each volume. Ibid., 1:911-914; 2:797-799; 3:753$755 ; 4: 1205-1207$. Froom also comments on the collecting of materials for his project at ibid., 1:11-12. 
The substance of the work moves chronologically, from the early fourth century BCE "on to approximately the middle of the nineteenth century [CE]." ${ }^{17}$ When dealing with expositors, Froom offers biographical and bibliographical information. ${ }^{18}$ Moreover, at points where he deems it appropriate, he speaks about broader historical circumstances that he finds relevant to the expositors and the expositions that he is examining. ${ }^{19}$ Of course, Froom's handling of his material also involves describing commentators' opinions concerning significant features in Daniel and Revelation. ${ }^{20}$ When those descriptions

${ }^{17}$ Ibid., 1:31; cf. 1:9, 17-26, 30-31, 887-909; 2:12-13, 783-796; 3:9-15, 738-751; 4:9-12. Curiously, in the lead up to the phrase just quoted, Froom actually says that his review of the interpretation of prophetic biblical texts begins with "the time of Daniel," which would mean the sixth century BCE for Froom. This is odd, on the one hand, because, if one considers "the prophetic source material," that is, the biblical texts themselves, as part of the survey, then Froom actually goes back to Abraham as described in Genesis. Ibid., 1:30-31, 109, 112-113. A look at the content of Daniel does not come until Froom has briefly looked at several prophetic texts elsewhere in the OT. Ibid., 1:113-125. It is odd, on the other hand, because, if one omits the biblical texts from the survey, then Froom begins with a Jewish tradition involving the book of Daniel and Alexander the Great, that is, a situation that supposedly happened in the early fourth century BCE, after the presumed "time of Daniel." Ibid., 1:167-169. It should be noted that Froom does include an epilogue of two chapters that covers material from after the middle of the nineteenth century. Ibid., 4:1175-1204. The investigation presented in this epilogue is less comprehensive than what Froom does elsewhere. Therefore, this section can be considered separate from the substance of Froom's work.

${ }^{18}$ Froom's biographical and bibliographical remarks about Arethas of Caesarea (ca. 860-ca. 940) and John Tillinghast (1604-1655) illustrate brief instances. Ibid., 1:572; 2:570. Such remarks about Hippolytus of Rome and about John Napier (1550-1617) exemplify lengthier cases. Ibid., 1:268-271; 2:455-457. There are, however, still lengthier instances, such as for Joachim of Fiore (ca. 1135-1202) or Jan Hus (ca. 13691415). Ibid., 1:683-690; 2:107-116. On the matter of biographical and bibliographical remarks, compare ibid., 1:10; 3:15-16.

${ }^{19}$ For example, see ibid., 1:373-382; 2:9-12, 102-107, 119-123.

${ }^{20}$ Presumably, what opinions Froom chose to mention for a particular interpreter were governed in part by the work or works that he had at his disposal. Nonetheless, he expresses that he is particularly interested in how past interpreters have treated "five 
touch upon the topic of the two witnesses, Froom may observe an expositor's

identification of the witnesses, but rarely does he include any of the reasons for it. Froom also provides several charts to summarize the positions that commentators have taken on elements in Daniel, Revelation, and other biblical passages. ${ }^{21}$ These charts state succinctly the identification of the witnesses for several interpreters. ${ }^{22}$ Although much of this information also appears in Froom's descriptions of expositors' opinions, some of it is not mentioned anywhere else.

One of Froom's aims in his expansive survey is to contribute to the historical understanding of how people have interpreted biblical prophecies. ${ }^{23}$ In particular, he desires to uncover a history that he believes has played a key role in the history of Christianity and has relevance to modern interpreters. ${ }^{24}$ Froom also conceives of his work as fulfilling an apologetic purpose for Christianity. ${ }^{25}$ Still, he intends some measure of objectivity in his presentation. ${ }^{26}$ Another of Froom's aims may be to encourage an

principal topics that [he finds] . . to be the key factors [that] . . . have conditioned the prophetic outlook of the Christian church through the centuries." Ibid., 1:30. The five topics are "(1) the outline prophecies, (2) the resurrection, (3) the millennium, (4) the Antichrist, and (5) the visible kingdom of God." Ibid. He defines "outline prophecies" at ibid., 1:32; cf. 1:29; 2:13n1. A definition for "millennium" appears at ibid., 1:33-34. With all this, compare ibid., 2:13-15; 3:15-16.

${ }^{21}$ Notice his remarks on this practice at ibid., $1: 13 ; 2: 14-15 ; 3: 16$.

${ }^{22}$ See ibid., 1:458, 896; 2:530, 787; 3:253, 745; 4:395, 399, 849, 1119.

${ }^{23}$ Ibid., 1:9; cf. 1:30.

${ }^{24}$ Ibid., 1:9-11; cf. 1:17-26.

${ }^{25}$ Ibid., 1:12.

${ }^{26}$ Ibid., 1:13. 
interest in the study of biblical prophecy, the substance of which when understood, so

Froom believes, meets the human desire for security in an unstable world. ${ }^{27}$

\section{Ten Works with Rev 11:3-13 as a Major Concern}

Ten of the twelve works that stand closest to the present study have Rev 11:3-13 with its motif of the two witnesses as a major concern. ${ }^{28}$ All of these were composed

${ }^{27}$ Ibid., 1:15-16; cf. 1:17, 26.

${ }^{28}$ Relative to the present study, numerous works stand between the ten works described in this section and the mass of literature outlined earlier. The many works in question are as follows: Allo, Saint Jean: L'Apocalypse, 149-150, 157-161, 220; David Edward Aune, Revelation 6-16, Word Biblical Commentary 52B (Nashville, TN: Thomas Nelson, 1998), 588-593, 599-602, 610, 612-613, 617, 631; Beale, Book of Revelation, 572-573, 575, 590, 601; Otto Böcher, Die Johannesapokalypse, 4th ed., Erträge der Forschung 41 (Darmstadt, Germany: Wissenschaftliche Buchgesellschaft, 1998), 63-68; Charles Brütsch, La Clarté de l'Apocalypse, 5th ed. (Geneva: Éditions Labor et Fides; Paris: Librairie protestante, 1966), 183-184, 196; Charles Brütsch, Die Offenbarung Jesu Christi. Johannes-Apokalypse, 3 vols., Zürcher Bibelkommentare (Zürich: Zwingli Verlag, 1970), 2:17-20, 36-37; Robert Edward Dalrymple, Revelation and the Two witnesses: The Implications for Understanding John's Depiction of the People of God and His Hortatory Intent (Eugene, OR: Resource Publications, 2011), 34-37; Wilhelm Martin Leberecht De Wette, Kurze Erklärung der Offenbarung Johannis, ed. Wilhelm Moeller, 3rd ed., Kurzgefasstes exegetisches Handbuch zum Neuen Testament 3, pt. 2 (Leipzig: S. Hirzel, 1862), 131-132, 150, accessed July 3, 2015, Google Books; Isabelle Donegani, "À cause de la parole de Dieu et du témoignage de Jésus . . .": Le témoignage selon l'Apocalypse de Jean: Son enracinement extra-biblique et biblique. Sa force comme parole de sens, Études bibliques, n.s., 36 (Paris: Librarie Lecoffre-J. Gabalda et Cie., 1997), 396, 420n88, 441-444, 445n166; Kamal Fahim Awad Hanna, La passione di Cristo nell'Apocalisse, Tesi Gregoriana, Serie Teologia, 77 (Rome: Editrice Pontificia Università Gregoriana, 2001), 274-276; Augustyn Jankowski, Apokalipsa świetego Jana: Wstep —Przekład z oryginatu—Komentarz, Katolicki Uniwersytet Lubelski, Pismo Święte Nowego Testamentu, 12 (Poznań, Poland: Pallottinum, 1959), 304-306; Hendrik Rijk van de Kamp, Israël in Openbaring: Een onderzoek naar de plaats van het joodse volk in het toekomstbeeld van de Openbaring aan Johannes (Kampen, Netherlands: Uitgeversmaatschappij J. H. Kok, 1990), 23, 37, 49, 89-90, 181-191, 201, 203; Kamp, Openbaring, 261-264; Craig Richard Koester, Revelation: A New Translation with Introduction and Commentary, Anchor Yale Bible 38A (New Haven: Yale University Press, 2014), 439-440, 497; Kovacs, Rowland, and Callow, Revelation, 122-123, 126130, 259-260; Robert Benjamin Kübel, Pastoralbriefe, Hebräerbrief und Offenbarung 
after 1900, but most appeared after 1989. Nearly all of them are originally theses or dissertations. Only a few have been formally published. All are discussed below in order of their appearance.

Johannis, ed. Eduard Riggenbach and Otto Zöckler, 2nd ed., Kurzgefaßter Kommentar zu den heiligen Schriften Alten und Neuen Testamentes sowie zu den Apokryphen, B. Neues Testament, 5 (Munich: C. H. Beck'sche Verlagsbuchhandlung, Oskar Beck, 1898), 163-164, 245-246; Hubert Le Bourdellès, "L'épisode des Deux Témoins dans l'Apocalypse (11, 1-19)," Graphè, no. 1 (1992): 70-73, 77n18; Madsen, Johannes' Aabenbaring, 503-510; Eugene John Mayhew, "Revelation 11, The Two Witnesses of," Dictionary of Premillennial Theology, ed. Mal Couch (Grand Rapids, MI: Kregel Publications, 1996), 364-366; Peter Morant, Das Kommen des Herrn: Eine Erklärung der Offenbarung des Johannes (Zurich: Thomas-Verlag; Paderborn, Germany: Verlag Ferdinand Schöningh, 1969), 203-207; Munck, Petrus und Paulus, 7-16; Johnson Puthussery, Days of Man and God's Day: An Exegetico-Theological Study of íné in the Book of Revelation, Tesi Gregoriana, Serie Teologia, 82 (Rome: Editrice Pontificia Università Gregoriana, 2002), 193-195; Daniel Ranisavljević, "Le témoignage de Jésus et celui des fidèles dans l'Apocalypse de Jean" (ThD thesis, Institut Catholique de Paris, 1991), main text: 150-160, 162-163, 167-168, 173-174; "Notes bibliographiques": 40n43, 40n52, 41n53, 41n55, 43n75; Akira Satake, Die Offenbarung des Johannes, ed. Thomas Witulski, Kritisch-exegetischer Kommentar über das Neue Testament 16 (Göttingen: Vandenhoeck \& Ruprecht, 2008), 263-265; Moses Stuart, A Commentary on the Apocalypse, 2 vols. (Andover, MA: Allen, Morrill and Wardwell; New York: M. H. Newman, 1845), 1:122, 215, 275, 466, 472; 2:147-148, 219-227, 231, note "*", accessed July 3, 2015, Internet Archive American Libraries Collection; Felise Tavo, Woman, Mother and Bride: An Exegetical Investigation into the "Ecclesial" Notions of the Apocalypse, Biblical Tools and Studies 3 (Leuven: Peeters, 2007), 8-9, 21-22, 197-199; Todd, Six Discourses, 162, note "x," 179, note "f," 182, note "h," 191-211, 236, note "n," 277, 279; Jarl Henning Ulrichsen, "Das eschatologische Zeitschema der Offenbarung des Johannes" (PhD dissertation, University of Trondheim, 1988), 179-183; Revere Franklin Weidner, Annotations on the Revelation of St. John the Divine, Lutheran Commentary 12 (New York: Christian Literature, 1898), xliii, lviii-lix, 143, 145-148, 242, accessed July 3, 2015, Google Books; Thomas Witulski, Apk 11 und der Bar Kokhba-Aufstand: Eine zeitgeschichtliche Interpretation, Wissenschaftliche Untersuchungen zum Neuen Testament, 2nd ser., 337 (Tübingen: Mohr Siebeck, 2012), 7-17; and Daniel Kei Kwong Wong, "The Two Witnesses in Revelation 11," BSac 154, no. 615 (July-September 1997): 344-347, 349-353, accessed November 11, 2015, EBSCOhost ATLA Religion Database with ATLASerials. Incidentally, two of the works just mentioned, those by Allo and Madsen, were also cited earlier for having mentioned in a significant way the history of the interpretation of the witnesses in their surveys of Revelation as a whole. In addition, the argumentation of Munck and of Todd concerning the witnesses is featured in chapter 3 of the present study. 


\section{Donatus Haugg}

The earliest of the ten works is a monograph by Donatus Haugg (1900-1943). ${ }^{29}$ Its third section contains two chapters that pertain to the history of the interpretation of the two witnesses. One chapter discusses the identity question in particular, ${ }^{30}$ while the other deals with the interpretation of the whole of Rev 11:1-13. ${ }^{31}$ Haugg presents the identifications that several ancient, medieval, and modern authors (up to 1936) have proposed, but his emphasis is on the older expositors from the days of the early church on through the medieval period. Only occasionally does he add any of the reasons for the identifications noted. Haugg deals with this history primarily as an aid to exposing the flaws of many previous explanations of the witnesses and the inadequacies of certain

${ }^{29}$ Haugg, Die zwei Zeugen. Haugg's argumentation about the two witnesses is featured in chapter 3 of the present study.

${ }^{30}$ Ibid., 89-114. This chapter consists of five sections with an introduction. The first three sections deal respectively with the three individuals who have often been identified as one of the witnesses, namely, Elijah, Enoch, and Moses. The fourth section covers numerous other options and the idea that John the Apostle, the presumed author of the Gospel of John and of Revelation, will come in the end-time as a third witness, working alongside Enoch and Elijah. The final section represents Haugg's attempt at establishing an identification. Accordingly, the comments relative to the history of interpretation are concentrated in the first four sections. More specifically, the remarks are evident when Haugg discusses Christian opinions as opposed to Jewish ones. I say this because Haugg also discusses here Jewish traditions related to various OT individuals who have been identified with the witnesses.

${ }^{31}$ Ibid., 120-137. This chapter consists of three sections with an introduction and finally a statement of the results for the whole study. Remarks relative to the history of the interpretation of the two witnesses appear in the first two sections. The first concerns the contemporary-historical (die zeitgeschichtliche) explanation of Rev 11:1-13, while the second has to do with two forms of the church-historical (die kirchengeschichtliche) or world-historical (weltgeschichtliche) explanation of the passage. The final section though deals with the eschatological (die endgeschichtliche) interpretation and represents the one that Haugg chooses. Accordingly, this section lacks the kind of references to the opinions of others that are found in the earlier two sections. 
approaches to interpreting the whole of Rev 11:1-13. Thus, he helps to establish his own interpretation of Rev 11:1-13.

\section{Walter E. Staten}

The second of the more specialized works is that of Walter E. Staten (19281988). ${ }^{32}$ While he briefly mentions identifications supposedly based upon the "spiritual approach" to interpretation, ${ }^{33}$ Staten's study centers on "the major futuristic views concerning the identity of the two witnesses." ${ }^{34}$ He divides these views into symbolic and literal categories; then, he subdivides those categories into particular identifications. ${ }^{35}$ Staten's manner of presentation is to state reasons and objections for each identification. ${ }^{36}$ Presumably, the information presented is drawn from others. ${ }^{37}$ Yet, the sources for the reasons and objections are not always evident. Nor is it always clear who advocates the identifications that Staten discusses. In fact, Staten expressly names only a few commentators as advocates of an identification. Those works that Staten does cite are all originally in English and come mostly from the first half of the twentieth century.

\footnotetext{
${ }^{32}$ Walter E. Staten, "Identity of the Two Witnesses in Revelation" (MTh thesis, Dallas Theological Seminary, 1955).

${ }^{33}$ Ibid., 4.

${ }^{34}$ Ibid., 2; cf. 4, 44, 46.

${ }^{35}$ Ibid., 1-2, 4, 20, 44-46. Staten could be said to deal with seven particular identifications; however, four of them concern only a known individual (Elijah, Enoch, John the Apostle, or Moses) being identified as one of the witnesses.

${ }^{36}$ Ibid., 2-43.

${ }^{37}$ Cf. ibid., 2-3.
} 
The same situation is evident when one looks at his entire bibliography for additional pieces that may be relevant to the study of Rev $11{ }^{38}$ Staten is aware, however, of the predominant early Christian opinion about the witnesses as Enoch and Elijah, and, by quoting a modern author on the matter, he points out some of the ancient literature that seem to espouse this view. ${ }^{39}$

By highlighting particular identifications and then offering reasons and objections to them, Staten's study reveals part of the history of the interpretation of the witnesses. His purpose, however, is not purely or even primarily historical in nature. Staten presents this material in order to evaluate it and thereby accept some of it, while rejecting other parts of it. ${ }^{40}$

\section{John Miesel}

The third study with a focus on Rev 11:3-13 is by John Miesel (born 1930). ${ }^{41}$ Most of Miesel's statements about the history of the interpretation of the witnesses appear in the section entitled, "Various Interpretations." ${ }^{42}$ Miesel divides the interpretations into three categories: the two witnesses are two individuals, they represent several individuals, and "they represent non-personal subjects." 43 For these

${ }^{38}$ See ibid., 52-56.

${ }^{39}$ Ibid., 29-30; cf. 48.

${ }^{40}$ Ibid., 2-3, 44-51.

${ }^{41}$ John Miesel, "The Two Witnesses: Revelation 11:3" (BD thesis, Grace Theological Seminary, 1957).

${ }^{42}$ Ibid., 16-22.

${ }^{43}$ Ibid., 2; cf. 17, 20, 22, 24, 27, 33. Miesel mentions twelve (his count) or 
interpretations, he cites several expositors, most of whom had their works originally published in the last half of the nineteenth century or in the first half of the twentieth century. Most of the cited pieces were originally written in English. He is also aware that the predominant early Christian opinion about the witnesses is that they are Enoch and Elijah. ${ }^{44}$ For about a third of the interpretations, Miesel goes beyond a simple description of an identification and notes some of the reasons for its acceptance.

Miesel's purpose in touching upon the history of the interpretation of the two witnesses is not strictly or even primarily historical nature. The presentation of different views on the witnesses forms the basis for an evaluation that results in most of the proposed identifications being set aside and one view gaining Miesel's support. ${ }^{45}$

\section{Thomas W. Mackay}

The fourth item that has a focus on Rev 11:3-13 is an essay by Thomas W. Mackay (born 1940). ${ }^{46}$ Mackay refers to the history of interpretation of the witnesses primarily to illustrate and highlight an apparent shift in the exegetical methodology of ancient Christian expositors. ${ }^{47}$ Nevertheless, he may also wish to influence the modern

thirteen (my count) specific identifications. Ibid., 16-22; cf. 24.

${ }^{44}$ Ibid., 18; cf. 32, 34-35.

${ }^{45}$ Ibid., 2, 23-40.

${ }^{46}$ Thomas W. Mackay, "Early Christian Millenarianist Interpretation of the Two Witnesses in John's Apocalypse 11:3-13," in By Study and Also by Faith: Essays in Honor of Hugh W. Nibley on the Occasion of His Eightieth Birthday, 27 March 1990, ed. John M. Lundquist and Stephen D. Ricks (Salt Lake City, UT: Deseret Book Co.; Provo, UT: Foundation for Ancient Research \& Mormon Studies, 1990), 1:222-331.

${ }^{47}$ Ibid., 1:222-223, 249-255, 309-310. 
reading of Revelation through his historical investigation. His final paragraph suggests a direct connection between the opinions espoused by so-called literal interpreters and John, the apparent author of Revelation. ${ }^{48}$

After an introduction, Mackay takes several pages to relay information that serves as a background to his focus on interpretations of the witnesses. A few references to identifications of the witnesses appear in this early part of the essay. ${ }^{49}$ Most of Mackay's statements involving the history of the interpretation of the witnesses, however, appear later in the essay. ${ }^{50}$ Besides his own remarks on what commentators have said about the witnesses, Mackay also provides a large catalog of quotations from expositions and other documents. ${ }^{51}$ The authors whom he names, both in his own remarks and in the catalog, are mostly "from the second century to the beginning of the Carolingian Renaissance [in the late eighth century]"; ${ }^{52}$ however, he does note a few individuals that are later than this period. ${ }^{53}$ Throughout his essay, Mackay presents mostly basic descriptions of proposed identities, without any of the reasons behind them. The quotations, however, do sometimes contain argumentation.

${ }^{48}$ Ibid., $1: 310$.

${ }^{49}$ See ibid., 1:225-245 passim.

${ }^{50}$ See ibid., 1:253-255.

${ }^{51}$ For this listing, see ibid., 1:255-308. Mackay also discusses briefly illustrations of the witnesses in manuscripts of the commentary on Revelation by Beatus of Liébana (ca. 730-ca. 800). Ibid., 1:308-309.

${ }^{52}$ Ibid., 1:223.

${ }^{53}$ Ibid., 1:253-255. 


\section{Paolo Byong-Seob Min}

The fifth notable work is the dissertation by Paolo Byong-Seob Min. ${ }^{54}$ It is an extensive study that includes a literature review of interpretations of Rev 11:1-13. This review comprises two chapters of the interpretive, exegetical section of the dissertation. The first chapter deals specifically with proposed identities of the two witnesses. ${ }^{55}$ The second involves the interpretation of the whole of Rev 11:1-13. ${ }^{56}$ Such an arrangement for the literature survey recalls that found in Haugg's work. Both chapters refer to several specific commentators from the early days of Christianity to the modern era (up to 1991).

In the first chapter, Min occasionally describes reasons behind particular identifications. His coverage of commentators' reasoning, however, varies. He describes the argumentation more extensively for identifications with individuals than he does for symbolic identifications. ${ }^{57}$ As for the second chapter, it too shows some of the reasoning

\footnotetext{
${ }^{54}$ Paolo Byong-Seob Min, "I due testimoni di Apocalisse 11,1-13: Storiainterpretazione - teologia" (ThD dissertation, Pontificia Universitas Gregoriana, 1991).

${ }^{55}$ Ibid., 112-152. This chapter consists of three sections with an introduction and a conclusion. The first section covers identifications of the witnesses with actual people from the OT era, particularly Elijah and Enoch, Elijah and Moses, and Elijah and Jeremiah. The second section covers identifications with actual people from the NT era, either specific individuals named in the NT or two future individuals yet to be identified. The third section covers symbolic identifications.

${ }^{56}$ Ibid., 153-197. This chapter contains five sections with an introduction and a conclusion. Each section deals with a way of interpreting Rev 11:1-13. The five ways are the symbolic, the eschatological, that related to the history of the church and the world, the contemporary-historical, and the tradition-historical.

${ }^{57}$ The most extensive descriptions of argumentation are for the proposals of Johannes Munck (1904-1965) and Haugg. Both identify the witnesses with individuals. Ibid., 133-135, 140-141. Compare my handling of their argumentation in the third chapter of the present study. The coverage of their reasoning contrasts, for instance, with the coverage of the reasoning of Ernest-Bernard Allo (1873-1945) and Kenneth Albert
} 
for particular identifications, but the coverage tends to be slight, like that for the symbolic identifications in the first chapter.

Min deals with the history of the interpretation of the witnesses primarily to evaluate past expositions and thereby determine which ideas are correct. ${ }^{58}$ Thus, he prepares the way for "a new in-depth exegetical examination" that leads to accepting one of the past proposals or forming a new one. ${ }^{59}$

\section{Rodney Lawrence Petersen}

The sixth specialized item is a study by Rodney Lawrence Petersen (born 1949). ${ }^{60}$ His study flows chronologically and centers upon the history of the interpretation of the two witnesses, particularly among Protestant thinkers in the sixteenth and seventeenth centuries. In spite of the focus upon a particular period, Petersen deals with many interpreters from the earlier days of Christianity and even some from the eighteenth and nineteenth centuries. Not all of the individuals that he discusses, however, have attempted to interpret Rev 11 formally. ${ }^{61}$ Petersen's statements about specific

Strand (1927-1997), both of whom argue for symbolic identifications of the witnesses. Ibid., 147-148, 151.

${ }^{58}$ Ibid., 112, 117, 123, 128-132, 135-136, 139, 141-142, 152, 166, 174-175, 182, 188-191, 196-197.

${ }^{59}$ Ibid., 198. The translation of Min is mine.

${ }^{60}$ Rodney Lawrence Petersen, Preaching in the Last Days: The Theme of 'Two Witnesses' in the Sixteenth and Seventeenth Centuries (New York: Oxford University Press, 1993).

${ }^{61}$ Incidentally, Petersen also briefly mentions medieval artistic representations of the two witnesses at ibid., 43-44. 
identifications are usually found amidst remarks about the lives of interpreters and about the historical, social, intellectual, and literary contexts in which they expressed their thoughts on the witnesses. Not surprisingly, the extent of the accompanying remarks varies. ${ }^{62}$ The statements themselves often involve a basic description of a view, without any of the reasons behind it.

Petersen's work is the study of a particular apocalyptic theme, the two witnesses of Rev 11, over time. His purpose in general is to advance the understanding of a part of human history. More specifically, he wants to expose and clarify the ways in which the figure of the two witnesses has been interpreted and how the interpretations have influenced thinking about other matters, such as ethics and politics, especially among Protestants in the sixteenth and seventeenth centuries. ${ }^{63}$

\section{Kevin John O'Brien}

The seventh work that has Rev 11:3-13 as a central concern is the dissertation by Kevin John O'Brien (born 1953). ${ }^{64}$ O'Brien's remarks involving the history of the

\footnotetext{
${ }^{62}$ The most substantial of these remarks are for those interpreters whom Petersen sees as most significant for illustrating the evolving understanding and usage of the motif of the two witnesses, at least for the periods and people in which he is interested. Therefore, for example, Petersen presents a great amount of related information for the interpretation of the witnesses by certain Protestants of the sixteenth and seventeenth centuries. As a specific instance, consider Petersen's discussion of Heinrich Bullinger at ibid., 120-137.

${ }^{63}$ Ibid., ix-x, 3-5, 232-247, 259-261.

${ }^{64}$ Kevin John O'Brien, "An Examination of the Meaning, the Purpose, and the Function of the Interlude within the Sevenfold Series of the Book of Revelation" ( $\mathrm{PhD}$ dissertation, Union Theological Seminary [in Richmond, VA], 1996), accessed July 3 , 2015, ProQuest Dissertations and Theses Global.
} 
interpretation of the witnesses are primarily in a section of his fourth chapter, entitled "The Meaning, Purpose, and Function of Rev 10:11-11:13." ${ }^{65}$ He divides several opinions into two groups, the witnesses as two individuals and the witnesses as a symbol, and arranges his discussion of the identity issue along these lines.

For many of the identifications that O'Brien notices, he offers some degree of argumentation and often connects that argumentation with various expositors. O'Brien links all the identifications to at least one interpreter, even for those identifications for which he does not give any argumentation. It is evident, however, that some of the cited commentators do not actually agree with the arguments or the identifications with which they are associated. They are being cited simply as secondary sources. In any case, a large majority of the authors cited for identifications and/or argumentation had their works published in the twentieth century, and most wrote originally in English. Incidentally, of those few works not coming from the twentieth century most are ancient pieces of literature.

O'Brien's specific purpose for presenting some of the history of the interpretation of the two witnesses is unclear. Other notable works that have detailed some of the argumentation for identifications have indicated in some way that they seek to evaluate matters. Such indications of intent are missing from O'Brien's work, and in fact, one finds little that counters the literal and symbolic opinions that O'Brien eventually rejects. What can be said though is that O'Brien offers this literature review in his attempt to

${ }^{65}$ Ibid., 190-282, for the whole chapter; 219-238, for the relevant part. 
identify the two witnesses and so help "to determine the proper meaning of Rev 11:113. $" 66$

\section{William Douglas Adamson}

The eighth notable work is the master's thesis by William Douglas Adamson. ${ }^{67}$ Content related to the history of the interpretation of the two witnesses is mostly concentrated in Adamson's third chapter, where he focuses on the identity question. ${ }^{68} \mathrm{~A}$ portion of his fourth chapter, however, also intersects this history. There Adamson looks at arguments concerning the specific timing of the witnesses' activity. ${ }^{69} \mathrm{He}$ cites numerous works on Revelation in these two parts of his study. A great majority of this literature was published in the twentieth century and was originally written in English. Adamson is aware, however, of early interpretations of the two witnesses and refers explicitly to at least one ancient expositor. ${ }^{70}$

In his third chapter, Adamson distinguishes two categories of identifications, the

${ }^{66}$ Ibid., 219; cf. 1-5.

${ }^{67}$ William Douglas Adamson, "The Identity and Ministry of the Two Witnesses of Revelation 11:1-13" (MTh thesis, Detroit Baptist Theological Seminary, 2002), accessed July 3, 2015, Theological Research Exchange Network (TREN).

${ }^{68}$ Ibid., 48-89.

${ }^{69} \mathrm{By}$ this point in his study, Adamson has determined that "the two witnesses are two actual people who [will] minister during the [future seven-year period of] Tribulation." Ibid., 90, cf. 2-3, 14, 72-73, 88-89, 103. Accordingly, the issue of timing is narrowed down to determining in which part of the Tribulation period the witnesses will be active. Arguments for seeing their activity in the first half of the period are presented at ibid., 91-92. Arguments for the choice of the second half are presented at ibid., 92-93. Adamson's evaluation and decision on the issue appear at ibid., 93-96.

${ }^{70}$ Ibid., 72, 73n254, 81, 83. 
symbolic and the literal, and divides his investigation accordingly. For the symbolic views, he discusses a symbolic approach to understanding the witnesses and Rev 11 and not so much the specific identifications proposed in accordance with that approach. ${ }^{71}$ This explains why he mentions specific identifications only a few times during this discussion. At the end of the discussion, however, Adamson does list several specific symbolic identifications for the two witnesses and associates most of them with particular commentators. $^{72}$

After arguing for a literal approach to understanding the two witnesses, ${ }^{73}$

Adamson examines arguments for and against six individuals who have been identified as being one of the witnesses and arguments for and against the idea that the witnesses are two unknown future prophets. ${ }^{74}$ In introducing most of these options, Adamson refers to one or more expositors. ${ }^{75}$ As for the argumentation, he often cites expositors for the points that he presents. It is evident, however, that some of the expositors that he mentions do not actually advocate the identifications or the arguments with which he has

${ }^{71}$ Ibid., 48-70. In the discussion, Adamson briefly lists arguments supporting a symbolic approach to interpreting Rev 11:1-13. Then he evaluates these arguments, judging them all inadequate. Finally, he offers four points that strike at the approach generally. Thereby, he rejects a symbolic approach.

${ }^{72}$ Ibid., 69n239; cf. 2n4, 17n64, 69n238, 69n240, 70n241.

${ }^{73}$ Ibid., 71-72.

${ }^{74}$ Ibid., 73-88. The six individuals are Elijah, Moses, Enoch, Jeremiah, John the Baptist, and John the Apostle. All are conceived as coming back to earth in the future. With a single argument, however, Adamson rejects identifications that involve matching details from the lives of historical individuals with specifics in the description of the witnesses; for example, some have argued that the witnesses are Peter and Paul, while others have said that they are the sons of Zebedee, James and John. See ibid., 72-73.

${ }^{75}$ Ibid., 73n254, 83, 84n304, 84n305, 86n311; cf. 2n5, 48n154. 
associated them. They are simply being cited as secondary sources.

As may be evident from what has been said already, Adamson's purpose for dealing with the history of the interpretation of the two witnesses is one of evaluation. ${ }^{76}$ He conducts this examination with the intent of drawing a conclusion about the identity of the witnesses. ${ }^{77}$ His handling then of the history of the interpretation of the witnesses is not strictly historical in nature and seems similar to what has been seen in the works of Staten and Miesel.

\section{Seth Turner}

The ninth notable work to look at in this chapter is the doctoral thesis by Seth Turner. ${ }^{78}$ His work offers "primarily a descriptive survey of the exposition of Revelation $11: 1-13, "$ covering interpretations from the early days of Christianity until the start of the twenty-first century. ${ }^{79}$ Turner does not limit his study to serious, formal attempts at exegesis, but also includes other interpretations, such as in narratives and devotional

${ }^{76}$ Cf. ibid., 2-3, 18, 48, 71, 102-103.

${ }^{77}$ Ibid., 2-3, 88-89, 102-103.

${ }^{78}$ Seth Turner, "Revelation 11:1-13: History of Interpretation" (DPhil thesis, University of Oxford, 2005), accessed July 7, 2015, Oxford University Research Archive (ORA).

${ }^{79}$ Ibid., 5; cf. 10, 304. Turner models his study upon the works of Pierre Prigent (for his format) and Sherman W. Gray (for the way in which he handles materials composed before 1700). and ibid., 6; cf. 304; Sherman W. Gray, The Least of My Brothers: Matthew 25:31-46: A History of Interpretation, Society of Biblical Literature Dissertation Series 114 (Atlanta, GA: Scholars Press, 1989); Pierre Prigent, Apocalypse 12: Histoire de l'exégèse, Beiträge zur Geschichte der biblischen Exegese 2 (Tübingen: J. C. B. Mohr [Paul Siebeck], 1959). 
pieces. ${ }^{80}$ Turner aims to be comprehensive only for material composed before 1000 CE. ${ }^{81}$ His handling of later material, however, is still quite extensive. Turner's survey moves generally in a chronological fashion. ${ }^{82}$

Turner devotes the majority of his remarks to describing various expositions of Rev 11:1-13. Accordingly, he says "relatively little" about the major contexts in which the expositions may be found, specifically, the historical and social contexts of the interpreters. ${ }^{83}$ The same can be said about the extent of his remarks on the interpreters' approaches to understanding the whole of Revelation. ${ }^{84}$ As for the actual descriptions, Turner lists expositors' conclusions concerning key features in Rev 11:1-13, such as the two witnesses, and sometimes offers a glimpse into the reasoning behind those conclusions. In order to economize his space, Turner does not present a detailed description for every interpreter cited in his study. At times, he links commentators together, letting one description speak for the similarities among them and letting additional remarks pinpoint the significant differences. Not surprisingly, the degree to which this happens increases as the study progresses, since the amount of available material on Rev 11:1-13 steadily grows as one nears the twenty-first century.

Turner intends his thesis to fill a gap in the study of the history of the

${ }^{80}$ For examples of these other interpretations, see Turner, "Revelation 11:1-13," 137-143 passim, 289-298 passim. Also, note Turner's remarks at ibid., 6-7.

${ }^{81}$ Ibid., 8-9; cf. 11-89.

${ }^{82}$ Ibid., 8; cf. 8-10.

${ }^{83}$ Ibid., 304; cf. 5 - 6.

${ }^{84}$ Ibid., 5 . 
interpretation of Revelation, conceiving that study as a separate, primarily historical endeavor, as opposed to being part of a larger effort, such as interpreting Rev 11:1-13. ${ }^{85}$ It is in keeping with this intention that his work contains little in the way of evaluation of expositions. ${ }^{86}$ Turner also hopes that his contribution "will serve as a valuable resource for other scholars of the history of interpretation of the Apocalypse," particularly "as a starting point" in "the important task of contextualizing interpretations," a task that for the most part Turner does not attempt. ${ }^{87}$

\title{
Christine Joy Tan
}

Christine Joy Tan's doctoral dissertation is the final notable work examined here. ${ }^{88}$ This is actually her second work on the two witnesses. ${ }^{89}$ In the dissertation, Tan

\author{
${ }^{85}$ Ibid., 1-5. \\ ${ }^{86}$ The only apparent evaluation seems to be in the conclusion. See ibid., 306-310. \\ ${ }^{87}$ Ibid., 5; cf. 304. \\ ${ }^{88}$ Tan, "Defense." Tan's argumentation about the two witnesses is featured in
} chapter 3 of the present study. It should be noted that large portions of Tan's dissertation have been published with some slight editing in a series of four articles. See Christine Joy Tan, "Preterist Views on the Two Witnesses in Revelation 11," BSac 171, no. 681 (January-March 2014): 72-95; Christine Joy Tan, "A Critique of Preterist Views of the Two Witnesses in Revelation 11," BSac 171, no. 682 (April-June 2014): 210-225; Christine Joy Tan, "A Critique of Idealist and Historicist Views of the Two Witnesses in Revelation 11," BSac 171, no. 683 (July-September 2014): 328-351; and Christine Joy Tan, "A Futurist View of the Two Witnesses in Revelation 11," BSac 171, no. 684 (October-December 2014): 452-471. Throughout the present study, I refer to Tan's dissertation instead of the articles for two reasons. The dissertation is the fuller study, and it is more convenient for myself and hopefully for my readers to refer to one document rather than to four.

${ }^{89}$ Christine Joy Tan, "The Identity of the Two Witnesses in Revelation 11" (ThM thesis, Dallas Theological Seminary, 2002), accessed June 12, 2015, Theological Research Exchange Network (TREN). A vast majority of the material found in the thesis is actually incorporated in the dissertation. 
(born 1975) intends "to defend the futurist [or eschatological] view of the two witnesses in Rev 11:3-13" as the one most likely to be correct, over against proposals from idealists and historicists (i.e., church-historical/world-historical interpreters) and most especially from preterists (i.e., contemporary-historical interpreters).$^{90}$ With respect to "the futurist view of the two witnesses," Tan means a conceptualization of the witnesses drawn from the common threads that bind several eschatological identifications together. ${ }^{91}$ In the end, she believes that she has proven her case for this understanding of the witnesses. ${ }^{92}$ Therefore, Tan's interactions with the history of the interpretation of the witnesses are meant to aid her apologetic project.

Tan touches upon the history of the interpretation of the witnesses at various points throughout her dissertation. In chapters 2 and 3, she examines particular preterist, idealist, and historicist views of the two witnesses and thereby exposes their weaknesses. ${ }^{93}$ Chapter 4 forms the defense proper of the chief eschatological opinion

${ }^{90}$ Tan, "Defense," 4; cf. 1-3, 7, 227.

${ }^{91}$ Specifically, Tan perceives that there is "a predominant futurist view of the two witnesses in Rev 11:3-13" that conceives of them as "two literal persons [appearing] in the yet-future Tribulation period, who [will] perform judgmental miracles and speak prophetically." Ibid., 4n13; cf. 5, 7, 119-120, 129, 169-170, 186, 186n306, 225-226, 228229.

${ }^{92}$ See ibid., 227-229.

${ }^{93}$ Chapter 2 focuses on three preterist views of the witnesses. Ibid., 10-78. It should be kept in mind, however, that for the first view Tan has actually grouped together four relatively distinct identifications under the commonality that they have the witnesses representing Christians in Jerusalem in 67-70 CE. In contrast, the second and third views each consist of two very similar, if not identical, proposals. Chapter 3 focuses on an idealist view and a historicist view. Ibid., 79-114. 
about the witnesses. ${ }^{94}$ The history of the interpretation of the witnesses plays a role in three parts of this chapter. It is first evident when Tan presents an eschatological reading of Rev 11:1-13 that is congruent with the chief futurist view of the witnesses. ${ }^{95}$ Later in chapter 4, Tan briefly reviews identifications for the witnesses in early Christian literature. ${ }^{96}$ After this, Tan looks at two debates among those who maintain the prevailing futurist view. One debate concerns the specific identity of the two individuals who will act as the witnesses. ${ }^{97}$ The second debate concerns the specific timing of the witnesses' activity. ${ }^{98}$ Tan's final interaction with the history of the interpretation of the witnesses is in the appendix to her dissertation. In order to illustrate that their identity is a contentious matter among interpreters of Revelation, she offers a multi-page table listing a wide variety of identifications. ${ }^{99}$

The nature of Tan's remarks relative to the history of the interpretation of the

${ }^{94}$ Ibid., 115-226.

${ }^{95}$ Ibid., 119-125. Tan also looks briefly at how Rev 11:3-13, so interpreted, meshes with a broader eschatological reading of Revelation. Ibid., 125-129.

${ }^{96}$ Ibid., 170-186.

${ }^{97}$ For the introduction to this debate on specific identifications, see ibid., 186-188. The body of the presentation concerns the witnesses as Enoch and Elijah, as Moses and Elijah, and as two currently unknown future prophets. See ibid., 188-214. The conclusion is at ibid., 214. With all this, compare ibid., 6-7, 119-121, 186, 225-226, 229.

${ }^{98}$ For the introduction to this debate on specific timing, see ibid., 214. Arguments for the witnesses operating during the first half of the seven-year Tribulation period are at ibid., 215-219. Arguments for the second half as the time of their activity are at ibid., 219-224. A conclusion appears at ibid., 224. With all this, compare ibid., 6-7, 123, 186, 225-226, 229.

${ }^{99}$ Concerning the purpose for the appendix, see ibid., 2. For the actual appendix, see ibid., 230-236. 
witnesses varies. First, her summaries of interpreters' proposals about the witnesses range from the simple to the complex. In some instances, she simply states an interpreter's identification of the witnesses. ${ }^{100}$ In other cases, she goes so far as to summarize an interpretation of the whole of Rev 11:1-13, mingling together material from different authors to form her description. ${ }^{101}$ There are also remarks that lie between these extremes. Second, differences exist in the amount of argumentation that Tan mentions for proposed identifications of the witnesses. Sometimes references to argumentation are absent. ${ }^{102}$ On the other hand, when she looks at the debate concerning whom specifically the witnesses will be, Tan presents several arguments for and against certain individuals being the two witnesses. ${ }^{103}$ There are also remarks that lie between these two extremes. Finally, Tan presents varying amounts of biographical and bibliographical information about the interpreters that she cites. ${ }^{104}$ In most instances, she

${ }^{100}$ See, for example, some of the summaries in the review of early Christian identifications at ibid., 170-186 passim. Also, note, for instance, most of the views expressed in the appendix at ibid., 230-236 passim. It should be noted, however, that several identifications mentioned in the appendix are discussed in detail elsewhere in the dissertation.

${ }^{101}$ See, for example, Tan's presentation of a preterist view on the witnesses at ibid., 12-17. Also, note, for instance, her presentation of a historicist view at ibid., 97104.

${ }^{102}$ See, for example, Tan's brief description of four different historicist views at ibid., 97n105. Also, note, for instance, a great majority of the views expressed in the appendix at ibid., 230-236 passim. It should be noted again, however, that several identifications mentioned in the appendix are discussed in detail elsewhere in the dissertation.

${ }^{103}$ Ibid., 188-214.

${ }^{104}$ For a few arguments, Tan does not name any sources. Moreover, she occasionally uses some interpreters as secondary sources. In those instances, they are not actually advocates of the positions with which they are associated. Otherwise, a great 
mentions only what is necessary to locate bibliographically an author's opinion on the witnesses or about related matters. ${ }^{105}$ Yet, in other cases, she says something about the life of the interpreter and about the works that speak about the witnesses. ${ }^{106}$

As already intimated, Tan interacts with the early history of the interpretation of the two witnesses. Specifically, she references several Christian authors from the beginning of the second century to the middle of the eighth century. ${ }^{107}$ As for her interactions with the later history of the interpretation of the witnesses, Tan deals with over one hundred modern works. Much of this literature was first published in the twentieth and the twenty-first centuries. Moreover, a significant portion of it was originally written in English.

\section{Summary and Conclusions}

Many modern researchers speak in a variety of ways and to different degrees about how people have identified the two witnesses of Rev 11:3-13. Twelve works stand out with respect to the state of the question of the identity of the witnesses. Like the

majority of the arguments that Tan mentions in her dissertation are linked to primary sources. As for Tan's references simply to identifications of the witnesses, all appear to be linked to one or more advocates.

${ }^{105}$ See, for example, Tan, "Defense," 82nn18-19, 97n105, 120n21, 120n23, $121 \mathrm{n} 24,123 \mathrm{n} 32$. Also, note, for instance, all the views expressed in the appendix at ibid., 230-236. It should be noted again, however, that several identifications mentioned in the appendix are discussed in detail elsewhere in the dissertation.

${ }^{106}$ See, for instance, ibid., 12n8, 18n34, 20n46, 98n106. Also consider how Tan handles nearly all of the commentators that she cites in the review of early Christian identifications. Ibid., 170-186 passim.

${ }^{107}$ Ibid., 170-186. For Tan's review of identifications for the witnesses in early Christian literature, she has been particularly aided by Mackay's essay, mentioned above. She has also drawn assistance from Petersen's work and is familiar with Haugg's work. 
present study, these twelve works involve a broad assortment of literature touching on the witnesses and present arguments for certain identifications. Because of this similarity to the present study, these works can adequately illustrate how the present study differs from the entire mass of literature that also touches upon the history of the interpretation of the two witnesses.

That all twelve works deal with a wide range of literature involving the witnesses means that they all exhibit one of four features that I consider critical for a more in-depth look at the state of the question concerning the exegetical identity of the witnesses. Of course, the breadth of that range varies among the works, with differences being apparent in terms of quantity and in terms of the time and language of publication.

That all twelve works mention at least some of the reasons for particular identifications points to the possibility that one or more of them exhibit another of the four critical features. Indeed, some of them could arguably be seen as containing exhaustive presentations of the arguments supporting certain identifications. ${ }^{108}$

As for the other two critical features, none of the twelve works explicitly focuses its remarks about the witnesses upon exegetical identifications, and none of them has a description of the broad issues of interpretation raised by commentators' arguments. Therefore, none of the twelve contains all four critical features.

In contrast, firstly, the present investigation expressly deals only with identifications that are arguably based on exegesis. Secondly, the present work contains an extensive description of the arguments underlying seven significant attempts to

${ }^{108}$ At the very least, the studies by Adamson and Tan; also perhaps those by Staten, Min, and O'Brien. 
identify the two witnesses, while also making reference to some of the arguments put forth in two other significant investigations. Thirdly, the choice to focus on these nine studies comes from having looked at a broad assortment of works published from the eighteenth century until the start of the twenty-first century and written in several languages. Finally, marking a different path from the twelve works, the present study describes and discusses the broad issues of interpretation that can be deduced from the various arguments. Thus, the present study contains all four critical features that I see as necessary for a more in-depth look at the state of the question of the identity of the witnesses, and thereby this study stands apart from the twelve notable works and, by extension, the mass of other works dealing with the history of the interpretation of the witnesses. 


\section{CHAPTER 3}

\section{THE TWO WITNESSES AS TWO INDIVIDUALS}

\section{Introduction}

\section{Content of the Chapter}

In the debate since 1700 over the exegetical identity of the two witnesses, one popular position is to identify them as two actual persons. Inasmuch as this view agrees with an initial or surface reading of Rev 11:3-13, it can be termed the literal view. The literal position, however, is one that embraces a variety of more specific identifications. This greater specificity comes from determining who the two people are and when they are supposed to appear, so that they can experience the things narrated in Rev 11.

This chapter presents a sample of the arguments that interpreters have offered on behalf of particular literal identifications. A detailed look at the argumentation of Donatus Haugg forms the foundation of the presentation. From there, the reasoning in four other significant expositions is briefly examined. ${ }^{1}$ Broad issues of interpretation in identifying the witnesses can be deduced from the arguments. At appropriate points in the chapter, these issues are determined. All this material together reveals an important piece of the debate since 1700 over the identity of the witnesses.

${ }^{1}$ Significant expositions are those that offer some measure of argumentation for an identification as opposed to just stating a view without any noticeable support. 
First, however, I must speak briefly about literal identifications through time. This history represents an important context for the state of this category of identifications after 1699. Moreover, it has influenced the choice of which expositions to feature in this chapter.

\section{Literal Identifications through Time}

Literal identifications can be divided roughly into two groups. The majority of interpreters who take the literal position also contend that the witnesses appear on the scene of history after the days in which John, the presumed author of Revelation, is writing. In other words, these expositors often regard the witnesses as two literal people appearing after the first century CE. Other interpreters that adhere to the literal position, however, locate the witnesses among John's contemporaries, among the people of the first century.

The following diachronic survey is similarly divided. First, there is a review of the futuristic perspective through time. Then, there is a review of the contemporary perspective through time. Each review focuses on trends in the thinking on the two witnesses, particularly in regards to literal identifications. The offered remarks depend primarily on the works of others about the history of the interpretation of the two witnesses, and this is reflected in the footnotes. Partly because of this circumstance, moreover, the remarks concern mainly interpreters from Western Europe or interpreters influenced by the biblical scholarship of Western Europe (e.g., those in the United 
States). ${ }^{2}$ In fact, such interpreters have authored nearly all the literature that undergirds the present study.

\section{The Futuristic View through Time}

The earliest extant identification of the two witnesses takes them as two people appearing after John. Hippolytus of Rome (ca. 170-ca. 236) mentions Rev 11 explicitly and identifies the witnesses as Enoch and Elijah appearing at the end of the world. ${ }^{3}$

${ }^{2}$ With respect to the history of the interpretation of the two witnesses, of Rev 11, or even of Revelation as a whole, less material exists, at least in Western European languages, that investigates interpreters living in areas influenced by Eastern Christian traditions.

${ }^{3}$ Hippolytus of Rome De anticristo 43 (trans. Enrico Norelli, Biblioteca patristica, 114-115); cf. 44-47 (114-121), and 64 (148-151). Note also Hippolytus of Rome Commentarium in Danielem 4.35, 50 (trans. Georg Nathanael Bonwetsch and Marcel Richard, GCS, 2nd ed., n.s., 7:276-279, 310-315). On Hippolytus's interpretation of the two witnesses among other opinions about them, see Enrico Norelli, "Commento," in L'Anticristo: De Antichristo, by Hippolytus, trans. and ed. Enrico Norelli, Biblioteca patristica (Florence: Nardini Editore - Centro Internazionale del Libro, 1987), 221-222, 227-231; Mackay, "Early Christian Millenarianist Interpretation," 1:229, 253, 261-265; Petersen, Preaching, 10-11; and Turner, "Revelation 11:1-13," 25-29, 30n67, 32, 40-41, 46-48, 65-66.

I disagree with the impression that Petersen gives when he groups Tertullian (Quintus Septimius Florens Tertullianus, ca. 160-ca. 225) with Hippolytus as providing "the clearest [and presumably earliest] datable references" to the witnesses. Petersen, Preaching, 10; cf. 10-11. Tertullian comes closest to speaking of the two witnesses in Tertullian De anima 50.5 (trans. Edwin A. Quain, FC, 10:290). He says simply that, although Enoch and Elijah are preserved from dying now, they will die in the future, so "that they may extinguish Anti-Christ with their blood." This statement does not refer explicitly to Rev 11, unlike the remarks of Hippolytus. Incidentally, Tertullian speaks elsewhere in De anima of the return of Elijah. See Tertullian De anima 35.5-6 (trans. Quain, FC, 10:264). He hints of that return also at Tertullian Adversus Marcionem 4.22.3 (trans. René Braun, SC, 456:276-279). Curiously, a little further from that passage, Tertullian connects Elijah and Moses, not Elijah and Enoch, to the two olive trees and the two branches of Zech 4:3, 11-12, 14. See Tertullian Adversus Marcionem 4.22.12-13 (trans. Braun, SC, 456:286-289). This is significant for the present discussion because Rev 11:4 likely alludes to those verses in Zech 4.

Mackay unfortunately also joins Tertullian to Hippolytus when speaking of early 
These remarks, however, are not part of a larger attempt to interpret Revelation. In contrast, Victorinus of Poetovio (died ca. 304) discusses Rev 11 and identifies the two witnesses among his comments on select portions of Revelation. Also unlike Hippolytus, Victorinus chooses to see Elijah and Jeremiah in the figures. Yet, this identification receives little reaffirmation. ${ }^{4}$ The Enoch-Elijah view, however, is often repeated by expositors' up through the Middle Ages (ca. 476-ca. 1453) and into the start of the modern era, being advanced alone or in combination with another identification, usually a

Christians identifying the witnesses with Enoch and Elijah. Mackay, "Early Christian Millenarianist Interpretation," 1:253; cf. 1:256-257. Mackay also includes Irenaeus (ca. 130-ca. 202) among these early church writers. Ibid., 1:253; cf. 1:257-261. This is problematic though. For one thing, Mackay's quotations from Irenaeus do not refer to Rev 11 or even the return of Enoch and Elijah. Ibid., 1:257-261. Even Mackay recognizes this situation. Ibid., 1:313n23; cf. 1:229, 257. Moreover, even among seemingly promising remarks that Mackay does not quote, no explicit connection to Rev 11 exists. In fact, even an implied connection to Rev 11 seems unlikely. I have in mind here some statements that are further on from the ones that Mackay quotes. In the latter part of Irenaeus Adversus hareses 5.5.1 (trans. Adelin Rousseau et al., SC, 153:60-67), Irenaeus suggests that the elders, the disciples of the original apostles, taught that Enoch and Elijah had been translated to Paradise and were to remain there until the end of this age, awaiting transformation to an incorruptible state. There is no mention here of a future ministry on earth, a conflict with the beast, or any other item that might imply a connection to Rev 11. Compare my thoughts here on Tertullian and Irenaeus with the sentiments expressed at Turner, "Revelation 11:1-13," 28, 38-39.

${ }^{4}$ Victorinus of Poetovio Commentarii in Apocalypsin 11.3 (trans. Martine Dulaey, SC, 423:94-97); cf. 7 (423:84-85), 11.4-5 (423:96-99), 12.4, 6 (423:102-105), 14.1 (423:110-111), 20.1 (423:114-115). On Victorinus' interpretation of the witnesses among other opinions about them, see Mackay, "Early Christian Millenarianist Interpretation," 1:232, 234, 242-245, 253, 266-269, 304-306, 309; Martine Dulaey, Victorin de Poetovio, premier exégète latin, 2 vols., Collection des Études Augustiniennes, Série Antiquité, 139-140 (Paris: Institut d'Études Augustiniennes, 1993), 1:192-194, 196, 208-209, 273, 314, 321; 2:174n11 (cf. 1:340); 2:183n127 (cf. 1:353); Martine Dulaey, "Commentaire," in Sur l'Apocalypse, suivi du Fragment chronologique et de La construction du monde, by Victorinus of Poetovio, trans. and ed. Martine Dulaey, Sources Chrétiennes 423 (Paris: Les Éditions du Cerf, 1997), 181, 188-189, 193; Petersen, Preaching, 11-12, 29, 51n92; and Turner, "Revelation 11:1-13," 46-51, 77, 80-83, 88. 
symbolic one. Thus, the Enoch-Elijah view prevails for centuries among interpreters of Rev 11, even though the influential writings of Tyconius (died ca. 390) and Joachim of Fiore (ca. 1135-1202) give prominence to symbolic identifications. ${ }^{5}$ In fact, the idea of Enoch and Elijah returning in the end-time has a life of its own, without any formal connection to Rev 11. Throughout this stage of history, documents exhibiting this phenomenon exist alongside texts that refer explicitly to Rev $11 .^{6}$

${ }^{5}$ Turner, "Revelation 11:1-13," 12-144 passim, 163n101, 304-305. Cf. Petersen, Preaching, 12-58 passim, 259. Such a trend in the identifications of the witnesses is more obvious in Turner's work. This is partly because Turner clearly states an interpreter's identification in a few cases where Petersen does not. Moreover, Turner mentions that an expositor's understanding includes the Enoch-Elijah view in two instances where Petersen does not. Notwithstanding this situation and the occasional disagreement between Petersen and Turner over an interpreter's opinion, Petersen's work can complement Turner's survey of the literature for this early period. Mackay, however, gives a different impression of the prevailing trend. He suggests widespread abandonment of the Enoch-Elijah view among interpreters who write after Tyconius introduces a solely symbolic interpretation of the two witnesses. Mackay, "Early Christian Millenarianist Interpretation," 1:222-223, 233-237, 245-246, 249-255, 308-310. Yet, Petersen and Turner show that several commentators still espoused the Enoch-Elijah view after Tyconius and on up through the Middle Ages. Admittedly, this view is frequently not the only understanding that an expositor has of the witnesses. Nonetheless, Mackay's reconstruction of the history of the interpretation of the witnesses appears inaccurate.

${ }^{6}$ Petersen, Preaching, 9-10, 25n107, 30, 43-44, 57n191; and Turner, "Revelation 11:1-13," 13-44 passim, 88, 140-144. Cf. Mackay, "Early Christian Millenarianist Interpretation," 1:253, 255-308 passim, 308-310. For early examples, see Apocalypse of Peter (Ethiopic) 2 (trans. Caspar Detlef Gustav Müller, NTApo, ed. Wilhelm Schneemelcher and Robert McLachlan Wilson, Rev. ed., 2:626); Apocalypse of Elijah (Coptic) 4.7-20; 5.32-35 (trans. Orval Stewart Wintermute, OTP, ed. James H. Charlesworth, 1:747-748, 752-753); and Gospel of Nicodemus 25 (trans. Felix Scheidweiler, NTApo, ed. Wilhelm Schneemelcher and Robert McLachlan Wilson, Rev. ed., 1:525). One might also include here as an early example Tertullian De anima 50.5 (trans. Quain, FC, 10:290), noted in a previous footnote. For later examples, see Ludus de Antichristo lines 329-401 (trans. John Wright, Mediaeval Sources in Translation, 7:9397); Cursor Mundi (Southern Version) lines 1467-1480, 18383-18402, 22361-22374 (ed. Sarah M. Horrall et al., The Southern Version of "Cursor Mundi", 1:80; 4:38-39; 5:66); and Jour du Jugement lines 151-183, 456-537, 1044-1201, 1410-1435 (trans. Richard 
With the arrival of the Reformation, the Enoch-Elijah view wanes in popularity among interpreters, becoming for a time solely a Catholic opinion. ${ }^{7}$ In this period before 1699, Protestants and even some Catholics abandon the Enoch-Elijah view of the witnesses, at least as it usually is conceived. ${ }^{8}$ In fact, many of these interpreters depart

Kenneth Emmerson and David F. Hult, Early European Drama Translation Series, 2:8, 21-23, 41-45, 52-53).

${ }^{7}$ For a picture of the interpretations of the witnesses during this period that includes the Reformation and some years after (1517-1700), see Turner, "Revelation 11:1-13," 145-231 passim, 305. Cf. Petersen, Preaching, 59-229 passim, 259. On just the Catholic interpretations of the two witnesses during this time, see Turner, "Revelation 11:1-13," 163-166, 179-181, 224-227, 229, 231. Cf. Petersen, Preaching, 222n94.

${ }^{8}$ The usual conception, of course, was that Enoch and Elijah would personally appear in the end-time. I add a qualification above, because some early Protestant thinkers seem to have transformed the expectation of Enoch and Elijah returning. Thus, they apparently did not completely dismiss the Enoch-Elijah view. The first type of transformation admittedly appears at the edges of the stream of serious interpretations of Revelation. It is clearly seen with Melchior Hoffman (ca. 1495-1543/1544). In his commentary on Dan 12, he evidently speaks of expecting Enoch and Elijah to appear. Yet, this may not be an expectation of them personally. In any case, years later, Hoffman accepts that he is the expected Elijah. Others are identified as Enoch. In this transformation, therefore, the witnesses become two individuals in the spirit of Enoch and Elijah, not them personally. On these matters, see Klaus Deppermann, Melchior Hoffman: Social Unrest and Apocalyptic Visions in the Age of Reformation, ed. Benjamin Drewery, trans. Malcolm Wren (Edinburgh: T. \& T. Clark, 1987), 72-75, 78, 113-118, 160-161, 218-219, 254-257, 266-267, 293-294, 334-335, 337-338, 353-355, 380, 389; Petersen, Preaching, 88-97; cf. 155, 234; and Turner, "Revelation 11:1-13," 147-148. Another kind of transformation might exist with François Lambert (ca. 1486-1530). According to Turner, Lambert favors a non-literal understanding of the two witnesses as Enoch and Elijah. Ibid., 149-150, 228. These two figures function "as types of true witnesses"; there will in fact be "as many witnesses as the Church of God will need to establish the truth" in the days of the final antichrist. Ibid., 149. Petersen, however, does not indicate such a transformation in Lambert. Petersen, Preaching, 144n120, 151-153. Another type of transformation might exist with Heinrich Bullinger (1504-1575). According to Petersen, Bullinger refers to Enoch and Elijah (and John the Revelator, sometimes seen as the end-time companion of Enoch and Elijah) to describe spiritual qualities of preachers in the end-time. This seems, however, to be only loosely connected to Rev 11 and Bullinger's interpretation of it. Ibid., 129-137; cf. 120-124, 127-128. Petersen also intimates that something similar may be seen in the writings of Sebastian 
from any futuristic, literal identification, opting instead for a solely symbolic

identification. ${ }^{9}$ After 1699, the Enoch-Elijah view still has a few proponents, not all of

whom are Catholic. ${ }^{10}$ Yet, the majority of expositors in this era direct their attentions

Meyer (ca. 1465-ca. 1545) and Matthias Flacius Illyricus (1520-1575). Ibid., 104, 144n121; cf. 153-155. Turner though is silent concerning such a transformation in Bullinger, Meyer, and Flacius. Turner, "Revelation 11:1-13," 153-156, 158, 229. Turner, however, makes evident a transformation similar to that of Bullinger, but more directly linked to Rev 11. According to him, Leo Jud (1482-1542) identifies the witnesses as "God's ministers in the spirit of Enoch and Elijah." Ibid., 160. Petersen does not discuss Jud. Not surprisingly, some interpreters from before the Reformation exhibit transformations like these. Petersen, Preaching, 31, 38, 41-43, 54n146; cf. 32, 36; and Turner, "Revelation 11:1-13," 98-101, 110-111, 129-130, 137-140. Also present in this earlier time is the phenomenon of seeing certain individuals as Enoch and Elijah returned, but it apparently exists only outside the stream of formal theological literature. Petersen, Preaching, 39, 43; and Turner, "Revelation 11:1-13," 138, 141-142.

${ }^{9}$ Turner, "Revelation 11:1-13," 145-229 passim, 305. Cf. Petersen, Preaching, 97-229 passim, 259.

${ }^{10} \mathrm{Here}$ are some examples, all of which are expositions that include argumentation. For more references like these, see Appendix A. Also, cf. Turner, "Revelation 11:1-13," 232-303 passim. From the eighteenth century (the noted work being originally published in 1771 and its author having lived 1722-1797), one can cite Charles Walmesley [Pastorini, pseud.], The General History of the Christian Church, from Her Birth to Her Final Triumphant State in Heaven: Chiefly Deduced from the Apocalypse of St. John, the Apostle and Evangelist, 5th American ed. (New York: D. \& J. Sadlier, 1851), 212-222, 242-244, 247-248, 270-276, accessed July 7, 2015, Google Books. From the nineteenth century (Seiss's work being originally published perhaps over 1869-1880), one can cite Carl Stern [died 1875], Commentar über die Offenbarung des Apostel Johannes (Schaffhausen, Switzerland: Hurter'schen Buchhandlung, 1854), 278-297, accessed July 8, 2015, Google Books; and Joseph Augustus Seiss [1823-1904], The Apocalypse. A Series of Special Lectures on the Revelation of Jesus Christ. With Revised Text, 11th ed., 3 vols. (New York: Charles C. Cook, 1913), 2:149-246, accessed July 9, 2015, Internet Archive American Libraries Collection. Finally, from the twentieth century, one can cite John Quincy Adams [born 1891], His Apocalypse-Wherein Is Set Forth a Detailed Panorama of The Prophetic Wonders of Daniel and Revelation. . . 2nd ed. (Dallas, TX: Prophetical Society of Dallas, 1925), 195-211; Ambrogio Arrighini [born 1887], L'Anticristo nelle sacre Scritture, nella storia, nella letteratura, 2nd ed., Le metamorfosi del sacro 15 (Genoa: I Dioscuri, 1988), 251-258; and Henry Madison Morris [1918-2006], The Revelation Record: A Scientific and Devotional Commentary on the 
elsewhere. Many adopt an alternative futuristic, literal identification, seeing other individuals in the witnesses. Taking the witnesses to be Moses and Elijah is one popular choice. According to this view, Moses, not Enoch, joins Elijah to return to earth for a new ministry that follows the narrative of Rev $11 .^{11}$ Another popular choice dispenses

Book of Revelation (Wheaton, IL: Tyndale House; San Diego, CA: Creation-Life Publishers, 1983), 189-205.

${ }^{11}$ Victorinus acknowledged the possibility of Moses being the companion of Elijah for the identity of the two witnesses. Yet, as intimated above, he rejects Moses as one of the witnesses and proposes Jeremiah. The earliest espousal therefore of the Moses-Elijah view may be from Hilary of Potiers (ca. 315-367/368) in the earliest extant Latin commentary on the Gospel of Matthew. Hilary of Poitiers In Matthaum 20.10 (trans. Jean Doignon, SC, 258:112-115); cf. 17.2-4 (258:62-67). Cf. Turner, "Revelation 11:1-13," 48, 163n101. Haugg though seems to have missed this in Hilary's commentary. See Haugg, Die zwei Zeugen, 105. After Hilary and on through the Middle Ages, there do not appear to be any advocates for this view. Yet, for some medieval thinkers, Moses and Elijah do have a non-literal significance for their identifications of the witnesses. This situation is apparent in the work of Joachim of Fiore, in a commentary on Jeremiah influenced by Joachim's thought, and possibly in the work of Gerhoh of Reichersberg (1093-1169). See Turner, "Revelation 11:1-13," 100-101, 105-111. Cf. Petersen, Preaching, 32-36. Later, in the modern era, a clear espousal of the Moses-Elijah view comes from Jean de Gagny (died 1549). Jean de Gagny, Breuissima et facillima in omnes D. Pauli epistolas scholia, vltra priores editiones, ex antiquissimis Gracorum authoribus, abundè locupletata. Itidem in septem Canonicas epistolas \& D. Ioannis Apocalypsim, breuissima scholia recens edita (Paris: Jean de Roigny, 1563), ff. 270r273r, accessed August 17, 2015, Google Books. Cf. Turner, "Revelation 11:1-13," 163. Then, near the end of the sixteenth century, a posthumously published study by Juan de Maldonado (ca. 1533-1583) shows this identification of the witnesses. Juan de Maldonado, Commentarii in quattuor Evangelistas. Nunc primùm in lucem editi, \& in duos Tomos divisi, Quorum prior eos, qui in Matthaum, \& Marcum; posterior eos, qui in Lucam, \& Ioannem, complectitur, 2 vols. (Pont-à-Mousson, France: Stephani Mecator, 1596-1597; reprint, Commentarii in quatuor Evangelistas. Quos pristinae integritati restitutos, novisque studiis auctos, ed. Johann Michael Raich, 2 vols., Illustrium theologorum in Sacras Novi Testamenti Scripturas commentarii 1-2, Mainz: Franz Kirchheim, 1874), 1:342-343, 346-348. Consider the English translation of these comments at Juan de Maldonado, A Commentary on the Holy Gospels, trans. and ed. George John Davie, 2nd ed., 2 vols., Catholic Standard Library (London: John Hodges, 1888), 2:65-66, 72-75, accessed August 17, 2015, Internet Archive Canadian Libraries Collection. Cf. Haugg, Die zwei Zeugen, 97, 105. Later still, an anonymous work, at least influenced by Franciscus Mercurius van Helmont (1614-1698/1699), argues for the 
with recognizable individuals who have an identifiable past. In this case, the witnesses

are two individuals unknown to the apocalypticist and his readers until they begin to fulfill the narrative of Rev $11 .^{12}$

Moses-Elijah view. Seder Olam sive Ordo Seculorum, historica enarratio doctrinae ([Leiden?], 1693), 159-164, accessed August 17, 2015, Bayerische StaatsBibliothek; and the translation Seder Olam: or, The Order, Series, or Succession of All the Ages, Periods, and Times of the Whole World Is Theologically, Philosophically, and Chronologically Explicated and Stated. . . trans. John Clarke (London: Sarah Howkins, 1694), 182-187, 234 accessed August 17, 2015, ProQuest Early English Books Online. Cf. Turner, "Revelation 11:1-13," 218. During this time, one also sees another instance of Moses and Elijah having a non-literal significance for the identification of the witnesses. This situation is evident in the work of Luis del Alcázar (1554-1613). See ibid., 180-181. Cf. Petersen, Preaching, 222n94. I am unaware of any exposition from the eighteenth century that argues that the witnesses are solely Moses and Elijah. Several such endeavors, however, exist for the nineteenth and twentieth centuries. Moreover, espousal of the view is present in the twenty-first century. I mention here three particular examples of defenses of this view. For a listing of other defenses, see Appendix A. Also, cf. Turner, "Revelation 11:1-13," 232-303 passim. These examples are notable in that their approach to interpreting the text, the high quality of their expositions, and the time of their composition make them appropriate foils for the endeavors of the three authors discussed briefly in this chapter after the detailed examination of Haugg. The three notable defenses of the Moses-Elijah view are William De Burgh [1801-1866], An Exposition of the Book of the Revelation, 5th ed. (Dublin: Hodges, Smith; London: Hamilton, Adams; London: Simpkin, Marshall, 1857), 188-209, 409-411, accessed July 10, 2015, Google Books; Robert Henry Charles [1855-1931], A Critical and Exegetical Commentary on the Revelation of St. John. . . . 2 vols., International Critical Commentary (New York: Charles Scribner's Sons, 1920), 1:269-292; and Adamson, "Identity and Ministry."

${ }^{12}$ The earliest example of this identification of which I am aware is an alternative interpretation of the witnesses offered by Francis Woodcock (ca. 1614-1651). Francis Woodcock, The Two Witnesses: Discovered in severall Sermons Upon the eleventh Chapter of the Revelation... (London: Luke Fawne, 1643), 91-95, accessed August 17, 2015, ProQuest Early English Books Online. Cf. Turner, "Revelation 11:1-13," 187, 217. Several years later, Richard Hayter (ca. 1611-1684) identifies the witnesses similarly, but not simply as an alternative. Richard Hayter, The Meaning of the Revelation, or, A Paraphrase With Questions on the Revelation of the Holy Apostle and Evangelist John the Divine.... (London: John Williams, 1675), 119-144, accessed August 17, 2015, ProQuest Early English Books Online. Cf. Turner, "Revelation 11:1-13," 217-218. An anonymous work does likewise, a few years after Hayter's document. A Modest Inquiry into the Meaning of the Revelations. In a Letter to All Such as Wait for the Kingdom of 


\section{The Contemporary View through Time}

Another type of literal view of the witnesses exists. Instead of relating the witnesses to individuals in John's future, some interpreters link them to individuals contemporary to John. Sure instances of such an identification, however, are not apparent until the Early Modern Age. Earlier literature does contain a few attempts at linking contemporary figures to Rev 11:3-13, but the intent is not to identify the witnesses with such figures. The authors involved merely saw similarities between the

Christ (London, 1688), 7-10, accessed August 17, 2015, ProQuest Early English Books Online. Cf. Turner, "Revelation 11:1-13," 218. This identification also seems to be espoused by Johann Wilhelm Petersen (1649-1727) at Johann Wilhelm Petersen, Der veste Grund Des In der siebenden Posaunen annoch zukünfftigen Reiches Christi . . . gründlich gezeiget Und Aus Gottes Wort bestättiget, 2 vols. (Frankfurt am Main, $1692-$ 1694), 2:108-127, accessed August 17, 2015, Google Books. Cf. Walter Nordmann, "Die Eschatologie des Ehepaares Petersen, ihre Entwicklung und Auflösung [Part 1]," Zeitschrift des Vereins für Kirchengeschichte der Provinz Sachsen und des Freistaates Anhalt 26 (1930): 96; Maier, Die Johannesoffenbarung und die Kirche, 374; and Maier, Kapitel 1-11, 455. At least one expositor, Herman Venema (1697-1787), seems to advocate solely this identification in the eighteenth century. Herman Venema, Pralectiones de methodo prophetica. . . . (Leeuwarden, Netherlands: Abraham Ferwerda, 1775), 271-273, accessed July 13, 2015, Google Books. Cf. Turner, "Revelation 11:113," 272. Johann Albrecht Bengel (1687-1752) and Johann Heinrich Jung-Stilling (17401817) might also be supporters solely of this view; however, I have doubts about Bengel being an advocate of solely this view (contrast this with Maier and Turner), while Turner suggests that Jung-Stilling is undecided between a literal and a collective understanding of the witnesses (contrast this with myself). Both are authors of more than one relevant work. Examples are Johann Albrecht Bengel, Erklärte Offenbarung Johannis oder vielmehr Jesu Christi. . . . New ed. (Stuttgart: Fr. Brodhag'sche Buchhandlung, 1834), 346-362, accessed August 17, 2015, Google Books; and Johann Heinrich Jung-Stilling, Die Siegsgeschichte der christlichen Religion in einer gemeinnützigen Erklärung der Offenbarung Johannis, in Johann Heinrich Jung's, genannt Stilling, sämmtliche Werke, New ed. (Stuttgart: J. Scheible's Buchhandlung, 1841-1842), 248-260, accessed August 17, 2015, Google Books. On Bengel, see Maier, Die Johannesoffenbarung und die Kirche, 436-437; Maier, Kapitel 1-11, 455; and Turner, "Revelation 11:1-13," 271-272. On Jung-Stilling, see ibid., 279-280. Identification of the witnesses solely with two currently unknown future individuals is better represented among commentators from the nineteenth century onward. Quality defenses of this opinion are examined below. See Appendix A for an accounting of other defenses of this identification. 
witnesses and individuals contemporary to John. ${ }^{13}$ The situation changes when one comes to the sixteenth century. Catholic Piero Caponsacchi di Pantaneto (ca. 1530-1591) intimates that the two witnesses are the Jewish high priests, Ananus and Jesus. ${ }^{14}$ These men were apparently killed during the turmoil in Jerusalem prior to the destruction of the

\footnotetext{
${ }^{13}$ First, Quodvultdeus (d. ca. 453) refers to Peter and Paul. Quodvultdeus Liber promissionum et præedictorum Dei, "Dimidium temporis in signis Antichristi" 13 (trans. René Braun, SC, 102:630-635). Cf. the English translation of this passage at Bernard McGinn, Visions of the End: Apocalyptic Traditions in the Middle Ages, Records of Civilization, Sources and Studies, 96 (New York: Columbia University Press, 1979; reprint, 1998), 53-54. Second, Primasius of Hadrumetum (d. ca. 560) mentions James and John, the sons of Zebedee. Primasius of Hadrumetum Commentarius in Apocalypsin 11.28-50 (ed. Arthur White Adams, CCSL, 92:166-167). Cf. the English translation of this passage at William Carl Weinrich, ed., Revelation, vol., Ancient Christian Commentary on Scripture, New Testament, 12 (Downers Grove, IL: InterVarsity Press, 2005), 159-160. Third, an ancient Spanish lectionary (seventh to ninth century) makes a link between Rev 10:8, 10;11:1, 3, 4, 15 and Peter and Paul. Liber commicus de toto circulo anni, "Legendum in diem Sanctorum Apostolorum Petri et Pauli" (ed. Justo Pérez de Urbel and Atilano Gonzáles y Ruíz-Zorrilla, Monumenta Hispaniae sacra, Serie liturgica, 3:451). Finally, there is an anonymous commentary possibly from the thirteenth century that has mistakenly been attributed to Alexander of Hales (ca. 11851245) and to Bonaventure (ca. 1217-1274). About it, see David Burr, "Mendicant Readings of the Apocalypse," in Apocalypse in the Middle Ages, ed. Richard Kenneth Emmerson and Bernard McGinn (Ithaca, NY: Cornell University Press, 1992), 89-92; and David Burr, "The Antichrist and the Jews in Four Thirteenth-Century Apocalypse Commentaries," in Friars and Jews in the Middle Ages and Renaissance, ed. Steven J. McMichael and Susan E. Myers, Medieval Franciscans 2 (Leiden: Brill, 2004), 23-24. This commentary refers to Peter and Paul as well as Simon and Jude. Eruditissimi Commentarii ... in Apocalypsim Sancti Ioannis 11.4 (ed. Jean de la Haye, 196, accessed August 16, 2015, Google Books) = Postilla, sive Commentarius in Sancti Joannis Apostol. Apocalypsin universam 11.4 (Sancti Bonaventuræ ... operum omnium ... . supplementum. ..., , vol. 2, col. 486, accessed August 16, 2015, Google Books). With all of these texts, cf. Petersen, Preaching, 15, 17, 57n189; and Turner, "Revelation 11:1$13, " 75-77,84,128-129,180$.

${ }^{14}$ Piero Caponsacchi di Pantaneto, In Iohannis apostoli Apocalypsim observatio (Florence: Giorgio Marescotti, 1572), 65, accessed August 17, 2015, Repositorio Institucional de la Universidad de Granada DIGIBUG. The whole of Rev 11 is discussed at ibid., 60-68. Cf. Turner, "Revelation 11:1-13," 166, 181.
} 
city in $70 \mathrm{CE}$, and their bodies were left unburied..$^{15}$ In the next century, the Catholic Juan de Mariana (ca. 1535-1624) clearly identifies the witnesses with two of John's contemporaries. While still espousing the identification popular among other Catholic interpreters of his time (the witnesses are the returning Enoch and Elijah), Mariana also identifies the witnesses as Peter and Paul. ${ }^{16}$ These two identifications, the Ananus-Jesus view and the Peter-Paul view, have several advocates in the following centuries. Not surprisingly, these are not the only two views advocated. Numerous interpreters through the nineteenth and twentieth centuries have advanced an alternative pair for the witnesses, but few of them agree on who this pair is. Most of the individuals who have been suggested are well-known figures of the early church. James, the brother of Jesus, and the sons of Zebedee, James and John, are the most popular individuals chosen as being one of the witnesses. ${ }^{17}$ Some expositors though prefer to leave the witnesses

${ }^{15}$ On these circumstances, see Titus Flavius Josephus [37-ca. 100] Bellum judaicum 4.5.2 (trans. Henry St. John Thackeray, LCL, 2 volume ed., 210:92-97).

${ }^{16}$ Juan de Mariana, Scholia in Vetus et Novum Testamentum (Paris, 1620), 890, accessed August 17, 2015, Google Books. Cf. Petersen, Preaching, 222n94; and Turner, "Revelation 11:1-13," 179-180, 269.

${ }^{17}$ See, for example, James Stuart Russell [1816-1895], The Parousia: A Critical Inquiry into the New Testament Doctrine of Our Lord's Second Coming, New ed. (London: T. Fisher Unwin, 1887; reprint, The Parousia: The New Testament Doctrine of Our Lord's Second Coming, Grand Rapids, MI: Baker Books, 1999), 430-444 (James, the brother of Jesus, and Peter); Benjamin Wisner Bacon [1860-1932], "The Elder John in Jerusalem," ZNW 26 (1927): 188-189 (James, the brother of Jesus, and John), accessed August 17, 2015, ProQuest Periodicals Archive Online; A. Greve, "»Mine to vidner«: Et fors $\varnothing \mathrm{g}$ på at identificere de to jerusalemitiske vidner (Apok. 11, 3-13)," DTT 40, no. 2 (1977): 128-138 (James, the brother of Jesus, and James, the brother of John); and Michael Oberweis, "Das Martyrium der Zebedaiden in Mk 10.35-40 (Mt 20.20-3) und Offb 11.3-13," NTS 44, no. 1 (January 1998): 74-92 (James and John, the sons of Zebedee). It is noticeable that occasionally, at least in the nineteenth century, Peter is paired up with another early church figure besides Paul. Thus, one has Russell's 
nameless, although still considering them two of John's contemporaries. ${ }^{18}$ In the end, when one considers specific identifications and looks just at the last hundred years or so, the Peter-Paul view dominates among those looking to connect Rev 11 to John's era.

\section{Influence on the Choice of Expositions Featured in This Chapter}

Looking diachronically at futuristic, literal identifications reveals that they have had advocates throughout the history of the interpretation of the witnesses. In fact, the choice of Enoch and Elijah has had the longest presence of any known identification. Considering interpretations after 1700, two other choices though have come to dominate this class of identifications, Moses and Elijah or two currently unknown figures.

Looking diachronically at literal identifications involving John's contemporaries reveals that they have had advocates only in the Modern Age. Ananus and Jesus or Peter and Paul have been the most popular choices for the contemporary figures. Yet, the Peter-Paul view has come to dominate over the last hundred years or so.

The two separate accounts about literal identifications, while useful, have nevertheless left out some important pieces of information. This information comes from putting together the literature for both classes of identifications and then considering the significant expositions since 1700. When this is done, it becomes clear that far more

identification of the witnesses. See Appendix B for more examples of pairings instead of Ananus and Jesus or Peter and Paul.

${ }^{18}$ See, for example, Albert Gelin [1902-1960], "Apocalypse: Traduite et commentée," in La Sainte Bible: texte latin et traduction française d'après les textes originaux: avec un commentaire exégétique et théologique, ed. Louis Pirot and Albert Clamer (Paris: Letouzey et Ané, 1946), 625-627 (two Christian prophets active during the first Jewish War). 
interpreters have adopted the futuristic perspective than have taken up the one involving contemporaries. Moreover, while the Peter-Paul view has come to prevail within its class, it ranks lower in popularity among all those advocating a literal view. The two main futuristic identifications - the Moses-Elijah view and the unknown-individuals view_-appear to have about an equal number of significant advocates. Either identification has been more popular than the Peter-Paul view, particularly when considering just the literature in the last hundred years or so.

All this additional information and the data presented in the two historical surveys have influenced the choice of the expositions to feature in the chapter as representatives of literal interpretations of the witnesses. Accordingly, most of those selected locate the witnesses in the future relative to John, usually beyond the first century CE. Three of them, including Haugg, put forth the popular opinion that the witnesses are two nowunknown future persons. ${ }^{19}$ A fourth interpreter, Christine Joy Tan, is not as specific about the identity of the witnesses. ${ }^{20}$ She chooses rather to argue only for the basic futuristic, literal position, albeit she does so from a particular theological stance. Therefore, these four expositors have been chosen to represent the side of the majority among those advancing literal identifications. Of course, this means that no exposition in support of the now-popular Moses-Elijah view or the once-popular Enoch-Elijah view is discussed in any detail. This omission, however, is not a major concern. The four featured interpreters who defend a literal, futuristic view refer to points of argument that

\footnotetext{
${ }^{19}$ Haugg, Die zwei Zeugen; Todd, Six Discourses; and Beckwith, Apocalypse. ${ }^{20}$ Tan, "Defense."
} 
could also be employed in defense of the Moses-Elijah view and the Enoch-Elijah view as literal, futuristic views. Reasons for these two views are not completely absent here. Moreover, I am confident from my close examination of much of the literature on the two witnesses that my handling of the literature here does not cause common broad issues of interpretation to be missed. Therefore, discussing these four expositions adequately represents a major segment in the debate since 1700 over the identity of the two witnesses.

The literal identifications that locate the witnesses among John's contemporaries are also discussed in this chapter. Indeed, the summaries of argumentation just noted intimate a few of the arguments that interpreters could use to support two contemporaries as the witnesses. These hints, however, are insufficient to show adequately the broad issues of interpretation for this class of identifications. Meanwhile, the historical surveys and the additional observations about the literature for literal identifications show that this is an important class of identifications. The argumentation for such positions merits some attention. Yet, expositions identifying the witnesses with two contemporaries merit less attention than what is given to the expositions looking to two future individuals. Accordingly, I have chosen to discuss only the work of Johannes Munck, who argues that the two witnesses represent Peter and Paul. ${ }^{21}$ Moreover, the discussion of Munck's work is briefer than it could be. An overview of the work and a sample of the argumentation are presented to give a taste of Munck's reasoning and to indicate the broad issues of interpretation that could be derived from the full exposition. Not surprisingly, these

\footnotetext{
${ }^{21}$ Munck, Petrus und Paulus.
} 
delimitations mean overlooking some distinctive points of argumentation for the PeterPaul view as well as many distinctive points on behalf of some other pair of contemporaries. Still, the common broad issues of interpretation involved in arguing for Peter and Paul as the two witnesses seem quite evident. Furthermore, I am confident that Munck's arguments raise many of the broad issues of interpretation that might be found in expositions promoting other contemporaries. Besides, Munck's methodology for interpreting the book of Revelation, a meld of tradition-historical criticism and contemporary-historical criticism, echoes the methodologies used by many who identify the witnesses as two contemporaries. Therefore, briefly discussing Munck's exposition complements the earlier discussion of futuristic, literal identifications of the witnesses and offers some exposure to another part of the debate since 1700 over their exegetical identity.

\section{Donatus Haugg}

Introduction

Donatus Haugg's (1900-1943) ${ }^{22}$ monograph on Rev 11:1-13 arose from a

\footnotetext{
${ }^{22}$ Donatus Haugg was a German Catholic scholar and clergyman. He earned a ThD from the University of Munich in 1930. His dissertation was published as Donatus Haugg, Judas Iskarioth in den Neutestamentlichen Berichten (Freiburg im Breisgau: Herder, 1930). He was habilitated through the University of Munich in 1935. The manuscript for his habilitation is represented by the monograph discussed in this chapter. Haugg authored several other works, but many of these are not academic studies of biblical texts. For several semesters, Haugg was an acting professor for New Testament studies, first at the State Academy at Braunsberg and then at the PhilosophicalTheological College in Freising. Government officials, however, ended his teaching career in the summer of 1939. After a short time as a choir director, Haugg was drafted in May 1940 and became a military chaplain, serving first in France and then in Russia. He appears to have been a casualty of the fighting along the front lines in Russia in January 1943. Concerning these and other aspects of Haugg's life, see Ludger Bäumer,
} 
suggestion by his teacher, Joseph Sickenberger (1872-1945), also a researcher on the Book of Revelation. ${ }^{23}$ Sickenberger subsequently examined the study as a habilitation thesis for Haugg. It was then published as part of the Neutestamentliche Abhandlungen in $1936 .{ }^{24}$ Haugg's work is one of the few scholarly monographs devoted to interpreting Rev 11:1-13 and identifying the two witnesses exegetically. Moreover, his study is well

"Donatus Haugg," Das Online-Gedenkbuch, accessed August 16, 2015, http://www.weltkriegsopfer.de/Kriegsopfer-Donatus-Haugg_Soldaten_0_144518.html; Dominik Burkard, "Die Theologische Fakultät der Staatlichen Akademie Braunsberg," in Institutionen und Strukturen, vol. 1 of Katholische Theologie im Nationalsozialismus, ed. Dominik Burkard and Wolfgang Weiß (Würzburg: Echter, 2007-2011), 32-33, 88-93; Engelbert Maximilian Buxbaum, ed., Vom "Waldler-Buben" zum Hochschulprofessor und regierenden Bischof: Studien und Dokumente Bd. I, vol. 1 of Dr. Joseph Freundorfer, Bischof von Augsburg (1949-1963). Sein Leben und Wirken nach eigenen und zeitgenössischen Dokumenten, Beiträge zur Augsburger Bistumsgeschichte 2 (Regensburg, Germany: Schnell \& Steiner, 2004), 61-63, 79-80; Dominikus Lindner, "Die Philosophisch-Theologische Hochschule Freising in der NS-Zeit," in Das Erzbistum München und Freising in der Zeit der nationalsozialistischen Herrschaft, ed. Georg Schwaiger (Munich: Verlag Schnell \& Steiner, 1984), 1:645, 649; Dominikus Lindner, "Die Philosophisch-Theologische Hochschule Freising von ihrer Hundertjahrfeier (1934) bis zu ihrer Auflösung (1969)," Sammelblatt des historischen Vereins Freisings 27 (1970): 36, 40, 63; Monika Nickel, "Die Philosophisch-Theologische Hochschule Freising," in Institutionen und Strukturen, vol. 1 of Katholische Theologie im Nationalsozialismus, ed. Dominik Burkard and Wolfgang Weiß (Würzburg: Echter, 2007-2011), 436-437, but especially 437n78; "Nuntia personarum," Bib 25, no. 1 (1944): 104; and Ingo Schröder, "Die staatlichen philosophisch-theologischen Hochschulen in Bayern von 1923 bis 1978" (PhD dissertation, Ludwig Maximilian University of Munich, 2004), 81, accessed August 16, 2015, Universitätsbibliothek der LMU München Elektronische Dissertationen.

${ }^{23}$ Haugg, Die zwei Zeugen, iii. On Sickenberger's life and work, see KlausGunther Wesseling, "Sickenberger, Joseph," BBKL, ed. Friedrich-Wilhelm Bautz and Traugott Bautz (Herzberg, Germany: Verlag Traugott Bautz, 1995), vol. 10, columns 1618, accessed August 16, 2015, http://www.bbkl.de/lexikon/bbkl-artikel.php?art= ./S/Si/sickenberger_j.art. For a sense of his work with Revelation, see Joseph Sickenberger, Erklärung der Johannesapokalypse, 2nd ed. (Bonn: Peter Hanstein Verlagsbuchhandlung, 1942).

${ }^{24}$ Haugg, Die zwei Zeugen, iii. 
recognized in the subsequent literature on Revelation. For these reasons, Haugg's

argumentation on the identity of the witnesses is a suitable foundation for the discussions in this chapter.

Haugg summarizes his views on Rev 11:1-13, including his identification of the witnesses, in a six-item list at the end of the monograph:

1. Rev 11:1-13 is a unified component of the whole of Revelation according to language, form, and content.

2. The intermediate piece 11:1-13 is a ritardando between the 6th and the 7th trumpet vision and resolves the question resulting from Rev 9:21 in a reassuring and comforting way: What will happen to the Christians in the eschatological events and tribulations, and how will they react?

3. Jerusalem as the "holy city" is not to be taken in the historical-geographical sense, since it concerns a vision. Rather, it is to be interpreted allegorically as the "church of God." The historical Jerusalem is the material substratum for the pictorial vision. To take the "great city" to be Rome as the seat of the Roman imperial power contradicts the view of the author of Revelation as well as early Christian convictions. 4. The mission of the two witnesses is to be a part of all that God undertakes against the attacks of Satan in the last time of the world to the benefit of the faithful Christians. Their activity has to be regarded as a typical example. They appear in the strength and power of a Moses and Elijah. Their mission is for the part of Christendom that has become lukewarm and heathen, not the Jews and not the Gentiles. They are therefore to be understood in the personal sense as two forerunners and prophets of the end-time who are sent by Christ.

5. In the whole nature of their appearance, the two witnesses are clearly characterized in the vision as a counter-image and counterweight towards the two beasts. They themselves have all power through Christ, as the two beasts receive their power from Satan. Their defeat, resurrection, and ascension are an analogy to the death, the resurrection, and the ascension of Christ.

6. Rev 11:1-13 can be interpreted sensibly and satisfactorily neither in a contemporary-historical way nor in a church-historical way, but only eschatologically. ${ }^{25}$

Thus, Haugg identifies the two witnesses as two unnamed end-time prophets. ${ }^{26}$

${ }^{25}$ Ibid., 136-137. All quotations from Haugg in English are my translations.

${ }^{26}$ Throughout his work, Haugg implies that the notion of "two" witnesses should be understood literally, but he never states explicitly why this ought to be the case. He does, however, offer three reasons for why there are "two" witnesses portrayed instead of some other number of witnesses. See ibid., 114. 
The argumentation for this position can be divided into two parts. First, there are arguments concerning the proper approach to interpreting Rev 11:1-13. As evident from the sixth conclusion above, Haugg favors an eschatological approach. His objections to alternative approaches manifest why he chooses this approach. The discussion of this portion of argumentation is abbreviated for the sake of space and readability. ${ }^{27}$ Second, there are arguments directly addressing the question of the identity of the witnesses. Most of these arguments concern the inadequacy of symbolic identifications and the reasonableness of a literal identification.

The Proper Approach to Interpreting Rev 11:1-13

Haugg rejects three kinds of interpretation of Rev 11:1-13. Each type of interpretation differs on how the data of the text relate to history. Thus, each kind of interpretation comes from approaching the interpretation of the text differently. Haugg rejects the contemporary-historical interpretation, which associates the text with people and events generally contemporary to the composition of Revelation. ${ }^{28} \mathrm{He}$ also dismisses two forms of a church-historical or world-historical interpretation. Both associate the text with people and events appearing in the course of history, mostly after the composition of Revelation. One form, like the contemporary-historical interpretation, relates the text to specific people and events. ${ }^{29}$ With the other form, the text addresses

\footnotetext{
${ }^{27}$ Most noticeable are the absence of certain objections related to the contemporary-historical approach. These objections appear at ibid., 65-71 passim, 121122.

${ }^{28} \mathrm{Haugg}$ 's illustration of the contemporary-historical approach appears at ibid., 6571 passim, 120-121.

${ }^{29}$ Haugg's illustration of this historical approach appears at ibid., 122-123.
} 
history abstractly. The text here is highly symbolic and speaks far more generally about the content of history. ${ }^{30}$ The eschatological interpretation, which Haugg accepts, relates the text to people and events at the end of the present course of history. ${ }^{31}$

Evident in remarks made at various points in Haugg's monograph are two ideas that form part of the objections to the other approaches and show why he finds the eschatological approach acceptable, not just for Rev 11:1-13, but also for much of Revelation. First, Haugg takes seriously the impression that certain passages of Revelation give, namely, that chapters 4-22 are prophetic, at least in the sense that they look toward the future beyond John. ${ }^{32}$ Specifically, this material relates to "final eschatological things," rather than to the span of history between John's day and the endtime. ${ }^{33}$ The passages that he has in mind include at least Rev 4:1 and 10:11, but probably also Rev 1:19 and perhaps 22:6. ${ }^{34}$ Second, Haugg maintains that Revelation contains few

${ }^{30}$ The illustration of this symbolic approach appears at ibid., 109-112, 124-130.

${ }^{31}$ Haugg offers his eschatological interpretation of Rev 11:1-13 at ibid., 130-136.

${ }^{32}$ Ibid., 66, 70-71, 124, 130, 135; cf. 75. Haugg believes that the author of Revelation is the apostle John, who also authored the Gospel of John. Among the many pages giving a sense of Haugg's opinion on the authorship of Revelation, see ibid., 7, 19, 70.

${ }^{33}$ Ibid., 124.

${ }^{34}$ Haugg refers to Rev 4:1; 10:11; and 21:8 at ibid., 66. The reference to 21:8 appears to be a mistake; thus, I suppose that he means 22:6. Haugg alludes to Rev 1:19 at ibid., 70. The context of the allusion suggests that he relates part of the verse to Rev 2-3 and the contemporary period and part of the verse to Rev 4-22 and the future. "Now


relate to Rev 2-3, whereas "Now write ... what is to take place after this" (cf. NRSV;

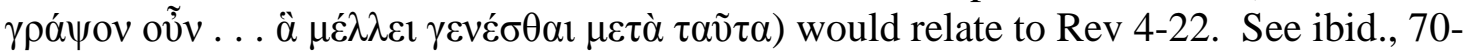
71 ; cf. 120, 130. Besides these verses, Haugg could also have thought of Rev 1:1, 3; 22:7, 10, 18-19 as indicating the future orientation of Rev 4-22. 
references to contemporary history, even in those parts apparently oriented toward the contemporary period, namely, Rev $2-3 .^{35}$ Of course, these two ideas render suspect, at least initially, any attempt to relate segments of Revelation, particularly those forming chapters 4-22, to matters contemporary to John and much of what comes after John. ${ }^{36}$

I offer more detail about Haugg's criticism of the interpretation that sees Rev 11:1-13 as presenting personifications and allegories related to church history or world history, because having in mind those criticisms makes more understandable his arguments that involve specifically the identity question. He usually labels this approach "the (purely) symbolic interpretation" 37 or "the (purely) symbolic-allegorical explanation." ${ }^{38} \mathrm{He}$ commends it for taking "into account the symbolic character of the visions, pictures, and numbers in Revelation." 39 Indeed, Haugg is not averse to

${ }^{35}$ Ibid., 70-71.

${ }^{36}$ I say here "at least initially" because Haugg is agreeable to some application of the contemporary-historical method to Revelation. Of course, Haugg is open to using the method for Rev 1-3. Ibid., 66, 70-71, 130. Moreover, he sees at least one reference to contemporary history in Rev 4-22. He mentions "the birth of the Messiah in chap. 12" at ibid., 74; cf. 26. If he sees one reference in Rev 4-22, perhaps he would agree to others.

${ }^{37}$ Ibid., 112-113, 124-125, 127-128.

${ }^{38}$ Ibid., 126, 130. Haugg refers to this type of interpretation differently on a few occasions. Once he uses the phrase "The Typical-Allegorical Interpretation" as the title for symbolic identifications of the witnesses. Ibid., 109. Similar to this is the phrase "the typical explanation," denoting the view of the witnesses advanced by several modern interpreters. Ibid., 111. Once he mentions the "strictly spiritualistic interpretation" as a characterization of Tyconius's reading of Revelation. Ibid., 109. Then there is the phrase "allegorical interpretation" to describe Luis del Alcázar's perspective on the two witnesses and that of a couple others. Ibid., 111. Haugg actually labels Alcázar's whole understanding of Revelation a "mystical interpretation." Ibid.

${ }^{39}$ Ibid., 124. 
interpreting aspects of Rev 11:1-13 symbolically. ${ }^{40}$ Moreover, he may even be sympathetic to aspects of this interpretation, like the notion that Rev 11:1-13 portrays "a judgment on the church, a persecution of Christianity by anti-Christian powers, which the confessors and martyrs (two witnesses) powerfully resist." ${ }^{41}$ Nevertheless, Haugg finds that using the consistently symbolic method involves the mishandling of "incidental" details in the text. ${ }^{42}$

Haugg later reiterates and expands upon the former criticism about the handling of minor elements in the text. Not only does the purely symbolic interpretation pay too much attention to the secondary details of the passage, but also it does not reveal the central message of the passage, which is presumably the goal of "an exegetical study" of the passage (cf. Haugg's sub-title). All that this interpretation provides are "generalities" or abstractions. ${ }^{43}$

Preceding this thought is a brief survey of the meanings that adherents to this approach have attached to many of the details of the passage. ${ }^{44}$ Presumably, Haugg

\footnotetext{
${ }^{40}$ Note, for example, his interpretation of Rev 11:1-2. See the discussion of this below.

${ }^{41}$ Haugg, Die zwei Zeugen, 124. With this result from the purely symbolic approach, compare Haugg's general reading of Rev 11:1-13 at ibid., 130-136.

${ }^{42}$ Ibid., 124; cf. 130.

${ }^{43}$ Ibid., 130. Haugg sees an inherent tendency toward the symbolic in Revelation and considers it possible for concrete portrayals to represent abstract realities. Ibid., 6; cf. 12. From this perspective, it is puzzling, at least initially, that he seems to disagree with the consistently symbolic approach to interpreting Rev 11:1-13 specifically because it turns the textual elements into abstract realities. Ibid., 130. Cf. Haugg's criticisms of identifications of the two witnesses that come from applying the purely symbolic method to $\operatorname{Rev} 11: 3-13$. Ibid., 112-113.
}

${ }^{44}$ Ibid., 124-130; cf. 109-112. 
intends for this survey to illustrate the distorted explanation that comes from applying this method to Rev 11:1-13.

Haugg's other criticism of the purely symbolic interpretation concerns relating Rev 11:1-13 to the whole period from Jesus' ascension to the end of the world. ${ }^{45}$ In fact, he calls this circumstance "its principal flaw." 46 This criticism also appears elsewhere in his study, in a part of the monograph that addresses directly the identity question. Accordingly, looking more deeply at this criticism permits a transition to Haugg's arguments that deal specifically with the identity of the witnesses as two unnamed prophets of the end-time.

\section{Arguments That Involve Specifically the Identity Question}

\section{The Temporal Situation of the Two Witnesses}

Haugg directs several arguments specifically at the matter of identifying the two witnesses. ${ }^{47}$ Most are for the purpose of dismissing symbolic identifications and promoting a literal one. Some clarify the literal identification. First, there are a few arguments concerning the temporal situation of the witnesses.

Followers of the purely symbolic approach differ from Haugg on when the witnesses are active in history and for how long they are active. Haugg has three arguments that pit these two conceptions of the temporal situation of the witnesses

${ }^{45}$ Ibid., 124; cf. 130.

${ }^{46}$ Ibid., 124.

${ }^{47}$ These arguments are concentrated in the segment entitled, "Are the Two Witnesses People or Personifications?" Ibid., 112-114. Nevertheless, material found elsewhere in Haugg's monograph aids in understanding these arguments. 
against each other. In this way, Haugg does not just move toward his identification of the two witnesses. He also indicates thereby why he considers the application of Rev 11:113 "to the time from Jesus' ascension until the end of the world" to be the "principal flaw" of the purely symbolic interpretation of this passage. ${ }^{48}$

Placement of the episode of the witnesses in relation to the trumpet series

The first argument is apparent when Haugg states, "The timing is given with the 6th and the 7th trumpet (= the 2 nd and the 3 rd woe). This observation alone should warn against an interpretation that would like to find in the two witnesses the symbol for the truth task of the church from its beginnings until the end of the world."49

Clearly, this first argument depends on Haugg's thinking about the sixth and seventh trumpets, the second and third woes, and the relationship of Rev 11:1-13 to these matters. Rev 9:13-21 includes the sounding of a sixth trumpet, the release of four bound angels, the destruction of a third of humanity, and the failure of the survivors to repent. This passage constitutes the sixth trumpet for Haugg. ${ }^{50}$ He then equates this material with the second woe, although the end of that woe is not declared until Rev 11:14. ${ }^{51}$ The seventh trumpet, which Haugg equates with the third woe, at least starts with Rev

\section{${ }^{48}$ Ibid., 124.}

${ }^{49}$ Ibid., 112; cf. 61, 71. The reference to "the truth task of the church [das Wahrheitsamt der Kirche]" might be another way of speaking about "the witness task of the church [das Zeugenamt der Kirche]." Ibid., 112-113; cf. 14, 17, 131, 134.

\footnotetext{
${ }^{50}$ Ibid., 33, 78; cf. 71-72, 75.

${ }^{51}$ Ibid., 33, 112, 130; cf. 61, 71-72, 75, 78, 118.
} 
11:15. ${ }^{52}$ Rev 11:1-13 joins Rev 10:1-11 to form an "intermediate piece" ${ }^{53}$ or a "ritardando" ${ }^{54}$ that delays the declaration of the end of the second woe. Furthermore, this passage, Rev 10:1-11:13, like other "intermediate pieces," 55 offers a message of "reassurance, composure, and protection" to "those faithful to God." ${ }^{56}$ It also functions to transfer readers "from the time of the pre-judgments into the important moment of the last act of judgment: 10:1-11:13 is organically connected with the whole of the apocalyptic events as a bridge and a link for chapters 4-9 and 11:14-20:10."57

Haugg's perspective on Rev 4-22 is also probably relevant to this first argument. As discussed above, Haugg sees these chapters as dealing chiefly with eschatological matters. ${ }^{58}$ This opinion likely underlies what he says concerning the trumpets, the woes, and Rev 10:1-11:13.

All this background information shows why, in Haugg's estimation, the two witnesses cannot represent "the truth task of the church," or any other reality for that

${ }^{52}$ Ibid., 76, 112; cf. 61, 71-72, 78, 118.

${ }^{53}$ For Rev 11:1-13 alone being called an "intermediate piece" (Zwischenstück), see ibid., 32, 76, 79, 116, 118, 136-137. For Rev 10:1-11:13 as an "intermediate piece," see ibid., 71-72, 75-76. Cf. the terms "intermedium" and "intermezzo" for 10:1-11:13 at ibid., 71-72, 76. For the connection of Rev 10:1-11 to 11:1-13, see ibid., 61, 65, 71, 74-78. ibid., 75.

${ }^{54}$ Ibid., 75, 136-137. Cf. the phrase "retarding piece" (retardierende Stück) also at

${ }^{55}$ Haugg mentions Rev 7:1-17 and 14:1-5. Ibid., 75-76.

${ }^{56}$ Ibid., 75; cf. 118, 130-131, 136-137.

${ }^{57}$ Ibid., 78; cf. 33, 75, 77, 87.

${ }^{58}$ Ibid., 66, 70-71, 124, 130, 135; cf. 75. 
matter, that operates from the "beginnings" of the church "until the end of the world."59 Rev 11:1-13 cannot be related to the start of the church after Jesus' ascension, because it functions to round out the picture of the eschatological time of "the pre-judgments" or "the preliminary acts of the final judgment (signs and tribulations)."60 The passage is oriented toward the end-time and therefore excludes all that happens before that.

The specific duration of the witnesses' activity

The second argument that pits the two views of the temporal situation of the witnesses against each other is stated thus: "The activity of the two witnesses is for a limited period; the 1,260 days cannot possibly represent the whole time of the existence of the church."61

Obviously, this argument depends upon Haugg's conception of the 1,260 days. As implied by the quotation, he reads Rev 11:3 as saying that the two witnesses will be active over this period. ${ }^{62}$ Presumably, adherents to the symbolic approach would agree with this. ${ }^{63}$ Haugg also believes that the ultimate sense of the temporal designation is a

${ }^{59}$ Ibid., 112. Haugg probably intends "the truth task of the church" to be representative of many symbolic identifications. After all, Haugg elsewhere associates the extensive post-ascension period for the witnesses' activity with the whole purely symbolic way of interpreting Rev 11:1-13. See ibid., 124. It is also confirmed when one considers Haugg's handling of specific identifications in the arguments that follow this one. See the discussion below. Compare the identifications of the witnesses in his arguments with the sampling of symbolic identifications at ibid., 109-112; cf. 127-129.

${ }^{60}$ Ibid., 77-78; cf. 75, 85-88, 118, 130-131, 133, 136-137.

${ }^{61}$ Ibid., 112.

${ }^{62}$ Cf. ibid., 12, 16, 21-23, 69, 134.

${ }^{63}$ Cf. ibid., 112. 
non-literal one ${ }^{64}$ Here too, followers of the symbolic approach would likely agree. ${ }^{65}$ The point of disagreement arises from Haugg taking the 1,260 days as a short, limited period. ${ }^{66}$ Haugg does this in part because he draws a parallel between the missionary activity of Jesus and that of the two witnesses. As Jesus was active in ministry for a short, limited time and then faced death, so it will also be for the two witnesses. ${ }^{67}$ Another factor in Haugg's understanding of the 1,260 days is his thinking about the 42 months of Rev 11:2. The 42 months, like the 1,260 days, has a non-literal meaning. ${ }^{68}$ John aims only to show that this period, in which the Gentiles and the beast dominate, "will be only of a short, limited duration, corresponding to the general early Christian expectation of the end."69 Thereby, John can offer readers "comfort" and "reassurance" concerning that time. ${ }^{70}$ Haugg can apply these thoughts about the 42 months to the 1,260

${ }^{64}$ Ibid., 12, 78, 134.

${ }^{65} \mathrm{Cf}$. ibid., 112. Although it concerns the 42 months, note also ibid., 126-127.

${ }^{66}$ Ibid., 20, 112; cf. 12, 16, 21-23, 69, 134.

${ }^{67}$ Ibid., 20, 23. This is not the only parallel that Haugg sees between Jesus and the two witnesses. See other parallels at ibid., 14, 27, 30, 32, 57, 136.

${ }^{68}$ Ibid., 12-13, 78, 134.

${ }^{69}$ Ibid., 13; cf. 87-88, 133. With this quotation, Haugg notes 1 Thess 4:13; 2 Thess 2; and Rev 12:12 for passages exhibiting "the general early Christian expectation of the end." Ibid., 13. He might also have in mind Matt 24:22 (= Mark 13:20). See ibid., 87-88.

${ }^{70}$ Ibid., 13; cf. 133. As noted earlier, Haugg perceives "comfort" and "reassurance" as part of the intended message for the whole of 11:1-13. See ibid., 75, $118,130-131,136-137$. 
days because he believes that the two periods are coextensive; they are actually one period designated in two ways. ${ }^{71}$

The tenses of the verbs used to speak about the witnesses

The third argument that pits one temporal scheme for the two witnesses against another involves the tenses of key verbs in Rev 11:1-13. Haugg asserts that the future

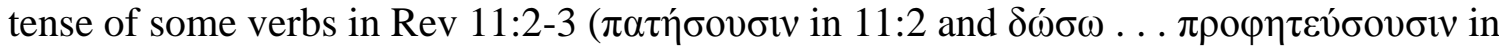
11:3) indicates "a distant future. ${ }^{172}$ Of course, this agrees with Haugg's belief, as noted above, that Rev 4-22 involves primarily people and events far beyond the time of John, in the end-time. ${ }^{73}$ Haugg concludes the argument by stating that the perfect tense would have been used instead of the future tense in these instances "if the activity of the two witnesses had already begun," as "the purely symbolic interpretation" requires. ${ }^{74}$

This argument becomes clearer when one recalls that the symbolic view supposedly connects the witnesses and the whole of 11:1-13 to an extensive period "from Jesus' ascension until the end of the world." 75 This period includes the time in which the

${ }^{71}$ Ibid., 61, 69, 134; cf. 12, 16, 20, 60. The 42 months of 11:2 and the 1,260 days of 11:3 are also coextensive with the 42 months of 13:5. See ibid., 63; cf. 12-13, 16, 78 . Like others, Haugg observes that 1,260 days and 42 months each amount to roughly three-and-a-half years and are apparently derived from the three-and-a-half "times" in the Book of Daniel. Ibid., 12; cf. 60, 133.

${ }^{72}$ Ibid., 112. Compare here Haugg's other comments on (indicative) verb tenses in this passage at ibid., 11, 23, 30-31, 50, 64. He seems to have confidence in the straightforward meaning of only the future tense (indicative) verbs in Revelation.

\footnotetext{
${ }^{73}$ Ibid., 66, 70-71, 124, 130, 135; cf. 75.

${ }^{74}$ Ibid., 112.

${ }^{75}$ Ibid., 124; cf. 112.
} 
book of Revelation was composed, regardless of whether one maintains an early or a late date. Consequently, the seer would presumably have used a past tense, like the perfect, to speak about this period, since it would have already begun from the seer's standpoint in time. Yet, this is not what the text contains.

\section{Rev 11:1-2 and the Two Witnesses}

The next three arguments all have a common starting point and lead to the same general conclusion. All three suggest that a proper reading of 11:1-2 does not allow for an interpretation of Rev 11:3-13 based on a symbolic view of the two witnesses. As can be seen then, the common starting point in these arguments is Haugg's interpretation of Rev 11:1-2. Before presenting the three arguments, that interpretation is summarized.

Yet, even before turning to that interpretation, it is important to consider Haugg's belief that Revelation derives from a visionary experience and what he perceives that that circumstance entails for interpretation. Haugg maintains that Revelation originates primarily from a visionary experience that John had. ${ }^{76}$ Drawn into that experience and affecting the resultant text are John's experiences prior to the visions and material extant in the OT and NT documents. ${ }^{77}$ Moreover, the text shows indications of John reflecting on his extraordinary experience and making predictions. ${ }^{78}$ Nevertheless, the visionary

${ }^{76}$ Ibid., 79; cf. 83, 85, 88.

${ }^{77}$ For experiences prior to the visions, there is at least the example of visiting the Herodian temple complex. See ibid., 7, 70-71; cf. 8-11; but see 131. On OT and NT material that might have influenced the composition of Revelation, see ibid., 79, 83-88.

${ }^{78}$ Ibid., 64; cf. 23, 31, 50, 88. 
experience with its visual and auditory elements, not to mention John's occasional personal involvement, dominates. ${ }^{79}$

The visions and so the text stemming from it involve symbolism. ${ }^{80}$ In fact, there is a tendency toward symbolism throughout the book. ${ }^{81}$ What this means is that interpreters cannot move immediately from the vision and text to the meaning in the real world. Entities mentioned in the text need to be translated, and the results may not be an exact equivalent to the originals. ${ }^{82}$ It also means that one cannot judge the visionary world according to aspects of the real world. Elements in the visionary world may not exist in the real world or may not follow the natural laws of the real world. ${ }^{83}$ These thoughts affect Haugg's interpretation of Rev 11:1-13 as whole, and presumably, they underlie his approach to interpreting the rest of the book as well. ${ }^{84}$

The meaning of Rev 11:1-2

Haugg's conception of Revelation as deriving from a visionary experience and the

${ }^{79}$ On the primacy of the visionary experience, see again ibid., 79; cf. 83, 85, 88 . Concerning the experience itself, see ibid., 64-65.

${ }^{80}$ Ibid., 6, 120, 124.

${ }^{81}$ As may be inferred from comments at ibid., 6 .

${ }^{82}$ On the need for interpretation, see ibid., 120. For examples of the interpretive movement from vision and text to meaning, see ibid., 7, 11, 70-71, 131-132, 136-137. The same things can also be said for numbers in Revelation. See ibid., 12-13, 27, 33, 78, $124,136$.

${ }^{83}$ With respect to things that may not exist in the real world, note the remarks at ibid., 71. With respect to the possible violation of natural laws, note the remarks at ibid., 29.

${ }^{84}$ On Rev 11:1-13 as a vision, see ibid., 65, 121, 130; cf. 3, 6-7, 11, 23, 29, 31, 50, 64, 69-71, 74, 78, 88, 113, 131, 136-137. 
implications that that has for interpretation have been sketched. Now his interpretation of Rev 11:1-2, which this thinking influences, can be summarized. Fundamental to Haugg's reading of Rev $11: 1-2^{85}$ is the notion that, at the visionary level, "the earthly temple" appears in these verses. ${ }^{86}$ Not surprisingly, also basic to his reading of these verses is the idea that "the historical [or earthly] Jerusalem is the material substratum for the pictorial vision. ${ }^{187}$ The act of measuring separates one area (sanctuary, altar, and worshipers, forming the inward part of the temple) from another (outer court of the temple and holy city) and thus protects the former from the Gentile invasion that is to overtake the latter. ${ }^{88}$ Beyond the vision, the city as a whole represents the spiritual Jerusalem, the Church. ${ }^{89}$ The measuring creates a division within the Church between the small group of Christians "who remain faithful to Christ and the altar," the "core of the Christian

\footnotetext{
${ }^{85}$ Haugg's interpretation of Rev 11:1-2 does have some similarities with those espoused by commentators that he examines. Specifically, the similarities lie with the opinions of adherents to a church-historical or world-historical approach. Ibid., 122, 125126. A critical difference is likely Haugg's future orientation for the matters portrayed in $11: 1-2$.

${ }^{86}$ Ibid., 6; cf. 11, 50, 78, 87, 132. Elsewhere Haugg not only indicates that the earthly temple is being portrayed, but he also identifies a particular temple. A contradiction though may exist in what he says in these places. Earlier in his work, Haugg contends that the seer, John, was well acquainted with the Herodian temple and that this memory came alive for him in the visionary experience underlying Rev 11:1-2. See ibid., 7, 70-71; cf. 8-11. Near the end of his work, however, Haugg rejects "the Herodian temple with its divisions of the court of men and the court of women" as the physical basis for the vision and sees rather a reference to the first temple or one like it"the Solomonic-Ezekielian one with inner court (1 Kings 6:34 [meaning perhaps 1 Kings 6:36]) and outer court (Ezek 10:5)." Ibid., 131.

${ }^{87}$ Ibid., 137; cf. 4, 7, 11, 50, 60-61, 70-71, 73, 78, 87-88, 131, 136.

${ }^{88}$ Ibid., 131; cf. 4-12, 67-69, 74, 88, 118-121, 132-133.

${ }^{89}$ Ibid., 120, 131-133, 136-137; cf. 70.
} 
people," and "the large masses of nominal Christians." ${ }^{10}$ This separation of the Church into two groups, one faithful and one weak in faith, reflects thoughts found in other NT writings. ${ }^{91}$ While God abandons the latter group to the Gentiles, so that its members become like them, He also preserves the former group from that fate. ${ }^{92}$ It is at the latter group that the mission of the two witnesses is primarily directed; they offer "God's call of grace one last time" to "the part of Christendom that has become weak."93

The witnesses and the need of the church

Three identity-related arguments arise from Haugg's understanding of Rev 11:1-2. Continuing his criticism of symbolic views of the witnesses, Haugg states for the first

${ }^{90}$ Ibid., 132; cf. 60-61, 75, 118-120, 133-134, 136-137. The mention of the altar here is surprising, and its meaning is unclear. Just a few sentences before, Haugg has indicated that, although the altar of burnt offering appears in the visionary depiction, it does not have a distinct meaning in the real world. The temple, the altar, and the worshippers are to be taken as a unit with respect to their ultimate meaning. See ibid., 132; cf. 7-8, 11, 70, 131.

${ }^{91}$ Ibid., 132. Haugg has in mind the parable of the wheat and the weeds (Matt 13:24-30, 36-43), the parable of the net with good and bad fish (Matt 13:47-50), and some thoughts from Paul. For Paul, he cites specifically Rom 14:1, 17; 2 Tim 2:19-21; and Heb 5:12, but perhaps he is also thinking about the context for these verses. See Rom 14:1-15:1; 2 Tim 2:14-21; and Heb 5:11-14. Haugg may also have in mind words from John the Baptist about separating the wheat from the chaff (Matt 3:11-12= Luke 3:16-17). Ibid., 133.

${ }^{92}$ Ibid., 131-133; cf. 4, 6, 8, 10-12, 24-25, 27, 60-61, 68-69, 71, 74, 87-88, 118 121, 134, 136-137. The Gentiles appear to represent non-Christians, since Haugg distinguishes them from the two ecclesiastical groups, the faithful and the weak.

${ }^{93}$ Ibid., 132-133; cf. 16, 34, 55, 69, 114, 118-120, 134, 136-137. While the nominal and apostate Christians are the primary target for the preaching of the witnesses, Haugg indicates that they are only part of the audience. The non-Christians, the Gentiles who have taken over and profaned this part of Christianity, will also be a target for the witnesses' preaching. Ibid., 29, 63, 88, 118, 120,131, 134, 136. Moreover, the witnesses are to play some role in benefiting the faithful Christians. Ibid., 133, 137. 
argument: "A recent mission of two prophets would likewise be unnecessary, if these meant only the doctrina and sanctitas of the church. Yet, for the especially hard times of the final events, what will be necessary for the church is the revival of the stagnant life of faith in the individual members of the church." 94

The first sentence ("A recent mission ... the church.") transitions readers from the previous three arguments about when and for how long the two witnesses are active. "A recent mission of two prophets" refers to the witnesses' activity according to the temporal scheme inherent in the purely symbolic interpretation of Rev 11:1-13. ${ }^{95}$ The previous three arguments show that this conception of the witnesses' activity is incorrect. Haugg though now brings this conception back into consideration. It can "likewise" or additionally be considered "unnecessary" under one condition.

The condition under which "a recent mission of two prophets ... would be unnecessary" is "these [two prophet-witnesses] meant only the doctrina and sanctitas of the church." ${ }^{96}$ Haugg is moving from the matters of when and how long the witnesses are active to the matter of what or who is actually active as the witnesses. Although Haugg seems to be dealing here with only one symbolic identification, he is presumably

${ }^{94}$ Ibid., 112. Italics added for the Latin words.

${ }^{95}$ As intimated, that scheme sees the witnesses as active "from ... [the] beginnings [of the church] until the end of the world." Whether viewed from the perspective of John or others after him, so conceived, the activity of the witnesses stands partly in the past and is therefore in some way "recent." This "recent mission" stands in contrast to the one that Haugg implies with his alternative temporal scheme. For Haugg, the witnesses have a "future" "mission." For all this, see ibid., 112; cf. 66, 70-71, 75, $124,130,135$.

${ }^{96}$ Ibid., 112. Again, italics added for the Latin words. 
concerned with more than one particular symbolic identification of the witnesses. Most likely, the doctrina-sanctitas view is meant to represent many symbolic identifications, including "the truth task of the church," mentioned previously. ${ }^{97}$ Thus, this first argument should be applied not just to the doctrina-sanctitas view, but also to the whole class of identifications of which this view is typical.

The second sentence in this argument ("Yet, for the especially hard times . . . the church.") clarifies the matter of necessity raised by the first sentence. It explains why an identification of the witnesses with "only the doctrina and sanctitas of the church" and, most likely, other symbolic identifications render "a recent mission" of the two witnesses "unnecessary." 98 Haugg clarifies by defining what Christians living in the end-time will need. ${ }^{99}$ Certain Christians at that time will need a transformation of their religious life, a

\footnotetext{
${ }^{97}$ As noted before, Haugg probably intends "the truth task of the church" to be representative of many symbolic identifications. That reference occurs as Haugg addresses the temporal scheme for the witnesses, which he elsewhere associates with the whole purely symbolic way of interpreting Rev 11:1-13. See ibid., 112, 124. Moreover, in the next argument to be discussed, Haugg mentions together a few other symbolic identifications of the two witnesses. Ibid., 112-113. The reference here to identifications, almost all of which have no explicit presence in the previous few arguments, reveals a pattern in this course of argumentation. With almost no repetition, Haugg periodically mentions specific symbolic identifications. This pattern suggests that, at every point where Haugg refers explicitly to one or a few symbolic identifications, he intends for the whole class of such identifications to be understood. Compare the identifications of the witnesses in his arguments with the sampling of symbolic identifications at ibid., 109-112; cf. 127-129.

${ }^{98}$ Ibid., 112. Again, italics added for Latin words.

${ }^{99}$ That Haugg should even speak of the end-time in relation to "a recent mission of two prophets" is appropriate, because that mission continues on to the end of the church age, according to the purely symbolic interpretation of Rev 11:1-13. See ibid., 112, 124.
} 
resurrection of their "life of faith." ${ }^{100}$ At this point, Haugg's interpretation of Rev 11:1-2 intersects with this argument. According to that interpretation, God abandons a large part of the church, the nominal Christians, to the Gentiles, and they become like the Gentiles. Spiritually, this group needs repentance and conversion.

Therefore, Haugg is saying that, if the two witnesses are just "the truth task of the church," simply the teaching (doctrina) and holiness (sanctitas) of the church, or solely one of many other symbolic identifications - if that is all that the image of the two witnesses means_- then their obviously spiritual mission would be unnecessary because it would do nothing for the spiritual need of end-time. ${ }^{101}$ Yet, for this argument to be effective against symbolic identifications, it seems to require the two prophet-witnesses to be the intended agents for meeting the need of the end-time church. Otherwise, there is no essential link between the need of Christians and the activity of the two witnesses to make an unnecessary mission problematic.

The witnesses and a reason for the presence of $\operatorname{Rev} 11: 1-2$

Haugg also remarks on how Rev 11:3-13 provides an explanation for the presence

of 11:1-2. Still addressing symbolic identifications of the witnesses, Haugg says:

The whole solemn introduction to the prophecy of the two witnesses, as it exists in Rev 11:1-2, would lack a rationale, if one is supposed to be told [in 11:3-13] only that martyrs and confessors, preaching and holiness, the Old and the New Testament forever bear witness for Christ. Why is there a differentiation of the temple and the outer forecourt, since wheat and weeds will always be together in the church? With the purely symbolic interpretation of the two witnesses, we would have in Rev 11:1-2

${ }^{100}$ Ibid., 112.

${ }^{101}$ Ibid. 
a powerful introduction that no really important content follows. ${ }^{102}$

In the second sentence, Haugg alludes to the parable of the wheat and the weeds from Matt 13. ${ }^{103}$ Haugg does two things in alluding to this parable. On the one hand, he uses the language of the parable to speak about the two entities (in fact, groups) distinguished by the measuring in Rev 11:1-2; thus, the measured temple equals the wheat (those faithful to God), and the unmeasured outer forecourt equals the weeds (those who are nominal Christians). On the other hand, he highlights a situation in the parable that contrasts with the message of Rev 11:1-2. In the parable, the wheat and the weeds stand together in the field until the time of the harvest (Matt 13:30), which means that the good and the bad stand together in the church until the end of the age (Matt 13:37-43). In Rev 11:1-2, a division is made between the temple and what is outside it, which means that the good and the bad in the church are now separated in some way. With respect to the parable, this situation is comparable only with the division that occurs at the time of harvest or the end of the age.

Therefore, Haugg is saying that, in contrast to the usual state of the Church with good and bad together, something decisive and different is portrayed in Rev 11:1-2 — the two groups are separated. It constitutes a "solemn" or "powerful" introduction to the episode of the witnesses and demands some further comment or explanation. Yet, if the two witnesses are just "martyrs and confessors, preaching and holiness, the Old and the New Testament," or some other abstract entity operating for Christ over time-if that is

${ }^{102}$ Ibid., 112-113.

${ }^{103}$ Cf. ibid., 132. 
all that the image of the witnesses means - then the expected explanation is absent, in Haugg's opinion. ${ }^{104}$ Thus, the purely symbolic interpretation of the witnesses leads to an unacceptable relationship between Rev 11:3-13 and 11:1-2. ${ }^{105}$

A transition: Concrete witnesses, not pure abstractions

The next argument completes the series of arguments focused on criticizing symbolic understandings of the witnesses. Moreover, it transitions readers to a series of arguments focused on promoting a literal understanding of the witnesses. Here Haugg contends, "The witness task of the church must always be carried out by definite personalities; mere abstractions are dead in themselves." ${ }^{106}$ At first, this statement appears quite basic and likely agreeable to those using a consistently symbolic approach. Accordingly, it is not clear at first how this statement strikes at the position of those interpreters. It is clear, however, that "mere abstractions" is Haugg's characterization of symbolic identifications of the witnesses. ${ }^{107}$ He has mentioned a few of these in the

${ }^{104}$ Ibid., 112-113. The reference here to three symbolic identifications helps to reveal a pattern in this course of argumentation. Haugg has mentioned only two other identifications so far among these arguments. One of these is not repeated here ("the truth task of the church"), while the other is perhaps alluded to ("the doctrina and sanctitas of the church" [italics added]). Ibid., 112. Therefore, with almost no repetition, Haugg periodically mentions specific symbolic identifications. This pattern suggests that at every point where Haugg refers explicitly to one or a few symbolic identifications he intends for the whole class of such identifications to be understood. Compare the identifications of the witnesses in his arguments with the sampling of symbolic identifications at ibid., 109-112; cf. 127-129.

${ }^{105}$ Elsewhere, Haugg comments on the importance of Rev 11:3-13 for 11:1-2, while discussing the unity of 11:1-13. Ibid., 61 .

${ }^{106}$ Ibid., 113.

${ }^{107}$ Ibid., 112-113, cf. 109-112, 130. 
previous arguments and, for some, made a clear link to witnessing. ${ }^{108}$ Thus, some symbolic identifications can refer to the witnessing activity of the church. Haugg, however, has a problem with this connection. Abstract entities cannot actively do anything; they cannot actually be witnesses for Christ. Why is this situation a problem though for those who understand the witnesses symbolically? ${ }^{109}$ Perhaps the solution is in Haugg's understanding of Rev 11:1-2. Those verses, as noted, portray a future need for the church, a need that witnesses for Christian truth could address. Of course, only real people could fill that role; abstract entities could not do it. Yet, maybe Haugg would have readers go further to see that concrete witnesses not only meet the need presented in Rev 11:1-2, but also lead to a substantial message for 11:3-13 and a reason for the presence of 11:1-2 in Revelation. In other words, perhaps this argument provides an alternative perspective on the witnesses, one that is meant to address concerns raised in the previous two arguments. The alternative is to consider the witnesses as "definite personalities" and not as "personifications."110 Raising this alternative looks forward to

${ }^{108}$ Ibid., 112-113; cf. 109-112. As mentioned in an earlier footnote, the reference to "the truth task of the church" might be another way of speaking about "the witness task of the church." Ibid., 112-113; cf. 14, 17, 131, 134.

${ }^{109}$ This question becomes even more significant when one considers what Haugg says earlier about abstractions. As noted in a previous footnote, from Haugg's discussion of the measuring commanded in Rev 11:1, it becomes clear that he sees an inherent tendency toward the symbolic in Revelation and considers it possible for concrete portrayals to represent abstract realities. See ibid., 6; cf. 12. From this perspective, it is puzzling, at least initially, that he seems to disagree with symbolic identifications of the witnesses specifically because they turn the two figures into abstract realities. Ibid., 112113. Cf. Haugg's criticisms of the purely symbolic interpretation of Rev 11:3-13 at ibid., 130.

${ }^{110}$ Ibid., 112-113; cf. 109-112. 
the other specifically identity-related arguments that follow this one. ${ }^{111}$

\section{The Scene for the Episode of the Witnesses}

Haugg now begins a series of arguments that are directed not simply at faulting symbolic identifications of the witnesses, but at promoting the witnesses as actual persons. The first argument can stand on its own in this series. Here Haugg asserts, "Also the restriction of the scene to the 'holy city' where Christ was crucified points to definite individual personalities." 112 Again, Haugg believes that at the visionary level the "holy city" of Rev 11:1-2 is the earthly Jerusalem. Haugg finds this same city in Rev 11:8. The "great city" of 11:8 is described as the place where the lord of the two witnesses was crucified. That lord, in Haugg's estimation, must be Christ, the one who sends the two witnesses. ${ }^{113}$ The "great city" then is the place where Christ was crucified, which is "unequivocally fixed" within history as Jerusalem. ${ }^{114}$ The same city, the earthly Jerusalem, therefore appears to the seer throughout Rev 11:1-13. ${ }^{115}$ These thoughts underlie the first part of Haugg's claim. The next sentence, however, explains why this

${ }^{111}$ Ibid., 113. See the continuing discussion below.

${ }^{112}$ Ibid.

${ }^{113}$ Ibid., 26; cf. 3, 27, 56-57, 63, 83, 114, 134, 136-137. There is some ambiguity in Haugg's work about who sends the two witnesses. Instead of Christ, Haugg at times indicates that God sends them. Ibid., 14, 17, 74, 131, 133; cf. 15-16, 18, 20-21, 29, 34, 114, 132, 134, 137. Other times, Haugg suggests that it is "God or Christ." Ibid., 13, 88, 113; cf. 14, 16. One time though he intimates that "God and Christ" send them. Ibid., 120.

${ }^{114}$ Ibid., 113; cf. 26, 56, 60, 136.

${ }^{115}$ Ibid., 24-26, 60-61, 136-137; cf. 11, 33, 55-56, 69, 113, 118-120, 130. 
"restriction of the scene" should indicate that the witnesses are actual individuals: "It is a weakness from the outset when the symbolic interpretation of the two witnesses must generalize the place of the crucifixion of Jesus, which is unequivocally fixed."116 In other words, many symbolic views require that the location for the events of Rev 11:1-13 not be limited to the single city of Jerusalem. ${ }^{117}$ Thus, they reveal their inadequacy. The ready alternative to symbolic views of the witnesses is, of course, to take them as "definite individual personalities." ${ }^{118}$

\section{The Activity and Fate of the Two Witnesses}

Haugg continues advancing the idea that the two witnesses are two actual people by making a broad claim: "The whole activity [of the two witnesses and] ... the special fate that ... [they] meet can be sensibly explained only if it concerns definite individual personalities." ${ }^{119}$ The "activity" of the witnesses refers to what is described in Rev 11:36, whereas their "fate" refers to the content of 11:7-12. ${ }^{120}$ Nonetheless, most of Haugg's

${ }^{116}$ Ibid., 113.

${ }^{117}$ Haugg cites here a specific example from Luis del Alcázar. For other examples of which Haugg is aware, see ibid., 26, 128. Apparently, some advocates of the symbolic approach to interpreting Rev 11:1-13 deal with the great city differently. These interpreters take the city to be Rome. Obviously, this too is objectionable to Haugg. Ibid., 26, 136-137; cf. 55-56.

${ }^{118}$ Ibid., 113.

${ }^{119}$ Ibid. Cf. ibid., 133-134.

${ }^{120}$ Cf. ibid., 12, 20-21, 23, 27, 57, 112, 121, 133-134, 137. 
support for the claim concerns the witnesses' end. That support consists of six arguments. $^{121}$

The description of the witnesses' end

For one supporting point, Haugg says, "The full meaning of the words about the death, resurrection, and ascension of the two witnesses can result only in 'personae propriae' [particular persons], not, however, in 'personae ficte' [fictitious persons]." ${ }^{122}$ When Haugg speaks of "the full meaning of the words" about the witnesses' fate, he presumably means taking the details of their end literally. ${ }^{123}$ Admittedly, adherents to the symbolic approach would probably agree that a literal reading of Rev 11:7-12 at least suggests that the witnesses are two individuals. ${ }^{124}$ Moreover, it seems likely that those proponents would also want "the full meaning of the words." 125 The point of

${ }^{121}$ The order in which I present the arguments differs from their original order, so that I can more easily present the logical relationships among them.

${ }^{122}$ Haugg, Die zwei Zeugen, 113. Italics are added for the Latin words.

${ }^{123}$ Compare here some of Haugg's criticism of the purely symbolic interpretation of Rev 11:1-13, which is discussed above and is present at ibid., 112-113, 124, 130. His statements in these places intimate that a non-literal interpretation can in some instances dilute the meaning or render the sense as somehow incomplete.

${ }^{124}$ For instance, the ancient commentator, Tyconius is aware that some take Rev 11:7-12 literally and so the two witnesses. He sets aspects of the literal view of the passage up against what could happen in the real world to show that the literal view as a whole is unrealistic and inappropriate. There would seem to be no point in arguing against that position in this particular way, if Tyconius did not agree with his opponents that the passage has at least the semblance of speaking about two actual people. See Tyconius Expositio Apocalypseos 3.78 (ed. Roger Gryson, CCSL, 107A:171). Cf. the discussion in a later footnote about the fragments of a commentary that has been associated with Tyconius.

${ }^{125}$ Haugg, Die zwei Zeugen, 113. 
disagreement therefore would be over Haugg's apparent assumption that the full significance of the language about the witnesses' fate can be found only through a literal reading. Two arguments discussed below offer bases for this assumption, in addition to supporting Haugg's broad claim about "definite individual personalities." 126

The witnesses rise and ascend, not just killed

Haugg also argues, "If it concerned the martyrs of the church in general in Rev 11:3, the historical evidence is absent that these are not only killed, but also have risen again from the dead and ascended into heaven in sight of the 'inhabitants of the earth.'"127 Of course, identifying the witnesses as the martyrs of the church is just one symbolic identification. Perhaps Haugg highlights this one because it comes closest to a literal reading of the situation described in Rev 11:7-12. ${ }^{128}$ Yet, in Haugg's estimation, this identification would not come close enough; the historical record apparently does not accord with the narrative. If this all truly reflects Haugg's thinking with this argument, he might also have intended it to have implications for other symbolic identifications. If this identification comes so close in paralleling the literal narrative of 11:7-12, yet still falls

${ }^{126}$ Ibid.

${ }^{127}$ Ibid.

${ }^{128}$ Compare the way in which Haugg seems to focus on the Ananus-Jesus identification when discussing the contemporary-historical approach. Ibid., 121. Ananus and Jesus, two first century Jewish high priests, were apparently killed during the turmoil in Jerusalem prior to the destruction of the city in $70 \mathrm{CE}$, and their bodies were left unburied. On these circumstances, see Josephus Bellum judaicum 4.5.2 (trans. Thackeray, LCL, 2 volume ed., 210:92-97). Such a situation has similarities with that of the two witnesses, and this fact has led some to connect them with the witnesses. 
critically short of genuine congruence, how much more then do the other symbolic identifications fall short.

Obviously though, for this argument to be effective, one must assume that the symbolic identifications should be judged according to a literal understanding of the witnesses' fate. Two arguments discussed below offer grounds for this assumption, besides supporting Haugg's broad claim about "definite individual personalities." 129

The riskiness of embellishment

Haugg also offers a quotation to support his broad claim. Specifically, he says: "Berengaudus is quite right to have brought up exactly Rev 11:9-11 [11:9-12?] as evidence against the allegorists. 'It is very risky to want to embellish with spiritual additions that clear historical fact that we recognize."'130

Haugg refers here to Berengaudus, a commentator likely from the ninth century. The quality and accuracy of Haugg's translation of Berengaudus might be debated, and his understanding of the statement in its literary context might be questioned. ${ }^{131}$

${ }^{129}$ Haugg, Die zwei Zeugen, 113.

${ }^{130}$ Ibid. The original German says, "Berengaudus hat mit vollem Recht gerade Apok 11,9-11 als Beweis gegen die Allegoristen ins Feld geführt. 'Es ist sehr gewagt, jene offene historische Tatsache, die wir erkennen, mit geistigem Beiwerk ausschmücken zu wollen.'"

${ }^{131}$ Haugg's quotation comes from Berengaudus' comments on Rev 11:9-12. Berengaudus Expositio super septem visiones libri Apocalypsis 11.9-12 (ed. Jacques-Paul Migne, PL, vol. 17, cols. 870D-871D, accessed June 28, 2015, Google Books). After quoting these verses, Berengaudus says: "Hoc si secundum historiam impleatur, hominibus quidem incognitum, Deo autem nota sunt omnia. Possumus autem et nos huic historiae spiritalem intelligentiam adjungere: sed temerarium videtur illam historiam, quam intelligimus, spiritalibus sensibus velle adornare. Nullam quippe domum extra positi, interius ornare valemus: sed ne omnino tacuisse videamur, pauca dicamus." According to my translation, he says, "Whether this is fulfilled according to the account 
Nevertheless, this argument, like Haugg's other ones, can still be examined as given, regardless of whether it is valid.

The "clear historical fact" apparently refers to Rev 11:9-12, which describes the reaction of people to the dead witnesses and then relates the witnesses' resurrection and ascension before a startled audience. The attempt to add spiritual insights to this account is what Berengaudus (and so Haugg) considers a risky endeavor. Those who want to expand this account are "the allegorists," that is, the followers of the consistently symbolic approach.

How though does this argument support Haugg's broad claim? Haugg, following Berengaudus, envisions that any effort to handle Rev 11:9-12 according the symbolic method will likely fail. Such efforts risk creating an erroneous interpretation. Therefore, by implication, the cautious approach is to take the text literally, which entails seeing the witnesses as "definite individual personalities."132

An underlying assumption, however, makes this argument effective. Haugg must

[i.e., literally] is indeed unknown to human beings, but all things are known to God. Nevertheless, we also can add spiritual meaning to this account; yet it seems reckless to want to embellish with spiritual senses that account that we perceive. Of course, situated on the outside we are unable to decorate a house on the inside; yet lest we seem to be entirely silent, we say a few words." Berengaudus Expositio super septem visiones libri Apocalypsis 11.9-12 (vol. 17, col. 871A). Accordingly, after these introductory remarks, Berengaudus departs to varying degrees from a literal reading of the verses. Concerning Berengaudus, see Achim Dittrich, "Berengaudus," BBKL, ed. Friedrich-Wilhelm Bautz and Traugott Bautz (Nordhausen, Germany: Verlag Traugott Bautz, 2010), accessed August 16, 2015, http://www.bbkl.de/lexikon/bbkl-artikel.php?art=./B/Be /berengaudus.art. About his interpretation of Rev 11:1-13, see Turner, "Revelation 11:113," 97-98. Cf. Petersen, Preaching, 30. Note also Haugg's other references to Berengaudus' interpretation of Rev 11:1-13 at Haugg, Die zwei Zeugen, 96, 101, 114-115, 124-130.

${ }^{132}$ Haugg, Die zwei Zeugen, 113. 
assume that Rev 11:9-12 contains nothing that readily warrants spiritualization and that therefore the verses should probably be taken literally. This assumed circumstance is what creates doubts about attempts to interpret these verses symbolically. The next two arguments examined help to justify this assumption, besides of themselves supporting the broad claim.

Evidence for a literal ascension of the witnesses

For the next argument examined here, Haugg says, "The attempt was not made to generalize the ascension of the Messiah in Rev 12:5." 133 He assumes here that Jesus' ascension is mentioned in Rev 12:5 and that followers of the symbolic approach take the text similarly. ${ }^{134}$ With this statement, Haugg calls into question the basis for generalizing the ascension in Rev 11, that is, transforming it into something non-literal and abstract. ${ }^{135}$ He leads readers to consider whether any reason actually exists for not understanding the ascension in Rev 11 literally, as has been done with the ascension in Rev 12. Presumably, Haugg wants readers to conclude that there is really no basis for the generalization in Rev 11 and that consistency calls for a literal understanding of this ascension as well. Of course, taking the ascension in Rev 11 in a literal way implies that the death and the resurrection of the witnesses cannot be generalized either.

Therefore, while arguing for consistency, Haugg appears to have shown the need

${ }^{133}$ Ibid.

${ }^{134}$ Haugg does mention Rev 12 elsewhere, but not the portrayal of the ascension. See ibid., 26, 70, 74, 78 .

${ }^{135} \mathrm{Cf}$. again some of Haugg's criticism of the purely symbolic interpretation of Rev 11:1-13, which is discussed above and is present at ibid., 112-113, 124, 130. 
for a literal understanding of the witnesses' fate. As suggested above, a literal understanding of their fate entails that they are in fact two actual people. Thus, this argument also supports Haugg's broad claim about "definite individual personalities." 136

Yet, this point actually does more than that. It also validates assumptions that Haugg makes in some of the other arguments for his broad claim. If consistency demands a literal understanding of the witnesses' end, then surely only this understanding can provide "the full meaning of the words about the death, resurrection, and ascension of the two witnesses." ${ }^{137}$ Moreover, since this understanding is required, certainly it should function as a standard for judging proposed symbolic identifications of the witnesses, like the one that sees them as a symbol for "the martyrs of the church in general."138 As well, if consistency requires a literal reading of the witnesses' fate as told in Rev 11:7-12, then the whole account of Rev 11:9-12 should likely be taken literally without needing to be generalized or spiritualized.

How the witnesses are introduced

Haugg advances a second argument that justifies some of the underlying assumptions noted above, besides just supporting his broad claim. For this, he says, "The specific introduction of the two witnesses by itself should make one cautious." 139 Presumably, he means being cautious of interpreting the witnesses symbolically.

\footnotetext{
${ }^{136}$ Ibid., 113.

${ }^{137}$ Ibid.

${ }^{138}$ Ibid.

${ }^{139}$ Ibid.
} 
Understanding this point requires knowing what Haugg means by "the specific introduction of the two witnesses." First, it involves the definite article that John uses

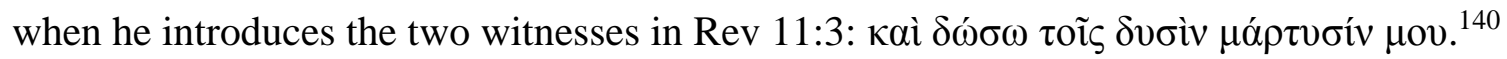
The presence of the article indicates that they are "familiar figures," even though there has been no prior mention of them in Revelation. ${ }^{141}$ Haugg explains this unusual circumstance by demonstrating that "the idea of forerunners or witnesses before the last judgment is already part of the heritage of apocalyptic traditions before the Revelation of John." ${ }^{142}$ Therefore, the definite article points readers to this concept and so helps to shape their understanding of the witnesses. ${ }^{143}$ Presumably, Haugg believes that this concept of messianic forerunners concerns "definite individual personalities." 144 Accordingly, Haugg has shown that the introduction of the witnesses indicates that they are actual people. Here then is the basis for Haugg's call for caution when one is tempted to interpret the witnesses symbolically.

Therefore, the argument here leads readers to favor a literal understanding of the two witnesses. Thus, it supports Haugg's broad claim about the importance of the witnesses' being "definite individual personalities." ${ }^{145}$ Yet, it does more than simply that.

${ }^{140}$ Ibid., 13, 21, 51.

${ }^{141}$ Ibid., 13; cf. 21, 51.

${ }^{142}$ Ibid., 15. For the actual demonstration, see ibid., 14-15; cf. 85-86.

${ }^{143}$ Ibid., 15, 78, 80, 137; cf. 87, 113.

${ }^{144}$ Ibid., 113; cf. 14-15, 85-86. Note also in this regard, a statement about John the Baptist: "Just as a real man, John the Baptist, preceded the Messiah at his first advent, so two prophets will introduce the Lord's second parousia." Ibid., 113.

${ }^{145}$ Ibid. 
This argument too validates assumptions evident in other arguments supporting that claim.

A response to Tyconius

To support his broad claim concerning the witnesses as two actual persons, Haugg also responds to an objection apparently made by the ancient commentator Tyconius. ${ }^{146}$ According to Haugg, Tyconius rejects the notion of the two witnesses as "individual personalities" because the time before the resurrection of the witnesses would be too

\footnotetext{
${ }^{146}$ Here and elsewhere in his monograph, for his understanding of Tyconius' thought, Haugg relies upon Tyconius Fragmenta commentarii in Apocalypsim. . . . (ed. Ambrogio Maria Amelli, Spicilegium Casinense . .., vol. 3, pt. 1, 261-331). So note Haugg, Die zwei Zeugen, 109, 113, 125-129. This piece is the first published edition of two fragments of a commentary on Revelation that has been linked to Tyconius. The commentary pieces belong to a tenth century manuscript that has been stored at the Biblioteca Nazionale Universitaria di Torino (the National University Library of Turin) since 1820. Although at times thought to represent portions of Tyconius' actual commentary on Revelation, the texts are in fact part of a revision of that lost work. For a discussion of the manuscript, the published editions, and the nature of the texts, see Roger Gryson, "Les sources," in Tyconii Afri Expositio Apocalypseos: Accedunt eiusdem Expositionis a quodam retractatae fragmenta Taurinensia, ed. Roger Gryson, Corpus Christianorum, Series Latina, 107A (Turnhout, Belgium: Brepols, 2011), 24-35. Cf. the older account to which Gryson occasionally refers at Francesco Lo Bue and Geoffrey Grimshaw Willis, "Introduction," in The Turin Fragments of Tyconius' Commentary on Revelation, ed. Francesco Lo Bue and Geoffrey Grimshaw Willis, Texts and Studies, Contributions to Biblical and Patristic Literature, n.s., 7 (Cambridge, United Kingdom: Cambridge University Press, 1963), 3-38. Gryson has provided a new edition of the Turin fragments in an appendix to his volume containing a reconstruction of Tyconius' lost commentary. See Tyconius Fragmenta Taurinensia (ed. Roger Gryson, CCSL, 107A:347-386). With all these matters and with the following paragraph, compare Mackay, "Early Christian Millenarianist Interpretation," 1:233-234, 245-249, 254, 269271, 316n45; Petersen, Preaching, 12-15, 24n83; Turner, "Revelation 11:1-13," 52-73; Weinrich, ed., Revelation, xxii-xxiv, xxix-xxx, 156-167 passim, 425; and David Charles Robinson, "The Mystic Rules of Scripture: Tyconius of Carthage's Keys and Windows to the Apocalypse" (PhD thesis, University of St. Michael's College, 2010), 7-10, 126-135, 189, 199-213, 226-232, accessed August 17, 2015, ProQuest Dissertations \& Theses Global.
} 
short for "the whole world" to "learn about the death of the two prophets." ${ }^{147}$ The idea that the time is too short appears to come from a literal understanding of the three-and-ahalf days during which the witnesses lie dead and unburied (Rev 11:9-10). In response, Haugg observes that Tyconius fails to notice "that here events are depicted within the vision." 148

Although the accuracy of Haugg's understanding of Tyconius might be debated, one can still look at this argument as it stands. ${ }^{149}$ For one thing, the response depends on

${ }^{147}$ Ibid., 113; cf. 29, 109.

${ }^{148}$ Ibid., 113; cf. 29.

${ }^{149}$ The passage from the Turin fragments that Haugg has in mind for the above arguments is as follows, without the editor's few notes and with some revisions in capitalization and punctuation: "(v. 11) . . . Et steterunt super pedes suos, et timor magnus cecidit super videntes eos.' (v. 12) 'Et audivi vocem magnam de calo dicentem: Ascendite huc, et ascenderunt in calum in nube.'-Hoc autem est quod Apostolus dicit: Rapiemur in nubibus obviam Christo in aera. (I. Thess. IV. 16). Ante adventum autem Domini scriptum est nulli hoc posse contingere, quoniam in adventum ipsius omnis caro probatur de sepulchris suis resurgere. Unde quorundam excluditur omnis suspitio, qui putant hos duos testes duos viros tantummodo esse, qui ante adventum Christi in nubibus dicunt ascendere. Nam quomodo poterunt habitantes terram de duorum hominum nece gaudere, si in una civitate morientur? Et quomodo invicem munera mittunt, si parvo tempore corpora eorum in plateis iacebunt, qui antequam gaudeant de nece eorum, statim contristabuntur de resurrectione eorum? Obstupescit in eis virtus et sensus, quod in tantam latitudinem terre non tam mortis eorum quam resurrectionis nuncius veniat. Aut qualis potest esse leticia aut voluntas apulantium, ubi cum aepulis foetor est mixtus mortuorum? Et timor magnus cecidit super eos videntes. Hoc de vivis hominibus dicit, qui in novissimo timore horribili quatientur, cum resurrectionem viderint dormientium" (plain script represented in italics in the original). Tyconius Fragmenta commentarii in Apocalypsim. . . 11.11-12 (ed. Amelli, Spicilegium Casinense . . . , vol. 3, pt. 1, 319320). Cf. Gryson's presentation of this passage at Tyconius Fragmenta Taurinensia $\S \S$ 397-403 (ed. Gryson, CCSL, 107A:379-380). According to my translation, the passage says, "'And they stood upon their feet, and a great fear fell upon those who saw them.' (v. 12) 'And I heard a loud voice from heaven, saying: Come up here, and they went up into heaven in a cloud.'-Now this is what the apostle says: We will be carried away in the clouds to meet Christ in the air. (1 Thess 4:16). Nevertheless, it is written that this cannot happen to anyone before the coming of the Lord, since all flesh is approved to rise 
Haugg's belief that Revelation originated primarily from a visionary experience and on what he perceives that that circumstance entails for interpretation. As noted, symbolism characterizes that experience and so the text that derives from it. The presence of symbolism means that the visionary world may not always correspond exactly with the real world and thus cannot be judged by its laws. It is this point that is significant for Haugg's response. Haugg considers Rev 11:1-13 to be one of the visions of Revelation, and therefore the content does not have to abide by the parameters that exist in the real world. More specifically, the statements in Rev 11:9-10 cannot be judged by the temporal and spatial norms of the real world. ${ }^{150}$ Consequently, Tyconius' supposed

again from their graves in relation to his coming. Hence, excluded is every suggestion of some who think that these two witnesses are only two men [and] who say that [they] will go up in the clouds before the coming of Christ. For how will those who inhabit the earth be able to rejoice about the death of the two men, if they [those two] will die in one city? Also, how do they [the inhabitants] send gifts to one another, if their bodies [the two men's bodies] will lie in the streets within a short interval? For they [the inhabitants] will immediately be saddened about their resurrection [the two men's resurrection] before they rejoice about their death [the two men's death]! Strength and reason are stupefied in them [the inhabitants], because a report, not so much of their death [the two men's death] as of [their] resurrection, comes into so great an extent of the earth. What kind of either joy or favor can there be for those feasting, when the stench of the dead has been mixed with food? And a great fear fell upon those who saw them. He says this about the living people who will be shaken in the end with terrible fear, when they see the resurrection of those who sleep." Haugg's response focuses on the rhetorical questions in the middle of this passage. Haugg characterizes the proposed problem as being one of enough time for news to travel about the death of the witnesses. This characterization seems misleading though when the actual passage is consulted. Indeed, there is a problem with a literal three-and-a-half days being too short, and there are references to hearing a report about the death and to distances in the world. Nevertheless, the passage emphasizes the shortness of time relative to celebrating the death of the witnesses, not hearing about their death. Moreover, it is possible that the passage envisions a compounding of the problem through the news of the resurrection spreading more rapidly than news of the death.

${ }^{150}$ Cf. again Haugg, Die zwei Zeugen, 29. 
objection becomes invalid because he has based it on the erroneous idea that Rev 11:1-13 on the literal level ought to adhere to the laws of the real world. ${ }^{151}$

Before moving on to other arguments, it is important to address a question that Haugg's response to Tyconius might elicit. Admittedly, some of the argumentation examined earlier also could have prompted this question. Now, however, with this argument against Tyconius, the question appears more pressing.

To bring the question into focus, first it is necessary to review elements of the discussion above. In dealing with Rev 11:1-2, Haugg differentiates at least two levels of meaning, the visionary level (apparently equivalent to the textual level) and the level of the real world. Accordingly, he treats these verses symbolically, with the visionary elements in 11:1-2 representing historical realities. For instance, the central element of the holy city with its temple complex is a symbol for the Christian church. In dealing with Rev 11:8, Haugg concludes that it is speaking of the same city as 11:1-2. Hence, there is one city throughout 11:1-13. Moreover, Haugg clearly sees this one city as the scene for the activity and the death of the witnesses. Therefore, the witnesses are depicted as living and dying within a setting that is symbolic. Haugg's answer to

${ }^{151}$ The argument as a whole may have been influenced by Wilhelm Hadorn (18691929), whom he quotes in the similar discussion at Haugg, Die zwei Zeugen, 29. See Wilhelm Hadorn, Die Offenbarung des Johannes, Theologischer Handkommentar zum Neuen Testament mit Text und Paraphrase 18 (Leipzig: A. Deichertsche Verlagsbuchhandlung D. Werner Scholl, 1928), 123.

While the intent of this argument is obviously to silence Tyconius' supposed objection, perhaps Haugg also intends to silence other similar objections. Essentially, Tyconius' objection points to a seemingly absurd circumstance that arises from a literal reading of Rev 11:3-13, so that he can demonstrate the error of a literal identification of the witnesses. Haugg's response could be used to address other objections formulated in this way. 
Tyconius corroborates this conclusion. When he affirms that the events involving the bodies of the witnesses ( $\operatorname{Rev} 11: 9-10)$ are visionary, he returns to the distinction between the visionary-textual level and the level of the real world. As with Rev 11:1-2 and 11:8, the visionary world is essentially an imaginary world characterized by things and events that do not and perhaps cannot exist in reality in their given form. Presumably, as with Rev 11:1-2 and 11:8, there is a symbolic significance here in 11:9-10. Once again, the witnesses are portrayed as existing within a setting that is symbolic.

Yet, when Haugg is expressly dealing with the identity of the witnesses, the overall thrust of his argumentation at that point is to expose the errors of symbolic identifications of the witnesses and to promote a literal identification of them. When speaking of the witnesses themselves, Haugg makes no mention of different levels of meaning. The figures in the vision apparently correspond exactly with figures in history. The question therefore might arise: How can Haugg advocate a literal identification of the witnesses and at the same time see them surrounded with a symbolic world? It is a question of consistency between his identification of the witnesses and his thoughts about the rest of the passage.

The answer to this question begins with the fact that Haugg disagrees with a thoroughgoing symbolic interpretation of Revelation, although he sees the book as predominantly symbolic. Therefore, in Haugg's thinking, the possibility exists for elements in the visionary-textual dimension to correspond exactly with elements in history. Incongruence between the levels of meaning does not necessarily exist in every case. Thus, it is possible for some items in Revelation to be understood literally. Hence, the two witnesses of the text could represent two witnesses in history. 
Another thing to consider is that Haugg is unsatisfied with saying that Rev 11:1-2 should be understood symbolically simply because symbolism prevails in Revelation. Although not detailed in the present discussion, Haugg advances specific arguments for taking 11:1-2 figuratively. This interpretive move is consistent with his rejection of a thoroughgoing symbolic perspective on Revelation.

The arguments that Haugg offers to promote specifically his view of the witnesses can now be seen in a different light. Again, he exposes the faults of a symbolic understanding of the witnesses and promotes the idea that the witnesses are literally two people. This part of his argumentation functions not only to elevate one kind of identification above others as the correct type. It also functions to justify a literal identification within the context of Haugg's understanding of Revelation as a book dominated by symbolism, but not absolutely so. In other words, the two witnesses of the text not only could represent two witnesses in history, but argumentation shows that they in fact do.

\section{Unnamed NT Era Prophets}

With the reasoning discussed so far, Haugg has established the witnesses as "two individual personalities sent by God or Christ before the end of time." ${ }^{152}$ Haugg though attempts to specify further who these witnesses are.

Haugg narrows the identification of the witnesses by claiming that they "will not be men of the Old Covenant, for example, Elijah, Moses, or Enoch, but personalities of

${ }^{152}$ Haugg, Die zwei Zeugen, 113; cf. 137. 
the New Covenant in the strength and power of Moses and Elijah." ${ }^{153}$ Involved here is Haugg's reading of the introduction of the witnesses in Rev 11:3. ${ }^{154}$ In the context of Rev 10:1-11:13, the phrase, "my two witnesses" (Rev 11:3), could identify them as Christ's witnesses. Haugg accepts this as probable. ${ }^{155}$ Presumably, he infers from this circumstance that the witnesses are Christian prophets, which means that they are part of the New Testament era.

Haugg makes a related claim when he says, "The Elijah-Enoch tradition cannot at all be based on Rev 11:1-13, while the Elijah-Moses tradition can be [based on it] only indirectly." ${ }^{156} \mathrm{He}$ is referring here to the other two significant futuristic, literal identifications. In this statement, Haugg contends that the Enoch-Elijah identification is utterly disconnected from the text of Rev 11. That this situation should render the identification unacceptable to Haugg is presumably because an exegetical identification, which is his apparent goal for the witnesses, must be grounded in the text. ${ }^{157}$ Haugg's

${ }^{153}$ Ibid., 113-114; cf. 133, 137.

${ }^{154}$ See ibid., 133. There Haugg says, "They are not men from Judaism ('my two witnesses'), not Old Testament prophets, but New Testament prophets." The phrase "my two witnesses" is drawn from the introduction of the witnesses in Rev 11:3. Its presence in this statement suggests a basis for the statement above. Since this statement is similar to the claim being discussed above, that claim too likely depends on the witnesses being introduced as "my two witnesses."

${ }^{155}$ Ibid., 3; cf. 26-27, 56-57, 63, 83, 114, 134, 136-137. Generally, however, Haugg seems indecisive about who sends the two witnesses and thus who would be the speaker in 11:3. Instead of Christ, Haugg sometimes says that God sends them. Ibid., 14, 17, 74, 131, 133; cf. 15-16, 18, 20-21, 29, 34, 114, 132, 134, 137. In other places, Haugg suggests that it is "God or Christ." Ibid., 13, 88, 113; cf. 14, 16. One time, he intimates that "God and Christ" send the witnesses. Ibid., 120.

${ }^{156}$ Ibid., 133.

${ }^{157}$ Ibid., 89, 98, 100-102. Recall the full title for Haugg's work. 
judgment concerning this identification probably comes in part from his review of certain Christian views of Enoch. ${ }^{158}$ These perspectives present no specific justification from Rev 11:3-13 for Enoch being considered one of the witnesses. In the above statement, Haugg also acknowledges some textual—and so exegetical—grounds for the MosesElijah identification. Elsewhere, he recognizes allusions in Rev 11:5-6 to the biblical stories of Moses and Elijah. ${ }^{159}$ Haugg believes that these references are used to depict the miraculous powers that the two witnesses possess. ${ }^{160}$ Yet, that is as far as the connection to Moses and Elijah goes. ${ }^{161}$ Other considerations prevent Haugg from going further. One of those has already been noted, namely, the portrayal of the witnesses as NT era prophets. Another is the fact that John leaves the witnesses nameless. Haugg infers from "this circumstance [that it] alone should warn [interpreters] . . . against capriciously inventing names." 162 Thus, he is unwilling to attach any names to the two witnesses, not just those of Moses and Elijah. In the end, expositors can draw some justification for the Moses-Elijah identification from the text of Revelation, but for Haugg it is insufficient to be able to declare this the exegetical identification of the witnesses.

$$
{ }^{158} \text { Ibid., 100-102; cf. 89, } 98 .
$$$$
{ }^{159} \text { Ibid., 17-20, 83, } 134 .
$$

${ }^{160}$ Ibid., 17-18, 20, 114, 133-134, 137; cf. 83. In fact, Haugg argues that the depiction of the supernatural powers of the witnesses is best taken literally. $\mathrm{He}$ concludes, "What was once possible at the time of Moses and Elijah could just as well be repeated in the time of the two final witnesses." Ibid., 134.

${ }^{161}$ Ibid., 114, 133. Note too when Haugg says, "The stated signs of power are borrowed from the story of Elijah and the story of Moses in the OT. The seer, however, in no way identifies the two witnesses with Moses and Elijah." Ibid., 134.

${ }^{162}$ Ibid., 133; cf. 98. 
Haugg has perhaps one more way of indicating that the witnesses should not be identified with prominent figures of the OT. He surveys various Jewish understandings of OT personalities to whom an eschatological role may have been assigned. ${ }^{163}$ Of particular interest among these reviews are those concerning Enoch, Moses, and Elijah, individuals that have often been associated with the witnesses. One intent of these brief surveys may be to address a particular kind of argument that interpreters might use to bolster their identifications of the witnesses with OT figures. One could argue that a certain OT individual, such as Moses, is to be seen as one of the witnesses because John has further developed an existing tradition concerning that individual. ${ }^{164}$ This is not a problem with respect to Elijah. Haugg presents evidence for the Jewish expectation of Elijah's eschatological return and notices its presence in Christian thinking. ${ }^{165}$ There is, however, in Haugg's opinion, less evidence for such an expectation concerning Enoch or Moses. ${ }^{166}$

\section{Summary and Conclusions}

Haugg's argumentation can be summarized with a view towards identifying the

${ }^{163}$ Ibid., 89-93, 98-100, 102-107.

${ }^{164}$ The intent to address this particular argument is suggested by Haugg's emphasis on examining traditions, particularly those involving individuals in eschatological roles. $\mathrm{He}$ is careful to point out whether evidence exists of a particular individual being assigned an eschatological function. This stands against the backdrop of the witnesses at times being considered eschatological entities, particularly when associated with Enoch, Moses, and Elijah.

${ }^{165}$ Haugg, Die zwei Zeugen, 89-93. Compare this with the discussion of forerunners of the end of time, at ibid., 14-15, 85-86.

${ }^{166}$ Ibid., 98-100 (Enoch), 102-105 (Moses). Compare this with the discussion of forerunners of the end of time, at ibid., 14-15, 85-86. 
broad issues of interpretation that are present in it. The issues identified here are listed in Figure 1 according to the order in which they are first mentioned.

To start, Haugg chooses to interpret Rev 11:1-13 eschatologically for several reasons. His reasoning can be divided into two parts. First, flaws are apparent in the alternative ways of reading the passage, the contemporary-historical approach and the two versions of the church/world-historical approach. Second, material from the book of Revelation itself not only helps to expose the flaws in the alternative approaches, but also points in a positive way towards approaching the passage eschatologically. Thus, verses of Revelation indicate that chapters 4-22 concern primarily the future relative to John.

1. Interpretive approach

2. Degree of symbolism

3. Context immediately after Rev 11:3-13 (11:15-18)

4. The three-and-a-half year period

5. Verb tenses in Rev 11:1-13

6. Context immediately before Rev 11:3-13 (11:1-2)

7. Setting for the episode of the two witnesses

8. Fate of the two witnesses (Rev 11:7-12)

9. Historical data

10. Origin of the book of Revelation

11. Introduction of the two witnesses (Rev 11:3)

12. Messianic forerunners

13. Lack of names for the two witnesses

14. Traditions about Enoch

15. Traditions about Moses

16. Traditions about Elijah

17. Miraculous powers of the two witnesses (Rev 11:5-6)

Figure 1. Broad issues of interpretation in Haugg's argumentation. 
More precisely, chapters 4-22 speak of the people and events linked to the last judgment. Complementing this circumstance is the apparent fact that even those parts of Revelation that do intersect with the time in which John is writing (i.e., Rev 2-3) contain few references to contemporary history. Also complementing this circumstance are specific indications within Rev 11:1-13 and its literary context that Rev 11:1-13 concerns people and events beyond John's era, near the time of the last judgment.

The overriding issue that these arguments suggest is a methodological one. What is the proper interpretive approach to Revelation and Rev 11:3-13 in particular? How can one best describe the relationship between history and the things portrayed in Revelation?

As for the specific matter of identifying the two witnesses, Haugg pays particular attention to the identifications that are offered by commentators who interpret Rev 11:113 in a purely symbolic way and in relation to the course of history since Christ. $\mathrm{He}$ endeavors to show that they are incorrect and that the two witnesses are "definite individual personalities." ${ }^{167}$ Inasmuch as Haugg is dealing with the option of a figurative interpretation of the two witnesses, he raises the issue of the degree to which symbolism plays a role in Revelation.

Haugg presents three arguments concerning the temporal situation of the witnesses. Relating the episode of the witnesses to the wider context of the series of seven trumpets orients the episode toward the end-time. The 1,260 days (approximately three and a half years) of activity for the witnesses represent a brief, limited period. The future verb tenses in Rev 11:2-3 orient the episodes in Rev 11:1-13 toward the time after

${ }^{167}$ Ibid., 112-114. 
John. Each argument here suggests a broad issue of interpretation. The first suggests the issue of the meaning of the context immediately after Rev 11:3-13, particularly the sounding of the seventh trumpet (11:15-18). The second implies the issue of the meaning of the three-and-a-half year period of the witnesses. The last argument implies the general issue of the verb tenses in Rev 11:1-13.

Haugg offers three arguments that focus on the meaning of Rev 11:1-2. These arguments raise the issue of what this immediate context before Rev 11:3-13 has to say about the identity question. He also offers a single argument that suggests the issue of the setting for the episode of the witnesses.

Several arguments center on the fate of the two witnesses - their death, resurrection, and ascension. The overriding issue for these arguments is therefore the significance that the portrayal of their fate has for the identity question. With respect to certain arguments, discussion of the witnesses' fate leads to the discussion of other issues.

The argument that points out that the witnesses are not just killed, but also rise and ascend, involves looking at the history of martyrs in the church. No record exists of their return to life. The broad issue of interpretation raised here is the role of historical data in identifying the two witnesses. As is clear from Haugg's argument, the issue concerns more than just historical data about people and events contemporary to John. Historical data from the time after John are also of interest.

Another issue is also raised by the argument that responds to Tyconius' apparent objection to seeing two individuals in the two witnesses. Haugg's response appeals to a preconception about the book of Revelation and its author. He has in mind a particular picture of the origin of the book of Revelation. 
To support his series of arguments centered on the fate of the witnesses, Haugg asserts that the way in which the witnesses are introduced in Rev 11:3 warns interpreters to beware of interpreting symbolically their fate and so the figures themselves. The introduction of the witnesses is therefore another issue of interpretation. This is probably not the only issue here when one considers Haugg's thoughts elsewhere about the introduction of the witnesses. There is also the issue of messianic forerunners. Haugg attaches this idea to the introduction of the witnesses as familiar figures.

The final component of Haugg's argumentation over the identity of the two witnesses is his attempt to specify further the identity of the witnesses. He concludes that they are two unnamed NT era prophets. Leading to this conclusion is Haugg's observation that the text attaches no names to the witnesses. This would seem to be another issue of interpretation. Likely leading to this conclusion is also Haugg's belief that these two witnesses are presented as Christ's witnesses and so prophets of the NT era. The issue of the introduction of the two witnesses is seen again. Another possible influence on this conclusion, however, is Haugg's examination of Jewish opinions about various OT figures whose names have sometimes been attached to the two witnesses, particularly Enoch, Moses, and Elijah. This influence is a negative one though, for these traditions obviously do not persuade Haugg to see the personal return of two OT personalities in the arrival of the two witnesses. His study of these traditions suggests an issue of interpretation related to each proposed individual. As might be expected, of particular importance are the issues of traditions about Enoch, of traditions about Moses, and of traditions about Elijah. Another issue here, one that helps to give rise to looking at the traditions about Moses and Elijah, concerns the miraculous powers of the two 
witnesses (Rev 11:5-6). Specifically, one may ask what does the description of powers have to say about the identity of the two witnesses?

Several broad issues of interpretation have been identified from Haugg's argumentation concerning the identity of the witness. What will soon be apparent is that many of these issues appear to be ones common in the debate over the identity question.

\section{Other Significant Expositions}

In this section, three other significant expositions on the identity of the two witnesses are examined. Like Haugg, the authors of these expositions identify the witnesses as two people appearing after the time in which John, the assumed author of Revelation, writes. These authors are James Henthorn Todd, Isbon Thaddeus Beckwith, and Christine Joy Tan. Haugg, of course, does identify the witnesses more precisely. For him, they are portrayed as nameless prophets at the end of the church age. They are thus unknown to some extent to John and the readers of Revelation until they fulfill the narrative of Rev 11:1-13. With this in mind, Beckwith's conclusion on the identity question stands very close to Haugg's. Todd is perhaps not as decisive as Haugg and Beckwith are when he offers a conclusion similar to theirs. Todd says so much about the Enoch-Elijah view that one might think that this was his preferred identification. That, however, would be a mistake. ${ }^{168}$ As for Tan, she concludes an earlier work in favor of an identification like Haugg's. Yet, in a later work, the one featured here, she steps back from such a specific identification, so that she can focus on strengthening the defense of a whole class of futuristic, literal identifications. Therefore, there is a degree of agreement

\footnotetext{
${ }^{168}$ Turner makes this mistake. See Turner, "Revelation 11:1-13," 273.
} 
among the conclusions presented by these four authors on the identity question. In fact, this degree of agreement in the conclusions stands in spite of the presence of other differences among them. For instance, they sometimes differ among each other in their conceptions about the book and its author, in the details of their approaches to interpreting Rev 11:1-13, and even in their conclusions about elements in the passage.

Both the measure of agreement and the differences are important for the purposes of this section inasmuch as one purpose is to expose other arguments that could be offered to support an identification similar to Haugg's. In some cases, these arguments could supplement the array of arguments found in Haugg's study. In other instances, they might function as alternatives.

Another purpose for this section is to show that many of the broad issues of interpretation deduced from Haugg's arguments have an existence beyond his study. They are truly issues in the debate over the identity of the two witnesses, at least among those commentators who understand them to be two people appearing after the days of John.

\author{
James Henthorn Todd
}

\title{
Introduction
}

James Henthorn Todd (1805-1869) discusses the identity of the two witnesses 
within a series of published lectures about the antichrist in Revelation. ${ }^{169}$ His arguments

on the identity of the two witnesses can be summarized with a view to exposing the broad

${ }^{169}$ Todd, Six Discourses. Todd was an Irish scholar and a clergyman of the Church of Ireland. He earned several degrees from Trinity College in Dublin (BA [1825], MA [1832], BD [1837], and DD [1840]). Todd became a fellow at Trinity College in 1831 and attained to the status of senior fellow in 1850. A year before becoming a senior fellow, he was appointed Professor of Hebrew. Todd was associated with Trinity College in other ways as well. Most notable among them was his involvement with the library. He was involved in the administration of the library in some capacity nearly every year from 1834 until his death. Outside the college, Todd was an active member of the Royal Irish Academy from 1833 onward, even functioning for a time as its president (1856-1861). He also helped establish the Irish Archaeological Society (1840) and was later elected as a fellow of the Society of Antiquaries of London (1853). Todd was also an editor and an author, having his hand in numerous literary projects. Evident in his activities for the Trinity College Library, in his actions as a member of learned societies, and in his literary efforts is Todd's key interest in Irish history and literature. Perhaps in line with that interest, Todd helped found St. Columba's College in 1843. It was intended to be a truly Irish church school, which meant in part that Irish language and literature would be taught there. An apparently less central interest for Todd is his interest in theology. The work under discussion in this chapter and Todd's complementary work on prophecies in the book of Daniel and in the writings of Paul are evidence of this interest. Both works represent the publication of lectures that Todd gave as the Donnellan lecturer for 1838 and 1841. The complementary work is James Henthorn Todd, Discourses on the Prophecies Relating to Antichrist in the Writings of Daniel and St. Paul. . . . (Dublin: Hodges and Smith; London: J. G. F. and J. Rivington, 1840), accessed August 17, 2015, Dallas Theological Seminary Turpin Library Rare Books Collection. Concerning these and other aspects of Todd's life and work, see Frederic Boase, "Todd, James Henthorn," Modern English Biography (Truro, United Kingdom: by the author, 1892-1921, reprint, London: Frank Cass \& Co., 1965), 3:980; Maurice Craig, "Academy House and Its Library," in The Royal Irish Academy: A Bicentennial History, 1785-1985, ed. T. Ó Raifeartaigh (Dublin: Royal Irish Academy, 1985), 325; The Dublin University Calendar, for the Year 19121913, vol. 3 (Dublin: Hodges, Figgis; London: Longmans, Green, 1913), 80, 82, 160-161, 163, 330, 334, 430-431, 445-446, 448, 592, accessed August 17, 2015, Internet Archive Canadian Libraries Collection; R. B. McDowell, "The Main Narrative," in The Royal Irish Academy: A Bicentennial History, 1785-1985, 34-35, 44-48, 56, 57-60, 72-73; G. F. Mitchell, "Antiquities," in The Royal Irish Academy: A Bicentennial History, 1785-1985, 100, 109-110, 114-115; "Obituary," Medical Times and Gazette, no. 992 (July 3, 1869): 22, accessed August 16, 2015, Google Books; "Presidents of the Royal Irish Academy: 1785 to 1985," in The Royal Irish Academy: A Bicentennial History, 1785-1985, 337; E. G. Quin, "Irish Studies," in The Royal Irish Academy: A Bicentennial History, 17851985, 166, 169-170, 174-175; Charles Anderson Read, "James Henthorn Todd (1805- 
issues of interpretation raised by them. The issues identified here are listed in Figure 2

(see the next page) according to the order in which they are first mentioned.

\section{Starting Points for Todd}

Two of Todd's convictions relative to the whole of Revelation significantly affect his handling of the identity of the two witnesses. Todd maintains that an eschatological approach is appropriate for Revelation in general, ${ }^{170}$ and he believes firmly in the primacy of the letter of the text when interpreting Revelation and in fact the whole Bible. ${ }^{171}$ One issue here is methodological, namely, what is the proper interpretive approach to Revelation and particularly the episode of the witnesses. Another issue here involves a broad preconception about Revelation and its author. Although Todd's

1869)," in The Cabinet of Irish Literature: Selections from the Works of the Chief Poets, Orators, and Prose Writers of Ireland, 4 vols., ed. Charles Anderson Read, Thomas Power O'Connor, and Katharine Tynan Hinkson, New ed. (London: Gresham, 19021903), 3:57-58, accessed August 16, 2015, Internet Archive American Libraries Collection; George Otto Simms, "James Henthorn Todd," Hermathena, no. 109 (Autumn 1969): 5-23, accessed August 17, 2015, JSTOR; W. B. Stanford, "Polite Literature," in The Royal Irish Academy: A Bicentennial History, 1785-1985, ed. T. Ó Raifeartaigh (Dublin: Royal Irish Academy, 1985), 192-196; Philip Henry Stanhope, "Address of the President, April 26, 1870," Proceedings of the Society of Antiquaries of London 2nd ser., 4 (November 21, 1867-June 16, 1870): 476-477, accessed August 16, 2015, Google Books; Elizabeth Marion Todd and Sinéad Agnew, "Todd, James Henthorn (18051869)," ODNB, ed. Henry Colin Gray Matthew and Brian Howard Harrison (Oxford: Oxford University Press, 2004), 54:883-884; and James Henthorn Todd, A Catalogue of Graduates Who Have Proceeded to Degrees in the University of Dublin, from the Earliest Recorded Commencements to July, 1866: With Supplement to December 16, 1868 (Dublin: Hodges, Smith, and Foster; London: Longmans, Green, Reader, and Dyer, 1869), 564, accessed August 17, 2015, Google Books.

${ }^{170}$ On this perspective, see Todd, Six Discourses, 3-45, 49-80, 83-85. Presumably, Todd does not include the addresses to the seven churches (Rev 2-3) among the parts of Revelation that are primarily eschatological. After all, Todd does not discuss these seven epistles in his work.

${ }^{171}$ On this matter, see, for example, ibid., v-xx. 
1. Interpretive approach

2. Degree of symbolism

3. Distinguishing the symbolic from the literal

4. Historical data

5. Image of the olive trees

6. Image of the lampstands

7. Person-oriented language for the two witnesses

8. Theme of testimony

9. Theme of prophecy

10. Miraculous powers of the two witnesses (Rev 11:5-6)

11. Fate of the two witnesses (Rev 11:7-12)

12. Duality of the witnesses

13. Early interpretation of the two witnesses

14. Traditions about Elijah

Figure 2. Broad issues of interpretation in Todd's argumentation.

assumption is about the primacy of the letter of the text, I would say that the broad issue here concerns the degree to which symbolism plays a role in Revelation. I know of no one who actually argues for a purely literal approach to Revelation. Like Todd, there is an acknowledgement of the presence of symbolism in Revelation. The divisions among interpreters arise over the degree of symbolism to be seen in Revelation. The issue is the same for those like Todd who prefer to understand things literally and for those unlike Todd who prefer to understand things symbolically. The differences exist in how interpreters address the issue. Although he does so briefly, Todd also remarks in this context on distinguishing the symbolic from the literal and so raises another methodological issue. ${ }^{172}$

${ }^{172}$ So, for example, note ibid., xix-xx. 
Todd's arguments that directly address Rev 11:3-13 begin with his comparison of the text of Rev 11:3-13 with extant knowledge of church history. This comparison confirms the propriety of interpreting Rev 11:3-13 eschatologically and at a great distance in time from John. ${ }^{173}$ Nothing like what is described there can be found in history, and thus, it is an unfulfilled prediction. ${ }^{174}$ The comparison suggests the general issue of how historical data affect the interpretation of the two witnesses. The discussion of this issue can refer not just to the people and events contemporary to John, but also to those appearing long after him.

\section{The Two Witnesses Are Two Literal Figures}

While Todd contends that the episode of the witnesses is still to be fulfilled, historically oriented interpretations of the passage abound. ${ }^{175}$ Therefore, Todd offers several arguments to counter these interpretations of Rev 11:3-13. His remarks on these interpretations are really directed only at views of the passage that understand the two witnesses symbolically. Specifically, he looks at two classes of symbolic identifications:

${ }^{173}$ Todd accepts that the Apostle John has composed Revelation. Among the many pages giving a sense of Todd's opinion on the authorship of Revelation, see ibid., viii-ix, xvi-xvii, xxxii-xxxiii.

${ }^{174}$ Ibid., 191; cf. 41-45.

${ }^{175}$ For historically oriented interpretations, Todd has in mind mostly (1) those that look to (primary) fulfillments during the time of the early church and (2) those that see fulfillments in the span of history from days of the first disciples to the end of the world. These two groups correspond to the contemporary-historical interpretation and to the church- (or world-) historical interpretation that is concerned with particular people and events. Todd finds these two types of interpretation reflected among his ecclesiastical contemporaries. Ibid., 41-42; cf. 23-40. Todd also has in mind, however, the allegorical interpretation as far as it embraces historical elements. Ibid., 22-23; cf. 12-22. 
first, that the witnesses represent a group or groups of people; second, that they symbolize impersonal or inanimate entities. He dismisses the latter class quite quickly, but has much more to say about the former. Both classes of identifications, however, are found inadequate.

For the first few arguments, Todd counters the claim that the designation of the witnesses as "the two olive trees and the two lampstands" (Rev 11:4, ESV) indicates that they represent churches. ${ }^{176}$ The use of olive trees in Jer 11:16 and Rom 11:17-26 and the use of lampstands in Rev 1:20 have apparently been offered in support of this claim. Todd observes, however, that the circumstances surrounding the appearance of the olive trees and the lampstands in Rev 11:4 are different from those in the other passages; thus, he doubts the alleged parallelism. He also highlights a unique circumstance for the figures in 11:4. Throughout 11:3-13, personal language is used to describe the two witnesses and the events involving them. ${ }^{177}$ Such language blunts the force of anything that can be drawn from the other passages to support a symbolic understanding of the witnesses. Moreover, Todd notices that Rev 11:4 alludes to the vision of Zech 4, particularly with respect to the olive trees. The olive trees in that passage are clearly two persons and not two churches. ${ }^{178}$ This indicates that the witnesses are two people too.

${ }^{176}$ Ibid., 192-194.

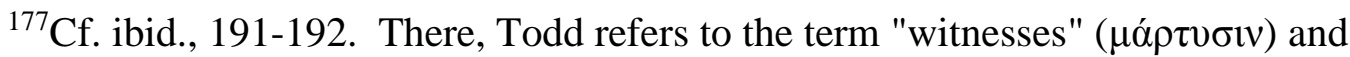
the term "prophets" ( $\pi \rho \circ \varphi \tilde{\eta} \tau \alpha)$. He also points to the fact that they wear sackcloth, can be hurt, perform wonders, are fought with, are killed, lie dead, stand on their feet, and hear a voice from heaven.

${ }^{178} \mathrm{Cf}$. Todd's other thoughts about the meaning of Zech 4 and the significance of the allusion to it in Rev 11:4 at ibid., 180-185. 
Two focal issues for the first few arguments are therefore the image of the olive trees and the image of the lampstands. One argument among these few suggests another issue of interpretation, namely, that of the person-oriented language that is used to describe the witnesses. Laying out that language raises some important secondary issues for Todd. Inasmuch as Todd refers to the terms "witnesses" and "prophets," he suggests the themes of testimony and prophecy. The other elements from Rev 11:3-13 that Todd highlights involve the miraculous powers (11:5-6) and the fate of the witnesses (11:7-12).

The next argument objects to the idea that the witnesses are themselves a symbol as opposed to their symbolic nature being indicated through Rev 11:4. In this argument, Todd argues from the perspective that literal elements in Revelation can be distinguished from symbolic elements. He suggests two principles by which one ought to abide. ${ }^{179}$ The first principle has to do with whether there is anything explicit in the text that indicates that a symbol is present. The second principle involves asking whether, if symbolism is simply assumed, does such an assumption lead to a convincing explanation of the passage. Therefore, Todd takes up once more the issue of distinguishing the symbolic from the literal in Revelation.

After this, Todd compares the actual text to the historical events and people that are supposedly portrayed in the episode of the witnesses. He does this at first broadly with respect to the major details in the description of the witnesses, ${ }^{180}$ but then he focuses his attention on the fate of the witnesses. ${ }^{181}$ The symbolic interpretations portray that fate

\footnotetext{
${ }^{179}$ Ibid., 194-195.

${ }^{180}$ Ibid., 198-202.

${ }^{181}$ Ibid., 202-204.
} 
as only seeming to happen - an apparent death, resurrection, and ascension. The text, however, according to Todd, has these events as actual occurrences, not mere illusions. Two issues seem clear from these comparisons. On the one hand, there is the broad issue of how historical data affect the identity question. On the other hand, there is the issue of the fate of the two witnesses.

Todd also disagrees with historical interpretations that identify the witnesses with impersonal or inanimate entities. ${ }^{182}$ At the very least, he refers generally to the linguistic details of the passage, while also highlighting a specific interpretive principle. For the latter, Todd puts forth a rule for identifying symbols in Rev 11 and presumably other contexts. He points out that it is unlikely that "persons should be employed as symbols of inanimate things." ${ }^{183}$ He returns therefore to the issue of distinguishing the symbolic from the literal in Revelation.

Todd's commentary on the two witnesses may contain two other points and so two other issues of interpretation. One point concerns the duality of the witnesses. Many historically oriented interpretations seem to ignore this facet of the text. ${ }^{184}$ The other point concerns the history of the interpretation of the two witnesses. Todd observes the harmony between his literal understanding of the witnesses and the general opinion of the early church. ${ }^{185}$

${ }^{182}$ Ibid., 195-196.

${ }^{183}$ Ibid., 196.

${ }^{184}$ Ibid., 191-192.

${ }^{185}$ Specifically, Todd observes that a literal view of the witnesses was the view of the early church until the advent of historically oriented interpretations of Revelation in 


\section{The Question of Greater Specificity}

The prior arguments have established Todd's approach to interpreting the passage and the witnesses. Thereby, he declares the witnesses to be two actual people appearing in the distant future relative to John. ${ }^{186}$ Todd then considers whether these two individuals might not be Enoch and Elijah returning to earth for a new ministry. ${ }^{187}$ After presenting the thoughts of earlier commentators and showing that Elijah will personally come again, Todd offers a decisive argument against more specificity. Todd observes that, while Elijah has a positive effect on people during his future ministry, the two witnesses do not have such an effect during their ministry. A positive effect on people

comes only after they have gone from the scene and an earthquake has shaken the city. ${ }^{188}$ The broad issue of interpretation here is the traditions about Elijah.

\section{Conclusion}

By expressing doubt about Elijah as one of the witnesses, Todd sets aside the two main attempts to specify further the identity of the two witnesses, namely, the MosesElijah view and the Enoch-Elijah view. Accordingly, he concludes his whole discussion

the fourteenth century. Ibid., 205; cf. 12-35, 49-51. Yet, he does not explicitly say that this circumstance bolsters his interpretation of the two witnesses. At least from the perspective of someone in the twenty-first century, Todd's statement about the unity in the early church on the interpretation of the tale of the witnesses seems oversimplified and misleading. Note the overview of some of this history at the beginning of the present chapter.

${ }^{186}$ Ibid., 204-205.

${ }^{187}$ Ibid., 206-211.

${ }^{188}$ Ibid., 211-212. 
of the two witnesses, stating, "All, therefore, that can be with certainty affirmed from the prophecy is, that two prophets will be raised up within the Jewish branch of the Church, after the apostacy $[s i c]$ and rejection of the Gentiles, who will continue to prophesy ... during ... the period of Antichrist's dominion." ${ }^{189}$ Thus, Todd concludes with an identification of the witnesses akin to that of Haugg, even though his opinions on related matters in Rev 11:3-13 conflict with aspects of Haugg's interpretation. ${ }^{190}$

Similarities and differences in the details aside, Todd's remarks concerning the two witnesses exhibit some of the broad issues of interpretation apparent in Haugg's comments, while also complementing them with other issues.

Isbon Thaddeus Beckwith

\section{Introduction}

Isbon Thaddeus Beckwith (1843-1936) speaks about the two witnesses in his commentary on Revelation. ${ }^{191}$ As was done for Todd's argumentation, Beckwith's

${ }^{189}$ Ibid., 212; cf. 194. After the portion quoted above, Todd's statement continues with a literal retelling of the witnesses' fate and the events in the city (Rev 11:7-13).

${ }^{190}$ Perhaps the most obvious difference from Haugg is about the audience for the witnesses. Haugg, as observed above, saw the apostate members of the church as the primary audience of the two witnesses. Recall, for instance, his fourth conclusion, which is quoted much earlier in this chapter and taken from Haugg, Die zwei Zeugen, 137. Todd, however, speaks of Jewish Christians. Todd, Six Discourses, 184-185; cf. 178, 186, 188, 190, 194.

${ }^{191}$ Beckwith, Apocalypse. Beckwith was an American scholar and a clergyman of the Episcopal Church. He earned a BA (1868) and a PhD (1872) from Yale. He studied theology and classical language and literature abroad (1872-1874), at the University of Göttingen and at Leipzig University. Beckwith later obtained a DD (1898) from Trinity College in Hartford, CT. Professionally, Beckwith was primarily an educator. He taught Greek at East Tennessee University in Knoxville (1868-1870), at Yale (1870-1872, 18741879), and at Trinity College (1879-1898). From 1898, however, he taught biblical studies, first at General Theological Seminary in New York City (1898-1906) and then at 
arguments about the identity of the two witnesses can now be summarized with a view to exposing the broad issues of interpretation raised by them. The issues identified here are listed in Figure 3 (see the next page) according to the order in which they are first mentioned.

\section{Starting Points for Beckwith}

One can find four reasons for why Beckwith places the episode of witnesses in the eschatological future. ${ }^{192}$ First, Beckwith believes that John, the author of Revelation, ${ }^{193}$ speaks considerably about people and events that are future to him and that are connected

Trinity College (1907 until at least 1910). Besides the commentary featured in the present chapter, Beckwith's other major literary effort was Euripides Bacchantes (ed. Isbon Thaddeus Beckwith, College Series of Greek Authors, accessed August 16, 2015, Google Books). Incidentally, Beckwith was also a member of some scholarly societies. Concerning these and other aspects of Beckwith's life, see Burton Scott Easton, "Notes and Comments," Anglican Theological Review 19, no. 1 (January 1937): 30, accessed November 16, 2015, EBSCOhost ATLA Religion Database with ATLA Serials; "Isbon Thaddeus Beckwith, B.A. 1868," Bulletin of Yale University 34, no. 6 (December 1, 1937): 9-10; = "Isbon Thaddeus Beckwith, B.A. 1868," Obituary Record of Graduates of Yale University, no. 96 (1936-1937): 9-10, accessed August 16, 2015, Yale University Library Manuscripts and Archives Yale Obituary Record 1859-1952; Who Was Who in America, vol. 2 (1950, reprint), s.v. "Beckwith, Isbon Thaddeus."; and Henry Parks Wright, ed., History of the Class of 1868, Yale College, 1864-1914 (New Haven, CT: Tuttle, Morehouse \& Taylor Press, 1914), 69-71, accessed August 17, 2015, Internet Archive American Libraries Collection.

${ }^{192}$ That they are entities of the eschatological future is apparent at Beckwith, Apocalypse, 272-274, 584-585, 588-590, 595-596; cf. 156-165.

${ }^{193}$ Beckwith favors the idea that author of Revelation is the apostle John, who also authored the Gospel of John. His detailed discussion of the matter appears at ibid., 343393. 
1. Interpretive approach

2. Context immediately after Rev 11:3-13 (11:15-18)

3. Central theme of Rev 11:1-13

4. Apocalyptic source for the episode of the witnesses

5. Lack of names for the two witnesses

6. Image of the olive trees

7. Miraculous powers of the two witnesses (Rev 11:5-6)

8. Traditions about Moses

9. Traditions about Elijah

10. Conception of Jesus in Revelation

11. Religious background of the author of Revelation

12. Crucified lord of Rev 11:8

13. Traditions about Enoch

14. Setting for the episode of the two witnesses

15. Context immediately before Rev 11:3-13 (11:1-2)

16. Person-oriented language for the two witnesses

17. Degree of symbolism

18. Interpretation of symbolism

Figure 3. Broad issues of interpretation in Beckwith's argumentation.

with the end of the present age. ${ }^{194}$ This is one component of Beckwith's overall interpretive approach to Revelation. ${ }^{195}$ Here raised is the broad issue of what is the proper interpretive approach to use in reading Revelation and Rev 11:3-13 in particular.

${ }^{194}$ Ibid., 166-169, 417-419, 442-443, 504-505, 515-516, 549, 554-555, 606-607; cf. 156-165, 216-217, 255-258, 261-262, 266-267, 269, 318, 335, 495.

${ }^{195}$ Other assumptions complete his approach as well as color what it means for Rev 11:1-13 and other passages to concern the eschatological future. First, although John has in mind future events and individuals, he grounds those things firmly in the people and events that exist in his present world. Ibid., 442-444; cf. 156-159, 216-217, 255-258, 261-262, 318, 335, 417-419, 504-505. Second, the content of Revelation is intended explicitly for a group of first-century readers. Ibid., 335; cf. 208-210, 255-259, 290-291, 423-424, 436-437, 446-447, 777. Third, although Revelation is a genuinely prophetic book, this does not mean that every prediction of Revelation must have an exact 
Second, Beckwith places the episode of the witnesses in the eschatological future because Rev 11:1-13 stands before the sounding of the seventh trumpet, which announces the last series of events leading to the eternal kingdom. ${ }^{196}$ The issue of interpretation here concerns the meaning of the immediate context after the episode of the witnesses.

Third, Beckwith conceives the central theme of Rev 11:1-13 as being an end-time event, namely, the eschatological repentance of Israel. ${ }^{197}$ Beckwith's argumentation here raises the issue of how the central theme of at least $\operatorname{Rev} 11: 3-13$ influences the identity question.

Fourth, Beckwith sees Rev 11:3-13 as concerning matters of the eschatological future, because he assumes that the whole of Rev 11:1-13 derives from a Jewish apocalyptic piece. ${ }^{198}$ He supposes that this source was a prediction concerning the temple, Jerusalem, and Moses and Elijah, all forming a chronicle of events before the

fulfillment. Ibid., 291-304; cf. vi-vii, 239-240, 334-336. Indeed, most of the predictions remain unfulfilled, but this is not a theological problem that needs to be avoided either through a thoroughgoing symbolic approach to their interpretation or through an approach that considers Revelation to be offering a genuine picture of the distant future. Ibid., 291-292, 296-299. Beckwith's perspective on the matter of unfulfilled prophecy appears at ibid., 299-301. It may also be noted that Beckwith's understanding of prophecy and of Revelation as a prophetic text corroborates his opinion about the primary audience for the book of Revelation. See ibid., 304-306; cf. vi, 208-213, 291, 334-336. All four assumptions (the three here and the one above) together form a kind of contemporary-historical approach to interpreting Revelation. Ibid., 334-336; cf. 1-3, 319320, 330-334.

${ }^{196}$ Ibid., 589-590; cf. 157-163, 274-275, 606.

${ }^{197}$ Ibid., 588-590; cf. 272-274, 586, 590-593, 596-599, 601-604. Beckwith intends his conception of the central theme of Rev 11:1-13 to address the perceived difficulty of meaningfully relating this passage to the rest of Revelation and the rest of the NT. See ibid., 584-586.

${ }^{198}$ Ibid., 584-588; cf. 174, 221-222, 273, 604-606. 
coming of the Jewish messiah. ${ }^{199}$ Inasmuch as the source is eschatological, the Christian re-working of this source, the present passage of Rev 11:1-13, could also be eschatological. The broad issue of interpretation suggested here is the possibility of an apocalyptic source for the episode of the witnesses.

\section{Arguments concerning the Witnesses as Two Particular Individuals}

Beckwith offers several arguments that are more directly connected to the question of the identity of the two witnesses. Four concern the two witnesses as not being Moses and Elijah personally, although the source document supposedly named them as these two figures. ${ }^{200}$ The two witnesses are now merely two individuals that fulfill their presumed future role. The first argument points out that the names of Moses and Elijah are lacking in the text. ${ }^{201}$ This circumstance is likely a transformation of the original source, which would have had the names of Moses and Elijah. ${ }^{202}$ This argument deals with the issue of there being no names given to the witnesses. For the second argument, Beckwith observes that part of the description of the two witnesses is in fact associated with two other figures, Zerubbabel and Joshua. ${ }^{203} \mathrm{He}$ has in mind here the

${ }^{199}$ Ibid., 587; cf. 585, 593-595.

${ }^{200}$ For reasons why Beckwith believes Moses and Elijah were in the original document, see ibid., 593-595; cf. 39-40.

${ }^{201}$ Ibid., 595; cf. 593.

${ }^{202}$ Ibid., 593; cf. 595.

${ }^{203}$ Ibid., 595. 
allusion to Zech 4 in Rev 11:4. ${ }^{204}$ Beckwith believes, as many do, that the "two olive trees" of Zech 4 refer to the two Jewish leaders in the days of Zechariah. This argument concerns the image of the olive trees. For the third argument, Beckwith looks to the description of the miraculous powers of the two witnesses. He recognizes that this description draws upon the stories of Moses and Elijah, the beginnings of which are in the OT. ${ }^{205}$ Yet, he also notices that John attaches the same powers to both witnesses. Each witness is portrayed in the likeness of Moses and in the likeness of Elijah. ${ }^{206}$ This argument raises the issue of the miraculous powers of the witnesses as well as the issues of the traditions about Moses and of traditions about Elijah.

In the fourth argument, Beckwith addresses why John transformed a prediction about Moses and Elijah returning into one concerning two prophets coming in their likeness. The author of Revelation might not have known the Christian opinion that regarded John the Baptist as the fulfillment of the prophesied return of Elijah.

Nonetheless, as a Jewish Christian, he surely believed Jesus to be the fulfillment of various OT prophecies. ${ }^{207}$ Thereby, the precedent is set that a prophecy can refer merely "to agents who should act in the 'spirit and power' (Lk. $\left.1^{17}\right)$ of former servants of God, and perform the offices of these." ${ }^{208}$ In this broad argument, there is at least the issue of

${ }^{204}$ Ibid., 273, 593, 600.

${ }^{205}$ Ibid., 595; cf. 273, 585, 593-594, 596, 600-601.

${ }^{206}$ Ibid., 595.

${ }^{207}$ On the significance here of John being a Jewish Christian, cf. ibid., 272-274, 588-591.

${ }^{208}$ Ibid., 595; cf. 402-403, 408. 
the possibility of an apocalyptic source for the episode of the witnesses. Other possible issues here are Elijah traditions and the conception of Jesus in Revelation. Inasmuch as Beckwith has in mind a particular conception of the author of Revelation as a JewishChristian, the religious background of the author is also a possible issue.

In harmony with this argumentation against the witnesses being Moses and Elijah personally, Beckwith contends that the witnesses are Christian prophets. ${ }^{209}$ While perhaps drawing again on his conception of John as a Jewish Christian, Beckwith definitely appeals to the apparent reference to Christ's crucifixion in Rev 11:8 to support this contention. $^{210}$ Therefore, he raises at least the issue of the meaning of the crucified lord of Rev 11:8. Possibly, there is also the issue of the religious background of the author of Revelation.

It should also be noted that Beckwith rejects the possibility that Enoch is to be associated with the witnesses. ${ }^{211}$ Implicit in this denial is a presumed knowledge of the traditions about Enoch. Such a knowledge must be in mind to say that there is no connection with Rev 11:3-13. Therefore, the issue of the traditions about Enoch also plays a role in Beckwith's argumentation.

\title{
Arguments against Interpreting Rev 11:1- 13 Figuratively
}

Beckwith also argues against attempts to understand the measuring episode (Rev

\author{
${ }^{209}$ Ibid., 591; cf. 595-596. \\ ${ }^{210}$ Ibid., 591; cf. 590, 601-602. \\ ${ }^{211}$ Ibid., 595; cf. 40, 321, 326, 331.
}


11:1-2) and the tale of the witnesses (11:3-13) figuratively, particularly as relating in some way to the church. ${ }^{212}$ Thus, in one place, Beckwith addresses the idea of interpreting the whole of Rev 11:1-13 symbolically. ${ }^{213}$ Specifically, he begins with the broad assertion that the passage does not indicate an intended allegory in relation to Christians and the church. Two points then confirm and complement this assertion. First, he argues that the earthly Jerusalem is pictured in Rev 11:1-13. ${ }^{214}$ Second, Beckwith demonstrates that the rest of the NT in fact associates neither Christians nor the church with the temple of Jerusalem or the city itself. ${ }^{215}$ These two points suggest two issues that are closely connected to each other through the figure of a city ( $\operatorname{Rev} 11: 2,8$, 13). There is the issue of the setting for the events of 11:3-13 and the issue of the meaning of the immediate context before 11:3-13 (11:1-2).

In another place, Beckwith dismisses an allegorical understanding specifically of

${ }^{212}$ Although he disagrees with a figurative interpretation of Rev 11:1-13, Beckwith cannot escape from seeing at least some critical aspects of the passage symbolically, including the time periods. Ibid., 181, 250-252, 273-274, 584-593, 596601. Consistency in Beckwith's thinking comes from the fact that his arguments against a figurative interpretation here are directed at the assumption of a thoroughgoing symbolism and at relating the supposed symbols in some way to Christians and the church. Beckwith, on the contrary, accepts symbolism on a smaller scale and relates the symbols to the people of Israel. For a discussion of symbolism in general in Revelation, see ibid., 249-255. There Beckwith expresses how there is a great degree of symbolism in Revelation and offers briefly some guidelines for interpreting its symbols.

${ }^{213}$ Ibid., 585-586.

${ }^{214}$ Ibid., 586; cf. 590-592, 599, 601-602, 604.

${ }^{215}$ As for the temple, 1 Cor 3:16 and 2 Cor 6:16, for instance, offer comparisons between Christians and a generic temple in which God abides, not the Jerusalem temple. As for the city itself, Gal 4:26 and Heb 12:22, for instance, make a connection between the church and the heavenly Jerusalem, not the earthly one. Ibid., 586. 
the witnesses. He asserts broadly that the passage does not indicate that the witnesses should be interpreted allegorically in relation to Christians and the church. ${ }^{216} \mathrm{He}$ confirms and complements this assertion, when he contends that John "conceives the Witnesses as actual persons, whose work and destiny he portrays with details as objective realities."217 This point suggests the issue of the person-oriented language used to describe the two witnesses.

Inasmuch as the argumentation in these two places also involves a figurative understanding of Rev 11:1-13, the degree to which symbolism plays a role in Revelation is another evident issue. Beckwith also discusses this issue in his introduction and adds some brief remarks on the interpretation of the symbols.

\section{Conclusion}

In the end, Beckwith's argues for an identification similar to that of Haugg and Todd. Moreover, the argumentation exhibits some of the broad issues of interpretation found in the works of those two, while also complementing them with other issues.

\section{Christine Joy Tan}

\section{Introduction}

Christine Joy Tan (born 1975) has authored both a master's thesis and a doctoral dissertation on the two witnesses of Rev 11, both through the Dallas Theological Seminary. ${ }^{218}$ Indeed, both items are unpublished, and Tan is not a prominent figure in the

${ }^{216}$ Ibid., 596.

${ }^{217}$ Ibid. Capitalization and italics are original.

${ }^{218}$ Tan, "Identity."; and Tan, "Defense." Dwight Pentecost and Thomas L. 
academic discussion of Revelation or any other part of the Bible. Nevertheless, her

works merit attention because she brings together many arguments that are scattered

among other works, particularly those approaching Revelation from a dispensationalist

perspective. $^{219}$

Constable were the readers for the thesis. Elliott E. Johnson, Stanley D. Toussaint, and Robert P. Lightner were the readers for the dissertation. All of these readers have been faculty members at the Dallas Theological Seminary. Interestingly, Tan holds a second $\mathrm{PhD}$ degree from the University of North Texas in the field of higher education. See Christine Joy Tan, "College Choice in the Phillipines" (PhD dissertation, University of North Texas, 2009), accessed August 17, 2015, ProQuest Dissertations \& Theses Global. While pursuing her doctoral degrees, Tan oversaw the Christian education at a church in Dallas, TX, lectured in various places about eschatology, and wrote an article for the journal, Christian Higher Education. Also of interest here is that her father is Paul Lee Tan (born 1937), who holds a ThD from Grace Theological Seminary and has authored books on biblical topics. C. J. Tan uses two of his works in her research, Paul Lee Tan, The Interpretation of Prophecy (Winona Lake, IN: BMH Books, 1974); and Paul Lee Tan, A Pictorial Guide to Bible Prophecy (Garland, TX: Bible Communications, 1991). Incidentally, C. J. Tan assists her father in organizing tours of places linked to the Bible and appears intent on writing further on biblical topics. Concerning these and other aspects of C. J. Tan's life, see Inc. (PTPM) Paul Lee Tan Prophetic Ministries, "Pilgrimages Bible Teachers," Bible Lands Study Tours, accessed August 16, 2015, http://www.tanbible.com/tol_tour/(B)\%20BibleTeachers(Biodata).htm.

${ }^{219}$ After discussing the sine qua non of traditional dispensationalism, Charles Caldwell Ryrie concludes: "The essence of dispensationalism, then, is the distinction between Israel and the church. This grows out of the dispensationalist's consistent employment of normal or plain or historical-grammatical interpretation, and it reflects an understanding of the basic purpose of God in all His dealings with mankind as that of glorifying Himself through salvation and other purposes as well." Charles Caldwell Ryrie, Dispensationalism, Rev. ed. (Chicago: Moody Press, 1995), 41. Cf. here Robert Bruce Compton, "Dispensationalism, the Church, and the New Covenant," Detroit Baptist Seminary Journal 8 (Fall 2003): 3n4. In the same footnote, Compton also points out that there is, however, "an ongoing debate" over how to define dispensationalism. To glimpse this debate and to see some different perspectives on the general history of dispensational theology, see Craig Alan Blaising, "Dispensationalism: The Search for Definition," in Dispensationalism, Israel and the Church: The Search for Definition, ed. Craig Alan Blaising and Darrell L. Bock (Grand Rapids, MI: Zondervan, 1992), 13-34; Craig Alan Blaising and Darrell L. Bock, "Dispensationalism, Israel and the Church: Assessment and Dialogue," in Dispensationalism, Israel and the Church: The Search for Definition, ed. Craig Alan Blaising and Darrell L. Bock (Grand Rapids, MI: Zondervan, 
Not surprisingly, the dissertation is more extensive than the thesis. In fact, it incorporates a vast majority of the material found in the thesis. The aim of the two documents, however, is not the same. In the thesis, Tan's purpose is to find "a biblical identification of the two witnesses in Revelation 11."220 Accordingly, she evaluates "biblically ... the various proposals and establish[es] the most probable identity of the two witnesses."221 She concludes that "the two witnesses ... will be two [currently] unknown future prophets," an identification similar to Haugg's, Todd's, and Beckwith's. ${ }^{222}$ In the dissertation though, Tan steps back from a precise futuristic identification in order to substantiate more fully the superiority of a general futuristic interpretation of the witnesses. Unlike Haugg, Todd, and Beckwith, Tan leaves open the question of whether the witnesses can be further specified. Her intent in the disseration is "to defend the futurist view of the two witnesses in Rev 11:3-13" as the one most likely to be correct, over against proposals from idealists and historicists (i.e., churchhistorical/world-historical interpreters) and most especially from preterists (i.e.,

1992), 377-394; Charles Caldwell Ryrie, "Update on Dispensationalism," in Issues in Dispensationalism, ed. Wesley R. Willis, John R. Master, and Charles Caldwell Ryrie (Chicago: Moody Press, 1994), 15-27; and Herbert W. Bateman, IV, "Dispensationalism Yesterday and Today," in Three Central Issues in Contemporary Dispensationalism: A Comparison of Traditional and Progressive Views, ed. Herbert W. Bateman IV (Grand Rapids, MI: Kregel Publications, 1999), 21-60. Tan appears to be a traditional dispensationalist. This stance, however, is more explicit in the thesis than it is in the dissertation. In her introduction to that work, see Tan, "Identity," 2.

$$
\begin{aligned}
& { }^{220} \text { Tan, "Identity," } 2 . \\
& { }^{221} \text { Ibid., 2; cf. } 3 . \\
& { }^{222} \text { Ibid., } 63 .
\end{aligned}
$$


contemporary-historical interpreters). ${ }^{223}$ With respect to "the futurist view of the two witnesses," Tan means a conceptualization of the witnesses drawn from the common threads that bind together several futuristic identifications (the Moses-Elijah view, the Enoch-Elijah view, and the view of the witnesses as two unknown prophets). Specifically, she perceives that there is "a predominant futurist view of the two witnesses in Rev 11:3-13" that conceives of them as "two literal persons [appearing] in the yetfuture Tribulation period, who [will] perform judgmental miracles and speak prophetically." 224 In the end, she believes that she has proven her case for this understanding of the witnesses. ${ }^{225}$ Of course, the "predominant futurist view" has affinities with Haugg's conclusions about the two witnesses, not to mention those of Todd

$$
\begin{aligned}
& { }^{223} \text { Tan, "Defense," 4; cf. 1-3, 7, } 227 . \\
& { }^{224} \text { Ibid., 4n13; cf. 5, 7, 119-120, 129, 169-170, 186, 186n306, 225-226, 228-229. }
\end{aligned}
$$
Tan presents an eschatological reading of Rev 11:1-13 that is congruent with this chief futurist view of the witnesses at ibid., 119-125. She also looks briefly at how 11:3-13, so understood, meshes with a broader eschatological reading of Revelation at ibid., 125-129.

Obviously, Tan is aware that some advocates of an eschatological understanding of Revelation do not follow this "predominant futurist view of the two witnesses." Ibid., 119-120; cf. 187n307. Their identifications differ from this view in that they consider the witnesses a symbol of a corporate entity, instead of a representation of two actual people. Ibid., 120n21; cf. 187n307. Tan explicitly counters this type of identification only in one place, and she does so briefly and only with respect to identifications of the witnesses with the church. See ibid., 187n307. She makes two points. One point directs readers to her arguments earlier in the dissertation against an idealist view of the witnesses. Those arguments appear at ibid., 87-93. Presumably, only some of those arguments are applicable to an identification of the witnesses with the end-time church. The other point is reminiscent of arguments that Tan puts forth earlier against preterist views of the witnesses. Consider ibid., 65, 68, 73, 76n314. On those pages are arguments involving apparent failures to interpret matters in either a consistently literal way or a consistently symbolic way. Given that these two points are connected to other arguments in the dissertation and that those arguments are discussed below, I do not feel the need to say anything further about these two points.

${ }^{225}$ See ibid., 227-229. 
and Beckwith. Moreover, arguing for such a perspective over against others that come at the text in a non-eschatological way echoes the endeavors of these other commentators.

What follows is a brief survey of the arguments from Tan's dissertation that relate to the identity question. ${ }^{226}$ Her arguments are spread over chapters 2 to 4 . Chapter 2 examines three preterist proposals about the two witnesses. ${ }^{227}$ Chapter 3 investigates an idealist proposal and a historicist proposal. ${ }^{228}$ Chapter 4 offers a lengthy, focused defense of the futurist view as she has defined it. ${ }^{229}$ Admittedly, there is repetition in the argumentation. Similar elements among the different proposals lead her to offer similar responses. ${ }^{230}$ Moreover, several arguments used to criticize the proposals reappear in some form in the defense proper of the work. ${ }^{231}$ The survey here centers on the defense

\footnotetext{
${ }^{226}$ It should be noted that large portions of Tan's dissertation have been published with some slight editing in a series of four articles. See Tan, "Preterist Views on the Two Witnesses," 72-95; Tan, "A Critique of Preterist Views," 210-225; Tan, "A Critique of Idealist and Historicist Views," 328-351; and Tan, "A Futurist View of the Two Witnesses," 452-471. Throughout the present study, I refer to Tan's dissertation instead of the articles for two reasons. The dissertation is the fuller study, and it is more convenient for myself and hopefully for my readers to refer to one document rather than to four.

${ }^{227}$ Tan, "Defense," 10-78. Indeed, Tan says that she is examining three preterist views of the witnesses. Ibid., 5, 12, 78, 227. It should be noted, however, that for the first view Tan has actually grouped together four relatively distinct identifications under the commonality that they have the witnesses representing Christians in Jerusalem in 67$70 \mathrm{CE}$. In contrast, the second and third views each consist of two very similar, if not identical, proposals.

${ }^{228}$ Ibid., 79-114.

${ }^{229}$ Ibid., 115-226.

${ }^{230}$ For example, some preterist interpreters, idealist interpreters, and historicist interpreters all present a corporate understanding of the two witnesses. Ibid., 15, 55, 66, 77, 87, 104. Tan responds to them similarly. Ibid., 56, 66, 69, 77, 87-88, 104.

${ }^{231}$ Taking again the idea of a corporate understanding of the two witnesses, notice
} 
proper, but items from the rest of the dissertation are inserted into the discussion of that main part at appropriate points. The survey also refers to the broad issues of interpretation that may be derived from Tan's argumentation. The issues identified here are listed in Figure 4 (see the next page) according to the order in which they are first mentioned.

\section{Textual Circumstances That Support the Futurist View}

In the actual defense segment of her work, Tan details five circumstances from the biblical text that indicate the "coherence and ... [the] probable accuracy of the predominant futurist view of the two witnesses of Rev 11, namely, that these witnesses will be two literal persons in the yet-future Tribulation period, who [will] perform judgmental miracles and speak prophetically." ${ }^{232}$ Each circumstance corresponds to a part of the "futurist view." Accordingly, one textual circumstance is that the witnesses represent actual persons and are not a symbol for some other reality. The second is that there will be exactly two witnesses. The third is the time when they will appear, namely, during an expected period of distress in the end-time, the so-called "Tribulation period." The fourth and fifth circumstances pertain to the main activities of the two witnesses according to the text, their prophesying and their working of miracles. Although these activities form part of the stated "futurist view," arguably they do not form an essential

Tan's arguments against such an idea in the defense proper at ibid., 134-136. Compare these arguments with her arguments from the chapters dealing with specific proposals ibid., 56, 66, 69, 77, 87-88, 104.

${ }^{232}$ Ibid., 129. 
1. Degree of Symbolism

2. Distinguishing the symbolic from the literal

3. $\pi v \varepsilon v \mu \alpha \tau 1 \kappa \tilde{\omega} \zeta$ in Rev 11:8

4. Person-oriented language for the two witnesses

5. Theme of testimony

6. Theme of prophecy

7. Miraculous powers of the two witnesses (Rev 11:5-6)

8. Fate of the two witnesses (Rev 11:7-12)

9. Duality of the witnesses

10. Image of the olive trees

11. Image of the lampstands

12. Traditions about Moses

13. Traditions about Elijah

14. Use of numbers in Revelation

15. Theme of warfare

16. Interpretive approach

17. Verb tenses for Rev 11:1-13

18. Historical data

19. Identity of the beast of Rev 11:7

20. Three-and-a-half year period

21. Context immediately before Rev 11:3-13 (11:1-2)

22. Composition date for Revelation

23. Relationship with Olivet discourse from the gospels

24. Terms for rapidity and nearness in Revelation

25. Setting for the episode of the two witnesses

26. Three-and-a-half day period

27. Audience to the fate of the witnesses

28. Earthquake of Rev 11:13

29. Sackcloth clothing of the two witnesses (Rev 11:3)

30. Relationship between Rev 10 and Rev 11:3-13

31. Early interpretation of the witnesses

32. Traditions about Enoch

33. Introduction of the two witnesses (Rev 11:3)

34. Lack of names for the two witnesses

35. Standing before the lord of the earth (Rev 11:4)

Figure 4. Broad issues of interpretation in Tan's argumentation. 
part of the "futurist" identification of the two witnesses. ${ }^{233}$ Consequently, the discussion below focuses on Tan's argumentation for the first three circumstances, that is, literal people, being exactly two in number, operating during the expected Tribulation.

Reference is made to the activities of the witnesses only as that is brought in to define the three key matters or as part of a related argument from elsewhere in the dissertation.

The circumstance of being actual people

One circumstance of the biblical text that Tan discusses is that the two witnesses are presented not as a symbol, but as literal people. She begins with what she perceives to be a proper way to read Revelation — and indeed the whole Bible — that is, the literal method. ${ }^{234}$ There is, however, an allowance for the presence of symbols. Still, the notion that the whole of Revelation is symbolic is dismissed, and there is a clear emphasis on the literal sense of the language. ${ }^{235}$ Therefore, Tan's methodology implicitly favors seeing

${ }^{233}$ Consider the expositors discussed above and their identifications. Indeed, they may refer to the activities as they argue for the essential components of their identification. Furthermore, they may even comment on the activities when they fill out their picture of the episode involving the witnesses. Nevertheless, saying that the two witnesses are two actual people appearing in the end-time - a material definition in space and time - is arguably what really sets these opinions and Tan's apart from ones expressed by preterists, idealists, historicists, and even some other futurists. It is also interesting that Tan mentions these three dimensions alone-(1) two (2) actual people (3) appearing in the end-time - when she introduces her review of early Christian views on the two witnesses: "This survey will show that the early church had a strong, longstanding (though by no means, unanimous) tradition that the two witnesses of Rev 11 would be two literal persons in the yet-future Tribulation period." Ibid., 170-171.

${ }^{234}$ Ibid., 130; cf. 61-62, 68, 87-89, 115, 117, 122-125, 130-131, 142, 210. As these pages show, this method may also be termed the "normal, grammatical interpretation," the "normal, literal approach," the "literal (or normal) hermeneutic," or even the "plain ... interpretation."

${ }^{235}$ Ibid., 130n49; cf. 115n3, 117. 
literal figures in Rev 11:3-13. ${ }^{236}$ This preconception about Revelation suggests the issue of the degree to which symbolism plays a role in Revelation.

Besides this preconception, Tan offers four arguments to support the position that the witnesses are literal people. First, she cites a particular principle for distinguishing symbolic elements from literal elements in prophetic texts. Specifically, one determines whether something is a symbol based on the presence of associated details that would be unnecessary for an "intended symbolism."237 According to the principle, the witnesses cannot be regarded as symbolic. Tan therefore has something to say about how one distinguishes the symbolic from the literal in Revelation.

Second, there is the presence of the term "spiritually" ( Tan maintains that John, the presumed author, intends to highlight the figurative nature of appellations to the "great city," amid an episode that he otherwise wants to be understood literally. ${ }^{238}$ Therefore, the witnesses should be understood literally as part of this primarily literal narrative. ${ }^{239}$ The issue of interpretation here appears to be the significance of the term "spiritually" ( $\pi v \varepsilon v \mu \alpha \tau \iota \kappa \tilde{\omega} \zeta)$ in Rev 11:8.

${ }^{236}$ This is not limited to the figure of the witnesses themselves. For instance, Tan argues extensively for the literal sense of the miraculous powers of the two witnesses over against interpreters who understand them figuratively. Ibid., 70-71, 90-91, 108-109; cf. $64,75-76,128,137-138$. As for those who understand the powers figuratively, note ibid., 22, 84-85, 101. Moreover, there is a literal understanding of the earthquake that comes after the ascension of the witnesses. Ibid., 74-75; cf. 24, 54, 125, 129.

${ }^{237}$ Ibid., 130-131; cf. 62. This principle and the two witnesses are discussed originally by C. J. Tan's father at Tan, The Interpretation of Prophecy, 160-161.

${ }^{238}$ Tan assumes a traditional position on the authorship of Revelation, so that the book is considered the work of the Apostle John. See particularly Tan, "Defense," 8.

${ }^{239}$ Ibid., 131; cf. 62, 92, 111, 124n38. 
Third, many terms and expressions are used to describe the witnesses and the events involving them, and these items suggest that literal people are in view. ${ }^{240}$ The issue here is the person-oriented language used to describe the two witnesses. Some important secondary issues are suggested by this reasoning. Inasmuch as she refers to the term "witnesses" and the terms designating the witnesses as prophets, Tan addresses the themes of testimony and of prophecy. She also refers to the miraculous powers of the two witnesses (11:5-6) and their fate (11:7-12).

Fourth, Rev 2:13 designates Antipas, a literal person, as a "witness" and observes that he was killed. This reference then suggests that Rev 11:3-13 also involves actual people who are designated as "witnesses" and really killed. ${ }^{241}$ In a small way, this point raises the theme of testimony as it pertains to the two witnesses.

The circumstance of being two in number

A second circumstance of the biblical text is that the witnesses appear as exactly two in number, not as a corporate entity. Apart from one argument aimed at a different eschatological proposal, Tan offers several general remarks in evidence of this circumstance. ${ }^{242}$ For one thing, she highlights two pieces of background information for

${ }^{240}$ Tan discusses the term "witnesses" ( $\left.\mu \alpha \dot{\rho} \tau v \sigma v v\right)$, the terms that designate them as prophets ( $\pi \rho \circ \varphi \eta \tau \varepsilon v ́ \sigma o v \sigma ı v, \pi \rho \circ \varphi \tilde{\eta} \tau \alpha)$, the term "dead body" $(\pi \tau \tilde{\omega} \mu \alpha)$, and the phrasing used to describe their revival after death. She also points to the fact that they speak, wear sackcloth, perform wonders, have body parts, are killed, and are considered corpses when dead. Ibid., 131-134; cf. 62-64.

${ }^{241}$ Ibid., 133; cf. 62-64, 131.

${ }^{242}$ The one argument in question is aimed at the idea that the witnesses symbolize the followers of God during the future Tribulation period. Ibid., 136-137. 
Rev 11:3-13. First, there is the Jewish legal principle of needing at least two witnesses to establish a matter in a legal case. Tan cites several biblical passages that concern the original principle or its use in a new situation. ${ }^{243}$ Second, there is Zech 4 with its image of two olive trees, to which Rev 11:4 alludes. ${ }^{244}$ In both cases, the relevant biblical passages involve two individuals and therefore suggest the same sense for Rev 11. The overriding issue for these two points is the duality of the witnesses. Each of the points, however, suggests an additional issue of interpretation. The first point suggests the theme of testimony, while the second suggests the image of the olive tree.

Before continuing with the argumentation that relates specifically to the second circumstance, other instances outside the defense proper where Tan refers to Rev 11:4 and its allusion to Zech 4 can be observed. Each instance involves arguing against an alternative to a literal, futuristic interpretation of the witnesses. In one place, Tan points to the need for an appropriate balance in how interpreters use elements in the description of the witnesses. Specifically, the reference in 11:4 to the two olives trees should not be overemphasized relative to other elements in the tale of the witnesses. ${ }^{245}$ Then, in two other places, Tan sharply distinguishes the lampstands in Rev 11:4 from those mentioned earlier in Rev 1:20. Those in 1:20 are identified explicitly with seven churches in Asia Minor, but no such explanation is given in 11:4. Instead, the lampstands in 11:4 are part

${ }^{243}$ Tan refers to Num 35:30; Deut 17:6; 19:15; Matt 18:16; John 8:17; 2 Cor 13:1; 1 Tim 5:19; and Heb 10:28. Ibid., 134-135; cf. 56, 69, 77.

${ }^{244}$ Ibid., 135; cf. 56, 59, 77.

${ }^{245}$ Ibid., 59. She is addressing here an argument used in one preterist interpretation of Rev 11:1-13. See the summary at ibid., 18-19. 
of an allusion to Zech $4 .{ }^{246}$ These arguments involve the image of the olive trees and the image of the lampstands. These are the two issues suggested by this set of arguments.

Also before continuing with respect to the second circumstance, Tan's thoughts about another background element to the description of the two witnesses can be observed. These thoughts too occur outside the defense proper as Tan argues against alternatives to a literal, futuristic view of the witnesses. She readily acknowledges that "the miraculous powers [of the two witnesses as] described in Rev 11:5-6" are similar to the powers "exercised by Moses and Elijah" in the OT. ${ }^{247}$ Differences do exist, however, and presumably, Tan mentions this circumstance in order to cast doubt upon the support that certain preterist interpreters draw from the connection to Moses and Elijah. ${ }^{248}$ Tan also points out in passing that Moses and Elijah were two individuals, thus suggesting that the two witnesses are also two people. ${ }^{249}$ This is not a point that she presses though, perhaps because of the differences between the powers of Moses and Elijah and those of the witnesses. Moreover, Tan argues that this connection to Moses and Elijah is unable to bolster the case for seeing the witnesses as the embodiment of Jewish civil and

${ }^{246}$ Ibid., 90, 108. In each instance, Tan is responding to an argument made to support an ecclesiastical view of the two witnesses. In one case, it is part of an idealist interpretation of Rev 11:1-13. In the other, it is part of a historicist interpretation of that passage. See the relevant portions of the summaries that Tan presents for each interpretation at ibid., 82-84, 97-101.

${ }^{247}$ Ibid., 60; cf. 77, 124n35, 128, 138.

${ }^{248}$ Ibid., 70, 77; cf. 60n233, 124n35, 128. On two occasions, she is addressing information used to support one type of preterist interpretation of the witnesses. See the summaries at ibid., 22, 24-26.

${ }^{249}$ Ibid., 77. She adds this remark on one of the occasions noted in the previous footnote. See again ibid., 24-26. 
religious authority. Neither Moses nor Elijah was formally involved with either the government or the priestly system of Israel. ${ }^{250}$ The arguments mentioned here suggest three issues, the issue of the miraculous powers of the witnesses as well as the issues of traditions about Moses and of traditions about Elijah.

Now one can continue to look at Tan's evidence for seeing the witnesses as precisely two in number. The duality of the witnesses continues to be the overriding issue of interpretation. Supporting this second circumstance in the biblical text, Tan refers to the actual description of the witnesses and of the events involving them. Elements herein suggest that two individuals are being presented. ${ }^{251}$ The elements to which Tan refers for this argument also raise some important secondary issues. The miraculous powers and the fate of the witnesses come into play again.

Moreover, Tan argues for understanding the number two in Rev 11 in a way that is consistent with how numbers are used elsewhere in Revelation. First, the numbers 42 (the months in 11:2), 1,260 (the days in 11:3), and three and a half (the days in 11:9,11) are best taken literally, and therefore so should the number two in Rev $11 .{ }^{252}$ Second,

\footnotetext{
${ }^{250} \mathrm{Ibid} ., 60$. She is addressing here an argument used in one preterist interpretation of Rev 11:1-13. See the summary at ibid., 18-19.

${ }^{251}$ First, Tan mentions the witnesses' miraculous powers and their death, resurrection, and ascension. She says that these are "too many details for ... [the witnesses] to represent a corporate body." Ibid., 135; cf. 56, 88. Perhaps underlying this thought is the interpretive principle that Tan mentions elsewhere and that is discussed above. Cf. ibid., 62, 130-131. Second, Tan refers to the fact that Rev 11:5 apparently depicts the enemies of the witnesses in such a way that they cannot be understood as a corporate entity, like a nation. If the enemies cannot be understood corporately, then surely the witnesses cannot be either. Ibid., 135. Third, she highlights the repetition of the number "two" four times in the episode of the witnesses. Ibid., 136.

${ }^{252}$ Ibid., 136; cf. 68-69, 73, 88-89, 142-165.
} 
John uses large numbers to describe corporate bodies (e.g., the 144,000 sealed individuals in $\operatorname{Rev} 7$ ), and therefore the absence of that phenomenon here speaks to the witnesses being just two individuals. ${ }^{253}$ An issue secondary to the overriding concern about the duality of the witnesses is identifiable, namely, the use of numbers in Revelation.

Finally, related to this second circumstance, Tan addresses the appropriateness of having just two individuals in this passage. Some may contend that just two individuals could hardly meet all the demands of the passage. ${ }^{254}$ Tan's response is that these individuals are filled with the Holy Spirit (according to 11:4) and provided with supernatural power (so 11:5-6). Thus, two such persons could fulfill the ministry described and would constitute a force against which opponents might wage a "war" (Rev 11:7). ${ }^{255}$ An issue secondary to the overriding concern for the duality of the witnesses appears only here in Tan's argumentation. The issue is the theme of warfare.

${ }^{253}$ Ibid., 136; cf. 56. Oddly, Tan also cites as an example the "great multitude" also in Rev 7. Of course, the oddity is that no number is actually used here "to describe a crowd"! She can still make her point though without this example.

${ }^{254}$ I have actually put two situations together here because Tan responds to them in similar ways. One instance is actually not part of Tan's discussion of the second circumstance, but still clearly relates to it. In this case, Tan claims that Moses Stuart justifies his corporate view of the two witnesses in part by arguing "that more than two persons [are] needed to meet the situation" presented in the text. Ibid., 55.

Unfortunately, she has misunderstood Stuart. She has misread some statements in his explanation of why there are two witnesses to mean what she claims for him. See Stuart, Commentary on the Apocalypse, 2:226. Cf. Tan, "Defense," 55n218. The other instance is part of Tan's discussion of the second circumstance. In this case, Tan claims that "some who opt for a corporate understanding of the witnesses ... argue that the beast would hardly make war against just two people." Ibid., 137. She correctly cites Robert Hayden Mounce as an example. See Robert Hayden Mounce, The Book of Revelation, Rev. ed., New International Commentary on the New Testament (Grand Rapids, MI: William B. Eerdmans, 1998), 220. Cf. Tan, "Defense," 137n86.

$$
{ }^{255} \text { Tan, "Defense," 55, } 137 .
$$


The circumstance of appearing during the expected tribulation period

A third textual circumstance for Tan is that the two witnesses are shown to be active during a still future "Tribulation period." 256 Her starting point is an eschatological approach towards the whole of Revelation. Elsewhere, she argues for the "coherence" of this methodology. ${ }^{257}$ According to her eschatological approach to interpreting the book, Rev 4-22 are visions of the yet-to-be-fulfilled eschatological future. Inasmuch as Rev 11:3-13 is a part of these chapters, it may well refer to this future era. Thus, the logical consistency of the eschatological way of interpreting the whole book affirms the end-time appearance of the two witnesses. ${ }^{258}$ Clearly, Tan is dealing here with the question of what is the proper approach to interpreting Revelation and Rev 11:3-13 in particular.

Beyond this starting point, Tan shares a few other points. First, two indicative verbs are used to introduce the witnesses in Rev 11:3. Tan infers from the future tense of these verbs that the witnesses will appear in the future, from John's perspective. ${ }^{259}$ She is addressing here the issue of the verb tenses of Rev 11:1-13. Second, there is no extant historical record of two literal people performing actual miracles and prophesying as narrated in Rev 11:3-13. This situation indicates that the prophecy is still to be fulfilled. ${ }^{260}$ With this point, Tan raises the issue of the role of historical data in the

${ }^{256}$ Ibid., 140.

${ }^{257}$ Ibid. Tan defines an eschatological approach to interpreting Revelation briefly at ibid., 115. Then her argumentation for it follows at ibid., 116-119.

${ }^{258}$ Ibid., 140; cf. 6, 75, 115, 119, 167, 225, 228.

${ }^{259}$ Ibid., 140-141; cf. 75, 167.

${ }^{260}$ Ibid., 141; cf. 167. 
interpretation of the witnesses. Third, the beast will attack and kill the two witnesses according to Rev 11:7. This beast is likely "the future antichrist." ${ }^{261}$ This suggests that the identity of the beast in 11:7 can also be an issue of interpretation in identifying the witnesses.

As a fourth point, Tan argues that the time during which the witnesses are active, the 1,260 days, is a period in the future. More specifically, this period forms half of a week of years that constitutes the still-expected final week of years of Daniel's prophecy of seventy weeks of years (Dan 9:24-27). ${ }^{262}$ These seven years are the so-called Tribulation period, and the descendants of Israel, not the church, have a special place in God's plans for humanity at this time. ${ }^{263}$ The main issue that Tan addresses here is the

${ }^{261}$ Ibid., 166; cf. 167. In a footnote, Tan refers to others to argue the case that the beast in Rev 11:7 likely represents "the future antichrist." See ibid., 166n224.

${ }^{262} \mathrm{~A}$ large part of Tan's dissertation is devoted to discussing this point about the time during which the witnesses are active. The discussion can be summarized as follows. Applying an interpretive principle gleaned from her father's work on prophecy, Tan first links the 1,260 days with Daniel's prophecy of seventy sevens (Dan 9:24-27), among other references to Daniel and Revelation (Dan 7:25; 12:7; Rev 12:14). Ibid., 142. She then argues that the "sevens" are sevens of years. Ibid., 142-144. Next, Tan describes and evaluates four key perspectives on the fulfillment of the prophecy of seventy sevens (or weeks) of years. She opts for the opinion that separates the final seven temporally from the first sixty-nine. According to this perspective, the first sixtynine sevens were fulfilled in history, from the days of Ezra and Nehemiah to the time of Jesus Christ. Meanwhile, the seventieth seven remains unfulfilled, until it begins with the future antichrist confirming a covenant with the people of Israel. Since the 1,260 days is one of the halves of this future period, it too must be in the future. Ibid., 144-165. With this section, compare ibid., 68-69, 88-89, 122-123, 125-129, 167. Note also that the 42 months of Rev 11:2 are taken to be half of this seventieth seven. Tan observes that most futurists identify the 42 months with the second half of the seven years. Ibid., 68-69, 88$89,122,127,142,216-217,220$. There is apparently no such consensus on the location of the 1,260 days within the seven years and consequently on when exactly the two witnesses are active. Ibid., 6-7, 123, 186, 214, 224-226, 229.

$$
{ }^{263} \text { Ibid., 142; cf. 88-90, 122-123, 125-129, 198n355, 214, } 224 .
$$


meaning of the three-and-a-half-year period of the witnesses.

This last idea — the centrality of Israel in God's plans concerning humanity during the Tribulation period—-shows most distinctly Tan's dispensationalist stance. Implicit here is the traditional dispensationalists' sharp distinction between Israel and the church in God's plans concerning humanity. ${ }^{264}$ Therefore, by linking the two witnesses to the Tribulation period, Tan is not simply locating the witnesses within time. She is also effectively setting aside the notion that the two witnesses relate to the church. ${ }^{265}$

Elsewhere in the dissertation, Tan presents similar lines of reasoning, albeit more explicitly. In two places, Tan argues against an ecclesiastical identification of the witnesses by claiming that "the immediate context of the two-witnesses prophecy [sic]Rev 11:1-2 - supports the idea that the events of this chapter occur during a period when God is especially dealing with Israel (and not the Church)."266 One can see from this reasoning the general issue of the meaning of the immediate context before Rev 11:3-13 (11:1-2). In another place, Tan expresses that the church will not even be on earth during

${ }^{264}$ See the footnote above that concerns traditional dispensationalism and Tan's adherence to it. It is at the start of the present discussion of Tan's work.

${ }^{265}$ The same thing is implied when Tan criticizes an ecclesiastical interpretation of the two witnesses at Tan, "Defense," 88-90. A summary of the whole interpretation of Rev 11:1-13 that she is then critiquing appears at ibid., 82-86.

${ }^{266}$ Ibid., 87, 104. In one place, Tan is responding to the idealist interpretation of Rev 11:1-13 that she summarizes at ibid., 82-86. In the other place, she is responding to the historicist interpretation of the text that she summarizes at ibid., 97-104. Support for Tan's claim about Rev 11:1-2 is in her thesis and consists of six points. See Tan, "Identity," 18-22. Tan does mention some of the same subjects in her dissertation. On the temple of God as a future Jerusalem temple, see Tan, "Defense," 38-41, 66-68, 121, 127. On the holy city as Jerusalem, see ibid., 92-93, 111-112, 122. On the 42 months as the second half of the final week of years of Daniel's prophecy, see ibid., 68-69, 88-89, $122,127,142,216-217,220$. 
the Tribulation period, when the witnesses will be active: "The entire body of Christ (i.e. the Church) will be raptured before any part of Daniel's seventieth week begins." ${ }^{267}$ In harmony with this thought, Tan also observes the nearly total absence of the term

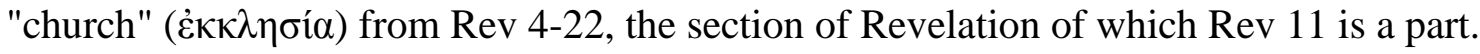
The absence is explainable if Christians are no longer on earth, but in heaven, having been raptured there before the events depicted in Rev 4-22. ${ }^{268}$ This pair of points has to do with a particular conception of the three-and-a-half-year period in which the witnesses are active. Finally, Tan contrasts the account of the witnesses with the experience of the church in the dispensation of grace. Specifically, she notices the witnesses' supernatural powers for defense and offense (Rev 11:5-6). This contrasts with NT commands for goodness toward enemies (e.g., Matt 5:44) and to be "innocent as doves" (Matt 10:16, ESV) and with the fact that several early Christian leaders had violence inflicted upon them. ${ }^{269}$ Tan has returned to the issue of the miraculous powers of the witnesses in this final point.

In connection with the third circumstance, the one pertaining to the timing of the witnesses' activity, several arguments that are unique to Tan's discussions of preterist, historicist, and idealist identifications of witnesses can be mentioned. To some degree, all of these arguments involve the fact that each of these views, like Tan's futuristic one,

\footnotetext{
${ }^{267}$ Tan, "Defense," 89-90; cf. 93. These remarks concern the idealist interpretation of Rev 11:1-13 that she summarizes at ibid., 82-86.

${ }^{268}$ Ibid., 93; cf. 89-90. These remarks also concern the idealist interpretation of Rev 11:1-13 that she summarizes at ibid., 82-86.

${ }^{269}$ Ibid., 91-92, 110. One instance concerns the idealist interpretation of Rev 11:113 that Tan summarizes at ibid., 82-86. The other instance concerns the historicist interpretation of the text that she summarizes at ibid., 97-104.
} 
are based on the contents of Rev 11 being related to history. Thus, all of these arguments in some way concern the timing of the witnesses' activity, and therefore, it is appropriate to mention them here.

Like other preterist (or contemporary-historical) interpreters of Rev 11, the preterist interpreters whose works Tan investigates link the text to historical events and people that are generally contemporaneous to the author of Revelation. One thing that Tan does with their interpretations is to dispute "various assumptions" that apparently underlie their "identifications of the two witnesses."270 To do this, she relies heavily on the works of others, referring "only [to] the main points" of those works. ${ }^{271}$ The preconceptions that she rejects are: (1) that Revelation was composed before $70 \mathrm{CE},(2)$ that the entire Olivet Discourse was fulfilled in the first century CE, (3) that certain temporal expressions in Revelation indicate a fulfillment of its prophecies in the firstcentury, (4) that Rev 11:1-2 pertains to the first-century Jerusalem temple and the devastation of both city and temple in the first Jewish war, (5) that the 42 months and the 1,260 days of Rev 11:2-3 relate to the first Jewish war, and (6) that the beast of Rev 13 and thus of 11:7 is a symbol of the Roman emperor Nero. ${ }^{272}$ All of these preconceptions function (some potentially, others necessarily) to ground the episode of the two witnesses in the time of the author of Revelation. ${ }^{273}$ Presumably, rejecting them opens up the

${ }^{270}$ Ibid., 27; cf. 5, 48, 58, 65, 78, 227.

${ }^{271}$ Ibid., 27; cf. 48, 227n1.

${ }^{272}$ Ibid., 27-48; cf. 52-53, 127n45, 166n224, 227n1. Compare Tan's evaluation of these preterist assumptions with the assumptions that she highlights in her summaries of preterist interpretations of Rev 11:1-13. See ibid., 13-15, 18, 20-21, 24-25.

${ }^{273}$ See ibid., 58, 65, 76; cf. 13, 18. 
possibility of relating that episode differently to history.

Each discussion of one of the six assumptions suggests a corresponding broad issue of interpretation. Discussion of the first assumption deals with the composition date of Revelation. Discussion of the second assumption raises the issue of the relationship between Revelation and the Olivet discourse (Matt 24-25; Mark 13; Luke 21). For discussion of the third one, the issue is the meaning of terms for rapidity and nearness in Revelation $(1: 1,3 ; 2: 16 ; 3: 11 ; 11: 14 ; 22: 6-7,10,12,20)$. For discussion of the fourth, there is a return to the issue of the meaning of the immediate context before Rev 11:3-13. Discussion of the fifth assumption is a return to the meaning of the three-and-a-half year period of Rev 11:3. Discussion of the sixth assumption deals anew with the identity of the beast in Rev 11:7.

Beyond the matter of assumptions, Tan criticizes these particular preterist interpreters for several inconsistencies that arise because of the historical claims that the interpreters imbed within their interpretations of Rev 11:1-13. On the one hand, historical features of the interpretations conflict with specifics of the biblical text. ${ }^{274}$ On the other hand, incongruences also exist between aspects of the interpretations and the historical record. In other words, these interpreters have dealt inadequately with the

${ }^{274}$ Ibid., 53-54, 57-58, 64-65, 72-73, 75-76. As for the preterist interpretations to which Tan is responding, see ibid., 12-24. One point in Tan's response to the view that the witnesses are James, the brother of Jesus, and Peter offers an example of where she finds incongruence between the historical features of an interpretation and the specifics of the biblical text. Specifically, Tan observes that, while the witnesses appear to operate together in Jerusalem, Peter's ministry reached areas beyond Jerusalem. Ibid., 57. 
extant historical data. ${ }^{275}$ Presumably, none of these various inconsistencies would exist if the interpretations were correct.

Tan presents similar criticisms for the historicist view that she evaluates. In this case, however, the historical claims imbedded in the interpretation concern occurrences from the early church on up through the Reformation. This interpretation too suffers from incongruences between elements in the text and historical features of the interpretation of Rev 11:1-13. ${ }^{276}$ It also contains inconsistencies between history and interpretation that reveal the interpreters' failings in dealing with the extant historical data. $^{277}$

${ }^{275}$ Ibid., 49-53, 57, 60-61, 74-75. As for the preterist interpretations to which Tan is responding, see ibid., 12-24. One point in Tan's response to the view that the witnesses symbolize Jewish civil and religious authority offers an example of where she finds incongruence between aspects of an interpretation and the historical record. According to that view of the witnesses, the death of the witnesses symbolizes the demise of Jewish civil and religious authority in the first Jewish war and the resurrection of the witnesses symbolizes the rise of the Christian church in the first century CE. Tan, however, observes that this preterist perspective on the death and resurrection of the witnesses does not conform to the realities evident in the history of Judaism and Christianity. This preterist perspective overemphasizes the extent to which Jewish civil and religious authority suffered from the events of the first Jewish war and the extent to which the church was triumphant around the same time. Ibid., 60-61.

${ }^{276}$ Ibid., 105-107, 111-113, and perhaps at the top of 110; cf. 113-114. As for the historicist interpretation to which Tan is responding, see ibid., 97-104. One point in Tan's response to the view that the witnesses symbolize Christian reformers from before and after the Protestant Reformation offers an example of where she finds incongruences between the historical features of an interpretation and the biblical text. Specifically, Tan observes that public interest in the deaths of the reformers occurred only at a local or national level, but the death of the witnesses captures the interest of the whole world.

${ }^{277}$ Ibid., 108-112; cf. 113-114. As for the historicist interpretation to which Tan is responding, see ibid., 97-104. One point in Tan's response to the view that the witnesses symbolize Christian reformers from before and after the Protestant Reformation offers an example of where she finds incongruence between aspects of an interpretation and the historical record. According to that view of the witnesses, the plague of turning water 
The numerous arguments that may be classed according to the two types of criticism, both for the preterist views and the one historicist view, raise several issues of interpretation. One obvious issue here is the role of historical data in addressing the identity question. With respect to the other issues apparent in this set of arguments, I note only those that have not yet been mentioned in this summary. There are the issues of the setting for the events of Rev 11:3-13, ${ }^{278}$ the meaning of the three and a half days, ${ }^{279}$ the audience to the fate of the witnesses, ${ }^{280}$ and the earthquake of Rev 11:13. ${ }^{281}$

Besides these problems specific to a certain historicist interpretation, Tan also

into blood represents the wars that came upon the enemies of the reformers. Tan, however, observes that this historicist perspective on one of the powers of the witnesses does not conform to the realities evident in the history of the reformers. History does not show reformers, like John Wycliffe and Jan Hus, having the power to cause wars as often as they desire. Ibid., 109-110.

${ }^{278}$ For this issue of the setting, note the three arguments that appear at ibid., 57-58, 111-112. These arguments assume a point that is argued separately, namely, that Jerusalem is "the great city" (Rev 11:8) in which the witnesses minister and die.

${ }^{279}$ For this issue of the three and a half days, note the argument that points out that Jewish civil and religious authority, a proposal for the identity of the witnesses, was not "dead" for only three and a half literal days after the fall of Jerusalem in 70 CE. Ibid., 6465. Note also the three arguments that Tan presents against the idea that the three and a half days represent the period from May 5, 1514 to October 31, 1517. Ibid., 112.

${ }^{280}$ For this issue of the audience to the fate of the witnesses, note the arguments over the identity of "the inhabitants of the earth" (Rev 11:10). Ibid., 53, 72-73. Note also the arguments that assume an international interest in the death of the witnesses at ibid., $76,113$.

${ }^{281}$ For the issue of the earthquake of Rev 11:13, note where Tan points out that nothing in the historical record matches with a literal understanding of that earthquake. Ibid., 53-54. Notice also the argument that associating this earthquake with Jesus' ascension and the sufferings of the Jewish nation presents an inaccurate view of Jewish history after $70 \mathrm{CE}$. Ibid., 75. 
presents five weaknesses of the historicist approach to interpreting Revelation. ${ }^{282}$ The first weakness concerns the multiplicity of interpretations of the major features of the book coming from historicist expositors. The second weakness centers on the historicist approach rendering the content of Revelation irrelevant to readers of any era. This weakness seems to stem from the first. The third weakness involves the questionable and unnecessary use of figurative interpretations of elements of the book. The fourth weakness centers on the common practice of historicists to limit prophetic fulfillments to European Christianity and to the period of the Middle Ages and the Reformation. The final weakness concerns the disappointment and fanaticism that historicist interpretations bring to life through calculations concerning the times of prophetic fulfillment. The issue of what is the proper interpretive approach for Revelation and Rev 11:3-13 in particular is suggested by these criticisms.

Tan also examines an idealist interpretation of the witnesses and Rev 11:1-13. This interpretation takes the witnesses to symbolize the church throughout its sojourn on earth. Unlike the preterist and historicist interpretations that Tan investigates, this idealist interpretation does not suffer from the problem of narrative details or historical facts not lining up with the interpretation. It has a quite different problem. Instead, it involves almost no specific historical claims. In other words, the idealist interpreters show little interest in seeing the details of the episode of the witnesses fulfilled in the specifics of history. Rather, their interpretation presents primarily abstractions and generalities. ${ }^{283}$

$$
{ }^{282} \text { Ibid., 96-97. }
$$

${ }^{283}$ Ibid., 88; cf. 81, 119, 141n105. As for the idealist interpretation to which Tan is responding, see ibid., 82-86. The above criticism shows that Tan agrees with the 
Actually, this error in the examined idealist interpretation mirrors on a small scale what Tan considers the major difficulty of the idealist interpretation of Revelation generally. ${ }^{284}$ The issue of what is the proper interpretive approach is suggested by this criticism.

Nevertheless, the examined idealist view proposes some general connections between the text and history and at least one specific connection. Here also, however, Tan finds problems. As for general connections, she observes that idealists interpret the powers of the witnesses figuratively with respect to the church. One problem with this is that it advances an "optimistic view of the nature of present-day ministry [that] does not cohere with the harsh realities of the persecuted church in this current dispensation of grace [i.e., the era of the church]." 285 This argument returns to the issue of the miraculous powers. The one specific connection concerns the fate of the witnesses. Tan suggests that idealists link the ascension of the witnesses with the future rapture of the church from earth. This is problematic though because the slow ascension of the

degree of correspondence that the preterists and the historicists expect to find between the prophetic text (prediction) and the actual people and events in the world (fulfillment). Her disagreement is over the purported fulfillments. This is not surprising, given that, at one point, she looks for something in history that corresponds precisely with the prophecy and finds nothing that does. The fulfillment therefore must still lie in the future. See the discussion above and ibid., 141; cf. 167.

${ }^{284}$ Ibid., 81; cf. 88.

${ }^{285}$ Ibid., 90-91; cf. 84-85. Tan has another more basic problem with this idealist understanding of the powers of the witnesses. As intimated before, she rejects seeing the powers figuratively. Besides the pages of her dissertation that are cited at the start of this note, see also ibid., 6, 49, 64, 70-71, 75-76, 108-109, 129-130, 137-138, 167, 169, 225, 228. 
witnesses before their enemies (Rev 11:12) contrasts with the apparently speedy "rapture of the Church" according to 1 Cor 15:51-52. ${ }^{286}$

Supplemental arguments

Several of Tan's arguments do not fit easily into a survey of the most pertinent textual circumstances supporting the prevailing futurist view of the two witnesses. These arguments appear within Tan's evaluations of preterist, idealist, and historicist interpretations of Rev 11. Moreover, many of the arguments relate indirectly to the identity question. Nevertheless, they all serve to raise doubts about the accuracy of the alternatives to the prevailing futurist proposal. Accordingly, they can all be noted before proceeding with the remainder of Tan's defense proper of this view of the witnesses. They can be categorized into four groups with only minimal overlapping.

First, several times Tan deals with the matter of consistency in interpretation. ${ }^{287}$ Second, she argues with several points that the temple in Rev 11:1-2 is an actual temple, not a symbol for the church. ${ }^{288}$ Third, Tan argues with several points that the great city in Rev 11:8 is the earthly Jerusalem. ${ }^{289}$ Finally, there are a few minor criticisms of elements

${ }^{286}$ Ibid., 93; cf. 86.

${ }^{287}$ Ibid., 55, 60, 65, 67-68, 71-74, 76n314, 93, 106, 108, 110-111, 113. Compare these remarks with elements in the summaries of the various views that Tan examines. See ibid., 13, 15, 18-25, 83, 97-104.

${ }^{288}$ Ibid., 66-68; cf. 87, 104, 121. These remarks concern an aspect of David Chilton's preterist interpretation of Rev 11:1-13, noted at ibid., 20-21. Cf. ibid., 83, 98, which mention similar thoughts in the idealist and the historicist interpretations that Tan examines.

${ }^{289}$ Ibid., 92-93, 111-112; cf. 122, 124. One set of remarks concerns an aspect of the idealist interpretation of Rev 11:1-13 that Tan examines. The other set concerns a similar feature of the historicist interpretation of the passage. See ibid., 85, 103. 
in David Chilton's (1951-1997) preterist interpretation of specifically Rev 11:3-13. ${ }^{290}$

Some of these arguments suggest more than one broad issue of interpretation.

Three issues are notably repeated among all these arguments. Several arguments refer to the immediate context before Rev 11:3-13 (11:1-2). ${ }^{291}$ Several concern the fate of the two witnesses. ${ }^{292}$ A few concern how the author of Revelation uses numbers. ${ }^{293}$ Two other issues stand out because they do not appear elsewhere in Tan's study. Related to one argument is the issue of the sackcloth clothing of the witnesses. Reference to this

${ }^{290}$ Tan suggests that another sense may be intended for the sackcloth clothing (Rev 11:3) than the one Chilton highlights. Ibid., 69; cf. 22, 140. She also contends that Chilton draws too much support from Matt 23:34-38 and Luke 13:33. Ibid., 72; cf. 23n66. Furthermore, Chilton's reasoning concerning the 7,000 killed in the earthquake does not persuade her (11:13). Ibid., 75; cf. 24. Finally, in more than one place, Tan claims that Chilton puts ideas together that should be understood separately. Ibid., 69-70, 73; cf. 21-24.

${ }^{291}$ Note the arguments over methodological consistency at ibid., 65, 76n314, 93. Note the argument against a historicist interpretation that lacks consistency in how it defines the relationship of the "true" Christians to the Papacy. Ibid., 106. There are also all the arguments over the literalness of the temple in Rev 11:1-2 at ibid., 66-68.

${ }^{292}$ Note the arguments over methodological consistency at ibid., 60, 72-74, 110, 113. Note the argument about an inconsistent historicist understanding of death in the passage of the witnesses at ibid., 110. Note the argument that the historicist interpretation of the ascension of the witnesses as the political ascendancy of the reformers contradicts the historicist understanding of the descent of the angel in Rev 10. Ibid., 113.

${ }^{293}$ Note the arguments concerning a consistent perspective when it comes to whether a number should be taken literally or symbolically. Ibid., 55, 68, 73. Note the argument over a methodological inconsistency in the interpretation of the three and a half days as representing three and a half years. Ibid., 111. 
issue is brief. ${ }^{294}$ Related to another argument is the issue of how Rev 10 relates to the episode of the witnesses. ${ }^{295}$

\section{The Testimony of the Early Church That Supports the Futurist View}

Tan's actual defense of the prevailing futurist view of the witnesses also includes a short, merely illustrative study of identifications for the witnesses in early Christian literature. ${ }^{296}$ She covers several authors and works from beginning of the second century to the middle of the eighth century. Her immediate purpose is to "show that the early church had a strong, longstanding (though by no means, unanimous) tradition that the two witnesses of Rev 11 would be two literal persons in the yet-future Tribulation

period." ${ }^{297}$ Her ultimate purpose, however, is to strengthen the likelihood that the prevailing futurist view of the witnesses is the correct one. ${ }^{298}$ The issue herein is that of the early interpretation of the two witnesses.

\section{Two Discussions Related to the Futurist View}

Tan's actual defense of the futurist view of the witnesses ends with a look at two debates among those who maintain this futurist view. One debate concerns the specific

${ }^{294}$ See the argument on the sense intended for the sackcloth clothing at ibid., 69.

${ }^{295}$ See again the argument that the historicist interpretation of the ascension of the witnesses as the political ascendancy of the reformers contradicts the historicist understanding of the descent of the angel in Rev 10. Ibid., 113.

${ }^{296}$ Ibid., 170-186.

${ }^{297}$ Ibid., 170-171.

${ }^{298}$ Ibid., 171; cf. 6, 184, 226, 229. 
identity of the two people who will act as the two witnesses. Tan focuses her attention on three significant proposals: the witnesses are Enoch and Elijah; they are Moses and Elijah; and they are two currently unknown future prophets. ${ }^{299}$ The second debate concerns the specific timing for the ministry of the two witnesses. Some argue that it is during the first half of the seven-year Tribulation period, while others choose the second half. ${ }^{300}$ Tan's aim in reviewing these disputes is to show that their existence does not diminish her case for the general futurist view. ${ }^{301}$

Tan's discussion of the first debate is more pertinent to the greater dispute over the identity of the two witnesses. In discussing the debate over a specific identity, Tan lays out supporting and opposing arguments that pertain to Elijah, Enoch, and Moses and such arguments as pertain to the opinion that the witnesses are simply two currently unknown future prophets. ${ }^{302}$ Although technically these are not her own arguments for a specific identity, looking at them reveals issues of interpretation that are not otherwise found in her work. For the sake of space, the arguments are not outlined here, but the issues raised by them may be noted. Most of these issues recall ones that may be derived

${ }^{299}$ For the introduction to this debate on specific identifications, see ibid., 186188. The body of the presentation appears at ibid., 188-214. It is discussed below. The conclusion is at ibid., 214. With all this, compare ibid., 6-7, 119-121, 186, 225-226, 229.

${ }^{300}$ For the introduction to this debate on specific timing, see ibid., 214. Arguments for the witnesses being active during the first half of the Tribulation period are at ibid., 215-219. Arguments for the alternative view are at ibid., 219-224. A conclusion appears at ibid., 224. With all this, compare ibid., 6-7, 123, 186, 225-226, 229.

${ }^{301}$ Ibid., 6-7, 186, 188, 214, 224-226, 229.

${ }^{302}$ There is some overlapping and repetition of material in this section because of the way Tan decides to arrange her presentation (OT figures are dealt with individually). 
from the works of Haugg, Todd, and Beckwith. Many arguments involve traditions about certain OT figures, Enoch, Moses, and Elijah. ${ }^{303}$ Some of those arguments also involve the miraculous powers of the two witnesses (Rev 11:5-6). ${ }^{304}$ There are some comments concerning the way in which the witnesses are introduced in Rev 11:3. ${ }^{305}$ One argument concerns the lack of names given to the witnesses. ${ }^{306}$ There are also some brief remarks that touch upon the images of the olive trees and of the lampstands. ${ }^{307}$ One issue though appears only in Tan, among the four commentators looked at so far, namely, the significance of the witnesses standing before the Lord of the earth according to Rev $11: 4 .^{308}$

\section{Conclusion}

All this summarizes what Tan espouses in defense of a general literal, eschatological identification of the two witnesses and shows the many broad issues of interpretation that can be deduced from that argumentation. The argumentation exhibits many of the broad issues of interpretation first seen above in the discussion of the studies of Haugg, Todd, and Beckwith. Also revealed are some additional issues that may complement the ones already identified.

${ }^{303}$ See the arguments spread out throughout Tan, "Defense," 189-214.

${ }^{304}$ See ibid., 189-191, 199-200.

${ }^{305}$ See the arguments at ibid., 188.

${ }^{306}$ See ibid., 213; cf. 205.

${ }^{307}$ See the argument at ibid., 212-213.

${ }^{308}$ The arguments related to this issue appear at ibid., 196-197. 


\section{Summary and Conclusions for}

Other Significant Expositions

This section has presented examinations of three significant expositions that, like Haugg's, also identify the two witnesses as two people appearing after the time of John, the assumed author of Revelation. The conclusions of Todd, Beckwith, and Tan about the identity of the witnesses are not exactly the same, nor even are they just like Haugg's conclusion, but there is still some harmony among them. In fact, this degree of agreement in the conclusions stands in spite of the presence of other differences among them.

This section has revealed other arguments that could be offered to support a conclusion like Haugg's. In some cases, these arguments could supplement the array of arguments found in Haugg's study. In other instances, they might function as alternatives.

This section has also shown that the broad issues of interpretation deduced from Haugg's arguments have an existence beyond his study. Todd, Beckwith, and Tan each deal with many of the broad issues seen in the examination of Haugg's exposition. These general issues truly play a role in the debate over the identity of the two witnesses, at least among those commentators who understand them to be two people appearing after the composition of Revelation. More is said in the conclusion to this chapter about the issues of interpretation shared among the four commentators examined so far.

\section{Johannes Munck}

Introduction

So far, the discussion in this chapter has centered on expositions that identify the two witnesses with two individuals who will appear in the future relative to John. The 
majority of scholarly interpreters who have advocated a literal understanding of the two witnesses have upheld this type of identification. As noted in the introduction to this chapter, however, several expositors who also promote a literal understanding of the witnesses have chosen to locate them instead in the era of John. Although advanced by far fewer interpreters over time, this type of identification deserves some discussion in this chapter. Yet, given its minority status over time, I have chosen to feature only one advocate, Johannes Munck. Furthermore, the examination of his work is briefer than it could be. No comprehensive account is attempted of the arguments that Munck advances for his proposed identification. After an overview of his work, a sample of his argumentation is presented. These two presentations together indicate nearly all the broad issues of interpretation that could be identified from a more detailed examination of Munck's argumentation.

Overview of Munck's Study of the Two Witnesses Johannes Munck (1904-1965) was a Danish New Testament scholar. ${ }^{309}$ His

\footnotetext{
${ }^{309}$ Johannes Munck was a Lutheran Danish scholar. He became a cand.theol. in 1926 through the University of Copenhagen. After studying abroad from 1926-1931, Munck returned to the University of Copenhagen, completing a ThD in 1933. His thesis was published as Johannes Munck, Untersuchungen über Klemens von Alexandria, Forschungen zur Kirchen- und Geistesgeschichte 2 (Stuttgart: W. Kohlhammer, 1933). This work and the work examined in this chapter stand among the many things that Munck authored. For instance, Munck produced other books and wrote several essays and numerous newspaper and journal articles. Munck's array of writings evidence his great interest in the history of early Christianity. Munck's literary accomplishments go beyond being an author. He was also an editor. For instance, he was the general editor for the Scandinavian theological journal, Studia Theologica, 1952-1964. Munck began a teaching career at the University of Copenhagen (1933-1938) and at Blaagaard Seminarium (1937-1939). In 1938, Munck went to work at Aarhus University and remained employed there for the rest of his life. He was a full professor of theology there - in fact, the first professor of theology there-, specializing in the New Testament,
} 
monograph on the two witnesses appears to have grown in part out of his interest in

"Paul's apostolate and the early Christian concept of apostle." 310 The monograph is also

the result of a few years of research. Some of the material in this work also appears in

two other shorter publications, one in Danish and one in English. ${ }^{311}$ From the latter

but he was also much more. He became involved in the university as an administrator and an organizer. Notably, he helped grow the separate theological faculty that was established in 1942 and served as rector for the university during a difficult time in Danish history (1943-1945). Beyond Aarhus University, Munck was actively involved in academic societies and visited universities abroad. In fact, he was even honored by two foreign institutions (the University of Oslo [honorary ThD, 1961] and the University of Glasgow [honorary DD, 1962). He was not without honors at home though. He was given Danish state honors in 1946 (Ridder af Dannebrog) and 1954 (Ridder af 1. grad af Dannebrog). Concerning these and other aspects of Munck's life and work, see J. Vikjær Andersen, "Bibliographie de l'œuvre de Johannes Munck," ST 19, no. 1-2 (1965): 3-21; Ragnar Bring, "Johannes Munck in memoriam," STK 41, no. 1 (1965): 63-64; Erling Hammershaimb, "Af Collegium Biblicums historie," DTT 35, no. 1-2 (1972): 2-11; Erling Hammershaimb and Bent Noack, "Johannes Munck, 3. marts 1904-22. februar 1965," in Aarsberetning 1964-1965 (Aarhus: Universitetsforlaget, 1965), 7-13, accessed August 16, 2015, Aarhus Universitet, AU Universitetshistorie Nekrologportal; Niels Hyldahl, "Træk af den nytestamentlige eksegeses historie i Danmark i det 20. århundrede," in Kirkehistoriske samlinger 1979, ed. Leif Grane, Martin Schwarz Lausten, and Jørgen Stenbæk (Copenhagen: Selskabet for Danmarks Kirkehistorie, 1979), 128129, 143-150; Niels Hyldahl and J. Nørregaard, "Johannes Munck," Dansk Biografisk Leksikon, 3rd ed. (Copenhagen: Gyldendal, 1979-1984), accessed August 17, 2015, http://www.denstoredanske.dk/index.php?sideId=294544; Elisabeth Munck, "Johannes Munck, 1904-1965," ST 19, no. 1-2 (1965): 1-2; Johannes Munck and Elisabeth Munck, Preface to The Acts of the Apostles: Introduction, Translation and Notes, by Johannes Munck, ed. William F. Albright and C. S. Mann, Anchor Bible (Garden City, NY: Doubleday, 1967), vii-viii; and Bent Noack, "Johannes Munck, exeget og teolog," DTT 35, no. 1-2 (1972): 126-134.

${ }^{310}$ Munck, Petrus und Paulus, 5. Any translations from Petrus und Paulus are my own.

${ }^{311}$ Johannes Munck, "Peter og Paulus i Johannes' Aabenbaring. Et Bidrag til Udlægning at Apokalypsen," Ny Kyrklig Tidskrift 18 (1949): 33-51; and Johannes Munck, "Peter and Paul in the Apocalypse of St. John," Nuntius Sodalicii Neotestamentici, no. 4 (1950): cols. 25-26. The longer Danish article covers the same subjects as covered by chapters 1-3 of Petrus und Paulus, which has a total of five chapters, but it is more concise, exhibits a few differences, and has no footnotes. The 
comes a simple statement of Munck's perspective on the identity of the two witnesses:

Rev 11:3-13 presents "evidence as to the early Christian apostolate, where Peter and Paul come with the power of Elijah and Moses and attack Antichrist. Defeated and killed by antichristian Rome, they rise again and ascend to heaven."1312

Munck's monograph begins with a survey of proposed interpretations for the tale of the two witnesses. Criticism of the surveyed views then follows. The criticism is primarily directed at the idea that the expectation of two messianic forerunners, taken as Moses and Elijah, forms the basis for the expectation in Rev 11. After the criticism, Munck offers a new proposal on the identity of the two witnesses, namely, that the witnesses are the apostles Peter and Paul. This proposal has advantages over the surveyed views. All this forms the first chapter. ${ }^{313}$

For the second chapter, Munck goes verse by verse through Rev 11:3-13, dealing only with "the features that are of particular interest for the explanation of the new

much shorter English piece summarizes for the most part the whole of Petrus und Paulus. Munck also authored two newspaper articles on Revelation, but these make no mention of the two witnesses. See Johannes Munck, "Johannes' Aabenbaring er en Trøstebog," Aarhuus Stiftstidende, October 20, 1940; and Johannes Munck, "Vor Tid er lydhør for Johannes' Aabenbaring," Aarhuus Stiftstidende, August 10, 1941.

${ }^{312}$ Munck, "Peter and Paul," col. 26.

${ }^{313}$ Petrus und Paulus and "Peter og Paulus" differ the most in their surveys of past interpretations of Rev 11:3-13 and criticism of them. The earlier discussion focuses less on individual interpreters than the later discussion does. In "Peter og Paulus," Munck focuses on four methods that have been used to interpret Rev 11:3-13: the spiritualistic, the consistently eschatological, the tradition-historical, and the contemporary-historical. He discusses and criticizes each method to a varying extent. Expositors are named, but they are not the focal point. Munck, "Peter og Paulus," 33-37. In Petrus und Paulus, however, Munck for the most part moves chronologically through the interpretations of key expositors and then presents his criticisms in a separate section. Munck, Petrus und Paulus, 7-16. 
interpretation." ${ }^{314}$ That being said, Munck deals with many of the features in the text, such as their introduction as witnesses, the clothing that they wear, their 1,260 days for ministry, where they minister, the designations as lampstands and olive trees, the miraculous powers, and the figures and events surrounding their death, resurrection, and ascension, including the earthquake of Rev 11:13. Much of what Munck presents here, while not directly pinpointing Peter and Paul as the two witnesses, is congruent with and supportive of his proposal. A significant portion of this material consists of comparative material related to Peter and Paul. Not surprisingly, Munck discusses at great length the beast from the abyss (11:7) and the identity of the great city (11:8). Inasmuch as the place of martyrdom and the agent of martyrdom are relatively well established in the traditions surrounding the deaths of Peter and Paul, he must address these two elements in particular for his proposal to be correct. Thus, Munck argues that the beast is linked with the Roman state and the city is linked to Rome.

Having discussed various aspects of Rev 11:3-13, Munck devotes the third chapter of his monograph to addressing how the passage connects with other parts of Revelation. He deals first with understanding the connection between Rev 11:3-13 and 11:1-2. He finds the views of others to be helpful in understanding this connection. Like some of them, he adopts a symbolic reading of Rev 11:1-2, where the imagery has to do with the church. The idea of comfort within the context of persecution ties Rev 11:1-2 to 11:3-13. ${ }^{315}$ Then Munck turns to how Rev 11:3-13 connects with what follows,

${ }^{314}$ Munck, Petrus und Paulus, 16. The actual chapter covers ibid., 17-46. ${ }^{315}$ Ibid., 47-49. 
particularly 11:14-19:10. Here the views of others are not as helpful, and Munck charts his own course. ${ }^{316}$ His thoughts on this matter are among the select arguments presented below. After dealing with how Rev 11:3-13 is connected to the rest of Revelation, particularly what follows, Munck believes that he has "reached an overall picture that can become a starting point for a new interpretation of the book [of Revelation]."317

Fundamental to Munck's proposal of Peter and Paul as the two witnesses is the assumption that historically these apostles died as martyrs in Rome. Munck recognizes, however, that doubts have been raised about this assumption. Thus, the first of two concerns in the fourth chapter is "the total problem of the martyr's death of the two apostles [Peter and Paul] in Rome." ${ }^{318}$ Munck's second concern is to understand the position of "the new tradition about the martyrs' death [of the two apostles (Rev 11:313)] among the already known traditions." ${ }^{319}$ He concludes that, while it is unprovable, the available evidence points to "the tradition in Revelation 11 [being] . . the oldest form of the tradition of the martyrdom of the two apostles," as opposed to being "a special tradition [eine Sondertradition]. ${ }^{1320}$

The fifth chapter of Munck's monograph is an extended discussion and eventual rejection of an idea presented by Joachim Jeremias (1900-1979) in his articles about

${ }^{316}$ Ibid., 49-55.

${ }^{317}$ Ibid., 55.

${ }^{318}$ Ibid., 56. The actual discussion of this matter appears at ibid., 56-70.

${ }^{319}$ Ibid., 56. The actual discussion of this topic appears at ibid., 71-81. ${ }^{320}$ Ibid., 80-81. 
Moses and Elijah for the Theologisches Wörterbuch zum Neuen Testament. ${ }^{321}$

Specifically, Jeremias argues that in ancient Jewish thought there existed the concepts of a suffering Moses and a suffering Elijah. These traditional images were used in the composition of the narrative of the two witnesses. ${ }^{322}$ Munck takes up this discussion of Jeremias' proposals presumably because he perceives Jeremias to have advanced a serious rival account of the origin of the figure of the two witnesses and thereby a

${ }^{321}$ The chapter covers ibid., 81-120. The articles in question are Joachim Jeremias, "H $\lambda(\varepsilon) i ́ a \varsigma, " ~ T W N T$, ed. Gerhard Kittel and Gerhard Friedrich (Stuttgart: W. Kohlhammer, 1933-1979), 2:930, line 32,-943, line 21; and Joachim Jeremias, "M $\omega v \sigma \tilde{\eta} \varsigma, " ~ T W N T$, ed. Gerhard Kittel and Gerhard Friedrich (Stuttgart: W. Kohlhammer, 1933-1979), 4:852, line 19,-878, line 22. English translations are available as Joachim Jeremias, "H $\lambda(\varepsilon) i ́ \alpha \varsigma, " T D N T$, ed. Gerhard Kittel and Gerhard Friedrich (Grand Rapids,

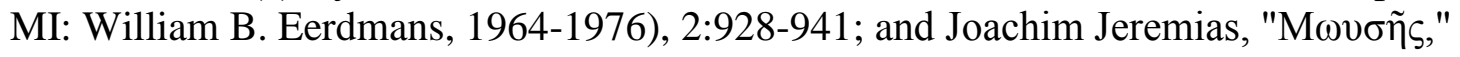
TDNT, ed. Gerhard Kittel and Gerhard Friedrich (Grand Rapids, MI: William B. Eerdmans, 1964-1976), 4:848-873.

${ }^{322}$ Consider Munck's summaries of Jeremias' proposals at Munck, Petrus und Paulus, 82-84, 113-114, 117-120; cf. 13n9. The specific sections of Jeremias' articles to which Munck pays particular attention are Jeremias, "H $\lambda(\varepsilon)$ í $\alpha$ s," TWNT, 2:940, line 13,-

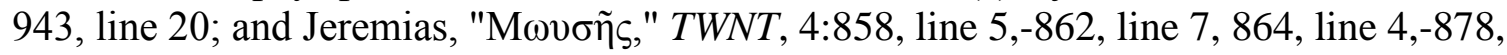
line 13. English translations are at Jeremias, "H $\lambda(\varepsilon) i ́$ ís," TDNT, 2:938-941; and Jeremias, "M $\omega v \sigma \tilde{\eta} \varsigma, " ~ T D N T, ~ 4: 853-857,859-873$. One should note that Jeremias' identification of the two witnesses varies slightly when one compares his dictionary article on Elijah with that on Moses. In the dictionary article about Moses, Moses himself is not represented in Rev 11:3-13, but "the second Moses" or "the prophet like Moses" is. Cf. with each other Jeremias, "H $\lambda(\varepsilon) i)^{\prime} \alpha \varsigma_{,}$TWNT, 2:940, line 13,-943, line 20;

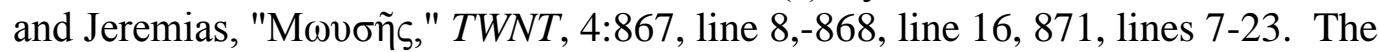

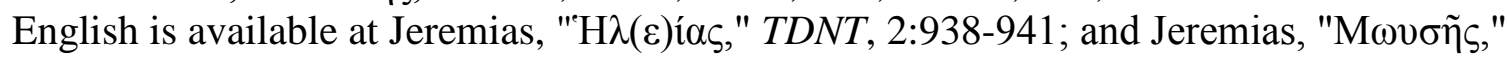
TDNT, 4:863-864, 866-867. It is unclear whether Munck notices this shift in thinking, since at one point in speaking about Jeremias' article on Moses he uses the phrase "the

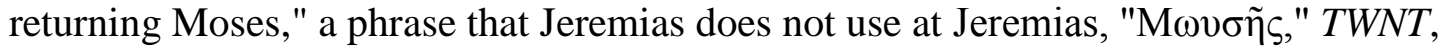
4:867, line 8,-868, line 16; cf. 871, lines 7-23. The English translation of this text is at Jeremias, "M $\omega v \sigma \tilde{\eta} \varsigma, " T D N T, 4: 863-864$; cf. 866-867. Munck uses the phrase "the returning Moses" at Munck, Petrus und Paulus, 118. Compare this text with all his remarks on Jeremias' thoughts about Moses and Rev 11 at ibid., 13n9, 82-84, 114, 118 120. 
weighty alternative identification for them. ${ }^{323}$ Most of Munck's discussion is actually an investigation of part of Wilhelm Bousset's (1865-1920) Der Antichrist, on which Jeremias' proposals depend. ${ }^{324}$ Thus, ends Munck's monograph on the two witnesses.

Select Arguments and Broad Issues of Interpretation

The overview of Munck's monograph already suggests some of the broad issues of interpretation exhibited by the work. Noted here are only those issues not evident from the selection of arguments presented below. The initial chapter raises the issue of messianic forerunners. Implicit in this chapter is also a rejection of symbolic views of the two witnesses. This rejection raises the question of what is the degree to which symbolism plays role in Revelation. Going carefully through the narrative of the witnesses, Munck deals with several issues. Included are the sackcloth clothing of the witnesses, the meaning of the three-and-a-half year period, the setting for the events of Rev 11:3-13, the image of the olive trees, the image of the lampstand, the miraculous powers of the witnesses, the identity of the beast of Rev 11:7, the fate of the witnesses, and the significance of the earthquake of 11:13. Munck also raises the issue of the

${ }^{323}$ Consider his assessment of the significance of the articles in general at Munck, Petrus und Paulus, 81; cf. 82. Note also his earlier discussion of Moses and Elijah as the two witnesses, in which he mentions Jeremias a few times, at ibid., 13-16.

${ }^{324}$ Jeremias refers to Wilhelm Bousset, Der Antichrist in der Überlieferung des Judentums, des neuen Testaments und der alten Kirche. Ein Beitrag zur Auslegung der Apocalypse (Göttingen: Vandenhoeck und Ruprecht, 1895), 134-139, accessed June 12, 2015, Google Books. The English translation appears at Bousset, Antichrist Legend, 203211. Cf. Jeremias, "H $\mathrm{H}(\varepsilon)$ í $_{\text {," }}$ TWNT, 2:942, lines 16-18, 39-41; and the English translation Jeremias, "H $\lambda(\varepsilon)$ ías," TDNT, 2:940. Munck's investigation of Bousset appears at Munck, Petrus und Paulus, 85-113. Although focusing on the segment of Bousset's work that Jeremias cites, Munck also brings into his discussion at least Bousset, Der Antichrist, 1-19, 129-132. The English translation is at Bousset, Antichrist Legend, 3-32, 195-200. Cf. Munck, Petrus und Paulus, 85, 99-100. 
meaning of the immediate context before the episode of the witnesses, Rev 11:1-2, as he tries to connect his interpretation of Rev 11:3-13 to a reasonable view of the literary context of the passage. The final chapter examining Jeremias's thoughts raises the issues of traditions about Moses and of traditions about Elijah.

Highlighted now are some of Munck's numerous arguments for his proposal that the witnesses are the apostles Peter and Paul. The arguments are divided into two groups. Enough arguments are presented here to give a taste of his reasoning as a whole. This portion of argumentation also affirms the presence of broad issues of interpretation that could be deduced just from the overview. The arguments, however, also reveal a few others not evident from the overview. In the end, the overview and the arguments presented here suggest nearly all the issues in the interpretation of the witnesses that one can find in Munck's work. All the issues identified from the overview and from the discussion below are listed in Figure 5 (see the next page) in the order in which they are first mentioned.

\section{Arguments concerning Rev 11:3}

The first set of arguments that I highlight are a portion of Munck's remarks on Rev 11:3. They appear at the beginning of his second chapter, in which he goes through Rev 11:3-13 verse by verse.

Rev 11:3 presents "my two witnesses." Munck begins by contending that Christ is the one speaking and calling these two his. ${ }^{325}$ They are Christ's witnesses. For some support, Munck refers readers to Rev 11:8, where it says that the bodies of the witnesses

\footnotetext{
${ }^{325}$ Munck, Petrus und Paulus, 17.
} 
1. Messianic forerunners

2. Degree of symbolism

3. Sackcloth clothing of the two witnesses (Rev 11:3)

4. Three-and-a-half year period

5. Setting for the episode of the two witnesses

6. Image of the Olive Trees

7. Image of the Lampstands

8. Miraculous powers of the two witnesses (Rev 11:5-6)

9. Identity of the beast of Rev 11:7

10. Fate of the two witnesses (Rev 11:7-12)

11. Earthquake of Rev 11:13

12. Context immediately before Rev 11:3-13 (11:1-2)

13. Traditions about Moses

14. Traditions about Elijah

15. Introduction of the two witnesses (Rev 11:3)

16. Crucified lord of Rev 11:8

17. Theme of testimony

18. Traditions about Peter

19. Traditions about Paul

20. Context immediately after Rev 11:3-13 (11:15-19:10)

21. Interpretive approach

22. Relationship between Rev 11:3-13 and the three "woes"

Figure 5. Broad issues of interpretation in Munck's argumentation.

"will lie in the street of the great city ..., where also their Lord was crucified" (NRSV).

Presumably, Munck takes "their" to refer to the witnesses and "Lord" to refer to Christ.

Being able to say that these are Christ's witnesses in Rev 11:3-13, of course, lines up with Munck's proposed identification, which he asserts in this context, before proceeding with further argumentation. ${ }^{326}$

${ }^{326}$ This is not the first time, however, that readers of Munck's monograph have seen his proposal. It appears first in the previous chapter, chapter 1, at ibid., 15-16. 
Munck next observes that the apostles are called witnesses in the New Testament (Luke 24:48; Acts 1:8; cf. Acts 1:22; 2:32; 3:15; 5:32; 10:39, 41; 13:31). He also observes that Paul appears as a witness in Acts 22:15;26:16, while 1 Pet 5:1 presents Peter, the apparent author, as a witness "in the same sense as the passages ... about the apostles as witnesses." 327 Perhaps to help show that these texts are comparable to Rev

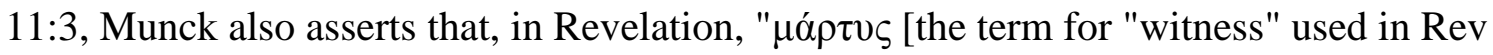
11:3] denotes the one who bears testimony and is not used with the later meaning 'martyr."'328

Munck realizes though that he must explain why these two particular witnesses, Peter and Paul, would be connected together in this passage. Munck mentions that, according to Gal 2:7-8, "the proclamation in the whole world was entrusted to them jointly, the gospel for the Jews to Peter and the gospel for the Gentiles to Paul." ${ }^{329}$ This seems to be an inadequate explanation, however, since "it is to be assumed that this fact had fallen into oblivion in the second half of the first century." ${ }^{330}$ By that time, "the church was no longer divided into Jewish Christians and Gentile Christians in the early Christian sense, but emerged more and more sizably as a Gentile church," which thus affected the conceptions of "Peter and the rest of the Twelve"; the Twelve now "are regarded as apostles to the Gentiles after the model of Paul." ${ }^{331}$ For a more suitable

${ }^{327}$ Ibid., 17.

${ }^{328}$ Ibid., 17; cf. 18n22.

${ }^{329}$ Ibid., 18.

${ }^{330}$ Ibid.

${ }^{331} \mathrm{Ibid}$. With respect to later conceptions of the Twelve as apostles to the 
explanation, Munck turns to the idea of Peter's and Paul's "martyrdom in Rome, which is supposed to have taken place at nearly the same time." ${ }^{332}$ He observes that it is this connection through martyrdom that is subsequently "repeated in the tradition about them, and the oldest form of which" could be found in and beneath Rev 11:3-13. ${ }^{333}$ From this stream of tradition about Peter and Paul, he highlights 1 Clem. 5 and Ign. Rom. 4.3 as evidence of "this connection" between the two men. ${ }^{334}$ Still, Munck does not completely leave Gal 2:7-8 out of the picture. Assuming that the place of martyrdom, Rome, was "a place with which [Peter and Paul] ... had no closer connection at all and to which, however, they presumably had to be taken from afar," the common martyrdom in Rome acts as "a proof of their special position, to which Gal 2:7-8 testifies." ${ }^{135}$ From this perspective, "when the Roman state wanted to reckon [abrechnen] with the new religion, it struck [er traf] at the same time the two leading men of the church [die beiden ersten

Gentiles, Munck refers to Johannes Munck, "Paulus' Apostolat og Apostelbegrebet i det Ny Testamente," DTT 11, no. 3 (1948): 156-157. The English version appears as Johannes Munck, "Paul, the Apostles, and the Twelve," ST 3, no. 1 (1949): 109-110.

${ }^{332}$ Munck, Petrus und Paulus, 18 . That Munck would go this direction is already intimated at ibid., 15-16.

${ }^{333}$ Ibid., 18. Cf. the discussions in his fourth chapter at ibid., 56-81.

${ }^{334}$ Ibid., 18. As noted above, Munck addresses doubts about the common Roman martyrdom of Peter and Paul in his fourth chapter. Much of that discussion involves looking at these two cited texts, 1 Clem. 5 and Ign. Rom. 4.3. For the whole discussion of the problem of the common martyrdom, see ibid., 56-70. Also, Munck comments on 1 Clem. 5 in other contexts in his monograph. See ibid., 21, 30, 39, 41, 71, 75-77.

${ }^{335}$ Ibid., 18. Munck says more about the kind of connection that Peter and Paul had to Rome at ibid., 66-70; cf. 64-65. 
Männer der Kirche], not like many usually want to understand it, two apostles who just by chance worked in the capital." 336

Five broad issues of interpretation can be deduced from this set of arguments. The starting point for these arguments is (1) the issue of the introduction of the two witnesses. To interpret that issue, Munck discusses (2) the crucified lord of Rev 11:8. The introduction also leads to a brief reference to (3) the theme of testimony and to an examination of (4) traditions about Peter and (5) traditions about Paul. Not surprisingly, the latter two issues are evident throughout much of Munck's argumentation, not just the set of arguments presented above.

\section{Arguments concerning the Connection of Rev 11:3-13 to the Passages That Follow}

Another set of arguments, one that is more involved, comes from Munck's third chapter and concerns how Rev 11:3-13 coheres with its context, particularly what follows the passage. Although this group of arguments is somewhat dependent on Munck's remarks concerning Rev 11:7, it can still be reasonably separated out from the rest of his argumentation for the sake of the present study.

While Munck finds the views of others to be helpful in understanding the connection between Rev 11:3-13 and Rev 11:1-2, this is not the case for the connection between Rev 11:3-13 and what follows it. He asserts that the majority of commentators have limited their examination of this connection because they believe that Rev 11:3-13

${ }^{336}$ Ibid., 18. 
"is part of an inserted piece that ends with 11:13."337 Thus, they apparently see the whole of $\operatorname{Rev} 10: 1-11: 13$ as an interruption in the series of seven trumpets $(8: 6-8,10,12 ; 9: 1$, $13 ; 11: 15)$ and in the series of three woes $(\operatorname{Rev} 9: 12 ; 11: 14){ }^{338}$

Munck charts his own course on this matter, apparently seeing a special connection between the material that follows Rev 11:3-13 and that passage. Concerning what follows 11:3-13, Munck notices first the announcement that the second woe is finished and the third woe is coming soon $(\operatorname{Rev} 11: 14) .{ }^{339}$ Then come the sounding of the seventh trumpet and "shouts of victory" that come from heaven, speaking of the establishment of the reign of God and of his anointed one over the world. ${ }^{340}$ The twentyfour elders then add their praises to these events. After this note of comfort and of hope comes "the necessary prelude" to the time of victory, namely, "the appearance and ... the reign of the Antichrist, ... the culmination of the anti-God forces in the world and of the suffering of the Church."341 All this is narrated "when the account of their death and resurrection and ascension is at an end." ${ }^{342}$ Munck juxtaposes this picture of the context with thoughts raised earlier in his examination of Rev 11:3-13: from outside Revelation, there is the idea "that the Antichrist comes at the death of the apostle Paul"; and, from

${ }^{337}$ Ibid., 49.

${ }^{338}$ Consider the majority of the opinions on Rev 11:3-13 in its larger context that Munck surveys briefly at ibid., 50-51.

${ }^{339}$ Ibid., 49, 51.

${ }^{340}$ Ibid., 49; cf. 51.

${ }^{341}$ Ibid., 50, cf. 51.

${ }^{342}$ Ibid., 51. 
within Rev 11:3-13, there is the picture of "the apostles Peter and Paul ... [dying] through the Antichrist displaying his power on them." ${ }^{343}$ By lining up all these ideas, Munck may wish readers to see that the antichrist functions as a point of contact between Rev 11:3-13 and what follows. There is, however, the potential for seeing conflict between these parts of Revelation because of this very figure. For Rev 11:3-13 describes the antichrist in action, while Rev 13, many verses later than Rev 11:3-13, describes the arrival of antichrist. In any case, Munck believes in a special connection between these parts of Revelation and therefore seeks to clarify the nature of that connection.

Munck's clarification begins by addressing "the composition of the

${ }^{343}$ Ibid. The earlier thoughts come particularly from Munck's discussion of Rev 11:7. He begins his discussion of that verse by placing it within the context of other traditions about the coming of the antichrist and the death of the apostles, particularly Paul. Perhaps the key text for comparison for Munck is 2 Thess 2:6-7, where Munck follows Oscar Cullmann (1902-1999) in interpreting the text as saying that the antichrist will come after Paul's death. Ibid., 24-25. He is relying specifically upon Oscar Cullmann, "Le caractère eschatologique du devoir missionnaire et de la conscience

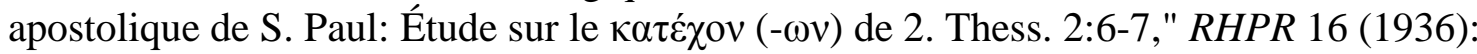
210-245. Other texts noted by Munck here are Acts 20:29-30; 1 Tim 4:1-5; and 2 Tim 3:1-9. Munck, Petrus und Paulus, 25-26. Separately, Munck also points to 2 Pet 3:1-13, where Peter, expecting death soon (2 Pet 1:12-15), predicts that the Church will see "great dangers." Ibid., 26n31. When compared to these passages from outside Revelation, Munck observes that the truly "novel thing" about Rev 11:7 "is that the Antichrist does not appear only when the apostles are gone, but that he causes their death." Ibid., 26. Munck identifies one other key difference between those other NT passages and Rev 11:7, but it is less relevant to the discussion above; that is, concerning the type of antichristian forces involved. He acknowledges "that the name Antichrist is used very rarely (only in 1 John $2: 18,22 ; 4: 3 ; 2$ John 7 ) and that the reality that the Antichrist denotes is as a rule a religious seduction, in accordance with the second beast, Rev 13:11-17, and not the antichristian world power, in accordance with the beast from the sea, Rev 13:1-8." Ibid., 25. The antichrist as a religious entity is clear in 1 John 2:1822 as well as 2 Thess 2:3-12. The texts of Acts 20:29-30; 1 Tim 4:1-5; 2 Tim 3:1-9; and perhaps 2 Pet $3: 1-13$ present a similar idea when they speak of certain antichristian forces. Ibid., 25-26. Munck contends that the novelty of the apostles' deaths through the antichrist power "was possible only if the Antichrist [in Rev 11:7] was regarded as the evil world power, not as the religious seduction, as in the other texts." Ibid., 26. 
Apocalypse." ${ }^{134}$ Specifically, he takes a more respectful view of the author of Revelation than he has found among many other interpreters. ${ }^{345}$ Thus, Munck argues that the author of Revelation composed his work in an intentional and meaningful way, even if he depends in some way on prior material. ${ }^{346}$

Munck continues with his clarification by pointing out a particular part of the author's meaningful intent: "Like the author of the book of Daniel and every later Christian report [jede spätere christliche Orientierung] about the age and the coming end of the world, the author of the Apocalypse gives an interpretation [eine Deutung] of his own age and the events that have preceded and that have significance for his present and future. ${ }^{1347}$ Munck then transitions to how this applies practically in the reader's interpretation of the Book of Revelation: "With the interpretation [Bei der Auslegung], what matters is determining the point where the author goes from the eschatologically interpreted [gedeuteten] present over in a broader sense to the actual future." 348 Specifically, Munck believes that this shift occurs with Rev 13. With that chapter "begins the complete revelation of the Antichrist and the last plagues over the earth up to

${ }^{344}$ Munck, Petrus und Paulus, 51.

${ }^{345}$ For instance, Munck feels that the "least interesting" question for Wilhelm Bousset is knowing "what the author actually meant by his prophetic words in chapter 11." Ibid. He appears to have in mind here Bousset, Die Offenbarung Johannis, 324325; cf. Munck, Petrus und Paulus, 50.

${ }^{346}$ Munck, Petrus und Paulus, 51-52. Munck's opinion on the specific identity of the author of Revelation is not clear from Petrus und Paulus, from the related journal articles, or from the earlier newspaper articles. He prefers to use just the term "author," even when he calls the book the "Revelation of John." See, for instance, ibid., 54.

${ }^{347}$ Ibid., 52.

${ }^{348}$ Ibid. 
the fall of Babylon and Christ's return." ${ }^{349}$ He cautions, however, that, while one can see where the author shifts his attention from matters of the present to matters of the future, one will not find the author presenting an exact timeline concerning the origins and development of antichrist. ${ }^{350}$

To continue his attempt at defining more exactly the connection between Rev 11:3-13 and the content that follows, Munck addresses the issue of the three woes and their relationship to the whole of Revelation. First, he identifies the "division into three woes" as appearing "for the first time after the 5th trumpet in Rev 9:12," which declares that the first woe is finished and two woes are still to come. ${ }^{351}$ The division then reappears in Rev 11:14, which declares that the second woe is finished and that the third is coming soon. Munck apparently disagrees with the idea of some commentators that the three woes line up with some of the seven trumpets. Instead, he maintains, "The second woe includes only the 6th trumpet, whereas the first woe probably takes in all the events from the beginning of the book; and the third woe naturally contains the last events from the end of the 11 th chapter until Christ's return." 352

${ }^{349}$ Ibid.

${ }^{350}$ Ibid. In the next sentence, Munck compares this uncertainty in the portrayal of the antichrist in Revelation to the words about the antichrist in 2 Thess 2:7: "For the mystery of lawlessness is already at work" (NRSV). As in Revelation, the antichrist is operating in the present, but there is something much more coming in the future, a full revelation of the antichrist. With these remarks concerning the development of the antichrist, one can compare Munck's discussion of the identity of the beast in Rev 11:7. Ibid., 27-30.

${ }^{351}$ Ibid., 52.

${ }^{352}$ Ibid., 52-53. As for the views of other commentators, consider, for example, the summary of Bousset's opinion about the three woes and the placement of Rev 10:1- 
Munck then outlines how "the synoptic apocalypse" also presents "a three-part division of the events that precede Jesus' return." ${ }^{353}$ Munck unpacks the three-part sequence of events in Revelation while keeping in mind that it is "by and large the same sequence of events as in the synoptic apocalypse." ${ }^{1354}$ Revelation 4-5 present the ascension of Christ, which the first of the three periods then follows. The first period encompasses the seven seals and the first five trumpets $(\operatorname{Rev} 6: 1-9: 11)$. $\operatorname{Rev} 9: 12$ transitions one to the second period $(\operatorname{Rev} 9: 12-11: 13)$. This period is marked by "persecution," but it is also the time "in which the gospel is announced in the whole world by the two apostles Peter and Paul." ${ }^{355}$ "Their dissemination of the gospel results in the attack of the Antichrist on the two apostles," which leads to a seeming defeat with their death. ${ }^{356} \operatorname{Rev} 11: 14$ announces the end of the second woe period and proclaims the coming of the third. The description of that period actually begins with Rev 12 or at least with Rev 13. ${ }^{357}$ With chapter 13 comes "the complete revelation of the Antichrist, after

11:13 at ibid., 50. For this summary, Munck refers to Bousset, Die Offenbarung Johannis, 297, 324.

${ }^{353}$ Munck, Petrus und Paulus, 53. The actual textual divisions are listed at ibid., 53n70.: "First period: Matt 24:4-8; Mark 13:5-8; Luke 21:8-11. Second period: Matt 24:9-14; Mark 13:9-13; Luke 21:12-19. Third period: Matt 24:15-28; Mark 13:14-23; Luke 21:20-24."

\section{${ }^{354}$ Ibid., 53.}

${ }^{355} \mathrm{Ibid} ., 54$. For discussion of the theme of persecution in Rev 11:1-13, see ibid., $48-49$.

${ }^{356}$ Ibid., 54.

${ }^{357}$ Munck notes that Rev 12 deals with persecution and suggests that it is "an insertion between the announcement of the third woe and its arrival." Ibid., 54n74; cf. 49. 
which this one and the great Babylon and its fall are the main topic. As soon as Babylon has fallen, Christ rides victoriously out of heaven with his whole army." ${ }^{358}$ Christ has returned and the third period ends. ${ }^{359}$

Munck combines these considerations on the three woes with his earlier thoughts on the composition of Revelation and its reflections about the past, present, and future, so that he can form a conclusion about the nature of the connection between Rev 11:3-13 and what follows. Contrary to the thinking of some commentators on Revelation, the juxtaposition of the fate of the two witnesses and the announcement of the end of the second woe is intentional, "not accidental." ${ }^{360}$ It is also something "of decisive importance," for the eleventh chapter presents "the decisive turning point in the Apocalypse, where the author turns away from the past and the present interpreted by him in order to speak of the immediate future, the reign and the fall of the Antichrist. He knows where he and his own age stand, namely, on the threshold between the second and the third apocalyptic period." 361 In other words, the nature of the connection between Rev 11:3-13 and what follows from 11:14 is one of a transition in the author's progressive

${ }^{358}$ Ibid., 54.

${ }^{359}$ Munck observes that there is no declaration of the end of the third woe and suggests, "Here a remark that the third woe is at an end would only intrude. When Christ appears, no pointer is needed [bedarf es keinen Zeigefingers], so that each Christian understands that the third woe is concluded." Ibid., $54 \mathrm{n} 75$.

${ }^{360}$ Ibid., 55.

${ }^{361}$ Ibid. He continues after the above quotation with a more specific description of the author's perspective on this historical situation between the two woes: "When the apostles left the world, it was clear that the age of the antichrist had dawned, and now it has come. The smaller persecutions that have already taken place are the first indications of the great age of affliction that is to come with the antichrist." Ibid. 
description of eschatologically significant events that happen between Christ's ascension and second coming. As noted above, these events center on the development of the antichrist.

One can now look at the broad issues of interpretation that this set of arguments exhibits. What gives rise to the many arguments, what they aim to address specifically, is the possible conflict in meaning, or at least a seeming disconnect, between Rev 11:3-13 and the passages that follow it. If Munck can successfully demonstrate a particular continuity between Rev 11:3-13, as he interprets it, and the later parts of Revelation, then he has another basis on which to commend his proposal that the witnesses are Peter and Paul. Obviously, therefore, the overriding issue concerns the meaning of the immediate context after the episode of the witnesses, specified in this context as Rev 11:15-19:10.

Within the arguments, Munck expresses an opinion on the manner in which the author composed his work (he intended to convey a particular message). He also makes an assumption about the nature of the content of the book (it presents an interpretation of historical events connected to the author's present world). Munck discusses the application of this idea in one's interpretation of the book and then applies it himself in order to say something about Rev 13 and ultimately Rev 11. This discussion raises in a small way the methodological issue of the proper interpretive approach to Revelation, inasmuch as it involves relating the contents of the book to history. Arguably, the issue of the proper approach can also be found in the initial chapter of Munck's monograph. There, however, its presence is quite implicit. Thus, for instance, Munck shows a preference for tradition-historical criticism and contemporary-historical criticism, particularly in his first chapter, in which he evaluates the proposals of other interpreters 
concerning the witnesses. Yet, such a preference must be deduced from his critical remarks about other proposals. ${ }^{362}$

One other issue evident from this set of arguments may be the placement of Rev 11:3-13 within the series of three woes mentioned in Rev 9:12 and 11:14.

\section{Summary and Conclusions}

This section has offered an abbreviated look at the study of Johannes Munck on the two witnesses of Revelation. First, the whole monograph has been summarized. Several broad issues of interpretation in identifying the witnesses have been identified simply based on this overview. Second, two sets of arguments have been highlighted. The first concerns Munck's interpretation of Rev 11:3. The second concerns his understanding of the connection between Rev 11:3-13 and the passages that follow it, particularly 11:14-19:10. This sampling of arguments gives a taste of Munck's reasoning as a whole. Moreover, other broad issues of interpretation have been deduced from these two sets of arguments. The broad issues of interpretation identified in this brief examination of Munck's research represent in fact nearly all such issues that could be identified from a more detailed examination of his argumentation.

Munck comes to a conclusion concerning the identity of the two witnesses that is quite different from that of the other expositors discussed in this chapter, and he argues for that conclusion in ways that might conflict with their arguments. Nevertheless,

${ }^{362}$ Ibid., 7-16. This section is in contrast to the corresponding section of Munck's shorter Danish article. As noted, there Munck focuses on four methods that have been used to interpret Rev 11:3-13: the spiritualistic, the consistently eschatological, the tradition-historical, and the contemporary-historical. He discusses and criticizes each method to a varying extent. Munck, "Peter og Paulus," 33-37. 
Munck deals with some of the same broad issues of interpretation, while he addresses the same question that they address. More is said in the conclusion to this chapter about these points of contact among the five commentators examined above.

Of course, Munck's exposition is one in a class of expositions that take the two witnesses as being figures from the era of the author of Revelation. Munck's exposition is one of the most detailed expositions from this class, if not the most detailed one. Given this situation and having personally looked at several other key expositions from this class, I am confident that the broad issues of interpretation present in Munck's monograph represent many of such issues exhibited by others in the same class of expositions.

\section{Summary and Conclusions for the Chapter}

The topic of this chapter has been those identifications of the two witnesses that understand them to be two actual people. A look at this kind of identification over time showed that the majority of its advocates have located the two individuals in the future, relative to the author of Revelation. In fact, the earliest known identification of the two witnesses is a literal, futuristic one. A smaller number of adherents to the literal view of the witnesses have identified them with the author's contemporaries in the first century CE. In accordance with this historical perspective on literal views of the witnesses, most of the chapter involved examining significant expositions for a futuristic identification. Some space though was given to the other type of literal identification.

\section{The Exposition of Donatus Haugg}

The first exposition examined was that of Donatus Haugg. He argues that the two witnesses are two now-unknown persons who will appear in the eschatological future, 
empowered as Moses and Elijah were. His detailed and well-known exposition functioned as the basis for the discussions in the rest of the chapter. He stands as the main representative in this chapter for those literal identifications that are oriented towards the author's future. Several broad issues of interpretation were deduced from Haugg's argumentation.

The Expositions of James Todd, Isbon Beckwith, and Christine Tan After Haugg, three other expositions were examined. Those of James Todd and Isbon Beckwith conclude with an identification similar to Haugg's. The research of Christine Tan, however, does not conclude with a specific literal, futuristic identification of the witnesses, but seeks to defend the whole class of such identifications, albeit from a dispensationalist perspective. The discussion of these three additional studies revealed arguments that could supplement or perhaps replace arguments found in Haugg's work. Moreover, the argumentation from each of these studies was found to exhibit several of the same broad issues of interpretation that were derived from Haugg's exposition, besides presenting new ones.

\section{Shared Issues of Interpretation}

Differences in argumentation among the four commentator do exist, but points of commonality in the issues addressed also exist. These can be highlighted in view of the coming chapter discussing the broad issues of interpretation. Table 1 (see the next page) displays these common points in the order in which they are first mentioned.

All four commentators raise the methodological issue of what is the proper interpretive approach to Revelation and to Rev 11:3-13 in particular. The argumentation of all of them touches upon the issue of the degree to which symbolism plays a role in 
Table 1. Broad issues of interpretation shared by Haugg, Todd, Beckwith, and Tan

\begin{tabular}{|l|c|c|c|c|}
\hline \multicolumn{1}{|c|}{ Broad Issues of Interpretation } & Haugg & Todd & Beckwith & Tan \\
\hline Interpretive approach & $\bullet$ & $\bullet$ & $\bullet$ & $\bullet$ \\
\hline Degree of symbolism & $\bullet$ & $\bullet$ & $\bullet$ & $\bullet$ \\
\hline Distinguishing literal from symbolic & & $\bullet$ & & $\bullet$ \\
\hline Miraculous powers of the witnesses & $\bullet$ & $\bullet$ & $\bullet$ & $\bullet$ \\
\hline Traditions about Elijah & $\bullet$ & $\bullet$ & $\bullet$ & $\bullet$ \\
\hline Immediate context before Rev 11:3-13 & $\bullet$ & & $\bullet$ & $\bullet$ \\
\hline Lack of names for the two witnesses & $\bullet$ & & $\bullet$ & $\bullet$ \\
\hline Setting for Rev 11:3-13 & $\bullet$ & & $\bullet$ & $\bullet$ \\
\hline Traditions about Enoch & $\bullet$ & & $\bullet$ & $\bullet$ \\
\hline Traditions about Moses & $\bullet$ & & $\bullet$ & $\bullet$ \\
\hline Fate of the two witnesses & $\bullet$ & $\bullet$ & & $\bullet$ \\
\hline Historical data & & $\bullet$ & $\bullet$ & $\bullet$ \\
\hline Image of the olive trees & & $\bullet$ & $\bullet$ & $\bullet$ \\
\hline Person-oriented language & $\bullet$ & & & $\bullet$ \\
\hline Introduction of the two witnesses & $\bullet$ & & & $\bullet$ \\
\hline Verb tenses of Rev 11:1-13 & $\bullet$ & & & $\bullet$ \\
\hline Three-and-a-half year period & & $\bullet$ & & $\bullet$ \\
\hline Theme of testimony & & $\bullet$ & & $\bullet$ \\
\hline Theme of prophecy & & $\bullet$ & & $\bullet$ \\
\hline Image of the lampstands & $\bullet$ & & $\bullet$ \\
\hline Duality of the witnesses & & & $\bullet$ & $\bullet$ \\
\hline Early interpretation of the witnesses & & $\bullet$ & & $\bullet$ \\
\hline Crucified lord of Rev 11:8 & & & $\bullet$ \\
\hline
\end{tabular}

Revelation. Todd and Tan go further to raise also the issue of how to distinguish the symbolic from literal in Revelation.

Each commentator also raises issues of interpretation that touch upon the linguistic details of Rev 11:3-13 and material drawn from the rest of Revelation or from the world outside Revelation. Several such issues can be identified as being shared by 
more than two of the commentators. Common to all four commentators are the general issues of the miraculous powers of the witnesses and of the traditions about Elijah. Haugg, Beckwith, and Tan together share six issues. Each deals with (1) the meaning of the immediate context before Rev 11:3-13 (11:1-2), (2) the lack of names ascribed to the witnesses, (3) the miraculous powers of the two witnesses, (4) the setting for the events of Rev 11:3-13, (5) traditions about Enoch, and (6) traditions about Moses. Haugg, Todd, and Tan together share two issues. Each raises the issue of the fate of the witnesses - their death, resurrection, and ascension — and the issue of the role of historical data in identifying the witnesses. Todd, Beckwith, and Tan together share two issues. Each expresses a concern for the image of the olive trees and for the personoriented traits of the witnesses.

Several issues of interpretation are common to just two commentators. Three issues are common to just Haugg and Tan. Each deals with (1) the manner in which the witnesses are introduced, (2) the verb tenses in Rev 11:1-13, and (3) the meaning of the three-and-a-half-year period. Five issues are common to just Todd and Tan. Each says something about (1) the theme of testimony, (2) the theme of prophecy, (3) the lampstand image, and (4) the duality of the two witnesses. Tan clearly so and Todd probably so appeal to (5) the early interpretations of the witnesses to bolster the rest of their arguments. Notable also is that Haugg and Beckwith both address the meaning of the crucified lord of Rev 11:8.

As noted, among literal, futuristic identifications of the witnesses, the MosesElijah view stands as the current main rival to the type of identification advanced by Haugg, Todd, and Beckwith. The Enoch-Elijah view, on the other hand, is the earliest 
known identification of the witnesses, and for many centuries, at least until more recent times, it has been popularly espoused. Although none of the expositors examined in this chapter advocate either of these views, the array of discussion within the works of Haugg, Todd, Beckwith, and Tan has provided a significant sample of arguments that could be offered to support these views as literal, futuristic identifications. Distinctive points for these two views may be absent, but present are points that advocates of these views might share with Haugg, Todd, Beckwith, and Tan.

Therefore, the presentation of these four expositions, those of Haugg, Todd, Beckwith, and Tan, has unveiled in a substantial way an important segment in the debate of the last few centuries over the exegetical identity of the two witnesses.

\section{The Exposition of Johannes Munck}

The final part of this chapter looked at the exposition of Johannes Munck on the two witnesses. Munck identifies the two witnesses with Peter and Paul, two contemporaries of the author of Revelation. After an overview of the whole of Munck's monograph on the witnesses, two sets of arguments were discussed. Fourteen broad issue of interpretation were identified simply from the overview of the work. Additional broad issues of interpretation were derived from the presented arguments. Most of the issues had been mentioned elsewhere in this chapter. The general issues of interpretation identified in this brief examination of Munck's work appear to represent nearly all such issues that could be identified from a more detailed look at his study of the witnesses. The broad issues shared between Munck and the other commentators discussed in this chapter can be highlighted. Table 2 (see the next page) displays the issues common to Munck, Haugg, Todd, Beckwith, and Tan in the order in which they are first mentioned. 
Table 2. Broad issues of interpretation shared by Munck, Haugg, Todd, Beckwith, and Tan

\begin{tabular}{|l|c|c|c|c|c|}
\hline Broad Issues of Interpretation & Haugg & Todd & Beckwith & Tan & Munck \\
\hline Interpretive approach & $\bullet$ & $\bullet$ & $\bullet$ & $\bullet$ & $\bullet$ \\
\hline Degree of symbolism & $\bullet$ & $\bullet$ & $\bullet$ & $\bullet$ & $\bullet$ \\
\hline Miraculous powers & $\bullet$ & $\bullet$ & $\bullet$ & $\bullet$ & $\bullet$ \\
\hline Traditions about Elijah & $\bullet$ & $\bullet$ & $\bullet$ & $\bullet$ & $\bullet$ \\
\hline Immediate context before 11:3-13 & $\bullet$ & & $\bullet$ & $\bullet$ & $\bullet$ \\
\hline Setting for Rev 11:3-13 & $\bullet$ & & $\bullet$ & $\bullet$ & $\bullet$ \\
\hline Traditions about Moses & $\bullet$ & & $\bullet$ & $\bullet$ & $\bullet$ \\
\hline Image of the olive trees & & $\bullet$ & $\bullet$ & $\bullet$ & $\bullet$ \\
\hline Fate of the two witnesses & $\bullet$ & $\bullet$ & & $\bullet$ & $\bullet$ \\
\hline Introduction of the two witnesses & $\bullet$ & & & $\bullet$ & $\bullet$ \\
\hline Three-and-a-half year period & $\bullet$ & & & $\bullet$ & $\bullet$ \\
\hline Theme of testimony & & $\bullet$ & & $\bullet$ & $\bullet$ \\
\hline Image of the lampstands & & $\bullet$ & & $\bullet$ & $\bullet$ \\
\hline Crucified lord of Rev 11:8 & $\bullet$ & & $\bullet$ & & $\bullet$ \\
\hline Immediate context after 11:3-13 & $\bullet$ & & $\bullet$ & & $\bullet$ \\
\hline Messianic forerunners & $\bullet$ & & & & $\bullet$ \\
\hline Sackcloth clothing & & & & $\bullet$ & $\bullet$ \\
\hline Identity of the beast of Rev 11:7 & & & & $\bullet$ & $\bullet$ \\
\hline Earthquake of Rev 11:13 & & & & $\bullet$ & $\bullet$ \\
\hline
\end{tabular}

Although Munck touches the topic only briefly or only implicitly, the issue of the proper interpretive approach to Revelation is a shared concern for all the commentators in this chapter. Something similar could be said about the issue of the degree to which symbolism plays a role in Revelation. The miraculous powers of the witnesses and traditions about Elijah are also a concern for all the commentators in this chapter.

A few issues are shared among Munck and three other commentators in this chapter. Munck shows an interest in three issues that also a concern for Haugg, Beckwith, and 
Tan. There is a common interest in (1) the meaning of the immediate context before Rev 11:3-13 (11:1-2), (2) the setting for the events of Rev 11:3-13, and (3) traditions about Moses. With Todd, Beckwith, and Tan, Munck addresses the image of the olive trees. With Haugg, Todd, and Tan, he addresses the issue of the fate of the witnesses. A few issues are also shared among Munck and two other commentators. With Haugg and Tan, there is a shared interest in the manner in which the witnesses are introduced and the three-and-a-half year period. Munck, Todd, and Tan all address the theme of testimony and the image of the lampstands in their argumentation. Munck joins Haugg and Beckwith in their interest in the meaning of the crucified lord of Rev 11:8 and in the immediate context after Rev 11:3-13.

When the four other commentators in this chapter are considered together as a group, Haugg, Beckwith, and especially Tan each exhibit issues of interpretation that are uniquely theirs. Each raises issues that are not present in the other three commentators. Adding Munck's argumentation to this group causes some issues to cease being unique. In other words, Munck shares some issues with just one other commentator from this chapter. There are four such issues. Haugg and Munck each express an interest in (1) the issue of messianic forerunners. Tan and Munck both have something to say about (2) the sackcloth clothing of the witnesses. They both refer to (3) the identity of the beast of Rev 11:7 in their expositions. They also both comment on (4) the earthquake of Rev 11:13. Clearly, although there exists a common interest in certain issues, Munck has at times something different to say about them from what the other four commentators say. In some cases, the differences in how they address the issues are reflected in the different identifications. 
Munck's detailed and well-known study was chosen to represent all those who understand the two witnesses as two actual people from the first century CE, the era of the author of Revelation. Given the significance of Munck's study and having personally looked at other significant studies that advance the same kind of identification, I am confident that the broad issues of interpretation present in Munck's monograph constitute many of such issues exhibited by these significant expositions.

Therefore, this brief presentation of Munck's exposition complements the discussion of futuristic, literal identifications of the witnesses and offers some exposure to another part of the debate of the last few centuries over their exegetical identity.

\section{Summation}

As a whole, this chapter has presented a sample of the arguments that interpreters have offered on behalf of specific literal identifications of the two witnesses. Common as well as distinct emphases are visible in the argumentation of the commentators examined here. Deducible from all the arguments presented here are several broad issues of interpretation. Many of these are common to at least two of the expositors examined. All this material together - the arguments and the issues of interpretation that may be derived from them — has revealed an important piece of the debate since 1700. 


\section{CHAPTER 4}

\section{THE TWO WITNESSES AS A SYMBOL}

\section{Introduction}

\section{Content of the Chapter}

In the debate since 1700 over the exegetical identity of the two witnesses, one popular position is to identify them as a symbol. This position is one that embraces a wide variety of more specific identifications. The greater specificity comes from determining whom or what the two individuals in Rev 11 symbolize and when the entity (or entities) so symbolized is (or are) supposed to appear, so that it (or they) can experience the things narrated in the passage.

This chapter presents a sample of the arguments that interpreters have offered on behalf of particular symbolic identifications. A detailed look at the argumentation of $\mathrm{G}$. K. Beale forms the foundation of the presentation. From there, the reasoning in three other significant expositions is briefly examined. ${ }^{1}$ Broad issues of interpretation in identifying the witnesses can be deduced from the arguments. At appropriate points in the chapter, these issues are determined. All this material together reveals an important piece of the debate since 1700 over the identity of the witnesses.

${ }^{1}$ Significant expositions are those that offer some measure of argumentation for an identification as opposed to just stating a view without any noticeable support. 
First, however, I must speak briefly about symbolic identifications through time. This history represents an important context for the state of this category of identifications after 1699. Moreover, it has influenced the choice of which expositions to feature in this chapter.

Symbolic Identifications through Time

Most symbolic identifications fall into one of two groups. What the witnesses represent concerns either God's chosen people or the writings that are sacred to God's people.

The following diachronic survey is similarly divided. First, there is a review over time of identifications with God's people. Then, there is a similar review of identifications with sacred writings. Each review focuses on trends in the thinking on the two witnesses, particularly in regards to symbolic identifications. The offered remarks depend primarily on the works of others about the history of the interpretation of the two witnesses, and this is reflected in the footnotes. Partly because of this circumstance, moreover, the remarks concern mainly interpreters from Western Europe or interpreters influenced by the biblical scholarship of Western Europe (e.g., those in the United States). ${ }^{2}$ In fact, such interpreters have authored nearly all the literature that undergirds the present study.

${ }^{2}$ With respect to the history of the interpretation of the two witnesses, of Rev 11, or even of Revelation as a whole, less material exists, at least in Western European languages, that investigates interpreters living in areas influenced by Eastern Christian traditions. 


\section{The View over Time That the Witnesses Indicate God's People}

As observed in the previous chapter, the earliest extant identification of the two witnesses takes them as two people appearing after John. The first known symbolic identification, however, appears over a century later in the commentary on Revelation by Tyconius (died ca. 390). Direct modern knowledge of this commentary though is limited to a few fragments concerning Rev $6: 6-13 .^{3}$ Other parts of the commentary are accessible only indirectly through paraphrases and quotations by other expositors. ${ }^{4}$ Roger Gryson has reconstructed all that can be drawn from the various sources. ${ }^{5}$

According to the reconstruction, Tyconius believes that the witnesses symbolize the church prophesying by means of the two testaments that form the Bible. ${ }^{6}$ The tale of the witnesses encompasses the time from the suffering of Jesus up to and including a final

${ }^{3}$ Gryson, "Les sources," 20-24.

${ }^{4}$ Ibid., 24-73.

${ }^{5}$ About Gryson's reconstruction, see Gryson, "La présente édition," in Tyconii Afri Expositio Apocalypseos, 74-102. Not having complete access to Gryson's reconstruction of Tyconius' commentary on Rev 11:1-13, Turner attempts to reconstitute Tyconius' thoughts on the passage from many of the available sources. Turner though does not formally present a reconstructed text of the passage. The substance of Turner's discussion of Tyconius' interpretation of Rev 11:1-13 suggests that he would largely agree with Gryson's reconstructed text. See Turner, "Revelation 11:1-13," 52-73. Note that, for the commentary on Rev 11:13, Turner agrees with most of a portion of Gryson's reconstructed text as it appears in his edition of Bede's commentary on Revelation. See ibid., 70-72. Cf. Roger Gryson, ed., Bedae Presbyteri Expositio Apocalypseos ad fidem codicum manuscriptorum edidit adnotationibus criticis instruxit prolegomenis munivit, vol., Corpus Christianorum, Series Latina, 121A (Turnhout, Belgium: Brepols, 2001), 378.

${ }^{6}$ Tyconius Expositio Apocalypseos 3.64, lines 1-5 (ed. Gryson, CCSL, 107A:167); cf. 3.66, lines 1-21 (107A:167-168), 3.71, lines 1-4 (107A:169). The French translation appears at Tyconius Expositio Apocalypseos 3.64 (trans. Roger Gryson, CCT, 10:167); cf. 3.66 (10:167-168), 3.71 (10:170). Cf. Turner, "Revelation 11:1-13," 55, 62, 66, 73. 
period of persecution and the resurrection of the dead. ${ }^{7}$ At different points in his exposition of Rev 11, Tyconius seems to argue against the idea that the two witnesses represent two individuals connected to Jerusalem during the final period of persecution. ${ }^{8}$ In other words, he seems to counter an already present literal interpretation of the witnesses. Tyconius' identification of the witnesses is the earliest representative of those symbolic identifications that relate the witnesses to the whole of God's people (variously defined) during a particular time.

Centuries later, Joachim of Fiore (ca. 1135-1202) gives prominence to another significant class of symbolic identifications. His opinion of the witnesses is an early representative of those symbolic identifications that relate the witnesses to just a portion of God's people during a particular time. ${ }^{9}$ Although he does not rule out a literal

${ }^{7}$ Tyconius Expositio Apocalypseos 3.64, lines 1-2, 5-10, 3.66, lines 1-4, 3.68, lines 1-5, 3.69, lines 1-5, 3.73, lines 1-11, 3.78, lines 1-7, 3.80, lines 1-4 (ed. Gryson, CCSL, 107A:167-172). The French translation appears at Tyconius Expositio Apocalypseos 3.64, 66, 68-69, 73, 78, 80 (trans. Gryson, CCT, 10:167-170, 172-173). Cf. Turner, "Revelation 11:1-13," 55-62, 65-70, 73.

${ }^{8}$ Tyconius Expositio Apocalypseos 3.64, lines 1-2, 5-10, 3.66, lines 1-4, 3.68, lines 1-5, 3.69, lines 1-5, 3.72, lines 1-4, 3.73, lines 1-11, 3.78, lines 1-17 (ed. Gryson, CCSL, 107A:167-171). The French translation appears at Tyconius Expositio Apocalypseos 3.64, 66, 68-69, 72-73, 78 (trans. Gryson, CCT, 10:167-170, 172). Cf. Turner, "Revelation 11:1-13," 55-62, 65-70, 73.

${ }^{9}$ Joachim's identification was arguably not the earliest representative of this class of symbolic identifications. There are the opinions of Bruno of Segni (ca. 1045-1123), Rupert of Deutz (ca. 1075-ca. 1130), and Gerhoh of Reichersberg (1093-1169). While primarily focusing on the witnesses as Enoch and Elijah, Bruno also sees them as a symbol of the teachers of the church. See Turner, "Revelation 11:1-13," 91-93, 101. Rupert understands the witnesses as representing two sets of individuals existing throughout church history. One set is like Enoch, while the other is like Elijah. See ibid., 98-101. Cf. Petersen, Preaching, 31. Gerhoh may conceive of the witnesses as symbolizing people acting in the spirit of Elijah and of Moses (or of Enoch). See Turner, "Revelation 11:1-13," 100-101. Speaking somewhat differently about Gerhoh and the 
understanding of the witnesses, ${ }^{10}$ Joachim seems to favor a figurative understanding. ${ }^{11}$ In this view, the witnesses represent two orders of men, one being an order of clerics

witnesses is Petersen, Preaching, 32. Reading Erich Meuthen and Peter Classen on this subject though suggests that Gerhoh discussed the witnesses, but left the matter of their identity unresolved. See Erich Meuthen, Kirche und Heilsgeschichte bei Gerhoh von Reichersberg, Studien und Texte zur Geistesgeschichte des Mittelalters 6 (Leiden: E. J. Brill, 1959), 139-140; and Peter Classen, Gerhoch von Reichersberg: Eine Biographie mit einem Anhang über die Quellen, ihre handschriftliche Überlieferung und ihre Chronologie (Wiesbaden, Germany: Franz Steiner Verlag, 1960), 219-220. In contrast to these views on the witnesses, Joachim's opinion seems to be more focused on a symbolic identification (unlike Bruno's view) and appears to be explicitly disconnected from the Enoch and Elijah view of the two witnesses (unlike the views of Bruno, Rupert, and Gerhoh). Tyconius' view, however, shares these two characteristics of Joachim's view. Moreover, like the writings of Tyconius, the writings of Joachim were quite influential.

${ }^{10}$ Although it is not the only place where Joachim touches on the topic of the two witnesses, his commentary on Rev 11:3-13 is arguably his most detailed discussion of the topic. See Joachim of Fiore Expositio in Apocalypsim pt. 3, 11:3-13 (ed. Silvestro Meuccio, 145v-152r, accessed August 16, 2015, Google Books). Other relevant passages are noted by Matthias Kaup, "Joachim von Fiore, De prophetia ignota-Anlaß, Aussage und Gestalt der Schrift," in "De prophetia ignota": Eine frühe Schrift Joachims von Fiore, trans. and ed. Matthias Kaup, Monumenta Germaniae Historica, Studien und Texte 19 (Hannover: Hahnsche Buchhandlung, 1998), 46-51; Petersen, Preaching, 35-36; Potestà, Il tempo, 63-65, 182-183; and Turner, "Revelation 11:1-13," 104-109.

That Joachim does not rule out the coming of two literal people to fulfill the prophecy of the witnesses seems evident from his conclusion, "Sint ergo viri isti iuxta litteram: quos deus melius ipse nouit" ("Therefore, according to the letter, let those men be whom God himself knows better"). Joachim Expositio in Apocalypsim pt. 3, 11:3-6 (ed. Meuccio, 148v). It is also apparent from his handling of Rev 11:4, 7-12. Joachim Expositio in Apocalypsim pt. 3, 11:3-12 (ed. Meuccio, 148v-151v passim). For instance, concerning the beast of Rev 11:7, Joachim says, "Sane si secundum litteram duo futuri sunt qui faciant ista: si etiam plures in duobus ordinibus: bestia hec que occidet eos: illa quarta bestia intelligenda est: quam scribit Daniel" ("Of course, if, according to the letter, there are to be two who do those things, even if [there are to be] many in two orders, this beast that will kill them is to be understood [as] that fourth beast about which Daniel writes"). Joachim Expositio in Apocalypsim pt. 3, 11:7 (ed. Meuccio, 149v). I mention all this because some writers about Joachim leave the impression that his view of the witnesses in his Expositio is singularly symbolic. See, for instance, Potestà, Il tempo, 311-313; and Turner, "Revelation 11:1-13," 107-109.

${ }^{11}$ At the very least, the figurative understanding seems more in harmony with the tenor of a passage from Jerome of Stridon (Eusebius Sophronius Hieronymus, ca. 347- 
modeled after Moses, the other an order of monks modeled after Elijah. ${ }^{12}$ These holy

men fight (presumably in a spiritual way) with the beast that comes up from the abyss

419/420) that Joachim uses in his investigation of the identity of the witnesses. In the passage, Jerome speaks about the need to interpret the witnesses and all of Revelation spiritually. For the passage, see Jerome of Stridon Epistula 593 (ed. Isidorus Hilberg, 2nd ed., Corpus Scriptorum Ecclesiasticorum Latinorum, 54:543-544). For discussion of the passage in Joachim's commentary, see Joachim Expositio in Apocalypsim pt. 3, 11:3-6 (ed. Meuccio, 146r-v, 148r-v). Furthermore, the figurative understanding is more clearly defined in contrast with the literal understanding. The less distinct treatment of the literal understanding is exhibited, for instance, in Joachim's conclusion, "Sint ergo viri isti iuxta litteram: quos deus melius ipse nouit" ("Therefore, according to the letter, let those men be whom God himself knows better"). Joachim Expositio in Apocalypsim pt. 3, 11:3-6 (ed. Meuccio, 148v). The vagueness of the literal understanding stems in part from the problems that Joachim finds with saying that the witnesses will be Enoch and Elijah or Moses and Elijah. See Joachim Expositio in Apocalypsim pt. 3, 11:3-6 (ed. Meuccio, 146r-148v). For a summation of this part of Joachim's discussion, see Potestà, Il tempo, 312-313. It may also be observed that at one point Joachim seems to subsume a literal understanding in the figurative one. He says, "Si autem tribus tantum annis et dimidio regnatura est hec bestia (vt opinio tenet) et sub eodem temporis spatio predicaturi sunt viri sancti preeuntibus eos duobus viris qui sint duces eorum: quid aliud datur intelligi: nisi quia circa finem regni sui factura est prelium contra sanctos . . . ?" ("But if this beast [of Rev 11:7] is to reign only three and a half years (as opinion holds) and during the same period of time holy men are to preach, while two men who are their leaders are to go before them, what else is given to be understood, except that near the end of its kingdom a battle against the holy ones is to occur . . . ?"). Joachim Expositio in Apocalypsim pt. 3, 11:7 (ed. Meuccio, 150r).

${ }^{12}$ Joachim Expositio in Apocalypsim pt. 3, 11:3-6 (ed. Meuccio, 146r-147r, 148v). Note also Elliott, Horce Apocalyptica, 4:401; Petersen, Preaching, 35; Potestà, Il tempo, 311-313; and Turner, "Revelation 11:1-13," 107.

Joachim has two particular ways of conceptualizing history. One way is threefold. According to this ordering, history consists of three overlapping states. Each is linked primarily to one of member of the trinity (Father, Son, and Holy Spirit) and to one order of people (married laity, clergy, and monks). The first state is associated with the Father and the married laity. While the second state is associated primarily with the Son and the clergy, it is also associated secondarily with the Holy Spirit and the monks. The Holy Spirit and the monks are of primary importance for the third state. Joachim's conception of the two witnesses as an order of clergy and an order of monks seems related to this threefold way of conceiving history. The nature of the relationship, however, is not immediately clear, and it seems best, at least for the present study, to consider it no further. The same can be said for the other places in Joachim's Expositio where he deals with various orders of people. Concerning the threefold arrangement of 
(Rev 11:7). ${ }^{13}$ That beast represents the multitude of the unfaithful who persecute the church from the passion of Christ all the way up to the time of the great antichrist. ${ }^{14}$

history and another twofold arrangement, see Emmett Randolph Daniel, "The Double Procession of the Holy Spirit in Joachim of Fiore's Understanding of History," Spec 55, no. 3 (July 1980): 469-483, accessed August 17, 2015, JSTOR; Emmett Randolph Daniel, "Joachim of Fiore: Patterns of History in the Apocalypse," in The Apocalypse in the Middle Ages, ed. Richard Kenneth Emmerson and Bernard McGinn (Ithaca, NY: Cornell University Press, 1992), 78-80, 83-85; Emmett Randolph Daniel, "Exodus and Exile: Joachim of Fiore's Apocalyptic Scenario," in Last Things: Death and the Apocalypse in the Middle Ages, ed. Caroline Walker Bynum and Paul H. Freedman, The Middle Ages Series (Philadelphia: University of Pennsylvania Press, 2000), 132-134; Bernard McGinn, The Calabrian Abbot: Joachim of Fiore in the History of Western Thought (New York: Macmillan; London: Collier Macmillan Publishers, 1985), 161-203; and Marjorie Ethel Reeves, The Influence of Prophecy in the Later Middle Ages: A Study in Joachimism (Oxford: Clarendon Press, 1969; reprint, Notre Dame, IN: University of Notre Dame Press, 1993), 18-20, 135-140.

${ }^{13}$ Joachim Expositio in Apocalypsim pt. 3, 11:3-6 (ed. Meuccio, 146r-v).

${ }^{14}$ Joachim Expositio in Apocalypsim pt. 3, 11:7 (ed. Meuccio, 149v). Joachim believed that there were many antichrists, but describes one in particular as very terrible. This antichrist fulfills the role of "the son of destruction" described in 2 Thess 2:3-4 and the "king of bold face" described in Dan 8:23-25 (cf. ESV). In Revelation, this person is symbolized by the beast from the earth (Rev 13:11-18) and by the seventh head of the dragon (Rev 12:3; cf. 17:3, 9-10). This is probably the antichrist about which Joachim is speaking when discussing the meaning of the beast from the abyss. Consider among other passages, Joachim of Fiore Liber introductorius in expositionem Apocalypsis chap. 8 (ed. Silvestro Meuccio, 10r-v, accessed August 16, 2015, Google Books); and Joachim Expositio in Apocalypsim pt. 3, 9:11; pt. 4, 13:12-13 (ed. Meuccio, 133r, 167v-168r). Also, note Elliott, Hora Apocalyptica, 4:397, 408-409; Emmerson, Antichrist in the Middle Ages: A Study of Medieval Apocalypticism, Art, and Literature, 25-26, 60-61; Robert E. Lerner, "Antichrists and Antichrist in Joachim of Fiore," Spec 60, no. 3 (July 1985): 553-570, accessed August 17, 2015, JSTOR; and Bernard McGinn, Antichrist: Two Thousand Years of the Human Fascination with Evil (New York: HarperSanFrancisco, 1994), 135-142. Speaking somewhat differently on the topic is Emmett Randolph Daniel, "Double Antichrist or antichrists [sic]: Abbot Joachim of Fiore," in Abbot Joachim of Fiore and Joachimism: Selected Articles, Variorum Collected Studies Series CS985 (Farnham, United Kingdom: Ashgate, 2011), article VII, pages 1-16. Yet, it seems incorrect to suggest as Lerner does that the beast from the sea represents along with the beast from the earth one antichrist. Compare Lerner, "Antichrists and Antichrist in Joachim of Fiore," 568-569; with, for instance, Joachim Expositio in Apocalypsim pt. 4, 13:12-13 (ed. Meuccio, 167v-168r). 
These men also proclaim in word and deed the message of repentance and of the divine kingdom that was proclaimed by John the Baptist and Jesus (see Matt 3:2; 4:17; cf. Matt 10:7 and Mark 1:15). ${ }^{15}$ Their activity lasts a symbolic 42 months, where each month represents a generation. ${ }^{16}$ Their 42 generations are probably equivalent to the 42 generations that Joachim saw as coming after Christ's advent into the world. ${ }^{17}$

\footnotetext{
${ }^{15}$ Joachim Expositio in Apocalypsim pt. 3, 11:3-6 (ed. Meuccio, 148v). Cf. Joachim Expositio in Apocalypsim pt. 3, 11:3-6; 11:7; 11:8 (ed. Meuccio, 147r, 149r, 150r).

${ }^{16}$ Joachim Expositio in Apocalypsim pt. 3, 11:3-6 (ed. Meuccio, 148v).

${ }^{17}$ Concerning the 42 generations after Christ, see Daniel, "Joachim of Fiore," 8084; Daniel, "Exodus and Exile," 132-135; and McGinn, The Calabrian Abbot, 187-189. The probability that the 42 generations of the two orders are the 42 after Christ is indicated in a statement that Joachim makes about the three and a half days of Rev 11: "Si secundum typicum intellectum in tribus annis et dimidio: omne tempus quo Bestia ista regnabit: accipimus (hoc est) ab aduentu domini: vsque ad tempus ruine et precipitationis ipsius: restat: vt in tribus diebus et dimidio breuiora temporum spatia designentur: post que dabitur regnum quod est subter omne celum populo sanctorum altissimi" ("If, according to the figurative understanding, we take in the three and a half years [meaning the 1,260 days] all the time that that beast [of Rev 11:7] will reign, (this is) from the coming of the Lord all the way up to the time of the fall and casting down of it, it remains that briefer periods of time are designated in the three and a half days, after which the kingdom that is under the whole of heaven will be given to the people of the holy ones of the Highest One"). Joachim Expositio in Apocalypsim pt. 3, 11:9-11 (ed. Meuccio, 150v). Cf. Elliott, Hora Apocalyptica, 4:403-404.

If this assumption about the 42 generations is correct, then the period is past, present, and future relative to Joachim. It is difficult to reconcile this temporal perspective with another expressed when Joachim seems to return to the topic of the two orders. Joachim sees one order represented by the "one like a son of man" seated on "a white cloud" with "a sharp sickle in his hand" that appears in Rev 14:14-16 (quoting from ESV). The men of this order imitate the life of Christ and his apostles. They are closely associated with spiritual instruction. These men act in the spirit of Moses to gather God's chosen ones for blessing. The other order is represented by the "angel [that] came out of the temple in heaven" with "a sharp sickle" in his hand that appears in Rev 14:17-20 (quoting again from ESV). The men of this order are hermits who imitate the life of angels. They are closely associated with sacred contemplation. These men act in the spirit of Elijah to gather those rejected by God for condemnation. The temporal perspective in this new discussion of the two orders seems to be that they are merely
} 
Even though the influential writings of Tyconius and Joachim give prominence to symbolic identifications, a literal identification prevails for centuries among interpreters of Rev 11. From at least the time of Hippolytus of Rome (ca. 170-ca. 236) up through the Middle Ages (ca. 476-ca. 1453) and into the start of the modern era, the witnesses are usually identified as Enoch and Elijah appearing at the end of the world, even in those instances when an expositor also advances another identification, usually a symbolic one. ${ }^{18}$

With the arrival of the Reformation, the Enoch-Elijah view wanes in popularity among interpreters, becoming for a time solely a Catholic opinion. ${ }^{19}$ In this period before

future to Joachim. The discussion appears at Joachim Expositio in Apocalypsim pt. 4, 14:14-20 (ed. Meuccio, 175r-176v). Portions are translated into English at McGinn, Visions of the End: Apocalyptic Traditions in the Middle Ages, 136-137. Cf. Petersen, Preaching, 35; and Turner, "Revelation 11:1-13," 107-108.

${ }^{18}$ Turner, "Revelation 11:1-13," 12-144 passim, 163n101, 304-305. Cf. Petersen, Preaching, 12-58 passim, 259. Such a trend in the identifications of the witnesses is more obvious in Turner's work. Notwithstanding this situation and the occasional disagreement between Petersen and Turner over an interpreter's opinion, Petersen's work can complement Turner's survey of the literature for this early period. Mackay, however, gives a different impression of the prevailing trend. He suggests widespread abandonment of the Enoch-Elijah view among interpreters who write after Tyconius introduces a solely symbolic interpretation of the two witnesses. Mackay, "Early Christian Millenarianist Interpretation," 1:222-223, 233-237, 245-246, 249-255, 308-310. Yet, Petersen and Turner show that several commentators still espoused the Enoch-Elijah view after Tyconius and on up through the Middle Ages. Admittedly, this view is frequently not the only understanding that an expositor has of the witnesses. Nonetheless, Mackay's reconstruction of the history of the interpretation of the witnesses appears inaccurate.

${ }^{19}$ For a picture of the interpretations of the witnesses during this period that includes the Reformation and some years after (1517-1700), see Turner, "Revelation 11:1-13," 145-231 passim, 305. Cf. Petersen, Preaching, 59-229 passim, 259. On just the Catholic interpretations of the two witnesses during this time, see Turner, "Revelation 11:1-13," 163-166, 179-181, 224-227, 229, 231. Cf. Petersen, Preaching, 222n94. 
1699, Protestants and even some Catholics abandon the Enoch-Elijah view of the witnesses, at least as it usually was conceived..$^{20}$ In fact, many of these interpreters depart from any futuristic, literal identification, opting instead for a solely symbolic identification. ${ }^{21}$ Prominent among Protestant interpreters of this era is an identification of the witnesses with a portion of the Christian church. Specifically, the witnesses symbolize the faithful leaders of the church who are active during a particular part of the history of the church. ${ }^{22}$ Some go so far as to join the civil authorities with the church

\footnotetext{
${ }^{20}$ The usual conception, of course, was that Enoch and Elijah would personally appear in the end-time. I add a qualification above, because some early Protestant thinkers seem to have transformed the expectation of Enoch and Elijah returning. Thus, they apparently did not completely dismiss the Enoch-Elijah view. More about this phenomenon appears in a similar footnote in the previous chapter. As already indicated in a footnote for the present chapter, some interpreters from before the Reformation (e.g., Rupert of Deutz and Gerhoh of Reichersberg) exhibit similar transformations of the Enoch-Elijah expectation. For these and others, see Petersen, Preaching, 31, 38, 41-43, 54n146; cf. 32, 36; and Turner, "Revelation 11:1-13," 98-101, 110-111, 129-130, 137 140. Also present in this earlier time is the circumstance of seeing certain individuals as Enoch and Elijah returned, but it apparently exists only outside the stream of formal theological literature. Petersen, Preaching, 39, 43; and Turner, "Revelation 11:1-13," $138,141-142$.

${ }^{21}$ Turner, "Revelation 11:1-13," 145-229 passim, 305. Cf. Petersen, Preaching, 97-229 passim, 259.

${ }^{22}$ So, for example, Heinrich Bullinger (1504-1575) identifies the witnesses as all the faithful preachers who from $763 \mathrm{CE}$ until the final judgment oppose the antichrist, which is understood to be the Papacy. See Heinrich Bullinger, In Apocalypsim Iesu Christi. . . . (Basel: Johannes Oporinus, 1559), 138-141, 143-144, 147-148, 172-173, 193194, accessed August 17, 2015, Google Books. For an English translation of these passages, see Heinrich Bullinger, A Hundred Sermons upon the Apocalips of Jesu Christe. ... trans. [John Daus?] (London: [John Day?], 1561), 310-317, 320-321, 323, 329-331, 386-388, 434-436, accessed August 17, 2015, Internet Archive Community Texts Collection. Occasionally, Bullinger identifies certain individuals, such as Jan Hus (ca. 1369-1415) and Jerome of Prague (ca. 1365-1416), as fulfilling the prophecy of the witnesses. See Bullinger, In Apocalypsim Iesu Christi, 144, 146, 148-149; cf. 141, 143, 145. Note the English translation at Bullinger, A Hundred Sermons, 322, 327-328, 331, 334-335; cf. 315-316, 320, 325. The whole of Rev 11:1-13 is covered at Bullinger, In
} 
leadership to form a composite referent for the witnesses. ${ }^{23}$ After 1699, the Enoch-Elijah view still has a few proponents, not all of whom are Catholic. ${ }^{24}$ Yet, the majority of

Apocalypsim Iesu Christi, 136-149. In English, Rev 11:1-13 is covered at Bullinger, A Hundred Sermons, 304-335. On Bullinger's interpretation of this passage, see Turner, "Revelation 11:1-13," 154-156. Note that I differ slightly from Turner concerning Bullinger's understanding of the year $763 \mathrm{CE}$ and of the timing of the witnesses' activity. Consider also the broader discussion of Bullinger's interpretation of the passage at Petersen, Preaching, 120-148. Notice, however, that Petersen incorrectly has Bullinger believing that the 42 months begin at $666 \mathrm{CE}$ at ibid., 132. The interpretation of the 42 months should be read in light of Bullinger's interpretation of the number 666 in Rev 13:18. Petersen fails to make this connection, even though he is aware of Bullinger's interpretation of 666, as attested by ibid., 134 .

${ }^{23}$ So, for example, David Pareus (1548-1622) identifies the witnesses as a succession of individuals, whether preachers, teachers, princes, or kings, who maintain true religion opposite antichrist, which is understood to be the Papacy. See David Pareus, In Divinam Apocalypsin S. Apostoli Et Evangeliste Johannis Commentarius (Heidelberg: Jonas Rosa, 1618), cols. 469A-476A, 479D-483D, 489C-D, 492A, 503-504, 511C-D, 512C-D, 597A-609D, accessed August 17, 2015, Google Books. An English translation appears at David Pareus, A Commentary Upon The Divine Revelation Of The Apostle And Evangelist Iohn, trans. Elias Arnold (Amsterdam, 1644), 221-224, 226-228, 231-232, 238, 242-243, 282-288, accessed August 17, 2015, Google Books. Pareus prefers to see the domination of antichrist (42 months) and the prophetic activity of the witnesses (1,260 days) as a single definite period, the start of which and the end of which are known only to God. Yet, if he had to choose a starting point, he would choose $606 \mathrm{CE}$. See Pareus, In Divinam Apocalypsin, cols. 264D-265D, 362B-D, 465D-468B, 476A478B, 486D-487A, 487C-D, 489D-490D, 501-504, 612C-613A. Note the English translation at Pareus, A Commentary Upon The Divine Revelation, 124, 170, 219-220, 224-225, 229-231, 238, 289. Besides pointing out specific individuals, such as Peter Waldo (ca. 1140-ca. 1218) and John Wycliffe (ca. 1330-1384), as fulfilling the prophecy of the witnesses, Pareus also adds that the time period appears to have been literally fulfilled in the 1,260 days before the death of Jan Hus (ca. 1369-1415). See Pareus, In Divinam Apocalypsin, cols. 478B-479D, 486A-C, 492C-493B, 503-504, 508C-509B, 511D-512C, 514C-515A, 515D-516B. Note the English translation at Pareus, $A$ Commentary Upon The Divine Revelation, 225-226, 229, 232-233, 238-239, 241-245. Pareus's whole discussion of Rev 11:1-13 appears at Pareus, In Divinam Apocalypsin, cols. 443-518A. The English translation of this portion of commentary appears at Pareus, A Commentary Upon The Divine Revelation, 209-245. On Pareus's interpretation of Rev 11:1-13, see also Petersen, Preaching, 165-169; and Turner, "Revelation 11:1-13," 172.

${ }^{24}$ Some examples, all of which are expositions that include argumentation, are cited in a footnote in the previous chapter. For more references like those, see Appendix 
expositors in this era direct their attentions elsewhere. Some adopt a symbolic interpretation in which the witnesses represent a group of God's people, like leaders of the Christian church, Christian martyrs, or Christian prophets, during a particular period of history. ${ }^{25}$ Meanwhile, many more adopt a symbolic interpretation in which the witnesses represent the totality of God's people, particularly the Christian church, during a certain period of history.

\section{The View over Time That the Witnesses Indicate Sacred Writings}

A whole class of symbolic identifications associates the two witnesses with sacred writings. Three instances of this type of interpretation come from an early time. One

A. Also, cf. Turner, "Revelation 11:1-13," 263, 271-274, 276, 280, 290.

${ }^{25}$ See, for instance, ibid., 249-250, 253-255, 261, 263, 266-267, 283-285. Some examples, all of which are expositions that include argumentation, are given here. For more references like these, see Appendix C. From an author whose life spanned the seventeenth and eighteenth centuries and who identifies the witnesses with Christian leaders, specifically the preachers, is Walter Garrett, An Exposition of Rev. xj. Containing the Famous Prophecy of the Witnesses; as also a Prediction of the Passing-away of the Turkish Wo; and of the Destruction of the Papacy ([London?], 1703), accessed August 17, 2015, Gale Eighteenth Century Collections Online. In the nineteenth century, François de Bovet (1745-1838) speaks posthumously of the witnesses as representing early Christian martyrs. François de Bovet, L'esprit de l'Apocalypse (Paris: Gaume Frères, 1840), 330-363, accessed August 17, 2015, Google Books. In the same century, James Glasgow (1805-1890) speaks of the ministry as being symbolized by the two witnesses. James Glasgow, The Apocalypse Translated and Expounded (Edinburgh: T. \& T. Clark, 1872), 288-313, accessed August 17, 2015, Google Books. Toward the end of that century, Robert Benjamin Kübel (1838-1894) sees in the witnesses God acting through prophets towards the world over the course of church history. Kübel, Pastoralbriefe, 242-251. In the twentieth century, Ernest-Bernard Allo (1873-1945) identifies the witnesses as the preachers of the good news, who embody the church as a whole. Allo, Saint Jean: L'Apocalypse, 143-167. A few years later, Martin Kiddle, assisted by M. K. Ross, identifies the witnesses as the martyrs of the church. Martin Kiddle and M. K. Ross, The Revelation of St. John, Moffatt New Testament Commentary (London: Hodder and Stoughton, 1940), 174-206. 
instance is found in the commentary pieces from a tenth century manuscript stored at the Biblioteca Nazionale Universitaria di Torino (the National University Library of Turin) since 1820. Although at times thought to represent portions of Tyconius' actual commentary on Revelation, the texts are in fact part of a revision of that lost work. ${ }^{26}$ Gryson has provided a new edition of the Turin fragments in an appendix to his volume containing a reconstruction of Tyconius' lost commentary. ${ }^{27}$ Gryson locates the origin of the revision with "Augustinian circles of north Africa, shortly after the death" of Augustine (Aurelius Augustinus, 354-430), the bishop of Hippo Regius. ${ }^{28}$ The witnesses are identified with the two testaments of the Bible, and the 1,260 days of their activity represent the time of the final persecution. ${ }^{29}$ These are revisions to Tyconius' interpretation and in fact stand at odds with portions of that interpretation left in the revised commentary. ${ }^{30}$

\footnotetext{
${ }^{26}$ For a discussion of the manuscript, the published editions, and the nature of the texts, see Gryson, "Les sources," 24-35. Cf. the older account to which Gryson occasionally refers at Lo Bue and Willis, "Introduction," 3-38. For the whole discussion above of the Turin fragments and their interpretation of the witnesses, compare Mackay, "Early Christian Millenarianist Interpretation," 1:233-234, 245-249, 254, 269-271, 316n45; Petersen, Preaching, 12-15, 24n83; Turner, "Revelation 11:1-13," 52-73; Weinrich, ed., Revelation, xxii-xxiv, xxix-xxx, 156-167 passim, 425; and Robinson, "The Mystic Rules of Scripture: Tyconius of Carthage's Keys and Windows to the Apocalypse," 7-10, 126-135, 189, 199-213, 226-232.

${ }^{27}$ See Tyconius Fragmenta Taurinensia (ed. Gryson, CCSL, 107A:347-386). The sections covering Rev 11:1-13 are Tyconius Fragmenta Taurinensia 324-419 (ed. Gryson, CCSL, 107A:374-381).

${ }^{28}$ Gryson, "Les sources," 34.

${ }^{29}$ Tyconius Fragmenta Taurinensia 334, 336 (ed. Gryson, CCSL, 107A:375).

${ }^{30}$ Thus, for instance, the witnesses are still the church when Rev 11:5 is discussed. Ibid., 351. 107A:376). Cf. Tyconius Expositio Apocalypseos 3.67, lines 1-4 (ed. Gryson, CCSL, 107A:168); and the French translation,Tyconius Expositio Apocalypseos 3.67
} 
The second instance is found in the commentary on Revelation by Caesarius of Arles (ca. 470-542). ${ }^{31}$ The witnesses are identified with the two testaments of the Bible, while the 1,260 days refer to the final persecution and a future period of peace and in fact represent the whole period following the suffering of Jesus. ${ }^{32}$ While this understanding of the time of the witnesses' activity derives from Tyconius, ${ }^{33}$ the identification of the witnesses as the two testaments stands at odds with other elements adopted from Tyconius' commentary. ${ }^{34}$

(trans. Gryson, CCT, 10:168). Or, for example, the time of the witnesses is not focused solely on the period of the final persecution when Rev 11:7 is discussed. Tyconius Fragmenta Taurinensia 364-365 (ed. Gryson, CCSL, 107A:377). Cf. Tyconius Expositio Apocalypseos 3.69, lines 1-5 (ed. Gryson, CCSL, 107A:169); and the French translation,Tyconius Expositio Apocalypseos 3.69 (trans. Gryson, CCT, 10:169).

${ }^{31}$ Comments on Rev 11:1-13 appear at Caesarius of Arles Expositio de Apocalypsi Sancti Iohannis item sequentia 8-item sequentia 9 (ed. Germain Morin, Opera omnia, 2:238, line 21-241, line 21). An English translation appears at Caesarius of Arles Expositio de Apocalypsi Sancti Iohannis The Continuation (Homily 8)-The Continuation (Homily 9) (trans. William C. Weinrich, Latin Commentaries on Revelation, 82-84).

${ }^{32}$ Caesarius Expositio de Apocalypsi Sancti Iohannis item sequentia 8 (ed. Morin, Opera omnia, 2:239, lines 2-6). Cf. the English at Caesarius Expositio de Apocalypsi Sancti Iohannis The Continuation (Homily 8) (trans. Weinrich, Latin Commentaries on Revelation, 82).

${ }^{33} \mathrm{Cf}$. Tyconius Expositio Apocalypseos 3.64, lines 7-10 (ed. Gryson, CCSL, 107A:167); and the French translation,Tyconius Expositio Apocalypseos 3.64 (trans. Gryson, CCT, 10:167).

${ }^{34}$ Thus, for instance, the witnesses are still the church when Rev 11:5 is discussed. Caesarius Expositio de Apocalypsi Sancti Iohannis item sequentia 8 (ed. Morin, Opera omnia, 2:239, lines 18-22). Notice the English at Caesarius Expositio de Apocalypsi Sancti Iohannis The Continuation (Homily 8) (trans. Weinrich, Latin Commentaries on Revelation, 83). Cf. Tyconius Expositio Apocalypseos 3.67, lines 1-4 (ed. Gryson, CCSL, 107A:168); and the French translation,Tyconius Expositio Apocalypseos 3.67 (trans. Gryson, CCT, 10:168). 
The third early instance of an identification of the witnesses with sacred writings is found in the commentary of Beatus of Liébana (ca. 750-ca. 800). ${ }^{35}$ Beatus' work compiles material from several sources, including Victorinus (via Jerome) and Tyconius. ${ }^{36}$ This is evident in his handling of the two witnesses. Victorinus identifies the witnesses as Elijah and Jeremiah operating during the three and a half years before the reign of a personal antichrist. This identification ${ }^{37}$ stands alongside Tyconius' identification of the witnesses as the church operating during the long period following the suffering of Jesus. ${ }^{38}$ Beatus works another figurative identification into this mixture. He identifies the witnesses as the two testaments of the Bible, characterizing one

\footnotetext{
${ }^{35}$ Comments on Rev 11:1-14 appear at Beatus of Liébana Tractatus de Apocalipsin 5.10, storia, lines 26-31; 5.10.39, line 158-5.13.20, line 73 (ed. Roger Gryson and Marie-Claire de Bièvre, CCSL, 107C:622-623, 632-649).

${ }^{36}$ See the discussion of the sources of Beatus' commentary at Roger Gryson and Marie-Claire de Bièvre, "Les sources de Beatus," in Beatus Liebanensis tractatus de Apocalipsin, ed. Roger Gryson and Marie-Claire de Bièvre, Corpus Christianorum, Series Latina, 107B (Turnhout, Belgium: Brepols, 2012), CXXXIV-CXLI.

${ }^{37}$ See, for instance, Beatus Tractatus de Apocalipsin 5.11.1, lines 2-5; 5.11.21, line 87-5.11.23, line 95 (ed. Gryson and Bièvre, CCSL, 107C:634-635, 639). Cf. Victorinus Commentarii in Apocalypsin 11.2-3 (trans. Dulaey, SC, 423:94-97).

${ }^{38}$ See, for instance, Beatus Tractatus de Apocalipsin 5.11.2, line 6-5.11.4, line 16; 5.11.4, lines 18-19 (ed. Gryson and Bièvre, CCSL, 107C:634-635). Cf. Tyconius Expositio Apocalypseos 3.64, lines 4-5, 7-10 (ed. Gryson, CCSL, 107A:167); and the French translation at Tyconius Expositio Apocalypseos 3.64 (trans. Gryson, CCT, 10:167). Noticeably, Beatus includes Tyconius' arguments directed against a literal interpretation of the witnesses and so creates a conflict with the position of Victorinus that he adopts. See Beatus Tractatus de Apocalipsin 5.13.2, line 5-5.13.8, line 27 (ed. Gryson and Bièvre, CCSL, 107C:646-647). Cf. Tyconius Expositio Apocalypseos 3.78, lines 1-17 (ed. Gryson, CCSL, 107A:171); and the French translation at Tyconius Expositio Apocalypseos 3.78 (trans. Gryson, CCT, 10:172). Turner also observes this conflict, mentioning it at Turner, "Revelation 11:1-13," 83.
} 
testament as the Law and the other as the Gospel. ${ }^{39}$ The symbolic understanding of the 1,260 days likely applies also in this case.

Identifying the witnesses as sacred writings becomes more significant with the coming of the Reformation. Several Protestant commentators spread out over the sixteenth and seventeenth centuries identify the witnesses as the Bible, either as a singular identification or as part of a composite view. ${ }^{40}$ Most of the examples after 1699, whether singular identifications or composite ones, come from the period after the start of the French Revolution (1789-1799). This circumstance is because several Protestant commentators from the end of the eighteenth century onward link the fate of the witnesses to how the Bible and Christianity were treated during the French Revolution. ${ }^{41}$

${ }^{39}$ Most clearly, Beatus Tractatus de Apocalipsin 5.11.2, lines 5-6; 5.11.4, lines 1618; 5.11.8, line 35-5.11.9, line 36; 5.11.20, line 83; 5.12.2, line 7-5.12.3, line 12; 5.12.15, lines 58-61 (ed. Gryson and Bièvre, CCSL, 107C:635-636, 638, 640-641, 643-644). Some of this material derives from Tyconius, but finds new meaning in Beatus' commentary. For instance, compare Tyconius Expositio Apocalypseos 3.66, lines 4-5; 3.71, lines 1-4; 3.76, lines 1-3; (ed. Gryson, CCSL, 107A:167, 169-171) and the French translation at Tyconius Expositio Apocalypseos 3.66; 3.71; 3.76 (trans. Gryson, CCT, 10:167, 170-171).

${ }^{40}$ Turner, "Revelation 11:1-13," 154, 158-159, 168, 170-172, 176, 188, 191-192, 204, 222-223, 228-231. Cf. Petersen, Preaching, 129-130, 144n128, 201-207. The first of this group of commentators is Theodor Bibliander (or Buchmann, ca. 1505-1564) with a singular interpretation of the witnesses (so Petersen, but not Turner). See Bibliander's brief references to Rev 11 at Theodor Bibliander, Ad omnium ordinum Reipublicae Christianae Principes uiros, populumque Christianum, Relatio fidelis Theodori Bibliandri. . . . (Basel: Johannes Oporinus, 1545), 58-59, 138-139, accessed August 17, 2015, Bayerische StaatsBibliothek. The timing of the activity of the witnesses varies among this group of expositors. Incidentally, Turner speaks of the witnesses as the two testaments of the Bible for one Catholic author, Niklaas Zegers (Tacitus Nicolaus Zegerus, late fifteenth century-1559). This view of the witnesses, however, is one of a few non-literal identifications to which Zegers seems open, while espousing the EnochElijah view. Turner, "Revelation 11:1-13," 164.

${ }^{41}$ Cf. Turner, "Revelation 11:1-13," 237-239, 242-244, 253-255, 261, 263, $267-$ 
Taking the witnesses as a symbol of the Bible continues to be espoused even throughout the twentieth century and on into the twenty-first century. Most of the advocates from this period, however, are associated with the same denomination, the Seventh-day Adventist Church. ${ }^{42}$

268, 273-274, 290. Although Turner misses it, three of the authors that he discusses do in fact have the Bible as part of their view of the witnesses. See Thomas Woolston [16681733], A Fourth Free-Gift To The Clergy; Being A Discourse On The Two Apocalyptical Witnesses. ... (London: by the author, 1724), accessed August 17, 2015, Gale Eighteenth Century Collections Online; William Cooke [1749-1824], The Revelations Translated, And Explained Throughout. ... (London: G. G. J. and J. Robinson, 1789), xxxi-xxxiv, xlii-xlv, xlviii-li, liv-lviii, 84-91, accessed August 17, 2015, Gale Eighteenth Century Collections Online; and England's Fall Is Babylon's Triumph. An Original Interpretation of the Apocalypse, with a Special Reference to the Greek Church (London: J. F. Shaw, 1855), 42-65, accessed August 17, 2015, Google Books. The last work had a second edition; so note An Original Interpretation of the Apocalypse, 2nd ed. (London: J. F. Shaw, 1857), 59-86, accessed August 17, 2015, Google Books. Contrast these references with Turner, "Revelation 11:1-13," 252, 257, 271.

${ }^{42}$ In other words, the popularity of this view has continued among those associated with Seventh-day Adventism, while its popularity apart from that denomination has diminished. The continued popularity of this view among Adventist circles seems to be for two reasons. First, William Miller (1782-1849) and some of his associates advocated that the two witnesses represent the Bible. See, for instance, William Miller, Evidence from Scripture and History of the Second Coming of Christ, about the Year 1843; Exhibited in a Course of Lectures (Boston: B. B. Mussey, 1840), 190-203, 295, accessed August 17, 2015, Google Books; Josiah Litch [1809-1886], Prophetic Expositions; or a Connected View of the Testimony of the Prophets Concerning the Kingdom of God and the Time of Its Establishment, 2 vols. (Boston: Joshua V. Himes, 1842), 2:201-226, accessed August 17, 2015, Google Books; and George Storrs [1796-1879], The Bible Examiner: Containing Various Prophetic Expositions, Second Advent Library 33 (Boston: Joshua V. Himes, 1843), 91-107, accessed August 17, 2015, Google Books. Seventh-day Adventism grew out of the movement that was based on William Miller's teachings about the second coming of Jesus Christ. Thus, this understanding of the two witnesses is probably part of the heritage that Adventism gained from Millerism. Second, Ellen Gould White (1827-1915) espoused this understanding of the witnesses. She mentions it first in Ellen Gould White, The Great Controversy between Christ and Satan from the Destruction of Jerusalem to the End of the Controversy, vol. 4 of The Spirit of Prophecy (Oakland, CA: Pacific Press; Battle Creek, MI: Review and Herald, 1884), accessed August 17, 2015, Internet Archive Community Texts Collection. Updated versions of the text appear later in two editions, 
As can be seen, most interpreters who identify the witnesses as symbolizing sacred writings have the two testaments of the Bible as the referent. An alternative referent that appears on occasion is the Law and the Prophets, key components of the OT. This seems to be limited to a few writers from the twentieth century. ${ }^{43}$

Ellen Gould White, The Great Controversy between Christ and Satan During the Christian Dispensation (Oakland, CA: Pacific Press, 1888), accessed August 17, 2015, Internet Archive American Libraries Collection; and Ellen Gould White, The Great Controversy between Christ and Satan: The Conflict of the Ages in the Christian Dispensation (Mountain View, CA: Pacific Press, 1911), accessed August 17, 2015, Internet Archive American Libraries Collection. The Seventh-day Adventist Church recognizes White as a prophet. Thus, her espousal of this view of the witnesses has perhaps been viewed as a divine endorsement.

${ }^{43}$ Perhaps the earliest identification of this kind though is with the spiritual reading of Revelation by Hendrik Jansen van Barrefelt (ca. 1520-ca. 1594). Van Barrefelt takes the whole narrative as having to do with the relationship of earthly humanity to the Law and the Prophets. Of course, van Barrefelt could mean the principles of law and prophecy as opposed to key components of the OT. For the text and annotations for Rev 11, see Hendrik Jansen van Barrefelt [Hiël, pseud.], Erklärung Der Offenbarung Johannis Aus dem Visionischen Gesichte, in das wahre Wesen Jesu Christi, trans. [Friedrich Breckling?] ([Amsterdam?], 1687), 58-64, accessed August 17, 2015, Google Books. Cf. Turner, "Revelation 11:1-13," 223. At first glance, Samuel Sheffield Snow (1806-1890), a former Millerite preacher, seems to espouse the two witnesses as the Law and the Prophets, meaning the OT scriptures. Yet, a more careful reading suggests that he sees the witnesses as two kinds of sacred written material united in testifying of Jesus Christ. One involves types, like the Law of Moses, and the other involves prophecy, like the writings of the Prophets. Otherwise, Snow's commentary on the witnesses reads like that of William Miller and some of his associates, seeing the word of God in obscurity during the hegemony of the Papacy, seeing it slain in France during the revolution, and seeing it exalted through the establishment of Bible societies and their publishing work. For Snow on Rev 11:1-13, see Samuel Sheffield Snow, The Voice of Elias: or, Prophecy Restored. Being a Complete and Truthful Exposition of the Visions of the Prophet Daniel and the Book of the Revelation (New York: Baker \& Godwin, 1863), 200-215, accessed August 17, 2015, Google Books.

The following are two genuine examples of the Law-Prophets view, both of which are expositions that include argumentation. For more references like these, see Appendix D. Léon Pierre François Gry [1879-1952], "Les chapitres XI et XII de l'Apocalypse," $R B$ 31, no. 2 (April 1922): 203-214; and M. Robert Mulholland, Jr. [born 1936], Revelation: Holy Living in an Unholy World, Fancis Asbury Press Commentary 


\section{Influence on the Choice of Expositions \\ Featured in This Chapter}

Looking diachronically at symbolic identifications reveals that they have had advocates throughout much of the history of the interpretation of the witnesses. Some have chosen a personal referent for the symbol (God's people), while others have chosen an impersonal referent (sacred writings). The two separate accounts about symbolic identifications, while useful, have nevertheless left out an important piece of information. This information comes from putting together the literature for both classes of identifications and then considering the significant expositions since 1700 . When these expositions are considered, it becomes clear that more interpreters have adopted the personal view of the witnesses than have taken up the one involving sacred writings.

This additional fact and the data presented in the two historical surveys have influenced the choice of the expositions to feature in the chapter as representatives of symbolic interpretations of the witnesses. Accordingly, most of those selected associate the two witnesses with the totality of God's people. The three of them, including Beale, put forth the popular opinion that the witnesses represent the Christian church. ${ }^{44}$ Therefore, these three expositors have been chosen to represent the side of the majority among those advancing symbolic identifications. Of course, this means that no exposition is discussed in any detail that views the witnesses as part of God's people. This omission, however, is not a major concern. Some of the arguments offered by the

(Grand Rapids, MI: Francis Asbury Press, 1990), 183-184, 202-209. Cf. Turner, "Revelation 11:1-13," 260, 295.

${ }^{44}$ Beale, Book of Revelation; Kamp, Openbaring; Maier, Kapitel 1-11; and Maier, Kapitel 12-22. 
three expositors could be used to support proposals where the witnesses are only a part of God's people, inasmuch as those other proposals are also symbolic and person-oriented identifications. Moreover, I am confident from my close examination of much of the literature on the two witnesses that my handling of the literature here does not cause common broad issues of interpretation to be missed. Therefore, discussing these three expositions adequately represents a major segment in the debate since 1700 over the identity of the two witnesses.

The symbolic identifications where the witnesses represent sacred writings are also discussed in this chapter. The summaries of argumentation elsewhere in this study say nothing about the distinctive arguments that interpreters might use to support this kind of symbolic identification. The historical surveys and the additional observation about the literature for symbolic identifications show, however, that this is an important class of identifications. The argumentation for such positions merits some attention. Yet, these expositions merit less attention than what is given to the expositions looking to the totality of God's people. Consequently, I have chosen to discuss only the work of Ekkehardt Müller, who argues that the two witnesses represent the Bible. ${ }^{45}$ Moreover, the discussion of Müller's work is briefer than it could be. An overview of the work and a sample of the argumentation are presented to give a taste of Müller's reasoning and to show all the broad issues of interpretation that could be derived from the full exposition. Not surprisingly, these delimitations mean overlooking some distinctive points of argumentation for the Scripture view as well as distinctive points on behalf of some other

\footnotetext{
${ }^{45}$ Müller, Der Erste und der Letzte.
} 
set of sacred writings. Still, common broad issues of interpretation involved in arguing for the Bible as the two witnesses seem quite evident. Furthermore, I am confident that Müller's arguments raise many of the broad issues of interpretation that might be found in expositions promoting other sets of sacred writings. Therefore, briefly discussing Müller's exposition complements the earlier discussion of personal symbolic identifications of the witnesses and offers some exposure to another part of the debate since 1700 .

\title{
Gregory Kimball Beale
}

\author{
Introduction
}

Gregory Kimball Beale (born 1949) ${ }^{46}$ has written a significant commentary on the Book of Revelation, notable both for its length and for its contribution to the continuing scholarly discussion of Revelation. ${ }^{47}$ One thing in particular that distinguishes his work from that of his predecessors is his attempt "to analyze the use of the OT in the book and

\footnotetext{
${ }^{46}$ Gregory Kimball Beale is an American scholar and an ordained minister of the Conservative Congregational Christian Conference. He holds a ThM from Dallas Theological Seminary (1976) and a PhD from the University of Cambridge (1981). His dissertation was published with revisions as Gregory Kimball Beale, The Use of Daniel in Jewish Apocalyptic Literature and in the Revelation of St. John (Lanham, MD: University Press of America, 1984). Besides his involvement in scholarly societies, Beale has authored several books, articles, essays, and reviews, related particularly to the topics of the use of the OT in the NT, Pauline studies, biblical theology, eschatology, the book of Revelation, and apocalypticism. He has been a professor since 1980, but serves as Professor of New Testament and Biblical Theology at Westminster Theological Seminary since 2010. The main sources for this information are Westminster Theological Seminary, "Gregory K. Beale," Faculty, accessed August 16, 2015, http://www.wts.edu/faculty/profiles/gbeale.html; and Westminster Theological Seminary, "Articles and Publications: Works and Projects of Gregory K. Beale," Faculty, accessed August 16, 2015, http://www.wts.edu/faculty/profiles/gbeale/gkbaandp.html.

${ }^{47}$ Beale, Book of Revelation.
} 
to trace the treatment in Jewish exegetical tradition of passages alluded to in Revelation and the bearing of that tradition on those references." ${ }^{48}$ In commenting on Rev 11, Beale offers numerous reasons for identifying the two witnesses as "the whole [Christian] community of faith," throughout its existence before Jesus' second coming and "whose primary function is to be a prophetic witness." 49 Because of the significance of the commentary as a whole and because of the arguments that Beale presents in relation to the identity of the two witnesses, Beale's discussion of the identity issue appropriately represents other discussions that conclude that the witnesses represent the whole church.

Before looking at Beale's comments that are specifically aimed at the identity of the two witnesses, one must consider aspects of the interpretive framework that he brings to Rev 11 and the issue of the witnesses' identity. That framework is important since it influences the argumentation that he offers for his identification of the two witnesses. Beale's interpretive framework is discernible through an examination of the lengthy introduction to his commentary. Due to its depth, only the parts of that framework most obviously pertinent to Rev 11 are detailed here. Even then, the discussion is abbreviated for the sake of space and readability.

\section{Beale's Interpretive Framework}

The most obvious components of Beale's interpretive framework, at least as it

\footnotetext{
${ }^{48}$ Ibid., 3. This is not to say that other prior commentaries have not also attempted to do these things in some way, but simply to point out that his attempt stands out. This would appear to be something that Beale has in fact sought to achieve with his commentary. In the preface, Beale implies that, with respect to the analysis of "the Old Testament allusions" at least, he has aimed to conduct his investigation "in a more trenchant manner." Ibid., xix.

${ }^{49}$ Ibid., 573; cf. 565-568, 572-575.
} 
influences his thinking on Rev 11, appear to be his perspective on how the OT is used in Revelation, his perspective on symbolism in the book, and his interpretive approach to the whole book.

\section{Use of the OT in Revelation}

Beale's understanding of how the OT is used in Revelation not only affects his reading of particular passages, but it is fundamental to his whole interpretive framework. Beale recognizes that the OT references in Revelation are primarily allusive instead of "formal quotations." ${ }^{50}$ Presumably, with this in mind, Beale lays out the criteria that he has employed in identifying "OT allusions in Revelation." 51

Identifying OT references within Revelation is only part of what it means to understand how the OT is used in Revelation. Accordingly, Beale also argues vigorously that many OT references in Revelation are intentional and exhibit some regard for the original OT contexts, whether literary, thematic, or historical. ${ }^{52}$

Given this perspective on how the OT is used in Revelation, Beale is inclined toward examining identified references in their original contexts and then using the information gathered from those investigations to further his understanding of the text of Revelation. This phenomenon is evident in various places throughout the commentary

${ }^{50}$ Ibid., 77.

${ }^{51}$ Ibid., 78. Beale speaks of clear allusions, probable allusions, and possible allusions.

${ }^{52} \mathrm{He}$ argues for authorial intentionality at ibid., 79-81. He argues for authorial regard for the original OT contexts at ibid., 82-86; cf. 96-99. Following all this argumentation, Beale discusses several types of usage of the OT in Revelation in part to supplement his argument that many references to the OT in Revelation have been made consciously and exhibit a certain degree of respect for the OT contexts. Ibid., 86-96; cf. $100-105$. 
where Beale identifies OT references in a passage of Revelation and senses some intentionality in the choice of that reference.

\section{Symbolism in Revelation}

Beale's understanding of symbolism in the book of Revelation, besides being a factor in his interpretation of the text, builds on his thoughts about how the OT is used in Revelation and affects his thinking with respect to other components of his interpretive framework. In discussing this topic in the introduction to his commentary, Beale looks at "the symbolic nature" of Revelation and gives insights into how to interpret the symbols in the book. ${ }^{53} \mathrm{He}$ includes a section that deals specifically with the symbolic meaning of numbers. ${ }^{54}$

With respect to "the symbolic nature" of Revelation, Beale concludes from his interpretation of Rev 1:1 "that the majority of the material in [Revelation] ... is revelatory symbolism (1:12-20 and 4:1-22:5 at the least)" and therefore should usually be interpreted "according to a nonliteral interpretive method." 55

\section{Interpretive Approach to the Content of Revelation}

The key aspect of Beale's interpretive framework is his interpretive approach, 69.

${ }^{53}$ Ibid., 50. The whole discussion of symbolism in Revelation appears at ibid., 50-

${ }^{54}$ Ibid., 58-64. Cf. here those instances where Beale mentions the broad use of number symbolically in Revelation: ibid., 24, 416-417, 496-497, 720-722, 874-875, 995, 1017, 1076-1078.

${ }^{55}$ Ibid., 52; cf. 488, 807-808, 973-974, 995, 1017. 
which can be defined as a broad outlook on the whole of Revelation that governs how one relates the content of the book to the events of history. In his introduction, he summarizes and evaluates briefly the "four main interpretative approaches to the book of Revelation." ${ }^{56}$ After discussing the preterist, historicist, futurist, and idealist approaches to Revelation, ${ }^{57}$ Beale presents his own approach, which he calls, "Eclecticism, or a Redemptive-Historical Form of Modified Idealism." ${ }^{15}$ In accordance with other aspects of his interpretive framework, ${ }^{59}$ Beale maintains that Revelation "symbolically portrays events throughout history, which is understood to be under the sovereignty of the Lamb as a result of his death and resurrection." ${ }^{60}$ In this portrayal, Revelation does look to the

${ }^{56}$ Ibid., 44.

${ }^{57}$ Ibid., 44-48. Beale says that further "assessment of these [four] views" appears "at various points throughout the commentary." Ibid., 44. In this regard, from the introduction, note for preterism ibid., 20-21, 25-26. Meanwhile, note for futurism ibid., $116-145,152-170$.

${ }^{58}$ Ibid., 48. With respect to the term "Eclecticism," Beale refers to Homer Hailey, Revelation: An Introduction and Commentary (Grand Rapids, MI: Baker Book House, 1979), 50. So Beale, Book of Revelation, 48n15. He also appears to compare his approach to the text with that of "Caird, Johnson, Sweet, and above all Hendirksen and Wilcock." Ibid., 49. The works that he has in mind are George Bradford Caird, $A$ Commentary on the Revelation of St. John the Divine, Harper's New Testament Commentaries (New York: Harper \& Row, 1966); Alan F. Johnson, "Revelation," in The Expositor's Bible Commentary, ed. Frank Ely Gaebelein and James Dixon Douglas (Grand Rapids, MI: Regency Reference Library, 1981); John Philip McMurdo Sweet, Revelation, SCM Pelican Commentaries (London: SCM Press, 1979); William Hendriksen, More Than Conquerors: An Interpretation of the Book of Revelation (Grand Rapids, MI: Baker Book House, 1965); and Michael Jarvis Wilcock, I Saw Heaven Opened: The Message of Revelation, The Bible Speaks Today (Downers Grove, IL: InterVarsity Press, 1975).

${ }^{59}$ One may note in particular Beale's understanding of Rev 1:19 and his outlook on the structure and plan of Revelation. See Beale, Book of Revelation, 116-145, 152 170 .

${ }^{60}$ Ibid., 48; cf. 49. 
future, but it does so primarily in a general way, so that for the most part one cannot perceive any "specific prophesied historical events." ${ }^{61}$ There are, however, some "exceptions" in the matter of discernible specific future events. ${ }^{62}$ The most significant exception is the assumption that Revelation foresees "a final consummation in salvation and judgment," more precisely "the final coming of Christ to deliver and judge and to establish the final form of the kingdom in a consummated new creation." 63 It is toward this grand event that the Lamb, as sovereign over history, "will guide the events depicted" in Revelation. ${ }^{64}$

Beale's Arguments Specifically concerning the Two Witnesses

Having presented key elements of the interpretive framework that Beale brings to his reading of the book of Revelation, one can now look at the evidence that he presents for identifying the two witnesses as "the whole [Christian] community of faith," throughout its existence before Jesus' second coming and "whose primary function is to be a prophetic witness." 65

Most of Beale's actual argumentation concerning the witnesses centers on showing that the two witnesses represent a "corporate" entity, ${ }^{66}$ specifically the church, as

${ }^{61}$ Ibid., 48; cf. 46, 49.

${ }^{62}$ Ibid., 48.

${ }^{63}$ Ibid. Other exceptions that Beale notes here are in Rev 2:10, 22 and 3:9-10. Ibid., 48n16.

${ }^{64}$ Ibid., 48.

${ }^{65}$ Ibid., 573; cf. 565-568, 572-575.

${ }^{66}$ Ibid., 574. 
opposed to "two individual prophets." ${ }^{67}$ Some of the argumentation, however, is directed at showing that the witnesses refer to the whole church and not just a portion, such as the martyrs. At the center of his argumentation are six main reasons. Beale does make one other point though, which can be mentioned here since it stands alone. Specifically, Beale contends that the two witnesses refer to persons as opposed to "concepts. ${ }^{\text {"68 }}$ His basis is the fact that "they are portrayed as people who perform actions and speak words." 69

\section{Six Main Reasons for Beale's Position on the Witnesses}

Reason one: The two witnesses are "two lampstands"

Beale contends that the designation of the two witnesses as "two lampstands" in Rev 11:4 identifies them "as the churches." ${ }^{70}$ In support of this, he points out that ancient Jewish writings interpret the single lampstand of Zech 4 as a reference to God's people. ${ }^{71}$

${ }^{67}$ Ibid., 572.

${ }^{68}$ Ibid., 573. The only example that Beale offers of this type of symbolic view of the witnesses is the opinion of Kenneth Albert Strand that the witnesses represent "the word of God" and "the testimony of Jesus." See ibid., 573n295. Cf. Kenneth Albert Strand, "The Two Witnesses of Rev 11:3-12," AUSS 19, no. 2 (Summer 1981): 127-135.

${ }^{69}$ Beale, Book of Revelation, 573. It is surprising for Beale to use the fact that the witnesses are described as people doing things and saying things as the basis for his contention that they represent something personal. He is clearly biased toward the symbolic in his reading of Revelation in general and Rev 11 in particular. In other words, his tendency is not to move in a straightforward way from the description to what it represents.

${ }^{70}$ Ibid., 574; cf. 55-56, 577.

${ }^{71}$ For a few examples, see ibid., 574. Compare the fuller listing on ibid., 208. Cf. also ibid., 206-207, 211, 579. 
Probably, this observation is relevant to Beale's contention because key features of Rev 11:4 - the lampstands, the olive trees, and the final clause - have all apparently been drawn from Zech 4, especially Zech 4:14. ${ }^{72}$ Presumably, it is also relevant because Beale assumes that Jewish exegetical traditions have a significant bearing on understanding the images and the concepts in Revelation. ${ }^{73}$ Perhaps also involved here is Beale's opinion that John understands the church to be the true Israel and that this is borne out in numerous places within Revelation. ${ }^{74}$

Beale, however, does offer a "more important" reason for his contention about "the lampstands" and "the churches." ${ }^{75}$ Specifically, he observes that Rev 1:20 explicitly identifies "the seven lampstands" mentioned in Rev 1-2 as "the seven churches" in Asia Minor to which John is to write $(1: 4,10-11) .{ }^{76}$ He argues elsewhere that "the seven churches" actually represent "all the churches in Asia Minor and probably, by extension,

${ }^{72}$ Cf. ibid., 577.

${ }^{73}$ Cf. ibid., xix, 3, 56.

${ }^{74}$ Cf. ibid., 576-577. There Beale interprets Zech 4, identifying the lampstand as Israel, like the Jewish exegetes, and then applies that interpretation to the situation of the church as the new Israel. In that instance, however, Beale appears to make the application because he already has in mind that the lampstands in Rev 11, which are linked to the witnesses, point to the church. Cf. also ibid., 187, 189, 207. For instances where Beale addresses in more detail the matter of the church as the new, true Israel, see ibid., 5-26, 84-85, 91-92, 94-96, 193-194, 196-197, 213-214, 239-243, 283-289, 360-362, 409-428, 431, 557-564, 568-571, 625-632, 642-645, 731-735, 737-741, 1012-1013, 10261028, 1043-1048, 1069-1071, 1073-1074. Also of possible relevance here are other discussions below that involve Beale's opinion about the church as the true Israel in Revelation.

${ }^{75}$ Ibid., 574.

${ }^{76}$ Ibid., 574; cf. 186, 203-204. 
the church universal."77 $\mathrm{He}$ also reasons that it is improbable that the image of lampstands in Rev 11 means something different from what it explicitly means in Rev $1{ }^{78}$ Moreover, Beale finds confirmation for reading Rev 11:4 in light of Rev 1:20 through the fact the lampstands in each case are associated "with kingly and priestly functions." ${ }^{79}$ This thought, however, requires some elaboration.

Beale says, "The lampstands ... [in Rev 1] are identified as 'a kingdom and priests."'80 Rev 1:20 itself does not make this connection, but, as just noted, it does expressly identify them with "seven churches" in Asia Minor. The quotation "a kingdom and priests" appears to come from Rev 1:6 (cf. NIV), but this verse also by itself does not make the connection about which Beale speaks. Consequently, one must speculate concerning the details of Beale's thinking here. The congregations symbolized by the lampstands in 1:20 are the immediate audience to whom the contents of Revelation are directed (see again 1:4, 10-11). ${ }^{81}$ Accordingly, this audience is the primary intended recipient of the "salutation" of which Rev 1:6 is a part. ${ }^{82}$ Consequently, the seven

${ }^{77}$ Ibid., 186. Beale's understanding of the seven churches in Asia Minor "as representative" of a greater number of congregations, perhaps even all congregations, is based on several reasons. See ibid., 186-187; cf. 189, 204-213, 226-227, 234, 326-327, $355,576-577$.

${ }^{78}$ Ibid., 55-56, 574, 577.

${ }^{79}$ Ibid., 574.

${ }^{80}$ Ibid.

${ }^{81}$ Concerning these verses, see ibid., 186, 203-204.

${ }^{82}$ Ibid., 186. Beale considers Rev 1:4-8 to be a "salutation" to Revelation. Ibid., 186; cf. 196. From this, vss. 4-5a are an "epistolary greeting." Ibid., 186; cf. 186-192. Vss. 5b-6 are a "doxology." Ibid., 191; cf. 190-196. Vss. 7-8 are a "conclusion." Ibid., 196; cf. 196-200. 
congregations with John form the primary antecedent for "us" in the key clause from 1:6 that says, "[Christ] has made us to be a kingdom and priests to serve his God and Father" (NIV). In this way, Rev 1:6 can be connected to 1:20, and "the seven lampstands" of Rev 1-2 can be seen as associated with priesthood and kingship.

Beale also associates the lampstands in Rev 11:4 "with kingly and priestly functions." 83 This association comes from the fact that this verse also designates the two witnesses as "two olive trees." ${ }^{84}$ As already noticed, the combination of olive trees and lampstands and the wording of the final clause of 11:4 all appear to derive from Zech 4, especially Zech 4:14. Zech 4:14 "interprets the olive trees as 'the anointed ones who are standing before the LORD of the whole earth.'"85 Beale understands this explanation to be a reference to the two Jewish leaders at the time of the vision, the high priest Joshua and the governor Zerubbabel. These two individuals are then taken as a priestly figure and a royal figure respectively. ${ }^{86}$ Beale understands Zech 4 to be saying that these two figures will be "the Spirit's key means for the establishment of the temple against opposition." 87 Designating the two witnesses as "the two olive trees" therefore appears to

${ }^{83}$ Ibid., 574.

${ }^{84}$ Ibid., 574, 577-579; cf. 195.

${ }^{85}$ Ibid., 577.

${ }^{86}$ Ibid., 577-578. In apparent support for his view of moving from Joshua and Zerubbabel to the more general priestly and kingly figures, Beale observes that "Jewish writings interpreted Zech. 4:2-3,11-14 as referring generally to priestly and royal figures . . . and sometimes understood the same verses as referring to priestly and kingly figures with specific messianic connotations." Ibid., 578.

${ }^{87}$ Ibid., 577-578. Beale derives his understanding about the two olive trees in Zechariah primarily from Zech 4:6-10, which he believes summarizes "the meaning of the entire vision in Zechariah 4." Ibid., 577. 
assign this same priestly-royal function to the witnesses. Beale seems to find confirmation for this in the fact that Rev 11:1-2, which precedes the introduction of the witnesses and is connected to it, speaks "of the establishment and preservation of the true temple, despite opposition." ${ }^{88}$

Reason two: The war against the witnesses

Beale's second main reason for saying that the two witnesses represent the church as opposed to two actual individuals comes from observations about Rev 11:7. That verse says that "the beast that comes up out of the abyss will make war with ... [the witnesses], overcome them, and kill them" (cf. NASB). Beale points out that this statement derives from Dan 7:21, "where the last evil kingdom prophesied by Daniel persecutes not an individual but the nation of Israel." 89 The implication is that, by alluding to this verse in Daniel, Rev 11:7 also has in mind an attack against God's people. ${ }^{90}$ Beale's opinion that John portrays the church as the true Israel throughout Revelation probably underlies this reasoning. ${ }^{91}$

Elsewhere Beale highlights some other verses in Revelation that confirm this understanding of Rev 11:7. First, he points to the use of Dan 7:21 in Rev 13:7: "It was

${ }^{88}$ Ibid., 577; cf. 578. For Beale's understanding of Rev 11:1-2, see ibid., 557-571.

${ }^{89}$ Ibid., 574; cf. 588-590.

${ }^{90}$ Cf. ibid., 588. See also ibid., 698. There he reasons similarly concerning Rev 13:7 and the allusion to Dan 7:21 (and Dan 7:8 [LXX]) in that verse.

${ }^{91}$ For instances where Beale addresses the issue of the church as the new, true Israel, see the discussion above of Beale's first main reason for his identification of the two witnesses. Also of possible relevance here are other discussions below that involve Beale's opinion about the church as the true Israel in Revelation. 
also given to ... [the beast] to make war with the saints and to overcome them" (cf.

NASB). Making a similar allusion to Dan 7:21, John substitutes "saints" for "witnesses" and thus supports Beale's understanding of Rev 11:7. ${ }^{92}$ Second, Beale calls attention to a text that is apparently similar to Rev 11:7, namely, Rev 20:7-10. ${ }^{93}$ He says that in these verses "the beast conducts the final 'war' against 'the camp of the saints and the beloved city.'"94 Finally, he notices the conflict in 19:19-21, but acknowledges that the reference is to a "battle" "subsequent" to that in 11:7.95 In Rev 19:19-21, "the beast is said 'to make war against' Christ and 'against his army.'"96

It is not immediately obvious how connecting Rev 19:19-21; 20:7-10 with 11:7 advances Beale's identification of the witnesses. One can speculate, however, on Beale's reasoning. Beale views God, Christ, the church in heaven, and the church on earth as the forces of good in a final conflict at the end of the church age. Opposing them are Satan and his various allies. This conflict is portrayed from various angles in Rev 11:7-13; 16:12-16; 19:19-21; and 20:7-10. ${ }^{97}$ Beale seems to reason then that, since Rev 11:7 deals

${ }^{92}$ Beale, Book of Revelation, 588; cf. 652, 698.

${ }^{93}$ Ibid., 588.

${ }^{94}$ Ibid. Technically speaking, Rev 20:7-10 speaks about Satan and the nations attacking the saints and the city, not the beast. Beale here obviously sees some interchangeability between Satan and the beast. A little further on from the above quotation, he explicitly notices the interchangeability between them. Ibid., 589-590; cf. $147,622-623,673,680-681,987$. For possible reasons why Beale would see the two entities as interchangeable, see ibid., 634, 683-687, 690-691, 694, 865, 871-872.

${ }^{95}$ Ibid., 588.

${ }^{96}$ Ibid.

${ }^{97}$ Beale's main references to this end-time conflict and the various parties involved in it are ibid., 132, 148-150, 588-591, 596-597, 812, 834-839, 960-961, 967-968, 976- 
with the same conflict as the other passages, the two witnesses must represent one of those entities on the side of good. The best candidate, presumably in Beale's opinion, is the church on earth, which Satan and the nations attack in Rev 20:7-10. ${ }^{98}$ This reasoning may explain his reference to that passage. In Rev 19:19-21, however, that part of the church that is in heaven is under attack, and this specific confrontation occurs in the latter half of the greater final conflict, when the result is punishment of the forces of evil. ${ }^{99}$ Still, since the depiction in 19:19-21 does involve the church, here too one might find an indication that the two witnesses represent the church. This reasoning seems to explain why Beale also offers a point about the identity of the witnesses based on Rev 19:19-21 in relation to 11:7.

Reason three: Worldwide visibility

Beale's third main reason for saying that the two witnesses symbolize the church as opposed to two actual individuals stems from the description of those who see "the defeat and resurrection of the witnesses" in Rev 11:9-13. ${ }^{100}$ The phrase "'those dwelling

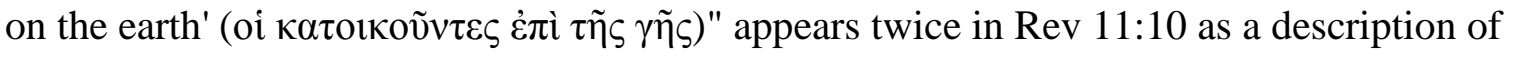
this audience. ${ }^{101}$ Beale contends that "this [phrase] is a technical term repeated

982, 986-987, 1022-1023, 1026-1028. With these references, cf. ibid., 22-23, 28-29, 171, 290, 292, 400-401, 513, 865, 872, 876-879, 920, 989, 993.

${ }^{98}$ Cf. ibid., 22-23, 28-29, 149, 290, 292, 588-591, 597, 835-837, 872, 876-877, 967-968, 986-987, 993, 1021-1028.

${ }^{99}$ Cf. ibid., 834-835, 878-881, 948, 960-961, 967-971.

${ }^{100}$ Ibid., 574.

${ }^{101}$ Ibid., 595 . 
throughout the book [of Revelation] . . . for unbelievers who suffer under incipient divine judgment because they persecute God's people $(6: 10 ; 8: 13) . "{ }^{102}$ He understands the phrase as having this sense also in Rev 11 and thus sees it as "a reference to persecutors dwelling throughout the earth." ${ }^{103}$ The audience is also described in Rev 11:9 (cf. NASB) as "those from the peoples, tribes, tongues, and nations" ( $\dot{\kappa} \kappa \tilde{\omega} \nu \lambda \alpha \tilde{\omega} \nu \kappa \alpha i ̀ ~ \varphi v \lambda \tilde{\omega} v$

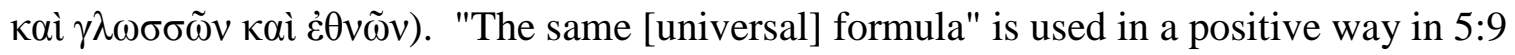
and 7:9 "for the redeemed throughout the earth."104 In 10:11, however, "which is part of the introduction to ch. 11," a variation of the phrase appears with a negative sense for the first time. ${ }^{105}$ Given the use of the phrase in 10:11 and given that in 11:9 it stands in

${ }^{102}$ Ibid. Beale identifies this phrase as appearing eleven times in Rev 3:10; 6:10; $8: 13 ; 11: 10(2 x) ; 13: 8,12,14(2 x) ; 17: 2$, 8. See ibid., 749; cf. with the other references below, but contrast 62 . Technically speaking, however, there are some slight differences among the occurrences beyond differences due to syntactical function in a clause; cf. those instances in 13:8,12;17:2,8 with the others. On the occurrence of this phrase earlier in 6:10 and 8:13, see ibid., 392-393, 472-473, 489-491. For additional information on defining this phrase, however, see ibid., 38, 45, 175-176, 289-290, 402404, 595-596, 748-749. From the last reference, it is clear that Beale believes that the

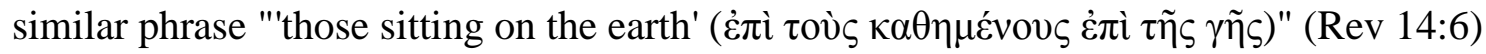
is likely synonymous with the one under discussion here. Ibid., 749.

${ }^{103}$ Ibid., 595.

${ }^{104}$ Ibid., 594. Beale identifies this phrase as appearing seven times in Rev 5:9; $7: 9 ; 10: 11 ; 11: 9 ; 13: 7 ; 14: 6 ; 17: 15$. See ibid., 360; cf. with the other references below for additional discussion of this expression. Technically speaking, however, there are some differences among these occurrences beyond those due to syntactical function. Apart from the variations in the order of the elements and differences with whether the elements are singular or plural, 10:11;11:9; 17:15 can be contrasted with the others. For further discussion of this expression in Revelation, including its derivation from Daniel, see ibid., 26, 45, 60-61, 91-92, 196-197, 359-360, 426, 430-431, 526-527, 553-555, 699-701, 749,882 . Where Beale addresses in the most significant way the occurrences of this expression in Rev 5:9 and 7:9, however, appears at ibid., 359-360, 426, 430-431.

${ }^{105}$ Ibid., 594. For Beale's comments on Rev 10:11, see ibid., 553-555. For his thoughts on Rev 10 as an introduction to Rev 11:1-13, see ibid., 520-521, 556. 
"parallel with 'those dwelling on the earth' in 11:10," Beale views "those from the people, tribes, tongues, and nations" in 11:9 "as a general reference to the whole world of unbelievers." ${ }^{106}$ Consequently, from these descriptions in Rev 11:9-10, one can see that those in 11:9-13 who look upon the defeated state of the witnesses and then watch it transformed into an apparent victory are "the entire world of unbelievers." ${ }^{107}$ Beale infers from this understanding of the audience that the witnesses, who are the object of their attention, represent something "visible throughout the world." 108 This is, of course, consistent with seeing the witnesses as a symbol of the church, since the church is a worldwide entity.

Reason four: Parallel passages involving three and a half years

Beale's fourth main reason for identifying the two witnesses as the church starts with the observations that "the two witnesses prophesy for three and a half years" and that for "the same length of time ... 'the holy city,' 'the woman,' and 'those tabernacling in heaven' are to be oppressed $(11: 2 ; 12: 6,14 ; 13: 6) .{ }^{109}$ Left unsaid here is the notion

${ }^{106}$ Ibid., 594; cf. 617.

${ }^{107}$ Ibid., 574; cf. 593.

${ }^{108}$ Ibid., 574.

${ }^{109}$ Ibid., 574; cf. 90, 132. Technically speaking, Rev 11:3 says that the two witnesses "prophesy" for 1,260 days, while 11:2 says that the nations "will trample the holy city for forty-two months" (ESV). Rev 11:2 provides an obvious image of oppression. Rev 12:6, 14 (ESV) speak of the time in which the woman is "nourished" in her "place" in the "wilderness" in two ways, 1,260 days (12:6) or "a time, and times, and half a time" (12:14). The picture of oppression here is not as obvious, but that does not mean that it is not there (e.g., note the water coming from the dragon's mouth in 12:1516). As for "those who dwell in heaven" in 13:6, they are blasphemed by the sea beast who is given "authority to act for forty-two months" (13:5 [NASB]). Thus, the attack on 
that the periods for all of these figures actually refer to a single period. Beale argues for this idea elsewhere. ${ }^{110}$ Thus, Beale has lined up the witnesses (Rev 11:3) in time alongside the holy city $(11: 2)$, the woman $(12: 4,16)$, and those who dwell in heaven (13:6). Beale continues with the contention that, if the latter three figures refer to a persecuted "community, then it is plausible to identify the witnesses likewise." 111

Perhaps to make the case stronger for this first point, Beale presents three others. For one thing, he says, "If the image of an individual woman signifies the community of faith existing during the three and a half years, then the image of two individual prophets might also represent the same reality during the same time period (similarly an individual harlot represents the ungodly community in ch. 17)." ${ }^{112}$ With this new thought, he seems to be saying that the witnesses may be a symbol that is similar in nature to that of the woman, namely, a few individuals representing a larger community, and thus for this reason also may have the same referent as the woman.

Then Beale asserts, "If it is correct to see 11:3 continuing what is in the preceding

"those who dwell in heaven" is linked only indirectly to the period of forty-two months. Each of these three designations - 1,260 days, forty-two months, and a time, times, and half a time - can be equated with approximately three and a half years. For Beale's handling of some of these details, see the footnote below concerning the identifications of "the holy city," "the woman," and "those who dwell in heaven" and see ibid., 538-540, 557-559, 565-568, 584, 589, 594-595, 642, 646-647, 668-669, 673-676, 695, 993.

${ }^{110}$ Ibid., 566-567, 695; cf. 539-540; 589, 646, 669.

${ }^{111}$ Ibid., 574. For Beale's identification of "the holy city," see ibid., 566-571. For his identification of "the woman," see ibid., 566-568, 624-632, 642-646, 648-650, 668680. And for his identification of the inhabitants in heaven that are mentioned in Rev 13:6, see ibid., 566-568, 694-698.

${ }^{112}$ Ibid., 574. For the prostitute of Rev 17, note ibid., 847-861, 883-886, 888. 
two verses, then the two witnesses are another depiction of the true Israel, 'the holy city,' [= the church] during its time of distress." ${ }^{113}$ This statement draws on Beale's contention

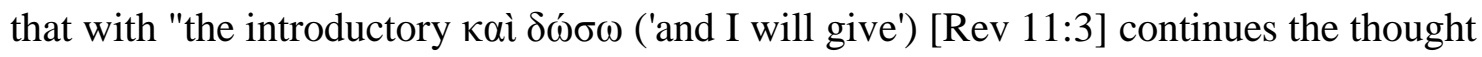
of $\mathrm{vv} 1-2$, , where the temple and the holy city are featured. ${ }^{114}$ With this additional thought, Beale seems to suggest that the witnesses and the holy city have the same referent because they are connected within the same flow of thought that moves from 11:1 and continues through 11:3 on up to $11: 13$.

Beale finishes his discussion of the two witnesses in relation to other entities also associated with the three and a half years, when he says:

The period of three and a half years is based on Dan. 7:25; 12:7, 11 (and perhaps Dan. 9:27), which prophesies a time of tribulation for Israel as a community. The number represents a concept rather than a literal enumeration, as with other numbers throughout the Apocalypse .... Here the figurative emphasis is on the true covenant community experiencing tribulation, irrespective of how long the tribulation lasts in literal time. ${ }^{115}$

Here Beale states that the three-and-a-half-year period that is common to the various entities in Rev 11-13 has a particular meaning that stems from its Danielic background. In Revelation, the period points to the godly community in distress, that is,

${ }^{113}$ Ibid., 574. Again, for the identification of the holy city, see ibid., 566-571. On Beale's opinion that John throughout Revelation portrays the church as the true Israel, see the discussion above of the lampstand imagery (Beale's first main reason for his identification of the witnesses). Also of possible relevance here are other discussions in this chapter that involve Beale's opinion about the church as the true Israel in Revelation. For example, there is the discussion of the war by the beast from the abyss (his second main reason).

${ }^{114}$ Ibid., 572.

${ }^{115}$ Ibid., 574; cf. 89-92, 538-540, 557-559, 565-568, 584, 589, 594-595, 642, 646647, 668-669, 673-675, 695, 993. 
the church in distress. Here Beale seems to be suggesting that the very thing that apparently places the witnesses in parallel with the other entities - the three and a half years-itself suggests that all these images have the same referent of the persecuted church.

Reason five: The Christian community as the source of testimony

For his fifth main reason for identifying the witnesses as the church and not two individuals, Beale simply observes that "often elsewhere in ... [Revelation] the entire community of believers is identified as the source of 'testimony' to Jesus $(6: 9 ; 12: 11,17$; 19:10; 20:4)."116 This statement in itself involves two assumptions. First, Beale assumes that the "testimony" mentioned in Rev 6:9 and 12:11 is also a reference to "the testimony of Jesus" even though "Jesus" is not explicitly linked to the term. Second, he assumes that "the entire community of believers" is in view in all these verses as opposed to only part of the faithful. ${ }^{117}$ Elsewhere in his commentary, Beale offers argumentation to justify these assumptions. ${ }^{118}$ The above statement, however, needs one other assumption

${ }^{116}$ Ibid., 575. The expression "the testimony of Jesus" also appears in Rev 1:2, 9. In these instances, however, John is the source. These two references stand in contrast to the larger number of definite and possible references to "the testimony of Jesus" that apparently have the church as the source. It should be noted here that Beale does not see "the testimony of Jesus" as exclusively "the testimony to Jesus." He is also open to the possibility that "the testimony of Jesus" refers to "the testimony that Jesus gave." See ibid., 183-184, 202, 947.

${ }^{117}$ Ibid., 575 (emphasis added).

${ }^{118}$ See Beale's discussion of relevant verses outside Rev 11, where the terms

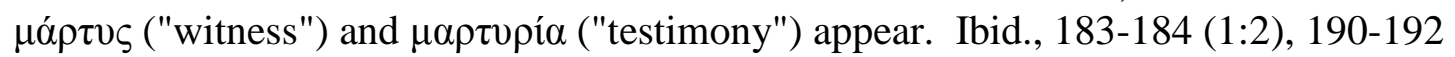
(1:5), 200-202 (1:9), 390-392 (6:9), 663-668 (12:11-12), 676-680 (12:17), 860-861 (17:6), 946-948 (19:10), 992, 995-1001 (20:4). Cf. with all these references ibid., 498$499,572,575,579,617,934,958,1128-1129$. 
if it is to function as support for Beale's identification of the two witnesses. Even if one accepts the first two assumptions and thus accepts the accuracy of Beale's statement, one must also assume that the activity of these "witnesses" (11:3), "their testimony" (11:7), constitutes "the testimony of Jesus" that Beale sees elsewhere in Revelation. ${ }^{119}$ When one adopts this proposition as well as Beale's observation, one can deduce that the two witnesses likely represent "the entire community of believers." ${ }^{120}$ Bases for this additional proposition are apparent elsewhere in Beale's comments on Rev $11 .^{121}$

Reason six: Equal distribution of miraculous powers

For his sixth main reason for seeing the two witnesses as a corporate entity, particularly the church, Beale observes "that the powers of both Moses and Elijah are

${ }^{119} \mathrm{Cf}$. ibid., 579.

${ }^{120}$ Ibid., 575.

${ }^{121}$ One basis may be the observation that several other instances of $\mu \alpha \dot{\rho} \tau \tau \varsigma$ ("witness") and $\mu \alpha \rho \tau v \rho i ́ \alpha$ ("testimony"), besides those in Rev 11, have Jesus as the central topic of the testimony. This suggests that the same may be the case here. See ibid., 572; cf. 579. Beale adopts this proposition also perhaps because the witnesses are modeled after Moses and Elijah and because Moses is linked to the Law and Elijah is linked to the Prophets. If the association with the Law and the Prophets is correct, the witnesses testify of Jesus, like the Law and the Prophets do. See ibid., 582-583; cf. 575, 581. The final reason for why Beale would believe that the activity of the "two witnesses" (11:3), "their testimony" (11:7), constitutes "the testimony of Jesus" lies in the connections that he sees between 11:7 and 6:9,11. For the connections, see ibid., 587588; cf. 146-147, 389-395, 585-587. Beale lines up the testimony of the witnesses with the testimony of the slain of 6:9. Meanwhile, he associates the testimony of the slain with "the testimony of Jesus" spoken of elsewhere. For this association, see ibid., 390. There Beale refers to his comments on Rev 1:2, 9, which speak of "the testimony of Jesus." Ibid., 183-184, 202. Note also other references to Rev 6:9 in the context of discussing "the testimony of Jesus": Ibid., 499, 575, 579, 617, 934, 946, 948n341, 958, 998. 
attributed to both the two witnesses equally" and are "not divided among them." ${ }^{122}$ Beale is referring here particularly to the miraculous powers of the two witnesses that are described in Rev 11:6. These powers appear to allude to miracles performed in the ministries of Moses and Elijah. ${ }^{123}$ With this observation, Beale is pointing out that the text does not ascribe the powers associated with Moses to one witness and then the powers associated with Elijah to the other witness. Instead, each witness has the same set of powers, and those powers are similar to those active in the lives of Moses and Elijah. While this observation does not directly lead to the conclusion that the two witnesses are a corporate entity, it does act as evidence against the notion that the two witnesses are the actual Moses and Elijah and thus makes a corporate interpretation more likely.

Presumably, it is with this thought in mind that Beale characterizes the above observation as "a final hint that these prophets are not two individuals." 124

\section{Additional Arguments for Beale's Position on the Witnesses}

These then are the six main reasons for identifying the two witnesses not as two individuals but as a symbol of the church. One can now look at a few other comments in Beale's discussion of Rev 11 that support his identification of the witnesses.

The witnesses are not just the martyrs of the church

Two comments come as Beale moves to a plain statement of his identification of

${ }^{122}$ Ibid., 575. Italics are in the original.

${ }^{123}$ Ibid., 582-583; cf. 580-581, 584.

${ }^{124}$ Ibid., 575. 
the two witnesses. Both comments are directed at those who would limit the two witnesses to being a symbol of the martyrs of the church and not the whole church. In the first comment, Beale observes that "the angel (!) who refuses John's attempts to worship him in 19:10 and 22:9 also identifies himself respectively as 'a fellow servant of yours and of your brothers who hold the testimony of Jesus ... the spirit of prophecy' and 'a fellow servant of yours and of your brothers the prophets."' ${ }^{125}$ He deduces from this circumstance that "prophets here [in Rev 11] and elsewhere in the book are not limited to martyrs. ${ }^{126}$ Beale's argument therefore seems to respond only to the idea of limiting the two witnesses to the Christian martyrs because they are called prophets (Rev 11:10; cf. 11:3, 6). Clarity concerning Beale's reasoning comes from looking at his comments on Rev 19:10. There Beale deduces that bearing "the testimony of Jesus" is a prophetic activity shared not just with other believers, but also with angels. ${ }^{127}$ If prophets are not limited to humanity, then one is also not bound to limit the notion to a subset of humans, like the Christian martyrs, which is Beale's conclusion in his comments on Rev 11.

The comment about prophets and martyrs is followed by one that seems to respond to the notion of limiting the two witnesses to the Christian martyrs because they

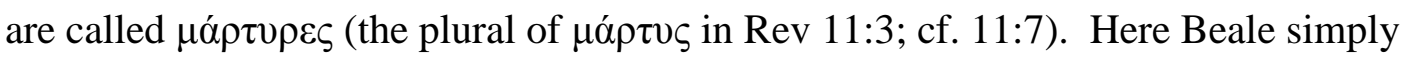

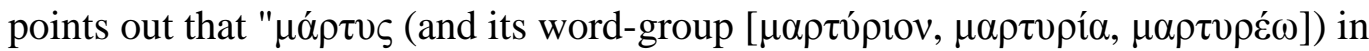
Revelation has not yet taken on the technical definition of 'martyr,'" but "means only

${ }^{125}$ Ibid., 573. Emphasis and ellipsis are in the original.

${ }^{126}$ Ibid.

${ }^{127}$ Ibid., 946-948; cf. 1128-1129. 
'witness.'"128

Again, the witnesses are not two individuals

Two other comments come right after Beale plainly states his identification of the two witnesses. One deals with the two witnesses being modeled after Moses and Elijah, a subject raised in the discussion of two of Beale's main reasons for a corporate identification. This comment supports the notion of modeling and goes against the idea of the witnesses being the actual Moses and Elijah. Beale points out the "precedent" of such modeling in the case of John the Baptist coming "in the spirit and power of Elijah" (Luke 1:17 [NASB]). ${ }^{129}$ John the Baptist was only Elijah-like; he was a "spiritualized Elijah." ${ }^{130}$ His relationship to Elijah suggests therefore the possibility that others can follow his example and also be "spiritualized Elijah[s]."131

Another comment here appears aimed at deterring any thought that John is speaking about two individual prophets at all. That is to say, Beale seems to be opposing here not just the identification of the witnesses as two individual prophets, which is

${ }^{128}$ Ibid., 573; cf. 190. Beale seems influenced by Norbert Brox, Zeuge und Märtyrer: Untersuchungen zur frühchristlichen Zeugnis-Terminologie, Studien zum Alten und Neuen Testament 5 (Munich: Kösel-Verlag, 1961), 97-105; and Allison Albert

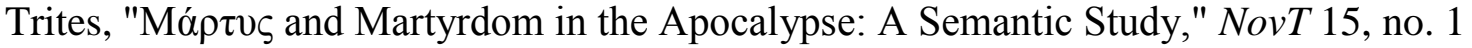
(January 1973): 72-80. So Beale, Book of Revelation, 190n36, 573n294. Beale also refers to a summary of the debate over the meaning of "testimony" in Revelation, namely, Paul Ellingworth, "The Marturia Debate," BT 41, no. 1 (January 1990): 138-139. So Beale, Book of Revelation, 190n37. Beale supports his assertion about the meaning of $\mu \alpha ́ \rho \tau v \varsigma$ and related words at ibid., 190.

\footnotetext{
${ }^{129}$ Beale, Book of Revelation, 573.

${ }^{130}$ Ibid., 573n297; cf. 576, 870.

${ }^{131}$ Ibid., 573n297.
} 
implied by the immediate context, ${ }^{132}$ but also the identification of the witnesses as "both the church throughout the age" and "two individuals who are to come at the end of the age." ${ }^{133}$ Specifically, Beale states: "The OT had prophesied that the entire eschatological community of God's people would receive the Spirit's gift of prophecy (Joel 2:28-32). The early Christian community understood that Joel's prophecy had begun fulfillment in their midst (Acts 2:17-21)." ${ }^{134}$ Perhaps to support the relevance of these thoughts for the account of the two witnesses, Beale adds that Acts 1:8 shows "this prophetic gift ... [as] the means by which the entire church would 'witness' to the whole world." ${ }^{135}$ These words recall, of course, Rev 11:3, 6-7, 10, where the two witnesses are appointed to prophesy and where their testimony amounts to prophecy.

With these statements, Beale seems to be pointing out that another NT writing sees prophetic authority as having been given to the whole church and that it indicates this in a way that exhibits parallels with Rev 11. Presumably, Beale wants readers to infer from these thoughts that the perspective of Acts on the prophetic authority of the church is also John's perspective in Revelation. From such a perspective, there is no need

132"The 'two witnesses' are not two individual prophets." Ibid., 572.

${ }^{133}$ Ibid., 573-574. Beale considers such a combination view as "improbable." Ibid., 573. As an advocate of this perspective, he refers to George Eldon Ladd, $A$ Commentary on the Revelation of John (Grand Rapids, MI: William B. Eerdmans, 1972), 154. So Beale, Book of Revelation, 574n298.

\footnotetext{
${ }^{134}$ Beale, Book of Revelation, 574.

${ }^{135}$ Ibid., 574; cf. 578.
} 
to be restricted to the literal level of two individuals just because John depicts the witnesses as two prophets; the picture of two prophets can represent a larger number of believers and in fact the whole Christian community, since all are technically prophets. ${ }^{136}$

${ }^{136}$ It is presumably with this perspective in mind that Beale mentions the prophetic role of the church elsewhere in his discussion of Rev 11:3-13. See ibid., 572-573, 576585; cf. 598-600. One notices also that this is not the only passage in which Beale sees the prophetic role being applied to the whole community. See ibid., 616-617 (11:18), 820 (16:6), 948 (19:10), 1128-1129 (22:9); cf. 190, 231-232, 546, 549, 916, 923-924, 11241126, 1148. At the same time, however, Beale occasionally sees this role being applied only to a particular group of believers and that John is a member of this smaller circle. See ibid., 1124-1126 (22:6); cf. 35-36, 82, 546, 948, 1128-1129, 1144-1146, 1148. These two perspectives are seemingly contradictory. If the whole church possesses the prophetic gift, then there would seem to be no need to speak of a separate group of prophets within the church. This is not to say that there is no way to reconcile these two perspectives and that they cannot coexist within the same overall outlook on Christian prophecy. It may well be that Beale is correct in seeing these two viewpoints within Revelation and that therefore John held on to both in his thinking. Yet, Beale seems to say little to explain exactly how John reconciles these two perspectives. He may be attempting an explanation when he says, "John is part of this general group [the prophetic church], but he is also part of a narrower class of NT prophets and apostles who continue the OT prophetic office (e.g., see [the comments] on 1:10; 4:1-2; 10:11; 17:1-3; cf. 22:9)." Ibid., 948; cf. 1124-1126. He may also be making such an attempt later when he contends that the term "prophets" in Rev 22:6 "is [likely] restricted to a special class of officeholders or of persons that God specially commissioned to reveal his word to the OT and [the] NT covenant communities"; he soon adds that "[Rev] 22:6 implies that John held a specific prophetic office." Ibid., 1125; cf. 1124-1128. In other words, Beale suggests two circumstances that made John and others stand out from the church as a whole: they either functioned in an authoritative capacity within the church in succession to the OT prophets or had a special divine charge, like the OT prophets, to take the word of God to his people. Part of the problem with these attempts is that Beale has drawn so many parallels, both implicitly and explicitly, between the prophetic role of the church and John's prophetic ministry. For one thing, John and the church are both designated as prophets and function as prophets in similar ways. See ibid., 35-36, 82-83, 169, 183, 190, 202-206, 215-216, 231-232, 317, 319, 525, 546, 549-556, 572-574, 576-584, 598600, 616-617, 820, 850, 916, 923-924, 948, 1065, 1124-1129, 1144-1146. Moreover, John and the church both minister and receive divine legitimation patterned after OT prophets. See ibid., 81-82, 170, 203-204, 213, 319, 550-553, 567-568, 572-574, 576, $582-584,598-600,850,948,1065,1127-1129$. All these parallels do not rule out something distinctive for the prophetic role of John (and others), but surely it makes any attempt to find distinctive elements difficult. One sees Beale in the awkward position of suggesting that there is a subset of Christian believers who are in some way the 
Why there are only two witnesses pictured

Beale has argued that the description of the two witnesses as lampstands (Rev 11:4) indicates that they represent "the churches." ${ }^{137}$ Key to this argument is drawing a connection between the two witnesses as lampstands $(\operatorname{Rev} 11: 4)$ and the seven churches as lampstands (Rev 1:20). Such a connection, of course, would seem more likely if there were seven witnesses in Rev 11 as opposed to only two. Thus, the fact that there are only two witnesses brings some of Beale's reasoning into question and casts doubt on his identification of the witnesses. It is probably with these thoughts in mind that, after the presentation of his six main reasons for his identification, Beale feels compelled to offer a credible explanation for "why ... there [are] two witnesses instead of, for example, seven, in accord with the number of the lampstands in ch. 1."138

Beale begins to address the matter of there being just two witnesses by stating that "the difference [between there being two as opposed to another number] is not intended to elicit the idea of individuality but just the opposite," that is, the notion of a unit. ${ }^{139}$ Presumably, he is speaking here against those who argue for two literal people in part on the basis that the witnesses are designated as two in number. Beale's explanation is that

successors of the OT prophets while at the same time arguing that the prophetic role that was once limited to a few in Israel has now been passed on to the whole church. An apparent contradiction seems to remain.

${ }^{137}$ Ibid., 574. This is Beale's first main reason for identifying the witnesses corporately; see the discussion above of this matter.

\footnotetext{
${ }^{138}$ Ibid., 575.

${ }^{139}$ Ibid.
} 
the number two is used to highlight the "just or valid legal" testimony of the witnesses. ${ }^{140}$

Beale comes to this conclusion in part by observing that "two witnesses" recalls "the OT law requiring at least two witnesses as a just basis for judging an offense against the law (Num. 35:30; Deut. 17:16; 19:15)."141 He also notices that this "legal principle is continued in the NT on the basis of Deut. 19:15."142 Beale may mention this latter situation to show that a reference to this principle in Revelation would not be unique among authoritative early Christian works.

In connection with his explanation, Beale also points out that, since the number two evokes the idea of "a just or valid legal" testimony, "God sometimes sends two angels to announce judgment, to execute judgment, or to validate the truth of a divine communication." ${ }^{143}$ With this thought, Beale seems to be suggesting that his explanation about the meaning of the number two functions in other contexts that bear similarities to that of Rev 11. The similarities are concerning the mission on which the messengers are sent and concerning the fact that God sends the messengers. In Beale's opinion, Christ

${ }^{140}$ Ibid.

${ }^{141}$ Ibid., 575; cf. 576, 581-582.

${ }^{142}$ Ibid., 575. Beale refers to the following passages: Matt 18:16; Luke 10:1-24; John 8:17; 2 Cor 13:1; 1 Tim 5:19; and Heb 10:28. Luke 10:1-24 is included among the references because Beale sees this legal principle at work in the sending out of seventy disciples in pairs, a mission of "thirty-five groups of two witnesses each" ibid.

${ }^{143} \mathrm{Ibid}$. Here Beale refers to the following passages as examples: 2 Macc 3:26, 33; 3 Macc 6:18; 2 En. 1:4; L.A.B. 27:10; 64:5-9; 3 En. 18:23-24; Luke 24:3-9; Acts 1:10-11; Gos. Pet. 36-42. He also notes an instance in which "two humans" function similarly, namely, 1Q22, but it is unclear which persons he has in mind, whether Moses and Eleazar or Eleazar and Joshua. See ibid. 
sends the two witnesses of Rev 11 to "announce judgment, to execute judgment, ... [and] to validate the truth of a divine communication." 144

Beale may intend to add further credibility to his proposal about the number two, when he says, "This legal atmosphere [from the use of the number two] is enhanced by the use of $\mu \alpha \rho \tau$ ¡í $\alpha$ ('witness')" in Rev 11:7. ${ }^{145}$ Beale observes that earlier in his commentary he has argued that this word bears the sense of a legal testimony. ${ }^{146}$ "This nuance," he asserts, is evident when one realizes that most instances of this term in Revelation clearly involve a testimony "that is rejected by the .. . legal system [of the world] and that results in penal consequences." 147 The same situation is apparent in Rev $11: 3-13 .^{148}$

Thus, Beale argues that the number two is used to highlight the "just or valid

${ }^{144}$ Ibid. Concerning the mission of the two witnesses, particularly that they are messengers of judgment, see ibid., 90, 146-147, 510-511, 521, 531, 556, 572, 575-576, 579-586, 595-596, 598-600, 606, 747-750, 802, 822, 900.

${ }^{145}$ Ibid., 575; cf. 576.

${ }^{146}$ See ibid., 200-202; cf. 573n294, 1143, 1154.

${ }^{147}$ Ibid., 575. Beale specifically states, "In at least six of the nine uses of the word $[\mu \alpha \rho \tau v \rho i \alpha]$ in the Apocalypse it refers to a witness that is rejected by the . . legal system [of the world] and that results in penal consequences (so 1:9; 6:9;12:11, 17; 20:4)." Ibid., 575 (italics added). The problem with this statement is that the texts cited at the end indicate only five of the nine uses of the term. Perhaps he is including Rev 11:7 since the next sentence shows that he sees the same phenomenon in 11:3-13. For Beale's thoughts on the term "testimony" in the five verses just noted, see ibid., 200-202 (1:9), 390-392 (6:9), 663-666 (12:11), 676-680 (12:17), 992, 995-1001 (20:4).

${ }^{148}$ In this regard, see ibid., 146-147, 510-511, 531, 556, 567-568, 575-576, 579$591,598-600,605,822,900$. It may be noted that Beale raises in other contexts within his commentary this notion of the Christian testimony being rejected and of Christians then being persecuted and that, in fact, it plays a part in the larger issues of the judgment of the persecutors and the vindication of the saints. See, for example, ibid., 146-149. 
legal" testimony of the witnesses. ${ }^{149} \mathrm{He}$ adds, however, that "another possible reason for the number two is that only two lampstands (churches) among the seven in the letters (chs. 2-3) are not rebuked for some inadequacy in their witness." ${ }^{150}$ Involved in this thought is Beale's opinion that "all of the letters deal generally with the issue of witnessing for Christ in the midst of a pagan culture." ${ }^{151}$ With this thought, Beale is also recalling that the messages to the churches in Smyrna (Rev 2:8-11) and Philadelphia (Rev 3:7-13) do not mention spiritual problems that must be rectified in order to avoid judgment. These churches "have proved themselves faithful and loyal to Christ's 'name' even in the face of persecution from both Jews and pagans." 152

Consequently, with this additional explanation for there being just two witnesses, Beale is suggesting that the two lampstands (witnesses) of Rev 11 are meant to recall the two lampstands (churches) of Rev 2-3 that have been fulfilling their function by being completely faithful in their witnessing. Beale then continues: if this is truly the case, "in v 3 this [connection to the two faithful churches] would emphasize further the effective witness of the church."153 Put differently, if the two witnesses represent the whole church

${ }^{149}$ Ibid., 575.

${ }^{150}$ Ibid.

${ }^{151}$ Ibid., 227; cf. 28-33, 38, 145, 189-190, 206-207, 223, 228, 230-232, 235, 245249, 259-260, 268-269, 272-281, 283, 285-289, 293, 296, 301-307, 309. For actual argumentation supporting this opinion on the theme of witnessing in the letters, however, just see ibid., 230-232, 260, 273-275, 287-289, 303-304.

${ }^{152}$ Ibid., 226. On the churches in Smyrna and Philadelphia, note particularly ibid., 28-33, 82, 215, 224-227, 239-246, 269-274, 280-281, 283-296, 305.

${ }^{153} \mathrm{Ibid} ., 575$. Italics in the original. On the matter of an effective witness, see ibid., 146, 189-190, 231-232, 285-289, 306-307, 556, 572, 576-578, 587-588. 
and intentionally bring to mind the fully faithful congregations in Smyrna and Philadelphia, then the model of the successful testimony of those two churches is meant to be part of the picture in Rev 11 of the witnessing activity of the whole church.

Beale continues his discussion of the number two by denying the validity of one other proposed explanation for the number two. He confronts the argument "that two lampstands, as opposed to the seven of chs. 2-3, indicate that [the two witnesses represent] only a part of the church," such as Jewish Christians, prophets, or martyrs. ${ }^{154}$ First, while acknowledging that "this is a possible figurative meaning," he claims, "It comes close to a literal view in that the conclusion is reached that 11:3-4 refers to twosevenths of the church." ${ }^{155}$ Beale's preference for seeing symbolism in Revelation may be at work here. Second, Beale recalls his opinion "that all the churches in chs. 1-3 were called to be witnessing 'lampstands,"' not just two. ${ }^{156}$ He concludes that, as the earlier chapters had all the churches in view, the present passage centers "on the church as a whole." ${ }^{157}$ Of course, Beale has made a leap here from seven congregations in the first century $\mathrm{CE}$ to the entire church in the interadventual period. Likely this move comes from his view that "the seven historical churches" actually represent "all the churches in

${ }^{154}$ Ibid., 575; cf. 572-573.

${ }^{155}$ Ibid., 575. For this conclusion, Beale refers to Caird, Commentary on the Revelation, 134-135, but rightly acknowledges that Caird does not stop with a literal reading. So Beale, Book of Revelation, 575n303.

${ }^{156}$ Beale, Book of Revelation, 575. For instances where lampstand imagery is connected to the witnessing of the churches, see ibid., 38, 206-207, 230-232, 235, 274; cf. 134, 208-209, 1115.

${ }^{157}$ Ibid., 575. 
Asia Minor and probably, by extension, the church universal." ${ }^{158}$ Thus, Beale has deduced from the witnessing lampstand churches of Rev 1-3 that the entire church is in view in Rev 11.

The witnesses as kingly and priestly figures represent the whole church

As mentioned in the discussion of Beale's first main reason for his identification of the witnesses, he associates them "with kingly and priestly functions." ${ }^{159}$ This association comes from their designation in Rev 11:4 as "two olive trees." 160 This designation appears to originate from Zech 4, especially Zech 4:14. Zech 4:14 "interprets the olive trees as 'the anointed ones who are standing before the LORD of the whole earth.'"161 Again, Beale understands this explanation to be a reference to the two Jewish leaders at the time of the vision, the high priest Joshua and the governor Zerubbabel. These two individuals are then taken as a priestly figure and a royal figure respectively. ${ }^{162}$ Beale understands Zech 4 to be saying that these two figures will be "the

${ }^{158}$ Ibid., 186. As noted before, Beale's understanding of the seven churches in Asia Minor "as representative" of a greater number of congregations, perhaps even all congregations, stems from several reasons. See ibid., 186-187; cf. 189, 204-213, 226$227,234,326-327,355,576-577$.

\footnotetext{
${ }^{159}$ Ibid., 574.

${ }^{160}$ Ibid., 574, 577-579; cf. 195.

${ }^{161}$ Ibid., 577.

${ }^{162}$ Ibid., 577-578.
} 
Spirit's key means for the establishment of the temple against opposition." ${ }^{163}$ Designating the two witnesses as "the two olive trees" therefore appears to assign this same priestlyroyal function to the witnesses.

On this basis, Beale offers a supplemental argument for his identification of the two witnesses. The thrust of Beale's argumentation has been that the two witnesses "represent the church universal." ${ }^{164}$ If this is true and the two witnesses are indeed presented as "priestly and kingly figures," then, as Beale asserts, "In contrast with Zechariah, the priestly and kingly figures are not individuals but represent the church universal." 165 This inference from Beale's reasoning is congruent with how the church is "explicitly" portrayed elsewhere in Revelation, specifically Rev 1:6; 5:10; 20:6. ${ }^{166}$ Concerning the last verse, Beale adds, "Rev. 20:4-6 shows that these king-priests [the witnesses] are not just martyrs or some other special group in the church but the whole people of God." 167 Indeed, Beale argues in his comments on Rev 20:4 that the blessings

${ }^{163}$ Ibid. As noted previously, Beale derives his understanding about the two olive trees in Zechariah primarily from Zech 4:6-10, which he believes summarizes "the meaning of the entire vision in Zechariah 4." Ibid., 577.

${ }^{164}$ Ibid., 578.

${ }^{165}$ Ibid.

${ }^{166}$ Ibid. For Beale's discussion of Rev 1:6, see ibid., 192-195. On Rev 5:10, see ibid., 360-364. With regard to Rev 20:4-6 and the portrayal there of the church as kings and priests, see ibid., 995-1003, 1012-1013. With all of these discussions, cf. ibid., 91, $174,258,268,311-312$, 322, 340-341, 439-440, 527-528, 563, 1011-1012, 1015, 1021, 1097, 1116, 1120.

${ }^{167}$ Ibid., 578. 
of priesthood and kingship $(20: 4,6)$ are meant for all the righteous and not just a select group among them. ${ }^{168}$

An allusion to Ps 79 and a link to Rev 6:9-11

Beale puts forth more support for his identification of the witnesses as the corporate body of the church when he raises the possibility that Ps 79 (78 in the LXX) stands behind the narrative of Rev 11:1-10. He notices that Rev 11:1-10 parallels several elements from Ps 79 in roughly the same order. ${ }^{169}$ Beale contends that "these parallels" are intentional "because ... ch. 11 develops [Rev] 6:9-11 in various ways and in particular is partly a continued answer to the saint's [sic] cry for vengeance in $6: 10$, which [itself] is based on Ps. 79:5, 10." ${ }^{170}$ Beale goes further, however, at this point and reasons that all of these conscious connections to Rev 11:1-13 "indicate again that more than only two individuals are in mind in 11:7-12 [and thus also 11:3-6] and that the two witnesses

${ }^{168}$ Ibid., 995-1003, 1012-1013.

${ }^{169}$ Ibid., 595.

${ }^{170} \mathrm{Ibid}$. One of these supposed developments of 6:9-11 in Rev 11 has been mentioned above (6:9, 11 and 11:7) in the discussion of "the testimony of Jesus" and Rev 11. Cf. ibid., 575, 587-588. Rev 11 functions "as a partial answer to the saints' plea for vengeance in 6:9-11" through the fact that the two witnesses execute judgment on those who reject their testimony and persecute them. Ibid., 595n352. For more information about this development of 6:9-11, see ibid., 556, 585-586; cf. 146-147, 575, 579-581, 587-588. Another development of 6:9-11 is probably in regards to the altar mentioned in 11:1. See ibid., 563; cf. 570-571. On Rev 6:10 drawing on Ps 79:5, 10, see ibid., 392393.

Compare the reasoning that Beale uses in regards to similarities between Ps 79 and Rev 16:6. See ibid., 803, 813, 817-819. Compare also the reasoning with respect to the similarities between that psalm and Rev 19:2. See ibid., 927-929. Beale may also be adding to the plausibility of an intentional reference to Ps 79 in Rev 11 when he mentions two passages in Jewish literature that have similar contexts to Rev 11:1-13 and a clear connection to Ps 79:2-3. Specifically, he notes 1 Macc 7:10-30 and 4QTanh (4Q176) 1. See ibid., 595. 
represent the faithful covenant community of Christians." 171 What lies behind this reasoning is probably the fact that, according to this scheme of connections, the two witnesses stand in parallel to the people of Israel in Ps 79 and to Christians in Rev 6:911. ${ }^{172}$ When this observation about the witnesses is combined with Beale's view that John considers the church the true Israel, ${ }^{173}$ then one can see how he would once again conclude that the witnesses represent something greater than a literal two individuals, namely, the Christian community.

\section{An allusion to Ezek 37}

Beale offers another argument in support of his identification of the two witnesses in the context of his comments on Rev 11:11. This verse describes "God raising the witnesses from the dead before the eyes of their enemies." ${ }^{174}$ Beale observes, "The portrayal of resurrection is taken directly from Ezek. 37:5, 10 LXX." ${ }^{175}$ Those verses are part of a prophecy in which "God's restoration of Israel out of the Babylonian exile" is

${ }^{171}$ Ibid.

${ }^{172}$ As to the identity of the slain and their fellow servants in Rev 6:9-11 as Christians, see ibid., 390-392, 394-395; cf. 146, 587-588.

${ }^{173}$ For instances where Beale particularly addresses the matter of the church as the new, true Israel in Revelation, see the discussion of the lampstand imagery (Beale's first main reason). Also of possible relevance here are other discussions in this chapter that involve Beale's opinion about the church as the true Israel in Revelation. For example, there are the discussions of the war by the beast from the abyss (his second main reason) and of the holy city as a parallel to the witnesses (his fourth main reason).

${ }^{174}$ Beale, Book of Revelation, 596; cf. 84.

${ }^{175}$ Ibid., 596-597; cf. 84. 
depicted as "bones coming to life." ${ }^{176}$ Not only does the wording of Rev 11:11 suggest this allusion, but also the fact that both Israel and the two witnesses are in a "slain" condition prior to their resurrections (Ezek 37:9; Rev 11:7-10). ${ }^{177}$

In the midst of his discussion of the prophecy of Ezek 37 in relation to Rev 11, Beale asserts, "Since Ezekiel prophesies the restoration of an entire faithful nation to God [see Ezek 37:10-13], John sees the fulfillment in all the faithful of the church, and not merely in two faithful individuals." 178 Beale seems to be suggesting here that the witnesses stand in parallel with a corporate body and therefore represent a corporate body. Also perhaps below the surface of this argument is the view that John sees continuity between ancient Israel and the church. ${ }^{179}$ In this case, Beale may also intend to say that the witnesses stand in parallel with Israel and therefore represent the new Israel, the church. ${ }^{180}$

The timing of the witnesses' activity

Before concluding this survey of Beale's argumentation concerning the witnesses, one must say something about the timing of the witnesses' activity. As noted in the discussion of the fourth reason, Beale associates the 1,260 days of prophesying of the

${ }^{176}$ Ibid., 597; cf. 84.

${ }^{177}$ Ibid., 85, 597.

${ }^{178}$ Ibid., 597.

${ }^{179} \mathrm{Cf}$. Beale's discussion of Ezek 37 in relation to Rev 11 as part of his larger discussion of the use of the OT in Revelation. Ibid., 84-85. There Beale uses language that explicitly reflects this perspective on John's understanding of the church and Israel.

${ }^{180}$ Cf. ibid. 
witnesses with the three and a half year period during which "'the holy city,' 'the woman,' and 'those tabernacling in heaven' are ... oppressed $(11: 2 ; 12: 6,14 ; 13: 6) . "{ }^{181}$ There is in actuality only a single period in which the witnesses act and the other entities suffer affliction. ${ }^{182}$ In accordance with his understanding of Revelation as generally a symbolic book, Beale interprets the three and a half years, like other numbers in Revelation, figuratively. "The figurative emphasis is on the true covenant community experiencing tribulation, irrespective of how long the tribulation lasts in literal time." ${ }^{183}$

At the same time, Beale does find limits to the period. In fact, these limits harmonize with an aspect of his eclectic interpretive approach, namely, that "the majority of the symbols in the book [of Revelation] are transtemporal in the sense that they are applicable to events throughout the 'church age."'184 Accordingly, he argues based on Rev $11: 2,8 ; 12: 5-6 ; 13: 3,5$ that the period begins with Jesus' death and resurrection. More specifically, Beale contends that Rev 11:8 with its reference to the crucifixion suggests when the 42 months of trampling of the holy city (i.e., the persecution of the people of God, Rev 11:2) is to begin. ${ }^{185}$ Moreover, Beale understands Rev 12:5 as

${ }^{181}$ Ibid., 574. See the footnotes above in the section on Beale's fourth reason.

${ }^{182}$ Again, notice the references in the section on Beale's fourth reason.

${ }^{183}$ Beale, Book of Revelation, 574; cf. 565-568, 646-647, 667.

${ }^{184}$ Ibid., 48.

${ }^{185}$ Ibid., 567, 646. Beale credits Mathias Rissi with this idea. So, ibid., 567n268, 646n86. See Mathias Rissi, Time and History: A Study on the Revelation, trans. Gordon C. Winsor (Richmond, VA: John Knox Press, 1966), 40. Cf. the original German at Mathias Rissi, Was ist und was geschehen soll danach. Die Zeit- und Geschichtsauffassung der Offenbarung des Johannes, 2nd ed., Abhandlungen zur Theologie des Alten und Neuen Testaments 46 (Zürich: Zwingli Verlag, 1965), 45. Beale does not exactly follow Rissi since Beale does not accept Rissi's view of only one 
referring to Christ's victory at his resurrection and then ascension. ${ }^{186}$ This is immediately followed by the flight of the woman into the wilderness (i.e., the protection and sustaining of the people of God, Rev 12:6) for 1,260 days. ${ }^{187}$ Finally, Beale understands Rev 13:3 as referring to the true defeat of Satan and his servant, the beast, from Jesus' death and resurrection. ${ }^{188}$ This means that the beast's activity of 42 months (Rev 13:5) begins at that point of true defeat, after which it appears to revive continuously. ${ }^{189}$ Beale's arguments for the end of the period are harder to define. In a couple of places, he determines the end based upon Rev 14:14-20. ${ }^{190}$ Thus, the end is Jesus' second coming in judgment. ${ }^{191}$ The problem is that Beale does not elaborate on why this should

city in Rev 11, the earthly Jerusalem. See Rissi, Time and History, 96-102. Cf. the original German at Rissi, Was ist und was geschehen soll danach, 101-105. With that notion in mind, Rissi makes the connection between Rev 11:2 and 11:8. The city acting against Jesus leads to the nations acting against the city. Beale, however, sees two symbolic cities in Rev 11, one pertaining to the church and one pertaining to "the ungodly world." So, Beale, Book of Revelation, 568-569, 591-593. With this conception of the cities in Rev 11, Beale cannot connect the act against Jesus to the act against the holy city in the same way that Rissi does. Instead, Beale attempts the connection through seeing Jesus' death as "the ultimate basis for the trampling" of the holy city, that is, for "the persecution of the church." Ibid., 567. The persecution comes as Satan responds to losses from Jesus' victorious death and resurrection. Cf. ibid., 666-668.

${ }^{186}$ Beale, Book of Revelation, 639-640; cf. 646.

${ }^{187}$ Ibid., 642-643; cf. 567, 646.

${ }^{188}$ Ibid., 687-689; cf. 646.

${ }^{189}$ Ibid., 690-692, 694-695; cf. 646.

${ }^{190}$ Ibid., 567, 646.

${ }^{191}$ See the interpretation of Rev 14:14-20 at ibid., 770-784; cf. 621, 784-785. Cf. Beale's words about the three-and-a-half-year symbolic period elsewhere, where the end point is merely implied rather than argued out. Ibid., 122-123, 539-540, 572, 588-589, 669; cf. 48.

Technically, the end of the activity of the witnesses would have to precede 
be the case. It could have to do with his understanding of Rev 12:1-15:5 as divided into seven sections. ${ }^{192}$ Rev 14:14-20 is the sixth section and functions, like the sixth seal, to depict the final judgment. ${ }^{193}$ In this case, perhaps it is to be seen as the chronological endpoint to the sequence that goes back to near the birth of Christ in Rev 12:1, which would then make it the endpoint for the woman's time in the wilderness (i.e., the protection and sustaining of the people of God, Rev 12:6). ${ }^{194}$

In harmony with his outlook on 1,260 days, Beale comments on the tenses and moods of verbs in Rev 11:1-13. He recognizes that "the future tense of $\delta \omega \sigma \omega \omega$ ("I will


("they will trample") . . [ [in 11:2] could mean that the events of . . [11:1-6] are yet to come from John's perspective." ${ }^{195}$ Of course, such a perspective would run contrary to the position that Beale adopts with respect to the 1,260 days. From his perspective, the

somewhat the second coming, since there are the intervening events of at least Rev 11:810. Beale appears to be aware of this detail and seems to address it by saying that the defeat of the witnesses (= the church) happens "immediately before Christ's second coming and the final vindication of all the saints [Rev 11:11-12]." Ibid., 587; cf. 122123, 590-591, 984-989. On Rev 11:11-12, see ibid., 596-601. Note also Rev 11:13 and the onset of judgment as discussed at ibid., 602-603, 607.

${ }^{192}$ Cf. ibid., 621-622, 730-731, 770 .

${ }^{193}$ Ibid., 770; cf. 621-622, 730-731.

${ }^{194}$ But note Beale's recognition of there not being "a strict chronological order" just within Rev 14. Ibid., 783-784. Presumably, Beale still has in mind a general chronological movement from 12:1-15:4. Otherwise, his highlighting of Rev 14:14-20 to show the end of the figurative three and a half years would make no sense.

${ }^{195}$ Ibid., 572; cf. 608. 
period embraces John's past, present, and future, indeed "the entire church age." 196 Accordingly, Beale contends that "the tense by itself" is not sufficient to decide the temporal perspective "because the tenses and moods [in 11:1-6] alternate from future to present and from indicative to subjunctive."197 Rather, one must consider "the context" to decide the temporal perspective. ${ }^{198}$

\section{Summary and Conclusions}

Beale's argumentation can be summarized with a view towards identifying the broad issues of interpretation present in it. The issues identified here are listed in Figure 6 (see the next page) according to the order in which they are first mentioned.

Beale's argumentation actually begins with the interpretive framework that he brings to bear on Rev 11:3-13. Three components can be highlighted. Beale has a particular assumption about how the OT is used in Revelation. Although the references to the OT are allusive as opposed to exact quotations, Beale contends that most references are intentional and made with respect for the original OT contexts. Beale sees Revelation as book filled with symbolism that must be interpreted. The high point of Beale's interpretive framework is his eclectic approach to the text that sees the images of Revelation as relating to the broad span of history, John's past, present, and future.

Beale's interpretive framework reveals at least five broad issues of interpretation.

${ }^{196}$ Ibid., 572; cf. 122-123, 539-540, 566-567, 589, 646, 669, 678, 695.

${ }^{197}$ Ibid., 572; cf. 608.

${ }^{198}$ Ibid., 572; cf. 1054. Incidentally, Beale explains the future tense verbs of Rev 11:2-3 as an emphasis on "divine determination rather than future time, just as aorist passive $\dot{\varepsilon} \delta$ ó $\theta \eta$ in . . . [11:2] has the same sense and does not refer primarily to past time." Ibid., 572. 
1. Interpretive approach

2. Use of the OT in Revelation

3. Degree of symbolism

4. Distinguishing the symbolic from the literal

5. Interpretation of symbolism

6. Image of the lampstands

7. Theme of warfare

8. Audience to the fate of the two witnesses

9. The three-and-a-half year period

10. Theme of testimony

11. Miraculous powers of the two witnesses (Rev 11:5-6)

12. Traditions about Moses

13. Traditions about Elijah

14. Theme of prophecy

15. Duality of the witnesses

16. Portrayal of the seven churches of Rev $2-3$

17. Image of the olive trees

18. Fate of the two witnesses (Rev 11:7-12)

19. Context immediately before Rev 11:3-13 (11:1-2)

20. Relationship to the fifth seal $(\operatorname{Rev} 6: 9-11)$

21. Person-oriented language for the two witnesses

22. Relationship to the two harvests (Rev 14:14-20)

23. Verb tenses in Rev 11:1-13

Figure 6. Broad issues of interpretation in Beale's argumentation.

His eclectic approach to interpreting Revelation points to the methodological issue of what is the proper interpretive approach to Revelation. Related to this approach are broad preconceptions about the book of Revelation and about its author. Thus, Beale also raises through his interpretive framework the issue of the use of the OT and the issue of the degree to which symbolism plays a role. With respect to symbolism, Beale also raises the question of how one separates the symbolic from the literal in Revelation and the question of how does one interpret the symbolism. 
Several arguments are brought together to form six main reasons for seeing the witnesses as a symbol of the church as opposed to the representation of two actual individuals. The first reason centers on the fact that the two witnesses are called two lampstands in Rev 11:4. The image of the lampstand is the overriding issue here. Beale argues that the identification with the lampstands leads to the witnesses being identified with the Christian churches. Basic to Beale's arguments for this point is Beale's method for interpreting symbols when the referent is not clear. This specific method recalls the broad preconception about the degree to which symbolism plays a role in Revelation and the general methodological question of how to interpret the symbolism. Following his method, Beale draws on other verses in Revelation (Rev 1:20 in context) and on other literature (rabbinic passages directed at the background passage of Zech 4) to interpret the image of the lampstands.

The second reason revolves around the war conducted against the witnesses by the beast from the abyss in Rev 11:7. Beale interprets the verse in light of Dan 7:21. Thus, he sees a war against the people of God. Arguments involving related passages from the rest of Revelation (particularly Rev 13:7; 19:19-21; 20:7-10) confirm this interpretation of 11:7. The theme of warfare is central to linking these texts and Dan 7:21 to Rev 11:7 and may be seen as the overriding issue here.

For Beale's third reason for identifying the witnesses as the church, he defines the audience of the witnesses' death and resurrection as "the entire world of unbelievers." 199 The issue of interpretation here is the audience to the fate of the two witnesses.

${ }^{199}$ Ibid., 574. 
The arguments of Beale's fourth reason center on entities in Revelation (11:2; $12: 6,14 ; 13: 6)$ that appear to share the same period (three and a half years) with the two witnesses (11:3). The final argument that Beale attaches to this reason, however, also dwells on the Danielic background for the period. The three-and-a-half-year period in Rev 11:3-13 is the starting point of the discussion and links all of the arguments together. The meaning of this period then is the broad issue of interpretation that may be inferred from the arguments of the fourth reason.

In the fifth reason, Beale observes that several other passages in Revelation indicate that "the entire community of [Christian] believers" is "the source of 'testimony' to Jesus." ${ }^{200}$ The links between Rev 11:3-13 and other parts of Revelation (1:9; 2:13; $6: 9-11 ; 12: 11,17 ; 17: 6)$ and between that passage and other literature (OT passages and texts from extrabiblical Jewish literature) suggest that the same phenomenon can be seen in Rev 11:3-13. One may infer here the theme of testimony that runs through Revelation and other texts and that touches upon Rev 11:3-13.

The sixth reason centers on the equal distribution of the miraculous powers of the witnesses in Rev 11:6. The description of the powers is drawn from the OT stories of Moses and Elijah. The powers of both men are ascribed to both witnesses. An issue involving linguistic details of Rev 11:3-13 leads to two issues involving the world outside Revelation. The miraculous powers of the two witnesses are a gateway to the discussion of traditions about Moses and traditions about Elijah.

Beale presents several additional arguments that supplement his six main reasons

${ }^{200}$ Ibid., 575. 
for identifying the witnesses with the church. First, there are two arguments for why the witnesses do not represent the martyrs only. In both cases, Beale looks to other parts of Revelation (Rev 19:10; 22:9; and wherever $\mu \alpha \dot{\rho} \rho \tau \nu \varsigma$ and related words appear) to help to define the two witnesses as "prophets" and as "witnesses." Beale once more deals with the theme of testimony, but now adds to it the theme of prophecy.

Second, Beale offers two arguments against the literal perspective on the witnesses. From Luke 1:17, Beale draws a precedent for not seeing the actual Moses and Elijah as having to return to fulfill the story of the witnesses. This argument implies three previously noted issues. The argument is based on the miraculous powers of the two witnesses, traditions about Moses, and traditions about Elijah. From Joel 2:28-32 and Acts $1: 8 ; 2: 17-21$, Beale has evidence that the entire "Christian community" would function as prophets, so that the witnesses need not be defined as two literal prophets just because they are called "prophets." 201 This argument raises the theme of prophecy.

Third, Beale offers three points to explain "why ... there [are] two witnesses instead of, for example, seven, in accord with the number of the lampstands in ch. 1."202 All three points raise the broad issue of the duality of the witnesses. Two of them represent two agreeable explanations for the presence of just two witnesses, while the third point disputes one particular explanation. Thus, for one point, Beale argues that the number two emphasizes that the testimony of the witnesses is legally "just or valid."203 To support his point, Beale draws on literature outside Revelation (OT and NT and

\footnotetext{
${ }^{201}$ Ibid., 574.

${ }^{202}$ Ibid., 575.

${ }^{203}$ Ibid.
} 


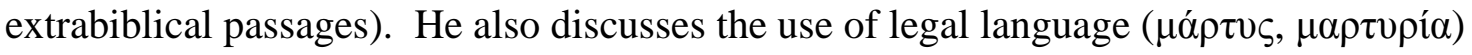
inside $\operatorname{Rev} 11: 3-13$ and in other parts of Revelation (Rev 1:9; 6:9; 12:11, 17; 20:4). Besides the overriding issue noted above, the testimony theme is repeated. For the second point, Beale points to the number two as emphasizing that the testifying of the witnesses is "effective" in harmony with there being two churches in Rev 2-3 that are without censure. ${ }^{204}$ For the third point, Beale rejects the notion that there are only two witnesses in order to indicate that only part of the church is being symbolized. Such an explanation runs contrary to the predominance of symbolism in Revelation and to the fact that all seven churches in Rev 2-3 are expected "to be witnessing 'lampstands.'" 205 The portrayal of the seven churches in Rev 2-3 binds the second and third points together. The lampstand image and the theme of testimony also continue to be relevant. For the third point, the preconception about the degree to which symbolism plays a role in Revelation also returns.

The fourth, fifth, and sixth additional arguments all give prominence to the world outside the book of Revelation inasmuch as each argument involves allusions to OT passages (Zech 4, Ps 79, Ezek 37). With Beale's view of the use of the OT in Revelation standing in the background, Beale discusses these allusions in light of Rev 11:3-13 and other passages in Revelation in order to support further his corporate identification of the witnesses. Two key issues can be identified here. On the one hand, there is the image of the olive trees (involving Zech 4). On the other hand, there is the portrayal of the fate of the witnesses - their death, resurrection, and ascension (involving Ps 79 and Ezek 37).

\footnotetext{
${ }^{204}$ Ibid. Italics are original.

${ }^{205}$ Ibid.
} 
The discussion of Ps 79 also draws in other passages from Revelation and thereby suggests two other issues of interpretation. The issue of the meaning of the immediate context before Rev 11:3-13 (11:1-2) is suggested when Beale sees the allusion to Ps 79 as stretching throughout Rev 11:1-10. Beale also links Rev 6:9-11, the events of the fifth seal, to Rev 11:3-13 and to Ps 79 in such a way as to point to intentionality behind the allusion to Ps 79 in Rev 11:1-10. This suggests that the meaning of the fifth seal is another issue in the interpretation of the witnesses.

One supplemental point that Beale makes is brief. It is aimed at a whole class of identifications. Beale points to the person-oriented traits of the witnesses to argue that they do not represent mere ideas.

Finally, there is the matter of the timing of the witnesses. In harmony with Beale's interpretive framework, particularly regarding the interpretation of symbols and his eclectic approach to the text, one can identify several places where Beale defines the timing of the two witnesses through his interaction with the linguistic details of Rev 11:313 and the rest of Revelation. Inasmuch as the timing of the witnesses centers on the meaning of the three-and-a-half-year period, the latter is suggested as an issue of interpretation. Additionally, Beale's discussion of the timing of the witnesses also suggests the issue of what Rev 14:14-20 has to say about the identity question and the issue of the verb tenses in Rev 11:1-13.

Several broad issues of interpretation have been identified from Beale's argumentation concerning the identity of the witness. What will soon be apparent is that many of these issues appear to be ones common in the debate over the identity question. 


\section{Other Significant Expositions}

In this section, two other significant expositions on the identity of the two witnesses are briefly examined. The authors are Hendrik Rijk van de Kamp and Gerhard Maier. Like Beale, these interpreters identify the witnesses as the Christian community. All three commentators share with each other some of the details that lead them to their similar identification. Therefore, among them exists a degree of harmony that goes beyond their conclusions on the identity question. These points of agreement stand in spite of the presence of differences among them. For instance, they sometimes differ among each other in their conceptions about the book and its author, in the details of their approaches to interpreting Rev 11:1-13, and even in their conclusions about elements in the passage. For the latter, one notes in particular the differences among them regarding the timing of the witnesses' activity. This reveals that their conclusions on the identity of the witnesses are not exactly the same.

The measure of agreement and the differences are important for the purposes of this section inasmuch as one purpose is to expose other arguments that could be offered to support an identification similar to Beale's. In some cases, these arguments could supplement the array of arguments found in Beale's study. In other instances, they might function as alternatives.

Another purpose for this section is to show that most of the broad issues of interpretation deduced from Beale's arguments have an existence beyond his study. They are truly issues in the debate over the identity of the two witnesses, at least among those commentators who understand them to be a personal symbol. 
Hendrik Rijk van de Kamp

\section{Introduction}

Hendrik Rijk van de Kamp (born 1951) ${ }^{206}$ has authored a commentary on Revelation as part of a series on the New Testament in Dutch. ${ }^{207}$ This is actually his second book on Revelation. The first was his doctoral thesis, which concerns the place of the Jewish people within the narrative of Revelation and which covers the two witnesses of Rev 11, among other topics. ${ }^{208}$ In both works, van de Kamp argues that the two witnesses symbolize "the whole church in its role as a witness towards humanity"209 during the time between the ascension of Jesus and his second coming. ${ }^{210}$ Moreover,

\footnotetext{
${ }^{206}$ Hendrik Rijk van de Kamp is a Dutch scholar and a pastor for the Reformed Churches in the Netherlands (Liberated). He earned a ThD in 1990 from the Theological University in Kampen, which is affiliated with his denomination. His thesis was published as Kamp, Israël. It too discusses the two witnesses of Rev 11. Among other things, van de Kamp has contributed to a Bible dictionary. See A. Noordegraaf and others, eds., Woordenboek voor bijbellezers (Zoetermeer, Netherlands: Boekencentrum, 2005). He is also the main contributor to a commentary on Hebrews, being assisted by his former thesis adviser. See Hendrik Rijk van de Kamp and Jakob van Bruggen, Hebreeën: Geloven is volhouden, Commentaar op het Nieuwe Testament, 3rd ser., Hebreeën sec. (Kampen, Netherlands: Uitgeverij Kok, 2010). The main source of this information about van de Kamp is Uitgeverij Kok, "Dr. H. R. van de Kamp," De reeks Commentaar op het Nieuwe Testament, accessed August 16, 2015, http://www.cnt-serie.nl/h-r-van-de-kamp/.

${ }^{207}$ Kamp, Openbaring.

${ }^{208}$ For this discussion of the two witnesses, see his sixth chapter at Kamp, Israël, 165-204.

${ }^{209}$ Kamp, Openbaring, 259; cf. 258, 273. Cf. also Kamp, Israël, 177, 181, 189, 191, 202. All translations from van de Kamp's works are my own.

${ }^{210}$ Kamp, Israël, 170, 201; cf. 178; and Kamp, Openbaring, 256-258; cf. 273. Indeed, in both works van de Kamp understands the period of the witnesses' activity as encompassing the era between the ascension and the second coming. Yet, the specific way in which that period is understood may differ between the two works. More is said below about the time period.
} 
both times that van de Kamp deals with Rev 11, he aims criticism directly at several specific proposals for the identity of the two witnesses and at one class of identifications. This is a notable feature of van de Kamp's argumentation. The details of the two discussions, however, differ in places, particularly in their treatment of Rev 11:1-2. This is not surprising given that several years exist between the two works, allowing van de Kamp to develop and change his thinking. Accordingly, the discussion here follows the later commentary.

The argumentation of van de Kamp can be summarized with a view towards exposing the broad issues of interpretation that underlie it. The issues identified here are listed in Figure 7 (see the next page) according to the order in which they are first mentioned.

\section{Van de Kamp's Interpretive Framework}

Although not described as elaborately as Beale's interpretive framework, van de Kamp's is nevertheless intimated by what he says at different points in the commentary. For one thing, van de Kamp embraces the idea of Revelation as a symbolic book. It is one of his presuppositions for interpreting Revelation. ${ }^{211}$ Van de Kamp sees Revelation as a book that speaks about matters in the past, the present, and the future and at times has one part recapitulating another part. This comes out clearly in his discussion of Rev

\footnotetext{
${ }^{211}$ Kamp, Openbaring, 42; cf. 43, 48-49, 281. With respect to Rev 11 in particular, note ibid., 35-36, 496, 526. Cf. Beale, Book of Revelation, 20-21; and Christopher Charles Rowland, The Open Heaven: A Study of Apocalyptic in Judaism and Early Christianity (New York: Crossroad, 1982), 512n16.
} 
1. Interpretive approach

2. Degree of symbolism

3. Image of the lampstands

4. Image of the olive trees

5. Duality of the witnesses

6. Theme of testimony

7. Miraculous powers of the two witnesses (Rev 11:5-6)

8. Traditions about Moses

9. Traditions about Elijah

10. Traditions about Enoch

11. Traditions about Peter

12. Traditions about Paul

13. Traditions about John the Baptist

14. Traditions about Jesus

15. Theme of prophecy

16. Crucified lord of Rev 11:8

17. Verb tenses in Rev 11:1-13

18. Person-oriented language for the two witnesses

19. Author of Revelation as a prophet

20. Three-and-a-half year period

21. Principle of concentration in time and space

Figure 7. Broad issues of interpretation in van de Kamp's argumentation.

1:19. ${ }^{212}$ Moreover, van de Kamp does not focus on specific events through the course of history, like preterists, historicists, and futurists do. Nor does he see Revelation as having nothing to do with historical events and even admits some specific events, like the comings of Christ. ${ }^{213}$ Given van de Kamp's perspective on the relationship of Revelation

${ }^{212}$ Kamp, Openbaring, 85-86.

${ }^{213} \mathrm{See}$, for example, his recognition of the birth of Christ in Rev 12 at ibid., 283284, 290-292. 
to time and history, one can compare his approach to the text with Beale's eclectic approach based on idealism.

Van de Kamp's interpretive framework implies two general issues of interpretation for the two witnesses. Although van de Kamp says nothing explicit about interpretive approaches in general, intimations of his own exist. There is therefore perhaps the methodological issue of what is the proper interpretive approach to take towards Revelation and Rev 11:3-13 in particular. Joining this issue is a broad preconception about Revelation and its author. Here is the issue of the degree to which symbolism plays a role.

\section{Specific Promotion of van de Kamp's Identification}

Van de Kamp offers three arguments to promote his identification of the two witnesses as the church. Two of the arguments focus respectively on the meaning of the lampstands and of the olive trees in Rev 11:4. Each image reflects a separate issue of interpretation for the identity question.

Van de Kamp's reference to the lampstand image starts with Rev 11:4 and then goes beyond it to Rev 1:20 in its immediate context. The connection between lampstands and Christian congregations in the latter passage is brought to bear on the interpretation of Rev 11:4..$^{214}$

Van de Kamp refers to the witnesses "as an embodiment of the priestly and royal form of the people of God" and so makes an implied reference to the olive trees of Rev

${ }^{214}$ Ibid., 259, 264; cf. 56, 77-79. 
11:4. ${ }^{215}$ The authors that van de Kamp cites here connect the olive trees of Rev 11:4 to those in Zech 4. ${ }^{216}$ In light of Zech 4, the olive tree image is seen to suggest that the witnesses are priestly and royal figures. The other authors notice and van de Kamp seems to agree that Revelation assigns those roles to the church ( $\operatorname{Rev} 1: 6 ; 5: 10)$. At the same time, however, van de Kamp does not seem to push this point very strongly, because his agreement is after all merely implied. Moreover, van de Kamp may downplay his agreement through a final statement about placement of the witnesses "in a prophetic context."217

The third argument accounts for why there are just two witnesses. ${ }^{218}$ The main issue is the duality of the witnesses. Specifically, van de Kamp contends that the duality has to do with the biblical requirement of needing two witnesses for a solid testimony (Num 35:30; Deut 17:6; 19:15). Such a background would make sense for an image of the witnessing church. On this basis, van de Kamp denies that the number two is meant to indicate only part of the complete church. ${ }^{219}$ Van de Kamp also uses his understanding

${ }^{215}$ Ibid., 259.

${ }^{216}$ As for the authors cited by van de Kamp, see Charles Homer Giblin, "Revelation 11:1-13: Its Form, Function, and Contextual Integration," NTS 30, no. 3 (July 1984): 433-459; Johannes Maria Nützel, "Gottesvolk aus Juden und Heiden: Zum SelbstVerständnis der Christen in der Johannes-Apokalypse," in Ekklesiologie des Neuen Testaments: Für Karl Kertelge, ed. Rainer Kampling and Thomas Söding (Freiburg im Breisgau, Germany: Herder, 1996), 458-478; and Aune, Revelation 6-16, 612-613, 631. Aune's explanation is the most detailed. Cf. Kamp, Openbaring, 259, 494, 508, 522.

${ }^{217}$ Kamp, Openbaring, 259. This idea is likely adopted from Giblin, who points out that the royal and priestly imagery of Rev 11 (and Rev 20) is "subordinated . . . to prophecy and/or testimony." Giblin, "Revelation 11:1-13," 457n31; cf. 441-442.

${ }^{218}$ Kamp, Openbaring, 259, 264; cf. 258.

${ }^{219}$ Ibid., 259. Van de Kamp has in mind here Caird's explanation of the witnesses. 
of the number two to deny any intended link to the two congregations (Smyrna and Philadelphia) that are without reproach in the seven letters to the seven congregations

(Rev 2-3). ${ }^{220}$ Inasmuch as Rev 11:3-13 concerns a duality of witnesses and van de Kamp looks to Num 35:30; Deut 17:6; 19:15 for his explanation, the theme of testimony is also an issue suggested by this argument.

\section{Criticism of Alternative Identifications}

The two witnesses are not returned OT figures

Van de Kamp also criticizes ten specific identifications of the two witnesses and one category of identifications. ${ }^{221}$ First, van de Kamp criticizes three proposals that see in the two witnesses the return of OT figures. Thus, he argues against the idea that the

Caird specifically argues that the witnesses represent the martyrs of the church. See Caird, Commentary on the Revelation, 130-140. Elsewhere, without explicitly disagreeing, van de Kamp mentions another view that takes the witnesses as part of the church. Here the witnesses represent "the office holders of the church." Kamp, Openbaring, 264.

${ }^{220}$ Kamp, Openbaring, 264.

${ }^{221}$ One view criticized is that of Frederick David Mazzaferri. He argues for seeing the witnesses as a representation of John's role as a prophet. Van de Kamp's only response is to restate the connection between the witnesses as lampstands and the Christian churches. Ibid., 263-264. Cf. Frederick David Mazzaferri, The Genre of the Book of Revelation from a Source-critical Perspective, Beiheft zur Zeitschrift für die neutestamentliche Wissenschaft und die Kunde der älteren Kirche 54 (Berlin: Walter de Gruyter, 1989), 318-325. Van de Kamp's response then introduces no new issues of interpretation. Meanwhile, apart from the ten identifications and the one class of identifications, there is one supposed alternative against which van de Kamp argues that is not so much an alternative identification as much as it is an alternative perspective on the audience for the ministry of the witnesses. Some commentators, while seeing the two witnesses as referring to a part or the whole of the church, see the message of the witnesses as directed solely at Jews. Van de Kamp, on the contrary, contends that the audience for the witnesses is "worldwide" and refers to Rev 11:2, 4, 6, 9-10. See Kamp, Openbaring, 263; cf. 254, 256, 259-261, 266-268. 
witnesses are Moses and Elijah, although he does recognize that they are modeled on Moses and Elijah. ${ }^{222}$ In particular, the miraculous powers of the witnesses recall the miracles in the lives of Moses and Elijah. Van de Kamp observes, however, that the powers are attributed to the witnesses equally, so that each one has the same powers. Thus, it is difficult to say that one witness looks like Moses and the other looks like Elijah. ${ }^{223}$

Van de Kamp could also be speaking against the Moses-Elijah identification when he responds to "the supposition ... that Revelation 11 takes up the Jewish expectation that the two great prophets return in the end time." ${ }^{224}$ He notices that, although Mal 4:5-6 indicate "the existence of the expectation that Elijah returns," nothing indicates "a tradition concerning the return of Elijah and Moses together."225

Van de Kamp may also speak against the Enoch-Elijah identification of the witnesses when he downplays the significance of evidence for "the existence of the expected return of Enoch and Elijah." ${ }^{226} \mathrm{He}$ observes that in Rev 11 in place of allusions to the biblical figure of Enoch are allusions to Moses. He also observes that some of the texts that express an expectation for the return of Enoch and Elijah understand the

${ }^{222}$ For discussion of the modeling of the two witnesses on Moses and Elijah, particularly in Rev 11:5-6, see Kamp, Openbaring, 258, 260-262, 266, 268-272.

${ }^{223}$ Ibid., 260-261.

${ }^{224}$ Ibid., 261.

${ }^{225}$ Ibid. Technically speaking, van de Kamp's denial of evidence for the existence of an expectation concerning the return of Moses and Elijah together applies only to the Bible. There is a rabbinic saying, Deut. Rab. 3.16-17, that does express such an expectation. See Beale, Book of Revelation, 582-583.

${ }^{226}$ Kamp, Openbaring, 261-262. 
mission of the witnesses differently from Rev 11. Moreover, van de Kamp points to the possibility that the traditions about Enoch and Elijah returning are "post-Christian rather than pre-Christian."227 Accordingly, such traditions would not have been something brought into Rev 11 and so shaping its meaning.

Van de Kamp criticizes another literal identification when he questions the opinion of Victorinus of Poetovio that the witnesses are Elijah and Jeremiah. ${ }^{228} \mathrm{He}$ observes that, whereas there are "the many [allusions] to Moses and Elijah," there is only one possibility for Jeremiah, namely, Jer 5:14 in Rev 11:5. ${ }^{229}$ In other words, a stronger case could be made for the Moses-Elijah identification than for the Elijah-Jeremiah identification. If the former is incorrect, how much more is the latter.

With respect to the Moses-Elijah view, the Enoch-Elijah view, and the ElijahJeremiah view — with all three views — van de Kamp touches upon the fact that the miraculous powers of the two witnesses show a connection between the witnesses and Moses and Elijah. Therefore, there is the issue of the miraculous powers of the witnesses (Rev 11:5-6) and two issues involving traditions about a particular OT figure (Moses and Elijah). Responding to the Enoch-Elijah view also entails addressing the issue of traditions about Enoch, particularly those that join him with Elijah to function as eschatological agents. ${ }^{230}$

${ }^{227}$ Ibid., 262.

${ }^{228}$ See Victorinus Commentarii in Apocalypsin 11.3 (trans. Dulaey, SC, 423:9497).

${ }^{229}$ Kamp, Openbaring, 262.

${ }^{230}$ Ibid., 261-262. 
The two witnesses are not contemporaries of the author of Revelation

Second, van de Kamp addresses two proposals that see the witnesses as being contemporaries of the author of Revelation. One is the Peter-Paul view, while the other is the view that the witnesses are John the Baptist and Jesus. ${ }^{231}$ The very proposal of either one of these pairs as being represented by the witnesses directs van de Kamp to consider four issues of interpretation. In the one case, he must consider traditions about Peter and those about Paul. In the other, he must consider traditions about John the Baptist and those about Jesus. In all these cases, van de Kamp fails to see the traditions about these figures lining up with the account of the two witnesses.

Concerning the Peter-Paul view, van de Kamp also points out the pair of "figures" in Rev 11 are presented "as witnesses and prophets, not as apostles."232 With this observation, van de Kamp raises the themes of testimony and prophecy. ${ }^{233}$

${ }^{231}$ Ibid., 262. For the Peter-Paul proposal, van de Kamp refers to Munck, Petrus und Paulus. Cf. Kamp, Openbaring, 521. For the John-Jesus proposal, he seems to refer to Otto Böcher, "Johannes der Täufer in der neutestamentlichen Uberlieferung," in Kirche in Zeit und Endzeit: Aufsätze zur Offenbarung des Johannes (Neukirchen-Vluyn, Germany: Neukirchener Verlag, 1983), 70-89. The latter is a reprint of Otto Böcher, "Johannes der Täufer in der neutestamentlichen Uberlieferung," in Rechtfertigung, Realismus, Universalismus in biblischer Sicht: Festschrift für Adolf Köberle zum 80 Geburstag, ed. Gotthold Müller (Darmstadt, Germany: Wissenschaftliche Buchgesellschaft, 1978), 45-68. Cf. Kamp, Openbaring, 498.

${ }^{232}$ Kamp, Openbaring, 262.

${ }^{233}$ Van de Kamp in fact presents one other criticism of Munck's Peter-Paul proposal. He contends that Munck's equation of the holy city with Rome is wrong according to his exegesis of Rev 11:1-2, wherein the holy city of Jerusalem is understood to symbolize the church. The problem with this argument, however, is that Munck does not equate the holy city with Rome. Rather, he chooses an interpretation more akin to van de Kamp's. See Munck, Petrus und Paulus, 49. Cf. Kamp, Openbaring, 256. Munck though does equate the great city with Rome, which is something that van de 
Concerning the John-Jesus view, van de Kamp also points out that "the witnesses are distinguished from their Lord" in Rev 11:8. ${ }^{234}$ This observation centers on the broad issue of the meaning of the crucified lord of Rev 11:8. Van de Kamp means to say here that the phrase at the end of 11:8, "where also their Lord was crucified" (NASB), implies that Jesus is Lord of the witnesses and thus not one of the witnesses. ${ }^{235}$

The two witnesses are not two yet unknown prophets

Third, van de Kamp criticizes the opinion that the witnesses are two yet unknown prophets. ${ }^{236}$ This opinion conflicts with van de Kamp's understanding of the timing of the witnesses' activity. ${ }^{237}$ More is said about the latter below. With respect to this opinion of the witnesses, van de Kamp also argues against seeing a special temporal importance in the use of future tenses in Rev 11:2-3. ${ }^{238}$ One may infer from this the issue of the verb tenses in Rev 11:1-13. Regarding this view of the witnesses, van de Kamp

Kamp would find too narrow according to his exegesis of Rev 11:8. See Munck, Petrus und Paulus, 33-35. Cf. Kamp, Openbaring, 265-266.

${ }^{234}$ Kamp, Openbaring, 262.

${ }^{235}$ Obviously, van de Kamp has rejected Böcher's suggestion that the final clause of 11:8 is actually an editorial addition to the original sentence. See Böcher, "Johannes der Täufer," 81-82. The citation refers to the reprint. Cf. Kamp, Israël, 185.

${ }^{236}$ Van de Kamp has in mind here the proposals of Donatus Haugg and Theodor Zahn. See Haugg, Die zwei Zeugen, 112-114, 130-137; and Theodor Zahn, Die Offenbarung des Johannes, 2 vols., 1st-3rd ed., Kommentar zum Neuen Testament 18 (Leipzig: A. Deichertsche Verlagsbuchhandlung Dr. Werner Scholl, 1924-1926; reprint, in one volume, Wuppertal, Germany: R. Brockhaus Verlag, 1986), 2:416-431.

${ }^{237}$ Kamp, Openbaring, 263.

${ }^{238}$ Ibid. 
also pays attention to John's definition of the future. ${ }^{239}$ Unlike the futurists that espouse this view, van de Kamp supposes that for John the future really begins in his own time as opposed to some distance from that time. ${ }^{240}$ Van de Kamp is therefore raising the question of what part or parts of history interest the author. Is the author concerned with events that are primarily in his past, in his present, or in the distant future or with events spread over the past, present, and future? This recalls the issue of the proper interpretive approach, inasmuch as that issue involves the question of how the contents of Revelation relate to history.

The two witnesses are not the Law and the Prophets

Fourth, van de Kamp argues against two symbolic identifications of the witnesses that identify the witnesses with the Law and the Prophets. One is the proposal of Léon Pierre François Gry (1879-1952). The Law and the Prophets are seen speaking throughout the OT era until the devastation of Jerusalem in 70 CE. ${ }^{241}$ Van de Kamp responds that the 1,260 days of the two witnesses should be interpreted differently. ${ }^{242}$ See more later about his interpretation of the period. Van de Kamp also raises the issue of the crucified lord of the witnesses (Rev 11:8) when he says, "The two witnesses are

${ }^{239}$ Van de Kamp argues that John, the author of the Gospel and the Letters of John, is also the author of Revelation. See ibid., 15-21.

${ }^{240}$ Ibid., 263; cf. 48.

${ }^{241}$ See Gry, "Les chapitres XI et XII," 203-214. Cf. Kamp, Openbaring, 262, 509.

${ }^{242}$ Kamp, Openbaring, 262. 
Christians who obey their Lord."243 By this statement, van de Kamp may mean to associate the witnesses with a different era from that proposed by Gry, the era of the NT as opposed to the era of the OT. Finally, van de Kamp says, "Moses stands here not as a legislator, but as the first and greatest prophet."244 Thus, while van de Kamp agrees that there are links to Moses in the portrayal of the witnesses, he has a reason for not going from those links to seeing a symbol of the Law. With this thought, van de Kamp raises in a small way the theme of prophecy.

Van de Kamp also responds briefly to a proposal similar to Gry's. The witnesses are again the Law and the Prophets, but the time of their activity is shifted to the present. $^{245}$ Van de Kamp responds, "But, for the New Testament era, the mission to prophesy is given to prophets who follow Christ."246 With this statement, van de Kamp seems to agree with the temporal focus of this proposal, while disagreeing with the impersonal nature of the proposal. Van de Kamp's response here suggests the issue of the person-oriented language used to describe the witnesses and the theme of prophecy.

The two witnesses are not a company of Christian prophets

Fifth, van de Kamp considers and rejects the proposal of Elisabeth Schüssler

${ }^{243}$ Ibid. Cf. Kamp, Israël, 186.

${ }^{244}$ Kamp, Openbaring, 262.

${ }^{245}$ For this proposal, van de Kamp refers to Feuillet, "Essai d'interprétation du chapitre XI," 183-200; and Hendrik Schroten, Openbaring van Johannes voor de gemeente verklaard: Klassiek reformatorisch commentaar op het laatste bijbelboek ('sGravenhage, Netherlands: Boekencentrum, 1988). Cf. Kamp, Openbaring, 263, 506, 528.

${ }^{246}$ Kamp, Openbaring, 263. 
Fiorenza (born 1938). For her, the witnesses symbolize the Christian prophets active during the era in which the whole body of Christians is persecuted. ${ }^{247}$ Van de Kamp responds by emphasizing the special prophetic role of John as opposed to other prophets named in passing (e.g., Rev 22:6,9). ${ }^{248}$ This situation makes it doubtful that "all of a sudden an important role [is] laid aside for a circle of prophets." 249 The issue of interpretation here is what does it mean for John to be portrayed as a prophet in Revelation.

The two witnesses are not historical figures who lived beyond the first century $\mathrm{CE}$

Finally, van de Kamp responds to the whole category of interpretations in which historical figures who lived beyond the first century are identified as the two witnesses. The very fact that so many individuals have been suggested makes van de Kamp reluctant

${ }^{247}$ See Elisabeth Schüssler Fiorenza, Revelation: Vision of a Just World, Proclamation Commentaries (Minneapolis: Fortress Press, 1991), 77-79. Mistakenly, van de Kamp references instead Elisabeth Schüssler Fiorenza, The Book of Revelation: Justice and Judgment (Philadelphia: Fortress Press, 1985). While the latter work does mention the two witnesses and even Christian prophets, it does not provide a detailed identification of the witnesses nor does it connect the witnesses to Christian prophets. Cf. Kamp, Openbaring, 263, 528. Perhaps the origin of this mistake is an apparent error in one of van de Kamp's sources, namely, Mazzaferri, Genre, 325n500.

${ }^{248}$ Kamp, Openbaring, 263. Cf. the apparent source of his response at Mazzaferri, Genre, 312, 325. Van de Kamp mistakenly also references here Rev 22:15, which has nothing to do with prophets. The mistake seems to be drawn from the error made at ibid., 312 n390. The reference likely meant was Rev 22:16, which refers to a plural "you" ( $\dot{v} \mu \mathrm{i} v)$. In the context, the pronoun could be construed as referring to a group of prophets. Rev 22:6, 9 are highlighted among the other possible references to prophets probably because they especially might refer to a specific group of prophets that function alongside John. Cf. Kamp, Openbaring, 263, 425, but note 486-487.

${ }^{249}$ Kamp, Openbaring, 263. 
to accept this type of identification. ${ }^{250}$ Presumably, the reluctance comes from the methodological assumption that the proper way of interpreting the text would not lead to such variety in the results. Therefore, the problem is a methodological one and the broad issue here seems to be the interpretive approach used to understand Revelation. Van de Kamp also rejects this class of identifications because of his understanding of the timing of the witnesses' activity. ${ }^{251}$ More is said about this below.

\section{The Timing of the Witnesses' Activity}

Van de Kamp also discusses the timing of the two witnesses. While this matter stands on its own, it is also brought up to argue against two specific views and against the class of views just discussed. ${ }^{252}$

Van de Kamp's understanding of the 1,260 days of prophesying by the two witnesses depends on his thinking about equivalent periods elsewhere in Revelation. In discussing the 42 months in Rev 11:2, van de Kamp points out that the temporal designations presented in $\operatorname{Rev} 11: 2-3 ; 12: 6,14$ really concern the same segment of time. ${ }^{253}$ The endpoints of the symbolic 1,260 days are the ascension and the second

${ }^{250}$ Ibid.

${ }^{251}$ Ibid.

${ }^{252}$ Ibid., 262-263. The two specific views are one of the Law-Prophets views and the opinion that the witnesses are two eschatological prophets.

${ }^{253}$ Ibid., 256. He might have added Rev 13:5, because he also relates the 42 months mentioned there to the periods presented in Rev 11 and 12. See ibid., 313. 
coming of Christ. ${ }^{254}$ In all this, he raises as the overriding issue the meaning of the threeand-a-half-year period.

Within the symbolic period, van de Kamp envisions a cycle involving testimony that occurs in various eras and in different places. ${ }^{255}$ He reaches this conclusion about Rev 11:3-13 by applying an assumption about how Revelation presents matters. Events are at times in the text made to concentrate in one place and one period, but in reality many places and many periods are meant. It is a principle that pertains not only to Rev 11:3-13, but also to other passages, like Rev 7:9-17. ${ }^{256}$ This principle can be thought of as a secondary issue in van de Kamp's discussion of the timing of the witnesses.

\section{Conclusion}

Several broad issues of interpretation can be deduced from van de Kamp's argumentation about the two witnesses. Many of these issues are also evident from Beale's argumentation.

${ }^{254}$ These limits to the period are expressed in a comment on Rev 11:2 at ibid., 256. The language and ideas expressed there about the three-and-a-half-year period are heavily influenced by Jacobus de Vuyst, De Openbaring van Johannes: Het laatste bijbelboek ingeleid en, voorzien van aantekeningen, vertaald (Kampen, Netherlands: Kok, 1987), 83, 91-92. An actual determination of the limits is not expressed until comments on Rev 12:6. Kamp, Openbaring, 292-293; cf. 214, 219, 221, 281-284, 290292, 300-301.

${ }^{255}$ Kamp, Openbaring, 265-266, 269, 273.

${ }^{256}$ Compare van de Kamp's conception of the great tribulation of Rev 7:14 as a singular event that summarizes all the persecutions happening repeatedly in time and in space. Ibid., 218-219; cf. 137-139, 199-203, 206-207, 256, 313. Compare van de Kamp's ideas discussed above with those expressed in one of his sources: Vuyst, De Openbaring, 23-26, 83, 91-93. 
Gerhard Maier

\section{Introduction}

Gerhard Maier (born 1937) ${ }^{257}$ has authored a two-volume commentary on the

book of Revelation for a German commentary series on the New Testament. ${ }^{258}$ This is in

fact Maier's second work on Revelation. His first work is a large volume concerning the

interpretation of Revelation from the early church up into the twentieth century. ${ }^{259}$ Given

${ }^{257}$ Gerhard Maier is a German Lutheran scholar and pastor. After studying law and art history, Maier turned to theological studies. He earned a dr. theol. degree from Eberhard-Karls-Universität in Tübingen in 1969. His dissertation was published as Gerhard Maier, Mensch und freier Wille: Nach den jüdischen Religionsparteien zwischen Ben Sira und Paulus, Wissenschaftliche Untersuchungen zum Neuen Testament 12 (Tübingen: J. C. B. Mohr [Paul Siebeck], 1971). As a pastor, he has been actively involved in the Evangelische Landeskirche in Württemberg, even attaining to the position of bishop from 2001-2005. As a scholar, he has authored some books and been involved in other literary projects, like specialized dictionaries. Notable among his works is one involving the history of the interpretation of Revelation, Maier, Die Johannesoffenbarung und die Kirche. He has held academic positions at Eberhard-Karls-Universität and has been a guest professor for the Evangelische Theologische Faculteit in Leuven, Belgium and for the Staatsunabhängige Theologische Hochschule Basel in Riehen, Switzerland. He has been honored with the Johann-Tobias-Beck-Preis (1991), an honorary doctorate from the Minsk Spiritual Academy in Belarus (2004), an honorary professorship from the Universitatea Dunărea de Jos din Galați in Romania (2004), and a medal of merit from the German state of Baden-Württemberg (2005). For this information and other details about Maier, see SCM R. Brockhaus, "Maier, Gerhard," Autoren, accessed August 16, 2015, http://www.scm-brockhaus.de/autoren/autor.html?tx_scmauthors_pi1 \%5Buid\%5D=6943\&tx_scmauthors_pi1\%5Bletter\%5D=M\&cHash=d263ffb823; Manfred Wagner, "Evangelische Landeskirche in Württemberg Beziehungen zu orthodoxen Kirchen," Dienst für Mission, Ökumene und Entwicklung (DiMOE), accessed August 16, 2015, http://www.dimoe.de/fileadmin/mediapool/einrichtungen /E_dimoe/Beziehungen_der_Landeskirche_zu_orth_Kirchen-3.pdf; and Wikipedia [German ed.], "Gerhard Maier," accessed August 16, 2015, http://de.wikipedia.org /wiki/Gerhard_Maier.

${ }^{258}$ Maier, Kapitel 1-11; and Maier, Kapitel 12-22.

${ }^{259}$ Maier, Die Johannesoffenbarung und die Kirche. This is one of the works cited in chapter 2 of this study. For the pre-Reformation era, Maier primarily reflects on key individuals in the western church tradition. For the Reformation and afterward, he focuses on figures in Germany. 
this earlier work, it is not surprising that Maier includes in his commentary a brief look at the broad history of the interpretation of Revelation. ${ }^{260}$ Nor is it surprising that he punctuates the commentary with excurses that focus on a variety of interpretations for key passages and for key elements of Revelation. ${ }^{261}$

Maier argues that the two witnesses represent the entire Christian community in the future distant from the days of John, ${ }^{262}$ the presumed author of Revelation. ${ }^{263}$ Maier's arguments on the two witnesses stand out for this emphasis on the future as the time of the witnesses. The entire span of literature on the two witnesses contains few significant expositions that combine a symbolic view of the witnesses with a focus on the distant future. Maier's argumentation is also notable for a few uncommon points that he makes. Maier's argumentation concerning the two witnesses can be summarized with a view towards exposing the broad issues of interpretation that underlie it. The issues identified here are listed in Figure 8 (see the next page) according to the order in which they are first mentioned.

\section{Maier's Interpretive Framework}

Although not described as elaborately as Beale's interpretive framework, Maier's, like van de Kamp's, is nevertheless intimated by what he says at different points in the commentary. Noted first is Maier's openness to the presence of symbolism in Revelation.

${ }^{260}$ See Maier, Kapitel 1-11, 59-76.

${ }^{261}$ For example, the excursus on interpretations of Rev 11 in the history of the church appears at ibid., 454-455.

${ }^{262}$ Ibid., 473-475, 478-479, 481, 483, 485-486, 492.

${ }^{263}$ On the authorship question, see particularly ibid., 18-25. 
1. Degree of symbolism

2. Interpretive approach

3. Unity of the two witnesses

4. Lack of names

5. Traditions about Enoch

6. Traditions about Moses

7. Traditions about Elijah

8. Messianic forerunners

9. Historical data

10. Miraculous powers of the two witnesses (Rev 11:5-6)

11. Setting for the episode of the two witnesses

12. Context immediately before Rev 11:3-13 (11:1-2)

13. Introduction of the two witnesses (Rev 11:3)

14. Theme of testimony

15. Image of the olive trees

16. Image of the lampstands

17. Fate of the two witnesses (Rev 11:7-12)

18. Three-and-a-half year period

Figure 8. Broad issues of interpretation in Maier's argumentation.

No major arguments or even statements speak to its importance for Revelation and for Rev 11 in particular, but the symbolic interpretation of key figures in Rev 11-13 suggests that symbolism is significant for Revelation, in Maier's opinion. ${ }^{264}$ Therefore, an opinion on the degree to which symbolism plays a role in Revelation is suggested by at least his exposition of Rev 11-13.

Maier's interpretive framework also consists of a mixed approach to interpreting

${ }^{264}$ Within Rev 11, for example, there is the interpretation of Rev 11:1-2 at ibid., 456-461. Or, there is the interpretation of Rev 11:8 at ibid., 475-478. For Rev 12, with the woman, the dragon, and the child, see Maier, Kapitel 12-22, 15-72. For Rev 13, with the two beasts, see ibid., 72-125. 
Revelation. Interpretive approaches are broad outlooks on Revelation that govern how one relates the contents of the book to the events of history. Maier is not content to focus on one approach, such as the eschatological, at the expense of all other options. ${ }^{265}$ Maier's outlook on certain passages in Revelation, particularly Rev 1:19, clarifies the components of his mixed approach. ${ }^{266}$ There is an openness to the contemporaryhistorical approach and the eschatological. ${ }^{267}$ Nevertheless, Maier stresses the importance of the eschatological for understanding Revelation. ${ }^{268}$

${ }^{265}$ Early in his work, Maier mentions his desire "to keep in mind as many methodological approaches as possible and to combine them together." Maier, Kapitel 111, 15. (All translations from Maier's German text are mine.) What he does not explicitly say here is what he means by "methodological approaches." A clue comes in a footnote attached to the comment. Examining the sources cited there, one finds that Maier primarily has in mind interpretive approaches to Revelation. The footnote in question is ibid., 15n15. Cited there in this order are Alfred Wikenhauser, Die Offenbarung des Johannes übersetzt und erklärt, 3rd ed., Regensburger Neues Testament 9 (Regensburg, Germany: Verlag Friedrich Pustet, 1959), 19-20; Isbon Thaddeus Beckwith, The Apocalypse of John: Studies in Introduction, with a Critical and Exegetical Commentary (New York: Macmillan, 1919; reprint, Grand Rapids, MI: Baker Book House, 1967), 334-335; Charles, Commentary on the Revelation, 1:clxxxiiiclxxxvii; and Donald Arthur Carson, Douglas J. Moo, and Leon Morris, An Introduction to the New Testament (Grand Rapids, MI: Zondervan, 1992), 482-483. What is vague from the references alone is which of these approaches have some validity and ought to be combined, since each reference lists a different set of options. Nevertheless, that Maier wants to combine approaches suggests that his own approach is a mixed one. $\mathrm{Cf}$. Maier, Kapitel 1-11, 38-39, 74-75.

${ }^{266}$ Maier, Kapitel 1-11, 80-81, 87-88, 128-129, 258; and Maier, Kapitel 12-22, $489,494$.

${ }^{267}$ On the one hand, Maier believes, according to his understanding of Rev 1:1, 3; $22: 6,10$, that the course of events leading to the new creation (see Rev 21:1-22:5) begins in John's era. Maier, Kapitel 1-11, 80-81, 87-88; and Maier, Kapitel 12-22, 489, 494. On the other hand, the events finish in a time quite distant from John's era. Maier, Kapitel 111, 43-44, 51-52, 129, 258; and Maier, Kapitel 12-22, 494.

${ }^{268}$ Maier, Kapitel 1-11, 38-39, 51-52. 
Examining Maier's interpretive approach reveals the methodological issue of what is the proper interpretive approach to take towards Revelation and Rev 11:3-13 in particular.

\section{Major Considerations Leading to Maier's Identification}

Maier offers three major considerations that suggest a symbolic and ecclesiastical identification of the two witnesses. All three indicate flaws in alternative identifications that see the witnesses as two literal individuals.

One consideration: A picture of two different people is impossible

The first consideration is the basic claim that one cannot relate the figure of the witnesses to two individuals. ${ }^{269}$ This basic claim could be expanded to show at least three arguments countering the Enoch-Elijah view and the Moses-Elijah view of the witnesses. ${ }^{270}$ One argument indicates the importance of how the witnesses are described as a unit. ${ }^{271}$ Another highlights the lack of names for the witnesses. ${ }^{272}$ Each of these arguments suggests a corresponding issue of interpretation.

${ }^{269}$ Ibid., 472.

${ }^{270}$ Maier mentions only briefly the view that the witnesses are two currently unknown persons that appear in the future, and only one of the counter-arguments comes close to addressing that view. See ibid., 471. The absence of counter-arguments for this could be because Maier is open to the possibility that two people fulfill "in a special way" the final portion of the narrative of the two witnesses (Rev 11:7-12). Ibid., 472. This possible fulfillment would occur in addition to the ecclesiastical fulfillment of the narrative.

${ }^{271}$ Ibid., 471; cf. 466, 468-469.

${ }^{272}$ Ibid., 471. 
For the third argument, Maier garners from Jewish eschatological thought evidence against either Enoch or Moses being a second expected witness, joining Elijah. ${ }^{273}$ With respect to Enoch as Elijah's companion, Maier points out that in Rabbinic thought Enoch, among others, is not associated with eschatology. ${ }^{274}$ Presumably, Maier wishes to indicate here that there was no expectation of a return of Enoch that would be contemporaneous with or prior to John's era. Without such a background, one that contrasts with the tradition of Elijah's return, it is less likely that Enoch is one of the two witnesses. ${ }^{275}$ Of course, for Maier's argument to work, one would have to assume that Rabbinic thought, which dates after John's era, reflects to some degree Jewish thinking available to John and his immediate audience. ${ }^{276}$

Maier offers two points of evidence against the expectation of Moses as the second witness. For one point, he appeals to an argument presented by Wilhelm Bousset (1865-1920) in his commentary on Revelation. ${ }^{277}$ Maier understands Bousset as proving

${ }^{273}$ Ibid.

${ }^{274}$ Ibid.

${ }^{275}$ Maier goes so far as to say that Enoch as one of the witnesses can be completely eliminated as an option. So, ibid.

${ }^{276}$ If Maier's reasoning has been properly reconstructed, his argument has an unfortunate weakness. While it may be that Enoch is not associated with the eschatology of Rabbinic literature, it has been argued that 1 Enoch 90:31 envisions at least the eschatological return of Enoch (and perhaps Elijah) to the earth, if not assigning an eschatological function to him (and perhaps to Elijah). See Haugg, Die zwei Zeugen, 99100; VanderKam, "1 Enoch," 98-100; and Richard Bauckham, "The Martyrdom of Enoch and Elijah: Jewish or Christian?," in The Jewish World around the New Testament: Collected Essays I, Wissenschaftliche Untersuchungen zum Neuen Testament 233 (Tübingen: Mohr Siebeck, 2008), 6-8, 18-20.

${ }^{277}$ Maier, Kapitel 1-11, 471. Maier cites the first edition of the commentary written by Bousset as opposed to the second edition. Maier cites Wilhelm Bousset, Die 
that Jewish thought envisioned the coming of only one messianic forerunner, namely, Elijah. ${ }^{278}$ This runs contrary to the Moses-Elijah view that envisions the coming of two messianic forerunners.

For the other point, Maier removes the support of Deut 18:14-20 for Moses being the second witness. ${ }^{279}$ Maier emphasizes that Deuteronomy speaks only of one like Moses, indeed a second Moses. Moreover, this is a prediction of the Messiah, not of a forerunner, as one sees from John 6:14-15, wherein people witnessing a miracle of Jesus equate the expected prophet with the Messiah.

This series of points forming a third argument suggest three issues, each concerning the traditions involving a biblical figure. Thus, one has the issues of the traditions about Enoch, of those about Moses, and of those about Elijah. This argument might also suggest the matter of the appearing of messianic forerunners, an idea that has been associated with the two witnesses.

A second consideration: The words of Jesus

For the second consideration that leans Maier towards a symbolic and ecclesiastical identification of the two witnesses, he looks to the preaching of Jesus in the Gospels for evidence of the expectation of two individuals preceding the second coming

Offenbarung Johannis, 5th ed., Kritisch-exegetischer Kommentar über das Neue Testament 16 (Göttingen: Vandenhoeck und Ruprecht, 1896), 375, accessed April 27, 2016, Google Books.

${ }^{278}$ Bousset and Maier have nothing to say about the one piece of evidence for the existence of an expectation concerning the return of Moses and Elijah together. There is a rabbinic saying, Deut. Rab. 3.16-17, that does express such an expectation. See Beale, Book of Revelation, 582-583.

${ }^{279}$ Maier, Kapitel 1-11, 471. 
of Jesus. Not only does he find no such evidence, but also he finds warnings about false forerunners. ${ }^{280}$ Evident here is the issue of the appearing of messianic forerunners.

A third consideration: Failed fulfillment of the Enoch-Elijah view

The final consideration is an argument that appears to be uncommon among those offered in the history of the interpretation of the two witnesses. Specifically, Maier mentions "the failure of the Elijah/Enoch-expectation during the Reformation with the Anabaptists." ${ }^{281}$ Here Maier alludes to circumstances noted in his introductory history of the interpretation of Rev 11 and presented in a wider context in his massive work on the history of the interpretation of Revelation. ${ }^{282}$ Specifically, he is referring to those who saw in themselves the fulfillment of the prophesied return of Enoch and Elijah, such as Thomas Müntzer (ca. 1489-1525), Melchior Hoffman (ca. 1495-1543/1544), and Jan Matthys (ca. 1500-1534). ${ }^{283}$ In the introductory history of the interpretation of Rev 11, Maier contends, "The shock of the failure of these self-appointed 'witnesses,' the Elijah and Enoch figures of the time of the Anabaptists, led later in Europe to hardly anyone wanting to slip into this role." 284 It seems therefore to have been a turning point of sorts

${ }^{280}$ Ibid., 472; cf. 471.

${ }^{281}$ Ibid., 472.

${ }^{282}$ See ibid., 454-455. Cf. Maier, Die Johannesoffenbarung und die Kirche, 209, 223, 234, 237-238, 250, 254, 256-258, 260, 266.

${ }^{283}$ Cf. Petersen, Preaching, 60-71, 88-97; and Turner, "Revelation 11:1-13," 147148.

${ }^{284}$ Maier, Kapitel 1-11, 455. Cf. Maier, Die Johannesoffenbarung und die Kirche, 267. 
for the Enoch-Elijah view in Europe. It was an experiential blow to the popular view of the witnesses, as opposed to the theological ones that would arise. Therefore, with this final considertation, Maier seems to be arguing that this failure of expectations in the past deters one from having such expectations in the future. The context of his argument suggests that Maier may intend this failure in the past to speak to the whole class of identifications involving the expected return of prominent biblical figures.

With this argument, Maier is touching upon the history of the interpretation of the witnesses and events in church history. Thus, Maier raises the issue of how do historical data affect the identification of the witnesses.

\section{Material that Complements Maier's Major Considerations}

Clarifying the picture of a church doing wonders

Beyond Maier's major considerations, one can find comments that for the most part speak positively on behalf of his symbolic ecclesiastical identification. For one thing, Maier answers a possible objection that centers on the meaning of the miraculous powers of the two witnesses. One might counter Maier's identification of the witnesses as the whole church by saying that Rev 11:5-6 with its description of miraculous powers could not possibly apply to the whole church. When was each member of the church ever endowed with this set of miraculous powers? Is one to suppose that such could possibly happen in the future? Maier's response to this possible objection does not deny the possibility of a literal fulfillment of the miracles described in these verses. In fact, his exposition of Rev 11:6 explicitly leaves open the question of whether a literal or a 
figurative fulfillment is meant. ${ }^{285}$ Rather, Maier responds with an appeal to Mark 16:17, suggesting that, while the authority to perform the miracles of 11:5-6 is delegated to the whole church, every member need not have those specific powers. It is not the case for Mark 16:17 in the wider context of the NT, so it does not have to be the case for Rev $11: 5-6 .^{286}$

The location of the the ministry of the two witnesses

Maier also demonstrates that the field of ministry for the witnesses covers the whole world. ${ }^{287}$ The issue of the setting for the events of Rev 11:3-13 is present in this argument. Maier's view on the setting is consistent with his identification of the witnesses. He holds to this view despite intimations that the place is Jerusalem, particularly as indicated in Rev 11:1-2. Maier, however, understands Rev 11:1-2 as symbolism concerning the Christian community, not as a reference to locations and events in Jerusalem. ${ }^{288}$ The meaning of the immediate context for Rev 11:3-13 (11:1-2) is therefore suggested here as a secondary issue. Maier also argues that the description of the powers of the witnesses in Rev 11:6, as well as their connection to the plagues of Egypt, point beyond the land of Israel. ${ }^{289}$ The miraculous powers of the witnesses are therefore another secondary issue. In other places, Maier points out further evidence to a

${ }^{285}$ See Maier, Kapitel 1-11, 468-470.

${ }^{286} \mathrm{Cf}$. Maier's treatment of the murder of the witnesses at ibid., 475.

${ }^{287}$ Ibid., 472-473.

${ }^{288}$ On Rev 11:1-2, see again ibid., 456-461.

${ }^{289}$ Ibid., 472-473; cf. 469-470. 
ministry in the whole world and not just a particular locality. ${ }^{290}$

The connection to Jesus

Maier also comments on what it means to call these figures "my two

witnesses." 291 One thing that this means is that the two witnesses belong to Jesus.

Another thing that Maier has in mind here is the witnesses are those who testify about Jesus, basing this on the use of the language in Revelation. ${ }^{292}$ These comments suggest the issue of the manner in which the witnesses are introduced and the theme of testimony.

The designation as two olive trees and two lampstands

Maier also discusses the designation of the witnesses as "two olive trees" and "two lampstands." Thus, the two issues related to these images are also present in Maier. He recognizes that the former image has its origin in the olive trees of Zech 4, which are identified in Zech 4:14 as two "sons of oil." ${ }^{293}$ Maier, following Robert

${ }^{290}$ Ibid., 466, 478-481.

${ }^{291}$ Ibid., 462.

${ }^{292}$ Ibid. Maier appears here to be following Hermann Strathmann's article about

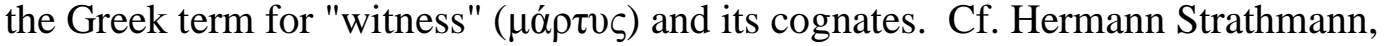

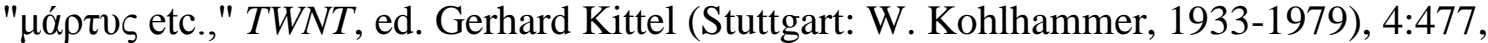

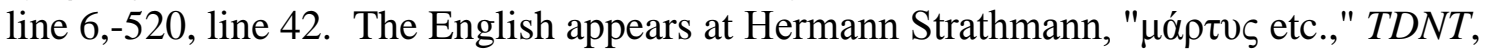
ed. Gerhard Kittel (Grand Rapids, MI: William B. Eerdmans, 1964-1976), 4:474-541. With respect to "witness" in Revelation, however, Strathmann seems to go in a different direction than Maier does. For Strathmann, the term "witness" in Revelation refers to a

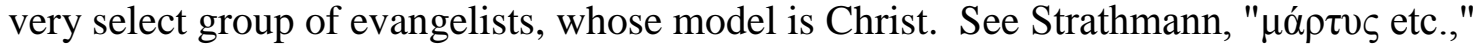


TDNT, 4:495-496. For Maier, however, the term "witness" is a general designation for Christians. Strathmann's words are used, but the restrictions on the term do not seem to be present.

${ }^{293}$ Maier, Kapitel 1-11, 464-465. 
Hanhart (born 1925), emphasizes that the two figures both in Zech 4 and in Rev 11:4 do not represent "messianic figures," as evidence from the writings of Qumran might indicate. ${ }^{294}$ Apparently, Maier has in mind here to address potential evidence for the individual identification of the two witnesses. ${ }^{295}$

Maier sees the image of the lampstands as being connected to the words of Jesus, both in the Gospels and in Revelation, about the church or churches as spiritual lights to the world. ${ }^{296}$ Designating the two witnesses as two lampstands indicates that they are to be spiritual lights in the world as the church as a whole is to be. ${ }^{297}$

The revival of the two witnesses

Finally, there is Maier's attempt to show that Rev 11:11 speaks strictly of a "revival" as opposed to a "resurrection." In this way, Maier speaks to the issue of the fate of the witnesses - their death, resurrection, and ascension. His staring point is the similarities in language between Rev 11:11 and Ezek 37:5, 10. ${ }^{298}$ From this starting point, Maier contends that the events of Rev 11:11 are meant to be seen through the lens of Ezek 37. ${ }^{299}$ Ezek 37 shows a revival of the people of Israel, and Rev 11:11 would then

${ }^{294}$ Ibid., 465; cf. 464-465. Cf. Robert Hanhart, Dodekapropheten 7.1: Sacharja 18, Biblischer Kommentar Altes Testament, vol. 14, pt. 7.1 (Neukirchen-Vluyn, Germany: Neukirchener Verlag, 1998), 304.

${ }^{295}$ Maier, Kapitel 1-11, 464-465, 470.

${ }^{296}$ Maier cites Matt 5:14-16; Mark 4:21-23; Luke 8:16-17; Rev 1:20; 2:5.

${ }^{297}$ Maier, Kapitel 1-11, 465.

${ }^{298}$ Ibid., 482.

${ }^{299}$ Ibid. 
envision of revival of the church. ${ }^{300}$ This transformation is a miracle that "is still far greater than a revival of two individuals would be." ${ }^{301}$

Maier contrasts this understanding of Rev 11:11 with one that sees Rev 11:11 through the lens of Jesus' resurrection. ${ }^{302}$ In fact, he argues quite strongly that a distinction should be made between the resurrection of Jesus (die Auferstehung Jesu) and the revival of the two witnesses (die Wiederbelebung der zwei Zeugen). ${ }^{303} \mathrm{He}$ goes from this distinction to concluding, "One better considers the revival of the two witnesses [die Wiederbelebung der zwei Zeugen] as an event of its own kind (sui generis) and not as a kind of second resurrection [eine Art zweite Auferstehung]." ${ }^{304}$ By drawing a clear line between reading Rev 11:11 relative to Ezek 37 rather than relative to Jesus' resurrection, Maier seems to be drawing a line between an understanding of Rev 11:11 that is more agreeable to a symbolic ecclesiastical identification and an understanding of that verse that is more suitable to a literal individual identification. Maier attempts to draw a

${ }^{300}$ Ibid., 482-483.
${ }^{301}$ Ibid., 483.
${ }^{302}$ Ibid., 482-483.

${ }^{303}$ Specifically, Maier presents four contrasts between Jesus' resurrection and the revival of the witnesses. First, the interval between death and revival is three days in the case of Jesus, but three and a half in the case of the witnesses. Such a prevalent teaching of the NT as the three days interval could not easily be changed into three and a half days. Second, the reports about the resurrection of Jesus do not speak of him standing on his feet, as the two witnesses do. Third, Jesus was put in a tomb, but the witnesses were left unburied. Fourth, "the two witnesses [with their so-called resurrection] are seen by an obviously much larger group of people than was the case with Jesus." Ibid., 483; cf. 483-484.

${ }^{304}$ Ibid., 484; cf. 493. 
similar distinction with respect to the ascension of the two witnesses, but it is clearly done with less force. ${ }^{305}$

\section{The Timing of the Witnesses' Activity}

The final component of Maier's view of the two witnesses is his locating them in the future or the end-time, which agrees with his stress on the importance of the eschatological approach for understanding Revelation. ${ }^{306}$ One can begin with Maier defining the future relative to his own place in time. This may be inferred from some of Maier's concluding reflections on Rev 11:1-14. ${ }^{307}$ There Maier points out that interpreters must choose whether the episode of the witnesses concerns the future or the past. The temporal location of the interpreter seems to define what is meant by the future and the past. The interpreter at hand is, of course, Maier.

That Maier appears to define the future relative to his own place in time is confirmed in his discussion of the sea beast of Rev 13:1-10, an entity apparently active at the same time as the witnesses. ${ }^{308}$ Maier's placement of the beast in the "future" means,

${ }^{305}$ Ibid., 485. Maier has no explicit contrasting lens through which to see the ascension of the witnesses, unlike the case with their resurrection. Moreover, while he can identify two points of contrast between the ascension of the witnesses and that of Jesus, Maier must admit that the presence of the cloud and the fact that there is an ascension do link the two events. In fact, Maier must also contend here with the fact that there are also similarities between the ascension of the witnesses and the disappearances of Enoch and Elijah. See ibid., 484-485; cf. 493.

${ }^{306}$ With respect to the connection with the future specifically, see ibid., 472-473, 492-493. With respect to the connection with the end-time specifically, see ibid., 478, $481,483,485,492$.

${ }^{307}$ See ibid., 492.

${ }^{308}$ On the the beast as also an entity of the "future," see Maier, Kapitel 12-22, 78, $80,84-85,87-88,96,98,121,123-125$. 
in his opinion, that views of it in purely contemporary-historical terms (e.g., the beast as the Roman Empire and its embodiment in the emperors) or in purely historicist terms (e.g., the beast as the papacy of the Middle Ages) do not go far enough in identifying it. ${ }^{309}$ The figures and events of the related historical periods (antiquity and the Middle Ages, respectively) form only "precursory models [vorlaufende Modelle]" of what will appear in the "end-time." ${ }^{310}$ From this perspective, the "future" does not refer to events in the era of John, nor even some events later than John's time. The "future" era of the sea beast - and so also of the two witnesses - is distant in time from John and presumably still future for Maier.

Why Maier would place the episode of the witnesses in the future relative to himself is suggested by his handling of the episodes in Rev 12-13. Maier reasons that the events of Rev 12-13, as he understands them, still await fulfillment, since nothing in church history matches such extraordinary occurrences. ${ }^{311}$ This thought can be extended to the events occurring during the three-and-a-half-year periods in Rev 11. For Maier equates the three-and-a-half-year time periods in Rev 11-13, so that what he says about one defines the others. ${ }^{312}$

${ }^{309}$ Ibid., 123-124; cf. 78, 80, 84-85, 87-88, 98.

${ }^{310}$ Ibid., 123-124; cf. 84-85, 87-88, 98, 111-112, 115.

${ }^{311}$ Ibid., 123. If he were more specific here, Maier would say that certain parts of Rev 12 refer to the past, such as the Messiah coming forth from Israel (Rev 12:1-5) and the victory of the cross over the devil (Rev 12:7-12). See ibid., 17-59 passim.

${ }^{312}$ Maier, Kapitel 1-11, 463; and Maier, Kapitel 12-22, 18, 38, 64, 88-89. 
The topic of time periods in Rev 11-13 raises the broad issue concerning the meaning of the three-and-a-half-year period. Meanwhile, the reference to church history suggests the issue of how historical data affect the identification of the witnesses.

Although Maier is undecided about the actual length of the period common to Rev 11-13, he still sees certain limits. ${ }^{313}$ The period starts with the church receiving special care from God as antichrist enters the scene. Here is the woman going into the wilderness and the arrival of the sea beast (Rev 12-13). ${ }^{314}$ The period ends with the great triumph of antichrist over the church, but soon after the triumph is reversed and the church revives to continue its work. Here is the death and resurrection of the two witnesses. ${ }^{315}$ That work must be short, for the time of heavenly reward comes and a time to punish the enemies of God and his people. Here is the ascension of the witnesses and the subsequent earthquake. ${ }^{316}$ These thoughts continue the discussion of the meaning of the three-and-a-half-year period.

${ }^{313}$ As for the length of the period, see Maier's remarks on the three-and-a-half "times" of the woman in the wilderness (Rev 12:14) at Maier, Kapitel 12-22, 64-65. Compare Maier's handling of the three and a half days that the witnesses lie dead. Maier, Kapitel 1-11, 479.

${ }^{314}$ On the woman as the people of God, see Maier, Kapitel 12-22, 19-22; cf. 18, $38,40,67,69$. On the beast as antichrist, see Maier, Kapitel 1-11, 472-473, 478-479, 483-486; and Maier, Kapitel 12-22, 75-76, 78-80, 82-84, 103, 121, 123.

${ }^{315}$ Regarding the triumph of the antichrist (Rev 11:7 and 13:7), see Maier, Kapitel 1-11, 473-475, 492; cf. 481, 483. Cf. also Maier, Kapitel 12-22, 75, 89-91, 96. For the revival of the church (Rev 11:11), see Maier, Kapitel 1-11, 482-483, 492.

${ }^{316}$ For the time of reward (Rev 11:12), see Maier, Kapitel 1-11, 484-486 492. For the punishment of the enemies of God and his people (Rev 11:13), see ibid., 486-488. 


\section{Conclusion}

Several broad issues of interpretation may be inferred from Maier's argumentation about the two witnesses. Many of these issues are also evident in the argumentation of Beale and van de Kamp.

\section{Summary and Conclusions for Other Significant Expositions}

This section has presented examinations of two significant expositions that, like Beale's, also identify the two witnesses as the totality of God's people, in this case, the Christian church. The conclusions of Beale, van de Kamp, and Maier about the identity of the witnesses are not exactly the same, however, particularly when it comes to the timing of the witnesses' activity. For Beale, the church is portrayed as acting over the church age and then having a time of trial in the end-time. Van de Kamp differs slightly, seeing the time of trial as one repeated over the church age. Maier, on the other hand, looks toward the future alone. For him, the witnesses symbolize the church active during an end-time distant from John, the presumed author of Revelation. Nevertheless, there exists a degree of harmony in the conclusions to the identity question. The points of agreement stand in spite of the presence of other differences among them.

This section has revealed other arguments that could be offered to support a conclusion like Beale's. In some cases, these arguments could supplement the array of arguments found in Beale's study. In other instances, they might function as alternatives.

This section has also shown that the broad issues of interpretation deduced from Beale's arguments have an existence beyond his study. Van de Kamp and Maier each deal with most of the broad issues seen in the examination of Beale's exposition. These general issues truly play a role in the debate over the identity of the two witnesses, at 
least among those commentators who understand them to be a symbol of God's people. More is said in the conclusion to this chapter about the issues of interpretation shared among Beale, van de Kamp, and Maier.

\section{Ekkehardt Müller}

Introduction

So far, the discussion in this chapter has centered on expositions that identify the two witnesses with God's people. The majority of scholarly interpreters who have advocated a symbolic understanding of the two witnesses have upheld this identification. As noted in the introduction to this chapter, however, several expositors who also promote a symbolic understanding of the witnesses have chosen to understand them as something impersonal, namely, sacred writings. Although advanced by far fewer interpreters over time, this type of identification deserves some discussion in this chapter. Yet, given its minority status over time, I have chosen to feature only one advocate, Ekkehardt Müller. Furthermore, the examination of his work is briefer than it could be. No comprehensive account is attempted of the arguments that Müller advances for his proposed identification. After an overview of his work, a sample of his argumentation is presented. These two presentations together reveal all the broad issues of interpretation that could be identified from a more detailed examination of Müller's argumentation.

An Overview of Müller's Study of the Two Witnesses

Ekkehardt Müller (born 1950) ${ }^{317}$ has authored a book containing various studies

${ }^{317}$ Ekkehardt Müller is a Seventh-day Adventist minister and scholar. He studied at Seminar Marienhöhe, in Darmstadt, at Ludwig-Maximilians-Universität, in Munich, and at Andrews University, in Berrien Springs, Michigan. From the latter school, he 
on the book of Revelation. Müller's work contains three main parts. The first part addresses the issue of apocalyptic, answers introductory questions, such as author and date, and speaks to methodological matters. The second part contains expositions on various parts of Revelation, while the final section concerns aspects of the theology of Revelation. Some chapters are based upon earlier English pieces, like the chapter on the two witnesses. ${ }^{318}$ The individual chapters are self-contained, which means that, while there is some overlap in the discussion, the work is well suited for selective reading. ${ }^{319}$ Nevertheless, it seems obvious that the introductory chapters form the foundation upon which the exegesis and the theological discussion rest. The two chapters most pertinent to Müller's identification of the two witnesses are his chapter on methods and steps for interpreting Revelation and, as to be expected, the chapter focusing on the two witnesses of Rev 11. Some reference, however, must be made to other statements in the work in order to have a clearer picture of Müller's placement of the witnesses in time.

received a DMin (1987) and a ThD (1994). The dissertation for his ThD was published as Ekkehardt Müller, Microstructural Analysis of Revelation 4-11, Andrews University Seminary Doctoral Dissertation Series 21 (Berrien Springs, Michigan: Andrews University Press, 1996). From 1972, Müller served first as a pastor and then in administrative positions in the Seventh-day Adventist Church in Europe. Since 1997, however, Müller has been a part of the Biblical Research Institute (BRI), first as an associate director and then as the deputy director. The BRI is an agency of the Seventhday Adventist Church that serves the world body of Adventists in the areas of theological research and apologetics. Besides editing some church-related publications, Müller has authored several articles as well as some essays and books. Besides Revelation, he has written and spoken about such topics as the Johannine epistles, the book of Hebrews, the doctrine of God, and hermeneutics.

${ }^{318}$ Thus, one may compare Müller, Der Erste und der Letzte, 209-225, with the earlier article, Ekkehardt Müller, "The Two Witnesses of Revelation 11," JATS 13, no. 2 (Autumn 2002): 30-45.

${ }^{319}$ Müller, Der Erste und der Letzte, 15. 
Müller believes that the two witnesses represent the Bible, consisting of the Old and New Testaments, while the 1,260 days of their activity refer to a particular 1,260 years in the history of the Bible. ${ }^{320}$ This viewpoint is argued opposite the identification of the witnesses with the church.

Müller's interpretive framework for reading Rev 11 is most apparent in his chapter on methods and steps for interpreting Revelation. This chapter starts with the fundamentals to interpreting any biblical text. ${ }^{321}$ The chapter ends with additional interpretive steps needed for interpreting Revelation in particular. While all the other methodological considerations clearly underlie Müller's discussion of the two witnesses, their presence is not as noticeable as that of the additional steps. Here noted are the most pertinent to interpreting Rev $11 .^{322}$

One step is the decision about what interpretive approach to use for Revelation. This means making a decision about whether to interpret Revelation as a preterist, an idealist, a futurist, or a historicist. Müller's decision for this step, the one that he finds

${ }^{320}$ Ibid., 83, 180, 193, 201, 203, 219-225, 230, 392, 407, 443n88, 445-446. Cf. Müller, "Two Witnesses," 39-45.

${ }^{321}$ Müller, Der Erste und der Letzte, 31-40. It may be noted that such basic considerations also lie deep below the surface of the interpretations of others examined in the present study. Müller stands out for making them explicit, albeit briefly, within his work on Revelation.

${ }^{322}$ The steps that I do not highlight here are as follows: "To familiarize oneself with apocalyptic prophecy"; "To take into account different literary genres"; "To examine the influences of extra-canonical literature on Revelation"; and "To pay attention particularly to typology" ibid., 41-44. All translations of Müller's German work are my own. 
"biblically justifiable," is for the historicist approach. ${ }^{323}$

Two other steps deal with backgrounds. Müller points out the importance of examining the OT and NT backgrounds of Revelation. Having a clear picture of these backgrounds helps to decipher some of the symbols of Revelation. ${ }^{324}$

Speaking of symbolism, Müller includes a step that speaks about distinguishing symbolic descriptions from literal ones. Unlike other books in the NT, Revelation is predominantly symbolic. Symbolism is concentrated in the apocalyptic part of the book (Rev 4:1-22:5). ${ }^{325}$ Distinguishing between symbolic and literal representations also involves dealing with time periods that appear in the text. ${ }^{326}$

The final step of note comes after symbols in Revelation have been understood. It completes the historicist's task of interpreting the text of Revelation. The expositor at this point, after a "thorough exegesis," connects the symbols in question with "historical realities." ${ }^{327}$ Müller carries out this step sparingly for the episode of the two witnesses. More is said about this below.

Müller begins his actual study of the two witnesses with a listing of proposed

$$
\begin{aligned}
& { }^{323} \text { Ibid., } 41 . \\
& { }^{324} \text { Ibid., 43-44. } \\
& { }^{325} \text { Ibid., 44; cf. 42-43. }
\end{aligned}
$$

${ }^{326}$ Müller has much to say about the symbolic significance of the 42 months, the 1,260 days, and the three and a half "times" (Rev 11:2-3; 12:6, 14; 13:5). Notice discussions of these periods below. As for other periods in Revelation, Müller speaks explicitly about the symbolic significance of only two of them, the five months of Rev 9:5, 10 and the hour, day, month, and year mentioned in 9:15. See ibid., 179, 194-197, 200-201.

${ }^{327}$ Ibid., 44-45. 
identifications found in the history of the interpretation of Rev 11. Müller contends that the episode of the witnesses "is obviously to be understood symbolically." ${ }^{328}$ From here, Müller narrows the vast field of proposals to just two main symbolic identifications, namely, the church or the Bible.

The final section before the conclusion contains the majority of Müller's arguments against the ecclesiastical identification and for the scriptural identification. He lays out nine points. ${ }^{329}$ Some of these points draw upon observations made earlier in the study. Müller addresses (1) the apparent unity of the two witnesses in the narrative. He looks at the fact that (2) fire comes from their mouths (Rev 11:5). He presents arguments dealing with some key concepts, (3) prophecy and (4) testimony. There is the role played by (5) cities in Rev 11. The (6) time span during which the witnesses operate leads to further argumentation. Müller also discusses (7) the image of the lampstands to designate the two witnesses and (8) the theme of judgment in the episode of the witnesses. Finally, Müller observes (9) a pattern found elsewhere in Revelation that seems apparent in Rev 11. From all these points, Müller finds confirmation for the "suggestion that the two witnesses represent the OT and the NT."330

References to the timing of the activity of the witnesses appear in Müller's actual study of the two witnesses. A clearer picture, however, arises from thoughts scattered throughout the rest of Müller's monograph.

${ }^{328}$ Ibid., 209. Cf. Müller, "Two Witnesses," 30.

${ }^{329}$ Müller, Der Erste und der Letzte, 219-225. Cf. Müller, "Two Witnesses," 3944.

${ }^{330}$ Müller, Der Erste und der Letzte, 225. Cf. Müller, "Two Witnesses," 45. 


\section{Select Arguments and Broad Issues of Interpretation}

This overview hints at most of the broad issues of interpretation that come from Müller's study of the witnesses. At the start, there is the methodological issue of what is the proper interpretive approach to Revelation. One may deduce also an issue involving preconceptions about the book and the author, since Müller notices the degree to which symbolism plays a role in Revelation.

Other issues come from the nine points supporting Müller's view of the witnesses. Five are noted here, while the rest are mentioned below in the presentation of select arguments. One issue is the portrayal of the witnesses as a unit. The reference to the fire from the mouths of the witnesses raises the issue of the miraculous powers of the two witnesses. The discussion involving the identities of the cities in Rev 11:1-13 suggests the issue of the meaning of the Rev 11:1-2. There is also the separate issue of a judgement theme. Müller, as noted, argues that Rev 11 contains a literary pattern visible in other parts of Revelation. This suggests the issue of whether there are parallel literary structures to what is narrated in Rev 11:3-13 and perhaps its immediate context.

Highlighted now are some of Müller's various arguments for his proposal that the witnesses represent the Bible. The arguments presented here are divided into groups, where each group reflects one of Müller's nine major points. Also below is a discussion of Müller's view on the timing of the activity of the two witnesses. Enough arguments are presented here to give a taste of his reasoning as a whole. This portion of argumentation also affirms the presence of broad issues of interpretation that could be deduced just from the overview. Furthermore, the discussion of Müller's understanding of the timing of the witnesses' activity reveals one issue not apparent in the overview. In the end, the overview and the arguments presented here suggest all the issues in the 
interpretation of the witnesses that one can find in Müller's work. All the issues identified from the overview and from the discussion below are listed in Figure 9 in the order in which they are first mentioned.

1. Interpretive approach

2. Degree of symbolism

3. Unity of the two witnesses

4. Miraculous powers of the two witnesses (Rev 11:5-6)

5. Context immediately before Rev 11:3-13 (11:1-2)

6. Theme of judgement

7. Parallel literary structures to Rev 11 and its context

8. Theme of prophecy

9. Theme of testimony

10. Three-and-a-half year period

11. Image of the lampstands

12. Context immediately after Rev 11:3-13 (11:15-18)

13. Year-for-a-day principle of interpretation

Figure 9. Broad issues of interpretation in Müller's argumentation.

\section{Arguments Involving the Key Concept of Prophecy}

Müller's third point deals with the importance of the theme of prophecy in Revelation and in Rev 11 in particular. The witnesses are clearly linked to the topic of prophecy through the verb for prophesying ( $\pi \rho \circ \emptyset \eta \varepsilon \varepsilon v \omega)$ in 11:3, the term for prophecy ( $\pi \rho \circ \varphi \eta \tau \varepsilon i ́ \alpha)$ in 11:6, and the designation of prophets ( $\pi \rho \circ \varphi \eta ́ \tau \varepsilon \varsigma)$ in 11:10. Müller observes that prophecy in Revelation has to do narrowly with the gift of prophecy and with its results, as expressed in the book of Revelation and by extension the whole 
Bible. ${ }^{331}$ This situation meshes better with the understanding of the witnesses as the Bible rather than the church, inasmuch as the witnesses are portrayed as prophets.

This set of two arguments reveals a single broad issue of interpretation, namely, the theme of prophecy.

\section{Arguments Involving the Key Concept of Testimony}

Müller's fourth point deals with the importance of the theme of testimony in Revelation and in Rev 11 in particular. Although the verb for testifying ( $\mu \alpha \rho \tau v \rho \varepsilon ́ \omega)$ is not in Rev 11, it is nevertheless significant for its association with the Bible, which in these passages is "embodied in the book of Revelation." ${ }^{332}$ Müller also emphasizes the importance of the word for testimony ( $\mu \alpha \rho \tau v \rho i ́ \alpha)$, which appears in relation to the witnesses in Rev 11:7. Most of the other eight occurrences ${ }^{333}$ pair testimony "with another expression, predominantly the 'word of God"' $(1: 2,9 ; 6: 9 ; 12: 11,17 ; 20: 4) .{ }^{334}$ Müller makes two other claims with respect to the term, "testimony," in Revelation. One

${ }^{331}$ Müller, Der Erste und der Letzte, 215-216; cf. 221. Cf. Müller, "Two Witnesses," 36; cf. 41.

${ }^{332}$ Müller, Der Erste und der Letzte, 212; cf. 212-213, 222. Cf. Müller, "Two Witnesses," 34; cf. 33-34, 41. Two instances $(1: 2 ; 22: 16)$ see the book of Revelation as the result of testifying. The other two instances concern Jesus' elevation of the book of Revelation to the level of the other sacred texts of the Bible (Rev 22:18, 20).

${ }^{333}$ Müller would say that there are another nine occurrences of the word, because he includes Rev 15:5 that uses the phrase, "the tabernacle of testimony" (NASB). See Müller, Der Erste und der Letzte, 213. Cf. Müller, "Two Witnesses," 34. The word translated "testimony" here, however, is not the same word appearing elsewhere as

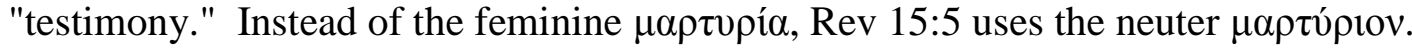

${ }^{334}$ Müller, "Two Witnesses," 34. Cf. Müller, Der Erste und der Letzte, 213. 
is that it "is not so much what believers proclaim, but what they have (Rev 12:17). ${ }^{1335} \mathrm{~A}$ second is that "testimony" "is associated with prophecy." ${ }^{336}$ From all these thoughts about $\mu \alpha \rho \tau v \rho i ́ \alpha$, Müller seems to want readers to infer that this term is also associated with the Bible.

Müller also approaches the topic of testimony in another way. Here he follows the argumentation of Kenneth A. Strand (1927-1997). Strand argues that there exists in Revelation and other biblical texts a so-called "two-witness" theology involving "the OT prophetic message and the NT apostolic witness." ${ }^{337}$ Strand asserts, and Müller seems to agree, "that the two witnesses of Rev 11 correspond to ... [this] two-witness theology" that is manifest in Revelation. ${ }^{338}$

This set of arguments concerns the theme of testimony.

\section{Arguments Involving the Timing of the Witnesses' Activity}

For Müller's sixth point, he acknowledges that the time period for the activity of the two witnesses is the same period, yet sometimes under different designations, as that

${ }^{335}$ Müller, Der Erste und der Letzte, 213. Cf. Müller, "Two Witnesses," 34.

${ }^{336}$ Müller, Der Erste und der Letzte, 213, 221-222. Cf. Müller, "Two Witnesses," 34 , cf. 41.

${ }^{337}$ Strand, "Two Witnesses," 134; cf. 131-134. Cf. Müller, Der Erste und der Letzte, 219-220, 222; and Müller, "Two Witnesses," 40-42. This two-witness theology is apparent in the book of Revelation through the pairing of "the word of God" with "the testimony of Jesus" and similar pairings. With respect to the texts outside Revelation that exhibit this theology, Müller refers to only some of those that Strand mentions, namely, Luke 24:27; John 5:46; and 1 Pet 1:10-12. What is left out is Strand's extended discussion of theology in the book of John.

${ }^{338}$ Müller, Der Erste und der Letzte, 222, cf. 219-220. Cf. also Strand, "Two Witnesses," 131, 134-135; and Müller, "Two Witnesses," 40-42. 
appearing twice in Daniel $(7: 25 ; 12: 7)$ and then four other times in Revelation $(11: 2$; 12:6, 14; 13:5). ${ }^{339}$ Nevertheless, Müller also draws a contrast between the portrayal of the 1,260 days in the episode of the witnesses and the picture of that period in other contexts. Although the same period of history is in view, the perspective on that period in the episode of the witnesses (a focus on the end of the period) differs from the perspective apparent in the other passages (a focus on the whole period). ${ }^{340}$ Moreover, what happens for the church at the end of the period contrasts with the imagery of what happens to the two witnesses at the same time. Müller observes, "Whereas the church is liberated at the end of the 1,260 years, the two witnesses are killed at the end of the same time span." 341 All this suggests that the ecclesiastical identification is unlikely.

These arguments raise the issue of the meaning of the three-and-a-half period.

\section{Arguments Involving the Witnesses as Lampstands}

Müller's seventh point concerns the designation of the two witnesses as two lampstands. He is responding to arguments that proponents of the ecclesiastical interpretation put forth in which they argue for a strong connection between the term "lampstand" ( $\lambda v \chi v i ́ \alpha)$ in 11:4 and its use as a reference to seven congregations in Asia Minor $(\operatorname{Rev} 1: 12,13,20 ; 2: 1,5){ }^{342}$

${ }^{339}$ Müller, Der Erste und der Letzte, 223; cf. 41n43, 44, 83, 180, 203n126, 211, 363, 368, 389n27, 392, 407, 443-446.

${ }^{340}$ Ibid., 223; cf. 83, 180, 193. Cf. Müller, "Two Witnesses," 43.

${ }^{341}$ Müller, Der Erste und der Letzte, 223. Cf. Müller, "Two Witnesses," 43.

${ }^{342}$ Müller, Der Erste und der Letzte, 214. Cf. Müller, "Two Witnesses," 35. Müller also notices here that some interpreters have gone so far as to identify the two 
Müller strikes at the supposition of consistent usage of the term, "lampstand." $\mathrm{He}$ observes instances in Revelation in which the same words are used with different meanings. ${ }^{343}$ To support such an idea with the lampstands of Rev 11:4, he points to the unique contextual connections of the lampstands here. ${ }^{344}$ Moreover, the lampstands in Rev 11:4 are in a different location from the lampstands earlier in the book: "Whereas Jesus walks among the seven lampstands on the earth (Rev 2:1), the two lampstands of Rev 11 stand before the Lord of the earth. ${ }^{345}$

As for the broad issues of interpretation present in this set of arguments, immediately noticeable is the issue of the image of the lampstand.

witnesses with the churches at Smyrna and Philadelphia, the two congregations that receive no rebuke (Rev 2:8-11; 3:7-13). Müller, Der Erste und der Letzte, 214; cf. 223224. Cf. Müller, "Two Witnesses," 35; cf. 43. It might be worth noting that from my study of the literature on the two witnesses this precise formulation is in fact a rare identification. For an example of an older espousal, see Henry Girdlestone, Notes on the Apocalypse.... (London: William Edward Painter, 1847), 37-38, accessed August 17, 2015, Google Books. For an example of a current espousal, see Ben Witherington, III, Revelation, New Cambridge Bible Commentary (Cambridge: Cambridge University Press, 2003), 158-159; cf. 43. With Witherington, however, that the witnesses are two specific churches does not seem to be the only possibility. Müller does respond to this specific identification at Müller, Der Erste und der Letzte, 223-224. Cf. Müller, "Two Witnesses," 43. The arguments are not presented here for the sake of brevity.

${ }^{343}$ Müller notes specifically the figure of angels (sometimes representative of humans, other times of heavenly beings) and the image of a lamp (in one place representative of a literal lamp, in another a symbol for the Lamb, Jesus). See Müller, Der Erste und der Letzte, 214. Cf. Müller, "Two Witnesses," 35.

${ }^{344}$ Müller, Der Erste und der Letzte, 214; 427. Cf. Müller, "Two Witnesses," 35.

${ }^{345}$ Müller, Der Erste und der Letzte, 214; cf. 216, 223. Cf. Müller, "Two Witnesses," 35-37, 43. 


\section{Thoughts concerning the Timing of the Witnesses' Activity}

Although there is some mention of the timing of the activity of the two witnesses in Müller's chapter on the two witnesses, one has to go outside that chapter to gain a clearer picture.

Speaking generally, Müller places the time of the witnesses before the end of human history, before the complete establishment of God's reign on earth. ${ }^{346}$ He bases this on understanding Rev 10:1-11:13 as an "expansion" of the sixth trumpet and so part of the second woe $(\operatorname{Rev} 9: 12 ; 11: 14) .{ }^{347}$ Inasmuch as the seventh trumpet follows and describes the absorption of the world into God's kingdom (11:15-18), the episode of the two witnesses portrays prior events. Of course, this all assumes that the trumpet series portrays a progression in history. ${ }^{348}$

Speaking more specifically, one notices, as above, that for Müller the 42 months, the 1,260 days, and the three and a half "times" (Rev 11:2-3; 12:6, 14; 13:5) are based on Dan 7:25; $12: 7$ and represent a single period. ${ }^{349}$ As in Daniel, Müller contends, the period is symbolic and should be interpreted according to the principle that a year is

${ }^{346}$ Müller, Der Erste und der Letzte, 209; cf. 180.

${ }^{347}$ Ibid., 209; cf. 88, 141-142, 176-179, 201-204, 225. Cf. Müller, "Two Witnesses," 30-31, 44.

${ }^{348}$ Müller devotes a whole chapter to the seven trumpets. See Müller, Der Erste und der Letzte, 175-207. Within this, a small section deals with the historical time covered by the trumpet series. See ibid., 179-180. Cf. also ibid., 83.

${ }^{349}$ Ibid., 41n43, 83, 180, 203n126, 211, 223, 363, 368, 389n27, 392, 407, 443-446. The only argument that Müller seems to offer for seeing only one period is that the length of the 1,260 days, the 42 months, and the three and a half "times" are equal. See ibid., 203n126, 363, 368. 
represented by each prophetic day. ${ }^{350}$ The result is a period of 1,260 years. In terms of Müller's identification of the witnesses as the Bible, this means that Rev 11 narrates over 1,260 years in the history of the Bible.

What are the starting point and the end of these 1,260 years? That the 1,260 years cover the period from 538 to $1798 \mathrm{CE}$ is clear in Müller's work. ${ }^{351}$ The actual dates of 538 and 1798 come from the interpretation of Dan 7:25. From there, the dates are applied to the other instances where the 1,260 years is mentioned (Dan 12:7; Rev 11:2-3; $12: 6,14 ; 13: 5) .{ }^{352}$ Dan $7: 25$ says that the little horn of the fourth beast oppresses the holy ones for a symbolic "time, times, and half a time" (NASB). There is a shift in the little horn's ability to act against the holy ones at the beginning and at the end of the period of 1,260 years. The years of 538 and 1798 respectively are chosen as these turning points,

${ }^{350}$ Ibid., 44; cf. 41n43, 180n20, 195n83, 197n95, 219, 360, 368-369. Müller offers at least three reasons for taking the period as symbolic. For these reasons, see ibid., 180n20, 195n83, 368-369. As for the year-day principle, Müller leaves justification for its existence primarily to other writers. One work of significance noted by Müller is William Henry Shea, Selected Studies on Prophetic Interpretation, ed. Frank B. Holbrook, Rev. ed., Daniel and Revelation Committee Series 1 (Silver Spring, MD: Biblical Research Institute, General Conference of Seventh-Day Adventists, 1992), 67110. See Müller, Der Erste und der Letzte, 44n53. Müller justifies the use of this principle in the case of the 1,260 days/42 months/three and a half "times" on the basis of its applicability to two other time prophecies in Daniel (see Dan 8 and 9). See ibid., $368 \mathrm{n} 44$. Use of the year-day principle for prophetic time periods in Daniel and Revelation is not unique to Seventh-day Adventists in the history of the interpretation of those books. It may be argued, however, that its use in twentieth and twenty-first century scholarly literature is mostly limited to Seventh-day Adventist interpreters.

${ }^{351}$ Müller, Der Erste und der Letzte, 83, 180, 193, 195, 445; cf. 392.

${ }^{352}$ Ibid., 368n44. 
once the little horn has been identified with a historical reality and its history has been consulted. ${ }^{353}$

Müller says only a little about what happens when the activity of the two witnesses is complete. In two places, Müller reveals that the "death" of the Bible (= the witnesses) has to do with Satan (= the beast from the abyss) working through the French Revolution to attack God's Word. ${ }^{354}$ No more specifics are given about the death of the witnesses. ${ }^{355}$ Müller says nothing about what happens after the two witnesses die. That Müller offers few thoughts on these matters, of course, does not mean that he has no opinion concerning them.

Understanding the timing of the witnesses' activity in a general way depends on one's interpretation of Rev 11:3-13 within its immediate and broader literary contexts.

${ }^{353}$ Ibid. In Müller's opinion, the little horn represents the Roman papacy. See ibid., 363-364, 407-408. These same pages show that the little horn and the sea beast of Rev 13 represent the same historical reality. In light of this, consider the papal identification in reference only to the sea beast at ibid., 199-200, 239n33, 410-411. As for the specific events in papal history that are seen as occurring in 538 and 1798 respectively, Müller only intimates what happened in 1798. For a fuller explanation, his major sources are "The Book of Daniel," in The Seventh-day Adventist Bible Commentary, ed. Francis D. Nichol et al. (Washington, DC: Review and Herald, 19531957), 4:834-838; and "The Revelation of St. John the Divine," in The Seventh-day Adventist Bible Commentary, ed. Francis D. Nichol et al. (Washington, DC: Review and Herald, 1953-1957), 7:817. See Müller, Der Erste und der Letzte, 364n28.

${ }^{354}$ Müller, Der Erste und der Letzte, 230, 407. For more on the beast from the abyss as Satan, consider the whole of Müller's eleventh chapter at ibid., 227-242. Also, cf. ibid., 217; and Müller, "Two Witnesses," 38. The connection between the death of the witnesses and the French Revolution is common among earlier commentators and particularly among Seventh-day Adventist interpreters. See earlier in this chapter the diachronic review of the identification of the witnesses as sacred writings. Cf. "The Revelation of St. John the Divine," 7:802-803.

${ }^{355}$ Müller does, however, refer to "The Revelation of St. John the Divine," 7:802803. See Müller, Der Erste und der Letzte, 230; cf. 385. 
The issue that is prominent here is the meaning of what follows Rev 11:3-13, particularly the seventh trumpet.

Understanding the timing of the activity in a more specific way depends on one's interpretation of the 1,260 day period of $\operatorname{Rev} 11: 3$. The issue that is prominent here is the meaning of the three-and-a-half-year period.

Müller employs a principle for interpreting certain temporal expressions in prophetic contexts. It functions, for Müller, as a necessary step to gaining a more precise dating of the activity of the two witnesses. The issue of interpretation at hand is the yearday principle.

\section{Summary and Conclusions}

This section has offered an abbreviated look at the study of Ekkehardt Müller on the two witnesses of Revelation. First, the pertinent chapters from his book on Revelation have been summarized. Seven broad issues of interpretation in identifying the witnesses have been identified simply based on this overview. Second, four of Müller's nine points concerning the witnesses have been highlighted and issues of interpretation have been identified. Third, Müller's thoughts on the timing of the witnesses' activity have been examined in detail. This sampling of arguments gives a taste of Müller's reasoning as a whole. Moreover, other broad issues of interpretation have been deduced from these sets of arguments, besides those noted from the overview. The broad issues of interpretation identified in this brief examination of Müller's research appear to represent all such issues that could be identified from a more detailed look at that research.

Most of the broad issues of interpretation evident in Müller's work are ones observed earlier in this chapter. Of course, there the issues were derived from arguments 
for an alternative symbolic identification, namely, the witnesses as the church. Müller comes to a conclusion concerning the identity of the two witnesses that is different from that of the other expositors discussed in this chapter, and he argues for that conclusion in ways that might conflict with their arguments. Nevertheless, Müller deals with some of the same broad issues of interpretation, while he addresses the same question that they address. More is said in the conclusion to this chapter about these points of contact among Beale, van de Kamp, Maier, and Müller.

Of course, Müller's exposition is one in a class of expositions that take the two witnesses as symbolizing sacred writings. Müller's exposition is one of the most detailed expositions from this class, if not the most detailed one. It also represents the common formulation of this type of identification. Given this situation and having personally looked at several other key expositions from this class, I am confident that the broad issues of interpretation present in Müller's monograph represent many of such issues exhibited by others in the same class of expositions.

\section{Summary and Conclusions for the Chapter}

The topic of this chapter has been those identifications of the two witnesses that understand them to be a symbol. A look at this kind of identification over time showed that the majority of its advocates see a symbol for God's people. A smaller number of adherents to the symbolic view of the witnesses have identified them with sacred writings. In accordance with this historical perspective on symbolic views of the witnesses, most of the chapter involved examining significant expositions for an ecclesiastical identification. Some space though was given to the other type of symbolic identification. 
The Exposition of G. K. Beale

The first exposition examined was that of G. K. Beale. Presented above were a summary look at aspects of Beale's interpretive framework for reading Rev 11 and a comprehensive look at his arguments directly bearing on the question of the identity of the witnesses. Beale argues that the two witnesses represent God's people between the first advent and the second advent of Jesus. His detailed exposition functioned as the basis for the discussions in the rest of the chapter. He stands as the main representative in this chapter for those symbolic identifications that associate the witnesses with God's people. Several broad issues of interpretation were deduced from Beale's argumentation and from the interpretive lens through which he reads Rev 11.

\section{The Expositions of H. R. van de Kamp and Gerhard Maier}

After Beale, two other expositions were briefly examined. The expositions of $\mathrm{H}$. R. van de Kamp and Gerhard Maier conclude with an identification similar to Beale's, namely, that the two witnesses represent the Christian community. The differences in their identifications have to do with how they view the timing of the two witnesses' activity. The discussion of these two additional studies revealed arguments that could supplement or perhaps replace arguments found in Beale's work. Moreover, the argumentation from each of these studies was found to exhibit several of the same broad issues of interpretation derived from Beale's exposition.

\section{Shared Issues of Interpretation}

Differences in argumentation among the three commentators do exist, but points of commonality in the issues addressed also exist. These can be highlighted in view of 
the coming chapter discussing the broad issues of interpretation. Table 3 (see the next page) displays these common points in the order in which they are first mentioned.

Beale, van de Kamp, and Maier share some concerns regarding broad preconceptions about the book and its author and regarding methodology. It must be noted, however, that the similarities are hard to see at first, because van de Kamp and Maier do not have the kind of detailed introduction that Beale has. Nevertheless, they are there. Beale and van de Kamp conceive Revelation as a book dominated by symbolism. Although Maier makes no explicit statement to that effect, his exposition of Rev 11-13 suggests agreement with Beale and van de Kamp on the degree to which symbolism plays a role in Revelation. Although the details are different, Beale and Maier have an explicit interest in what the proper interpretive approach to Revelation is. Van de Kamp seems to have an interpretive approach, but he does not explicitly discuss the issue of interpretive approaches.

Each commentator also raises issues of interpretation that touch upon the linguistic details of Rev 11:3-13 and material drawn from the rest of Revelation or from the world outside Revelation. Several such issues can be identified as being shared by at least two of the commentators. Seven issues are common to all three commentators. Each shows an interest in the images of (1) the lampstands and (2) the olive trees. Each refers to (3) the theme of testimony and pays attention to (4) the miraculous powers of the two witnesses. Primarily because of the description of those powers and because of the proposed identification of the witnesses with Moses and Elijah, each expositor also refers to (5) traditions about Moses and (6) about Elijah. All three are concerned with (7) the meaning of the three-and-a-half-year period that appears in Rev 11:3. 
Table 3. Broad issues of interpretation shared by Beale, van de Kamp, and Maier

\begin{tabular}{|l|c|c|c|}
\hline \multicolumn{1}{|c|}{ Broad Issues of Interpretation } & Beale & Kamp & Maier \\
\hline Degree of symbolism & $\bullet$ & $\bullet$ & $\bullet$ \\
\hline Interpretive approach & $\bullet$ & $\bullet$ & $\bullet$ \\
\hline Image of the lampstands & $\bullet$ & $\bullet$ & $\bullet$ \\
\hline Image of the olive trees & $\bullet$ & $\bullet$ & $\bullet$ \\
\hline Theme of testimony & $\bullet$ & $\bullet$ & $\bullet$ \\
\hline Miraculous powers of the witnesses & $\bullet$ & $\bullet$ & $\bullet$ \\
\hline Traditions about Moses & $\bullet$ & $\bullet$ & $\bullet$ \\
\hline Traditions about Elijah & $\bullet$ & $\bullet$ & $\bullet$ \\
\hline Three-and-a-half year period & $\bullet$ & $\bullet$ & \\
\hline Person-oriented language & $\bullet$ & $\bullet$ & \\
\hline Verb tenses in Rev 11:1-13 & $\bullet$ & $\bullet$ & \\
\hline Duality of the two witnesses & $\bullet$ & $\bullet$ & \\
\hline Theme of prophecy & $\bullet$ & & $\bullet$ \\
\hline Fate of the two witnesses & $\bullet$ & & $\bullet$ \\
\hline Immediate context before Rev 11:3-13 & & $\bullet$ & $\bullet$ \\
\hline Traditions about Enoch & & & $\bullet$ \\
\hline
\end{tabular}

Certain issues are specific to Beale and van de Kamp. Both highlight the personoriented description of the two witnesses. They both reflect on the verb tenses present in Rev 11:1-13. Both offer reasons for why there are only two witnesses. Both see importance for the identity question in the fact that the witnesses are portrayed as prophets.

Two issues are specific to Beale and Maier, and one issue is specific to van de Kamp and Maier. Beale and Maier both discuss the fate of the two witnesses - their death, resurrection, and ascension — relative to the identity question. They both refer in their argumentation to the meaning of the immediate context before the episode of the witnesses (Rev 11:1-2). Because of the existence of the Enoch-Elijah view in the history 
of the interpretation of the witnesses, van de Kamp and Maier both have something to say about traditions involving Enoch.

As noted, among symbolic identifications of the witnesses, other specific variations exist for the understanding of the witnesses as associated with God's people. For example, there is the conceptualization of the witnesses as strictly the martyrs of the church or a group of prophets operating within the church. Although none of the expositors examined in this chapter advocate any of these views, the array of discussion within the works of Beale, van de Kamp, and Maier has provided a number of the reasons used for those views, some of them being the same as those of the works examined and some of them being distinct reasons for these alternative identifications.

Therefore, the presentation of these three expositions, those of Beale, van de Kamp, and Maier, has unveiled in a substantial way an important segment in the debate of the last few centuries over the exegetical identity of the two witnesses.

\section{The Exposition of Ekkehardt Müller}

The final part of this chapter looked at the exposition of Ekkehardt Müller on the two witnesses. Müller identifies the two witnesses with the Bible, consisting of two testaments. Müller's views on the two witnesses are found in a collection of studies on Revelation. A few sets of arguments from his handling of the identity question were discussed, following an overview of Müller's chapters on methodology and on the two witnesses in particular. Seven broad issues of interpretation were noted simply from the overview of these chapters. Additional broad issues of interpretation were derived from the presented arguments. Most of the issues had been mentioned elsewhere in this chapter. The general issues identified in this brief examination of Müller's research 
appear to represent all such issues that could be identified from a more detailed examination of his study of the witnesses.

The issues shared between Müller and the other commentators discussed in this chapter can be highlighted. Table 4 displays the issues common to Müller, Beale, van de Kamp, and Maier in the order in which they are first mentioned.

Table 4. Broad issues of interpretation shared by Müller, Beale, van de Kamp, and Maier

\begin{tabular}{|l|c|c|c|c|}
\hline \multicolumn{1}{|c|}{ Broad Issues of Interpretation } & Beale & Kamp & Maier & Müller \\
\hline Degree of symbolism & $\bullet$ & $\bullet$ & $\bullet$ & $\bullet$ \\
\hline Interpretive approach & $\bullet$ & $\bullet$ & $\bullet$ & $\bullet$ \\
\hline Three-and-a-half year period & $\bullet$ & $\bullet$ & $\bullet$ & $\bullet$ \\
\hline Image of the lampstands & $\bullet$ & $\bullet$ & $\bullet$ & $\bullet$ \\
\hline Miraculous powers of the witnesses & $\bullet$ & $\bullet$ & $\bullet$ & $\bullet$ \\
\hline Theme of testimony & $\bullet$ & $\bullet$ & $\bullet$ & $\bullet$ \\
\hline Theme of prophecy & $\bullet$ & $\bullet$ & & $\bullet$ \\
\hline Context immediately before $11: 3-13$ & $\bullet$ & & $\bullet$ & $\bullet$ \\
\hline Unity of the two witnesses & & & $\bullet$ & $\bullet$ \\
\hline
\end{tabular}

Müller shares with the other commentators examined in this chapter concerns about symbolism in Revelation and the proper interpretive approach to the book. He also shows a common interest with them in the 1,260 days of the witnesses, the lampstand image, their miraculous powers, and the topic of testimony. With Beale and van de Kamp, Müller addresses the theme of prophecy. With Beale and Maier, he addresses the significance that the immediate context before Rev 11:3-13 (11:1-2) has for the identity question.

When the three other commentators in this chapter are considered together as a 
group, Beale, van de Kamp, and Maier each exhibit issues of interpretation that are uniquely theirs. Each raises issues that are not present in the other two commentators. Adding Müller's argumentation to this group causes one issue to cease being unique. Müller and Maier both discuss how the witnesses are described in a unified way.

Clearly, however, although there exists a common interest in certain issues, Müller often has something different to say about them from what the other three commentators say. In many cases, the differences in how they address the issues are reflected in the different identifications.

Müller's detailed exposition was chosen to represent all those who understand the two witnesses as sacred writings, particularly the popular view that they represent the Bible. This kind of identification, as noted, has not been as popular as ones associating the witnesses with God's people. Müller's study of the witnesses stands out for the extent to which it goes to identify exegetically the witnesses with sacred writings. Given this significance that his exposition has and having personally looked at other substantial studies that advance the same kind of identification, I am confident that the broad issues of interpretation present in Müller's exposition constitute many of such issues exhibited by these substantial expositions.

Therefore, this brief presentation of Müller's exposition complements the discussion of identifications associating the witnesses with God's people and offers some exposure to another part of the debate of the last few centuries over their exegetical identity.

\section{Summation}

As a whole, this chapter has presented a sample of the arguments that interpreters 
have offered on behalf of specific symbolic identifications of the two witnesses.

Common as well as distinct emphases are visible in the argumentation of the commentators examined here. Deducible from all the arguments presented here are several broad issues of interpretation. Many of these are common to at least two of the expositors examined. Some of these same broad issues were also evident from the arguments presented in chapter three. It is becoming clearer that these issues are not limited to just one work, but truly reflect the broad issues of interpretation present in the debate over the identity of the witnesses. All this material together- the arguments and the issues of interpretation that may be derived from them — has revealed an important piece of the debate since 1700 . 


\section{CHAPTER 5}

\section{DISCUSSION OF BROAD ISSUES OF INTERPRETATION}

\section{Introduction}

In the last two chapters, I have identified several broad issues of interpretation in the debate over the identity of the two witnesses. In the conclusions to those chapters, I have pointed out shared issues of interpretation. One goal of the present chapter is to bring together data from both chapters and recognize all the shared issues. With one exception, issues espoused by only one of the nine studied commentators are not discussed here for the sake of brevity.

There are a few new commonalities because the data of both chapters has been pooled together, but most of the common points have been seen before. Now, however, they are seen from a different perspective. The expositions of the nine featured commentators together as representative works reveal a very significant portion of the debate over the identity of the witnesses. Seeing this total representation is a new vantage point for looking at the issues of interpretation. From this perspective, one can

reasonably speak about some issues playing a greater role in the debate than others. The issues that have had the greatest role in the past discussion of the identity question can then be assigned a significant place in any further discussion. To engage in the debate, seeking to support a past proposal or to offer a new one, would seem to require at a 
minimum that one address these main issues. Another goal of the present chapter then is to show what the main issues are.

Nevertheless, just because an issue has not been discussed as much does not necessarily mean that it should not have a place next to the main issues. Perhaps further discussion of these seemingly lesser issues could significantly change the debate over the identity of the witnesses for the better. Another goal of the present chapter then is to identify those issues that should join the main issues in a new investigation of the identity question.

Of course, there are issues that are discussed by only a few of the examined expositors and that do not merit a place next to the main issues. Leaving these issues out would not significantly affect the outcome of a new investigation of the identity question. Accordingly, those issues of lesser relevance are identified in the present chapter.

In this chapter, the issues are not simply identified according to their relevance to the identity question. Included here are small summaries of what the studied commentators have said in addressing the broad issues of interpretation. In a brief way, argumentation from the two preceding chapters can be seen together and is arranged first by issue, rather than by commentator. Arrangement by commentator still appears though in a secondary way. Briefly reviewing how the issues have been addressed offers guidance for future investigation of the issues.

Another matter addressed in this chapter is how a new investigation of the identity of the witnesses might look. After reviewing how the studied commentators arrange their argumentation, I propose a research plan that includes the main issues and some of the seemingly lesser issues. Because of the delimitation of discussing only common issues of 
interpretation, however, the plan is not exhaustive. Nevertheless, what is included are the essential issues necessary for an adequate engagement with the debate over the identity of the witnesses.

In discussing the various broad issues of interpretation, I have tried in a general fashion to go from those that are most common to those that are least common. I do not do this rigidly, however, since the mention of one issue may naturally suggest mentioning other issues. Table 5 (see the next two pages) shows the issues shared among the nine commentators in the order in which the issues are first discussed.

\section{The Common Broad Issues Discussed}

Interpretive Approach

Each commentator has something to say that pertains to an interpretive approach to Revelation. Again, an interpretive approach is a broad outlook on how the contents of the book relate to history. Haugg and Tan explicitly address the issue of approach in their focused studies on the two witnesses. ${ }^{1}$ Beckwith, Beale, and Müller are also explicit in their discussions, but the context for the discussions is the total study of Revelation. ${ }^{2}$ Todd, Munck, van de Kamp, and Maier implicitly address the issue. Hints in their texts reveal where they stand. ${ }^{3}$ The choices adopted on this question vary. Haugg and Tan

${ }^{1}$ Haugg, Die zwei Zeugen, 65-71, 120-137; and Tan, "Defense," 10-129 passim.

${ }^{2}$ Beckwith, Apocalypse, 334-336; Beale, Book of Revelation, 20-21, 25-26, 44-49, 116-145, 152-170; and Müller, Der Erste und der Letzte, 41-42.

${ }^{3}$ Todd, Six Discourses, 3-45, 49-80, 83-85; and Munck, Petrus und Paulus, 7-16. For van de Kamp, notice his discussion of Rev 1:19 at Kamp, Openbaring, 85-86. Also, consider his treatment of history in his exposition of Rev 11:1-13 and 12:1-17 at ibid., 252-274, 280-305. For Maier, note Maier, Kapitel 1-11, 15, 43-44, 51-52, 80-81, 87-88, 128-129, 258; and Maier, Kapitel 12-22, 489, 494. 


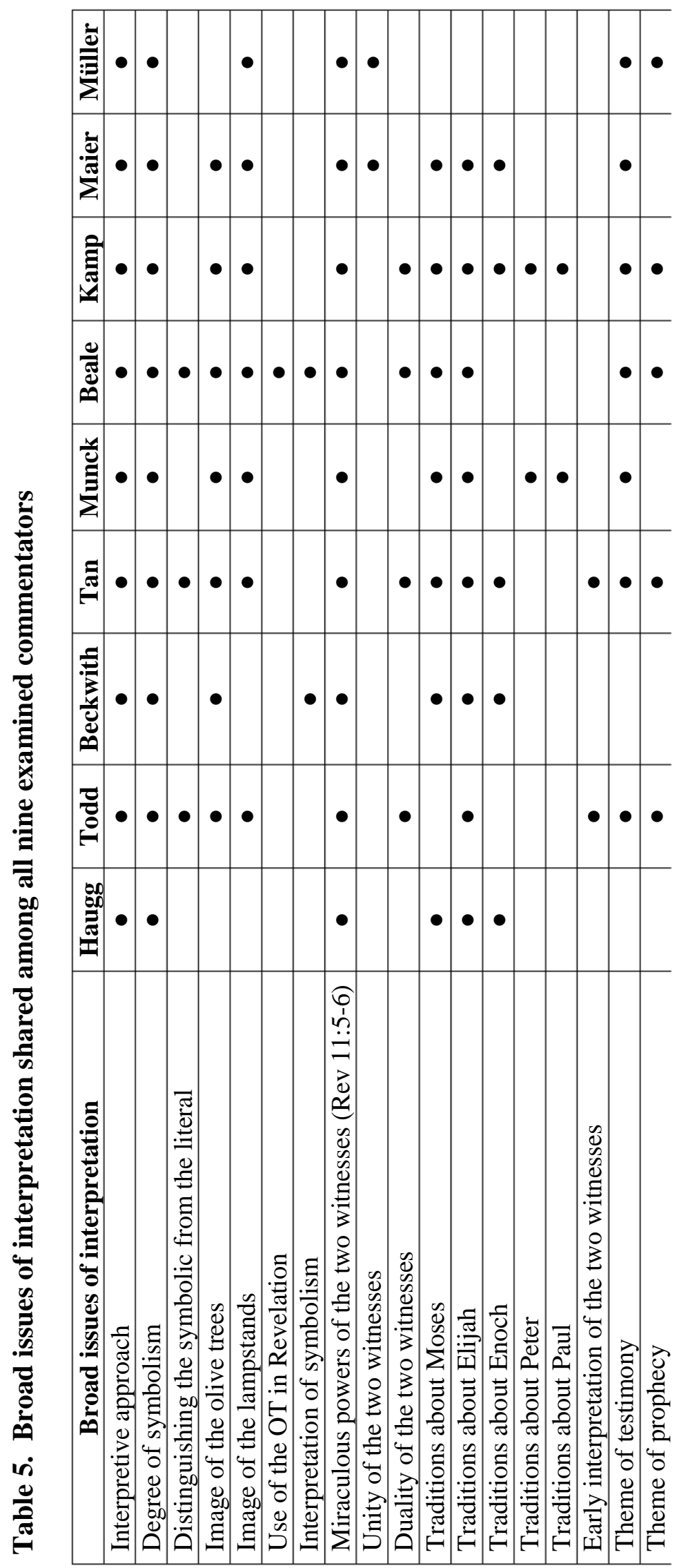




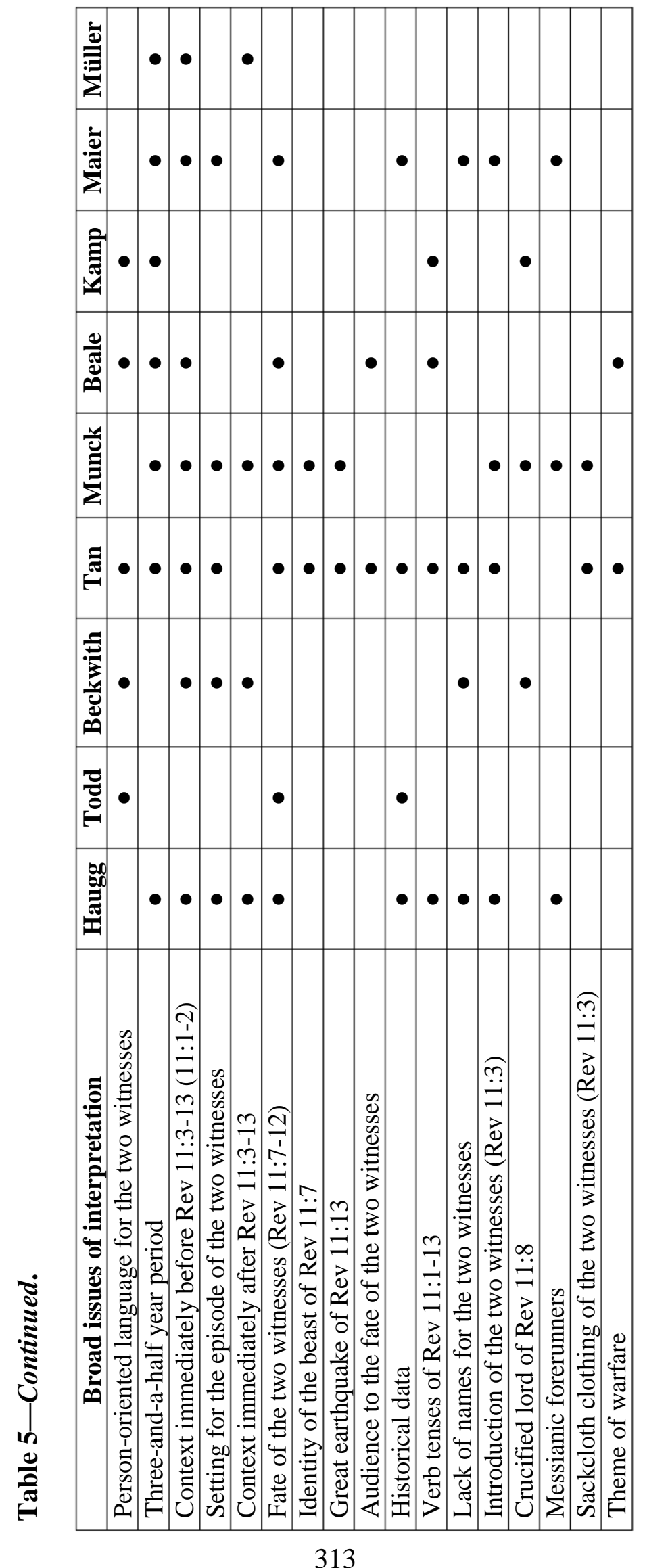


consider themselves proponents of an eschatological approach. Todd might also be considered as such. Beckwith considers a contemporary-historical approach as the proper one. Munck would likely agree. Müller considers himself a historicist. Beale presents himself as espousing an eclectic approach that is based on idealism. Van de Kamp would likely agree with Beale. Maier, on the other hand, though explicitly open to various approaches, has an approach that is clearly based on futurism. One wonders, however, if they are not all technically eclectic in their approaches. For instance, terming Haugg a futurist goes only so far. Haugg acknowledges that portions of Revelation, particularly the letters relate to contemporary-historical matters. Alternatively, consider Beckwith. While he emphasizes the contemporary-historical grounding of the prophecies of Revelation, he acknowledges that the author looks to the future beyond the time of composition. Perhaps, therefore, it is more helpful to say that each of these commentators is eclectic with particular emphases or bases to their approaches.

In any case, the more pertinent question than the value of labels for the different approaches is how the issue relates to identifying the two witnesses. Clearly, an approach to the whole of Revelation has a potential influence on how one approaches a particular aspect of the book. The relevance of the issue is without question. Also clear is that answers to this issue can affect the placement of the witnesses within history. Are they entities of the era of John or of a future time, even one quite distant from his era? Equally clear from the expositions examined in this study, however, is that the choice of an approach to the book does not absolutely determine whether the witnesses are figures of the era of John or figures future to his position in time. The choice of an approach is only a potential influence on the identity of the witnesses. Other factors must be 
considered in order to place the witnesses within history. This circumstance is most readily apparent when one looks at the expositions of Beckwith and Munck. Both can be seen as proponents of a contemporary-historical approach, or at least one that has a contemporary-historical emphasis. The determination of where the witnesses exist in time, however, is not the same. Beckwith locates the witnesses in the author's future, while Munck associates the witnesses with people and events in the near past to the composition of Revelation.

The Degree to Which Symbolism Plays Role

The argumentation of all the commentators studied here leads to another important issue involving a preconception about Revelation. All of them raise the issue of the degree to which symbolism plays a role in Revelation, but they do so in different ways. Haugg shows an openness to the presence of symbolism in Revelation, perhaps even seeing symbolism as the main means of communicating the meaning of the contents of the book. ${ }^{4}$ Furthermore, he puts a number of figurative views of the witnesses in opposition to a literal view of them. ${ }^{5}$ Todd premises his study of passages in Revelation on the idea that the literal text takes primacy in discerning the meaning of the contents of the book. ${ }^{6}$ Although not explicit, Todd pits figurative views of the witnesses against a literal view of them. ${ }^{7}$ He also takes the extra step of speaking about ways of

\footnotetext{
${ }^{4}$ Haugg, Die zwei Zeugen, 6, 120, 124.

${ }^{5}$ Ibid., 112-113.

${ }^{6}$ Todd, Six Discourses, v-xx.

${ }^{7}$ Ibid., 191-205.
} 
distinguishing symbolic elements in Revelation from literal ones. ${ }^{8}$ Beckwith seems to believe that symbolism plays a major role in presenting the meaning of the contents of Revelation. ${ }^{9}$ He offers brief remarks on how to interpret the symbolism in the book. ${ }^{10}$ He also comments on figurative understandings of Rev 11:1-13 and of the two witnesses in particular, while maintaining his own literal view of the latter. ${ }^{11}$ Tan upholds the idea that the literal text takes primacy in discerning the meaning of the contents of Revelation. ${ }^{12}$ She also criticizes numerous figurative views of the witnesses, while maintaining a literal view of them. ${ }^{13}$ She too takes the extra step of speaking about ways of distinguishing symbolic elements in Revelation from literal ones. ${ }^{14}$ Munck shows an openness to seeing major entities in Revelation as symbolic through the choices that he makes in interpreting facets of Rev 11:1-13. ${ }^{15}$ Moreover, while he focuses his criticism on other literal views of the witnesses, he does acknowledge at least the existence of symbolic views. ${ }^{16}$ Meanwhile, Beale dismisses literal views of the witnesses and argues

${ }^{8}$ Ibid., xix-xx, 194-196.

${ }^{9}$ Beckwith, Apocalypse, 249-255.

${ }^{10}$ Ibid., 249-250.

${ }^{11}$ Ibid., 585-586, 596.

${ }^{12}$ Tan, "Defense," 61-62, 87, 115, 117, 130.

${ }^{13}$ Ibid., 55-56, 58-78, 87-93, 104-114.

${ }^{14}$ Ibid., 62, 130-131.

${ }^{15}$ Munck, Petrus und Paulus, 17-49 passim.

${ }^{16}$ Ibid., 8-13. 
extensively for a symbolic interpretation. ${ }^{17}$ In fact, he premises his whole study of Revelation on the idea that symbolism plays a major role in presenting the meaning of the contents of the book. ${ }^{18}$ He goes further though by offering guidelines for identifying the symbols in Revelation and for interpreting them. ${ }^{19}$ Van de Kamp shows a clear openness to the presence of symbolism in Revelation, perhaps even seeing symbols as the main means of communicating meaning in the book. ${ }^{20}$ Maier shows an openness to seeing major entities in Revelation as symbolic through the choices that he makes in interpreting facets of Rev 11-13. ${ }^{21}$ His main discussion of the identity of the witnesses puts literal views in opposition to symbolic views. ${ }^{22}$ Müller gives primacy to symbolism for revealing the meaning in the contents of Revelation. ${ }^{23}$ Moreover, while he focuses his criticism on an alternative symbolic view of the witnesses, Müller does acknowledge at least literal views of them. ${ }^{24}$

Like the issue of the proper interpretive approach, there is no question of the relevancy of the issue of the degree to which symbolism plays a role in Revelation. Answers to this issue can undoubtedly affect one's identification of the two witnesses.

\footnotetext{
${ }^{17}$ Beale, Book of Revelation, 572-608 passim.

${ }^{18}$ Ibid., 50-69.

${ }^{19}$ Ibid., 55-58.

${ }^{20}$ Kamp, Openbaring, 42-43, 48-49, 281; cf. 35-36.

${ }^{21}$ Maier, Kapitel 1-11, 451-506 passim; and Maier, Kapitel 12-22, 15-125 passim.

${ }^{22}$ Maier, Kapitel 1-11, 470-472.

${ }^{23}$ Müller, Der Erste und der Letzte, 44.

${ }^{24}$ Ibid., 209.
} 
The clearest divide among interpretations of the witnesses is over whether they are a symbol. From the expositions presented, however, it is likewise evident that one's determinations concerning the degree to which symbolism plays a role in Revelation do not necessarily decide whether the witnesses are a symbol. The conclusions regarding the degree of symbolism in Revelation are only a potential influence on the identity of the witnesses. Other factors must be considered in deciding whether the witnesses are a symbol. The exposition of Beckwith shows this most clearly. His study of Revelation is premised on the primacy of symbolism in communicating the meaning in the contents of the book. This preconception about the book does not preclude him from interpreting the two witnesses as literal figures.

Distinguishing the Symbolic from the Literal

The issue of the degree to which symbolism plays a role in Revelation suggests another issue. As already intimated above, Todd, Tan, and Beale address the issue of distinguishing the symbolic from the literal in Revelation. Even though most of the commentators studied do not say anything about this issue, or simply say a little, this issue still seems to be important and relevant to the debate over the identity of the witnesses. Probably no commentator would say that there is no symbolism at all in Revelation. Thus, addressing this issue in some way must occur for an adequate interpretation. As noted, determinations about the degree of symbolism in Revelation do not necessarily lead to a particular perspective on the witnesses. Other grounds must be given. Actual guidelines for determining whether something is a symbol are able to function as one of those other grounds. 
The Image of the Olive Trees, the Image of the

Lampstands, Use of the OT, and How to Interpret Symbolism

The two witnesses are related to the image of olive trees and the image of lampstands in Rev 11:4. Discussion of these motifs plays a role in the works of most of the commentators examined.

Although not all the commentators studied relate the image of the olive trees to their argumentation about the identity of the witnesses, all of them do recognize a literary relationship between the olive trees in Rev 11:4 and those in Zech $4 .{ }^{25}$ Although not all the commentators examined speak about the image of the lampstands in their argumentation about the identity of the witnesses, all but Maier affirm a literary relationship between the two lampstands in Rev 11:4 and the single lampstand in Zech $4{ }^{26}$ These facts indicate that Zech 4 may play an important role in understanding the image of the olive trees and the image of the lampstands, regardless of how that understanding influences one's answer to the identity question.

Determining the exact role that Zech 4 plays in understanding the images of Rev 11:4 requires that another issue be addressed, namely, how John uses the OT in Revelation. Its presence is not completely absent from the commentators examined.

\footnotetext{
${ }^{25}$ See Haugg, Die zwei Zeugen, 16-17; Todd, Six Discourses, 181-185, 192-194; Beckwith, Apocalypse, 593, 595, 600; Tan, "Defense," 56, 59, 77, 135; Munck, Petrus und Paulus, 20-21; Beale, Book of Revelation, 576-579; Kamp, Openbaring, 258-259; Maier, Kapitel 1-11, 464-466; and Müller, Der Erste und der Letzte, 213-214.

${ }^{26}$ See Haugg, Die zwei Zeugen, 16-17; Todd, Six Discourses, 181-185; Beckwith, Apocalypse, 593, 600; Tan, "Defense," 90, 108; Munck, Petrus und Paulus, 20-21; Beale, Book of Revelation, 574, 576-579; Kamp, Openbaring, 258-259; and Müller, Der Erste und der Letzte, 214-215. Maier denies the connection at Maier, Kapitel 1-11, 465.
} 
Beale offers an extensive discussion of the issue and his conclusions affect other parts of his interpretive framework. ${ }^{27}$ Yet, the issue is not brought to bear directly on the identity question. Its influence is indirectly felt in those places where Beale discusses allusions to specific OT texts (Zech 4, Ps 79, and Ezek 37). ${ }^{28}$ Haugg, Beckwith, van de Kamp, and Müller also remark briefly on this issue, but their thoughts were not mentioned previously because they do not have any obvious connection to their arguments about the identity of the witnesses. ${ }^{29}$

The matter of how John uses the OT is a topic that has received more attention among scholars since the 1980s. ${ }^{30}$ The topic is complex by itself. Scholars have not always agreed about different aspects of the topic. It has its own debate. In light of this, I am not suggesting that those who engage in the debate over the identity of the two

${ }^{27}$ Beale, Book of Revelation, 76-99.

${ }^{28}$ Ibid.

${ }^{29}$ Haugg, Die zwei Zeugen, 83-86; Beckwith, Apocalypse, vii-viii, 174, 221-222; Kamp, Openbaring, 45; and Müller, Der Erste und der Letzte, 43.

${ }^{30}$ For detailed reflections on seven key studies from the 1980s and the first half of the 1990s, see Gregory Kimball Beale, John's Use of the Old Testament in Revelation, Journal for the Study of the New Testament Supplement Series 166 (Sheffield, United Kingdom: Sheffield Academic Press, 1998), 13-59. For a detailed look at the history of investigating the relationship between the OT and Revelation, see Ricardo Antonio Pérez Márquez, L'Antico Testamento nell'Apocalisse: Storia della ricerca, bilancio e prospettive, Studi e ricerche, Sezione biblica (Assisi: Cittadella Editrice, 2010), 123-305. Pérez Márquez covers research in the twentieth century and in the first decade of the twenty-first century. His coverage of the first decade of the twenty-first century, however, is marked by some noticeable absences. For instance, he does not comment on Beate Kowalski, Die Rezeption des Propheten Ezechiel in der Offenbarung des Johannes, Stuttgarter biblische Beiträge 52 (Stuttgart: Verlag Katholisches Bibelwerk, 2004); or Vesa Marko Jauhiainen, The Use of Zechariah in Revelation, Wissenschaftliche Untersuchungen zum Neuen Testament, ser. 2, 199 (Tübingen: Mohr Siebeck, 2005). 
witnesses must first become participants in the debate over John's use of the OT. What I am suggesting is that such interpreters must become familiar with the debate and form their own conclusions. Once formed, these conclusions can then be brought to bear directly on the identity question and so shape the discussions that involve looking at OT texts.

What might be helpful is an example of where a resolution to the issue of how John uses the OT could help in interpreting the two witnesses. Tan and Beale both agree that the olive trees in Zech 4 originally referred to Zerubbabel and Joshua, the two local leaders in Zechariah's time. ${ }^{31}$ Tan argues that the original reference to two individuals should be carried over to Rev 11:4, so that the two witnesses refer to two individuals. ${ }^{32}$ Beale, on the other hand, sees no difficulty in disassociating the olive trees in Rev 11:4 from two individuals. ${ }^{33}$ It is granted that Beale offers arguments to support his view of the transformation from the two individuals of Zech 4 to the corporate entity of Rev 11:4. Specifically, he refers to the transference of royal and priestly functions, which are represented by Zerubbabel and Joshua in Zech 4, to the church, citing Rev 1:6; 5:10; and 20:6. Moreover, he refers to transformations of the meaning of the olive trees present in ancient Jewish literature. Yet, Beale would have no reason to offer such support unless he was already comfortable with the possibility that John comprehends the two olive trees in Zech 4 as a corporate entity. The gateway for Beale's supporting points is his

\footnotetext{
${ }^{31}$ Tan, "Defense," 56, 59, 77n321, 135; and Beale, Book of Revelation, 577.

${ }^{32}$ Tan, "Defense," 56, 77, 135.

${ }^{33}$ Beale, Book of Revelation, 577-578.
} 
view of how John uses Zech 4, which in turn has to do with his broader view of how John uses the OT. Arguably, something similar is conceivable for Tan's thinking.

The term for lampstands $(\lambda v \chi v i ́ \alpha)$ appears not just in Rev 11:4, but also 1:12-13, $20 ; 2: 1,5$. These other occurrences are all in reference to seven golden lampstands that appear in the initial vision of John. Rev 1:20 expressly identifies the seven lampstands with the seven congregations that form the immediate audience for the book of Revelation (see Rev 1:4, 11). The relationship between the lampstands in Rev 11:4 and the seven lampstands earlier in Revelation is central to the discussion of the image of the lampstands among most of the commentators examined. On one side, there are those (Beale and van de Kamp) who infer that the two witnesses as two lampstands have to do with the church, because the seven congregations are symbolized as seven lampstands earlier in Revelation. ${ }^{34}$ On the other side, there are those (Todd, Tan, and Müller) who argue against such a connection between the two sets of lampstands. ${ }^{35}$ These facts suggest the need for future discussion of the lampstand image to include a discussion of the relationship between the image of the lampstands in Rev 11:4 and the image of lampstands elsewhere in Revelation.

The discussion that occurs in many of the examined expositors concerning the

${ }^{34}$ Ibid., 55-56, 574, 577; and Kamp, Openbaring, 259, 264. Maier's reference to Rev 1-2 is qualitatively different from those in Beale and van de Kamp. Maier refers to the earlier lampstands as one of several references that associate light with God's people. He does not follow Beale and van de Kamp as highlighting the previous association (lampstand points to congregation) as grounds for seeing a renewal of that association in Rev 11:4. See Maier, Kapitel 1-11, 465.

${ }^{35}$ Todd, Six Discourses, 192-194; Tan, "Defense," 90, 108; and Müller, Der Erste und der Letzte, 214, 223-224. 
relationship between these two sets of lampstands points to another issue of interpretation. This issue has already been intimated in discussing the issue of the degree to which symbolism plays a role in Revelation. It is the general matter of how to interpret symbols in Revelation. Obviously, this issue is more relevant for those who see Revelation as a book filled primarily with symbolism. Having taken a stance on the degree of symbolism in Revelation, having then distinguished symbolic elements from the literal ones, it makes sense to follow these steps by applying guidelines for interpreting the symbolic elements. Being an extensive commentary on Revelation, it is not surprising that Beale's work contains remarks concerning all three issues. Arguably, even though not explicit, each commentator studied has in place some guidelines for interpreting symbols in Revelation. They would not be able to say anything, for example, about the meaning of the lampstands unless some guidelines were assumed.

The image of the lampstands and the image of the olive trees are agreed upon as being symbols. Even those who are predisposed to seeing literalism as dominant in Revelation do not take the witnesses for literal trees or literal lampstands. Each commentator studied — and arguably every serious commentator, no matter the stance taken on the degree of symbolism in Revelation — has distinguished these two elements as being symbols. With respect to these elements of Rev 11:3-13, each of the commentators studied must have in mind, stated or unstated, some guidelines for dealing with the images. It is a given, however, that differences may appear among interpreters even though the guidelines are shared. ${ }^{36}$

${ }^{36}$ The discussion of the image of the lampstands offers illustration. Differences on the relationship between the seven lampstands of Rev 1-2 and the two lampstands of 
The Miraculous Powers of the Two Witnesses

Another issue of interpretation is the miraculous powers of the two witnesses

detailed in Rev 11:5-6. All of the studied commentators have something to say about the powers of the witnesses, particularly that they allude to miracles attributed to Moses and Elijah. ${ }^{37}$ The degree to which they bring their discussions of the miraculous powers into their argumentation varies. On the one hand, there is Haugg, with his simple denial of the Moses-Elijah view in spite of the apparent connection between Rev 11:5-6 and the

Rev 11:4 do not appear to be due to different principles of interpreting symbolism. Beale says, "Sometimes John explains his implied metaphors by giving explicit identifications of an image following visionary depictions of them. Where he does not, the immediate and broad context of the book is the most important factor in determining which meanings are intended. Where he does give such an explicit identification and repeats the image later in the book without such identification, it should be assumed that the early identification probably holds true for the later use of the image or is at least included." Beale, Book of Revelation, 55-56; cf. 574, 577. Beale uses these guidelines to say that the lampstands in Rev 1-2 and those in Rev 11:4 both refer to the church. Todd, Tan, and Müller, on the other hand, all argue that the two sets of lampstands cannot both refer to the church, even though they are probably open to the two sets lampstands sharing some points of comparison. It is hard to conceive of these three as disputing Beale's stated guidelines. They do not deny that the earlier, explicit identification of an image likely "holds true for the later use of the image or is at least included." They recall, however, that this is only a likelihood. The possibility exists for an earlier, explicit identification not to be repeated in a later appearance of a particular image. They argue that this is the case with the lampstands of Rev 11:4, because different circumstances surround each appearance of the image of the lampstands. Consequently, these three commentators simply have a different emphasis from Beale. He emphasizes the previous, explicit identification, while they stress the surrounding circumstances for each instance of the image.

${ }^{37}$ See Haugg, Die zwei Zeugen, 17-20, 83, 113-114, 133-134; Todd, Six Discourses, 185-186; Beckwith, Apocalypse, 593-595, 600-601; Tan, "Defense," 49-52, 57-58, 60, 64, 70-71,75-77, 90-92, 108-110, 123-124, 128, 133-134, 137-138, 189-191, 199-200, 212-213; Munck, Petrus und Paulus, 21-24; Beale, Book of Revelation, 573, 575, 580-584; Kamp, Openbaring, 260-261; Maier, Kapitel 1-11, 466-472; and Müller, Der Erste und der Letzte, 219-221. 
stories of Moses and Elijah. ${ }^{38}$ On the other hand, there is Tan, who brings up the miraculous powers several times in her argumentation against non-futuristic readings of Rev 11:3-13. ${ }^{39}$ Tan also refers to the powers in her presentation of the debate among futurists over a more specific literal identity. ${ }^{40}$

The Unity and the Duality of the Witnesses

One observation common to some of the studied commentators is that the same miraculous powers are assigned to each of the witnesses. ${ }^{41}$ The powers are held in common. There is no distribution of the powers of Moses to one witness and the powers of Elijah to the other witness. Maier takes matters further and raises the issue of the unity of the two witnesses. The powers are just one element that is assigned to both witnesses. Maier observes,

"[The witnesses] have the same task, the same duration for their work, the same authority, the same miraculous power, the same weapons ('fire from their mouth'), the same characterization ('olive trees' and 'lampstands'), [and] the same universality. It is impossible to allot anything to them individually." 42

Müller seems to go even further than Maier does by arguing,

${ }^{38}$ Haugg, Die zwei Zeugen, 113-114, 133-134.

${ }^{39}$ Tan, "Defense," 49-52, 57-58, 60, 64, 70-71, 75-77, 90-92, 108-110, 133-134.

${ }^{40}$ Ibid., 189-191, 199-200, 212-213.

${ }^{41}$ Beckwith, Apocalypse, 595; Munck, Petrus und Paulus, 21; and Beale, Book of Revelation, 575. Tan also mentions this idea, but she does so in the context of her survey of the debate over a more specific literal identity for the witnesses. Tan, "Defense," 191, 200.

${ }^{42}$ Maier, Kapitel 1-11, 471; cf. 466, 468-469. 
"In addition to their joint action and fate, the text supplies us with an interesting and important detail. Nouns that are connected with the two witnesses are often found in the singular and not in the plural. This change from plural to singular emphasizes the fact that the two witnesses always appear together." 43

Although the wider issue of the unity of the two witnesses appears with only two of the expositors, it still seems to be an important issue. Addressing this issue shapes how one addresses the more evident issue of the duality of the witnesses. For the latter issue, Todd and Tan on the one hand stress the literalness of the duality, while Beale and van de Kamp explain the duality in a figurative way. ${ }^{44}$ It appears relevant to both sides of this divide to address the duality and the unity found in the figure of the witnesses.

Traditions about Moses, about Elijah, and about Enoch

Bringing attention to the issue of the powers of the witnesses brings into view the separate issues of traditions about Moses and traditions about Elijah. The studied commentators agree that the miraculous powers have connections to miracles attributed to Moses and Elijah. The connections here have suggested to interpreters that other connections may exist between the narrative of the witnesses and matters associated with Moses and Elijah. Todd explores connections between the tale of the witnesses and the expectation expressed in the Bible that Elijah will return. ${ }^{45}$ Tan only presents what other interpreters have said as they debate whether the Moses-Elijah identification is biblically

${ }^{43}$ Müller, Der Erste und der Letzte, 220.

${ }^{44}$ Todd, Six Discourses, 191-192; Tan, "Defense," 55-56, 69, 77, 113, 134-137; Beale, Book of Revelation, 575; and Kamp, Openbaring, 259, 264.

${ }^{45}$ Todd, Six Discourses, 210-212. 
valid. ${ }^{46}$ Many of the studied expositors address this possibility of other connections by discussing whether John has further developed Jewish expectations of Moses and Elijah returning to earth. ${ }^{47}$

Beckwith and Beale answer this last question positively, even though the details of their discussions differ. These two, however, do not see an unaltered adoption of the expectations. Beckwith envisions an apocalyptic source that presents a personal return of Moses and Elijah. John transforms the coming figures into ones merely like them. Beale envisions there being expectations of a return of both figures that John accepts as fulfilled in the appearance of the Christian church. With these two expositors, it is also difficult to see their discussions about adopted expectations as being expressly related to the identity question.

Haugg, Maier, Munck, and van de Kamp answer the question negatively. Haugg and Maier find no evidence of an expectation of an eschatological role for Moses that John might have worked with in Rev 11. Munck disputes Jeremias's proposal that John brought into his work the expectations of Elijah and Moses coming back to earth to suffer. Van de Kamp agrees that there is evidence for expecting the return of Elijah, but finds nothing expressing that Moses and Elijah return together. With their negative answers, these commentators remove possible grounds for arguing that the witnesses represent Moses and Elijah.

${ }^{46}$ Tan, "Defense," 189, 191-195, 200-214.

${ }^{47}$ Haugg, Die zwei Zeugen, 89-93, 102-105; Beckwith, Apocalypse, 585-588, 593595; Munck, Petrus und Paulus, 81-120; Beale, Book of Revelation, 582, 585; Kamp, Openbaring, 261-262; and Maier, Kapitel 1-11, 471. 
One may also speak about traditions concerning Enoch. This issue arises because of the strong church tradition of seeing Enoch as one of the witnesses. Like her presentation of traditions concerning Moses and Elijah, Tan deals with what other interpreters have said as they debate whether Enoch is one of the witnesses. ${ }^{48}$ The other studied commentators who also address the issue of Enoch traditions do so from the perspective of whether points of contact exist between the traditions and the text of Rev 11:3-13. They answer the question negatively, seeing little that connects the figure of Enoch to Rev $11 .^{49}$

Examining the traditions of Moses and Elijah, beyond the more obvious connections in Rev 11:5-6, would seem to be quite relevant. Additional connections between Rev 11:3-13 and the traditions of Elijah and of Moses could function as evidence for the Moses-Elijah view of the witnesses. That view is a popular modern proposal, so that serious participation in the debate over the identity of the witnesses may well require looking at this possible avenue of evidence. Most of the studied expositors appear to take it as a requirement inasmuch as they all discuss traditions about Moses and about Elijah relative to their interpretations of Rev 11:3-13.

Examining traditions about Enoch is critical for proving or disproving the EnochElijah identification of the witnesses, since any markers in the text for Enoch are less obvious than those for Moses and for Elijah. The issue of traditions about Enoch is relevant to the degree that one takes the Enoch-Elijah view as a serious option. Since the

${ }^{48}$ Tan, "Defense," 196-199.

${ }^{49}$ Haugg, Die zwei Zeugen, 89, 98-102, 113-114, 133; Beckwith, Apocalypse, 595; Kamp, Openbaring, 261-262; and Maier, Kapitel 1-11, 471. 
Enoch-Elijah view has so few serious advocates in modern times, some might question the usefulness of spending time dealing with it. If one does not address the view, there is no need to address the issue of traditions about Enoch, at least from the perspective of discovering the identity of the witnesses. ${ }^{50}$ The issue is also relevant to the degree that one wants to interact with a view that was promoted with near unanimity for such a long time. Since so much effort was put into the Enoch-Elijah view in times past, one might feel that the view and so its critical connection to Enoch traditions deserve some mention. In any case, unlike some other issues, such as the traditions of Moses, there is more reason to question the relevancy of the issue for the identity question.

Traditions about Peter and Traditions about Paul Speaking about issues of traditions, one can notice that Munck makes use of traditions about Peter and traditions about Paul in order to support his proposal for the two witnesses. ${ }^{51}$ Van de Kamp responds specifically to this aspect of Munck's work. ${ }^{52}$ It must be remembered that the Peter-Paul view of the witnesses is an important proposal in the past debate over the two witnesses. When one considers specific identifications and looks just at the last hundred years or so, the Peter-Paul view dominates among those

\footnotetext{
${ }^{50}$ I recognize that one can look at Enoch traditions and Rev 11 from perspectives other than exegetically identifying the two witnesses. Particularly, I have in mind strictly tradition-historical endeavors that situate extra-biblical references to the return of Enoch and Elijah and the text of Rev 11 within the stream of eschatological thinking. Note, for example, Bousset, Der Antichrist; and Berger, Die Auferstehung des Propheten und die Erhöhung des Menschensohnes.

${ }^{51}$ Munck, Petrus und Paulus, 17-81 passim.

${ }^{52}$ Kamp, Openbaring, 262.
} 
looking to connect Rev 11 to John's era. This circumstance suggests that the issues of traditions about Peter and of traditions about Paul are quite relevant, even though van de Kamp is the only one of the examined commentators who responds to the proposal in any detail. $^{53}$

\section{Early Interpretation of the Witnesses}

Tan can be seen as appealing to traditions of a different kind to support her view on the witnesses. ${ }^{54}$ This phenomenon may also be present in Todd's argumentation. ${ }^{55}$ In any case, Tan refers to the early interpretation of the two witnesses as evidence for the proper view. Tan highlights that the witnesses were interpreted primarily as two individuals appearing in the future. Although aware that the majority of early interpreters saw Enoch and Elijah as those two, she does not highlight this aspect of the early history of interpretation of the witnesses. This is in keeping with the goal of her study to defend a general identification of the witnesses.

The issue of the early interpretation of the witnesses may be relevant, although addressed by only Tan and perhaps Todd. The issue is relevant to the degree that one

${ }^{53}$ It may be observed that Haugg recognizes the proposal as espoused by Juan de Mariana, but offers no further comment on it. See Haugg, Die zwei Zeugen, 122. Beale gives a flat denial of the Peter-Paul view, and for criticism of Munck he refers readers to Akira Satake, Die Gemeindeordnung in der Johannesapokalypse, Wissenschaftliche Monographien zum Alten und Neuen Testament 21 (Neukirchen-Vluyn, Germany: Neukirchener Verlag, 1966), 128-129. See Beale, Book of Revelation, 572. Müller recognizes the proposal, but quickly sets it aside along with other literal identifications when he asserts that Rev 11:3-13 is to be interpreted symbolically. See Müller, Der Erste und der Letzte, 209.

${ }^{54}$ Tan, "Defense," 170-186.

${ }^{55}$ Todd, Six Discourses, 205. 
sees the possibility of a connection between the early interpretation of the church and John's own understanding of the two witnesses. It is relevant as long as the possibility exists that John passed on his understanding of the two witnesses to the next generation.

The Themes of Testimony and Prophecy

All of the studied expositors say something about the themes of testimony and prophecy in interpreting Rev 11:3-13. ${ }^{56}$ This is not surprising given that the figures introduced in Rev 11:3 are presented as witnesses assigned to prophesy and as prophets assigned to testify $(11: 3,6-7,10)$. Most of the commentators connect their remarks on testimony and prophecy to the identity question. In a few of the instances where this occurs, however, the themes play only a secondary role in the discussion. Thus, Todd touches upon these two themes only as part of a larger issue of interpretation, namely, the person-oriented language used to describe the witnesses. Moreover, while these themes do function as primary issues of interpretation for Tan, Beale, and van de Kamp, the theme of testimony also plays a secondary role in their discussions of the duality of the two witnesses. Tan also discusses the themes of testimony and of prophecy secondary to her concern for the person-oriented language used to describe the witnesses. It is possible that the theme of prophecy plays a secondary role once for van de Kamp, when he seems to emphasize the personal nature of the witnesses. Yet, regardless of whether the discussion has one of these themes in a primary role or in a secondary role, treating

\footnotetext{
${ }^{56}$ See Haugg, Die zwei Zeugen, 14-15; Todd, Six Discourses, 191-192; Beckwith, Apocalypse, 590, 599-600; Tan, "Defense," 62-63, 131-133, 138-140; Munck, Petrus und Paulus, 17-19; Beale, Book of Revelation, 572-576; Kamp, Openbaring, 258-259, 262263; Maier, Kapitel 1-11, 462-463, 481; and Müller, Der Erste und der Letzte, 212-213, 215-216, 221-222.
} 
either topic mainly involves relating relevant terms in Rev 11 to occurrences of the same concept in literary contexts outside that chapter. The rest of Revelation, the rest of the NT, and even content from the OT serve as such contexts. Müller's treatment of the theme of testimony illustrates the phenomenon. Specifically, he relates the testimony terminology of Rev 11 to occurrences of the concept elsewhere in Revelation and elsewhere in the NT and then draws out implications for the identity question. The way in which many of the examined expositors treat these two themes suggests a procedural path for other researchers who plan on exploring these themes.

The Person-oriented Language Used to Describe the Witnesses As just noted, Todd, Tan, and perhaps van de Kamp highlight the personal nature of the witnesses. ${ }^{57}$ Beckwith and Beale also have this emphasis. ${ }^{58}$ Todd, Beckwith, and Tan, however, go further in their inferences than either Beale or van de Kamp. For the former three, it is not enough to say that the witnesses refer to real people as opposed to something impersonal, like sacred writings. These three believe that the person-oriented language used to describe the witnesses indicates that one is dealing with two actual people. They implicitly reject the idea that such a detailed description of two individuals can function as a symbol. Whether or not such a description can function as a symbol is therefore the key difference of opinion with respect to the person-oriented language. This division suggests the need to address another issue before dealing with the one concerning the person-oriented language. That prior issue has been noted already and is

\footnotetext{
${ }^{57}$ Todd, Six Discourses, 191-192; Tan, "Defense," 62-64, 131-134; and Kamp, Openbaring, 263.

${ }^{58}$ Beckwith, Apocalypse, 596; and Beale, Book of Revelation, 573.
} 
the distinguishing of the symbolic from the literal. Having in mind guidelines to distinguish between these two kinds of material permits one to address the fact that the witnesses are described as persons and to decide what that implies.

The Meaning of the Three-and-a-half-year Period

The witnesses are said to prophesy for 1,260 days, which is approximately three and a half years. For most of the studied expositors, the significance of this period plays a role in their argumentation about the identity of the witnesses. For all of them, however, the 1,260 days of $\operatorname{Rev} 11: 3$ are related in some way to the other three-and-ahalf-year periods mentioned in Revelation $(11: 2 ; 12: 6,14 ; 13: 5) .{ }^{59}$ All of them also observe that these periods derive from time periods found in the prophecies of Daniel. ${ }^{60}$ Of particular interest are the three-and-a-half "times" mentioned in Dan 7:25 and 12:7. These two facts suggest that these six other verses, the four from Revelation and the two from Daniel, may be important for understanding the meaning of the period of the witnesses' activity and so the identity of the witnesses.

More can be said about what aspects of the three-and-a-half-year period influence the argumentation of many of the studied expositors. Critical to Haugg's thoughts on the

${ }^{59}$ See Haugg, Die zwei Zeugen, 12; Todd, Six Discourses, 165, 171-172, 176-178, 248; Beckwith, Apocalypse, 181, 252, 591, 599-600, 624; Tan, "Defense," 68, 89, 142; Munck, Petrus und Paulus, 19; Beale, Book of Revelation, 566-567; Kamp, Openbaring, 256, 258, 313; Maier, Kapitel 1-11, 463; Maier, Kapitel 12-22, 18, 38, 64, 88-89; and Müller, Der Erste und der Letzte, 83, 180, 203n126, 211, 223, 368, 389n27, 445-446.

${ }^{60}$ See Haugg, Die zwei Zeugen, 12; Todd, Six Discourses, 179; Beckwith, Apocalypse, 181, 252; Tan, "Defense," 68, 89, 142; Munck, Petrus und Paulus, 19, 38n53; Beale, Book of Revelation, 565, 567; Kamp, Openbaring, 253-254, 256-257, 301302; Maier, Kapitel 1-11, 460; Maier, Kapitel 12-22, 64; and Müller, Der Erste und der Letzte, 41n43, 44, 180, 223, 363, 368, 407, 443, 445-446. 
identity question is the length of the period in actual history. For him, the 1,260 days refer to a period that is much narrower than the whole era of the church. ${ }^{61}$ Tan, Beale, van de Kamp, and Müller share a concern for some specificity in saying when the period of the witnesses occurs in the course of history. Tan argues for its placement within a particular future period of seven years. ${ }^{62}$ Beale and van de Kamp relate the period to the whole era of the church. ${ }^{63}$ Müller highlights a particular segment of the era of the church. ${ }^{64}$ Critical to Munck's thinking on the identity question is that the 1,260 days of the witnesses do not refer to an actual three-and-a-half year period of history. This is a premise shared with some of the other examined commentators. For Munck, the reference to the three-and-a-half years has a qualitative sense. It defines the nature of the time in which the witnesses are active. At the same time, it surely does not represent a long segment of time. Such a view of the 1,260 days is compatible with his proposed identification of the witnesses as Peter and Paul. ${ }^{65}$ Finally, Beale and Müller share a concern for the entities associated with the three-and-a-half year periods in the rest of

${ }^{61}$ Haugg, Die zwei Zeugen, 112.

${ }^{62}$ Tan, "Defense," 88-89, 142-165.

${ }^{63}$ Beale, Book of Revelation, 566-567, 639-640, 642-643, 646, 687-692, 694-695, 770-784; Kamp, Openbaring, 214, 219, 221, 256, 265-266, 269, 273, 281-284, 290-293, 300-301.

${ }^{64}$ Müller, Der Erste und der Letzte, 41n43, 44, 83, 180, 193, 195, 197n95, 203n126, 209, 211, 219, 223, 360, 363-364, 368-369, 389n27, 392, 407-408, 443-446.

${ }^{65}$ Munck, Petrus und Paulus, 19-20, 22, 37-38. 
Revelation and in Daniel. ${ }^{66}$ Both see an association of these periods with the people of God, but they diverge after that.

The Immediate Context before the Episode of the Witnesses (Rev 11:1-2)

For most of the studied commentators, the interpretation of Rev 11:1-2 plays a role in the argumentation over the identity of the witnesses. These, however, do not interact with the subject in the same way. Haugg contends that the sense of 11:3-13 coheres with that of 11:1-2, only when the witnesses are considered two concrete persons instead of a symbol. ${ }^{67}$ Beckwith and Tan dispute suggested interpretations of Rev 11:1-2 and thus cast doubt on the related interpretations of 11:3-13. ${ }^{68}$ Munck highlights thematic links between Rev 11:1-2 and 11:3-13 to commend further his proposal about the witnesses. ${ }^{69}$ Müller identifies the "holy city" (11:2) with the church and so doubts that the witnesses would also refer to the church. ${ }^{70}$ Haugg, Beckwith, Tan, and Müller also deal with the meaning of Rev 11:1-2 as a secondary issue. ${ }^{71}$ For Beale and Maier,

${ }^{66}$ Beale, Book of Revelation, 574; and Müller, Der Erste und der Letzte, 223.

${ }^{67}$ Haugg, Die zwei Zeugen, 112-113. For the actual detailed interpretation of Rev 11:1-2, see ibid., 3-13, 131-133.

${ }^{68}$ Beckwith, Apocalypse, 585-586; and Tan, "Defense," 38-41, 65-68, 76n314, 87, 93, 104, 106. Beckwith presents a detailed interpretation of Rev 11:1-2 at Beckwith, Apocalypse, 588-590, 596-599. Tan offers a general account of Rev 11:1-2 from a futurist perspective at Tan, "Defense," 121-122, 127.

${ }^{69}$ Munck, Petrus und Paulus, 47-49.

${ }^{70}$ Müller, Der Erste und der Letzte, 222-223.

${ }^{71}$ For Haugg, Beckwith, and Tan, the meaning of Rev 11:1-2 and the identity of the "great city" of 11:8 stand behind the issue of the place where the events of 11:3-13 occur. Haugg, Die zwei Zeugen, 11, 24-26, 33, 50, 55-56, 60-61, 69-71, 113, 118-120, 
the meaning of Rev 11:1-2 is strictly secondary to wider concerns. ${ }^{72}$

There is a common element in these varied interactions with the issue of the meaning of Rev 11:1-2. It is what makes the issue relevant for each of these commentators. Each interaction appears to operate from the assumption that the sense of 11:1-2 and that of 11:3-13 are closely linked. In other words, the meaning of one set of verses affects the meaning of the other set of verses. In practical terms, accepting this proposition and so accepting the relevancy of this issue of interpretation means that one's identification of the witnesses must be checked against a credible interpretation of Rev $11: 1-2$

The Setting for the Events of Rev 11:3-13

Linked at times to the meaning of Rev 11:1-2 is the general issue of the setting for the events of Rev 11:3-13. This is an issue of interpretation for five of the studied commentators.

Haugg sees a single "city" present in Rev 11:1-13, namely, the earthly Jerusalem. ${ }^{73}$ This is where the events of Rev 11:1-13 occur at the visionary level,

130-131, 136-137; Beckwith, Apocalypse, 586, 590-593, 599, 601-604; and Tan, "Defense," 92-93, 111-112. Müller joins Rev 11:1-2 to 11:3-13 to demonstrate a pattern that he contends is found elsewhere in Revelation. Müller, Der Erste und der Letzte, 225.

${ }^{72}$ In a couple of places, while dealing with particular allusions to the OT, Beale looks at Rev 11:1-13 as a whole. Beale, Book of Revelation, 577-578, 595. For Beale's detailed discussion of the meaning of Rev 11:1-2, see ibid., 557-571. Maier refers to his interpretation of Rev 11:1-2 in his discussion of the place where the events of 11:3-13 occur. Maier, Kapitel 1-11, 473. That interpretation appears at ibid., 456-461.

${ }^{73}$ Haugg, Die zwei Zeugen, 11, 24-26, 33, 50, 55-56, 60-61, 69-71, 113, 118-120, 130-131, 136-137. 
although not at the historical level. ${ }^{74}$ Many symbolic interpretations of the witnesses cannot mesh with this view of the place of action, leaving interpreters to turn to a literal identification of them. ${ }^{75}$ For Haugg, the primary issue in this part of his argumentation is the setting for the action, but the meaning of Rev 11:1-2 does function in a secondary role.

Beckwith and Tan also see the earthly Jerusalem as the single "city" portrayed in Rev 11:1-13. ${ }^{76}$ In contrast to Haugg, however, they see Jerusalem as the place where the events of Rev 11:1-13 occur also at a historical level. ${ }^{77}$ As with Haugg, certain symbolic interpretations of the witnesses are rendered suspect because they fail to account for this portrayal of the place of action. ${ }^{78}$ For Tan, the preterist identification of the witnesses as James, the brother of Jesus, and Peter is similarly rendered suspect. ${ }^{79}$ The primary issue for Beckwith and Tan in these portions of their argumentation is the setting for the events of Rev 11:3-13. Secondary is the meaning of Rev 11:1-2.

Munck sees more than one setting for the events of Rev 11:3-13. He argues that

${ }^{74}$ Ibid., 11, 60-61, 70-71, 113, 131, 136-137.

${ }^{75}$ Ibid., 113.

${ }^{76}$ Beckwith, Apocalypse, 586, 590-593, 599, 601-604; and Tan, "Defense," 92-93, $111-112$.

${ }^{77}$ Notice that Beckwith takes the additional step of seeing Jerusalem as representative of the whole of Israel. Beckwith, Apocalypse, 588-590.

${ }^{78}$ Ibid., 586; and Tan, "Defense," 92-93, 111-112.

${ }^{79}$ Tan, "Defense," 57-58. 
the "great city" of Rev 11:3-13 is Rome, not Jerusalem. ${ }^{80}$ Thus, one has the place where the ministry of the witnesses ends. Moreover, the text does not limit the actual ministry of the witnesses to the "great city." 81 This perspective on the setting for the narrative of 11:3-13 permits one to identify the witnesses with Peter and Paul. There is no secondary role for Rev 11:1-2 in this picture, since Munck deals with the "holy city" of 11:1-2 in a completely separate discussion. ${ }^{82}$

Maier is open to the possibility that there may be more than one setting for the events of Rev 11:3-13. He complements his symbolic view of the witnesses by arguing that the whole world is portrayed as the place where the witnesses minister. Their activity is not limited to Jerusalem, even though the "great city" might represent the earthly Jerusalem. ${ }^{83}$ If the "great city" is Jerusalem, the setting shifts at the end of the witnesses' activity from the whole world to a particular representative location. ${ }^{84}$ More likely though the "great city" represents the world in its hostility towards God. ${ }^{85}$ In this case, the setting of Rev 11:3-13 remains fixed on the whole world. In all this, the setting for the episode of the witnesses is the primary issue. The meaning of Rev 11:1-2 plays a secondary role inasmuch as Maier puts forth his view on where the witnesses minister opposite those who see Jerusalem as the "city" for the whole of 11:1-13.

\footnotetext{
${ }^{80}$ Munck, Petrus und Paulus, 30-35.

${ }^{81}$ Ibid., 20.

${ }^{82}$ Ibid., 48-49.

${ }^{83}$ Maier, Kapitel 1-11, 466, 469-470, 472-473, 476-481.

${ }^{84}$ Ibid., 477-478.

${ }^{85}$ Ibid., 478.
} 
For Haugg, Beckwith, and Tan, the identity of the "holy city" and of the "great city" helps determine the place of action for the events of Rev 11:3-13. Munck and Maier, on the other hand, separate the "holy city" from the "great city" and see the possibility of having the latter identified with one location and the place of the ministry of the witnesses with a wider venue. For all five commentators, thoughts on the setting for the events of Rev 11:3-13 allow for only certain identifications of the witnesses, thus showing the relevance of the issue for the identity question to these commentators. That relevance suggests the relevance of the issue for future discussion about the identity of the witnesses.

The Immediate Context after the Episode of the Witnesses (at least Rev 11:15-18)

There is another issue involving the literary context of 11:3-13 that appears with some of the studied commentators. Here the concentration is on what follows the episode of the witnesses, which includes at least the sounding of the seventh trumpet and what immediately follows (11:15-18). Here the commentators assume the sense of 11:3-13 and that of what follows are closely linked. This assumption causes the issue to be relevant for them.

In their thoughts on where the episode of the witnesses is to be located in history, Beckwith and Müller see significance in the episode being narrated before the sounding of the seventh trumpet. ${ }^{86}$ Although they differ on their interpretations of the seventh trumpet and on other aspects related to the timing of the witnesses' activity, Beckwith and

\footnotetext{
${ }^{86}$ Beckwith, Apocalypse, 274-275, 589-590, 606; and Müller, Der Erste und der Letzte, 180, 209.
} 
Müller agree that the episode of the witnesses occurs prior to the end of the present age, which is associated with the sounding of the seventh trumpet. For each of them, other data pinpoint the timing of the witnesses' activity more specifically.

Haugg likewise sees significance in the placement of the episode of the witnesses before the sounding of the seventh trumpet. This interest, however, is combined with an interest in the narrative of the witnesses being placed after the sounding of the sixth trumpet. ${ }^{87}$ For Haugg, it is important that the narrative of the witnesses stands between descriptions of events having to do with the end of the present age. The literary placement of the passage is suggestive of the place that the events described therein have in the course of history. The witnesses appear in the immediate course of events leading up to the end.

Munck handles the issue of the meaning of what follows Rev 11:3-13 differently from Haugg, Beckwith, and Müller. His focus is not on the timing of the witnesses in history, although his remarks do speak about it. Instead, Munck attempts to define the meaningful connection that he assumes exists between the episode of the witnesses and all the material that follows. ${ }^{88}$ He comes at this from his perspective on Rev 11:3-13 and thereby seeks to support the correctness of his proposal about the witnesses.

Considering what these four commentators say about the meaning of the content after Rev 11:3-13 suggests that what is necessary to address this issue and thereby to check one's identification of the witnesses is simply a general understanding of the

${ }^{87}$ Haugg, Die zwei Zeugen, 33, 61, 71-72, 75-79, 87, 112, 118, 130.

${ }^{88}$ Munck, Petrus und Paulus, 49-55. 
content following Rev 11:3-13. More detailed interpretations of content that appears especially linked to Rev 11:3-13 (e.g., Rev 12:6, 14; 13:5) can be left to the discussion of other issues of interpretation (e.g., the issue of the meaning of the three-and-a-half-year period).

The Fate of the Witnesses

An important issue of interpretation seems to be the fate of the two witnesses, namely, their death, resurrection, and ascension. Six of the studied commentators touch upon the fate of the witnesses in their arguments for a specific identification. None of them, however, does this in exactly the same way. Haugg essentially argues that, when the description of the death, resurrection, and ascension is properly understood, it indicates that the witnesses are two real people. ${ }^{89}$ Todd's point in speaking about the fate of the witnesses is that any interpretation of the witnesses, whether literal or figurative, must envision the "death" of the witnesses as an actual event as opposed to one that merely looks like a "death."90 A proper understanding of the "death" then leads to a proper understanding of the "resurrection" and the "ascension." Tan does not have a central focus to her remarks on the fate of the witnesses relative to their identity. Rather, she mentions the fate of the witnesses several times, as she pinpoints weaknesses in nonfuturist identifications of the witnesses. ${ }^{91}$ Munck speaks about the fate of the witnesses and related matters to show that the narrative of Rev 11:7-12 can function as a picture of

\footnotetext{
${ }^{89}$ Haugg, Die zwei Zeugen, 113.

${ }^{90}$ Todd, Six Discourses, 202-204.

${ }^{91}$ Tan, "Defense," 49, 60-61, 72-74, 76, 110-113.
} 
the fate of Peter and Paul. ${ }^{92}$ Beale and Maier draw inferences from the texts that they see underlying the narrative of the fate of the witnesses..$^{93}$

Beale and Maier agree that Ezek 37:5, 10 LXX furnish the language used to describe the resurrection of the witnesses in Rev 11:11. Some of the other studied commentators notice at least the verbal similarity between Rev 11:11 and Ezek 37:10. ${ }^{94}$ All this suggests that Ezek 37 may play an important role in understanding the fate of the witnesses and through this their identity. One is reminded of the importance of understanding how John uses the OT as a more fundamental issue in interpreting the two witnesses.

The Identity of the Beast in Rev 11:7 and the Meaning of the Great Earthquake

There are three issues of interpretation that concern at least two commentators and that relate to the fate of the two witnesses. Two of the three appear only in the works of Tan and Munck. Both commentators see the identity of the beast of Rev 11:7 as relevant in identifying the witnesses. Munck accepts the beast as antichrist and relates the symbol to the Roman state, which fits with the idea that the witnesses are Peter and Paul. ${ }^{95}$ In a couple of places, Tan simply finds problems with a proposed identity for the beast (in one case, Nero; in the other, Satan), which are then supposed to cast doubt on a related

\footnotetext{
${ }^{92}$ Munck, Petrus und Paulus, 24-43.

${ }^{93}$ Beale, Book of Revelation, 595-597; and Maier, Kapitel 1-11, 482-484.

${ }^{94}$ Haugg, Die zwei Zeugen, 30; Beckwith, Apocalypse, 603; Tan, "Defense," 63, 133-134; Kamp, Openbaring, 268; and perhaps Munck, Petrus und Paulus, 38.

${ }^{95}$ Munck, Petrus und Paulus, 24-30.
} 
proposal for the witnesses. ${ }^{96}$ In a couple of other places, Tan disputes the identification of the beast with Nero and thereby casts doubt on the notion of a first century CE fulfillment of the prophecy of the witnesses. ${ }^{97}$ Elsewhere, she promotes the identification of the beast with a future individual antichrist as one of her reasons for placing the fulfillment of the prophecy of the witnesses in the future. ${ }^{98}$ Although addressed by only two of the studied commentators, this issue still seems relevant inasmuch as only certain identifications of the beast and of the witnesses are congruent with each other. Of course, the identity of the beast in 11:7 presents its own set of questions. This could mean that only a tentative identification is possible for the beast. In that case, perhaps not too much weight should be put on identifying the beast in order to identify the witnesses.

Both Tan and Munck also mention the earthquake of Rev 11:13 in their argumentation. Tan disputes a couple of proposed views of the earthquake and its destruction and thereby casts doubt on either the notion of a first century CE fulfillment of the prophecy of the witnesses or a related proposal for the witnesses. ${ }^{99}$ Munck argues that the earthquake is not the end-time super earthquake prophesied in Ezek 38:19-20, but is actually a normal earthquake. ${ }^{100} \mathrm{He}$ is probably answering a possible objection to his proposal for the witnesses: If this is the end-time earthquake, then perhaps the witnesses are figures who appear just before the end of the present age. The connection between

\footnotetext{
${ }^{96}$ Tan, "Defense," 57, 71; cf. 12-17, 20-24.

${ }^{97}$ Ibid., 44-48, 52-53; cf. 12-17.

${ }^{98}$ Ibid., 166.

${ }^{99}$ Ibid., 53-54, 74-75; cf. 12-17, $20-24$.

${ }^{100}$ Munck, Petrus und Paulus, 43.
} 
the identity of the witnesses and the identity of the earthquake does not seem very strong. For that reason and for the fact that only two commentators mention the earthquake, the relevance of the earthquake for the interpretation of the witnesses seems low.

\section{The Audience to the Fate of the Witnesses}

Two of the studied commentators address in their argumentation a third issue related to the fate of the witnesses. ${ }^{101}$ This is the issue of the audience for the death, resurrection, and ascension. Tan disputes a localized interpretation of the audience, "those who dwell on the earth" (11:10, NASB), preferring to see them as the worldwide body of unbelievers. She presents this argument as a problem for the idea that the narrative of the witnesses refers to events in the first century CE. ${ }^{102}$ She returns to the issue of this audience in three other places and thereby casts doubt on related proposals for the two witnesses. ${ }^{103}$ Beale contends that the audience, being "those from the peoples, tribes, tongues, and nations" (Rev 11:9, cf. NASB) and "those who dwell on the earth" (11:10 NASB), represents the totality of those who are unbelievers. ${ }^{104}$ This speaks to the witnesses as being "visible throughout the earth," which implies to him that the

${ }^{101}$ Other of the studied commentators have something to say about the audience of the fate of the witnesses, but it is not brought into connection with the identity question. See Haugg, Die zwei Zeugen, 27, 29, 136; Beckwith, Apocalypse, 602-603; Munck, Petrus und Paulus, 36-38; Kamp, Openbaring, 266-268; Maier, Kapitel 1-11, 478-481; and Müller, Der Erste und der Letzte, 217.

${ }^{102}$ Tan, "Defense," 53.

${ }^{103}$ Ibid., 72-73, 76, 113.

${ }^{104}$ Beale, Book of Revelation, 593-596. 
witnesses are a corporate entity. ${ }^{105}$ He notices though that there are interpreters who simply point to modern technology and communication to explain the visibility of the witnesses to the whole world. ${ }^{106}$ Tan can be seen as one of those interpreters. ${ }^{107}$ Noticeably, therefore, Tan and Beale make similar observations, but end with different explanations for the worldwide visibility of the witnesses. The issue of the audience to the fate of the witnesses may be considered of low relevance because only two of the examined expositors make it a part of the identity question and because there is no clear reason for seeing a greater relevance.

\section{Historical Data}

Some of the commentators relate historical data to the identity question. They do this in four different ways. First, Todd, Tan, and Maier make a general reference to history to argue that the episode of the witnesses is an unfulfilled prediction. ${ }^{108}$ Second,

${ }^{105}$ Ibid., 574.

${ }^{106}$ Beale references as his example Hal Lindsey, There's a New World Coming: "A Prophetic Odyssey" (New York: Bantam Books, 1975), 151. So Beale, Book of Revelation, 574n299. Presumably, Beale objects to such a reading because of his interpretive framework, particularly his view of Revelation as book filled with symbolism and his understanding of what that entails. See ibid., 50-55.

${ }^{107}$ Tan, "Defense," 53.

${ }^{108}$ Todd, Six Discourses, 191; Tan, "Defense," 141; and Maier, Kapitel 12-22, 123. Technically, Maier does not offer this type of argument for Rev 11:1-14. Rather, the citation is to an argument concerning Rev 12-13. Yet, it seems appropriate to infer that the argument would also apply to Rev 11:1-14, because of the close relationship that Maier sees between Rev 11:1-14 and Rev 12-13. All these passages concern the same span of history, in Maier's opinion. See Maier, Kapitel 1-11, 463; and Maier, Kapitel 12$22,18,38,64,88-89$. Therefore, I have added Maier to Todd and Tan for this type of argument. 
Haugg, Todd, and Tan make more specific references to history and thereby expose incongruences between the biblical text and historical aspects of certain interpretations of Rev 11:3-13. ${ }^{109}$ Third, Tan makes specific references to history and thereby shows inconsistencies between the historical record and elements of certain interpretations of 11:3-13. ${ }^{110}$ Finally, Maier refers to a series of historical occurrences that he believes cast doubt on at least a particular identification, if not on a whole class of identifications. ${ }^{111}$

What is involved with this issue is more than simply talking about people and

${ }^{109}$ Haugg, Die zwei Zeugen, 113; Todd, Six Discourses, 196-204; and Tan, "Defense," 53-54, 57-58, 64-65, 72-73, 75-76, 105-107, 110, 112-113. Haugg can also be considered to have made this type of argument in a secondary or even tertiary way while investigating interpretive approaches to Rev 11:1-13. See Haugg, Die zwei Zeugen, 66-69, 121. In these pages, the references to 11:3-13 are mixed together with references to $11: 1-2$.

${ }^{110}$ Tan, "Defense," 49-53, 60-61, 74-75, 108-112. Haugg can be considered to have made this type of argument in a tertiary way while investigating interpretive approaches to Rev 11:1-13. See Haugg, Die zwei Zeugen, 67, 69-70. In these pages, the references to 11:3-13 are mixed together with references to 11:1-2.

${ }^{111}$ Maier, Kapitel 1-11, 472. Here specific data indicate that certain readings of Rev 11:3-13 in which Enoch and Elijah are the witnesses failed to become reality at the time of the Reformation. Maier then uses this historical data to deny the validity of at least the Enoch-Elijah view, if not a whole class of literal identifications. Elsewhere, however, his logic seems to go in an opposite direction. In a footnote just above, I infer that an argument involving Rev 12-13 applies also to Rev 11:1-14. If that inference is correct, Maier is affirming a futuristic reading of the narrative of Rev 11:3-13.

Moreover, his basis of affirmation would be general historical data that indicate that his reading of the episode has apparently yet to become reality. In this case, Maier is affirming one reading based on its failure to manifest generally. Yet, in the case of the Enoch-Elijah readings, he is denying them based on their failure to manifest specifically. Maier would seem to be in an odd position. On the one hand, he appears to recognize that both his reading of Rev 11:3-13 and the Enoch-Elijah readings of Rev 11:3-13 have failed to become reality. On the other hand, he follows this recognition by treating his reading differently from the other set of readings. From this perspective, arguing on the basis that a reading has not become reality is rendered meaningless. Maier is left with only different grounds to say that one reading is better than others are. Of course, all this depends on whether my inference is correct. 
events with which John and his initial audience were familiar. The discussion of the issue takes in historical data from beyond John's time, particularly after John's time. Moreover, each specific argument involving this issue seems premised on the idea that Revelation is referring to actual people and events. The perspective of the discussion is that the contents of Revelation reflect things actually happening and appearing within history, whether in the past, the present, or the future, relative to John. It is a perspective shared at least by Beale, van de Kamp, and Müller. ${ }^{112}$

Now one comes to the question of the relevancy of this issue of interpretation. If one limits oneself to discovering the exegetical identity of the two witnesses, can one really delve into a discussion of historical data that would not be readily recognizable to John and his initial audience? Tan and Maier can argue that Rev 11:3-13 is an unfulfilled

${ }^{112}$ This is clear in Beale, Book of Revelation, 48-49; and Müller, Der Erste und der Letzte, 41-42. For van de Kamp, it may be inferred from his actual exposition. Take, for instance, the broad span of the history of God's people that he associates with the content of Rev 12. Kamp, Openbaring, 280-305. The perspectives of Beckwith and Munck are not so straightforward. Beckwith locates material in Revelation, including the episode of the witnesses, in John's future, but not the distant future. This entails that much of Revelation remains unfulfilled, even though it is a genuinely prophetic book. That situation is not a problem for Beckwith, because of his particular outlook on biblical prophecy. For him, there need not be exact fulfillments of all the contents of the book. Consider Beckwith, Apocalypse, 291-304; cf. vi-vii, 239-240, 334-336. Munck's perspective on how the contents of Revelation relate to actual historical events is not clear. While he believes that the author had actual visions, it is unclear to what extent he believes that Revelation is a genuinely prophetic text. For instance, he does not address to what extent the episode of the witnesses reflects actual historical occurrences in the lives of Peter and Paul. While he argues for the historicity of the martyrdom of the two figures in Rome, he does not go beyond that. Moreover, while Munck sees that some of the contents of Revelation reflect the author's view of the future, there is no evidence for or against the idea that the predictions of Revelation must be fulfilled exactly or even the idea that those predictions speak genuinely about future events. Munck simply did not address some topics, whether implicitly or explicitly. On Revelation as stemming from actual visions, see Munck, Petrus und Paulus, 54, 71. 
prediction based on the failure to find a literal fulfillment in known history, but is that an exegetical argument? The historicists with which Todd and Tan debate can argue that Rev 11:3-13 is a prediction fulfilled at some point within church history, after the era of John, but is that an exegetical argument? Inasmuch as exegesis, as was defined in chapter 1, has to do with uncovering what authors meant by their writings, it would seem beyond the scope of exegesis to delve into a discussion of expectations being fulfilled after John's era has ended. It is one thing for Tan to argue that the two witnesses according to the text are two people unknown to John and his first readers who will appear in the end-time. It is another thing for her to contend that this will receive a fulfillment in the future, relative to herself. It is one thing for historicists to argue that the two witnesses according to the text symbolize two groups of God's people appearing during a time of crisis for God's people. It is another thing for them to contend that this has received a fulfillment in two specific groups of people during a specified period of church history, before their own time. To suppose that part of what the author of Revelation meant was to tell of events and people happening decades or even centuries after his era seems to run contrary to the impression that John expected the history of the present age to end soon, relative to himself. ${ }^{113}$

None of this is to say that a fulfillment will not come or has not come at some point distant from John's time. It seems within the greater realm of theological inquiry to pose the question of whether the two witnesses will appear in the commentator's future or have appeared in the commentator's past, but distant from John's time. Yet, it seems not to be a question of exegesis.

${ }^{113}$ This impression comes from at least Rev 1:1, 3; 2:16; 3:11: 22:6-7, 10, 12. 
Therefore, referring to historical data seems relevant to an extent. It is relevant for the identity question to determine whether historical data available to John and his initial readers has anything to say about the identity of the two witnesses. The issue need not be relevant only to those who interpret Rev 11:1-13 in a contemporary-historical way. It is conceivable that something from history could function simply as a model for the portrait of the witnesses, instead of the witnesses representing something from contemporary history.

The Verb Tenses of Rev 11:1-13

Some of the examined expositors relate the verb tenses of Rev 11:1-13 to the identity question. On the one hand, Haugg and Tan highlight the future tense of key (indicative) verbs in 11:2-3 to promote the idea that the witnesses appear in the distant future, relative to John. ${ }^{114}$ On the other hand, Beale and van de Kamp question this inference by highlighting the variety of verb tenses present in Rev 11:1-13. ${ }^{115}$ Although addressed by only a few of the examined expositors, settling who is right in the debate over the meaning of the tenses seems critical to being able to speak about the timing of the witnesses' activity.

\section{The Lack of Names}

Haugg, Beckwith, and Maier note the lack of names for the two witnesses in their argumentation over the witnesses' identity. Tan mentions the lack of names as being observed by those debating whether one can identify the witnesses with specific

${ }^{114}$ Haugg, Die zwei Zeugen, 112; and Tan, "Defense," 75, 140-141, 167.

${ }^{115}$ Beale, Book of Revelation, 572; and Kamp, Openbaring, 263. 
figures. ${ }^{116}$ Beckwith and Maier note specifically that the names of Moses and Elijah are not used, so that they may counter the Moses-Elijah view of the witnesses. ${ }^{117}$ Haugg suggests the lack of names rules out any naming of them. ${ }^{118}$ Although this is a small issue and one addressed by a few of the studied expositors, it remains relevant, bringing up a piece of information about the witnesses that needs some reckoning with by those who, on other grounds, would identify the witnesses with some known figures.

\section{The Introduction of the Witnesses}

Haugg, Munck, and Maier find significance for the identity question in the way the witnesses are introduced. Meanwhile, Tan notices that others have found such significance in the way they are introduced.

Haugg believes that the definite article that is used to introduce the witnesses

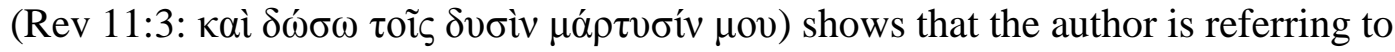
familiar characters, even though they have not been mentioned before in Revelation. ${ }^{119}$ Specifically, he sees the article as a reference to the idea of messianic forerunners. From this viewpoint, the text takes up a common eschatological expectation. ${ }^{120}$ If correct, Haugg would have further evidence for two literal individuals since the concept of messianic forerunners involves actual people.

${ }^{116}$ Tan, "Defense," 205, 213.

${ }^{117}$ Beckwith, Apocalypse, 593, 595; and Maier, Kapitel 1-11, 471.

${ }^{118}$ Haugg, Die zwei Zeugen, 133.

${ }^{119}$ Ibid., 13, 21, 51. Tan notices others who believe similarly, when she discusses the debate over a specific literal identity for the witnesses. Tan, "Defense," 188.

${ }^{120}$ Haugg, Die zwei Zeugen, 14-15, 78, 80, 85-87, 113, 137. 
Tan points out that others have seen the definite article as pointing to familiar figures, which could in turn refer to prominent figures from the OT. ${ }^{121}$ Yet, she does not mention the possible link to messianic forerunners.

In addition, Haugg, Munck, and Maier all draw attention to the connection made to the one who speaks forth the introduction. The witnesses belong to the speaker, whom they identify as Jesus. ${ }^{122}$ The implication is that the witnesses must be identified as Christians as opposed to figures from the OT era. ${ }^{123}$ Tan notices one commentator who draws attention to the connection with the speaker, but for whom a link to OT figures is made by means of the connection! ${ }^{124}$

The question of the role that the definite article has in the introduction of the witnesses seems to make this issue relevant, even though only a few of the examined expositors address it. There is, however, perhaps some doubt about the relevancy of this issue, because the question of the connection with the speaker does not appear to be a very decisive matter. Moreover, major aspects of the actual introduction (e.g., naming them witnesses or depicting them as prophets) are covered by other issues of interpretation. Perhaps the best thing to do is to narrow the issue of interpretation down to the appearance of the definite article.

${ }^{121}$ Tan, "Defense," 188.

${ }^{122}$ Haugg, Die zwei Zeugen, 3, 14; Munck, Petrus und Paulus, 17; and Maier, Kapitel 1-11, 462.

${ }^{123}$ Haugg, Die zwei Zeugen, 113-114, 133; Munck, Petrus und Paulus, 13-17; and Maier, Kapitel 1-11, 462, 470-472.

${ }^{124}$ Tan, "Defense," 188n312. 
The Crucified Lord of Rev 11:8

The same point about the witnesses being Christians as opposed to figures from the OT era is argued from the meaning of the crucified lord of Rev 11:8 ("where also their Lord was crucified" [NRSV]). Beckwith and Munck both interpret the crucified lord as a reference to Jesus and assume that "their" refers to the witnesses. ${ }^{125}$ Van de Kamp sees that part of 11:8 in the same way, but makes two points, only one being similar to that of Beckwith and Munck. Van de Kamp's similar point is that the witnesses must be identified as Christians as opposed to the Law and the Prophets. ${ }^{126} \mathrm{He}$ also observes that 11:8 distinguishes the witnesses from "their Lord," so that Jesus himself cannot be one of the witnesses. ${ }^{127}$

The relevance of the meaning of the crucified lord for the interpretation of the witnesses is low because so few of the examined expositors address it and there is no clear reason for a higher relevance.

\section{Messianic Forerunners}

As noted, Haugg discusses the issue of messianic forerunners in relation to the introduction of the witnesses. Munck and Maier, however, are critical of associating this idea with the two witnesses. Munck accepts that there was in Jewish thought the idea of messianic forerunners, but nothing quite parallels what is found in Rev 11:3-13. ${ }^{128}$ Maier

\footnotetext{
${ }^{125}$ Beckwith, Apocalypse, 591; and Munck, Petrus und Paulus, 13-17.

${ }^{126}$ Kamp, Openbaring, 262.

${ }^{127}$ Ibid.

${ }^{128}$ Munck, Petrus und Paulus, 13-15.
} 
observes that the preaching of Jesus says nothing about forerunners for his second coming. In place of such an expectation is the prediction of the coming of false messiahs and false prophets (Matt 24:24). ${ }^{129}$

Maier also claims that there was only one expected forerunner, namely, Elijah, so ruling out Moses as a messianic forerunner. ${ }^{130}$ Haugg and Munck would disagree. Haugg sees other individuals being assigned such a role. ${ }^{131}$ Munck mentions besides Elijah that there was the expectation of a large group of forerunners, among whom are Moses and Enoch. Yet, he does not cite any evidence for this. ${ }^{132}$

Although the issue of messianic forerunners is mention by only three of the examined commentators, it may still be relevant. Dealing with the issue anew might create clarity for the mix of thoughts just illustrated.

\section{The Sackcloth Clothing}

Tan and Munck both make reference in their argumentation to the sackcloth clothing of the witnesses. In response to one commentator's use of the sackcloth clothing

${ }^{129}$ Maier, Kapitel 1-11, 472.

${ }^{130}$ Ibid., 471. This point reveals that the issue of messianic forerunners intersects with the issue of traditions about Moses. In fact, the issue intersects with the issue of traditions about Elijah and the issue of traditions about Enoch.

Something not mentioned by Munck and Maier is a rabbinic saying, Deut. Rab. 3.16-17, that seems to express an expectation of Moses and Elijah returning to earth together. See Beale, Book of Revelation, 582-583. Haugg is aware of the saying and sees it as portraying Moses in the role of a messianic forerunner. He downplays its significance for Revelation, however, seeing it as too late and as not reflecting an earlier tradition. Haugg, Die zwei Zeugen, 104-105.

${ }^{131}$ Haugg, Die zwei Zeugen, 14-15.

${ }^{132}$ Munck, Petrus und Paulus, 13. 
as evidence of his view, Tan accepts that sackcloth was the clothing of prophets, but points out that other meanings are possible. ${ }^{133}$ Munck identifies two possible symbolic meanings for the sackcloth, either of which is agreeable with his view of the two witnesses. ${ }^{134}$ The presence of the sackcloth seems to have more to do with the activity of the witnesses than their identity. For this reason and since only two commentators mention this issue, this issue may be considered one of low relevance.

\section{The Theme of Warfare}

In their argumentation, Tan and Beale both make reference to the war against the witnesses noted in Rev 11:7. Tan deals with the theme briefly by addressing a possible support for a corporate view of the two witnesses. She responds negatively to the contention that seeing the beast at war with just two individuals makes little sense. ${ }^{135}$ Beale argues, however, through the theme of warfare, that the two witnesses are a collective entity. He does not make that same point to which Tan responds. Rather, he appeals to the background text of Dan 7:21 and to other instances in Revelation of evil forces at war with God's people. ${ }^{136}$ In the background text and in those other verses in Revelation, a collective entity is clearly the target of hostility. Although this issue of interpretation is raised by only two of the studied commentators it still seems relevant for

${ }^{133}$ Tan, "Defense," 69. This argument is a little odd in the wider context of Tan's dissertation. Tan implies that another nuance might be apparent here in place of the one involving prophetic garb, but in a later discussion she highlights the sackcloth as prophetic garb. See ibid., 140.

${ }^{134}$ Munck, Petrus und Paulus, 19.

${ }^{135}$ Tan, "Defense," 137.

${ }^{136}$ Beale, Book of Revelation, 574, 588-590. 
further investigation of the identity question. Particularly Beale's argumentation here reveals that the theme of warfare can have significant implications for deciding whether the witnesses function as a symbol and, if so, what kind of entity is being represented.

\section{A Research Plan for Identifying the Two Witnesses}

Categorizing the Issues of Interpretation

The preceding discussion has dealt with thirty-four different issues of interpretation. Fourteen issues can be identified as main issues inasmuch as each is addressed by a majority of the nine studied commentators. These issues are listed in Figure 10 according to the order in which they were discussed.

1. Interpretive approach

2. Degree of symbolism

3. Image of the olive trees

4. Image of the lampstands

5. Miraculous powers

6. Traditions about Elijah

7. Traditions about Moses
8. Theme of testimony

9. Theme of prophecy

10. Person-oriented language

11. Meaning of the three-and-a-half-year period

12. Immediate context before (Rev 11:1-2)

13. Setting for events of Rev 11:3-13

14. Fate of the witnesses

Figure 10. List of main issues of interpretation.

Seventeen other issues can arguably be added to these main issues for a research plan. These issues are listed in Figure 11 (see the next page) according to the order in which they were discussed. Although its relevance may be debated, I have included here the issue of traditions about Enoch, considering it important to respond to the dominant 
early identification of Enoch and Elijah. I have also included a narrowing of the general issue of how the two witnesses are introduced: the appearance of the definite article in their introduction.

1. Distinguishing the symbolic from the literal

2. Use of the OT

3. How to interpret symbolism

4. Unity of the witnesses

5. Duality of the witnesses

6. Traditions about Enoch

7. Traditions about Peter

8. Traditions about Paul

9. Early interpretation of the witnesses
10. Immediate context after (at least Rev 11:15-18)

11. Identity of the beast of Rev 11:7

12. Historical data

13. Verb tenses in Rev 11:1-13

14. Lack of names

15. The use of the definite article

16. Messianic forerunners

17. Theme of warfare

Figure 11. List of supplementary issues of interpretation.

Four issues remain of low relevance to any new investigation of the two witnesses: (1) the earthquake of Rev 11:13; (2) the audience to the fate of the witnesses; (3) the crucified lord of Rev 11:8; and (4) the sackcloth clothing of the witnesses.

The Arrangement of Argumentation in the Studied Commentators Beyond the issues themselves, there is the question of how should one address the broad issues of interpretation in a new investigation of the identity of the witnesses. More specifically, one wonders whether the issues should be addressed in a particular order. In answering this question, the studied commentators may be consulted.

The heart of Haugg's argumentation comes as a response to the history of the interpretation of the witnesses. Framing the response is the question of literal versus 
symbolic identifications. The actual discussion centers on the timing of the witnesses' activity, the immediate context before the witnesses appear, and the fate of the witnesses. The arguments depend heavily upon content found elsewhere in his monograph. This could be considered a weakness in Haugg's organization. Later in his monograph, Haugg looks at interpretations of Rev 11:1-13 divided according to interpretive approaches. In doing this, Haugg returns to the timing of the witnesses' activity. One wonders, however, if it would have been better for Haugg to discuss in full this material regarding approaches before focusing on the witnesses. Deciding on an approach to the passage as a whole — deciding on how the passage relates to history—seems better as a foundation for an identification of the witnesses than something that comes afterwards. Haugg's own argumentation seems to confirm this thought, since he finds it necessary to deal in some way with the witnesses' relationship to history even before his full discussion of approaches.

A critical look at popular, historically-oriented interpretations of the witnesses shapes Todd's argumentation. Once those interpretations are found wanting, he looks at the possibility of a more specific literal identification. Todd's organization of his argumentation does not seem useful, however, since it is dependent on what was popular in his day.

Beckwith begins with the problem of fitting a literal reading of Rev 11:1-13 into the broader eschatological thought in Revelation and the rest of the NT. He refuses to expound the passage on the basis of a church-oriented symbolism. Instead he fits Rev 11:1-13 into the broader stream of Christian eschatological thought by supposing that a source was used to portray Israel coming to repentance for various sins, including 
rejection of the Messiah. Arguments more directly related to the identity question appear in an overview of the whole passage from Beckwith's chosen perspective. Further arguments appear in a section devoted to the identity of the witnesses. This material is arranged according to the thought that a source text has been reworked into the present passage. There is, however, a separate debate on whether an apocalyptic source or sources stand behind Rev 11:1-13. Organizing based on a highly debated point seems questionable.

The organizing principle for Tan's work is interpretive approaches. She critiques preterist, idealist, and historicist interpretations of the witnesses and then turns to defending a general futurist identification. A weakness of her organization of matters is that there is a large degree of repetition.

The beginning and the ending of Munck's study on the witnesses responds to alternative identifications of them. He is particularly concerned with the supposed modelling of the witnesses on an expectation of the return of Moses and the return of Elijah. Two chapters offer much of Munck's argumentation for his Peter-Paul proposal. In one chapter, he goes verse by verse through Rev 11:3-13 pointing out material relevant to his proposal. In the other chapter, he shows that his proposed interpretation coheres with the immediate literary context before and after the passage. Munck also devotes part of a separate chapter to discuss the historical datum upon which his proposal depends, namely, the martyrdom of Peter and Paul in Rome.

The heart of Beale's arguments about the identity of the witnesses appears in a special section attached to comments on Rev 11:3. Further arguments are suggested by comments on aspects of individual verses of Rev 11:3-13. There is a noticeable reliance 
upon other parts of the commentary to fill in details for certain arguments. For instance, discussion of the timing of the witnesses' activity takes place primarily outside of comments on Rev 11:3-13. Beale's arrangement seems inconsistent with some arguments in a major section on the witnesses and some distributed among the rest of the comments. Much of van de Kamp's argumentation comes as a response to the history of the interpretation of the witnesses. After comments on Rev 11:5-6, he critiques several alternatives for the identification of the witnesses, before pronouncing support for a symbolic and ecclesiastical one. There is some reliance upon comments found elsewhere in the commentary to fill in details of argumentation on the timing of the witnesses' activity. There is also some argumentation appearing outside of van de Kamp's key section on the witnesses. Van de Kamp's arrangement suffers from a certain inconsistency in the presentation, like Beale's arrangement does.

Maier presents the core of his argumentation in a special section after talking about Rev 11:5-6. All of the arguments are negative ones, criticizing literal identifications. Further arguments are suggested primarily by comments on aspects of individual verses of Rev 11:3-13. Some of this material is positive in nature, directly promoting a symbolic identification. This arrangement, however, seems unbalanced with all the arguments being negative ones in his special section on the identity of the witnesses. Moreover, it seems inconsistent with some arguments in a major section on the witnesses and some distributed among the rest of the comments.

Müller lays out nine points for his identification of the witnesses. I do not discern why the nine topics are arranged as they are in his essay. Further argumentation for his proposal appears in the rest of the piece, in which he comments on the literary context 
and remarks on the traits of the witnesses according to Rev 11:3-13. Müller's arrangement also suffers from inconsistency in the presentation because the argumentation appears in more than one location.

\section{A New Plan for Research}

Among all these arrangements, I find Munck's the most useful. I can easily envision separate sections dealing with issues of the text, those related to the history of the interpretation of the witnesses, and those of the literary context. With this in mind, I offer an outline for dealing with the issues of interpretation discussed in this chapter (see Figure 12 on the next page).

While all the issues are separated from each other for the sake of a research plan, it must be recognized that issues of interpretation can be connected with one another, so that one must revisit previously discussed issues. For instance, in dealing with the duality of the witnesses, one may discuss the possibility of an OT legal background. Thus, the theme of testimony arises in a secondary way.

The issues of interpretive framework are arranged in a progression leading to the interpretive approach. While being issues that can stand on their own, the issue of use of the OT and the issues involving symbolism are some of the elements that can go into determining an interpretive approach.

The issues of text roughly follow the appearance of elements in Rev 11:3-13. I say roughly, because some issues involve more than one verse. For example, there is the theme of testimony, the issue of verb tenses for Rev 11:1-13, or the issue of personal traits. Others could be mentioned. 
A. Issues of the interpretive framework

1. Use of the OT in Revelation

2. Degree of symbolism

3. Distinguishing the symbolic from the literal

4. Interpreting symbolism

5. Interpretive approach

B. Issues of the text

1. Use of the definite article

2. Theme of testimony

3. Theme of prophecy

4. Duality of the witnesses

5. Unity of the witnesses

6. Meaning of the three-and-a-half-year period

7. Verb tenses for Rev 11:1-13

8. Person-oriented language

9. Lack of names

10. Image of the olive trees

11. Image of the lampstands

12. Miraculous powers of the witnesses

13. Theme of warfare

14. Identity of the beast of Rev 11:7

15. Setting for the events of Rev 11:3-13

16. Fate of the witnesses

C. Issues of the history of interpretation

1. Early interpretation of the witnesses

2. Enoch traditions

3. Elijah traditions

4. Moses traditions

5. Messianic forerunners

6. Paul traditions

7. Peter traditions

D. Issues of literary context

1. Immediate context before (Rev 11:1-2)

2. Immediate context after (at least Rev 11:15-18)

E. Historical Data

Figure 12. Research plan for identifying the two witnesses. 
I have ordered the issues of the history of the interpretation of the witnesses as a progression that gets further and further away from that dominant early view of the witnesses as Enoch and Elijah.

Traditions about Moses and traditions about Elijah have a strong connection to the issue of the miraculous powers of the two witnesses. The primary focus, however, of the issues concerning these traditions is on traditions not directly associated with the miraculous powers, such as expectations of the return of one of the OT figures. The primary focus involves data that might support one or more particular identifications of the two witnesses, not just the Moses-Elijah view. This is why I have included these two issues, the traditions about Moses and the traditions about Elijah, among issues of the history of the interpretation of the witnesses.

I have placed discussion of traditions about Paul and about Peter in with issues of the history of interpretation, since the discussion is primarily a response to the Peter-Paul proposal. Something similar could be said for having the discussion of Enoch traditions associated with issues of the history of interpretation.

The issue of messianic forerunners is close to the issues of traditions about Enoch, Elijah, and Moses. Accordingly, I have included it among the issues of the history of interpretation. Besides, addressing it can come as a response to the proposal that the two witnesses are modelled on an expectation of messianic forerunners.

\section{Conclusion}

In this chapter, all the broad issues of interpretation shared by the nine studied commentators are presented. Thirty-five issues of interpretation are common to at least two of the commentators. Fourteen of these issues are each addressed by five or more of 
the studied expositors and so represent a set of main issues of interpretation. One can argue that seventeen other issues that are mentioned less should be examined along with the main issues in any new investigation of the identity of the two witnesses. Four issues appear to be of such low relevance that they need not be a part of that study. Also included in this chapter are summaries of what the studied expositors have said on particular topics. These summaries pull together material from the previous two chapters and so act as guidance in the new investigation. Finally, a research plan was proposed for dealing with the most essential issues of interpretation. 


\section{CHAPTER 6}

\section{SUMMARY AND CONCLUSIONS}

The present study is premised on the idea that a more thorough and more extensive exegetical investigation into the identity of the two witnesses of Rev 11:1-13 could prove to be a fruitful enterprise. Before looking forward, however, it seems profitable to look backward and paint a picture of the state of the identity question. Other examinations of the history of the interpretation of the witnesses were assessed according to four criteria that I argue lead to a more complete picture of the state of the question. The four criteria are: (1) a focus on exegetical works as opposed to devotional or homiletical pieces; (2) the involvement of a wide range of works; (3) exhaustive presentations of the arguments that underlie particular identifications; and (4) a description of the broad issues of interpretation that may be derived from commentators' arguments. Although these other examinations are helpful for various reasons, none of them had all four features. The present study is an attempt to meet this need. This study can function as the review of literature necessary for a new investigation into the identity question.

To paint the picture, the present endeavor has first presented overviews of classes of identifications through time. The literature can be divided into interpretations that understand the two witnesses literally and those that see the witnesses as a symbol. Since 1700, futuristic, literal interpretations of the witnesses appear to have been more popular 
than the views that understand the witnesses to be two of John's contemporaries. The futuristic group is dominated by two views, the Moses-Elijah view and the unknownprophets view. For the contemporaries group, the Peter-Paul view has come to dominate over the last hundred years or so. Since 1700, symbolic interpretations that associate the witnesses with the people of God appear to have been more popular than the views that understand the witnesses to represent sacred writings. For the group oriented toward God's people, seeing the whole church as being symbolized by the witnesses has come to dominate. For the group oriented toward the sacred writings, the main view is the two witnesses symbolizing the Bible, consisting of the Old and New Testaments. All this information has influenced the choice of the nine expositions featured in the body of the present work.

To paint the picture, the present study secondly summarized the arguments from the nine expositions and derived broad issues of interpretation from those arguments. These nine were drawn from a wide range of exegetical literature, encompassing a significant piece of time in the modern era and representing more than one language. These nine are representative works for the larger pool of literature. The identifications defended, the arguments offered, and the underlying issues from these nine works all represent much of what is present in the larger set of literature.

The expositions of Haugg, Todd, Beckwith, Tan, and Munck expose readers to the arguments and derivative issues for those interpretations in which the two witnesses are two actual people. The expositions of Beale, van de Kamp, Maier, and Müller expose readers to the arguments and issues for those interpretations in which the witnesses represent some other reality than two actual people. 
The works of Haugg and Beale have formed the foundation for the presentations of arguments and the discovery of issues of interpretation. Todd, Beckwith, and Tan offer arguments that could function as supplements or replacements for arguments made by Haugg. Meanwhile, van de Kamp and Maier do the same for the arguments of Beale. The presentations for these seven works are exhaustive to a degree. I have attempted to encapsulate the whole of at least their arguments directly related to the identity question.

The works of Munck and Müller represent positions on the witnesses that have become prevalent when considering certain sets of identifications (the witnesses as John's contemporaries and the witnesses as sacred writings). Nevertheless, when the totality of identifications is considered, these two positions are less popular among scholars than the positions espoused by the other seven works. Given this circumstance and the need to make the present study more readable, the presentations of arguments for these two expositors are shortened, so that only a sample of the argumentation is summarized. Nevertheless, overviews of the expositions as a whole have been provided and were able to suggest some of the broad issues of interpretation raised by the reasoning that was not summarized.

To paint the picture of the state of the identity question, the present endeavor has thirdly discussed the derivative issues of interpretation, at least those held in common by two or more of the nine commentators. Thirty-five issues of interpretation are common to at least two of the commentators. Fourteen of these issues are each addressed by five or more of the studied expositors and so represent a set of main issues of interpretation. One can argue that seventeen other issues that are mentioned less should be examined along with the main issues in any new investigation of the identity of the two witnesses. 
Four issues appear to be of such low relevance that they need not be a part of that study. Having identified what appear to be the most essential issues of interpretation, I have proposed a research plan including those issues.

As part of the discussion of the broad issues of interpretation, summaries have been given of what the studied expositors have said on particular topics. These summaries pull together material from the previous two chapters and so act as guidance in the new investigation.

Summarized arguments, the deduction of broad issues of interpretation from the arguments, and the development of a research plan revolving around the most essential issues all work to form a picture of the state of the question of the identity of the two witnesses in Rev 11:1-13. Having this picture, the stage is set for a deeper investigation of the exegetical identity of the two witnesses.

In closing, I note that the present study has a function beyond that of aiding in the quest to identify the witnesses. The present study serves as a model for how one can begin to deal with other difficult figures in Revelation. 


\section{APPENDIX A \\ LITERAL, FUTURISTIC IDENTIFICATIONS OF THE TWO WITNESSES}

\section{Introduction}

Here presented are references to endeavors to argue that the two witnesses are two actual people who are to appear sometime after John has composed Revelation. At times, the specific timing for the witnesses is seen as in the future distant from John. These pieces are significant in that they offer some measure of argumentation for an identification as opposed to just stating a view without any noticeable support. There is, however, variation in the amount of argumentation among these works. No attempt has been made here to distinguish the expositions according the quantity of argumentation. The time frame for these works is from 1700 onward.

These expositions represent the three main identifications in this class of opinions: (1) the witnesses are Enoch and Elijah having come back to earth for a new ministry; (2) they are Moses and Elijah having come back to earth for a new ministry; and (3) they are two individuals unknown until they fulfill Rev 11:3-13. Some of them are discussed in chapter 3 . Reference is also made to proposals that mix the idea of two literal people with a symbolic understanding of the witnesses.

For many of the citations below, I have included pages that also cover Rev 11:1-2 to give context for the particular readings of 11:3-13. At times, commentators have 
included 11:14 in their discussions. Where appropriate, the pages covering that verse are also a part of the citation.

If an author has espoused a particular view of the witnesses over more than one work, I cite for the most part only the main piece. When an author's viewpoint has changed from one work to another, I try to cite all the relevant works from that author.

\section{Enoch and Elijah}

Attempts to defend the Enoch-Elijah view that originate in the eighteenth century are those by Samuel Hardy (1720-1793), François Malot (1708-1785), Laurent-Étienne Rondet (1717-1785), Charles Walmesley (1722-1797), and Robert Witham (died 1738). ${ }^{1}$

From the nineteenth century come comments from Anatole Chauffard (born 1827), the practically anonymous "G.," Antoine-Eugène de Genoude (1792-1849), Robert Govett (1813-1901), Joseph Augustus Seiss (1823-1904), Carl Stern (1819-1875), and Jean Wendel Wurtz (ca. 1766-1826). ${ }^{2}$

${ }^{1}$ Samuel Hardy, The Principal Prophecies Of the Old and New Testaments; Particularly Those In the Revelation Of St. John; Compared And Explained. . . . (London: by the author, 1770), 340-362, accessed July 9, 2015, Gale Eighteenth Century Collections Online; [François Malot?], Dissertation sur l'époque du rappel des Juifs. . . . 2nd ed. (Paris: Veuve Mequignon \& Fils, 1779), xxxix, note 1, accessed July 7, 2015, Google Books; Laurent-Étienne Rondet, Dissertation sur le rappel des Juifs, et sur le chapitre onzième de l'Apocalypse. . . . (Paris: Lottin l'aîné, 1778), 63-65, 341-349, accessed July 1, 2015, Google Books; Walmesley, General History, 212-222, 242-244, 247-248, 270-276; and Robert Witham, Annotations on the New Testament of Jesus Christ. . . vol. 2 ([Douai, France?], 1730), 2:479-483, accessed July 7, 2015, Gale Eighteenth Century Collections Online. Walmesley's work originally appeared in 1771.

${ }^{2}$ Anatole Chauffard, L'Apocalypse et son interprétation historique, 2 vols. (Avignon: Seguin Frères; Paris: E. Thorin, 1888), 2:II-VI, 60-66, 140-157, 420-421, 576581, 625-627, accessed July 7, 2015, Google Books; G., "The Burial of Moses," Journal of Sacred Literature, n.s., 6, no. 11 (April 1854): 150-165, accessed November 11, 2015, Google Books; Antoine-Eugène de Genoude, Sainte Bible en latin et en francais. 
Items defending this view that come from the twentieth century are those by John Quincy Adams (born 1891), Ambrogio Arrighini (born 1887), Samuel Fennell Hurnard (1870-1949), George Henry Lang (1874-1958), Jean de Monléon (1890-1981), Henry Madison Morris (1918-2006), Joseph Peschek (1873-1933), Ignaz Rohr (1866-1944), Charles William Merrill Turner (1866-1942), and M. M. Wilson. ${ }^{3}$ John Phillips (19272010) argues that Elijah is probably one of the witnesses and Enoch is possibly the other. ${ }^{4}$ Charles Maitland (1815-1866) notices the possibility that Enoch may join Elijah

Traduction nouvelle d'après la Vulgate, avec des notes littéraires, critiques et historiques. . . vol. 5, 4th ed. (Paris: Sapia; Pourrat Frères, 1840), 736-758, accessed July 6, 2015, Google Books; Robert [Matheetees Govett, pseud.], The Apocalypse Expounded by Scripture, 4 vols. (London: James Nisbet, 1861-1865; reprint, Govett on Revelation, 2 vols., Miami Springs, FL: Conley \& Schoettle, 1981), vol. 1, pt. 2, 491-587; Seiss, Apocalypse, 2:149-246; Stern, Commentar über die Offenbarung, 278-297; and Jean Wendel Wurtz, Les précurseurs de l'Antechrist; . . o ou, La révolution française prédite par S. Jean l'évangéliste. . . 6th ed. (Lyon, France: Rusand, 1817), 286-293, accessed October 20, 2015, Google Books. Seiss's work originally appeared in 1865.

${ }^{3}$ Adams, His Apocalypse, 195-211; Arrighini, L'Anticristo, 251-258; Samuel Fennell Hurnard, Revelation: The Book with a Blessing (London: Marshall, Morgan \& Scott, [1930?]), 70-75; George Henry Lang, The Revelation of Jesus Christ: Selected Studies (Miami Springs, FL: Conley \& Schoettle, 1985), 181-187; Jean de Monléon, Le Sens Mystique de l'Apocalypse: Commentaire textuel d'après la Tradition des Pères de l'Eglise (Paris: Nouvelles Éditions Latines, 1984), 171-172, 176-181; Morris, Revelation Record, 189-205; Joseph Peschek, Geheime Offenbarung und Tempeldienst: Eine Darstellung des Aufbaues der Apokalypse des heiligen Apostels Johannes samt Text und Erklärung (Paderborn, Germany: Verlag Ferdinand Schöningh, 1929), 94-97; Ignaz Rohr, Der Hebräerbrief und die geheime Offenbarung des heiligen Johannes, 4th ed., Die Heilige Schrift des Neuen Testaments übersetzt und erklärt in Verbindung mit Fachgelehrten (Bonn: Peter Hanstein, Verlagsbuchhandlung, 1932), 104-106; Charles William Merrill Turner, Outline Studies in the Book of the Revelation and Key to the Chart of the Ages, 2nd ed. (Plain City, Ohio: by the author, 1916), 59-65; and M. M. [Kalamos Wilson, pseud.], Prophetical Suggestions: Being Expository of the Books of Revelation and Daniel, 2nd ed. (London: Digby, Long, 1909), 73-81. The works of Arrighini, Lang, and Monléon were originally published earlier in the twentieth century.

${ }^{4}$ John Phillips, Exploring Revelation (Chicago: Moody Press, 1974), 152-158. 
before the second coming, but Moses or the Apostle John could fill the role of Elijah's companion. For Maitland, the Bible does not make the matter of the second witness as clear as it does for Elijah as the first witness. ${ }^{5}$

\section{Moses and Elijah}

I am unaware of any expositions in the eighteenth century that support solely the Moses-Elijah view. There are, however, some that defend the view along with another. They are mentioned in a separate section below for mixed proposals. Endeavors solely on behalf of the Moses-Elijah view do exist in the following centuries and on into the twenty-first century. Significant ones that come from the nineteenth century are by Pierre-Jean Agier (1748-1823), Friedrich Bleek (1793-1859), William de Burgh (18011866), Philip Charles Soulbieu Desprez (ca. 1812-1879), Karl Erbes (born 1853), Georg Heinrich August Ewald (1803-1875), Johann Christian Konrad von Hofmann (18101877), Isaac Peter Labagh (1804-1869), Édouard Guillaume Eugène Reuss (1804-1891), Michael Ferrebee Sadler (1819-1895), Eberhard Vischer (1865-1946), and Friedrich Jakob Züllig (1780-1844). ${ }^{6}$

${ }^{5}$ Charles Maitland, The Apostles' School of Prophetic Interpretation: With Its History Down to the Present Time (London: Longman, Brown, Green, and Longmans, 1849), 28-41, 63-64, 139-141, 422-423, 442-444 accessed July 12, 2015, Google Books.

${ }^{6}$ Pierre-Jean Agier, Commentaire sur l'Apocalypse, 2 vols. (Paris: J.-M. Eberhart, 1823), 1:277-334, accessed August 24, 2015, Google Books; Friedrich Bleek, Dr. Friedrich Bleek's Vorlesungen über die Apokalypse, ed. Theodor Hossbach (Berlin: Georg Reimer, 1862), 107-109, 112-116, 255-268, accessed July 10, 2015, Google Books; Friedrich Bleek, Dr. Friedrich Bleek's Lectures on the Apocalypse, ed. Theodor Hossbach, trans. and ed. Samuel Davidson (London: Williams and Norgate, 1875), 106107, 110-114, 247-259, accessed July 10, 2015, Google Books; De Burgh, Exposition, 188-209, 409-411; Philip Charles Soulbieu Desprez, John, or the Apocalypse of the New Testament (London: Longmans, Green, 1870), 113-136, accessed July 10, 2015, Google 
In the first two decades of the twentieth century, one finds pieces by Wilhelm Bousset (1865-1920), Shirley Jackson Case (1872-1947), James Martin Gray (18511935), Heinrich Julius Holtzmann (1832-1910), Clarence Larkin (1850-1924), Hans

Books; Karl Erbes, Die Offenbarung Johannis kritisch untersucht (Gotha, Germany: Friedrich Andreas Perthes, 1891), 66-84; Georg Heinrich August Ewald, Johannes' Apokalypse. . . . vol. 2 of Die johanneischen Schriften überse[t]zt und erklärt (Göttingen: Verlag der Dieterichschen Buchhandlung, 1862), 220-233, accessed July 10, 2015, Google Books; Johann Christian Konrad von Hofmann, Weissagung und Erfüllung im Alten und im Neuen Testamente. Ein theologischer Versuch, 2 vols. (Nördlingen, Germany: Druck und Verlag der C. H. Beck'schen Buchhandlung, 1841-1844), 2:301304, 343-348, accessed July 10, 2015, Internet Archive European Libraries Collection; Isaac Peter Labagh, The Two Witnesses, additional section to A Connected View of Some of the Scripture Evidence of the Redeemer's Speedy Personal Return. . . , by James A. Begg, 1st American ed. (New York: John Moffet; New York: William Burbeck, 1842), 281-303, accessed July 10, 2015, Google Books; Isaac Peter Labagh, Twelve Lectures on the Great Events of Unfulfilled Prophecy. . . . (New York: by the author, 1859), 83-107, accessed July 10, 2015, Google Books; Édouard Guillaume Eugène Reuss, L'Apocalypse, vol. 4 of La Bible: traduction nouvelle avec introductions et commentaires, Nouveau Testament (Paris: Librairie Sandoz et Fischbacher, 1878), 89-94, accessed October 20, 2015, Google Books; Michael Ferrebee Sadler, The Revelation of St. John the Divine. With Notes Critical and Practical, 2nd ed., Church Commentary on the New Testament, with Notes, Critical and Practical (London: George Bell and Sons, 1894), 131-148, accessed July 12, 2015, Internet Archive American Libraries Collection; Eberhard Vischer, Die Offenbarung Johannis: Eine jüdische Apokalypse in christlicher Bearbeitung, Texte und Untersuchungen zur Geschichte der altchristlichen Literatur 2, issue 3 (Leipzig: J. C. Hinrichs'sche Buchhandlung, 1886), 13-19, accessed July 10, 2015, Google Books; and Friedrich Jakob Züllig, Johannes des Gottbesprachten, eschatologische Gesichte, genannt: die Apokalypse; übersetzt, auf ihre Kunstform zurückgeführt, und zum Erstenmal erklärt, auch für Nicht-Gelehrte, 2 vols. (Stuttgart: E. Schweizerbart's Verlagshandlung, 1834-1840), 2:122-139, 143-169. For Desprez, this identification represents a change from an earlier work. See Philip Charles Soulbieu Desprez, The Apocalypse Fulfilled in the Consummation of the Mosaic Economy and the Coming of the Son of Man. . . . 3rd ed. (London: Longman, Green, Longman, and Roberts, 1861), 244-285, accessed July 12, 2015, Google Books. Later, Desprez changed his mind again. See Philip Charles Soulbieu Desprez, Daniel and John: or, The Apocalypse of the Old and That of the New Testament (London: C. Kegan Paul, 1878), 242-259, accessed August 2, 2015, Internet Archive American Libraries Collection. In these two other cases, Desprez goes with a contemporary-historical view of the witnesses. With Ewald's later work, compare Georg Heinrich August Ewald, Commentarius in Apocalypsin Johannis exegeticus et criticus (Leipzig: Librariae Hahnianae, 1828), 192207. 
Preuß (1876-1951), Daniel Völter (1855-1942), and Johannes Weiss (1863-1914). ${ }^{7}$

Perhaps the work of Charles Archibald Anderson Scott (1859-1941) also belongs to this period. $^{8}$

After this time and before 1950, one finds items by Keith Leroy Brooks (18871954), Robert Henry Charles (1855-1931), George Wesley Davis (born 1861), Martin Ralph De Haan (1891-1965), Henry Weston Frost (1858-1945), Ernst Lohmeyer (1890-

\footnotetext{
${ }^{7}$ Bousset, Die Offenbarung Johannis, 315-330; Shirley Jackson Case, The Revelation of John: A Historical Interpretation (Chicago: University of Chicago Press, 1919), 288-296; James Martin Gray, Christian Workers' Commentary on the Old and New Testaments. . . . (New York: Fleming H. Revell, 1915), 438; Heinrich Julius Holtzmann, Evangelium, Briefe und Offenbarung des Johannes, ed. Walter Bauer, 3rd ed., Hand-Commentar zum Neuen Testament 4 (Tübingen: J. C. B. Mohr [Paul Siebeck], 1908), 459-462, accessed July 10, 2015, Google Books; Clarence Larkin, The Book of Revelation: A Study of the Last Prophetic Book of Holy Scripture (Glenside, PA: Rev. Clarence Larkin Estate, 1919), 83-88, accessed July 10, 2015, Internet Archive American Libraries Collection; Hans Preuß, Der Antichrist, Biblische Zeit- und Streitfragen zur Aufklärung der Gebildeten, 5th ser., 4 (Gr. Lichterfelde-Berlin: Edwin Runge, 1909), 2224; Daniel Erhard Johannes Völter, Die Offenbarung Johannis neu untersucht und erläutert, 2nd ed. (Strasbourg: J .H. Ed. Heitz (Heitz \& Mündel), 1911), 72-76, accessed June 25, 2015, HathiTrust Digital Library; and Johannes Weiss, Die Offenbarung des Johannes. Ein Beitrag zur Literatur- und Religionsgeschichte, Forschungen zur Religion und Literatur des Alten und Neuen Testaments 3 (Göttingen: Vandenhoeck \& Ruprecht, 1904), 126-134, 151-155, accessed July 10, 2015, Google Books. Weiss has another exposition that comes from this period, but the latest edition is one updated after his death by Wilhelm Heitmüller (1869-1926). See Johannes Weiss and Wilhelm Heitmüller, "Die Offenbarung des Johannes," in Das Johannes-Evangelium, die Johannes-Briefe und die Offenbarung des Johannes. Sachregister zum ganzen Werke, vol. 4 of Die Schriften des Neuen Testaments neu übersetzt und für die Gegenwart erklärt, ed. Wilhelm Bousset and Wilhelm Heitmüller, 3rd ed. (Göttingen: Vandenhoeck \& Ruprecht 1918), 277-279.

${ }^{8}$ Charles Archibald Anderson Scott, Revelation: Introduction; Authorized Version; Revised Version with Notes; Index and Map, The New-Century Bible (New York: Henry Frowde; Edinburgh: T. C. \& E. C. Jack, n.d.), 216-224, accessed July 22, 2015, Internet Archive American Libraries Collection. Scott seems to espouse a different view of the witnesses, a symbolic one, in another work. See Charles Archibald Anderson Scott, The Book of the Revelation, Practical Commentary on the New Testament (New York: A. C. Armstrong \& Son, 1906), 208-217, accessed December 1, 2015, Internet Archive American Libraries Collection.
} 
1946), Alfred Firmin Loisy (1857-1940), and Louis Thompson Talbot (1889-1976). ${ }^{9}$

Perhaps the work of William Hoste (1861-1938) also belongs to this period. ${ }^{10}$

For the 1950s through the 1980s, there are the works by William Barclay (1907-

1978), Donald Grey Barnhouse (1895-1960), Thomas Francis Glasson (1906-1998),

David Lee Hocking (born 1941), John Miesel (born 1930), Gilles Quispel (1916-2006),

Jacob Brubaker Smith (1870-1951), James Dean Strauss (1929-2014), and Merrill Chapin

\footnotetext{
${ }^{9}$ Keith Leroy Brooks, Prophecies of Daniel and Revelation (Verse by Verse Interpretation by the Cross Reference Method), Rev. ed. (Los Angeles: Bible Institute of Los Angeles, Biola Book Room, 1927), 82-86; Charles, Commentary on the Revelation, 1:269-292; George Wesley Davis, The Patmos Vision: An Exposition of the Revelation of Jesus Christ (Los Angeles: Bible Institute of Los Angeles, Biola Book Room, 1924), 158-172; Martin Ralph De Haan, Revelation: 35 Simple Studies in the Major Themes in Revelation, 6th ed. (Grand Rapids, MI: Zondervan, 1946), 155-163; Henry Weston Frost, Matthew Twenty-four and the Revelation: An Analysis, Literal Translation and Exposition of Each (New York: Oxford University Press, 1924), 208-215; Ernst Lohmeyer, Die Offenbarung des Johannes erklärt, 3rd ed., Handbuch zum Neuen Testament 16 (Tübingen: J. C. B. Mohr [Paul Siebeck], 1970), 87-94; Alfred Firmin Loisy, L'Apocalypse de Jean (Paris: Émile Nourry, 1923; reprint, [Frankfurt am Main?]: Minerva, 1972), 203-217; and Louis Thompson Talbot, The Revelation of Jesus Christ: An Exposition on the Book of Revelation, Rev. ed. (Grand Rapids, MI: William B. Eerdmans, 1937), 145-150. Lohmeyer's work was originally published in 1926.

${ }^{10}$ William Hoste, The Visions of John the Divine: An Exposition, Chapter by Chapter, of the Book of Revelation (Kilmarnock, UK: John Ritchie, [1932?]), 75-85.
} 
Tenney (1904-1985). ${ }^{11}$ Perhaps, the work by Ivan Barchuk (1903-1986) also belongs to this group. ${ }^{12}$

In the last decade of the twentieth century and on into the twenty-first century, attempts to show that the witnesses are solely Moses and Elijah are those by William Douglas Adamson, Bernie Lee Calaway (born 1942), Joachim Cochlovius (born 1943), Heinrich Kraft (1918-1998), Jeffery Lynn (Jeff) Lasseigne (born 1955), John Fullerton MacArthur, Jr. (born 1939), Robert Lewis Thomas (born 1928), James Claire VanderKam (born 1946), and John Clement Whitcomb (born 1924). ${ }^{13}$

${ }^{11}$ William Barclay, The Revelation of John, 2 vols., 3rd ed., New Daily Study Bible (Louisville, KY: Westminster John Knox Press, 2004), 2:73-82; Donald Grey Barnhouse, Revelation: An Expository Commentary (Grand Rapids, MI: Ministry Resources Library, 1971), 192-207; Thomas Francis Glasson, The Revelation of John, Cambridge Bible Commentary on the New English Bible (Cambridge: Cambridge University Press, 1965), 64-70; David Lee Hocking, The Coming World Leader: Understanding the Book of Revelation (Portland, OR: Multnomah Press, 1988), 177-186; Miesel, "The Two Witnesses."; Gilles Quispel, The Secret Book of Revelation: The Last Book of the Bible (New York: McGraw-Hill, 1979), 72-75; Jacob Brubaker Smith, A Revelation of Jesus Christ: A Commentary on the Book of Revelation, ed. J. Otis Yoder (Scottdale, PA: Herald Press, 1961), 23, 163-176, 296-297, 340-346; James Dean Strauss, The Seer, the Saviour, and the Saved; the Lord of the Future, Rev. ed., Bible Study Textbook Series (Joplin, MO: College Press, 1979), 174-180; and Merrill Chapin Tenney, Interpreting Revelation (Grand Rapids, MI: William B. Eerdmans, 1957; reprint, 1988), 18, 177, 191. Barclay's work was originally published in 1959.

${ }^{12}$ Ivan Barchuk, Explicacion del libro de Apocalipsis, trans. José A. Holowaty (Barcelona: Clie, [1970?]), 179-190.

${ }^{13}$ Adamson, "Identity and Ministry."; Bernie L. Calaway, Revealing the Revelation: A Guide to the Literature of the Apocalypse (San Francisco: International Scholars Publications, 1998), 310-333; Joachim Cochlovius, Siehe, ich mache alles neu: Das Buch der Offenbarung Jesu Christi (Nuremberg, Germany: VTR, 2011), 181-200; Heinrich Kraft, Die Bilder der Offenbarung des Johannes (Frankfurt am Main: Peter Lang, 1994), 119-126; Jeffery Lynn Lasseigne, Unlocking the Last Days: A Guide to the Book of Revelation \& the End Times (Grand Rapids, MI: Baker Books, 2011), 146-158; John Fullerton MacArthur, Jr., Revelation 1-11, MacArthur New Testament Commentary (Chicago: Moody Press, 1999), 289-306; Robert Lewis Thomas, Revelation 8-22: An 
A few commentators are more hesitant about the Moses-Elijah identification,

adding that the witnesses are perhaps meant to be only like Moses and Elijah. See Rice Hopkins Clayton (1897-1984), Timothy Francis (Tim) LaHaye (born 1926), Ford Cyrinde Ottman (1859-1929), Joseph Sickenberger (1872-1945), William Henry Simcox (18431889), Revere Franklin Weidner (1851-1915), and Alfred Wikenhauser (1883-1960). ${ }^{14}$ With Samuel MacLean Gilmour (1905-1970), Johannes Ernst Richard Lilje (1899-1977), Eduard Lohse (1924-2015), Alexander Ramsay, and Martin Rist (18961979), the two witnesses can be identified with Moses and Elijah, while functioning as models for future martyrs. ${ }^{15}$

Exegetical Commentary (Chicago: Moody Press, 1995), 78-102; VanderKam, "1 Enoch," 88-100; and John Clement Whitcomb, "The Two Witnesses," in Dispensationalism Tomorrow \& Beyond: A Theological Collection in Honor of Charles C. Ryrie, ed. David E. Olander and Christopher Cone (Ft. Worth, TX: Tyndale Seminary Press, 2008), 359373. For Kraft, note that a different opinion seems apparent in his earlier commentary. See Heinrich Kraft, Die Offenbarung des Johannes, Handbuch zum Neuen Testament 16a (Tübingen: J. C. B. Mohr [Paul Siebeck], 1974), 150-160.

${ }^{14}$ Rice Hopkins Clayton, Future History in "The Revelation" (London: Marshall, Morgan \& Scott, 1944), 96-99; Timothy Francis LaHaye, Revelation Unveiled (Grand Rapids, MI: Zondervan, 1999), 182-191; Ford Cyrinde Ottman, The Unfolding of the Ages in the Revelation of John (New York: Baker \& Taylor, 1905), 259-273, accessed July 10, 2015, Google Books; Sickenberger, Erklärung der Johannesapokalypse, 107115; William Henry Simcox, The Revelation of S. John the Divine: With Notes and Introduction, ed. George Augustus Simcox, Cambridge Greek Testament for Schools and Colleges (Cambridge: Cambridge University Press, 1893; reprint, 1909), 115-122, 222224; Weidner, Annotations on the Revelation of St. John the Divine, xxxvii, xxxix, 135148; and Wikenhauser, Die Offenbarung des Johannes, 84-89.

${ }^{15}$ Samuel MacLean Gilmour, "The Revelation of John," in The Interpreter's OneVolume Commentary on the Bible: Introduction and Commentary for Each Book of the Bible Including the Apocrypha; with General Articles, ed. Charles M. Laymon (Nashville, TN: Abingdon Press, 1971), 958-959; Johannes Ernst Richard Lilje, Das letzte Buch der Bibel: Eine Einführung in die Offenbarung Johannes, 6th ed., Die urchristliche Botschaft 23 (Hamburg: Furche-Verlag, 1960), 149-155; Eduard Lohse, Die Offenbarung des Johannes übersetzt und erklärt, 8th ed., Das Neue Testament Deutsch, 


\section{Two Unknown Figures}

In the eighteenth century, at least one expositor, Herman Venema (1697-1787), seems to advocate solely the identification of the witnesses as two individuals unknown until the events of Rev 11:3-13 transpire. ${ }^{16}$ Venema's comments, however, are very brief and appear without argumentation. Johann Heinrich Jung-Stilling (1740-1817), on the other hand, argues for a similar view of the two witnesses at the end of the eighteenth century. ${ }^{17}$

The view that the witnesses are two unknown figures becomes more common starting with the nineteenth century. Significant expositions from the nineteenth century come from Johann Tobias Beck (1804-1878), Karl Heinrich August von Burger (18051884), Wilhelm Martin Leberecht de Wette (1780-1849), Henry Dunn (1800-1878), Friedrich Hermann Christian Düsterdieck (1822-1906), Hermann Friedrich Wilhelm Gebhardt (1824-1899), Georg Ludwig Detlef Theodor (Louis) Harms (1808-1865), James Kelly, Peder Madsen (1843-1911), Benjamin Wills Newton (1807-1899), James Henthorn Todd (1805-1869), and Joseph Tyso (1774-1852) ${ }^{18}$

Neues Göttinger Bibelwerk, 11 (Göttingen: Vandenhoeck \& Ruprecht, 1993), 10, 13-14, 64-68, 119-120; Alexander Ramsay, The Revelation and the Johannine Epistles: With Introduction and Notes, Westminster New Testament (New York: Fleming H. Revell; London: Andrew Melrose, [1910?]), 135-143, accessed July 13, 2015, EBSCOhost American Theological Library Association (ATLA) Historical Monographs Collection, Series 2; and Martin Rist, "Exegesis of the Revelation of St. John the Divine," in The Interpreter's Bible (New York: Abingdon-Cokesbury Press, 1951-1957), 12:443-449.

${ }^{16}$ Venema, Pralectiones de methodo prophetica. . . . 271-273. Cf. Turner, "Revelation 11:1-13," 272.

${ }^{17}$ Jung-Stilling, Die Siegsgeschichte, 248-260. Jung-Stilling's work was originally published in 1799.

${ }^{18}$ Johann Tobias Beck, Erklärung der Offenbarung Johannis: Cap. 1-12, ed. 
That the witnesses are two unknown prophets is defended in the first three

decades of the twentieth century by Isbon Thaddeus Beckwith (1843-1936), Ethelbert

William Bullinger (1837-1913), James Henry McConkey (1858-1937), Ludwig Prager,

William Coit Stevens (born 1853), James Edmond Thompson (born 1853), George

Williams (1850-1928), and Theodor Zahn (1838-1933). ${ }^{19}$

Julius Lindenmeyer (Gütersloh, Germany: C. Bertelsmann, 1884), 162-187, accessed July 22, 2015, EBSCOhost American Theological Library Association (ATLA) Historical Monographs Collection, Series 1; Karl Heinrich August von Burger, Die Offenbarung St. Johannis nach dem Grundtexte deutsch erklärt (Munich: Christian Kaiser, 1877), 157172, accessed July 22, 2015, Google Books; De Wette, Kurze Erklärung, 125-135; Henry [Delta Dunn, pseud.], The Revelation of St. John, Simply Analyzed and Briefly

Expounded (London: James Nisbet, 1850), 123-137, accessed September 9, 2015, Google Books; Düsterdieck, Kritisch exegetisches Handbuch, 354-378; Hermann Friedrich Wilhelm Gebhardt, Der Lehrbegriff der Apokalypse und sein Verhältniss zum Lehrbegriff des Evangeliums und der Episteln des Johannes (Gotha, Germany: Rud. Besser, 1873), 269-277, accessed July 22, 2015, Google Books; Hermann Friedrich Wilhelm Gebhardt, The Doctrine of the Apocalypse, and Its Relation to the Doctrine of the Gospel and Epistles of John, trans. John Jefferson, Clark's Foreign Theological Library, n.s., 58 (Edinburgh: T. \& T. Clark, 1878), 256-263, accessed July 22, 2015, Google Books; Georg Ludwig Detlef Theodor Harms, Die Offenbarung St. Johannis, 8th ed. (Hermannsburg, Germany: Druck und Verlag der Missionshandlung, 1910), 144-156; James Kelly, The Apocalypse Interpreted in the Light of "The Day of the Lord", 2 vols. (London: James Nisbet, 1849-1851), 2:118-162, accessed July 20, 2015, Internet Archive American Libraries Collection; Madsen, Johannes' Aabenbaring, 488-512; Benjamin Wills Newton, Thoughts on the Apocalypse, 3rd ed. (London: Houlston \& Sons; London: Lucas Collins, 1904), 190-198, 202-211, 213-214, accessed July 22, 2015, Internet Archive Canadian Libraries Collection; Todd, Six Discourses, 163-213; and Joseph Tyso, An Elucidation of the Prophecies, Being an Exposition of the Books of Daniel and the Revelation. ... (London: Jackson and Walford, 1838), 181-186. The works of de Wette, Harms, and Newton were originally published at earlier times.

${ }^{19}$ Beckwith, Apocalypse, 584-606; Ethelbert William Bullinger, The Apocalypse; or, "The Day of the Lord", 3rd ed. (London: Eyre \& Spottiswoode, 1935), 343-368; James Henry McConkey, The Book of Revelation: A Series of Outline Studies in the Apocalypse (Pittsburgh, PA: Silver, 1921), 65-71; Ludwig Prager, Die Offenbarung Johannis auf Grund der heiligen Schrift eingehend erklärt, 2 vols. (Leipzig:

Kommissionsverlag der A. Deichert'schen Verlagsbuchhandlung Nachfolger (Georg Böhme), 1901), 2:88-122, 134-137, accessed July 15, 2015, Google Books; William Coit Stevens, The Book of Revelation, vol. 2 of Revelation, the Crown-Jewel of Biblical 
In the 1930s and 1940s, this identification appears in the expositions of Donatus

Haugg (1900-1943), Adolph Ernst Knoch (1874-1965), Ella Arjenette Rust (1885-1975), Gerhard Wilhelm Helmut Adolf Theodor Tolzien (1870-1946), and Walter Leon Tucker $(1871-1934) .^{20}$

Through the 1950s on up through the 1980s, this view of the witnesses as unknown individuals appears in the expositions of Gary G. Cohen (born 1934) and Salem Kirban (1925-2010), W. Robert Cook, Fritz Grünzweig (1914-1989), Elmer Michael Rusten (born 1937), Douglas J. Simpson, Walter E. Staten (1928-1988), Wilber B. Wallis (1912-2008), and John Flipse Walvoord (1910-2002). ${ }^{21}$

Prophecy ([Harrisburg, PA?]: Christian Alliance, 1928; reprint, Revelation, the Crown Jewel of Biblical Prophecy: The Book of Revelation, Harrisburg, PA: Christian Publications, [1973?]), 177-186; James Edmond Thompson, The History of the Fall and Dissolution of Christendom (Nashville, TN: McQuiddy Printing, 1917), 177-195; George Williams, The Student's Commentary on the Holy Scriptures: Analytical, Synoptical, and Synthetical, New ed. (Grand Rapids, MI: Kregel Publications, 1971), 1042; and Zahn, Die Offenbarung des Johannes, 2:416-431. The works of Bullinger and Williams were originally published at earlier times.

${ }^{20}$ Haugg, Die zwei Zeugen; Adolph Ernst Knoch, The Unveiling of Jesus Christ, Commonly Called the Revelation of St. John. . . . (Los Angeles: Concordant Publishing Concern, 1935), 302-321; Ella Arjenette Rust, An Exposition of the Revelation of Jesus Christ ([Worthington, MN?], 1939), 142-150; Gerhard Wilhelm Helmut Adolf Theodor Tolzien, Die Offenbarung des Johannes für bibellesende Gemeindeglieder erklärt (Hamburg: Agentur des Rauhen Hauses, 1947), 86-94; and Walter Leon Tucker, Studies in Revelation: An Expositional Commentary (Binghamton, NY: J. Young, 1935; reprint, Kregel Bible Study Classics, Grand Rapids, MI: Kregel Publications, 1980), 231-254.

${ }^{21}$ Gary G. Cohen and Salem Kirban, Revelation Visualized: Verse by Verse, King James Version (Chicago: Moody press, 1971), 214-227; W. Robert Cook, The Theology of John (Chicago: Moody Press, 1979), 223-224; Fritz Grünzweig, JohannesOffenbarung, 2 vols., EDITION C-Bibel-Kommentar 24-25 (Neuhausen-Stuttgart, Germany: Hänssler-Verlag, 1981-1982), 1:268-288; Elmer Michael Rusten, "A Critical Evaluation of Dispensational Interpretations of the Book of Revelation" (PhD dissertation, New York University, 1977), 408-423, accessed July 22, 2015, ProQuest Dissertations \& Theses Global; Douglas J. Simpson, The Apocalypse: A Premillennial 
This view of the witnesses is represented in the last decade of the twentieth century and the first fifteen years of the twenty-first by the remarks of Charles Lee Feinberg (1909-1995), Marco Frenschkowski (born 1960), Robert William Klund (born 1953), Eugene John Mayhew (born 1949), Thomas Michael (born 1962), Leighton Paige Patterson (born 1942), Helmut Seng (born 1961), Bebe Rebecca Skaggs (born 1950) and Priscilla Carla Benham (1950-2000), Christine Joy Tan (born 1975), Jarl Henning Ulrichsen (born 1947), and Daniel Kei Kwong Wong. ${ }^{22}$

Interpretation of the Book of Revelation (Nashville, TN: Randall House Publications, 1975), 61-64; Staten, "Identity."; Wilber B. Wallis, The Coming of the Kingdom: A Survey of the Book of Revelation (N.p.: Biblical Studies Minsitries International, 2000), accessed July 14, 2015, http://www.bsmi.org/wallis\%5Fkingdom.htm; and John Flipse Walvoord, The Revelation of Jesus Christ: A Commentary (Chicago: Moody Press, 1966), 175-183. The piece from Wallis reprints an article originally published in 1982.

${ }^{22}$ Charles Lee Feinberg, "The Book of Revelation," in The KJV Parallel Bible Commentary, ed. Jerry Falwell, Edward E. Hindson, and Woodrow Michael Kroll (Nashville, TN: Thomas Nelson Publishers, 1994), 2683-2684; Marco Frenschkowski, "Die Entrückung der zwei Zeugen zum Himmel (Apk 11,11-14)," in Der Himmel, ed. Dorothea Sattler and Samuel Vollenweider, Jahrbuch für biblische Theologie 20 (Neukirchen-Vluyn, Germany: Neukirchener Verlag, 2006), 261-290; Robert William Klund, "The Plot of Revelation 4-22" (PhD dissertation, Dallas Theological Seminary, 2002), 124-130, accessed July 22, 2015, ProQuest Dissertations \& Theses Global; Mayhew, "Revelation 11," 364-366; Thomas Michael, "Evangelistic Motifs in the Book of Revelation: A Critical Analysis of the Book of Revelation with Regard to Its Various Evangelistic Motifs" (PhD dissertation, Southeastern Baptist Theological Seminary, 2000), 146-166, accessed July 22, 2015, ProQuest Dissertations \& Theses Global; Leighton Paige Patterson, Revelation, New American Commentary 39 (Nashville, TN: B \& H Publishing Group, 2012), 236-251; Helmut Seng, "Apk 11,1-14 im Zusammenhang der Johannesapokalypse. Aufschluss aus Lactantius und Hippolytus," Vetera Christianorum 27 (1990): 111-121; Bebe Rebecca Skaggs and Priscilla Carla Benham, Revelation: Pentecostal Commentary, Pentecostal Commentary Series (Blandford Forum, UK: Deo, 2009), 111-118; Tan, "Identity."; Ulrichsen, "Das eschatologische Zeitschema," 166-183; and Wong, "Two Witnesses." Note that Tan backs away from a specific futurist identification in her dissertation also on the two witnesses. See chapter 3 and Tan, "Defense." 


\section{Mixed Proposals}

Thomas Woolston (ca. 1670-1733) argues that the two witnesses are Moses and Elijah, but adds that they also represent the two testaments of the Bible. ${ }^{23}$

Antoine Augustin Calmet (1672-1757) continues the tradition of the witnesses as

Enoch and Elijah, but sees an additional sense. The witnesses also symbolize the

Christians martyred during the persecution begun by Diocletian. ${ }^{24}$

Johann Albrecht Bengel (1687-1752) argues for two eschatological prophets like Moses and Elijah, but adds that the two witnesses also represent two communities, one from Judah and one from Israel. ${ }^{25}$

Andrew Robert Fausset (1821-1910) seems to see the two witnesses in a primary sense as Moses and Elijah. He also appears to see the two witnesses as representative figures. They represent the redeemed from among the Jews and from among the Gentiles. On the other hand, they may also represent the two testaments of the Bible. ${ }^{26}$

${ }^{23}$ Woolston, Fourth Free-Gift.

${ }^{24}$ Antoine Augustin Calmet, Les épîtres de St. Paul, les épîtres canoniques, et l'Apocalypse, vol. 8 of Commentaire littéral sur tous les livres de l'Ancien et du Nouveau Testament (Paris: Emery; Saugrain; Pierre Martin, 1726), 918, 969-973, 1032-1034, accessed September 13, 2015, Google Books.

${ }^{25}$ Bengel, Erklärte Offenbarung Johannis oder vielmehr Jesu Christi. . . . 346362; and Johann Albrecht Bengel, Sechzig erbauliche Reden über die Offenbarung Johannis oder vielmehr Jesu Christi. . . New ed. (Stuttgart: Johann Christoph Erhard, 1788), 536-572, accessed August 24, 2015, Google Books. The first edition of the former was published in 1740. The first edition of the latter was published in 1747. With these two pieces, cf. Johann Albrecht Bengel, Ernst Bengel, and Johann Christian Friedrich Steudel, Gnomon of the New Testament, ed. Andrew Robert Fausset, trans. William Fletcher, vol. 5, 6th ed. (Edinburgh: T. \& T. Clark, 1866), 248-253, accessed November 28, 2015, Internet Archive American Libraries Collection. The original Latin edition of this piece appeared in 1742 .

${ }^{26}$ Andrew Robert Fausset, "Zechariah," in A Commentary, Critical and 
Michael Paget Baxter (1834-1910) understands that Elijah will return accompanied by Enoch, Moses, or the Apostle John. He is open, however, to an additional fulfillment in history through events related to the church or to the Bible. ${ }^{27}$

Henry Allan Ironside (1876-1951) contends that the witnesses are active in the first three-and-a-half years of a final seven years before the realization of Jesus' kingdom on earth. The witnesses could be two like Moses and Elijah or they might represent a group of Israelites that have come to accept Jesus as their Messiah and that appear elsewhere in Revelation. ${ }^{28}$ Frederick Albert Tatford (1901-1986) puts forth a similar view. $^{29}$

Like Ironside, Lucy Mary Dorman and Arno Clemens Gaebelein (1861-1945) argue that the two witnesses represent an end-time group of believers in Christ. Unlike Ironside, they say that, in addition to representing a group, the two witnesses could be two like Moses and Elijah who lead the group. ${ }^{30}$

Explanatory, on the Old and New Testaments (Hartford, CT: S. S. Scranton, 1871), 1:720-722, accessed October 26, 2015, Google Books; and Andrew Robert Fausset, "The Revelation of St. John the Divine," in A Commentary, Critical and Explanatory, on the Old and New Testaments (Hartford, CT: S. S. Scranton, 1871), 2:575-577, accessed October 26, 2015, Google Books.

${ }^{27}$ Michael Paget Baxter, Forty Coming Wonders between 1888-9 and 1901 as Foreshown in the Prophecies of Daniel and Revelation. ... 6th ed. (London: Christian Herald Office, 1887), 214-216, 297-305, accessed September 13, 2015, Google Books.

${ }^{28}$ Henry Allen Ironside, Lectures on the Revelation: Delivered in the Gospel Auditorium, Oakland, Calif., 2nd ed. (New York: Loizeaux Brothers, 1930; reprint, Revelation, Ironside Expository Commentaries, Grand Rapids, MI: Kregel, 2004), 108113, 126, 156.

${ }^{29}$ Frederick Albert Tatford, The Final Encounter: An Exposition of the Book of Revelation (Newtown, Australia: Christian Outreach Book Service, 1983), 343-358.

${ }^{30}$ Lucy Mary Dorman, The Unveiled Future: An Interpretation of the Revelation 
William Kelly (1821-1906) and Walter Scott (1838-1933) interpret the number two as primarily being a reference to a valid testimony. Accordingly, the witnesses may be two or more prophets appearing during the period between the rapture of the church and the arrival of the millennial kingdom. ${ }^{31}$

Peter Morant argues that the two witnesses represent the church bearing witness between the comings of Jesus, but he leaves open the possibility that Enoch and Elijah might return to join in the testimony at the end of the age. ${ }^{32}$

Thomas Samuel Kepler (1897-1963) argues that the two witnesses are two eschatological prophets acting like Moses and Elijah or Enoch and Elijah, but is open to the possibility that the witnesses represent the churches of Smyrna and Philadelphia, which receive only praise among the seven churches addressed in the letters section (Rev $2-3) .{ }^{33}$

Given to St. John (London: Marshall, Morgan \& Scott, 1936), 94-100; and Arno Clemens Gaebelein, The Revelation: An Analysis and Exposition of the Last Book of the Bible (New York: Publication Office "Our hope"; Glasgow: Pickering \& Inglis; Auckland: H. L. Thatcher, 1915), 67-72.

${ }^{31}$ William Kelly, Lectures on the Book of Revelation, New ed. (London: W. H. Broom, 1871), 216-231, 239-247, accessed September 15, 2015, Google Books; and Walter Scott, Exposition of the Revelation of Jesus Christ, 4th ed. (London: Pickering \& Inglis, [1948?]), 226-238.

${ }^{32}$ Morant, Das Kommen des Herrn, 192-217.

${ }^{33}$ Thomas Samuel Kepler, The Book of Revelation: A Commentary for Laymen (New York: Oxford University Press, 1957), 117-125; and Thomas Samuel Kepler, Dreams of the Future: Daniel and Revelation, Bible Guides 22 (London: Lutterworth Press; New York: Abingdon Press, 1963), 72, 81-82. 
George Eldon Ladd (1911-1982) sees a primary reference to two eschatological prophets in the witnesses, but is open to the idea that they also represent the witness of the church to Israel during the present age. ${ }^{34}$

Grant R. Osborne (born 1942), Eduard Schick (1906-2000), and Antoninus King Wai Siew all argue that the two witnesses have both a corporate and an individual dimension. The witnesses are two eschatological prophets and represent the church in a limited period before the end of the age. ${ }^{35}$

${ }^{34}$ Ladd, Commentary on the Revelation, 149-160.

${ }^{35}$ Grant R. Osborne, Revelation, Baker Exegetical Commentary on the New Testament (Grand Rapids, MI: Baker Academic, 2002), 408-437; Eduard Schick, The Revelation of St. John, 2 vols., trans. Werner Kruppa, New Testament for Spiritual Reading 24-25 (New York: Herder and Herder, 1971), 1:99-110; and Antoninus King Wai Siew, The War between the Two Beasts and the Two Witnesses: A Chiastic Reading of Revelation 11.1-14.5, Library of New Testament Studies 283 (London: T \& T Clark, 2005), 84-122, 214-278. 


\section{APPENDIX B \\ IDENTIFICATIONS OF THE TWO WITNESSES AS CONTEMPORARIES OF JOHN}

\section{Introduction}

Here presented are references to endeavors to argue that the two witnesses are two actual people who are contemporaries of John. These pieces are significant in that they offer some measure of argumentation for an identification as opposed to just stating a view without any noticeable support. There is, however, variation in the amount of argumentation among these works. No attempt has been made here to distinguish the expositions according the quantity of argumentation. The time frame for these works is from 1700 onward.

These expositions represent several identifications, of which the two main ones are the Jewish high priests Ananus and Jesus and the apostles Peter and Paul. Some of these expositions are noted in chapter 3.

For many of the citations below, I have included pages that also cover Rev 11:1-2 to give context for the particular readings of 11:3-13. At times, commentators have included 11:14 in their discussions. Where appropriate, the pages covering that verse are also a part of the citation.

If an author has espoused a particular view of the witnesses over more than one work, I cite only the main piece. When an author's viewpoint has changed from one 
work to another, I try to cite all the relevant works from that author.

\section{Ananus and Jesus}

One of the main ways of identifying the witnesses as contemporaries of John is to see them as the Jewish high priests Ananus and Jesus. From the eighteenth century, one finds this opinion espoused by Johann Gottfried Eichhorn (1752-1827) and Johann Gottfried von Herder (1744-1803). ${ }^{1}$ In the nineteenth century, there are the works by Philip Charles Soulbieu Desprez (ca. 1812-1879) and Friedrich Anton Levin Matthäi. ${ }^{2}$ Two works from the twentieth century are that by Karl August Eckhardt and that by James Joseph Louis Ratton (1845-1924). ${ }^{3}$

George Wesley Buchanan (born 1921) and Guy Fau (born 1909) both suggest the

${ }^{1}$ Johann Gottfried Eichhorn, Commentarius in Apocalypsin Joannis, 2 vols. (Göttingen: Johann Christian Dieterich, 1791), 2:50-74; and Johann Gottfried von

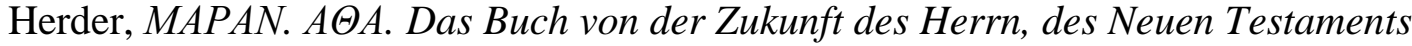
Siegel, in Herders Sämtliche Werke, ed. Bernhard Ludwig Suphan (Berlin: Weidmannsche Buchhandlung, 1893; reprint, Sämtliche Werke, Hildesheim, Germany: Georg Olms Verlagsbuchhandlung, 1967), 9:160-166.

${ }^{2}$ Philip Charles Soulbieu Desprez, The Apocalypse Fulfilled in the Consummation of the Mosaic Economy and the Coming of the Son of Man. . . . 2nd ed. (London: Longman, Brown, Green, and Longmans, 1855), 244-285, accessed July 29, 2015, Google Books; Desprez, Apocalypse Fulfilled, 3rd ed., 244-285; and Friedrich Anton Levin Matthäi, Die Offenbarung Johannes aus dem Griechischen übersetzt, und mit einer vollständigen Erklärung begleitet, 2 vols. (Göttingen: Dieterich'schen Buchhandlung, 1828), 2:112-120, accessed August 2, 2015, Google Books. Note that Desprez changed his opinion on the two witnesses in later works. See Desprez, John, 113-136; and Desprez, Daniel and John, 242-259.

${ }^{3}$ Karl August Eckhardt, Der Tod des Johannes als Schlüssel zum Verständnis der Johanneischen Schriften, Studien zur Rechts- und Religionsgeschichte 3 (Berlin: Walter de Gruyter, 1961), 61-72; and James Joseph Louis Ratton, The Apocalypse of St. John: A Commentary on the Greek Text, 2nd ed. (London: R. \& T. Washbourne; New York: Benziger Brothers, 1915), 250-262, accessed July 23, 2015, Google Books. 
possibility that the witnesses represent Ananus and Jesus, ${ }^{4}$ but this is not the only possibility for them. Buchanan offers two other possible identifications. He suggests that the witnesses represent the Hasmonean king, Mattathias Antigonus, and his general, Pappus, who were in conflict with Herod the Great during the years 40-37 BCE, but they could also be two unknown prophets operating in Jerusalem at the time of this conflict with Herod. ${ }^{5}$ Fau sees it as more likely that the two witnesses are Judas of Galilee and the Pharisee Zadok, both of whom were supposedly involved in the founding of the Zealots around the year $7 \mathrm{CE} .^{6}$

\section{James, the Brother of Jesus, and Another Individual}

Gustav Hermann Joseph Philipp Volkmar (1809-1893) seems to see a twofold sense where 11:3-6 involve the foremost witnesses of the OT speaking to the messiahship of Jesus and then 11:7-12 involve two actual martyrs for Jesus (James, the brother of Jesus, and James, the son of Zebedee). ${ }^{7}$ Later, A. Greve offers as a singular sense the idea that these two Jameses are the two witnesses. ${ }^{8}$

${ }^{4}$ George Wesley Buchanan, The Book of Revelation: Its Introduction and Prophecy, Mellen Biblical Commentary, New Testament Series, 22 (Lewiston, NY: Mellen Biblical Press, 1993), 263-264; and Guy Fau, "L'Apocalypse de Jean," Cahiers du Cercle Ernest Renan 10, no. 36 (Fourth Quarter 1962): 30.

${ }^{5}$ Buchanan, The Book of Revelation: Its Introduction and Prophecy, 260-263. The complete discussion of Rev 11:1-13 appears at ibid., 245-268.

${ }^{6} \mathrm{Fau}$, "L'Apocalypse de Jean," 29-30. Other remarks concerning Rev 11 appear at ibid., 19, 30-33.

${ }^{7}$ Gustav Hermann Joseph Philipp Volkmar, Commentar zur Offenbarung Johannes (Zurich: Orell, Füßli, und Comp., 1862), 174-179, accessed November 11, 2015, Google Books.

${ }^{8}$ Greve, "»Mine to vidner«," 128-138. 
In the eighteenth century, Ferdinand Christian Baur (1792-1860) suggests that the two witnesses are James, the brother of Jesus, and Simeon, another relative of Jesus. ${ }^{9}$ Later in the century, James Stuart Russell (1816-1895) and Israel Perkins Warren (18141892) argue that the witnesses are James, the brother of Jesus, and Peter. ${ }^{10}$

In the twentieth century, David Keppel (1846-1938) argues that James and Jude, the brothers of Jesus, are the two witnesses. ${ }^{11}$ Meanwhile, Benjamin Wisner Bacon (1860-1932) promotes James, the brother of Jesus, and John, the son of Zebedee, as the two witnesses. ${ }^{12}$ Later, Margaret Barker (born 1944) argues that the two witnesses are Jesus and his brother, James, but she is open to the possibility that John the Baptist and James are meant. ${ }^{13}$

\section{Peter and One of the Sons of Zebedee}

William L. Roy (ca. 1796-1879) argues that the witnesses are Peter and John. ${ }^{14}$ In

${ }^{9}$ Ferdinand Christian Baur, "Kritik der neuesten (Hengstenberg'schen) Erklärung der Apokalypse," Theologische Jahrbücher 11 (1852): 451-466, accessed September 29, 2015, Google Books.

${ }^{10}$ Russell, Parousia, 423-444; and Israel Perkins Warren, The Book of Revelation: A Exposition.... (New York: Funk \& Wagnalls, 1886), 140-155, accessed August 28, 2011, Google Books.

${ }^{11}$ David Keppel, The Book of Revelation Not a Mystery (New York: Methodist Book Concern, 1918), 56-58.

${ }^{12}$ Bacon, "The Elder John," 188-189.

${ }^{13}$ Margaret Barker, The Revelation of Jesus Christ, Which God Gave to Him to Show to His Servants What Must Soon Take Place (Revelation 1.1) (London: T \& T Clark, 2000), 187-195.

${ }^{14}$ William L. Roy, A New and Original Exposition of the Book of Revelation.... (New York: D. Fanshaw, 1848), 134-150, accessed October 14, 2015, Google Books. 
one of Desprez's discussions of the witnesses, the witnesses are identified as Peter and James. ${ }^{15}$

\section{Peter and Paul}

Endeavors to argue for the apostles Peter and Paul as the two witnesses are those by Marie-Emile Boismard (1916-2004), Joseph Bonnet (1858-1912), John M. Court, Bertrand Fauvarque (born 1954), Stanislas Giet (1898-1968), Johannes Munck (19041965), Josef Schmidt (born 1949), James Hubbard Swetnam (born 1928), and Cuthbert

Hamilton Turner (1860-1930). ${ }^{16}$ Almost all of these expositions come from the twentieth century.

\section{James and John, the Sons of Zebedee}

Three authors from the twentieth century propose that the witnesses are James and

${ }^{15}$ Desprez, Daniel and John, 242-259. As intimated above, Desprez expressed more than one identification for the two witnesses during his life.

${ }^{16}$ Marie-Emile Boismard, "'L'Apocalypse', ou 'Les Apocalypses' de S. Jean," RB 56 (1949); Joseph Bonnet, Eclaircissement de l'Apocalypse (Fribourg: Imprimerie SaintPaul, 1908); John M. Court, Myth and History in the Book of Revelation (London: SPCK, 1979), 82-105; Bertrand Fauvarque, "Pierre et Paul: Les Deux Témoins de l'Apocalypse? Le rapprochement et ses limites aux IVe-Ve Siècles," Graphè, no. 3 (1994): 31-49; Stanislas Giet, L'Apocalypse et l'histoire: Étude historique sur l'Apocalypse johannique (Paris: Presses Universitaires de France, 1957), 14-16, 24-31, 36-43; Munck, Petrus und Paulus; Josef Schmidt, "NOY $\Sigma$ und $\Sigma$ OФIA in Offb 17," NovT 46, no. 2 (January 2004): 176-186, accessed November 11, 2015, EBSCOhost ATLA Religion Database with ATLASerials; James Hubbard Swetnam, "Apocalypse 11,1-14: A Suggested Interpretation," in "Cieux nouveaux et terre nouvelle » (Ap 21,1): Pertinence du livre de l'Apocalypse pour l'Église d'Afrique ... , ed. Jean-Bosco Matand Bulembat (Kinshasa, Democratic Republic of the Congo: Association panafricaine des exégètes catholiques, 2004), 85-101; and Cuthbert Hamilton Turner, "St. John in Asia Minor: The Apocalypse," in Studies in Early Church History: Collected Papers (Oxford: Clarendon Press, 1912), 212-214, accessed July 6, 2015, Google Books. Turner's essay was originally published as an article in 1894. 
John, the sons of Zebedee. These authors are Robert Eisler (1882-1949), John J.

Gunther, and Michael Oberweis. ${ }^{17}$

\section{Other Identifications of This Type}

Otto Böcher (born 1935) interprets the witnesses as Jesus and John the Baptist. ${ }^{18}$ Albert Gelin (1902-1960) sees two unknown prophets active during the first Jewish war against Rome. ${ }^{19}$ Hubert Le Bourdellès argues that the witnesses are Stephen and James,

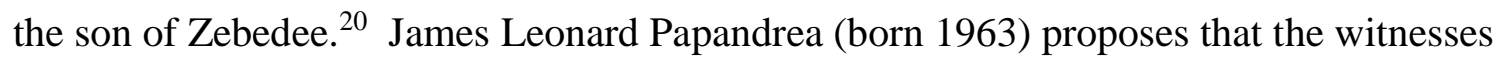
represent two Christian leaders in first century Jerusalem, but recognizes that they could symbolize all the Christians martyred in Jerusalem. ${ }^{21}$ Recently, Thomas Witulski (born 1964) has argued that the two witnesses are two figures from the Bar Kokhba revolt, namely, Bar Kokhba himself and the priest Eleazar. ${ }^{22}$

\footnotetext{
${ }^{17}$ Robert Eisler, The Enigma of the Fourth Gospel: Its Author and Its Writer (London: Methuen, 1938), accessed July 23, 2015, Internet Archive Microfilm Collection; John J. Gunther, "The Elder John, Author of Revelation," JSNT, no. 11 (April 1981), accessed November 11, 2015, EBSCOhost ATLA Religion Database with ATLASerials; Oberweis, "Das Martyrium." 1978.

${ }^{18}$ Böcher, "Johannes der Täufer," 81-86. This essay was originally published in

${ }^{19}$ Gelin, "Apocalypse," 12:625-627.

${ }^{20}$ Le Bourdellès, "L'épisode des Deux Témoins," 67-78.

${ }^{21}$ James Leonard Papandrea, The Wedding of the Lamb: A Historical Approach to the Book of Revelation (Eugene, OR: Pickwick Publications, 2011), 32-33, 39-40, 63, 7375, 79, 117-122.
}

${ }^{22}$ Witulski, Apk 11. 


\section{APPENDIX C \\ IDENTIFICATIONS OF THE TWO WITNESSES \\ AS THE PEOPLE OF GOD}

\section{Introduction}

Represented below are endeavors to argue that the two witnesses symbolize the people of God. These pieces are significant in that they offer some measure of argumentation for an identification as opposed to just stating a view without any noticeable support. The time frame for these works is from 1700 onward.

These expositions represent several identifications, of which the main one is the witnesses as the church. Some of the identifications look to only a part of the people of God, such as the martyrs of the church, the prophets, or the ministers. Some of these expositions are noted in chapter 4 . The set of identifications represented here is not comprehensive.

For many of the citations below, I have included pages that also cover Rev 11:1-2 to give context for the particular readings of 11:3-13. At times, commentators have included 11:14 in their discussions. Where appropriate, the pages covering that verse are also a part of the citation. On occasion, how commentators view the timing of the witnesses' activity is made plain in some other part of their work. I mention those pages as well as necessary.

If an author has espoused a particular view of the witnesses over more than one 
work, I cite only the main piece. When an author's viewpoint has changed from one work to another, I try to cite all the relevant works from that author.

\section{The Witnesses as the Church in General}

Significant expositions that argue that the witnesses are the church in general abound. I am aware of well over a hundred works with such interpretations. Given the size of this set of literature, I limit my remarks here primarily to pieces that have several arguments or that are authored by well-known commentators on Revelation.

While authors might agree that the witnesses represent the church, they do not necessarily agree on the timing for the witnesses' activity. In fact, the timing of the witnesses' activity is sometimes not clearly defined. This is reflected in the remarks offered here.

A viewpoint featured in chapter 4 is that of the witnesses as the church during its sojourn between the comings of Jesus to earth, that is, the church age. Representatives of this viewpoint include Gregory Kimball Beale (born 1949), Joseph Bonsirven (18801958), Louis Andrew Brighton (1927-2015), Lucien Cerfaux (1883-1968) and JulesMarie Cambier (1915-1992), Isabelle Donegani, Heinz Giesen (born 1940), Wilfrid John Harrington (born 1927), William Hendriksen (1900-1982), Philip Edgcumbe Hughes (1915-1990), Hendrik Rijk van de Kamp (born 1951), Craig S. Keener (born 1960), Simon J. Kistemaker (born 1930), Craig Richard Koester (born 1953), Raymond Joseph Loenertz (1900-1976); Philip Lee Mayo (born 1960), William Milligan (1821-1893), Markus Öhler (born 1967), Alfred Plummer (1841-1926) with Thomas Randall and Arthur Thomas Bott, Pierre Prigent (born 1928), Akira Satake, Stephen Stewart Smalley 
(born 1931), Henry Barclay Swete (1835-1917), and Felise Tavo. ${ }^{1}$

Another viewpoint featured in chapter 4 agrees that the witnesses are the church,

${ }^{1}$ Beale, Book of Revelation, 536-608, 621-622, 639-640, 642-643, 646-647, 687692, 694-695, 730-731, 770; Joseph Bonsirven, L'Apocalypse de Saint Jean: Traduction et commentaire, Verbum Salutis 16 (Paris: Beauchesne et ses fils, 1951), 189-190, 192200, 223-224; Louis Andrew Brighton, Revelation, Concordia Commentary (St. Louis, MO: Concordia Publishing House, 1999), 282-303; Lucien Cerfaux and Jules-Marie Cambier, L'Apocalypse de Saint Jean lue aux Chrétiens, Lectio divina 17 (Paris: Les Éditions du Cerf, 1955), 90-97; Donegani, "À cause de la parole", 381-445; Heinz Giesen, Die Offenbarung des Johannes, Regensburger Neues Testament (Regensburg, Germany: Verlag Friedrich Pustet, 1997), 239-261; Wilfrid John Harrington, Revelation, ed. Daniel J. Harrington, Sacra Pagina Series 16 (Collegeville, MN: Liturgical Press, 1993), 118-125; Hendriksen, More Than Conquerors: An Interpretation of the Book of Revelation, 151-159, 172-174; Philip Edgcumbe Hughes, The Book of the Revelation: A Commentary (Leicester, United Kingdom: Inter-Varsity Press; Grand Rapids, MI: William B. Eerdmans, 1990), 120-131; Kamp, Openbaring, 214, 219, 221, 252-274, 281284, 290-293, 300-301, 313; Craig S. Keener, Revelation, NIV Application Commentary (Grand Rapids, MI: Zondervan, 2000), 286-303; Simon J. Kistemaker, Exposition of the Book of Revelation, New Testament Commentary 20 (Grand Rapids, MI: Baker Books, 2001), 321-340; Koester, Revelation, 438-441, 483-487, 494-512; Raymond Joseph Loenertz, The Apocalypse of Saint John, trans. Hilary J. Carpenter (London: Sheed \& Ward, 1947), 79-85, 92, 94-95; Mayo, "Those Who Call", 115-143; William Milligan, "The Revelation of St. John the Divine," in A Popular Commentary on the New Testament, ed. Philip Schaff (New York: Scribner's Sons; Edinburgh: T. \& T. Clark, 1879-1883), 4:92-96 (being part of the seperate pagination for the whole section on Revelation), accessed October 27, 2015, Google Books; William Milligan, The Book of Revelation, Expositor's Bible (New York: A. C. Armstrong \& Son, 1896), 168-189, accessed October 27. 2015, Google Books; Markus Öhler, Elia im Neuen Testament: Untersuchungen zur Bedeutung des alttestamentlichen Propheten im frühen Christentum, Beihefte zur Zeitschrift für die neutestamentliche Wissenschaft und die Kunde der älteren Kirche 88 (Berlin: Walter de Gruyter, 1997), 263-288; Alfred Plummer and others, Revelation, Pulpit Commentary (New York: Funk \& Wagnalls, [1880?]), 288-294, accessed August 18, 2015, Internet Archive American Libraries Collection; Prigent, L'Apocalypse, 260-277; Prigent, Commentary on the Apocalypse, 337-359; Satake, Die Offenbarung des Johannes, 115, 259-272; Stephen Stewart Smalley, The Revelation to John: A Commentary on the Greek Text of the Apocalypse (Downers Grove, IL: InterVarsity Press, 2005), 246-247, 250-255, 269-287; Henry Barclay Swete, The Apocalypse of St. John: The Greek Text with Introduction, Notes and Indices, 3rd ed. (London: Macmillan, 1911), cxxxvii-cxxxviii, 132-141, 152, accessed August 9, 2015, Internet Archive Canadian Libraries Collection; and Tavo, Woman, Mother and Bride, 173-223. 
but places them in a special era that is in the future relative to John (either near or far) and that comes before the second coming. Representatives of this viewpoint include David Edward Aune (born 1939), George Raymond Beasley-Murray (1916-2000), Maynard Eugene Boring (born 1935), Ian Kieran Boxall (born 1964), Theodor Friedrich Dethlof Kliefoth (1810-1895), Jan Lambrecht (born 1926), Gerhard Maier (born 1937), Robert Hayden Mounce (born 1921), John Philip McMurdo Sweet (1927-2009), and Anton Vögtle (1910-1996). ${ }^{2}$ Ben Witherington III (born 1951) seems to espouse something similar to this perspective, but he notes the possibility that the two witnesses represent the two faithful congregations visible in the letters to the seven churches. ${ }^{3}$

Some other significant expositions also relate the witnesses to the church, but they are more ambiguous about the timing of the witnesses' activity. Here is Alan Sumner Bandy (born 1973), Richard Bauckham (born 1946), Brian Keith Blount (born 1956),

${ }^{2}$ Aune, Revelation 6-16, 575-632; George Raymond Beasley-Murray, The Book of Revelation, New Century Bible Commentary (Grand Rapids, MI: William B. Eerdmans; London: Marshall, Morgan \& Scott, 1981), 168-169, 176-187; Maynard Eugene Boring, Revelation, Interpretation, a Bible Commentary for Teaching and Preaching (Louisville, KY: John Knox Press, 1989), 69, 142-148, 158; Ian Kieran Boxall, The Revelation of Saint John, Black's New Testament Commentaries 19 (Peabody, MA: Hendrickson Publishers; London: Continuum, 2006), 155, 158-167; Theodor Friedrich Dethlof Kliefoth, Die Offenbarung des Johannes, 3 vols. (Leipzig: Dörffling und Franke, 1874), 2:177-221, accessed October 20, 2015, Google Books; Jan Lambrecht, "Apokalyps 11,114: Uitleg en actualisatie," in De sluier opgelicht? Apokalyptiek in Oud en Niew Testament (Leuven: Vlaamse bijbelstichting; Acco uitgeverij, 1979), 62-80; Maier, Kapitel 1-11, 451-493; Maier, Kapitel 12-22, 18-22, 38, 64-65, 75-76, 78-80, 82-84, 8891, 96, 103, 121, 123; Mounce, The Book of Revelation, 211-224; John Philip McMurdo Sweet, Revelation, Westminster Pelican Commentaries (Philadelphia: Westminster Press, 1979), 180-189; and Anton Vögtle, Das Buch mit den sieben Siegeln: Die Offenbarung des Johannes in Auswahl gedeutet (Freiburg im Breisgau, Germany: Herder, 1981), 8591.

${ }^{3}$ Witherington, Revelation, 42-43, 46, 157-160, 169-170, 182. 
Édouard Cothenet (born 1924), Jeremy Shawn Crenshaw (born 1976), Robert Edward

Dalrymple (born 1966), Gordon Donald Fee (born 1934), David Earl Holwerda (born

1932), Jonathan Morshead Knight (born 1959), Joseph Layton Mangina (born 1957), J.

Ramsey Michaels (born 1931), Johannes Maria Nützel (born 1935), James Lynn

Resseguie (born 1945), Benjamin Steen Stubblefield (born 1983), and Robert Walter

Wall (born 1947). ${ }^{4}$

\footnotetext{
${ }^{4}$ Alan Sumner Bandy, The Prophetic Lawsuit in the Book of Revelation, New Testament Monographs 29 (Sheffield, United Kingdom: Sheffield Phoenix Press, 2010), 135-136, 219-220, 223-227; Richard Bauckham, The Climax of Prophecy: Studies on the Book of Revelation (London: T \& T Clark, 1993), 266-283; Brian Keith Blount, Revelation: A Commentary., New Testament Library (Louisville, KY: Westminster John Knox Press, 2009), 201-218, 232; Édouard Cothenet, "Prophétisme dans le Nouveau Testament," DBSup, ed. Louis Pirot et al. (Paris: Letouzey \& Ané, 1926-), vol. 8, cols. 1329-1331; Édouard Cothenet, Le Message de l'Apocalypse ([Paris?]: Mame/Plon, 1995), 96-102; Jeremy Shawn Crenshaw, "Will the Real Church Please Stand Up? An Exegetical Examination of Revelation 11:1-13," in But These Are Written . . . Essays on Johannine Literature in Honor of Professor Benny C. Aker, ed. Craig S. Keener, Jeremy S. Crenshaw, and Jordan Daniel May (Eugene, OR: Pickwick Publications, 2014), 194213; Dalrymple, Revelation and the Two witnesses, 3-58; Gordon Donald Fee, Revelation: A New Covenant Commentary, New Covenant Commentary Series (Eugene, OR: Cascade Books, 2011), 145-156; David Earl Holwerda, "The Church and the Little Scroll (Revelation 10, 11)," CTJ 34, no. 1 (April 1999): 155-161, accessed November 11, 2015, EBSCOhost ATLA Religion Database with ATLASerials; Jonathan Morshead Knight, Revelation, 2nd ed., Readings: A New Biblical Commentary (Sheffield, United Kingdom: Sheffield Phoenix Press, 2011), 90-94; Joseph Layton Mangina, Revelation, Brazos Theological Commentary on the Bible (Grand Rapids, MI: Brazos Press, 2010), 134-141, 143; J. Ramsey Michaels, Revelation, IVP New Testament Commentary Series 20 (Downers Grove, IL: InterVarsity Press, 1997), 136-143, 148, 152; Johannes Maria Nützel, "Zum Schicksal der eschatologischen Propheten," BZ 20, no. 1 (1976): 59-94; James Lynn Resseguie, The Revelation of John: A Narrative Commentary (Grand Rapids, MI: Baker Academic, 2009), 159-167, 172, 175-176; Benjamin Steen Stubblefield, "The Function of the Church in Warfare in the Book of Revelation" (PhD Dissertation, Southern Baptist Theological Seminary, 2012), 151-166, 187-190, accessed October 22, 2015, ProQuest Dissertations \& Theses Global; and Robert Walter Wall, Revelation, New International Biblical Commentary 18 (Peabody, MA: Hendrickson Publishers, 1991), $141-150$.
} 


\section{The Witnesses Distinctively as the "True" Church}

There is a primarily older line of interpretation that associates the witnesses with the "true" church or the "faithful" Christians over a large segment of time that begins in the early centuries of Christianity. Some of those who take up this line of interpretation go so far as to identify particular individuals and communities as being the fulfillment to the specifics of the prophecy. Examples of this line of interpretation are Joseph Baylee (1808-1883), Joseph Frederick Berg (1812-1871), David Cambell, Alexander Clark, Robert Culbertson (1765-1823), William Cuninghame (ca. 1775-1849), Hermann Johann Gräber (1814-1904), Matthew Habershon (1789-1852), Edward Huntingford (18201905), and James Ivory Holmes (1779-1868). ${ }^{5}$ Others include Bryce Johnston (1747-

${ }^{5}$ Joseph Baylee, The Times of the Gentiles. . . . (London: James Nisbet, 1871), 15 20, 91-98, 168-169, accessed September 2, 2015, Google Books; Joseph Frederick Berg, Prophecy and the Times; or, England and Armageddon. An Application of Some of the Predictions of Daniel and St. John to Current Events (Philadelphia: Higgins and Pirkinpine, 1856), 137-200, accessed August 25, 2015, Google Books; David Cambell, Illustrations of Prophecy; Particularly the Evening and Morning visions of Daniel, and the Apocalyptical Visions of John (Boston: by the author, 1840), 344-352, accessed August 20, 2015, Google Books; [Alexander Clark?], The Book of Prophecy opened: Or, A Plain Discovery of the Hidden Treasure of Wisdom and Knowledge, Contained in the Book with Seven Seals. . . . (London: by the author, 1779), 154-182, accessed October 20, 2015, Google Books; Robert Culbertson, Lectures, Expository and Practical, on the Book of Revelation, New ed., 3 vols. (Edinburgh: Oliver \& Boyd, 1826), 2:404-457, accessed August 27, 2015, Google Books; William Cuninghame, A Dissertation on the Seals and Trumpets of the Apocalypse, and the Prophetical Period of Twelve Hundred and Sixty Years, 3rd ed. (London: Thomas Cadell; Hatchard \& Son; James Nisbet; Edinburgh: Waugh \& Innes; J. Lindsay; Glasgow: John Smith \& Son, 1832), xxi-xxii, 127-163, 252260, 279-290, accessed November 3, 2015, Google Books; Hermann Johann Gräber, Versuch einer historischen Erklärung der Offenbarung des Johannes. . . . (Heidelberg, Germany: Karl Winter, 1857), 172-192, accessed August 27, 2015, Google Books; Edward Huntingford, A Practical Interpretation of the Revelation of St. John the Divine, 3rd ed. (London: Bickers \& Son, 1900), 186-201, 271-275, 422-434; Matthew Habershon, An Historical Exposition of the Prophecies of the Revelation of St. John. . . . (London: James Nisbet; B. Wertheim, 1841), 215-288, accessed August 27, 2015, Google Books; James Ivory Holmes, The Revelation of Saint John the Divine Elucidated. . . 2 
1805), Robert Nevin (1817-1893), Thomas Pyle (1674-1756), James Robertson (died

1732), Justin Almerin Smith (1819-1896) and James Robinson Boise (1815-1895), John

St. Clair, and Frederic Thruston (ca. 1787-1821). ${ }^{6}$ Oral Edmond Collins's (1928-2013)

exposition is a rare more recent example. ${ }^{7}$

vols. (London: J. Hatchard, 1815), 1:324-378, accessed August 27, 2015, Google Books. The work of Culbertson was originally published at an earlier time. Baylee seems to have narrowed his definition of the witnesses in a later commentary. See Joseph Baylee, The Apocalypse: The Voice of Jesus Christ from the Throne of Glory. With an Exegetical and Practical Commentary (London: James Nisbet, 1876), 253-270. Meanwhile, Habershon expands his definition of the witnesses in a later edition. See Matthew Habershon, An Historical Exposition of the Prophecies of the Revelation of St. John. . . . 2nd ed., 2 vols. (London: James Nisbet; B. Wertheim, 1844), 1:229-276, accessed November 3, 2015, Google Books.

${ }^{6}$ Bryce Johnston, A Commentary on the Revelation of St. John, New ed., 2 vols. (Edinburgh: William Creech, 1807), 1:356-403, accessed October 27, 2015, Google Books; Robert Nevin, Studies in Prophecy. In Two Parts. Part I. Studies in the Old Testament—chiefly Ezekiel and Daniel. Part II. The Apocalypse (Londonderry, United Kingdom: James Montgomery, 1890), 395-414; Thomas Pyle, A Paraphrase on the Acts of the Holy Apostles, upon All the Epistles of the New Testament, and upon the Revelations. ... vol. 3, New ed. (Oxford: J. Parker; London: Law and Whittaker, 1817), 3:119-121, 123-131, accessed October 20, 2015, Internet Archive American Libraries

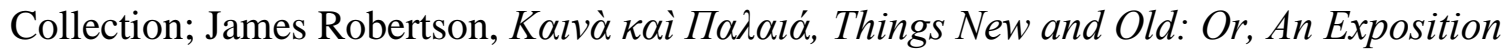
Of the Book of the Revelation of John the Apostle. ... (Edinburgh: by the author, 1730), 171-200, accessed August 27, 2015, Gale Eighteenth Century Collections Online; Justin Almerin Smith and James Robinson Boise, Commentary on the Revelation, American Commentary on the New Testament (Philadelphia: American Baptist Publication Society, 1884), 150-161, 179-183, accessed August 30, 2015, Internet Archive American Libraries Collection; John St. Clair, Observations On Certain Passages in Daniel And The Apocalypse of John. . . (London: S. Crowder and H. Woodgate, 1755), 115-121, accessed August 27, 2015, Gale Eighteenth Century Collections Online; and Frederic Thruston, England Safe and Triumphant: or, Researches into the Apocalyptic Little Book, and Prophecies, Connected and Synchronical, 2 vols. (Coventry, United Kingdom: F. C. and J. Rivington, 1812), 1:128-231, accessed October 27, 2015, West Bengal Public Library Network DSpace. The works of Johnston and Pyle were originally published at earlier times.

${ }^{7}$ Oral Edmond Collins, The Final Prophecy of Jesus: An Introduction, Analysis, and Commentary on the Book of Revelation (Eugene, OR: Wipf and Stock, 2007), 237266. 
There is a group of commentators whose thinking is similar to those just cited, but who emphasize the ministers or preachers of the select congregations. This type of exposition is found in Clement Moore Butler (1810-1890), Benajah Harvey Carroll (1843-1914), John Cumming (1807-1881), Edward Bishop Elliott (1793-1875), John Gill (1697-1771), P. W. Grant, David Nevins Lord (1792-1880), William James Reid (18341902), Thomas Scott (1747-1821), Ethan Smith (1762-1849), Joseph Tanner, Daniel Denison Whedon (1808-1885), Edward William Whitaker (1752-1818), Thomas Wickes (1814-1870), and James Aitken Wylie (1808-1890). ${ }^{8}$ Herman Hoeksema's (1886-1965)

${ }^{8}$ Clement Moore Butler, Lectures on the Book of Revelations (New York Robert Carter \& Brothers; Washington, DC: William Ballantyne, 1860), 170-198, accessed August 20, 2015, Google Books; Benajah Harvey Carroll, The Book of Revelation, ed. James Britton Cranfill, Interpretation of the English Bible (New York: Fleming H. Revell, 1913), 149-157, accessed August 30, 2015, Internet Archive American Libraries Collection; John Cumming, Apocalyptic Sketches. Lectures on the Book of Revelation. First Series (Philadelphia: Lindsay and Blakiston, 1854), 166-208, accessed August 30, 2015, Google Books; Elliott, Hora Apocalyptica, 2:181-488, 3:260-305; John Gill, An Exposition of the Revelation of S. John the Divine, Both Doctrinal and Practical. . . . (London: George Keith, 1776), 116-129, accessed August 30, 2015, Google Books; P. W. Grant, The Revelation of John. An Exposition (London: Hodder and Stoughton, 1889), 273-301; David Nevins Lord, An Exposition of the Apocalypse, New ed. (New York: Franklin Knight, 1859), 249-307, accessed November 1, 2015, Google Books; William James Reid, Lectures on the Revelation (Pittsburgh: Stevenson, Foster, 1878), 228-250, accessed August 30, 2015, Google Books; Thomas Scott, The Holy Bible: Containing the Old and New Testaments, According to the Authorized Version; with Explanatory Notes, Practical Observations, and Copious Marginal References, vol. 6, Stereotype ed. (Boston: Samuel T. Armstrong; Crocker and Brewster; New York: J. P. Haven, 1824), 6:736-741, accessed August 30, 2015, Google Books; Ethan Smith, Key to the Revelation. In Thirty-Eight Lectures, Taking the Whole Book in Course, 2nd ed. (Boston: Whipple \& Damrell, 1837), 141-161, 222-223, accessed August 31, 2015, Google Books; Joseph Tanner, Daniel and the Revelation: The Chart of Prophecy, and Our Place in It. A Study of the Historical and Fururist Interpretation (London: Hodder and Stoughton, 1898), 105-106, 108-116, 134-147; Daniel Denison Whedon, Titus-Revelation, vol. 5 of Commentary on the New Testament: Intended for Popular Use (New York: Eaton \& Mains; Cincinnatti: Jennings \& Graham, 1908), 315-316, 404-410, 416-417, 421, accessed August 31, 2015, Google Books; Edward William Whitaker, A General And Connected View Of The Prophecies Relating To The Times Of The Gentiles, Delivered by 
exposition is similar to this latter group as to what the witnesses represent, but differs significantly as to the timing of the witnesses' activity. ${ }^{9}$ The interpretation of Charles Daubuz (1673-1717) is also similar to this latter group as to whom the witnesses are.

While seeing the true church as a whole in the witnesses, Daubuz also finds an emphasis on ecclesiastical and civil leaders. ${ }^{10}$

\section{The Witnesses as Part of God's People}

Edward Payson Blair (1910-2008), François de Bovet (1745-1838), George

Bradford Caird (1917-1984), Martin Kiddle and M. K. Ross, Leon Morris (1914-2006), Mitchell Glenn Reddish (born 1953), Allison Albert Trites (born 1936), and John R. Yeatts (born 1946) argue that the witnesses represent the martyrs of the church. ${ }^{11}$ The

our Blessed Saviour, the Prophet Daniel, and the Apostles Paul and John. . . (Egham, United Kingdom: C. Boult, 1795), 176-186, 269-272, 272, note " $\dagger$ ", accessed October 28, 2015, Google Books; Thomas Wickes, An Exposition of the Apocalypse, in a Series of Discourses (New York: M. W. Dodd, 1851), 145-161, 173-177, 185-189, accessed August 31, 2015, Google Books; and James Aitken Wylie, The Seventh Vial; or, The Past and Present of Papal Europe as Shown in the Apocalypse, New ed. (London: Hamilton, Adams; Edinburgh: Andrew Elliot, 1868), 55-125. The works of Gill, Scott, and Whedon were originally published at earlier times.

${ }^{9}$ Herman Hoeksema, Behold, He Cometh! An Exposition of the Book of Revelation, ed. Homer Cooper Hoeksema (Grand Rapids, MI: Reformed Free Publishing Association, 1969), 361-398.

${ }^{10}$ Charles Daubuz, A Perpetual Commentary on the Revelation of St. John. . . . (London: Benjamin Tooke, 1720), 50-51, 60-61, 489-544, 618-621, accessed November 2, 2015, Google Books.

${ }^{11}$ Edward Payson Blair, The Acts and Apocalyptic Literature, Guide for Bible Readers (New York: Abingdon-Cokesbury Press, 1946), 133-135; Bovet, L'esprit de l'Apocalypse, 330-363; Caird, Commentary on the Revelation, 130-140; Kiddle and Ross, Revelation, 174-206; Leon Morris, The Book of Revelation: An Introduction and Commentary, Rev. ed., Tyndale New Testament Commentaries (Leicester, United Kingdom Inter-Varsity Press; Grand Rapids, MI: William B. Eerdmans, 1987), 140-148; Mitchell Glenn Reddish, Revelation, Smyth \& Helwys Bible Commentary. (Macon, GA: 
timing for the witnesses' activities and the circumstances of their ministry is not

necessarily the same among these commentators.

Ernest-Bernard Allo (1873-1945), Joseph Sylvester Considine (1893-1973),

Walter Garrett (died 1716), James Glasgow (1805-1890), William Anthony Holmes

(1782-1843), John Lawrie, Lambertus Johannes Lietaert Peerbolte (born 1963), Ulrich B.

Müller (born 1938), Moses Stuart (1780-1852), and Thomas Whittemore (1800-1861)

argue that the witnesses represent a group of Christian teachers, preachers, or ministers. ${ }^{12}$

The timing for the witnesses' activities and the circumstances of their ministry is not

necessarily the same among these commentators.

Smyth \& Helwys, 2001), 205-214, 219-224; Allison Albert Trites, The New Testament Concept of Witness, Society for New Testament Studies, Monograph Series, 31 (Cambridge: Cambridge University Press, 1977), 164-170; and John R. Yeatts, Revelation, Believers Church Bible Commentary (Scottdale, PA: Herald Press, 2003), 181-182, 191-199, 204-214.

${ }^{12}$ Allo, Saint Jean: L'Apocalypse, 143-167; Considine, "The Two Witnesses: Apoc. 11:3-13," 377-392; Garrett, Exposition of Rev. xj; Glasgow, Apocalypse, 288-313; William Anthony Holmes, The Time of the End; Being a Series of Lectures on Prophetical Chronology (London: R. B. Seeley and W. Burnside, 1833), 137-168, accessed August 19, 2015, Google Books; John Lawrie, The Completion of Prophecy, The Clearest evidence of the Truth of Christianity. . . . (Edinburgh: Wheldon and Waller; London: Leigh and Sothebay, 1781), 128-167, accessed August 19, 2015, Google Books; Lambertus Johannes Lietaert Peerbolte, The Antecedents of Antichrist: A TraditioHistorical Study of the Earliest Christian Views on Eschatological Opponents, Supplements to the Journal for the Study of Judaism 49 (Leiden: E. J. Brill, 1996), 121128, 143, 167-168; Ulrich B. Müller, Die Offenbarung des Johannes, Ökumenischer Taschenbuchkommentar zum Neuen Testament 19 (Gütersloh, Germany: Gütersloher Verlagshaus Gerd Mohn; Würzburg, Germany: Echter Verlag, 1984), 204-221; Stuart, Commentary on the Apocalypse, 2:213-240; and Thomas Whittemore, A Commentary on the Revelation of St. John, the Divine (Boston: James M. Usher, 1848), 185-191, accessed November 2, 2015, Google Books. Lietaert Peerbolte seems to advance a more general ecclesiastical view of the witnesses at Lambertus Johannes Lietaert Peerbolte, "Sodom, Egypt, and the Two Witnesses of Revelation 11:8," in Sodom's Sin: Genesis 18-19 and Its Interpretation, ed. Edward Noort and Eibert J. C. Tigchelaar, Themes in Biblical Narrative 7 (Leiden: Brill, 2004), 63-82. 
Henricus Maria Féret (1904-1992) argues that the two witnesses go beyond simply representing Christian religious leaders. They also refer to Christian political leaders. ${ }^{13}$

Alan F. Johnson (born 1933), Robert Benjamin Kübel (1838-1894), Barclay Moon Newman (born 1931), Jürgen Roloff (1930-2004), Elisabeth Schüssler Fiorenza (born 1938), Matthew J. Streett, and Bernhard Weiss (1827-1918) believe that Rev 11 is talking about a group of Christian prophets. ${ }^{14}$ The timing for the witnesses' activities and the circumstances of their ministry is not necessarily the same among these commentators.

Two commentators link the witnesses to the general body of Christians in Jerusalem before the fall of the city in 70 CE. Here are Henry Cowles (1803-1881) and Hubert J. Richards (1921-2010). ${ }^{15}$ Mathias Rissi (1920-2006) also associates the

${ }^{13}$ Henricus Maria Féret, The Apocalypse of St. John, trans. Elizabeth Corathiel (Westminster, MD: Newman Press, 1958), 145-150, 195-196.

${ }^{14}$ Alan F. Johnson, "Revelation," in The Expositor's Bible Commentary, ed. Tremper Longman III and David E. Garland, rev. ed. (Grand Rapids, MI: Zondervan, 2006), 13:679-689; Kübel, Pastoralbriefe, 242-251; Barclay Moon Newman, Jr., Rediscovering the Book of Revelation (Valley Forge, PA: Judson Press, 1968), 73-75; Jürgen Roloff, The Revelation of John: A Continental Commentary, trans. John E. Alsup, Continental Commentary (Minneapolis: Fortress Press, 1993), 127-135; Schüssler Fiorenza, Revelation: Vision of a Just World, 76-79; Matthew J. Streett, Here Comes the Judge: Violent Pacifism in the Book of Revelation, Library of New Testament Studies 462 (New York: T \& T Clark, 2012), 205-209; and Bernhard Weiss, Apostolische Briefe, Offenbarung Johannis, vol. 2 of Das Neue Testament nach D. Martin Luthers berichtigter Übersetzung mit fortlaufender Erläuterung versehen, 2nd ed. (Leipzig: J. C. Hinrichs'sche Buchhandlung, 1907), 505-507. Kübel's commentary was originally published in 1888.

${ }^{15}$ Henry Cowles, The Revelation of John; with Notes, Critical, Explanatory, and Practical. ... (New York: D. Appleton, 1871), 124-133, 247-254, accessed October 29, 2015, Google Books; and Hubert J. Richards, What the Spirit Says to the Churches: A 
witnesses with the Jerusalem church, but he differs from the other two commentators in respect to the timing of the witnesses' activity. ${ }^{16} \mathrm{He}$ sees the time of the witnesses' activity as the era between the comings of Christ to earth. Rissi seems to differ in additional way from the other two. Rissi's handling of the tale of the witnesses suggests that he believes that what is happening to the Jerusalem Christians speaks to what is happening to the larger church in the world. ${ }^{17}$

Some, mostly older expositions, speak about a group of people in succession who oppose the supposed failings of the Papacy over the course of many years. Some of these go so far as to identify particular individuals and communities as being the fulfillment to the specifics of the prophecy. Here one can consider Michael Arthur, John James Bachmair (died 1778), Albert Barnes (1798-1870), David Brown (1803-1897), Alexander Fraser (1749-1802), Henry Gauntlett (1762-1833), Alexander Hislop (1807-1865), Samuel Langdon (1723-1797), Moses Lowman (1680-1752), Alexander McLeod (17741833), James Murray (1732-1782), Thomas Newton (1704-1782), Lauchlan Taylor (died 1785), Thomas Williams (1755-1839), and John Chappel Woodhouse (ca. 1749-1833). ${ }^{18}$

Key to the Apocalypse of John (New York: P. J. Kenedy and Sons, 1967), 83-86.

${ }^{16}$ Rissi, Time and History, 26-28, 39-41, 87-88, 96-104, 114. Cf. the original German at Rissi, Was ist und was geschehen soll danach, 31-32, 44-46, 90-92, 99-107, 117.

${ }^{17}$ Rissi, Time and History, 99-103, 114. Cf. Rissi, Was ist und was geschehen soll danach, 103-106, 117.

${ }^{18}$ Michael Arthur, The two Witnesses prophesying a Thousand two Hundred and Threescore Says in Sackloth [sic]. . . . (Glasgow: by the author, 1779), accessed September 4, 2015, Gale Eighteenth Century Collections Online; John James Bachmair, The Revelation of St. John Historically Explained. . . (London, 1778), 161-205, accessed September 4, 2015, Google Books; Albert Barnes, Notes, Explanatory and Practical, on 
Another relatively older exposition expands the identification of the witnesses to include not only opponents of the apparent spiritual tyranny of the Papacy, but also

the Book of Revelation (New York: Harper \& Brothers, 1851), 300-328, accessed August 20, 2015, Google Books; David Brown, The Apocalypse: Its Structure and Primary Predictions (London: Hodder and Stoughton, 1891), 112-123, 145-161, 215-216, accessed September 6, 2015, Internet Archive American Libraries Collection; Alexander Fraser, A Key to the Prophecies of the Old \& New Testament, Which Are Not Yet Accomplished. ... (Edinburgh: Bell \& Bradfute; London: G. G. \& J. Robinson, 1795), 41-51, 137-146, 157-167, accessed September 6, 2015, Internet Archive American Libraries Collection; Henry Gauntlett, An Exposition of the Book of Revelation. . . . 2nd ed. (London: L. B. Seeley; J. Hatchard and Son, 1821), 139-165, accessed September 6, 2015, Google Books; Alexander Hislop, The Red Republic; or, Scarlet-Coloured Beast of the Apocalypse: Being an Inquiry into the Period of the Prophesying of the Two Witnesses, and the Character of the Beast That Kills Them. . . (Edinburgh: William Whyte; Glasgow: W. Collins and D. Bryce; London: Longman, Brown, 1849), accessed October 19, 2015, Google Books; Samuel Langdon, Observations On The Revelation Of Jesus Christ to St. John. . . . (Worcester, MA: Isaiah Thomas, 1791), 140-155, accessed September 7, 2015, Gale Eighteenth Century Collections Online; Moses Lowman, A Paraphrase and Notes on the Revelation of St. John, 4th ed. (London: W. Baynes, 1807), 126-141, 183-190, accessed September 7, 2015, Google Books; Alexander McLeod, Lectures upon the Principal Prophecies of the Revelation (New York: Whiting and Watson; Eastburn, Kirk; Philadelphia: William W. Woodward, 1814), 309-348, 365-370, accessed September 7, 2015, Internet Archive American Libraries Collection; James Murray, Lectures Upon The Book of the Revelation, Of John the Divine: Containing A new Explanation of the History, Visions, and Prophesies, contained in that Book, 2 vols. (Newcastle upon Tyne, United Kingdom, 1778), 2:230-235, 240-251, accessed September 7, 2015, Gale Eighteenth Century Collections Online; Thomas Newton, Dissertations on the Prophecies, Which Have Remarkably Been Fulfilled, and at This Time Are Fulfilling in the World, New ed. (London: Longman; John Richardson; J. M. Richardson; et al., 1832), 211-212, 486-516, 603-612, accessed September 7, 2015, Google Books; Lauchlan Taylor, An Essay On some Important Passages Of The Revelation Of The Apostle John; Compared with correspondent Passages of the Book Of Daniel, 2nd ed. (Edinburgh: by the author, 1770), x-xi, 57-59, 85-86, 98-100, 110-147, accessed September 7, 2015, Google Books; Thomas Williams, The Cottage Bible and Family Expositor; Containing the Authorized Translation of the Old and New Testaments, with Practical Reflections, and Short Explanatory Notes, Calculated to Elucidate Difficult and Obscure Passages, vol. 3 (London: W. Simpkin and R. Marshall, [1828?]), 3:825-829, accessed October 19, 2015, Google Books; and John Chappel Woodhouse, Annotations on the Apocalypse. . . (London: J. Hatchard and Son, 1828), 223-238, 272-277, accessed September 9, 2015, Google Books. The works of Lowman and Newton were originally published at earlier times. 
opponents of civil tyranny. This is the position of James Bicheno (1752-1831) and

Joseph Lomas Towers (1770-1831). ${ }^{19}$

\section{Other Views Relating the Witnesses to God's People}

Although they may not all have in mind exactly the same conception of the groups and the time of their activity, John Aquila Brown (1774-1830), John Hersey

(1786-1862), Francis John Bodfield Hooper (1810-1888), Henry William Lovett,

Edmondo F. Lupieri (born 1950), and Hans Wood argue that the witnesses are Jews and

Christians. ${ }^{20}$ Similar to this is the view of Catherine Gunsalus González (born 1934) and

${ }^{19}$ James Bicheno, The Signs of the Times: In Three Parts, New ed. (London, 1808), 40-71, 84-95, accessed November 3, 2015, Google Books; and [Joseph Lomas Towers?], Illustrations Of Prophecy: In The Course Of Which Are Elucidated Many Predictions, Which Occur In Isaiah, Or Daniel, In The Writings Of The Evangelists, Or The Book Of Revelation. . . 2 vols. (London, 1796), 1:79-154, 2:363-375, accessed November 9, 2015, Google Books. Bicheno's work is drawn from three earlier publications. He originally discusses the witnesses in 1793 in an edition of the first part of the later work. Thus, Towers can reflect upon the work of Bicheno in 1796.

${ }^{20}$ John Aquila Brown, The Jew, the Master-key of the Apocalypse. ... (London: Hatchard and Son; Seeley and Son; Nisbet, 1827), 56-57, 62-64, 85-88, accessed September 7, 2015, Google Books; John Hersey, The Identity of the Two Apocalyptic Witnesses. ... (Baltimore: Armstrong \& Berry; Philadelphia: Higgins \& Perkinpine, 1857), 15-184, accessed September 7, 2015, Internet Archive American Libraries Collection; Francis John Bodfield Hooper, The Revelation of Jesus Christ by John, 2 vols. (London: J. \& F. H. Rivington; Edinburgh: A. \& C. Black, 1861), 1:452-497, accessed September 7, 2015, Google Books; Henry William Lovett, The Revelation of Saint John Explained, 2nd ed. (London: Whittaker, 1838), 325-357, 413, 440, accessed October 20, 2015, Google Books; Edmondo F. Lupieri, A Commentary on the Apocalypse of John, trans. Maria Poggi Johnson and Adam Kamesar, Italian Texts and Studies on Religion and Society (Grand Rapids, MI: William B. Eerdmans, 2006), 172-184, 194197, 204-206; Hans [John M-D Wood, pseud.], The Revelation of St. John, Considered As Alluding to Certain Services of the Jewish Temple. ... (London: by the author, 1787), 126-149, 160-161, 166-167, 428-429, 474-479, accessed May 20, 2012, Google Books. 
Justo Luis González (born 1937). They argue that the witnesses represent Israel and the Church. $^{21}$

Some commentators are not satisfied with seeing the witnesses either as two actual people or as a group of individuals. Rather, they argue that, although the description of the witnesses may be tied to actual persons, the witnesses themselves are a symbol for Christian testimony in action. The witnesses can then function as a model or paradigm for the audience of Revelation. This way of understanding the two witnesses is expressed by Johannes Behm (1883-1948), Adela Yarbro Collins (born 1945), David DeSilva (born 1967), Charles Homer Giblin (1928-2002), Ernst Wilhelm Hengstenberg (1802-1869), Paul Sevier Minear (1906-2007), George Thomas Montague (born 1929), Ulrike Riemer (born 1969), Christopher Charles Rowland (born 1947), and Charles Archibald Anderson Scott (1859-1941). ${ }^{22}$ Richard Charles Henry Lenski (1864-1936)

${ }^{21}$ Catherine Gunsalus González and Justo Luis González, Revelation, Westminster Bible Companion (Louisville, KY: Westminster John Knox Press, 1997), 70-73.

${ }^{22}$ Johannes Behm, Die Offenbarung des Johannes: Übersetzt und erklärt, 5th ed., Das Neue Testament Deutsch, Neues Göttinger Bibelwerk, 11 (Göttingen: Vandenhoeck \& Ruprecht, 1949), 57-61; Adela Yarbro Collins, The Apocalypse, New Testament Message 22 (Collegeville, MN: Liturgical Press, 1979), 68-73; David Arthur DeSilva, Seeing Things John's Way: The Rhetoric of the Book of Revelation (Louisville, KY: Westminster John Knox Press, 2009), 75-78, 86, 102, 113, 140, 154, 223-225, 231, 266, 342; Giblin, "Revelation 11:1-13," 433-459; Ernst Wilhelm Hengstenberg, Die Offenbarung des heiligen Johannes für solche die in der Schrift forschen, 2nd ed. (Berlin: L. Oehmigke's Verlag, 1861-1862), 1:344-377, accessed September 8, 2015, Google Books; George Thomas Montague, The Apocalypse and the Third Millennium: Today's Guide to the Book of Revelation (Ann Arbor, MI: Servant Publications, 1998), 145-150; Paul Sevier Minear, I Saw a New Earth: An Introduction to the Visions of the Apocalypse (Washington: Corpus Books, 1968), 95-104; Ulrike Riemer, Das Tier auf dem Kaiserthron? Eine Untersuchung zur Offenbarung des Johannes als historischer Quelle, Beiträge zur Altertumskunde 114 (Stuttgart: B. G. Teubner, 1998), 65-69; Christopher Charles Rowland, Revelation, Epworth Commentaries (London: Epworth Press, 1993), 97-101; and Scott, The Book of the Revelation, 208-217. For what appears to be a 
also emphasizes the testimony in action, but does not say anything about it serving as a model for the readers. ${ }^{23}$

Although the details of their interpretations differ, Samuel Davies Baldwin (1818-1866) and Johann Peter Lange (1802-1884) understand the witnesses as representing the Christian church and the Christian state. ${ }^{24}$

Kamal Fahim Awad Hanna (born 1961), Thomas Alexander Lacey (1853-1931), and Paolo Byong-Seob Min see a combined image of the Spirit and the followers of Christ. $^{25}$ Homer Hailey (1903-2000) is quite similar, putting forth two options. ${ }^{26}$ If the duality of the witnesses is literal, then the two witnesses represent the Holy Spirit and the apostles. If the duality of the witnesses is figurative, then the saints generally, as

slightly different identification for Rowland, cf. Christopher Charles Rowland, "The Book of Revelation," in The New Interpreter's Bible (Nashville, TN: Abingdon Press, 1994-2002), 12:640-643, 646. Scott seems to espouse a different view of the witnesses, a literal one, in another work. See Scott, Revelation, 216-224.

${ }^{23}$ Richard Charles Henry Lenski, The Interpretation of St. John's Revelation (Minneapolis, MN: Augsburg Publishing House, 1963), 326-351.

${ }^{24}$ Samuel Davies Baldwin, Armageddon. . . . Rev. ed. (Nashville: Southern Methodist Publishing House, 1884), 294-304, 462-464, accessed September 14, 2015, Google Books; Johann Peter Lange, Die Offenbarung des Johannes. Theologischhomiletisch bearbeitet., Theologisch-homiletisches Bibelwerk, Die Heilige Schrift, Des Neuen Testamentes, 16 (Bielefeld, Germany: Velhagen und Klasing, 1871), 148-155, accessed September 14, 2015, Google Books; and Johann Peter Lange, The Revelation of John, ed. Elijah Richardson Craven, trans. Evelina Moore, Commentary on the Holy Scriptures, New Testament, 10 (New York: Charles Scribner's Sons, 1874), 222-227, 229-232, accessed September 14, 2015, Google Books. Baldwin's work was originally published in 1854.

${ }^{25}$ Hanna, La passione di Cristo, 271-292; Thomas Alexander Lacey, "The Two Witnesses," JTS 11, no. 1 (1910): 55-60; and Min, "I due testimoni."

${ }^{26}$ Hailey, Revelation: An Introduction and Commentary, 42, 47-48, 249-261, 288. 
recipients of the message of the apostles, are included in the referent for the symbol of the two witnesses.

In the other appendices, other significant expositions are mentioned that combine some view of the witnesses with the view that they represent the people of God. 


\section{APPENDIX D \\ IDENTIFICATIONS OF THE TWO WITNESSES \\ AS SACRED WRITINGS}

\section{Introduction}

Represented below are endeavors to argue that the two witnesses symbolize sacred writings. These pieces are significant in that they offer some measure of argumentation for an identification as opposed to just stating a view without any noticeable support. There is, however, variation in the amount of argumentation among these works. No attempt has been made here to distinguish the expositions according the quantity of argumentation. The time frame for these works is from 1700 onward.

These expositions represent two identifications, of which the main one is the witnesses as the Bible. Some of these expositions are noted in chapter 4. Reference is also made to proposals that mix the idea of a symbol of sacred writings with another symbolic understanding of the witnesses.

For many of the citations below, I have included pages that also cover Rev 11:1-2 to give context for the particular readings of 11:3-13. At times, commentators have included 11:14 in their discussions. Where appropriate, the pages covering that verse are also a part of the citation. On occasion, how commentators view the timing of the witnesses' activity is made plain in some other part of their work. I mention those pages as well as necessary. 
If an author has espoused a particular view of the witnesses over more than one work, I cite only the main piece. When an author's viewpoint has changed from one work to another, I try to cite all the relevant works from that author.

\section{The Witnesses as the Law and the Prophets}

The notion that the witnesses represent the Law and the Prophets seems limited to the twentieth century, when looking at matters from 1700 onwards. Although the details of their interpretations and even their conceptions of the text of Revelation differ, James Lowell Blevins (1936-2004), André Feuillet (1909-1998), Léon Pierre François Gry (1879-1952), Edward Allison McDowell, Jr. (1898-1975), M. Robert Mulholland, Jr. (born 1936), Michael Robert Newbolt (1874-1956), John Wood Oman (1860-1939), Ronald Hadyn Preston (1913-2001) and Anthony Tyrell Hanson (1916-1991), Erwin Reisner (1890-1966), and Richard Whitwell all argue that the witnesses, while portrayed as Moses and Elijah, represent the Law and the Prophets. ${ }^{1}$ Eugenio Corsini agrees with

\footnotetext{
${ }^{1}$ James Lowell Blevins, Revelation as Drama (Nashville, TN: Broadman Press, 1984), 73-76; Feuillet, "Essai d'interprétation du chapitre XI," 183-200; Gry, "Les chapitres XI et XII," 203-214; Edward Allison McDowell, Jr., The Meaning and Message of the Book of Revelation (Nashville, TN: Broadman Press, 1951), 112-116, 132, 140; Mulholland, Revelation, 183-184, 202-209; Michael Robert Newbolt, The Book of Unveiling: A Study of the Revelation of St. John (London: SPCK, 1952), 117-121; John Wood Oman, Book of Revelation: Theory of the Text: Rearranged Text and Translation: Commentary (Cambridge, United Kingdom: Cambridge University Press, 1923), 51, 95, 111-113; Ronald Hadyn Preston and Anthony Tyrrell Hanson, The Revelation of Saint John the Divine: Introduction and Commentary, Torch Bible Commentaries (London: SCM Press, 1949), 35, 37, 88-90; Erwin Reisner, Das Buch mit den sieben Siegeln (Göttingen: Vandenhoeck \& Ruprecht, 1949), 95-100; and Richard Whitwell, The Apocalypse: An Inquiry into the Mystical and Prophetic Meaning of the Revelation Granted to St. John the Divine (London: "The Rally", 1940), 66-69. Feuillet appears to alter his interpretation of the witnesses later at André Feuillet, "La moisson et la vendange de l'Apocalypse (14,14-20). La signification chrétienne de la révélation johannique [Pt. 2]," NRTh 94, no. 3 (March 1972): 239-242.
} 
this perspective to an extent. He goes further to see the witnesses as ultimately referring to individuals slain for their adherence to the Law and the Prophets during the era prior to Christ's death and resurrection. ${ }^{2}$ Thus, Corsini's view is actually more like those that see the witnesses as representing the people of God (covered in Appendix C).

\section{The Witnesses as the Bible}

A popular understanding of the witnesses as the Bible sees historical fulfillment of the death and resurrection of the two witnesses in events related to the French Revolution (1789-1799). While the revolution was still going on, Alexander Pirie (17371804) argued along this line of thinking. ${ }^{3}$ In the nineteenth century, interpretations of this type were offered by Sidney Smith Brewer (1804-1889), Nikolaus von Brunn (17661849), George Croly (1780-1860), James Hatley Frere (1779-1866), Edward Irving (1792-1834), Alfred Jenour (1797-1868), Barton Warren Johnson (1833-1894), Josiah Litch (1809-1886), William Miller (1782-1849), Samuel Ralston (1756-1851), Alexander Shand, Uriah Smith (1832-1903), George Storrs (1796-1879), and Josiah White. ${ }^{4}$ In the

${ }^{2}$ Eugenio Corsini, The Apocalypse: The Perennial Revelation of Jesus Christ, trans. and ed. Francis J. Moloney, Good News Studies 5 (Wilmington, DE: Michael Glazier, 1983), 182-183, 191-201.

${ }^{3}$ Alexander Pirie, The French Revolution Exhibited, In The Light Of The Sacred Oracles: Or, A Series Of Lectures On The Prophecies Now Fulfilling (Perth, United Kingdom: R. Morison \& Son, 1795), 15-123, accessed September 30, 2015, Google Books.

${ }^{4}$ Sidney Smith Brewer, The Slaying of the Witnesses. The Second Woe Is Past and Behold the Third Woe Cometh Quickly, 10th ed. (Yarmouth, ME: I. C. Wellcome; Boston: O. Goodrich; Philadelphia: J. D. Brown, 1868), accessed September 24, 2015, http://www.andrews.edu/library/car/cardigital/digitized/documents/b1415321x.pdf; Nikolaus von Brunn, Blicke eines alten Knechts, der auf seinen Herrn wartet, in die Offenbarung des Herrn Jesus Christus. . . . (Basel: J. G. Neukirch, 1832), 345-395; George Croly, The Apocalypse of St. John. . . . 3rd ed. (London: J. G. \& F. Rivington, 
twentieth century, interpretations in which the two witnesses are the Bible and their death and resurrection involves the French Revolution are argued by Roy Allan Anderson (1895-1985), Ludwig Richard Conradi (1856-1939), Cyril Mervyn Maxwell (19251999), Ekkehardt Müller (born 1950), John Jay Schaumburg (1874-1948), William Ambrose Spicer (1865-1952), and Jean Vuilleumier (1864-1956). ${ }^{5}$ This type of interpretation is also present in the exposition of Revelation in The Seventh-day Adventist

1838), 127-145, accessed September 24, 2015, Google Books; James Hatley Frere, A Combined View of the Prophecies of Daniel, Ezra, and St. John. . . Corr. ed. (London: J. Hatchard; Seeley; Nisbet; Panton, 1826), 38-39, 90-91, 93, 97-98, 113-114, accessed September 30, 2015, Google Books; Edward Irving, Babylon and Infidelity Foredoomed of God. . . . 2 vols. (Glasgow: Chalmers and Collins; Edinburgh: William Whyte; William Oliphant; Dublin: R. M. Tims; William Curry, Jr.; London: G. B. Whitaker, 1826), 1:115-145; Jenour, Rationale Apocalypticum, 1:331-334, 400-456, 475-479; Barton Warren Johnson, Vision of the Ages; or, Lectures on the Apocalypse. A Complete View of the Book of Revelation, 4th ed. (St. Louis, MO: Christian, 1881), 206-229; Litch, Prophetic Expositions, 2:201-226; Miller, Evidence from Scripture, 190-203, 295; Samuel Ralston, A Brief Explication of the Principal Prophecies of Daniel and John, As They Regard the Church of God. . . (Pittsburgh, PA: Luke Loomis, 1842), 53-63, 89-96, 114-115, accessed September 20, 2015, Internet Archive American Libraries Collection; [Alexander Shand?], An Explanation of the Interesting Prophecy Respecting the Two Apocalyptic Witnesses. .. . (London: by the author, 1817), accessed September 19, 2015, Google Books; Uriah Smith, Thoughts, Critical and Practical, on the Book of Revelation (Battle Creek, MI: Steam Press of the Seventh-day Adventist Pub. Association, 1865), 187-196, accessed September 24, 2015, Internet Archive Community Texts Collection; Storrs, Bible Examiner, 91-107; and Josiah White, The Two Witnesses. Rev. XI (Enfield, MA: by the author, 1823).

${ }^{5}$ Roy Allan Anderson, Unveiling Daniel and Revelation (Nampa, ID: Pacific Press, 2006), 96-97, 152-153, 281-286, 293; Ludwig Richard Conradi, Die Offenbarung Jesu Christi (Hamburg: Internationale Traktatgesellschaft, 1907), 263-279; Cyril Mervyn Maxwell, The Message of Revelation, vol. 2 of God Cares (Boise, ID: Pacific Press, 1985), 270-273, 276-307; Müller, Der Erste und der Letzte, 41n43, 44, 83, 180, 193, 195, 197n95, 201, 203, 209-225, 230, 360, 363, 368-369, 389n27, 392, 407, 443-446; John Jay Schaumburg, The Two Witnesses of Revelation Eleven, and Their "Sackcloth" Testimony (Oakland, CA: Messiah's Advocate, [1922?]); William Ambrose Spicer, Beacon Lights of Prophecy (Washington, DC: Review and Herald, 1935), 247-259; and Jean Vuilleumier, L'Apocalypse: Hier, aujourd'hui, demain, 4th ed. (Dammarie-les-Lys, France: Les Signes des Temps, 1949), 158-184, 189-190, 230-233. 
Bible Commentary. ${ }^{6}$ Also representing this type of interpretation and perhaps coming from the twentieth century is the exposition of Samuel Forsey (1858-1942). ${ }^{7}$ Erwin Roy Gane (born 1931) also promotes the witnesses as the Bible and sees a historical fulfillment involving the French Revolution, but he is open to another fulfillment in the future. ${ }^{8}$

There are some expositors who see the two witnesses as the Bible and who envision a historical fulfillment that does not involve the French Revolution. Examples of this type of exposition are Alfred Brunson (1793-1882), Andrew Burn (1742-1814), Robert Bransby Cooper (1762-1845), Abraham Cummings (1755-1827), William Jones (1762-1846), John Ranicar Park (1778-1847), and William Albertus Spurgeon (18521940). ${ }^{9}$ There are also those making this identification who do not mention the matter of

\footnotetext{
6"The Revelation of St. John the Divine," in The Seventh-day Adventist Bible Commentary, ed. Francis D. Nichol et al., rev. ed. (Washington, DC: Review and Herald, 1976-1980), 7:799-804. Note also for the forty-two months and 1,260 days comments at "The Book of Daniel," in The Seventh-day Adventist Bible Commentary, ed. Francis D. Nichol et al., rev. ed. (Washington, DC: Review and Herald, 1976-1980), 4:826-828, 833-838.
}

${ }^{7}$ Samuel Forsey, "My Two Witnesses": An Exposition of Revelation XI,3-14. . . (London: Spottiswoode, n.d.), accessed September 24, 2015, http://www.andrews.edu/library/car/cardigital/digitized/documents/b14333466.pdf.

${ }^{8}$ Erwin Roy Gane, Trumpet after Trumpet: Will Revelation's Seven Trumpets Sound Again? (Nampa, ID: Pacific Press, 2012), 221-280.

${ }^{9}$ Alfred Brunson, A Key to the Apocalypse: or, Revelation of Jesus Christ to St. John in the Isle of Patmos (Cincinnati, OH: Walden and Stowe; New York: Philips \& Hunt, 1880), 57-67, accessed September 27, 2015, EBSCOhost American Theological Library Association (ATLA) Historical Monographs Collection, Series 1; Andrew Burn, Resurrection of the Two Witnesses. .. . 2nd ed. (London: W. Richardson, 1813), accessed September 19, 2015, Google Books; Robert Bransby Cooper, Commentary on the Revelation of St. John, or the Apocalypse (London: J. G. \& F. Rivington, 1833), 108-132, accessed September 24, 2015, Google Books; Abraham Cummings, A Dissertation On 
a historical fulfillment. Examples of this type of exposition are Tankiso Letseli Letseli (born 1962) and Edwin Earl Reynolds (born 1948). ${ }^{10}$

\section{Mixed Proposals}

Several commentators argue that, while the two witnesses in one way represent the Bible, they also have another meaning. One option understands the two witnesses as a symbol for the Bible and for the people of God, variously defined. Sylvester Bliss (1814-1863), Ranko Stefanović, and Basil Stewart define the people of God as the church for their mixed proposals. ${ }^{11}$ Hans Karl LaRondelle (1929-2011), Samuel Schor (18591933), and the unknown author of An Original Interpretation of the Apocalypse also

The Introduction And Glory Of The Millennium. To Which Is Prefixed A Discourse on the Two Witnesses (Boston: Manning \& Loring, 1797), accessed September 19, 2015, Gale Eighteenth Century Collections Online; William Jones, Lectures on the Apocalypse (London: Holdsworth and Ball; Edinburgh: Waugh and Innes; Dublin: Curry, 1830), 364378, accessed September 27, 2015, Internet Archive American Libraries Collection; John Ranicar Park, A New Exposition of the Apocalypse, So Far as the Prophecies Are Fulfilled. ... 3rd ed. (London: Smith, Elder, 1832), 30-32, 63, 138-146, accessed September 24, 2015Google Books; and William Albertus Spurgeon, The Conquering Christ: An Interpretation of the Revelation (Muncie, IN, 1936), 129-140, 168-169.

${ }^{10}$ Tankiso Letseli Letseli, "The Kingship of God as a Theological Motif in the Hymns of the Apocalypse of John" (DLittPhil thesis, Rand Afrikaans University, 2001), 148-159, accessed September 23, 2015, UJDigispace (the Institutional Repository of the University of Johannesburg) Theses and Dissertations Community, Department of Religious Studies Collection; and Edwin Earl Reynolds, "The Sodom/Egypt/Babylon Motif in the Book of Revelation" (PhD dissertation, Andrews University, 1994), 53-55, 67-70, 174-178, 186-189, 211-225, 262-281, 293-298, accessed September 23, 2015, ProQuest Dissertations and Theses Global.

${ }^{11}$ Sylvester Bliss, A Brief Commentary on the Apocalypse, 2nd ed. (Boston: J. V. Himes, 1853), 116-133, accessed October 6, 2015, Google Books; Ranko Stefanović, Revelation of Jesus Christ: Commentary on the Book of Revelation, 2nd ed. (Berrien Springs, MI: Andrews University Press, 2009), 343-364; and Basil Stewart, Revelation Fulfilled in History: The Visions of St. John in Patmos a Pictorial Foreview of European History... . (London: John Bale, Sons \& Danielsson, 1934), 69-87, 90-91, 97, 160-162. 
define the people of God as the church, but with the qualification that these are the faithful believers. ${ }^{12}$ The unknown author of An Original Interpretation of the Apocalypse goes so far as to propose a third referent for the symbol of the witnesses. This author considers the witnesses to represent also two nations filled with many oppressed believers. ${ }^{13}$ For his mixed proposal, Jacques Benjamin Doukhan (born 1940) defines the people of God as Israel and the church, the two groups associated with the two testaments of the Bible. ${ }^{14}$ John Barnard (1681-1770) seems to have proposed something similar, but in a much earlier period of history. ${ }^{15}$

There may be emphasis put on the Bible or the people of God as the referent for the symbol of the witnesses. Thus, Joseph Galloway (1731-1803), Kenneth Albert Strand (1927-1997), John Tripp (1761-1847), and Christopher Wordsworth (1807-1885) emphasize the Bible in their identification of the witnesses. ${ }^{16}$ With less force, each of

\footnotetext{
${ }^{12}$ Hans Karl LaRondelle, How to Understand the End-Time Prophecies of the Bible: The Biblical-Contextual Approach (Sarasota, FL: First Impressions, 1997), 211233, 236-262; Samuel Schor, The Apocalypse. A Simple Exposition, 3rd ed. (London: Barbican Mission to the Jews, n.d.), 38-44, 48-49; and Original Interpretation, 59-86. The first edition of the last work appeared as England's Fall.

${ }^{13}$ Original Interpretation, 62.

${ }^{14}$ Jacques Benjamin Doukhan, Secrets of Revelation: The Apocalypse through Hebrew Eyes (Hagerstown, MD: Review and Herald, 2002), 94-100.

${ }^{15}$ [John Barnard?], The Religion of Antichrist: or, Notes on the Book of the Revelation of John, and Other Prophecies. . . (London: John Chater; Thomas Vernor, 1770), 71-83, accessed October 6, 2015, Gale Eighteenth Century Collections Online.

${ }^{16}$ Joseph Galloway, Brief Commentaries upon Such Parts of the Revelation and Other Prophecies as Immediately Refer to the Present Times. . . . (London: by the author, 1802), 40-114, accessed October 7, 2015, Google Books; Strand, "Two Witnesses," 127 135; John Tripp, A Discourse on the Character and Work, and the Death and Resurrection of the Two Witnesses (Portland, ME: A. Shirley, 1824), accessed September 20, 2016, Google Books; and Christopher Wordsworth, Lectures on the Apocalypse;
} 
these commentators also relate the two witnesses to the church. Meanwhile, William Ettrick (1757-1847) and Roy C. Naden (born 1934) emphasize the people of God in their identification of the witnesses. ${ }^{17}$ While Naden sees the people of God as the church for his mixed proposal, Ettrick sees the people of God as the Jews and the Protestant Christians. William Cooke (1749-1824) also mixes the Bible, conceived of as the Law and the Gospel, with the people of God, but for the latter aspect he puts an emphasis upon the faithful preachers and ministers of the church. ${ }^{18}$

John Adam Battenfield (1876-1952) and Philip Yancey Pendleton (1863-1930) not only argue that the witnesses represent the two testaments of the Bible and their corresponding "churches" (the Jewish and the Gentile), but they are also open to a secondary fulfillment of two actual people experiencing what is narrated in Rev 11:3$13 .{ }^{19}$

Amzi Armstrong (1771-1827) goes beyond simply identifying the witnesses as

Critical, Expository, and Practical, Delivered before the University of Cambridge, 3rd ed. (London: Francis \& John Rivington, 1852), 48-61, 149-151, 169-183, 198-204, accessed October 6, 2015, Google Books.

${ }^{17}$ William Ettrick, The Second Exodus. . . . 2nd ed., 3 vols. (Sunderland, United Kingdom: by the author, 1814), 1:180-224, 2:121-131, 3:265-281, 288-296, 311-313, 332-335, accessed October 6, 2015, Google Books; and Roy C. Naden, The Lamb among the Beasts: A Christological Commentary on the Revelation of John That Unlocks the Meaning of Its Many Numbers (Hagerstown, MD: Review and Herald, 1996), 169-180, 186, 190, 196.

${ }^{18}$ Cooke, Revelations Translated, xxxi-xxxiv, xlii-xlv, xlviii-li, liv-lviii, 84-91.

${ }^{19}$ John Adam Battenfield and Philip Yancey Pendleton, The Great Demonstration: A Harmony of All the Prophetic Visions of the Holy Bible: I. Daniel and Revelation (Cincinnati, OH: Standard, 1914), 293-297, 320-321, 332. 
the Bible. ${ }^{20}$ He argues that they represent God's Word and his sacred ordinances, presented in relationship to the church. Nevertheless, the death and resurrection of the witnesses are still fulfilled historically in events occurring during the French Revolution.

Frederick George Smith (1880-1947) understands the witnesses prophesying over 1,260 days to represent the Word of God and the Holy Spirit during a period of 1,260 years. ${ }^{21}$ Earlier, Samuel Lee (1783-1852) argues that the two witnesses represent not only the Word of God and the Holy Spirit, but also the ministers of the Word. He relates the episode of the witnesses to the early centuries of Christianity. ${ }^{22}$

${ }^{20}$ Amzi Armstrong, A Syllabus of Lectures on the Visions of the Revelation (Morris-town, NJ: P. A. Johnson, 1815), 78-95, 220-232, accessed October 6, 2015, Internet Archive American Libraries Collection.

${ }^{21}$ Frederick George Smith, The Revelation Explained: An Exposition, Text by Text, of the Apocalypse of St. John. . . 6 6th ed. (Anderson, IN: Gospel Trumpet, 1908), 103-107, 180-210.

${ }^{22}$ Samuel Lee, An Inquiry into the Nature, Progress, and End of Prophecy, in Three Books . . . To Which Is Prefixed a Preface and Introduction, in Three Parts. . . (Cambridge: Cambridge University Press, 1849), 349-358, accessed October 7, 2015, Google Books. Cf. though the identification of the witnesses earlier in Samuel Lee, Six Sermons on the Study of the Holy Scriptures ... To Which Are Annexed Two Dissertations: The First on the Reasonableness of the Orthodox Views of Christianity ... ; the Second on the Interpretation of Prophecy Generally, with an Original Exposition of the Book of Revelation. . . . (London: James Duncan, 1830), 321323, 361-365, accessed October 7, 2015, Internet Archive American Libraries Collection. There the witnesses are the Law and the Gospel. 


\section{BIBLIOGRAPHY}

Adams, John Quincy. His Apocalypse-Wherein Is Set Forth a Detailed Panorama of The Prophetic Wonders of Daniel and Revelation. . . . 2nd ed. Dallas, TX:

Prophetical Society of Dallas, 1925.

Adamson, William Douglas. "The Identity and Ministry of the Two Witnesses of Revelation 11:1-13." MTh thesis, Detroit Baptist Theological Seminary, 2002. Accessed July 3, 2015. Theological Research Exchange Network (TREN).

Agier, Pierre-Jean. Commentaire sur l'Apocalypse. 2 vols. Paris: J.-M. Eberhart, 1823. Accessed August 24, 2015. Google Books.

Alford, Henry. The Greek Testament. . . . Vol. 4. 4th ed. Boston Lee and Shepard; New York: Lee, Shepard, and Dillingham, 1874. Accessed November 14, 2015. Internet Archive American Libraries Collection.

Allan, George. A Key to the Apocalypse. Paisley, United Kingdom, 1818. Accessed July 5, 2015. Google Books.

Allen, Cady Hews. The Message of the Book of Revelation. Nashville, TN: Cokesbury Press, 1939.

Allo, Ernest-Bernard. "À propos d'Apocalypse XI et XII." Revue biblique 31, no. 4 (October 1922): 572-583.

. Saint Jean: L'Apocalypse. 3rd ed. Études bibliques. Paris: Librarie LecoffreJ. Gabalda et Cie., 1933.

Amundson, Wallace Llewellyn. "Who Are the Two Witnesses of Revelation 11:4?" Honors Project, Andrews University, 1978.

Andersen, J. Vikjær. "Bibliographie de l'œuvre de Johannes Munck." Studia Theologica 19, no. 1-2 (1965): 3-21.

Anderson, Roy Allan. Unveiling Daniel and Revelation. Nampa, ID: Pacific Press, 2006.

Andrews, Herbert Tom. "Revelation." In A Commentary on the Bible, edited by Arthur Samuel Peake and Alexander James Grieve, 926-943. New York: Thomas Nelson \& Sons; London: T. C. \& E. C. Jack, 1920. Accessed October 21, 2015. Internet Archive American Libraries Collection. 
Apocalypse of Elijah (Coptic). Translated by Orval Stewart Wintermute. Old Testament Pseudepigrapha, edited by James H. Charlesworth, 1:721-753. Garden City, NY: Doubleday, 1983-1985.

Apocalypse of Peter (Ethiopic). Translated by Caspar Detlef Gustav Müller. New Testament Apocrypha, edited by Wilhelm Schneemelcher and Robert McLachlan Wilson, Rev. ed., 2:620-638. Cambridge, United Kingdom: James Clarke; Louisville, KY: Westminster/John Knox Press, 1991-1992.

The Apocalypse Unveiled. . . 2 vols. New York: E. French, 1853. Accessed November 3, 2015. Google Books.

The Apocalyptic Drama. New York: Fleming H. Revell, 1891. Accessed October 26, 2015. Internet Archive American Libraries Collection.

Argyriou, Astérios. Les exégèses grecques de l'Apocalypse à l'époque turque (14531821): Esquisse d'une histoire des courants idéologiques au sein du peuple grec asservi. Epistemonikai pragmateiai, Seira philologike kai theologike, 15. Thessalonica, Greece: Hetaireia Makedonikon Spoudon, 1982.

Armstrong, Amzi. A Syllabus of Lectures on the Visions of the Revelation. Morris-town, NJ: P. A. Johnson, 1815. Accessed October 6, 2015. Internet Archive American Libraries Collection.

Arrighini, Ambrogio. L'Anticristo nelle sacre Scritture, nella storia, nella letteratura. 2nd ed. Le metamorfosi del sacro 15. Genoa: I Dioscuri, 1988.

Arthur, Michael. The two Witnesses prophesying a Thousand two Hundred and Threescore Says in Sackloth [sic]. . . Glasgow: by the author, 1779. Accessed September 4, 2015. Gale Eighteenth Century Collections Online.

Ashe, Isaac. The Book of Revelation with Compendious Notes, According to the Exposition Which Has Been Most Generally Received in the Church. Dublin: William Curry, Jr.; London: Simpkin and Marshall, 1835. Accessed October 6, 2015. Google Books.

Auberlen, Karl August. Der Prophet Daniel und die Offenbarung Johannis in ihrem gegenseitigen Verhältniss betrachtet und in ihren Hauptstellen erläutert. 3rd ed. Basel: Bahnmaier's Verlag (C. Detloff), 1874. Accessed August 17, 2015. Google Books.

Aune, David Edward. Apocalypticism, Prophecy and Magic in Early Christianity: Collected Essays. Wissenschaftliche Untersuchungen zum Neuen Testament 199. Tübingen: Mohr Siebeck, 2006.

. Revelation 6-16. Word Biblical Commentary 52B. Nashville, TN: Thomas Nelson, 1998. 
Bachmair, John James. The Revelation of St. John Historically Explained. . . L London, 1778. Accessed September 4, 2015. Google Books.

Bacon, Benjamin Wisner. "The Elder John in Jerusalem." Zeitschrift für die neutestamentliche Wissenschaft und die Kunde der älteren Kirche 26 (1927): 187202. Accessed August 17, 2015. ProQuest Periodicals Archive Online.

. "John and the Pseudo-Johns." Zeitschrift für die neutestamentliche Wissenschaft und die Kunde der älteren Kirche 31 (1932): 132-150. Accessed August 17, 2015. ProQuest Periodicals Archive Online.

Baggs, John. A Scriptural View Of The Millennium: Or, An attempt to display the Harmony Of The Bible On The Last-Day Glory. Bath, United Kingdom, 1797. Accessed November 2, 2015. Google Books.

Baldwin, Samuel Davies. Armageddon. . . . Rev. ed. Nashville: Southern Methodist Publishing House, 1884. Accessed September 14, 2015. Google Books.

Baljon, Johannes Marinus Simon. Commentaar op de Openbaring van Johannes. Utrecht, Netherlands: J. van Boekhoven, 1908. Accessed November 12, 2015. Google Books.

Bandstra, Andrew John. "Jerusalem and Rome in the Apocalypse." Calvin Theological Journal 1, no. April (1966): 67-69.

Bandy, Alan Sumner. The Prophetic Lawsuit in the Book of Revelation. New Testament Monographs 29. Sheffield, United Kingdom: Sheffield Phoenix Press, 2010.

Barchuk, Ivan. Explicacion del libro de Apocalipsis. Translated by José A. Holowaty. Barcelona: Clie, [1970?].

Barclay, William. The Revelation of John. 2 vols. 3rd ed. New Daily Study Bible. Louisville, KY: Westminster John Knox Press, 2004.

Barker, Margaret. The Revelation of Jesus Christ, Which God Gave to Him to Show to His Servants What Must Soon Take Place (Revelation 1.1). London: T \& T Clark, 2000.

[Barnard, John?]. The Religion of Antichrist: or, Notes on the Book of the Revelation of John, and Other Prophecies. . . London: John Chater; Thomas Vernor, 1770. Accessed October 6, 2015. Gale Eighteenth Century Collections Online.

Barnes, Albert. Notes, Explanatory and Practical, on the Book of Revelation. New York: Harper \& Brothers, 1851. Accessed August 20, 2015. Google Books.

Barnhouse, Donald Grey. Revelation: An Expository Commentary. Grand Rapids, MI: Ministry Resources Library, 1971. 
Barrefelt, Hendrik Jansen van [Hiël, pseud.]. Erklärung Der Offenbarung Johannis Aus dem Visionischen Gesichte, in das wahre Wesen Jesu Christi. Translated by [Friedrich Breckling?]. [Amsterdam?], 1687. Accessed August 17, 2015. Google Books.

Barton, Freeman. "The Mysterious Numbers of Biblical Prophecy." Henceforth 8, no. 2 (1980): 115-144.

Bateman, Herbert W., IV. "Dispensationalism Yesterday and Today." In Three Central Issues in Contemporary Dispensationalism: A Comparison of Traditional and Progressive Views, edited by Herbert W. Bateman IV, 21-60. Grand Rapids, MI: Kregel Publications, 1999.

Battenfield, John Adam, and Philip Yancey Pendleton. The Great Demonstration: A Harmony of All the Prophetic Visions of the Holy Bible: I. Daniel and Revelation. Cincinnati, OH: Standard, 1914.

Bauckham, Richard. The Climax of Prophecy: Studies on the Book of Revelation. London: T \& T Clark, 1993. . "The Martyrdom of Enoch and Elijah: Jewish or Christian?" In The Jewish World around the New Testament: Collected Essays I, 3-25. Wissenschaftliche Untersuchungen zum Neuen Testament 233. Tübingen: Mohr Siebeck, 2008.

Bäumer, Ludger. "Donatus Haugg." Das Online-Gedenkbuch. Accessed August 16, 2015. http://www.weltkriegsopfer.de/Kriegsopfer-Donatus-Haugg_Soldaten_0_144518 .html.

Baur, Ferdinand Christian. "Kritik der neuesten (Hengstenberg'schen) Erklärung der Apokalypse." Theologische Jahrbücher 11 (1852): 305-400, 441-469. Accessed September 29, 2015. Google Books.

Baxter, Michael Paget. Forty Coming Wonders between 1888-9 and 1901 as Foreshown in the Prophecies of Daniel and Revelation. . . . 6th ed. London: Christian Herald Office, 1887. Accessed September 13, 2015. Google Books.

Baylee, Joseph. The Apocalypse: The Voice of Jesus Christ from the Throne of Glory. With an Exegetical and Practical Commentary. London: James Nisbet, 1876. . The Times of the Gentiles. ... London: James Nisbet, 1871. Accessed September 2, 2015. Google Books.

Beagley, Alan James. The "Sitz im Leben" of the Apocalypse with Particular Reference to the Role of the Church's Enemies. Beiheft zur Zeitschrift für die neutestamentliche Wissenschaft und die Kunde der älteren Kirche 50. Berlin: Walter de Gruyter, 1987. 
Beale, Gregory Kimball. The Book of Revelation: A Commentary on the Greek Text. New International Greek Testament Commentary. Grand Rapids, MI: William B. Eerdmans; Carlisle, United Kingdom: Paternoster Press, 1999.

. John's Use of the Old Testament in Revelation. Journal for the Study of the New Testament Supplement Series 166. Sheffield, United Kingdom: Sheffield Academic Press, 1998.

. The Use of Daniel in Jewish Apocalyptic Literature and in the Revelation of St. John. Lanham, MD: University Press of America, 1984.

Beasley-Murray, George Raymond. The Book of Revelation. New Century Bible Commentary. Grand Rapids, MI: William B. Eerdmans; London: Marshall, Morgan \& Scott, 1981.

. "Revelation, Book of." Dictionary of the Later New Testament and Its Developments. Edited by Ralph P. Martin and Peter H. Davids. Downers Grove, IL: InterVarsity Press, 1997. 1025-1038.

Beatus of Liébana Tractatus de Apocalipsin. Edited by Roger Gryson and Marie-Claire de Bièvre. Corpus Christianorum, Series latina, 107B-107C. Turnhout, Belgium: Brepols, 2012.

Beck, Johann Tobias. Erklärung der Offenbarung Johannis: Cap. 1-12. Edited by Julius Lindenmeyer. Gütersloh, Germany: C. Bertelsmann, 1884. Accessed July 22, 2015. EBSCOhost American Theological Library Association (ATLA) Historical Monographs Collection, Series 1.

Beckwith, Isbon Thaddeus. The Apocalypse of John: Studies in Introduction, with a Critical and Exegetical Commentary. New York: Macmillan, 1919. Accessed June 12, 2015. Google Books.

. The Apocalypse of John: Studies in Introduction, with a Critical and Exegetical Commentary. New York: Macmillan, 1919. Reprint, Grand Rapids, MI: Baker Book House, 1967.

Behm, Johannes. Die Offenbarung des Johannes: Übersetzt und erklärt. 5th ed. Das Neue Testament Deutsch, Neues Göttinger Bibelwerk, 11. Göttingen: Vandenhoeck \& Ruprecht, 1949.

Beile, Rüdiger. Zwischenruf aus Patmos: Eine neue Gesamteinschätzung der Apokalypse des Johannes von Ephesus. 2nd ed. Göttingen: V \& R unipress, 2005.

Bengel, Johann Albrecht. Erklärte Offenbarung Johannis oder vielmehr Jesu Christi. . . . New ed. Stuttgart: Fr. Brodhag'sche Buchhandlung, 1834. Accessed August 17, 2015. Google Books. 
Sechzig erbauliche Reden über die Offenbarung Johannis oder vielmehr Jesu Christi. . . . New ed. Stuttgart: Johann Christoph Erhard, 1788. Accessed August 24, 2015. Google Books.

Bengel, Johann Albrecht, Ernst Bengel, and Johann Christian Friedrich Steudel. Gnomon of the New Testament. Vol. 5. Edited by Andrew Robert Fausset. Translated by William Fletcher. 6th ed. Edinburgh: T. \& T. Clark, 1866. Accessed November 28, 2015. Internet Archive American Libraries Collection.

Berengaudus Expositio super septem visiones libri Apocalypsis. Edited by Jacques-Paul Migne. Patrologiæ cursus completus . . . series [latina]. . . , vol. 17, cols. 765A970C. Paris: by the editor, 1845. Accessed June 28, 2015. Google Books.

Berg, Joseph Frederick. Prophecy and the Times; or, England and Armageddon. An Application of Some of the Predictions of Daniel and St. John to Current Events. Philadelphia: Higgins and Pirkinpine, 1856. Accessed August 25, 2015. Google Books.

Berger, Klaus. Die Auferstehung des Propheten und die Erhöhung des Menschensohnes: Traditionsgeschichtliche Untersuchungen zur Deutung des Geschickes Jesu in frühchristlichen Texten. Studien zur Umwelt des Neuen Testaments 13. Göttingen: Vandenhoeck \& Ruprecht, 1976.

Die griechische Daniel-Diegese: Eine altkirchliche Apokalypse: Text, Übersetzung und Kommentar. Studia Post-Biblica 27. Leiden: E. J. Brill, 1976.

Betz, Hans Dieter. The Sermon on the Mount: A Commentary on the Sermon on the Mount, Including the Sermon on the Plain (Matthew 5:3-7:27 and Luke 6:20-49). Edited by Adela Yarbro Collins. Hermeneia-A Critical and Historical Commentary on the Bible. Minneapolis: Fortress Press, 1995.

Bewes, Richard. The Church Overcomes: A Guided Tour through the Book of Revelation. London: Mowbray, 1984.

Beyschlag, Willibald. Zur deutsch-christlichen Bildung. Popular-theologische Vorträge. 2nd ed. [Halle an der Saale, Germany?], 1899. Accessed November 12, 2015. EBSCOhost American Theological Library Association (ATLA) Historical Monographs Collection, Series 2.

Bibliander, Theodor. Ad omnium ordinum Reipublicae Christianae Principes uiros, populumque Christianum, Relatio fidelis Theodori Bibliandri. . . . Basel: Johannes Oporinus, 1545. Accessed August 17, 2015. Bayerische StaatsBibliothek.

Bicheno, James. The Signs of the Times: In Three Parts. New ed. London, 1808. Accessed November 3, 2015. Google Books. 
Bickersteth, Edward. A Practical Guide to the Prophecies, with Reference to Their Interpretation and Fulfilment, and to Personal Edification. 7th ed. London: Seeley, Burnside, and Seeley, 1844. Accessed November 3, 2015. Google Books.

Biguzzi, Giancarlo. Apocalisse: Nuova versione, introduzione e commento. I Libri Biblici, Nuovo Testamento, 20. Milan: Paoline, 2005.

. Gli splendori di Patmos: Commento breve all'Apocalisse. La Parola e la sua ricchezza 22. Milan: Paoline, 2007.

L'Apocalisse e i suoi enigmi. Studi Biblici 143. Brescia, Italy: Paideia Editrice, 2004.

Birchmore, John W. Prophecy Interpreted by History; Including Present Events. Being a Brief and Popular Explanation of Daniel and of St. John. New York: E. P. Dutton; Boston: A. Williams, 1871. Accessed November 12, 2015. Google Books.

Birks, Thomas Rawson. Thoughts on the Times and Seasons of Sacred Prophecy. London: Hodder and Stoughton, 1880. Accessed November 3, 2015. Google Books.

Black, Matthew. "The 'Two Witnesses' of Rev. 11:3f. in Jewish and Christian Apocalyptic Tradition." In Donum Gentilicium: New Testament Studies in Honour of David Daube, edited by Ernst Bammel, Charles Kingsley Barrett, and William David Davies, 227-237. Oxford: Clarendon Press, 1978.

Blair, Edward Payson. The Acts and Apocalyptic Literature. Guide for Bible Readers. New York: Abingdon-Cokesbury Press, 1946.

Blaising, Craig Alan. "Dispensationalism: The Search for Definition." In Dispensationalism, Israel and the Church: The Search for Definition, edited by Craig Alan Blaising and Darrell L. Bock, 13-34. Grand Rapids, MI: Zondervan, 1992.

Blaising, Craig Alan, and Darrell L. Bock. "Dispensationalism, Israel and the Church: Assessment and Dialogue." In Dispensationalism, Israel and the Church: The Search for Definition, edited by Craig Alan Blaising and Darrell L. Bock, 377394. Grand Rapids, MI: Zondervan, 1992.

Blaney, Harvey J. S. "Revelation." In The Wesleyan Bible Commentary, edited by Charles Webb Carter, Ralph Earle, William Ralph Thompson, and Lee Haines, 6:399-523. Grand Rapids, MI: William B. Eerdmans, 1964-1969.

Bleek, Friedrich. Dr. Friedrich Bleek's Lectures on the Apocalypse. Edited by Theodor Hossbach. Translated and edited by Samuel Davidson. London: Williams and Norgate, 1875. Accessed July 10, 2015. Google Books. 
. Dr. Friedrich Bleek's Vorlesungen über die Apokalypse. Edited by Theodor Hossbach. Berlin: Georg Reimer, 1862. Accessed July 10, 2015. Google Books.

Blevins, James Lowell. Revelation as Drama. Nashville, TN: Broadman Press, 1984.

Bliss, Sylvester. A Brief Commentary on the Apocalypse. 2nd ed. Boston: J. V. Himes, 1853. Accessed October 6, 2015. Google Books.

Blomberg, Craig L. "Elijah, Election, and the Use of Malachi in the New Testament." Criswell Theological Review, no. 2 (Fall 1987): 99-117. Accessed November 11, 2015. EBSCOhost ATLA Religion Database with ATLASerials.

Blount, Brian Keith. Revelation: A Commentary. New Testament Library. Louisville, KY: Westminster John Knox Press, 2009.

Boase, Frederic. "Todd, James Henthorn." Modern English Biography: Containing Many Thousand Concise Memiors of Persons Who Have Died between the Years 18511900; with an Index of the Most Interesting Matter. Truro, United Kingdom: by the author, 1892-1921. Reprint, London: Frank Cass \& Co., 1965. 3:980.

Böcher, Otto. "Das beglaubigende Vaticinium ex eventu als Strukturelement der Johannes-Apokalypse." Revue d'histoire et de philosophie religieuses 79, no. 1 (1999): 19-30.

"Die Johannes-Apokalypse und die Texte von Qumran." In Aufstieg und Niedergang der Römischen Welt: Geschichte und Kultur Roms im Spiegel der Neueren Forschung, edited by Hildegard Temporini and Wolfgang Haase. Vol. 2.25.5, 3894-3898. Berlin: Walter de Gruyter, 1988.

. Die Johannesapokalypse. 4th ed. Erträge der Forschung 41. Darmstadt, Germany: Wissenschaftliche Buchgesellschaft, 1998.

. "Israel und die Kirche in der Johannesapokalypse." In Kirche in Zeit und Endzeit: Aufsätze zur Offenbarungs des Johannes, 28-57. Neukirchen-Vluyn: Neukirchener, 1983.

. Johannes-Offenbarung und Kirchenbau: Das Gotteshaus als Himmelsstadt. Neukirchen-Vluyn, Germany: Neukirchener Theologie; Ostfildern, Germany: Patmos, 2010.

. "Johannes der Täufer in der neutestamentlichen Uberlieferung." In Kirche in Zeit und Endzeit: Aufsätze zur Offenbarung des Johannes, 70-89. NeukirchenVluyn, Germany: Neukirchener Verlag, 1983.

. "Johannes der Täufer in der neutestamentlichen Uberlieferung." In Rechtfertigung, Realismus, Universalismus in biblischer Sicht: Festschrift für Adolf Köberle zum 80 Geburstag, edited by Gotthold Müller, 45-68. Darmstadt, Germany: Wissenschaftliche Buchgesellschaft, 1978. 
. "Lukas und Johannes der Täufer." Studien zum Neuen Testament und seiner Umwelt 4 (1979): 27-44.

Bock, Darrell L. "Opening Questions: Definition and Philosophy of Exegesis." In Interpreting the New Testament Text: Introduction to the Art and Science of Exegesis, edited by Darrell L. Bock and Buist Martin Fanning, 23-32. Wheaton, IL: Crossway Books, 2006.

Boismard, Marie-Emile. "'L'Apocalypse', ou 'Les Apocalypses' de S. Jean." Revue biblique 56 (1949): 507-541.

Bonnet, Joseph. Eclaircissement de l'Apocalypse. Fribourg: Imprimerie Saint-Paul, 1908.

Bonsirven, Joseph. L'Apocalypse de Saint Jean: Traduction et commentaire. Verbum Salutis 16. Paris: Beauchesne et ses fils, 1951.

"The Book of Daniel." In The Seventh-day Adventist Bible Commentary, edited by Francis D. Nichol, Raymond F. Cottrell, Don F. Neufeld, and Julia Neuffer, 4:743-881. Washington, DC: Review and Herald, 1953-1957.

"The Book of Daniel." In The Seventh-day Adventist Bible Commentary, edited by Francis D. Nichol, Raymond F. Cottrell, Don F. Neufeld, and Julia Neuffer, rev. ed., 4:743-881. Washington, DC: Review and Herald, 1976-1980.

Boring, Maynard Eugene. Revelation. Interpretation, a Bible Commentary for Teaching and Preaching. Louisville, KY: John Knox Press, 1989.

Bousset, Wilhelm. The Antichrist Legend: A Chapter in Christian and Jewish Folklore. Translated by Augustus Henry Keane. London: Hutchinson, 1896. Reprint, American Academy of Religion, Texts and Translations Series, 24, Atlanta, GA: Scholars Press, 1999.

. Der Antichrist in der Überlieferung des Judentums, des neuen Testaments und der alten Kirche. Ein Beitrag zur Auslegung der Apocalypse. Göttingen:

Vandenhoeck und Ruprecht, 1895. Accessed June 12, 2015. Google Books.

. Die Offenbarung Johannis. 5th ed. Kritisch-exegetischer Kommentar über das Neue Testament 16. Göttingen: Vandenhoeck und Ruprecht, 1896. Accessed April 27, 2016. Google Books.

. Die Offenbarung Johannis. 6th ed. Kritisch-exegetischer Kommentar über das Neue Testament 16. Göttingen: Vandenhoeck und Ruprecht, 1906. Accessed July 3, 2015. Google Books.

Bovet, François de. L'esprit de l'Apocalypse. Paris: Gaume Frères, 1840. Accessed August 17, 2015. Google Books. 
Bowman, John Wick. The Drama of the Book of Revelation: An Account of the Book... with a New Translation in the Language of Today. Philadelphia: Westminster Press, 1955.

Boxall, Ian Kieran. The Revelation of Saint John. Black's New Testament Commentaries 19. Peabody, MA: Hendrickson Publishers; London: Continuum, 2006.

. Revelation: Vision and Insight: An Introduction to the Apocalypse. London: SPCK, 2002.

Braaten, Mark. Come, Lord Jesus: A Study of Revelation. Collegeville, MN: Liturgical Press, 2007.

Bredin, Mark. Jesus, Revolutionary of Peace: A Nonviolent Christology in the Book of Revelation. Paternoster Biblical and Theological Monographs. Carlisle, United Kingdom: Paternoster Press, 2003.

Brewer, Sidney Smith. The Slaying of the Witnesses. The Second Woe Is Past and Behold the Third Woe Cometh Quickly. 10th ed. Yarmouth, ME: I. C. Wellcome; Boston: O. Goodrich; Philadelphia: J. D. Brown, 1868. Accessed September 24, 2015. http://www.andrews.edu/library/car/cardigital/digitized/documents /b1415321x.pdf.

Briggs, Thomas Pearl. Revelation: A Paraphrase and Exposition in Verse. Boston: James H. Earle, 1892. Accessed October 26, 2015. Google Books.

Brighton, Louis Andrew. Revelation. Concordia Commentary. St. Louis, MO: Concordia Publishing House, 1999.

Bring, Ragnar. "Johannes Munck in memoriam." Svensk Teologisk Kvartalskrift 41, no. 1 (1965): 63-64.

Brooks, Keith Leroy. Prophecies of Daniel and Revelation (Verse by Verse Interpretation by the Cross Reference Method). Rev. ed. Los Angeles: Bible Institute of Los Angeles, Biola Book Room, 1927.

Brown, David. The Apocalypse: Its Structure and Primary Predictions. London: Hodder and Stoughton, 1891. Accessed September 6, 2015. Internet Archive American Libraries Collection.

Brown, Ian Robertson. "The Two Witnesses (Rev 11:3-13) as Two Individuals Appearing near the End of the Age: A Selective Literature Review and Issues of Interpretation." MA thesis, Andrews University, 1999.

Brown, Jeannine K. Scripture as Communication: Introducing Biblical Hermeneutics. Grand Rapids, MI: Baker Academic, 2007. 
Brown, John Aquila. The Jew, the Master-key of the Apocalypse. . . . London: Hatchard and Son; Seeley and Son; Nisbet, 1827. Accessed September 7, 2015. Google Books.

Browne, Henry. John's Apocalypse, Literally Translated, and Spiritually Interpreted. Manchester: Tubbs, Brook, \& Chrystal; London: Simpkin, Marshall, 1881. Accessed October 19, 2015. Google Books.

Brox, Norbert. Zeuge und Märtyrer: Untersuchungen zur frühchristlichen ZeugnisTerminologie. Studien zum Alten und Neuen Testament 5. Munich: Kösel-Verlag, 1961.

Brunn, Nikolaus von. Blicke eines alten Knechts, der auf seinen Herrn wartet, in die Offenbarung des Herrn Jesus Christus. . . Basel: J. G. Neukirch, 1832.

Brunson, Alfred. A Key to the Apocalypse: or, Revelation of Jesus Christ to St. John in the Isle of Patmos. Cincinnati, OH: Walden and Stowe; New York: Philips \& Hunt, 1880. Accessed September 27, 2015. EBSCOhost American Theological Library Association (ATLA) Historical Monographs Collection, Series 1.

Brütsch, Charles. Die Offenbarung Jesu Christi. Johannes-Apokalypse. 3 vols. Zürcher Bibelkommentare. Zürich: Zwingli Verlag, 1970.

. La Clarté de l'Apocalypse. 5th ed. Geneva: Éditions Labor et Fides; Paris: Librairie protestante, 1966.

Buchanan, George Wesley. The Book of Revelation: Its Introduction and Prophecy. Mellen Biblical Commentary, New Testament Series, 22. Lewiston, NY: Mellen Biblical Press, 1993.

Bullinger, Ethelbert William. The Apocalypse; or, "The Day of the Lord". 3rd ed. London: Eyre \& Spottiswoode, 1935.

Bullinger, Heinrich. A Hundred Sermons upon the Apocalips of Jesu Christe. . . . Translated by [John Daus?]. London: [John Day?], 1561. Accessed August 17, 2015. Internet Archive Community Texts Collection.

. In Apocalypsim Iesu Christi. . . . Basel: Johannes Oporinus, 1559. Accessed August 17, 2015. Google Books.

Burchard, Christoph. "Kerygma and Martyria in the New Testament." In Christian Witness and the Jewish People: The Report of a Consultation Held under the Auspices of the Lutheran World Federation, Department of Studies, Oslo, August 1975, edited by Arne Sovik, 2nd ed., 10-25. Geneva: Lutheran World Federation, 1977. 
Burger, Karl Heinrich August von. Die Offenbarung St. Johannis nach dem Grundtexte deutsch erklärt. Munich: Christian Kaiser, 1877. Accessed July 22, 2015. Google Books.

Burkard, Dominik. "Die Theologische Fakultät der Staatlichen Akademie Braunsberg." In Institutionen und Strukturen. Vol. 1 of Katholische Theologie im Nationalsozialismus, edited by Dominik Burkard and Wolfgang Weiß, pt. 2, 24123. Würzburg: Echter, 2007-2011.

Burn, Andrew. Resurrection of the Two Witnesses. . . 2nd ed. London: W. Richardson, 1813. Accessed September 19, 2015. Google Books.

Burnet, Adam Wilson. The Lord Reigneth: The Russell Lectures for 1944 on the Book of Revelation. London: Hodder \& Stoughton, 1946.

Burr, David. "The Antichrist and the Jews in Four Thirteenth-Century Apocalypse Commentaries." In Friars and Jews in the Middle Ages and Renaissance, edited by Steven J. McMichael and Susan E. Myers, 23-38. Medieval Franciscans 2. Leiden: Brill, 2004.

. "Mendicant Readings of the Apocalypse." In Apocalypse in the Middle Ages, edited by Richard Kenneth Emmerson and Bernard McGinn, 89-102. Ithaca, NY: Cornell University Press, 1992.

Burton, Alfred Henry. The Apocalypse Expounded. London: Advent Witness Office; Pickering \& Inglis, 1932.

Burton, George. An Essay Towards reconciling the Numbers of Daniel and St. John, Determining the Birth of our Saviour, And fixing a precise Time for the Continuance of the present Desolation of the Jews; With Some Conjectures and Calculations, Pointing out the Year 1764, to have been one of the most remarkable Epochas in History. 2nd ed. London: W. Nicoll; J. Robson; J. Whitson, and B. White, 1769. Accessed October 26, 2015. Gale Eighteenth Century Collections Online.

Burton, Lary Miner. "Johannine and Pauline Ecclesiological Metaphors: A Comparative Study." PhD dissertation, New Orleans Baptist Theological Seminary, 1992. Accessed November 12, 2015. ProQuest Dissertations \& Theses Global.

Butler, Clement Moore. Lectures on the Book of Revelations. New York Robert Carter \& Brothers; Washington, DC: William Ballantyne, 1860. Accessed August 20, 2015. Google Books.

Buxbaum, Engelbert Maximilian, ed. Vom "Waldler-Buben" zum Hochschulprofessor und regierenden Bischof: Studien und Dokumente Bd. I. Vol. 1 of Dr. Joseph Freundorfer, Bischof von Augsburg (1949-1963). Sein Leben und Wirken nach eigenen und zeitgenössischen Dokumenten. Beiträge zur Augsburger Bistumsgeschichte 2. Regensburg, Germany: Schnell \& Steiner, 2004. 
C., M. A. E. Jews and Gentiles; or, The Mystery of Redemption in the Two Covenants, and the Two Witnesses in Revelations XI. Explained by Scripture Evidence Alone. . . L London: Wertheim \& Macintosh; Ashford, United Kingdom: Henry Igglesden, 1857. Accessed November 3, 2015. Google Books.

Caesarius of Arles Expositio de Apocalypsi Sancti Iohannis. Edited by Germain Morin. Sancti Caesarii Episcopi Arelatensis opera omnia nunc primum in unum collecta, 2:209-277. [Bruges, Belgium?]: Maretioli, 1942.

Expositio de Apocalypsi Sancti Iohannis. Translated by William C. Weinrich. Latin Commentaries on Revelation: Victorinus of Petovium, Apringius of Beja, Caesarius of Arles and Bede the Venerable, Ancient Christian Texts, 63-109. Downers Grove, IL: InterVarsity Press, 2011.

Caird, George Bradford. A Commentary on the Revelation of St. John the Divine. Harper's New Testament Commentaries. New York: Harper \& Row, 1966.

Calaway, Bernie L. Revealing the Revelation: A Guide to the Literature of the Apocalypse. San Francisco: International Scholars Publications, 1998.

Calmet, Antoine Augustin. Les épîtres de St. Paul, les épîtres canoniques, et l'Apocalypse. Vol. 8 of Commentaire littéral sur tous les livres de l'Ancien et du Nouveau Testament. Paris: Emery; Saugrain; Pierre Martin, 1726. Accessed September 13, 2015. Google Books.

Calmet, Augustin. Dissertations qui peuvent servir de prolégomènes de l'Écriture Sainte. Revîess, corrigées, considérablement augmentées, et mises dans un ordre méthodique. 3 vols. Paris: Emery Père; Emery Fils; Saugrain l'ainé; Pierre Martin, 1720. Accessed October 26, 2015. Google Books.

Cambell, David. Illustrations of Prophecy; Particularly the Evening and Morning visions of Daniel, and the Apocalyptical Visions of John. Boston: by the author, 1840. Accessed August 20, 2015. Google Books.

Campbell, David. The Judgment Period Preparatory to the Establishment of the Kingdom of Heaven. Comprising Twelve Chapters on the Apocalypse. Edited by Zenas B. Chase. Bangor, ME: Zenas B. Chase, 1886.

Caponsacchi di Pantaneto, Piero. In Iohannis apostoli Apocalypsim observatio. Florence: Giorgio Marescotti, 1572. Accessed August 17, 2015. Repositorio Institucional de la Universidad de Granada DIGIBUG.

Carey, William Gregory. Elusive Apocalypse: Reading Authority in the Revelation to John. Studies in American Biblical Hermeneutics 15. Macon, GA: Mercer University Press, 1999. 
Carlson, Stephen Wayne. "The Relevance of Apocalyptic Numerology for the Meaning

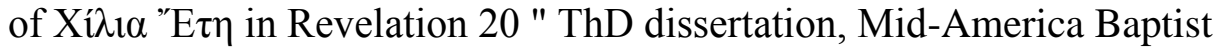
Theological Seminary, 1990. Accessed November 12, 2015. ProQuest Dissertations \& Theses Global.

Carpenter, William Boyd. "The Revelation of St. John." In A New Testament Commentary for English Readers, edited by Charles John Ellicott, 3:523-641. London: Cassell, 1897. Accessed October 20, 2015. Google Books.

Carrington, Philip. The Meaning of the Revelation. London: Society for Promoting Christian Knowledge; New York: Macmillan, 1931.

Carroll, Benajah Harvey. The Book of Revelation. Edited by James Britton Cranfill. Interpretation of the English Bible. New York: Fleming H. Revell, 1913. Accessed August 30, 2015. Internet Archive American Libraries Collection.

Carson, Donald Arthur, Douglas J. Moo, and Leon Morris. An Introduction to the New Testament. Grand Rapids, MI: Zondervan, 1992.

Case, Shirley Jackson. The Revelation of John: A Historical Interpretation. Chicago: University of Chicago Press, 1919.

Cerfaux, Lucien, and Jules-Marie Cambier. L'Apocalypse de Saint Jean lue aux Chrétiens. Lectio divina 17. Paris: Les Éditions du Cerf, 1955.

Charles, Robert Henry. A Critical and Exegetical Commentary on the Revelation of St. John. . . . 2 vols. International Critical Commentary. New York: Charles Scribner's Sons, 1920. . Studies in the Apocalypse. . . Edinburgh: T. \& T. Clark, 1913. Accessed July 3, 2015. Internet Archive Canadian Libraries Collection.

Charlier, Jean-Pierre. Comprendre l'Apocalypse. 2 vols. Lire la Bible 89-90. Paris: Les Éditions du Cerf, 1991.

. "Mort et résurrection du Témoin de Dieu selon le cinquième évangile." Vie Spirituelle 133 (1979): 324-336.

Chauffard, Anatole. L'Apocalypse et son interprétation historique. 2 vols. Avignon: Seguin Frères; Paris: E. Thorin, 1888. Accessed July 7, 2015. Google Books.

Chevalier, Jacques M. A Postmodern Revelation: Signs of Astrology and the Apocalypse. Toronto: University of Toronto Press, 1997.

Christie, Thomas William. The Book of Revelation. A Sketch Showing the Fourth Beast of Daniel: Its Carcase; Its Millennial and Jewish Fables; a Sign of the End. London: John F. Shaw, 1866. 
Chryssides, George D. "'Come on up, and I Will Show Thee': Heaven's Gate as a Postmodern Group." In Controversial New Religions, edited by James R. Lewis and Jesper Aagaard Petersen, 353-370. New York: Oxford University Press, 2005.

[Clark, Alexander?]. The Book of Prophecy opened: Or, A Plain Discovery of the Hidden Treasure of Wisdom and Knowledge, Contained in the Book with Seven Seals.... London: by the author, 1779. Accessed October 20, 2015. Google Books.

Classen, Peter. Gerhoch von Reichersberg: Eine Biographie mit einem Anhang über die Quellen, ihre handschriftliche Überlieferung und ihre Chronologie. Wiesbaden, Germany: Franz Steiner Verlag, 1960.

Clayton, Rice Hopkins. Future History in "The Revelation". London: Marshall, Morgan \& Scott, 1944.

Clayton, Robert. A Dissertation On Prophecy, Wherein The Coharence and Connexion of the Prophecies in both the Old and New Testament are fully considered; Together With An Explanation Of The Revelation of St. John. Dublin: J. P. Droz, 1749. Accessed November 3, 2015. Gale Eighteenth Century Collections Online.

Cochlovius, Joachim. Siehe, ich mache alles neu: Das Buch der Offenbarung Jesu Christi. Nuremberg, Germany: VTR, 2011.

Cohen, Gary G. Understanding Revelation: An Investigation of the Key Interpretational and Chronological Questions Which Surround the Book of Revelation. Chicago: Moody Press, 1978.

Cohen, Gary G., and Salem Kirban. Revelation Visualized: Verse by Verse, King James Version. Chicago: Moody press, 1971.

Colclasure, Chuck. The Overcomers: The Unveiling of Hope, Comfort, and Encouragement in the Book of Revelation. Nashville, TN: Thomas Nelson, 1981.

Collins, Adela Yarbro. The Apocalypse. New Testament Message 22. Collegeville, MN: Liturgical Press, 1979.

. "Numerical Symbolism in Jewish and Early Christian Apocalyptic Literature." In Aufstieg und Niedergang der Römischen Welt: Geschichte und Kultur Roms im Spiegel der Neueren Forschung, edited by Hildegard Temporini and Wolfgang Haase. Vol. 2.21.2, 1221-1287. Berlin: Walter de Gruyter, 1984.

Collins, Oral Edmond. "Antichrist in the Book of Revelation." Henceforth 4, no. 1 (1975): 5-42.

. The Final Prophecy of Jesus: An Introduction, Analysis, and Commentary on the Book of Revelation. Eugene, OR: Wipf and Stock, 2007. 
Comblin, José. Le Christ dans l'Apocalypse. Bibliothéque de théologie, théologie biblique, ser. 3, 6. Paris: Desclée, 1965.

Compton, Robert Bruce. "Dispensationalism, the Church, and the New Covenant." Detroit Baptist Seminary Journal 8 (Fall 2003): 3-48.

Conradi, Ludwig Richard. Die Offenbarung Jesu Christi. Hamburg: Internationale Traktatgesellschaft, 1907.

Considine, Joseph Sylvester. "The Two Witnesses: Apoc. 11:3-13." Catholic Biblical Quarterly 8, no. 4 (October 1946): 377-392.

Contreras Molina, Francisco. "El Espíritu Santo y la misión de Iglesia (Los dos testigosprofetas: Ap 11, 1-13)." Estudios Trinitarios 33 (1999): 75-101.

Cook, Augusta. Light from Patmos: The Apocalypse Simply and Concisely Explained in Forty Short Chapters for All Beginners in Prophetic Interpretation. London: Robert Banks \& Son, 1916.

Cook, W. Robert. The Theology of John. Chicago: Moody Press, 1979.

Cooke, William. The Revelations Translated, And Explained Throughout. . . London: G. G. J. and J. Robinson, 1789. Accessed August 17, 2015. Gale Eighteenth Century Collections Online.

Cooper, Henry G. The Book of Man's Destiny: A Simple and Comprehensive Interpretation of the Revelation of St. John. . . Grantham, United Kingdom: Lawrence Ridge; London: Simpkin, Marshall, 1866. Accessed November 3, 2015. Google Books.

Cooper, Robert Bransby. Commentary on the Revelation of St. John, or the Apocalypse. London: J. G. \& F. Rivington, 1833. Accessed September 24, 2015. Google Books.

Corsani, Bruno. "Messaggio e coscienza profetica: Le loro fonti secondo l'Apocalisse de Giovanni." Protestantesimo 49, no. 1 (1994): 2-12.

Corsini, Eugenio. The Apocalypse: The Perennial Revelation of Jesus Christ. Translated and edited by Francis J. Moloney. Good News Studies 5. Wilmington, DE: Michael Glazier, 1983.

. "I numeri nell'Apocalisse." In Apokalypsis: Percorsi nell'Apocalisse in onore di Ugo Vanni, edited by Elena Bosetti and Angelo Colacrai, 391-416. Commenti e Studi biblici, Sezione Studi biblici. Assisi: Cittadella Editrice, 2005.

Cothenet, Édouard. Le Message de l'Apocalypse. [Paris?]: Mame/Plon, 1995. 
. "Prophétisme dans le Nouveau Testament." Dictionnaire de la Bible,

Supplément. Edited by Louis Pirot, André Robert, Henri Cazelles, André Feuillet, Jacques Briend, and Michel Quesnel. Paris: Letouzey \& Ané, 1926-. Vol. 8, cols. 1222-1337.

Couchoud, Paul Louis. The Book of Revelation: A Key to Christian Origins. Translated by C. Bradlaugh Bonner. London: Watts, 1932.

Court, John M. Myth and History in the Book of Revelation. London: SPCK, 1979. . Revelation. New Testament Guides. Sheffield: JSOT Press, 1994.

Cowles, Henry. The Revelation of John; with Notes, Critical, Explanatory, and Practical. . . New York: D. Appleton, 1871. Accessed October 29, 2015. Google Books.

Craig, Maurice. "Academy House and Its Library." In The Royal Irish Academy: A Bicentennial History, 1785-1985, edited by T. Ó Raifeartaigh, 313-327. Dublin: Royal Irish Academy, 1985.

Crawford, Charles. An Essay upon the Eleventh Chapter of the Revelation of St. John; in Which is Shewn That the Words, "And in the Same Hour Was There a Great Earthquake, and the Tenth Part of the City Fell, and in the Earthquake Were Slain of Men, Seven Thousand," Relate to Jerusalem, and Not to Rome or France. Philadelphia: Asbury Dickins, 1800. Accessed November 3, 2015. Readex Early American Imprints, Evans, 1639-1800, Collection.

Crenshaw, Jeremy Shawn. "Will the Real Church Please Stand Up? An Exegetical Examination of Revelation 11:1-13." In But These Are Written . . . Essays on Johannine Literature in Honor of Professor Benny C. Aker, edited by Craig S. Keener, Jeremy S. Crenshaw, and Jordan Daniel May, 194-213. Eugene, OR: Pickwick Publications, 2014.

Croly, George. The Apocalypse of St. John. . . 3rd ed. London: J. G. \& F. Rivington, 1838. Accessed September 24, 2015. Google Books.

Culbertson, Robert. Lectures, Expository and Practical, on the Book of Revelation. 3 vols. New ed. Edinburgh: Oliver \& Boyd, 1826. Accessed August 27, 2015. Google Books.

Cullmann, Oscar. "Le caractère eschatologique du devoir missionnaire et de la

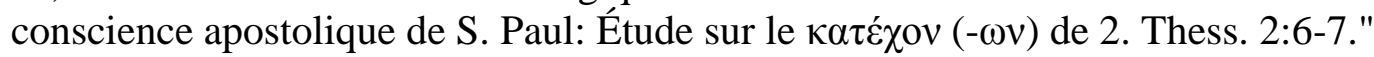
Revue d'histoire et de philosophie religieuses 16 (1936): 210-245.

Cumming, John. Apocalyptic Sketches. Lectures on the Book of Revelation. First Series. Philadelphia: Lindsay and Blakiston, 1854. Accessed August 30, 2015. Google Books. 
Cummings, Abraham. A Dissertation On The Introduction And Glory Of The Millennium. To Which Is Prefixed A Discourse on the Two Witnesses. Boston: Manning \& Loring, 1797. Accessed September 19, 2015. Gale Eighteenth Century Collections Online.

Cuninghame, William. A Dissertation on the Seals and Trumpets of the Apocalypse, and the Prophetical Period of Twelve Hundred and Sixty Years. 3rd ed. London: Thomas Cadell; Hatchard \& Son; James Nisbet; Edinburgh: Waugh \& Innes; J. Lindsay; Glasgow: John Smith \& Son, 1832. Accessed November 3, 2015. Google Books.

Currey, G. "The Revelation of St. John the Divine." In The New Testament of Our Lord and Savior Jesus Christ: According to the Authorized Version: With a Brief Commentary by Various Authors. Vol. 7 [without page numbers]. London: Society for the Promotion of Christian Knowledge, 1875.

Cursor Mundi (Southern Version). Edited by Sarah M. Horrall, Roger R. Fowler, Henry J. Stauffenberg, Peter H. J. Mous, Laurence M. Eldredge, and Anne L. Klinck. The Southern Version of "Cursor Mundi," 5 vols. Ottawa: University of Ottawa Press, 1978-2000.

D'Aragon, Jean-Louis. "The Apocalypse." In The Jerome Biblical commentary, edited by Raymond E. Brown, Joseph A. Fitzmyer, and Roland E. Murphy, 467-493. Englewood Cliffs, NJ: Prentice-Hall, 1968.

Dalrymple, Robert Edward. Revelation and the Two witnesses: The Implications for Understanding John's Depiction of the People of God and His Hortatory Intent. Eugene, OR: Resource Publications, 2011.

Daniel, Emmett Randolph. "Double Antichrist or antichrists [sic]: Abbot Joachim of Fiore." In Abbot Joachim of Fiore and Joachimism: Selected Articles, article VII, pages 1-16. Variorum Collected Studies Series CS985. Farnham, United Kingdom: Ashgate, 2011.

. "The Double Procession of the Holy Spirit in Joachim of Fiore's Understanding of History." Speculum 55, no. 3 (July 1980): 469-483. Accessed August 17, 2015. JSTOR.

. "Exodus and Exile: Joachim of Fiore's Apocalyptic Scenario." In Last Things: Death and the Apocalypse in the Middle Ages, edited by Caroline Walker Bynum and Paul H. Freedman, 124-139. The Middle Ages Series. Philadelphia: University of Pennsylvania Press, 2000.

. "Joachim of Fiore: Patterns of History in the Apocalypse." In The Apocalypse in the Middle Ages, edited by Richard Kenneth Emmerson and Bernard McGinn, 72-88. Ithaca, NY: Cornell University Press, 1992. 
Darby, John Nelson. Notes on the Book of Revelations; to Assist Inquirers in Searching into That Book. London: Central Tract Depôt, 1839. Accessed November 3, 2015. Google Books.

Darling, I. A New Commentary, or Explanation, of What Is Commonly Called the Revelations of St. John — the Divine, Adapted to Ordinary Minds. . . Cleveland, 1849. Accessed November 2, 2015. Internet Archive Microfilm Collection.

Daubuz, Charles. A Perpetual Commentary on the Revelation of St. John. . . . London: Benjamin Tooke, 1720. Accessed November 2, 2015. Google Books.

Davis, George Wesley. The Patmos Vision: An Exposition of the Revelation of Jesus Christ. Los Angeles: Bible Institute of Los Angeles, Biola Book Room, 1924.

De Burgh, William. An Exposition of the Book of the Revelation. 5th ed. Dublin: Hodges, Smith; London: Hamilton, Adams; London: Simpkin, Marshall, 1857. Accessed July 10, 2015. Google Books.

De Haan, Martin Ralph. Revelation: 35 Simple Studies in the Major Themes in Revelation. 6th ed. Grand Rapids, MI: Zondervan, 1946.

De Santo, Charles. The Book of Revelation: A Study Manual. Shield Bible Study Outlines. Grand Rapids, MI: Baker Book House, 1967.

De Smidt, Jacobus Christoffel. "Hermeneutical Perspectives on the Spirit in the Book of Revelation." Journal of Pentecostal Theology 14 (April 1999): 27-47. Accessed November 10, 2015. EBSCOhost ATLA Religion Database with ATLASerials.

De Wette, Wilhelm Martin Leberecht. Kurze Erklärung der Offenbarung Johannis. Edited by Wilhelm Moeller. 3rd ed. Kurzgefasstes exegetisches Handbuch zum Neuen Testament 3, pt. 2. Leipzig: S. Hirzel, 1862. Accessed July 3, 2015. Google Books.

Dean, John Taylor. Visions and Revelations: Discourses on the Apocalypse. Edinburgh: T. \& T. Clark, 1911. Accessed August 31, 2011. Internet Archive Canadian Libraries Collection.

Delafaye, Theodore. A Distinct And Compleat View Of The Revelation Of St. John the Divine. . . London: by the author, 1767. Accessed November 12, 2015. Gale Eighteenth Century Collections Online.

[Denny, Edward?]. The Great Epistle General of John, to the Seven Churches in Asia, in Connexion with Daniel's Prophecy of Seventy Weeks. London: W. H. Broom, n.d.

Deppermann, Klaus. Melchior Hoffman: Social Unrest and Apocalyptic Visions in the Age of Reformation. Edited by Benjamin Drewery. Translated by Malcolm Wren. Edinburgh: T. \& T. Clark, 1987. 
DeSilva, David Arthur. Seeing Things John's Way: The Rhetoric of the Book of Revelation. Louisville, KY: Westminster John Knox Press, 2009.

Desprez, Philip Charles Soulbieu. The Apocalypse Fulfilled in the Consummation of the Mosaic Economy and the Coming of the Son of Man. . . 2nd ed. London: Longman, Brown, Green, and Longmans, 1855. Accessed July 29, 2015. Google Books.

. The Apocalypse Fulfilled in the Consummation of the Mosaic Economy and the Coming of the Son of Man. ... 3rd ed. London: Longman, Green, Longman, and Roberts, 1861. Accessed July 12, 2015. Google Books.

. Daniel and John: or, The Apocalypse of the Old and That of the New Testament. London: C. Kegan Paul, 1878. Accessed August 2, 2015. Internet Archive American Libraries Collection.

. John, or the Apocalypse of the New Testament. London: Longmans, Green, 1870. Accessed July 10, 2015. Google Books.

Dick, David. An Explanation of the Revelation of St. John the Divine. . . Edinburgh: by the author, 1799. Accessed October 18, 2015. Gale Eighteenth Century Collections Online.

Dittrich, Achim. "Berengaudus." Biographisch-Bibliographisches Kirchenlexikon. Edited by Friedrich-Wilhelm Bautz and Traugott Bautz. Nordhausen, Germany: Verlag Traugott Bautz, 2010. Vol. 31, columns 90-92. Accessed August 16, 2015. http://www.bbkl.de/lexikon/bbkl-artikel.php?art=./B/Be/berengaudus.art.

Donegani, Isabelle. "À cause de la parole de Dieu et du témoignage de Jésus . . .": Le témoignage selon l'Apocalypse de Jean: Son enracinement extra-biblique et biblique. Sa force comme parole de sens. Études bibliques, n.s., 36. Paris: Librarie Lecoffre_-J. Gabalda et Cie., 1997.

Dorman, Lucy Mary. The Unveiled Future: An Interpretation of the Revelation Given to St. John. London: Marshall, Morgan \& Scott, 1936.

Doukhan, Jacques Benjamin. The Mystery of Israel. Hagerstown, MD: Review and Herald, 2004.

. Secrets of Revelation: The Apocalypse through Hebrew Eyes. Hagerstown, MD: Review and Herald, 2002.

Doyle, Stephen C. Apocalypse: A Catholic Perspective on the Book of Revelation. Cincinnati, OH: St. Anthony Messenger Press, 2005.

Du Preez, James. "Mission Perspective in the Book of Revelation." Evangelical Quarterly 42, no. July-September (1970): 152-167. 
Du Rand, Jan A. "The Ethical Response of an Alternative Community in a Critical Situation: Marturia and Martyrdom in the Apocalypse of John." In Identity, Ethics, and Ethos in the New Testament, edited by Jan Gabriël van der Watt and François Stephanus Malan, 565-593. Beihefte zur Zeitschrift für die neutestamentliche Wissenschaft und die Kunde der älteren Kirche 141. Berlin: Walter de Gruyter, 2006.

. "'. . . Let Him Hear What The Spirit Says . . .: The Functional Role and Theological Meaning of the Spirit in the Book of Revelation." Ex Auditu 12 (1996): 43-58. Accessed November 10, 2015. EBSCOhost ATLA Religion Database with ATLASerials.

. "'Your Kingdom Come "on Earth as It Is in Heaven"': The Theological Motif of the Apocalypse of John." Neotestamentica 31, no. 1 (1997): 59-75. Accessed November 29, 2015. EBSCOhost ATLA Religion Database with ATLASerials.

The Dublin University Calendar, for the Year 1912-1913. Vol. 3. Dublin: Hodges, Figgis; London: Longmans, Green, 1913. Accessed August 17, 2015. Internet Archive Canadian Libraries Collection.

Dulaey, Martine. "Commentaire." In Sur l'Apocalypse, suivi du Fragment chronologique et de La construction du monde, by Victorinus of Poetovio, translated and edited by Martine Dulaey, 151-231. Sources Chrétiennes 423. Paris: Les Éditions du Cerf, 1997.

. Victorin de Poetovio, premier exégète latin. 2 vols. Collection des Études Augustiniennes, Série Antiquité, 139-140. Paris: Institut d'Études Augustiniennes, 1993.

Dunn, Henry [Delta, pseud.]. The Revelation of St. John, Simply Analyzed and Briefly Expounded. London: James Nisbet, 1850. Accessed September 9, 2015. Google Books.

Dunn, James Douglas Grant. Christology in the Making: A New Testament Inquiry into the Origins of the Doctrine of the Incarnation. Philadelphia: Westminster Press, 1980 .

Düsterdieck, Friedrich Hermann Christian. Kritisch exegetisches Handbuch über die Offenbarung Johannis. 4th ed. Kritisch exegetischer Kommentar über das Neue Testament 16. Göttingen: Vandenhoeck und Ruprecht's Verlag, 1887. Accessed July 3, 2015. Google Books.

Duvall, J. Scott. Revelation. Teach the Text Commentary Series. Grand Rapids, MI: Baker Books, 2014.

Easton, Burton Scott. "Notes and Comments." Anglican Theological Review 19, no. 1 (January 1937): 30-34. Accessed November 16, 2015. EBSCOhost ATLA Religion Database with ATLA Serials. 
Ebrard, Johannes Heinrich August. Die Offenbarung Johannes. Biblischer Commentar über sämmtliche Schriften des Neuen Testaments zunächst für Prediger und Studirende 7. Königsberg, Prussia [=Kaliningrad, Russia]: August Wilhelm Unzer, 1853. Accessed June 25, 2015. Google Books.

Eckhardt, Karl August. Der Tod des Johannes als Schlüssel zum Verständnis der Johanneischen Schriften. Studien zur Rechts- und Religionsgeschichte 3. Berlin: Walter de Gruyter, 1961.

Edwards, Jonathan. An Humble Attempt. In Apocalyptic Writings, edited by Stephen J. Stein, 307-436. Works of Jonathan Edwards 5. New Haven, Connecticut: Yale University Press, 1977.

. Notes on the Apocalypse. In Apocalyptic Writings, edited by Stephen J. Stein, 95-305. Works of Jonathan Edwards 5. New Haven, Connecticut: Yale University Press, 1977.

Efird, James M. Daniel and Revelation: A Study of Two Extraordinary Visions. Valley Forge, PA: Judson Press, 1978. . Revelation for Today: An Apocalyptic Approach. Nashville, TN: Abingdon Press, 1989.

Eichhorn, Johann Gottfried. Commentarius in Apocalypsin Joannis. 2 vols. Göttingen: Johann Christian Dieterich, 1791.

Eisler, Robert. The Enigma of the Fourth Gospel: Its Author and Its Writer. London: Methuen, 1938. Accessed July 23, 2015. Internet Archive Microfilm Collection.

Eller, Vernard. The Most Revealing Book of the Bible: Making Sense Out of Revelation. Grand Rapids, MI: William B. Eerdmans, 1974.

Ellingworth, Paul. "The Marturia Debate." The Bible Translator 41, no. 1 (January 1990): 138-139.

Elliott, Edward Bishop. Horce Apocalyptica; or, A Commentary on the Apocalypse, Critical and Historical. . . . 4 vols. 5th ed. London: Seeley, Jackson, and Halliday, 1862. Accessed July 3, 2015. Internet Archive American Libraries Collection.

Elwell, Walter A. "Revelation." In Evangelical Commentary on the Bible, edited by Walter A. Elwell, 1195-1229. Baker Reference Library 3. Grand Rapids, MI: Baker Book House, 1989.

Emmerson, Richard Kenneth. Antichrist in the Middle Ages: A Study of Medieval Apocalypticism, Art, and Literature. Seattle: University of Washington Press, 1981. 
England's Fall Is Babylon's Triumph. An Original Interpretation of the Apocalypse, with a Special Reference to the Greek Church. London: J. F. Shaw, 1855. Accessed August 17, 2015. Google Books.

Erbes, Karl. Die Offenbarung Johannis kritisch untersucht. Gotha, Germany: Friedrich Andreas Perthes, 1891.

Eruditissimi Commentarii . . . in Apocalypsim Sancti Ioannis. Edited by Jean de la Haye. Paris: Anthony Bertier, 1647. Accessed August 16, 2015. Google Books.

Ettrick, William. The Second Exodus. . . 3 vols. 2nd ed. Sunderland, United Kingdom: by the author, 1814. Accessed October 6, 2015. Google Books.

Euripides Bacchantes. Edited by Isbon Thaddeus Beckwith. College Series of Greek Authors. Boston: Ginn, 1885. Accessed August 16, 2015. Google Books.

Evans, Mary J. "The Prophethood of All Believers." In Mission and Meaning: Essays Presented to Peter Cotterell, edited by Antony Billington, Anthony N. S. Lane, and Max Turner, 31-40. Carlisle, UK: Paternoster Press, 1995.

Everett, Grace Morrison. "Saint John's Vision [Part 3]." Methodist Review 112 (May 1929): 398-408.

Ewald, Georg Heinrich August. Commentarius in Apocalypsin Johannis exegeticus et criticus. Leipzig: Librariae Hahnianae, 1828. . Johannes' Apokalypse. . . . Vol. 2 of Die johanneischen Schriften überse[t]zt und erklärt. Göttingen: Verlag der Dieterichschen Buchhandlung, 1862. Accessed July 10, 2015. Google Books.

Ezell, Douglas. Revelations on Revelation: New Sounds from Old Symbols. Waco, TX: Word Books, 1977.

Faber, George Stanley. A Dissertation on the Prophecies, That Have Been Fulfilled, Are Now Fulfilling, or Will Hereafter Be Fulfilled. . . 3 vols. 5th ed. London: F. C. and J. Rivington, 1814-1818. Accessed October 26, 2015. Google Books. . The Sacred Calendar of Prophecy: or A Dissertation on the Prophecies. . . 3 vols. London: C. \& J. Rivington, 1828. Accessed October 14, 2015. Google Books.

Farkasfalvy, Denis M. "'Prophets and Apostles': The Conjunction of the Two Terms before Irenaeus." In Texts and Testaments: Critical Essays on the Bible and Early Church Fathers: A Volume in Honor of Stuart Dickson Currie, edited by Wallace Eugene March, 109-134. San Antonio: Trinity University Press, 1980. 
Farrer, Austin Marsden. A Rebirth of Images: The Making of St. John's Apocalypse. Glasgow: University of Glasgow Press, 1949. Reprint, Albany, NY: State of University of New York Press, 1986.

. The Revelation of St. John the Divine: Commentary on the English Text. Oxford: Clarendon Press, 1964.

Fau, Guy. "L'Apocalypse de Jean." Cahiers du Cercle Ernest Renan 10, no. 36 (Fourth Quarter 1962): 1-36.

Fausset, Andrew Robert. "The Revelation of St. John the Divine." In A Commentary, Critical and Explanatory, on the Old and New Testaments, 2:546-605. Hartford, CT: S. S. Scranton, 1871. Accessed October 26, 2015. Google Books.

. "Zechariah." In A Commentary, Critical and Explanatory, on the Old and New Testaments, 1:715-736. Hartford, CT: S. S. Scranton, 1871. Accessed October 26, 2015. Google Books.

Fauvarque, Bertrand. "Pierre et Paul: Les Deux Témoins de l'Apocalypse? Le rapprochement et ses limites aux IVe-Ve Siècles." Graphè, no. 3 (1994): 31-49.

Fee, Gordon Donald. New Testament Exegesis: A Handbook for Students and Pastors. 3rd ed. Louisville, KY: Westminster John Knox Press, 2002.

. Revelation: A New Covenant Commentary. New Covenant Commentary Series. Eugene, OR: Cascade Books, 2011.

Feinberg, Charles Lee. "The Book of Revelation." In The KJV Parallel Bible Commentary, edited by Jerry Falwell, Edward E. Hindson, and Woodrow Michael Kroll, 2651-2721. Nashville, TN: Thomas Nelson Publishers, 1994.

Féret, Henricus Maria. The Apocalypse of St. John. Translated by Elizabeth Corathiel. Westminster, MD: Newman Press, 1958.

Ferrar, William John. The Apocalypse Explained for Readers of To-day. London: Society for Promoting Christian Knowledge, 1936.

Ferraro, Giuseppe. La gioia di Cristo nel Quarto Vangelo, nelle lettere giovannee e nell'Apocalisse. Letture bibliche 13. Vatican City: Libreria Editrice Vaticana, 2000.

Feuillet, André. "Essai d'interprétation du chapitre XI de l'Apocalypse." New Testament Studies 4, no. 3 (April 1958): 183-200.

. L'Apocalypse: État de la question. Studia neotestamentica, Subsidia, 3. Paris: Desclée de Brouwer, 1963. 
. "La moisson et la vendange de l'Apocalypse (14,14-20). La signification chrétienne de la révélation johannique [Pt. 1]." La nouvelle revue theologique 94, no. 2 (February 1972): 113-132.

. "La moisson et la vendange de l'Apocalypse (14,14-20). La signification chrétienne de la révélation johannique [Pt. 2]." La nouvelle revue theologique 94, no. 3 (March 1972): 225-250.

Filippini, Roberto. "I due testimoni (Ap 11,1-13)." Parole di vita 45, no. 3 (May-June 2000): 38-43.

. "La forza della verità: sul concetto di testimonianza nell'Apocalisse." Rivista biblica 38, no. 4 (October-December 1990): 401-449.

. " «La testimonianza di Gesù è lo Spirito della profezia» (Ap 19,10): Profezia come testimonianza nell' Apocalisse." Ricerche storico bibliche 5, no. 1 (JanuaryJune 1993): 97-110.

. "La testimonianza nell'Apocalisse." Parole di vita 45, no. 4 (July-August 2000): 39-44.

Fitch, Charles. Letter to Rev. J. Litch, on the Second Coming of Christ; with the Sentiments of Cotton Mather on the Same Subject, Approved by Thomas Prince, Both Eminent Ministers of Boston in the Last Century. Second Advent Library 7. Boston: Joshua V. Himes, 1841. Accessed November 2, 2015. Google Books.

. A Wonderful and Horrible Thing. Second Advent Library 16. Boston: Joshua V. Himes, 1842. Accessed November 2, 2015. Google Books.

Fleming, Lorenzo Dow. A Synopsis of the Evidences of the Second Coming of Christ, about A.D. 1843. 3rd ed. Second Advent Library 12. Boston: Joshua V. Himes, 1842. Accessed November 2, 2015. Google Books.

Fleming, Robert. The Rise and Fall of Papacy. Edited by Thomas Thomson. Edinburgh: Johnstone, Hunter; London: Hamilton, Adams, 1870. Accessed November 3, 2015. Google Books.

Floyer, John. An Exposition Of The Revelations, By Shewing The Agreement of the Prophetick Symbols with the History of the Roman, Saracen, and Ottoman empires, and of the Popedom. ... London: M. Johnson, 1719. Accessed November 3, 2015. Gale Eighteenth Century Collections Online.

Ford, Desmond. Crisis! A Commentary on the Book of Revelation. 3 vols. Newcastle, CA: Desmond Ford Publications, 1982.

Ford, Josephine Massyngberde. Revelation: Introduction, Translation and Commentary. Anchor Bible 38. Garden City, NY: Doubleday, 1975. 
Forsey, Samuel. "My Two Witnesses": An Exposition of Revelation XI,3-14. . . London: Spottiswoode, n.d. Accessed September 24, 2015. http://www.andrews.edu /library/car/cardigital/digitized/documents/b14333466.pdf.

Foulkes, Ricardo. El Apocalipsis de San Juan: Una lectura desde América Latina. Buenos Aires: Nueva Creación; Grand Rapids, MI: William B. Eerdmans, 1989.

Franco, Ettore. "Profeti e profezia nell'Apocalisse." In Apokalypsis: Percorsi nell'Apocalisse in onore di Ugo Vanni, edited by Elena Bosetti and Angelo Colacrai, 335-369. Commenti e Studi biblici, Sezione Studi biblici. Assisi: Cittadella Editrice, 2005.

Fraser, Alexander. A Key to the Prophecies of the Old \& New Testament, Which Are Not Yet Accomplished. ... Edinburgh: Bell \& Bradfute; London: G. G. \& J. Robinson, 1795. Accessed September 6, 2015. Internet Archive American Libraries Collection.

Fredericks, Richard Louis. "A Sequential Study of Revelation 1-14 Emphasizing the Judgment Motif: With Implications for Seventh-day Adventist Apocalyptic Pedagogy." PhD dissertation, Andrews University, 1987. Accessed November 12, 2015. ProQuest Dissertations \& Theses Global.

Frenschkowski, Marco. "Die Entrückung der zwei Zeugen zum Himmel (Apk 11,11-14)." In Der Himmel, edited by Dorothea Sattler and Samuel Vollenweider, 261-290. Jahrbuch für biblische Theologie 20. Neukirchen-Vluyn, Germany: Neukirchener Verlag, 2006.

Frere, James Hatley. A Combined View of the Prophecies of Daniel, Ezra, and St. John. . . Corr. ed. London: J. Hatchard; Seeley; Nisbet; Panton, 1826. Accessed September 30, 2015. Google Books.

Froom, Le Roy Edwin. The Prophetic Faith of Our Fathers: The Historical Development of Prophetic Interpretation. 4 vols. Washington, DC: Review and Herald, 19461954. Accessed July 3, 2015. General Conference of Seventh-day Adventists, Office of Archives, Statistics, and Research Online Archives, Books Section

Frost, Henry Weston. Matthew Twenty-four and the Revelation: An Analysis, Literal Translation and Exposition of Each. New York: Oxford University Press, 1924.

G. "The Burial of Moses." Journal of Sacred Literature, n.s., 6, no. 11 (April 1854): 135165. Accessed November 11, 2015. Google Books.

Gaebelein, Arno Clemens. The Revelation: An Analysis and Exposition of the Last Book of the Bible. New York: Publication Office "Our hope"; Glasgow: Pickering \& Inglis; Auckland: H. L. Thatcher, 1915. 
Gagny, Jean de. Breuissima et facillima in omnes D. Pauli epistolas scholia, vltra priores editiones, ex antiquissimis Graecorum authoribus, abundè locupletata. Itidem in septem Canonicas epistolas \& D. Ioannis Apocalypsim, breuissima scholia recens edita. Paris: Jean de Roigny, 1563. Accessed August 17, 2015. Google Books.

Galloway, Joseph. Brief Commentaries upon Such Parts of the Revelation and Other Prophecies as Immediately Refer to the Present Times. . . London: by the author, 1802. Accessed October 7, 2015. Google Books.

Galloway, William Brown. The Gate of Prophecy; Being the Revelation of Jesus Christ by St. John, Theologically and Historically Expounded, and Shown to Elucidate Various Prophecies of Isaiah, Ezekiel, Daniel, Zechariah, \& St. Paul. 2 vols. London: Francis \& John Rivington, 1846. Accessed October 27, 2015. Dallas Theological Seminary Turpin Library Rare Books Collection.

Gane, Erwin Roy. Trumpet after Trumpet: Will Revelation's Seven Trumpets Sound Again? Nampa, ID: Pacific Press, 2012.

Garrett, Walter. An Exposition of Rev. xj. Containing the Famous Prophecy of the Witnesses; as also a Prediction of the Passing-away of the Turkish Wo; and of the Destruction of the Papacy. [London?], 1703. Accessed August 17, 2015. Gale Eighteenth Century Collections Online.

Gascoyne, Richard. A New Solution in Part of John's Revelation, Showing That Chapters I.-XI. Chiefly Describe the Apostasy, and Chapters XII.-XXII. the True Church. 3rd ed. London: James Nisbet, 1875. Accessed November 2, 2015. Google Books.

Gauntlett, Henry. An Exposition of the Book of Revelation. . . . 2nd ed. London: L. B. Seeley; J. Hatchard and Son, 1821. Accessed September 6, 2015. Google Books.

Gebhardt, Hermann Friedrich Wilhelm. Der Lehrbegriff der Apokalypse und sein Verhältniss zum Lehrbegriff des Evangeliums und der Episteln des Johannes. Gotha, Germany: Rud. Besser, 1873. Accessed July 22, 2015. Google Books.

. The Doctrine of the Apocalypse, and Its Relation to the Doctrine of the Gospel and Epistles of John. Translated by John Jefferson. Clark's Foreign Theological Library, n.s., 58. Edinburgh: T. \& T. Clark, 1878. Accessed July 22, 2015. Google Books.

Gelin, Albert. "Apocalypse: Traduite et commentée." In La Sainte Bible: texte latin et traduction française d'après les textes originaux: avec un commentaire exégétique et théologique, edited by Louis Pirot and Albert Clamer, 12:581-667. Paris: Letouzey et Ané, 1946.

Genoude, Antoine-Eugène de. Sainte Bible en latin et en francais. Traduction nouvelle d'après la Vulgate, avec des notes littéraires, critiques et historiques. . . . Vol. 5. 4th ed. Paris: Sapia; Pourrat Frères, 1840. Accessed July 6, 2015. Google Books. 
Gettys, Joseph M. How to Study the Revelation. Richmond, VA: John Knox Press, 1947.

Gib, Adam. A Memorial And Remonstrance, Read before the Associate Synod, at Edinburgh; May 2. 1782: Relative to a printed Sermon which had been preached before them. ... Edinburgh, 1784. Accessed November 3, 2015. Gale Eighteenth Century Collections Online.

Giblin, Charles Homer. The Book of Revelation: The Open Book of Prophecy. Good News Studies 34. Collegeville, MN: Liturgical Press, 1991.

. "Revelation 11:1-13: Its Form, Function, and Contextual Integration." New Testament Studies 30, no. 3 (July 1984): 433-459.

Giesen, Heinz. Die Offenbarung des Johannes. Regensburger Neues Testament. Regensburg, Germany: Verlag Friedrich Pustet, 1997.

Giet, Stanislas. "À propos d'un ouvrage récent sur l'Apocalypse." Revue des sciences religieuses 38, no. 1 (January 1964): 71-92. Accessed November 11, 2015. Persée Religion and Theology Collections.

. L'Apocalypse et l'histoire: Étude historique sur l'Apocalypse johannique. Paris: Presses Universitaires de France, 1957.

. "L'Apocalypse johannique." Archives de Sociologie des Religions, no. 4 (JulyDecember 1957): 149-157. Accessed November 11, 2015. Persée Religion and Theology Collections.

. "Retour sur l'Apocalypse." Revue des sciences religieuses 38, no. 3 (July 1964): 225-264. Accessed November 11, 2015. Persée Religion and Theology Collections.

Gill, John. An Exposition of the Revelation of S. John the Divine, Both Doctrinal and Practical. ... London: George Keith, 1776. Accessed August 30, 2015. Google Books.

Gilmour, Samuel MacLean. "The Revelation of John." In The Interpreter's One-Volume Commentary on the Bible: Introduction and Commentary for Each Book of the Bible Including the Apocrypha; with General Articles, edited by Charles M. Laymon, 945-968. Nashville, TN: Abingdon Press, 1971.

Girdlestone, Henry. Notes on the Apocalypse. . . London: William Edward Painter, 1847. Accessed August 17, 2015. Google Books.

Glasgow, James. The Apocalypse Translated and Expounded. Edinburgh: T. \& T. Clark, 1872. Accessed August 17, 2015. Google Books.

Glasson, Thomas Francis. The Revelation of John. Cambridge Bible Commentary on the New English Bible. Cambridge: Cambridge University Press, 1965. 
González, Catherine Gunsalus, and Justo Luis González. Revelation. Westminster Bible Companion. Louisville, KY: Westminster John Knox Press, 1997.

Gospel of Nicodemus. Translated by Felix Scheidweiler. New Testament Apocrypha, edited by Wilhelm Schneemelcher and Robert McLachlan Wilson, Rev. ed., 1:501-536. Cambridge, United Kingdom: James Clarke; Louisville, KY:

Westminster/John Knox Press, 1991-1992.

Govett, Robert. How Interpret the Apocalypse? As Naturalists or As Supernaturalists? A Refutation of the Historic Interpretation, with Special Reference to the Rev. G. Guinness' "Approaching End of the Age". Norwich, United Kingdom: Josiah Fletcher and Son, [1879?]. Reprint, How Interpret the Apocalypse? Miami Springs, FL: Conley \& Schoettle, 1985.

Govett, Robert [Matheetees, pseud.]. The Apocalypse Expounded by Scripture. 4 vols. London: James Nisbet, 1861-1865. Reprint, Govett on Revelation, 2 vols., Miami Springs, FL: Conley \& Schoettle, 1981.

Gräber, Hermann Johann. Versuch einer historischen Erklärung der Offenbarung des Johannes. . . Heidelberg, Germany: Karl Winter, 1857. Accessed August 27, 2015. Google Books.

Grant, P. W. The Revelation of John. An Exposition. London: Hodder and Stoughton, 1889.

Grasso, Santi. "Tempo e storia nell'Apocalisse." Parole di vita 45, no. 5 (SeptemberOctober 2000): 4-7.

Gray, James Martin. Christian Workers' Commentary on the Old and New Testaments. . . . New York: Fleming H. Revell, 1915.

Gray, Sherman W. The Least of My Brothers: Matthew 25:31-46: A History of Interpretation. Society of Biblical Literature Dissertation Series 114. Atlanta, GA: Scholars Press, 1989.

Greve, A. "»Mine to vidner «: Et forsøg på at identificere de to jerusalemitiske vidner (Apok. 11, 3-13)." Dansk Teologisk Tidsskrift 40, no. 2 (1977): 128-138.

Grimsrud, Ted. Triumph of the lamb: A Self-Study Guide to the Book of Revelation. Scottdale, PA: Herald Press, 1987.

Grünzweig, Fritz. Johannes-Offenbarung. 2 vols. EDITION C-Bibel-Kommentar 24-25. Neuhausen-Stuttgart, Germany: Hänssler-Verlag, 1981-1982.

Gry, Léon Pierre François. "Les chapitres XI et XII de l'Apocalypse." Revue biblique 31, no. 2 (April 1922): 203-214. 
Gryson, Roger, ed. Bedae Presbyteri Expositio Apocalypseos ad fidem codicum manuscriptorum edidit adnotationibus criticis instruxit prolegomenis munivit. Corpus Christianorum, Series Latina, 121A. Turnhout, Belgium: Brepols, 2001.

. "La présente édition." In Tyconii Afri Expositio Apocalypseos: Accedunt eiusdem Expositionis a quodam retractatae fragmenta Taurinensia, edited by Roger Gryson, 74-102. Corpus Christianorum, Series Latina, 107A. Turnhout, Belgium: Brepols, 2011.

. "Les sources." In Tyconii Afri Expositio Apocalypseos: Accedunt eiusdem Expositionis a quodam retractatae fragmenta Taurinensia, edited by Roger Gryson, 20-73. Corpus Christianorum, Series Latina, 107A. Turnhout, Belgium: Brepols, 2011.

Gryson, Roger, and Marie-Claire de Bièvre. "Les sources de Beatus." In Beatus Liebanensis tractatus de Apocalipsin, edited by Roger Gryson and Marie-Claire de Bièvre, CXXXIV-CXLI. Corpus Christianorum, Series Latina, 107B. Turnhout, Belgium: Brepols, 2012.

Günther, Hans Werner. Der Nah- und Enderwartungshorizont in der Apokalypse des heiligen Johannes. Forschung zur Bibel 41. [Würzburg, Germany?]: Echter Verlag, 1980.

Gunther, John J. "The Elder John, Author of Revelation." Journal for the Study of the New Testament, no. 11 (April 1981): 3-20. Accessed November 11, 2015. EBSCOhost ATLA Religion Database with ATLASerials.

Habershon, Matthew. An Historical Exposition of the Prophecies of the Revelation of St. John. . . London: James Nisbet; B. Wertheim, 1841. Accessed August 27, 2015. Google Books.

. An Historical Exposition of the Prophecies of the Revelation of St. John. . . 2 vols. 2nd ed. London: James Nisbet; B. Wertheim, 1844. Accessed November 3, 2015. Google Books.

Hadorn, Wilhelm. Die Offenbarung des Johannes. Theologischer Handkommentar zum Neuen Testament mit Text und Paraphrase 18. Leipzig: A. Deichertsche Verlagsbuchhandlung D. Werner Scholl, 1928.

Haggith, David. End-time Prophecies of the Bible. New York: G. P. Putnam's Sons, 1999.

Hailey, Homer. Revelation: An Introduction and Commentary. Grand Rapids, MI: Baker Book House, 1979.

Hall, John R., Philip Daniel Schuyler, and Sylvaine Trinh. Apocalypse Observed: Religious Movements and Violence in North America, Europe and Japan. London: Routledge, 2000. 
Hallifax, Samuel. Twelve Sermons On The Prophecies Concerning the Christian Church; And, In Particular, Concerning the Church of Papal Rome. . . London: T. Cadell, 1776. Accessed November 3, 2015. Gale Eighteenth Century Collections Online.

Hammershaimb, Erling. "Af Collegium Biblicums historie." Dansk Teologisk Tidsskrift 35, no. 1-2 (1972): 2-11.

Hammershaimb, Erling, and Bent Noack. "Johannes Munck, 3. marts 1904-22. februar 1965." In Aarsberetning 1964-1965, 7-13. Aarhus: Universitetsforlaget, 1965. Accessed August 16, 2015. Aarhus Universitet, AU Universitetshistorie Nekrologportal.

Hangyas, Laszlo I. "The Use and Abuse of Authority: An Investigation of the 'E Passages in Revelation." PhD dissertation, Andrews University, 1997. Accessed November 16, 2015. ProQuest Dissertations \& Theses Global.

Hanhart, Robert. Dodekapropheten 7.1: Sacharja 1-8. Biblischer Kommentar Altes Testament, vol. 14, pt. 7.1. Neukirchen-Vluyn, Germany: Neukirchener Verlag, 1998.

Hanna, Kamal Fahim Awad. La passione di Cristo nell'Apocalisse. Tesi Gregoriana, Serie Teologia, 77. Rome: Editrice Pontificia Università Gregoriana, 2001.

Hardy, Samuel. The Principal Prophecies Of the Old and New Testaments; Particularly Those In the Revelation Of St. John; Compared And Explained. . . London: by the author, 1770. Accessed July 9, 2015. Gale Eighteenth Century Collections Online.

Harms, Georg Ludwig Detlef Theodor. Die Offenbarung St. Johannis. 8th ed. Hermannsburg, Germany: Druck und Verlag der Missionshandlung, 1910.

Harrington, Wilfrid John. Revelation. Edited by Daniel J. Harrington. Sacra Pagina Series 16. Collegeville, MN: Liturgical Press, 1993. . Understanding the Apocalypse. Washington, DC: Corpus Books, 1969.

Harrison, Benjamin. Prophetic Outlines of the Christian Church and the Antichristian Power, as Traced in the Visions of Daniel and St. John. . . . London: Francis \& John Rivington, 1849. Accessed November 4, 2015. Google Books.

Haskell, Stephen Nelson. The Story of the Seer of Patmos. South Lancaster, MA: Bible Training School, 1905. Accessed November 2, 2015. Google Books.

Haugen, Philip S. "The Consummation of the Exodus: A Study of the Exodus Motif in the Revelation." MSTh thesis, Concordia Seminary, 1985. Accessed November 10, 2015. Theological Research Exchange Network (TREN). 
Haugg, Donatus. Die zwei Zeugen: Eine exegetische Studie über Apok 11, 1-13. Neutestamentliche Abhandlungen 17, issue 1. Münster in Westphalia: Verlag der Aschendorffschen Verlagsbuchhandlung, 1936.

. Judas Iskarioth in den Neutestamentlichen Berichten. Freiburg im Breisgau: Herder, 1930.

Hayter, Richard. The Meaning of the Revelation, or, A Paraphrase With Questions on the Revelation of the Holy Apostle and Evangelist John the Divine. . . . London: John Williams, 1675. Accessed August 17, 2015. ProQuest Early English Books Online.

Heinze, André. Johannesapokalypse und johanneische Schriften: Forschungs- und traditionsgeschichtliche Untersuchungen. Beiträge zur Wissenschaft vom Alten und Neuen Testament, 8th ser., 2. Stuttgart: Verlag W. Kohlhammer, 1998.

Hendriksen, William. More Than Conquerors: An Interpretation of the Book of Revelation. Grand Rapids, MI: Baker Book House, 1965.

Hengstenberg, Ernst Wilhelm. Die Offenbarung des heiligen Johannes für solche die in der Schrift forschen. 2nd ed. Berlin: L. Oehmigke's Verlag, 1861-1862. Accessed September 8, 2015. Google Books.

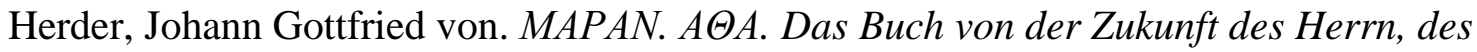
Neuen Testaments Siegel. In Herders Sämtliche Werke, edited by Bernhard Ludwig Suphan, 9:101-288. Berlin: Weidmannsche Buchhandlung, 1893. Reprint, Sämtliche Werke, Hildesheim, Germany: Georg Olms Verlagsbuchhandlung, 1967.

Herghelegiu, Monica-Elena. Siehe, er kommt mit den Wolken! Studien zur Christologie der Johannesoffenbarung. Europäische Hochschulschriften, 23rd ser., Theologie, 785. Frankfurt am Main: Peter Lang, 2004.

Hersey, John. The Identity of the Two Apocalyptic Witnesses. . . Baltimore: Armstrong \& Berry; Philadelphia: Higgins \& Perkinpine, 1857. Accessed September 7, 2015. Internet Archive American Libraries Collection.

Hilary of Poitiers In Matthceum. Translated by Jean Doignon. Sources Chrétiennes 254, 258. Paris: Les Éditions du Cerf, 1978-1979.

Hill, David. New Testament Prophecy. New Foundations Theological Library. Atlanta, GA: John Knox Press, 1979.

. "Prophecy and Prophets in the Revelation of St John." New Testament Studies 18, no. 4 (July 1972): 401-418.

Hill, H. Erskine. "The Two Witnesses." The Expositor 47 [8th ser., vol. 22], no. 130 (October 1921): 311-318. 
Hinton, Isaac Taylor. The Prophecies of Daniel and John, Illustrated by the Events of History. St. Louis: Turnbull \& Pray; Woodward \& Mathews; David Keith, 1843. Accessed November 3, 2015. Google Books.

Hippolytus of Rome Commentarium in Danielem. Translated by Georg Nathanael Bonwetsch and Marcel Richard. Die griechischen christlichen Schriftsteller der ersten Jahrhunderte, n.s., 7, 2nd ed. Berlin: Akademie Verlag, 2000.

De anticristo. Translated by Enrico Norelli. Biblioteca patristica. Florence: Nardini Editore-Centro Internazionale del Libro, 1987.

Hirschberg, Peter. Das eschatologische Israel: Untersuchungen zum Gottesvolkverständnis der Johannesoffenbarung. Wissenschaftliche Monographien zum Alten und Neuen Testament 84. Neukirchen-Vluyn, Germany: Neukirchener Verlag, 1999.

Hislop, Alexander. The Red Republic; or, Scarlet-Coloured Beast of the Apocalypse: Being an Inquiry into the Period of the Prophesying of the Two Witnesses, and the Character of the Beast That Kills Them. ... Edinburgh: William Whyte; Glasgow: W. Collins and D. Bryce; London: Longman, Brown, 1849. Accessed October 19, 2015. Google Books.

Hocking, David Lee. The Coming World Leader: Understanding the Book of Revelation. Portland, OR: Multnomah Press, 1988.

Hoeksema, Herman. Behold, He Cometh! An Exposition of the Book of Revelation. Edited by Homer Cooper Hoeksema. Grand Rapids, MI: Reformed Free Publishing Association, 1969.

Hofmann, Johann Christian Konrad von. Weissagung und Erfüllung im Alten und im Neuen Testamente. Ein theologischer Versuch. 2 vols. Nördlingen, Germany: Druck und Verlag der C. H. Beck'schen Buchhandlung, 1841-1844. Accessed July 10, 2015. Internet Archive European Libraries Collection.

Holden, George Frederick. Lectures on the Revelation of S. John the Divine. 2nd ed. London: Hugh Rees, 1903.

Holmes, James Ivory. The Fulfilment of the Revelation of St. John Displayed. . . . London: Ogle, Duncan; J. Hatchard; Edinburgh: Ogle, Allardice, and Thomson; Glasgow: M. Ogle; Dublin: Johnston and Deas, 1819. Accessed October 19, 2015. Google Books.

. The Revelation of Saint John the Divine Elucidated. . . 2 vols. London: J. Hatchard, 1815. Accessed August 27, 2015. Google Books.

Holmes, William Anthony. The Time of the End; Being a Series of Lectures on Prophetical Chronology. London: R. B. Seeley and W. Burnside, 1833. Accessed August 19, 2015. Google Books. 
Holtz, Traugott. Die Offenbarung des Johannes. Edited by Karl-Wilhelm Niebuhr. Das Neue Testament Deutsch, Neues Göttinger Bibelwerk, 11. Göttingen: Vandenhoeck \& Ruprecht, 2008.

Holtzmann, Heinrich Julius. Evangelium, Briefe und Offenbarung des Johannes. Edited by Walter Bauer. 3rd ed. Hand-Commentar zum Neuen Testament 4. Tübingen: J. C. B. Mohr (Paul Siebeck), 1908. Accessed July 10, 2015. Google Books.

Holwerda, David Earl. "The Church and the Little Scroll (Revelation 10, 11)." Calvin Theological Journal 34, no. 1 (April 1999): 148-161. Accessed November 11, 2015. EBSCOhost ATLA Religion Database with ATLASerials.

Hommel, Fritz. "Die «zwei verschwundenen Götter» der Adapa-Legende und Apocalypse 11,3-13." In Altorientalische Studien: Bruno Meissner zum sechzigsten Geburtstag am 25. April 1928, 87-95. Mitteilungen der Altorientalischen Gesellschaft 4. Leipzig: Otto Harrassowitz, 1928-1929.

Hooper, Francis John Bodfield. The Revelation of Jesus Christ by John. 2 vols. London: J. \& F. H. Rivington; Edinburgh: A. \& C. Black, 1861. Accessed September 7, 2015. Google Books.

[Hooper, John?]. The Revelation of Jesus Christ, Explained Agreeably to the Analogy of Holy Scripture: and the Interpretation of Its Symbols. London: Joseph Masters, 1850. Accessed October 19, 2015. Google Books.

Hopkins, Martin. "Historical Perspective of Apocalypse 1-11." Catholic Biblical Quarterly 27, no. 1 (January 1965): 42-47. Accessed November 12, 2015. EBSCOhost ATLA Religion Database with ATLASerials.

. "History in the Apocalypse." The Bible Today 1, no. 20 (1965): 1340-1344.

Hoste, William. The Visions of John the Divine: An Exposition, Chapter by Chapter, of the Book of Revelation. Kilmarnock, UK: John Ritchie, [1932?].

Hoyt, Edyth Viola Sage Armstrong. Studies in the Apocalypse of John of Patmos: A NonInterpretative and Literary Approach to the Last Book of the English Bible. 4th ed. Ann Arbor, MI: Edwards Brothers, 1959.

Hughes, Philip Edgcumbe. The Book of the Revelation: A Commentary. Leicester, United Kingdom: Inter-Varsity Press; Grand Rapids, MI: William B. Eerdmans, 1990.

Huntingford, Edward. The Apocalypse: With a Commentary and an Introduction on the Reality of Prediction, the History of Christendom, the Scheme of Interpretation, and the Antichrist of St. Paul and St. John. London: Kegan Paul, Trench, 1881. Accessed October 29, 2015. Google Books.

. A Practical Interpretation of the Revelation of St. John the Divine. 3rd ed. London: Bickers \& Son, 1900. 
Hurnard, Samuel Fennell. Revelation: The Book with a Blessing. London: Marshall, Morgan \& Scott, [1930?].

Hyldahl, Niels. "Træk af den nytestamentlige eksegeses historie i Danmark i det 20. århundrede." In Kirkehistoriske samlinger 1979, edited by Leif Grane, Martin Schwarz Lausten, and Jørgen Stenbæk, 127-150. Copenhagen: Selskabet for Danmarks Kirkehistorie, 1979.

Hyldahl, Niels, and J. Nørregaard. "Johannes Munck." Dansk Biografisk Leksikon. 3rd ed. Copenhagen: Gyldendal, 1979-1984. Accessed August 17, 2015. http://www.denstoredanske.dk/index.php?sideId=294544.

Irenaeus Adversus hareses. Translated by Adelin Rousseau, Louis Doutreleau, Bertrand Hemmerdinger, and Charles Mercier. Sources Chrétiennes 100, 152-153, 210 211, 263-264, 293-294. Paris: Les Éditions du Cerf, 1965-2002.

Ironside, Henry Allen. Lectures on the Revelation: Delivered in the Gospel Auditorium, Oakland, Calif. 2nd ed. New York: Loizeaux Brothers, 1930. Reprint, Revelation, Ironside Expository Commentaries, Grand Rapids, MI: Kregel, 2004.

Irving, Edward. Babylon and Infidelity Foredoomed of God. . . . 2 vols. Glasgow: Chalmers and Collins; Edinburgh: William Whyte; William Oliphant; Dublin: R. M. Tims; William Curry, Jr.; London: G. B. Whitaker, 1826.

Isaac, Jean. Apocalypse de Jésus-Christ: Les épreuves de l'Alliance et le sens de l'Histoire. Paris: Les Éditions du Cerf, 1991.

"Isbon Thaddeus Beckwith, B.A. 1868." Obituary Record of Graduates of Yale University, no. 96 (1936-1937): 9-10. = "Isbon Thaddeus Beckwith, B.A. 1868." Bulletin of Yale University 34, no. 6 (December 1, 1937): 9-10. Accessed August 16, 2015. Yale University Library Manuscripts and Archives Yale Obituary Record 1859-1952.

Jankowski, Augustyn. Apokalipsa świetego Jana: Wstęp —Przekład z oryginału— Komentarz. Katolicki Uniwersytet Lubelski, Pismo Święte Nowego Testamentu, 12. Poznań, Poland: Pallottinum, 1959.

Jauhiainen, Vesa Marko. The Use of Zechariah in Revelation. Wissenschaftliche Untersuchungen zum Neuen Testament, ser. 2, 199. Tübingen: Mohr Siebeck, 2005.

Jenour, Alfred. Rationale Apocalypticum: Or, A Systematic Exposition of the Apocalypse; with Historical Proofs and Illustrations. . . . 2 vols. London: Thomas Hatchard, 1852. Accessed July 3, 2015. Internet Archive American Libraries Collection.

Jeremias, Joachim. "H $\lambda(\varepsilon)$ ías." Theological Dictionary of the New Testament. Edited by Gerhard Kittel and Gerhard Friedrich. Translated and edited by Geoffrey W. Bromiley. Grand Rapids, MI: William B. Eerdmans, 1964-1976. 2:928-941. 
. "H $\lambda(\varepsilon)$ (́) s." Theologisches Wörterbuch zum Neuen Testament. Edited by

Gerhard Kittel and Gerhard Friedrich. Stuttgart: W. Kohlhammer, 1933-1979.

2:930, line 32,-943, line 21.

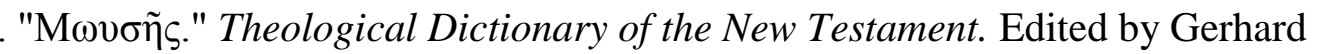

Kittel and Gerhard Friedrich. Translated and edited by Geoffrey W. Bromiley.

Grand Rapids, MI: William B. Eerdmans, 1964-1976. 4:848-873.

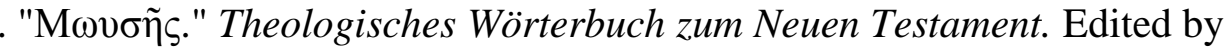

Gerhard Kittel and Gerhard Friedrich. Stuttgart: W. Kohlhammer, 1933-1979.

4:852, line 19,-878, line 22.

Jerome of Stridon Epistula 59. Edited by Isidorus Hilberg. Corpus Scriptorum Ecclesiasticorum Latinorum 54:541-547, 2nd ed. Vienna: Verlag der Österreichischen Akademie der Wissenschaften, 1996.

Jeske, Richard L. "Spirit and Community in the Johannine Apocalypse." New Testament Studies 31, no. 3 (July 1985): 452-466.

Joachim of Fiore Expositio in Apocalypsim. Edited by Silvestro Meuccio. Expositio magni prophete Abbatis Ioachim in Apocalipsim . . . Cui adiecta sunt. Eiusdem psalterium decem cordarum . . ., 26v-224r. Venice: Heirs of Ottaviano Scotto, 1527. Accessed August 16, 2015. Google Books.

Liber introductorius in expositionem Apocalypsis. Edited by Silvestro Meuccio. Expositio magni prophete Abbatis Ioachim in Apocalipsim . . Cui adiecta sunt. Eiusdem psalterium decem cordarum. . . 2v-26v. Venice: Heirs of Ottaviano Scotto, 1527. Accessed August 16, 2015. Google Books.

Johnson, Alan F. "Revelation." In The Expositor's Bible Commentary, edited by Frank Ely Gaebelein and James Dixon Douglas, 12:397-603. Grand Rapids, MI: Regency Reference Library, 1981.

. "Revelation." In The Expositor's Bible Commentary, edited by Tremper Longman III and David E. Garland, rev. ed., 13:571-789. Grand Rapids, MI: Zondervan, 2006.

Johnson, Barton Warren. Vision of the Ages; or, Lectures on the Apocalypse. A Complete View of the Book of Revelation. 4th ed. St. Louis, MO: Christian, 1881.

Johnston, Bryce. A Commentary on the Revelation of St. John. 2 vols. New ed. Edinburgh: William Creech, 1807. Accessed October 27, 2015. Google Books.

Johnston, Warren. "Thomas Beverley and the 'Late Great Revolution': English Apocalyptic Expectation in the Late Seventeenth Century." In Scripture and Scholarship in Early Modern England, edited by Ariel Hessayon and Nicholas Keene, 158-175. Aldershot, Hampshire, UK: Ashgate, 2006. 
Jones, William. Lectures on the Apocalypse. London: Holdsworth and Ball; Edinburgh: Waugh and Innes; Dublin: Curry, 1830. Accessed September 27, 2015. Internet Archive American Libraries Collection.

Josephus, Titus Flavius. Bellum judaicum. Translated by Henry St. John Thackeray. Loeb Classical Library 203, 210, 2 volume ed. Cambridge, MA: Harvard University Press, 1989-1990.

Jour du Jugement. Translated by Richard Kenneth Emmerson and David F. Hult. Early European Drama Translation Series 2. Asheville, NC: Pegasus Press, 1998.

Jue, Jeffrey K. Heaven upon Earth: Joseph Mede (1586-1638) and the Legacy of Millenarianism. Archives internationales d'histoire des idées 194. Dordrecht, Netherlands: Springer, 2006.

Jung-Stilling, Johann Heinrich. Die Siegsgeschichte der christlichen Religion in einer gemeinnützigen Erklärung der Offenbarung Johannis. In Johann Heinrich Jung's, genannt Stilling, sämmtliche Werke, New ed., 3:3-494. Stuttgart: J. Scheible's Buchhandlung, 1841-1842. Accessed August 17, 2015. Google Books.

. Nachtrag zur Siegsgeschichte. In Johann Heinrich Jung's, genannt Stilling, sämmtliche Werke, New ed., 3:495-696. Stuttgart: J. Scheible's Buchhandlung, 1841. Accessed October 26, 2015. Google Books.

Kamlah, Wilhelm. Apokalypse und Geschichtstheologie: Die mittelalterliche Auslegung der Apokalypse vor Joachim von Fiore. Historische Studien 285. Berlin: Verlag Dr. Emil Ebering, 1935. Reprint, Vaduz, Liechtenstein: Kraus Reprint, 1965.

Kamp, Hendrik Rijk van de. Israël in Openbaring: Een onderzoek naar de plaats van het joodse volk in het toekomstbeeld van de Openbaring aan Johannes. Kampen, Netherlands: Uitgeversmaatschappij J. H. Kok, 1990.

. Openbaring: Profetie vanaf Patmos. Commentaar op het Nieuwe Testament, 3rd ser., Katholieke Brieven en Openbaring sec. Kampen, Netherlands: Uitgeverij Kok, 2000.

Kamp, Hendrik Rijk van de, and Jakob van Bruggen. Hebreeën: Geloven is volhouden. Commentaar op het Nieuwe Testament, 3rd ser., Hebreeën sec. Kampen, Netherlands: Uitgeverij Kok, 2010.

Kaup, Matthias. "Joachim von Fiore, De prophetia ignota-Anlaß, Aussage und Gestalt der Schrift." In "De prophetia ignota": Eine frühe Schrift Joachims von Fiore, translated and edited by Matthias Kaup, 1-69. Monumenta Germaniae Historica, Studien und Texte 19. Hannover: Hahnsche Buchhandlung, 1998.

Kealy, Sean P. The Apocalypse of John. Message of Biblical Spirituality 15. Wilmington, DE: Michael Glazier, 1987. 
Keener, Craig S. Revelation. NIV Application Commentary. Grand Rapids, MI: Zondervan, 2000.

Keferstein, Selmar. Die Offenbarung St. Johannis nach rein symbolischer Auffassung. Gütersloh, Germany: C. Bertelsmann, 1907. Accessed October 14, 2015. Internet Archive Microfilm Collection.

Kelly, James. The Apocalypse Interpreted in the Light of "The Day of the Lord". 2 vols. London: James Nisbet, 1849-1851. Accessed July 20, 2015. Internet Archive American Libraries Collection.

Kelly, William. Lectures Introductory to the Study of the Acts, the Catholic Epistles, and the Revelation. London: W. H. Broom, 1870. Accessed November 4, 2015. Google Books.

Lectures on the Book of Revelation. New ed. London: W. H. Broom, 1871. Accessed September 15, 2015. Google Books.

. The Revelation Expounded. 3rd ed. London: Thomas Weston, 1904. Accessed November 4, 2015. Google Books.

Kempson, Wayne Richard. "Theology in the Revelation of John." PhD dissertation, Southern Baptist Theological Seminary, 1982. Accessed November 12, 2015. ProQuest Dissertations \& Theses Global.

Kepler, Thomas Samuel. The Book of Revelation: A Commentary for Laymen. New York: Oxford University Press, 1957. . Dreams of the Future: Daniel and Revelation. Bible Guides 22. London: Lutterworth Press; New York: Abingdon Press, 1963.

Keppel, David. The Book of Revelation Not a Mystery. New York: Methodist Book Concern, 1918.

Kiddle, Martin, and M. K. Ross. The Revelation of St. John. Moffatt New Testament Commentary. London: Hodder and Stoughton, 1940.

Kistemaker, Simon J. Exposition of the Book of Revelation. New Testament Commentary 20. Grand Rapids, MI: Baker Books, 2001.

Klaassen, Walter. Living at the End of the Ages: Apocalyptic Expectation in the Radical Reformation. Lanham, MD: University Press of America; Waterloo, ON, Canada: Institute for Anabaptist and Mennonite Studies, Conrad Grebel Colloge, 1992.

Kliefoth, Theodor Friedrich Dethlof. Die Offenbarung des Johannes. 3 vols. Leipzig: Dörffling und Franke, 1874. Accessed October 20, 2015. Google Books. 
Klund, Robert William. "The Plot of Revelation 4-22." PhD dissertation, Dallas Theological Seminary, 2002. Accessed July 22, 2015. ProQuest Dissertations \& Theses Global.

Knight, Jonathan Morshead. Revelation. 2nd ed. Readings: A New Biblical Commentary. Sheffield, United Kingdom: Sheffield Phoenix Press, 2011.

Knoch, Adolph Ernst. The Unveiling of Jesus Christ, Commonly Called the Revelation of St. John. . . L Los Angeles: Concordant Publishing Concern, 1935.

Koester, Craig R. Revelation and the End of All Things. Grand Rapids, MI: William B. Eerdmans, 2001.

Koester, Craig Richard. Revelation: A New Translation with Introduction and Commentary. Anchor Yale Bible 38A. New Haven: Yale University Press, 2014.

Kovacs, Judith L., Christopher Charles Rowland, and Rebekah Callow. Revelation: The Apocalypse of Jesus Christ. Blackwell Bible Commentaries. Malden, MA: Blackwell, 2004.

Kowalski, Beate. Die Rezeption des Propheten Ezechiel in der Offenbarung des Johannes. Stuttgarter biblische Beiträge 52. Stuttgart: Verlag Katholisches Bibelwerk, 2004.

Kraft, Heinrich. Die Bilder der Offenbarung des Johannes. Frankfurt am Main: Peter Lang, 1994.

. Die Offenbarung des Johannes. Handbuch zum Neuen Testament 16a.

Tübingen: J. C. B. Mohr (Paul Siebeck), 1974.

Kraybill, J. Nelson. Apocalypse and Allegiance: Worship, Politics, and Devotion in the Book of Revelation. Grand Rapids, MI: Brazos Press, 2010.

Krey, Philip D. W. "The Apocalypse Commentary of 1329: Problems in Church History." In Nicholas of Lyra: The Senses of Scripture, edited by Philip D. W. Krey and Lesley Smith, 267-288. Studies in the History of Christian Thought 90. Leiden: Brill, 2000.

Krodel, Gerhard A. Revelation. Augsburg Commentary on the New Testament. Minneapolis, MN: Augsburg Publishing House, 1989.

Kübel, Robert Benjamin. Pastoralbriefe, Hebräerbrief und Offenbarung Johannis. Edited by Eduard Riggenbach and Otto Zöckler. 2nd ed. Kurzgefaßter Kommentar zu den heiligen Schriften Alten und Neuen Testamentes sowie zu den Apokryphen, B. Neues Testament, 5. Munich: C. H. Beck'sche Verlagsbuchhandlung, Oskar Beck, 1898. 
Kusche, Roger William. "The Concept of the Community of Believers in the Apocalypse of John: A Study in the Doctrine of the Church." PhD thesis, Vanderbilt University, 1960.

Kuyper, Abraham. The Revelation of St. John. Translated by John Hendrik de Vries. Grand Rapids, MI: William B. Eerdmans, 1935.

L'Hote, Jean Baptiste. The Book of Revelation Explained by History. A Commentary. Philadelphia, PA: Lippincott, Grambo, 1854. Accessed October 30, 2015. Internet Archive American Libraries Collection.

Labagh, Isaac Peter. Twelve Lectures on the Great Events of Unfulfilled Prophecy. . . New York: by the author, 1859. Accessed July 10, 2015. Google Books.

The Two Witnesses, additional section to A Connected View of Some of the Scripture Evidence of the Redeemer's Speedy Personal Return. . . , by James A. Begg. 1st American ed. New York: John Moffet; New York: William Burbeck, 1842. Accessed July 10, 2015. Google Books.

Lacey, Thomas Alexander. "The Two Witnesses." Journal of Theological Studies 11, no. 1 (1910): 55-60.

Lacunza y Díaz, Manuel de [Juan Josafat Ben-Ezra, pseud.]. The Coming of Messiah in Glory and Majesty. Translated by Edward Irving. 2 vols. London: L. B. Seeley and Son, 1827. Accessed November 4, 2015. Google Books.

. Venida del Mesías en gloria y magestad. 3 vols. [Cádiz, Spain?]: Felipe

Tolosa, [1812?]. Accessed November 4, 2015. Google Books.

Ladd, George Eldon. A Commentary on the Revelation of John. Grand Rapids, MI: William B. Eerdmans, 1972.

LaHaye, Timothy Francis. Revelation Unveiled. Grand Rapids, MI: Zondervan, 1999.

LaHaye, Timothy Francis, and Jerry Bruce Jenkins. Apollyon: The Destroyer is Unleashed. [Left Behind ${ }^{\circ}$ Book Series 5]. Carol Stream, IL: Tyndale House, 1999.

. Armageddon: The Cosmic Battle of the Ages. [Left Behind® Book Series 11]. Wheaton, IL: Tyndale House, 2003.

. Assassins: Assignment: Jerusalem, Target: Antichrist. [Left Behind® Book Series 6]. Wheaton, IL: Tyndale House, 1999.

. Desecration: Antichrist Takes the Throne. [Left Behind® Book Series 9].

Wheaton, IL: Tyndale House, 2001. 
. Glorious Appearing: The End of Days. [Left Behind $®$ Book Series 12].

Wheaton, IL: Tyndale House, 2004.

. The Indwelling: The Beast Takes Possession. [Left Behind® Book Series 7].

Wheaton, IL: Tyndale House, 2000.

. Kingdom Come: The Final Victory. [Left Behind® Book Series Sequel]. Carol Stream, IL: Tyndale House, 2007.

. Left Behind $®:$ A Novel of the Earth's Last Days. [Left Behind ${ }^{\circledR}$ Book Series

1]. Wheaton, IL: Tyndale House, 1995.

. Nicolae: The Rise of Antichrist. [Left Behind® Book Series 3]. Wheaton, IL:

Tyndale House, 1997.

. The Rapture: In the Twinkling of an Eye: Countdown to the Earth's Last Days.

[Left Behind ${ }^{\circledR}$ Book Series, Prequel, 3]. Carol Stream, IL: Tyndale House, 2006.

. The Regime: Evil Advances: Before They Were Left Behind. [Left Behind®

Book Series, Prequel, 2]. Carol Stream, IL: Tyndale House, 2005.

. The Remnant: On the Brink of Armageddon. [Left Behind $®$ Book Series 10].

Wheaton, IL: Tyndale House, 2002.

. The Rising: Antichrist is Born: Before They Were Left Behind. [Left Behind ${ }^{\circledR}$

Book Series, Prequel, 1]. Wheaton, IL: Tyndale House, 2005.

. Soul Harvest: The World Takes Sides. [Left Behind® Book Series 4].

Wheaton, IL: Tyndale House, 1998.

. Tribulation Force: The Continuing Drama of Those Left Behind. [Left

Behind® Book Series 2]. Carol Stream, IL: Tyndale House, 1996.

Lambrecht, Jan. "Apokalyps 11,1-14: Uitleg en actualisatie." In De sluier opgelicht?

Apokalyptiek in Oud en Niew Testament, 62-80. Leuven: Vlaamse bijbelstichting; Acco uitgeverij, 1979.

. "De verrijzenis van de twee getuigen in Apok. 11,1-14: Theologische reflectie." In De sluier opgelicht? Apokalyptiek in Oud en Niew Testament, 81-94. Leuven: Vlaamse bijbelstichting; Acco uitgeverij, 1979.

Lang, George Henry. The Revelation of Jesus Christ: Selected Studies. Miami Springs, FL: Conley \& Schoettle, 1985.

Langdon, Samuel. Observations On The Revelation Of Jesus Christ to St. John. . . . Worcester, MA: Isaiah Thomas, 1791. Accessed September 7, 2015. Gale Eighteenth Century Collections Online. 
Lange, Johann Peter. Die Offenbarung des Johannes. Theologisch-homiletisch bearbeitet. Theologisch-homiletisches Bibelwerk, Die Heilige Schrift, Des Neuen Testamentes, 16. Bielefeld, Germany: Velhagen und Klasing, 1871. Accessed September 14, 2015. Google Books.

. The Revelation of John. Edited by Elijah Richardson Craven. Translated by Evelina Moore. Commentary on the Holy Scriptures, New Testament, 10. New York: Charles Scribner's Sons, 1874. Accessed September 14, 2015. Google Books.

Lange, Samuel Gottlieb. Die Apokalypse oder Offenbarung Johannis. Vol. 1 of Die Schriften Johannis des vertrauten Schülers Jesu. Neustrelitz, Germany: Hofbuchhandlung, 1795.

Larkin, Clarence. The Book of Revelation: A Study of the Last Prophetic Book of Holy Scripture. Glenside, PA: Rev. Clarence Larkin Estate, 1919. Accessed July 10, 2015. Internet Archive American Libraries Collection.

LaRondelle, Hans Karl. How to Understand the End-Time Prophecies of the Bible: The Biblical-Contextual Approach. Sarasota, FL: First Impressions, 1997.

Lasseigne, Jeffery Lynn. Unlocking the Last Days: A Guide to the Book of Revelation \& the End Times. Grand Rapids, MI: Baker Books, 2011.

Lawrie, John. The Completion of Prophecy, The Clearest evidence of the Truth of Christianity.... Edinburgh: Wheldon and Waller; London: Leigh and Sothebay, 1781. Accessed August 19, 2015. Google Books.

Layclerc, H. W. The Unveiling of the Apocalypse of St. John the Divine, Chapter X: The Angel of the Reformation. New ed. London: Thynne, 1936.

Le Bourdellès, Hubert. "L'épisode des Deux Témoins dans l'Apocalypse (11, 1-19)." Graphè, no. 1 (1992): 67-78.

Lee, Samuel. An Inquiry into the Nature, Progress, and End of Prophecy, in Three Books ... To Which Is Prefixed a Preface and Introduction, in Three Parts. ... Cambridge: Cambridge University Press, 1849. Accessed October 7, 2015. Google Books.

. Six Sermons on the Study of the Holy Scriptures ... To Which Are Annexed Two Dissertations: The First on the Reasonableness of the Orthodox Views of Christianity ... ; the Second on the Interpretation of Prophecy Generally, with an Original Exposition of the Book of Revelation. . . . London: James Duncan, 1830. Accessed October 7, 2015. Internet Archive American Libraries Collection.

Leifchild, John. A Help to the Private and Domestic Reading of the Holy Scriptures. ... 2nd ed. London: Samuel Bagster, 1831. Accessed October 29, 2015. Google Books. 
Lenski, Richard Charles Henry. The Interpretation of St. John's Revelation. Minneapolis, MN: Augsburg Publishing House, 1963.

Lerner, Robert E. "Antichrists and Antichrist in Joachim of Fiore." Speculum 60, no. 3 (July 1985): 553-570. Accessed August 17, 2015. JSTOR.

Letseli, Tankiso Letseli. "The Kingship of God as a Theological Motif in the Hymns of the Apocalypse of John." DLittPhil thesis, Rand Afrikaans University, 2001. Accessed September 23, 2015. UJDigispace (the Institutional Repository of the University of Johannesburg) Theses and Dissertations Community, Department of Religious Studies Collection.

Liber commicus de toto circulo anni. Edited by Justo Pérez de Urbel and Atilano Gonzáles y Ruíz-Zorrilla. Monumenta Hispaniae sacra, Serie liturgica, 2-3. Madrid: Consejo Superior de Investigaciones Científicas, 1950-1955.

Lichtenberger, Hermann. Die Apokalypse. Theologischer Kommentar zum Neuen Testament 23. Stuttgart: Verlag W. Kohlhammer, 2014.

Lietaert Peerbolte, Lambertus Johannes. The Antecedents of Antichrist: A TraditioHistorical Study of the Earliest Christian Views on Eschatological Opponents. Supplements to the Journal for the Study of Judaism 49. Leiden: E. J. Brill, 1996.

. "Sodom, Egypt, and the Two Witnesses of Revelation 11:8." In Sodom's Sin: Genesis 18-19 and Its Interpretation, edited by Edward Noort and Eibert J. C. Tigchelaar, 63-82. Themes in Biblical Narrative 7. Leiden: Brill, 2004.

Lilje, Johannes Ernst Richard. Das letzte Buch der Bibel: Eine Einführung in die Offenbarung Johannes. 6th ed. Die urchristliche Botschaft 23. Hamburg: FurcheVerlag, 1960.

Lindner, Dominikus. "Die Philosophisch-Theologische Hochschule Freising in der NSZeit." In Das Erzbistum München und Freising in der Zeit der nationalsozialistischen Herrschaft, edited by Georg Schwaiger, 1:639-656. Munich: Verlag Schnell \& Steiner, 1984.

. "Die Philosophisch-Theologische Hochschule Freising von ihrer Hundertjahrfeier (1934) bis zu ihrer Auflösung (1969)." Sammelblatt des historischen Vereins Freisings 27 (1970): 29-67.

Lindsay, Stan A. Revelation: The Human Drama. Bethlehem, PA: Lehigh University Press; London: Associated University Presses, 2001.

Lindsey, Hal. There's a New World Coming: "A Prophetic Odyssey". New York: Bantam Books, 1975. 
Litch, Josiah. Prophetic Expositions; or a Connected View of the Testimony of the Prophets concerning the Kingdom of God and the Time of Its Establishment. 2 vols. Boston: Joshua V. Himes, 1842. Accessed August 17, 2015. Google Books.

Lo Bue, Francesco, and Geoffrey Grimshaw Willis. "Introduction." In The Turin Fragments of Tyconius' Commentary on Revelation, edited by Francesco Lo Bue and Geoffrey Grimshaw Willis, 1-42. Texts and Studies, Contributions to Biblical and Patristic Literature, n.s., 7. Cambridge, United Kingdom: Cambridge University Press, 1963.

Loenertz, Raymond Joseph. The Apocalypse of Saint John. Translated by Hilary J. Carpenter. London: Sheed \& Ward, 1947.

Lohmeyer, Ernst. Die Offenbarung des Johannes erklärt. 3rd ed. Handbuch zum Neuen Testament 16. Tübingen: J. C. B. Mohr (Paul Siebeck), 1970.

Lohse, Eduard. Die Offenbarung des Johannes übersetzt und erklärt. 8th ed. Das Neue Testament Deutsch, Neues Göttinger Bibelwerk, 11. Göttingen: Vandenhoeck \& Ruprecht, 1993.

Loisy, Alfred Firmin. L'Apocalypse de Jean. Paris: Émile Nourry, 1923. Reprint, [Frankfurt am Main?]: Minerva, 1972.

López Rosas, Ricardo, and Pablo Richard Guzmán. Evangelio y Apocalipsis de San Juan. Biblioteca Bíblica Básica 17. Estella, Spain: Editorial Verbo Divino, 2006.

Lord, David Nevins. An Exposition of the Apocalypse. New ed. New York: Franklin Knight, 1859. Accessed November 1, 2015. Google Books.

Love, Julian Price. The First, Second, and Third Letters of John, the Letter of Jude, the Revelation to John. The Layman's Bible Commentary 25. Atlanta, GA: John Knox Press, 1960.

Lovett, Henry William. The Revelation of Saint John Explained. 2nd ed. London: Whittaker, 1838. Accessed October 20, 2015. Google Books.

Lowery, Robert A. Revelation's Rhapsody: Listening to the Lyrics of the Lamb: How to Read the Book of Revelation. Joplin, MO: College Press, 2006.

Lowman, Moses. A Paraphrase and Notes on the Revelation of St. John. 4th ed. London: W. Baynes, 1807. Accessed September 7, 2015. Google Books.

Lucas, Roger Paul. "The Time of the Reign of Christ in 1 Corinthians 15:20-28 in Light of Early Christian Session Theology." PhD dissertation, Andrews University, 1997. Accessed July 2, 2015. ProQuest Dissertations \& Theses Global. 
Lücke, Friedrich. Versuch einer vollständigen Einleitung in die Offenbarung des Johannes oder Allgemeine Untersuchungen über die apokalyptische Litteratur überhaupt und die Apokalypse des Johannes insbesondere. 2 vols. 2nd ed. Commentar über die Schriften des Evangelisten Johannes, pt. 4, vol. 1. Bonn: Eduard Weber, 1852. Accessed November 10, 2015. Google Books.

Ludus de Antichristo. Translated by John Wright. Mediaeval Sources in Translation. Toronto: Pontifical Institute of Mediaeval Studies, 1967.

Lupieri, Edmondo F. A Commentary on the Apocalypse of John. Translated by Maria Poggi Johnson and Adam Kamesar. Italian Texts and Studies on Religion and Society. Grand Rapids, MI: William B. Eerdmans, 2006.

MacArthur, John Fullerton, Jr. Revelation 1-11. MacArthur New Testament Commentary. Chicago: Moody Press, 1999.

MacDonald, William. "The Revelation of Jesus Christ." In Believer's Bible Commentary, edited by Arthur L. Farstad, 2349-2383. Nashville, TN: Thomas Nelson, 1995.

[MacKenzie, George?]. Synopsis Apocalyptica: Or, A Short Plain Explication and Application Of Daniel's Prophecy And Of St. John's Revelation, In Concent with It, and Consequential to It. Edinburgh, 1708. Accessed October 30, 2015. Gale Eighteenth Century Collections Online.

Mackay, Thomas W. "Early Christian Millenarianist Interpretation of the Two Witnesses in John's Apocalypse 11:3-13." In By Study and Also by Faith: Essays in Honor of Hugh W. Nibley on the Occasion of His Eightieth Birthday, 27 March 1990, edited by John M. Lundquist and Stephen D. Ricks, 1:222-331. Salt Lake City, UT: Deseret Book Co.; Provo, UT: Foundation for Ancient Research \& Mormon Studies, 1990.

Madsen, Peder. Johannes' Aabenbaring, indledet og fortolket. 2nd ed. Copenhagen: G. E. C. Gad, 1896. Accessed July 3, 2015. EBSCOhost American Theological Library Association (ATLA) Historical Monographs Collection, Series 2.

Maggin, Elliot S. Kingdom Come. Based on a story by Mark Waid and Alex Ross. New York: Warner Books, Warner Aspect, 1998.

Maher, Erin, and Kay Reindl. "Instinct." Script prepared for The Dead Zone, USA Network, August 2004. Accessed July 2, 2015. http://www2.usanetwork.com /series/thedeadzone/theshow/episodeguide/episodes/s3_instinct/instinct.pdf.

Maier, Gerhard. Die Johannesoffenbarung und die Kirche. Wissenschaftliche Untersuchungen zum Neuen Testament 25. Tübingen: J. C. B. Mohr (Paul Siebeck), 1981. 
Die Offenbarung des Johannes: Kapitel 1-11. Historisch-Theologische Auslegung, Neues Testament. Witten, Germany: SCM R. Brockhaus; Giessen, Germany: Brunnen Verlag, 2009.

. Die Offenbarung des Johannes: Kapitel 12-22. Historisch-Theologische Auslegung, Neues Testament. Witten, Germany: SCM R. Brockhaus; Giessen, Germany: Brunnen Verlag, 2012.

. Mensch und freier Wille: Nach den jüdischen Religionsparteien zwischen Ben Sira und Paulus. Wissenschaftliche Untersuchungen zum Neuen Testament 12. Tübingen: J. C. B. Mohr (Paul Siebeck), 1971.

Maier, Harry O. Apocalypse Recalled: The Book of Revelation after Christendom. Minneapolis, MN: Fortress Press, 2002.

Maitland, Charles. The Apostles' School of Prophetic Interpretation: With Its History Down to the Present Time. London: Longman, Brown, Green, and Longmans, 1849. Accessed July 12, 2015. Google Books.

Maldonado, Juan de. Commentarii in quattuor Evangelistas. Nunc primùm in lucem editi, \& in duos Tomos divisi, Quorum prior eos, qui in Matthoum, \& Marcum; posterior eos, qui in Lucam, \& Ioannem, complectitur. 2 vols. Pont-à-Mousson, France: Stephani Mecator, 1596-1597. Reprint, Commentarii in quatuor Evangelistas. Quos pristinae integritati restitutos, novisque studiis auctos, ed. Johann Michael Raich, 2 vols., Illustrium theologorum in Sacras Novi Testamenti Scripturas commentarii 1-2, Mainz: Franz Kirchheim, 1874.

A Commentary on the Holy Gospels. Translated and edited by George John Davie. 2 vols. 2nd ed. Catholic Standard Library. London: John Hodges, 1888. Accessed August 17, 2015. Internet Archive Canadian Libraries Collection.

[Malot, François?]. Dissertation sur l'époque du rappel des Juifs. . . . 2nd ed. Paris: Veuve Mequignon \& Fils, 1779. Accessed July 7, 2015. Google Books.

Mangina, Joseph Layton. "God, Israel, and Ecclesia in the Apocalypse." In Revelation and the Politics of Apocalyptic Interpretation, edited by Richard B. Hays and Stefan Alkier, 85-103. Waco, TX: Baylor University Press, 2012.

. Revelation. Brazos Theological Commentary on the Bible. Grand Rapids, MI: Brazos Press, 2010.

Mangold, G. M. Blicke in die Vergangenheit, Gegenwart und Zukunft, oder, Enthüllungen wichtiger prophetischer Weissagungen und Anmerkungen über die Offenbarung Jesu Christi an seinen Knecht Johannes. Zürich: Zürcher und Furrer, 1862.

Mariana, Juan de. Scholia in Vetus et Novum Testamentum. Paris, 1620. Accessed August 17, 2015. Google Books. 
Matthäi, Friedrich Anton Levin. Die Offenbarung Johannes aus dem Griechischen übersetzt, und mit einer vollständigen Erklärung begleitet. 2 vols. Göttingen: Dieterich'schen Buchhandlung, 1828. Accessed August 2, 2015. Google Books.

Maurice, John Frederick Denison. Lectures on the Apocalypse or Book of the Revelation of St. John the Divine. 2nd ed. London: Macmillan, 1893. Accessed November 2, 2015. Google Books.

Maxwell, Cyril Mervyn. The Message of Revelation. Vol. 2 of God Cares. Boise, ID: Pacific Press, 1985.

Mayhew, Eugene John. "Revelation 11, The Two Witnesses of." Dictionary of Premillennial Theology. Edited by Mal Couch. Grand Rapids, MI: Kregel Publications, 1996. 364-366.

Mayo, Philip Lee. "Those Who Call Themselves Jews": The Church and Judaism in the Apocalypse of John. Princeton Theological Monograph Series 60. Eugene, OR: Pickwick Publications, 2006.

Mazzaferri, Frederick David. The Genre of the Book of Revelation from a Source-critical Perspective. Beiheft zur Zeitschrift für die neutestamentliche Wissenschaft und die Kunde der älteren Kirche 54. Berlin: Walter de Gruyter, 1989.

McConkey, James Henry. The Book of Revelation: A Series of Outline Studies in the Apocalypse. Pittsburgh, PA: Silver, 1921.

McCutcheon, Lillie Stella. "The Church in Prophecy." In Dynamics of the Faith: Evangelical Christian Foundations, edited by Gene Miller, Max Riesland Gaulke, and Donald Smith, 145-161. [Houston, TX?]: Gulf-Coast Bible College, 1972.

McDowell, Edward Allison, Jr. The Meaning and Message of the Book of Revelation. Nashville, TN: Broadman Press, 1951.

McDowell, R. B. "The Main Narrative." In The Royal Irish Academy: A Bicentennial History, 1785-1985, edited by T. Ó Raifeartaigh, 1-92. Dublin: Royal Irish Academy, 1985.

McGinn, Bernard. Antichrist: Two Thousand Years of the Human Fascination with Evil. New York: HarperSanFrancisco, 1994.

. The Calabrian Abbot: Joachim of Fiore in the History of Western Thought. New York: Macmillan; London: Collier Macmillan Publishers, 1985.

. Visions of the End: Apocalyptic Traditions in the Middle Ages. Records of Civilization, Sources and Studies, 96. New York: Columbia University Press, 1979. Reprint, 1998. 
McIver, Tom. The End of the World: An Annotated Bibliography. Jefferson, NC: McFarland, 1999.

McLeod, Alexander. Lectures upon the Principal Prophecies of the Revelation. New York: Whiting and Watson; Eastburn, Kirk; Philadelphia: William W. Woodward, 1814. Accessed September 7, 2015. Internet Archive American Libraries Collection.

McNicol, Allan J. The Conversion of the Nations in Revelation. Library of New Testament Studies 438. New York: T \& T Clark, 2011.

. "Revelation 11:1-14 and the Structure of the Apocalypse." Restoration Quarterly 22, no. 4 (1979): 193-202. Accessed November 10, 2015. EBSCOhost ATLA Religion Database with ATLASerials.

Melton, John Gordon. "Applewhite Jr., Marshall Herff." Religious Leaders of America: A Biographical Guide to Founders and Leaders of Religious Bodies, Churches, and Spiritual Groups in North America. 2nd ed. Detroit, MI: Gale Research, 1999. 21.

Meulen, Ruurd Jan van der. "De Openbaring in het laatste bijbelboek." ThD thesis, Vrije Universiteit te Amsterdam, 1948.

Meuthen, Erich. Kirche und Heilsgeschichte bei Gerhoh von Reichersberg. Studien und Texte zur Geistesgeschichte des Mittelalters 6. Leiden: E. J. Brill, 1959.

Michael, Thomas. "Evangelistic Motifs in the Book of Revelation: A Critical Analysis of the Book of Revelation with Regard to Its Various Evangelistic Motifs." PhD dissertation, Southeastern Baptist Theological Seminary, 2000. Accessed July 22, 2015. ProQuest Dissertations \& Theses Global.

Michaels, J. Ramsey. Revelation. IVP New Testament Commentary Series 20. Downers Grove, IL: InterVarsity Press, 1997.

Miesel, John. "The Two Witnesses: Revelation 11:3." BD thesis, Grace Theological Seminary, 1957.

Miller, William. Dissertations on the True Inheritance of the Saints, and the Twelve Hundred and Sixty Days of Daniel and John; with an Address to the Conference of Believers in the Advent Near. Boston: Joshua V. Himes, 1842. Accessed November 2, 2015. Google Books.

. Evidence from Scripture and History of the Second Coming of Christ, about the Year 1843; Exhibited in a Course of Lectures. Boston: B. B. Mussey, 1840. Accessed August 17, 2015. Google Books.

Milligan, Ezra McLeod. Is the Kingdom Age at Hand? An Interpretation of Portions of Daniel's Prophecy and the Book of the Revelation of Jesus Christ. New York: George H. Doran, 1924. 
Milligan, William. The Book of Revelation. Expositor's Bible. New York: A. C. Armstrong \& Son, 1896. Accessed October 27. 2015. Google Books.

. "The Revelation of St. John the Divine." In A Popular Commentary on the New Testament, edited by Philip Schaff, 4:27-161 (being part of the seperate pagination for the whole section on Revelation). New York: Scribner's Sons; Edinburgh: T. \& T. Clark, 1879-1883. Accessed October 27, 2015. Google Books.

Min, Paolo Byong-Seob. "I due testimoni di Apocalisse 11,1-13: Storiainterpretazione - teologia." ThD dissertation, Pontificia Universitas Gregoriana, 1991.

Minear, Paul Sevier. I Saw a New Earth: An Introduction to the Visions of the Apocalypse. Washington: Corpus Books, 1968.

. "Ontology and Ecclesiology in the Apocalypse." New Testament Studies 12, no. 2 (January 1966): 89-105.

Mitchell, G. F. "Antiquities." In The Royal Irish Academy: A Bicentennial History, 17851985, edited by T. Ó Raifeartaigh, 93-165. Dublin: Royal Irish Academy, 1985.

Mnisi, Mhingwana George. "How God Takes Responsibility for His Church in This World with Reference to Revelation 11." DLittPhil thesis, Rand Afrikaans University, 2004. Accessed November 11, 2015. UJDigispace (the Institutional Repository of the University of Johannesburg) Theses and Dissertations Community, Department of Religious Studies Collection.

A Modest Inquiry into the Meaning of the Revelations. In a Letter to All Such as Wait for the Kingdom of Christ. London, 1688. Accessed August 17, 2015. ProQuest Early English Books Online.

Moffatt, James. "The Revelation of St. John the Divine." In The Expositor's Greek Testament, edited by William Robertson Nicoll, 5:279-494. New York: Dodd, Mead, 1910. Accessed October 26, 2015. Google Books.

Monléon, Jean de. Le Sens Mystique de l'Apocalypse: Commentaire textuel d'après la Tradition des Pères de l'Eglise. Paris: Nouvelles Éditions Latines, 1984.

Montague, George Thomas. The Apocalypse and the Third Millennium: Today's Guide to the Book of Revelation. Ann Arbor, MI: Servant Publications, 1998.

Moody, Robert. Observations On Certain Prophecies In The Book of Daniel And The Revelation of St. John, Which Relate To The Second Appearing of Our Lord . . . To Which Are Added, Some Remarks Concerning the Last Antichrist and the Killing of the Witnesses. [London?]: by the author, 1787. Accessed October 29, 2015. Gale Eighteenth Century Collections Online. 
Morant, Peter. Das Kommen des Herrn: Eine Erklärung der Offenbarung des Johannes. Zurich: Thomas-Verlag; Paderborn, Germany: Verlag Ferdinand Schöningh, 1969.

Morris, Henry Madison. The Revelation Record: A Scientific and Devotional Commentary on the Book of Revelation. Wheaton, IL: Tyndale House; San Diego, CA: Creation-Life Publishers, 1983.

Morris, Leon. The Book of Revelation: An Introduction and Commentary. Rev. ed. Tyndale New Testament Commentaries. Leicester, United Kingdom Inter-Varsity Press; Grand Rapids, MI: William B. Eerdmans, 1987.

Mounce, Robert Hayden. The Book of Revelation. Rev. ed. New International Commentary on the New Testament. Grand Rapids, MI: William B. Eerdmans, 1998.

Mulholland, M. Robert, Jr. Revelation: Holy Living in an Unholy World. Fancis Asbury Press Commentary. Grand Rapids, MI: Francis Asbury Press, 1990.

Müller, Ekkehardt. Der Erste und der Letzte: Studien zum Buch der Offenbarung. Adventistica, Forschungen zur Geschichte und Theologie der Siebenten-TagsAdventisten, 11. Frankfurt am Main: Peter Lang, 2011.

. Microstructural Analysis of Revelation 4-11. Andrews University Seminary Doctoral Dissertation Series 21. Berrien Springs, Michigan: Andrews University Press, 1996.

. "The Two Witnesses of Revelation 11." Journal of the Adventist Theological Society 13, no. 2 (Autumn 2002): 30-45.

Müller, Ulrich B. Die Offenbarung des Johannes. Ökumenischer Taschenbuchkommentar zum Neuen Testament 19. Gütersloh, Germany: Gütersloher Verlagshaus Gerd Mohn; Würzburg, Germany: Echter Verlag, 1984.

Munck, Elisabeth. "Johannes Munck, 1904-1965." Studia Theologica 19, no. 1-2 (1965): $1-2$.

Munck, Johannes. "Johannes' Aabenbaring er en Trøstebog." Aarhuus Stiftstidende, October 20, 1940. 110.

. "Paul, the Apostles, and the Twelve." Studia Theologica 3, no. 1 (1949): 96-

. "Paulus' Apostolat og Apostelbegrebet i det Ny Testamente." Dansk Teologisk Tidsskrift 11, no. 3 (1948): 141-157.

. "Peter and Paul in the Apocalypse of St. John." Nuntius Sodalicii Neotestamentici, no. 4 (1950): cols. 25-26. 
. "Peter og Paulus i Johannes' Aabenbaring. Et Bidrag til Udlægning at Apokalypsen." Ny Kyrklig Tidskrift 18 (1949): 33-51.

. Petrus und Paulus in der Offenbarung Johannis: Ein Beitrag zur Auslegung der Apokalypse. Det Lærde Selskabs Skrifter, Teologiske Skrifter, 1. Copenhagen: Rosenkilde og Bagger, 1950.

. Untersuchungen über Klemens von Alexandria. Forschungen zur Kirchenund Geistesgeschichte 2. Stuttgart: W. Kohlhammer, 1933.

. "Vor Tid er lydhør for Johannes' Aabenbaring." Aarhuus Stiftstidende, August 10, 1941.

Munck, Johannes, and Elisabeth Munck. Preface to The Acts of the Apostles: Introduction, Translation and Notes, by Johannes Munck, ed. William F. Albright and C. S. Mann. Anchor Bible. Garden City, NY: Doubleday, 1967.

Murphy, Frederick James. Fallen is Babylon: The Revelation to John. The New Testament in Context. Harrisburg, PA: Trinity Press International, 1998.

Murray, James. Lectures Upon The Book of the Revelation, Of John the Divine: Containing A new Explanation of the History, Visions, and Prophesies, contained in that Book. 2 vols. Newcastle upon Tyne, United Kingdom, 1778. Accessed September 7, 2015. Gale Eighteenth Century Collections Online.

Naden, Roy C. The Lamb among the Beasts: A Christological Commentary on the Revelation of John That Unlocks the Meaning of Its Many Numbers. Hagerstown, MD: Review and Herald, 1996.

Nevin, Robert. Studies in Prophecy. In Two Parts. Part I. Studies in the Old Testamentchiefly Ezekiel and Daniel. Part II. The Apocalypse. Londonderry, United Kingdom: James Montgomery, 1890.

Newbolt, Michael Robert. The Book of Unveiling: A Study of the Revelation of St. John. London: SPCK, 1952.

Newman, Barclay Moon, Jr. Rediscovering the Book of Revelation. Valley Forge, PA: Judson Press, 1968.

Newport, John P. The Lion and the Lamb. Nashville, TN: Broadman Press, 1986.

Newton, Benjamin Wills. Thoughts on the Apocalypse. 3rd ed. London: Houlston \& Sons; London: Lucas Collins, 1904. Accessed July 22, 2015. Internet Archive Canadian Libraries Collection.

Newton, Isaac. Observations Upon The Prophecies Of Daniel, And The Apocalypse Of St. John. London, 1733. Accessed November 2, 2015. Google Books. 
Newton, Thomas. Dissertations on the Prophecies, Which Have Remarkably Been Fulfilled, and at This Time Are Fulfilling in the World. New ed. London: Longman; John Richardson; J. M. Richardson; et al., 1832. Accessed September 7, 2015. Google Books.

Nickel, Monika. "Die Philosophisch-Theologische Hochschule Freising." In Institutionen und Strukturen. Vol. 1 of Katholische Theologie im Nationalsozialismus, edited by Dominik Burkard and Wolfgang Weiß, pt. 1, 419-443. Würzburg: Echter, 2007-2011.

Noack, Bent. "Johannes Munck, exeget og teolog." Dansk Teologisk Tidsskrift 35, no. 1-2 (1972): 126-134.

Noordegraaf, A., G. Kwakkel, S. Paas, H. G. L. Peels, and A. W. Zwiep, eds. Woordenboek voor bijbellezers. Zoetermeer, Netherlands: Boekencentrum, 2005.

Nordmann, Walter. "Die Eschatologie des Ehepaares Petersen, ihre Entwicklung und Auflösung [Part 1]." Zeitschrift des Vereins für Kirchengeschichte der Provinz Sachsen und des Freistaates Anhalt 26 (1930): 83-108.

Norelli, Enrico. "Commento." In L'Anticristo: De Antichristo, by Hippolytus, translated and edited by Enrico Norelli, 157-266. Biblioteca patristica. Florence: Nardini Editore-Centro Internazionale del Libro, 1987.

"Nuntia personarum." Biblica 25, no. 1 (1944): 104.

Nützel, Johannes Maria. Die Verklärungserzählung im Markusevangelium: Eine redaktionsgeschichtliche Untersuchung. Forschung zur Bibel 6. [Würzburg, Germany?]: Echter Verlag, 1973.

. "Gottesvolk aus Juden und Heiden: Zum Selbst-Verständnis der Christen in der Johannes-Apokalypse." In Ekklesiologie des Neuen Testaments: Für Karl Kertelge, edited by Rainer Kampling and Thomas Söding, 458-478. Freiburg im Breisgau, Germany: Herder, 1996.

. "Zum Schicksal der eschatologischen Propheten." Biblische Zeitschrift 20, no. 1 (1976): 59-94.

O'Brien, Kevin John. "An Examination of the Meaning, the Purpose, and the Function of the Interlude within the Sevenfold Series of the Book of Revelation." PhD dissertation, Union Theological Seminary [in Richmond, VA], 1996. Accessed July 3, 2015. ProQuest Dissertations and Theses Global.

Oberweis, Michael. "Das Martyrium der Zebedaiden in Mk 10.35-40 (Mt 20.20-3) und Offb 11.3-13." New Testament Studies 44, no. 1 (January 1998): 74-92.

"Obituary." Medical Times and Gazette, no. 992 (July 3, 1869): 22. Accessed August 16, 2015. Google Books. 
Oertel, Eucharius Ferdinand Christian. Die Offenbarung Johannis oder das tausendjährige Reich 1836. 2nd ed. Dresden: Walthersche Hofbuchhandlung, 1837.

Öhler, Markus. Elia im Neuen Testament: Untersuchungen zur Bedeutung des alttestamentlichen Propheten im frühen Christentum. Beihefte zur Zeitschrift für die neutestamentliche Wissenschaft und die Kunde der älteren Kirche 88. Berlin: Walter de Gruyter, 1997.

Oman, John Wood. Book of Revelation: Theory of the Text: Rearranged Text and Translation: Commentary. Cambridge, United Kingdom: Cambridge University Press, 1923.

An Original Interpretation of the Apocalypse. 2nd ed. London: J. F. Shaw, 1857. Accessed August 17, 2015. Google Books.

Osborne, Grant R. Revelation. Baker Exegetical Commentary on the New Testament. Grand Rapids, MI: Baker Academic, 2002.

Ottman, Ford Cyrinde. The Unfolding of the Ages in the Revelation of John. New York: Baker \& Taylor, 1905. Accessed July 10, 2015. Google Books.

Owen, Joshua David. "Martyrdom as an Impetus for Divine Retribution in the Book of Revelation." PhD dissertation, Southern Baptist Theological Seminary, 2008. Accessed November 11, 2015. ProQuest Dissertations \& Theses Global.

[Pae, David?]. The Coming Struggle among the Nations of the Earth: or, The Political Events of the Next Fifteen Years, Described in Accordance with Prophecies in Ezekiel, Daniel, and the Apocalypse. . . London: Houlston \& Stoneman; Edinburgh: Thomas Grant; Glasgow: W. R. McPhun; Dublin: George Herbert; Belfast W. McComb, 1853. Accessed November 3, 2015. HathiTrust Digital Library.

. A Supplement to "The Coming Struggle among the Nations of the Earth": Containing Replies to Some Objections Brought Against That Pamphlet; with a Development of the Theory of the Two Witnesses and the 1260 Years. . . London: Houlston \& Stoneman; Edinburgh: Thomas Grant, 1853. Accessed November 3 , 2015. Google Books.

Papandrea, James Leonard. The Wedding of the Lamb: A Historical Approach to the Book of Revelation. Eugene, OR: Pickwick Publications, 2011.

Pareus, David. A Commentary Upon The Divine Revelation Of The Apostle And Evangelist Iohn. Translated by Elias Arnold. Amsterdam, 1644. Accessed August 17, 2015. Google Books.

. In Divinam Apocalypsin S. Apostoli Et Evangelista Johannis Commentarius. Heidelberg: Jonas Rosa, 1618. Accessed August 17, 2015. Google Books. 
Park, John Ranicar. A New Exposition of the Apocalypse, So Far as the Prophecies Are Fulfilled. . . . 3rd ed. London: Smith, Elder, 1832. Accessed September 24, 2015 Google Books.

Partridge, Christopher. "The Eschatology of Heaven's Gate." In Expecting the End: Millennialism in Social and Historical Context, edited by Kenneth G. C. Newport and Crawford Gribben, 49-66, 251-257. Waco, TX: Baylor University Press, 2006.

Pattemore, Stephen. The People of God in the Apocalypse: Discourse, Structure, and Exegesis. Society for New Testament Studies, Monograph Series, 128. Cambridge: Cambridge University Press, 2004.

Patterson, Leighton Paige. Revelation. New American Commentary 39. Nashville, TN: B \& H Publishing Group, 2012.

Paul Lee Tan Prophetic Ministries, Inc. (PTPM). "Pilgrimages Bible Teachers." Bible Lands Study Tours. Accessed August 16, 2015. http://www.tanbible.com /tol_tour/(B)\%20BibleTeachers(Biodata).htm.

Peake, Arthur Samuel. The Revelation of John. Hartley Lecture 19. London: Holborn Press, 1919. Accessed November 11, 2015. Internet Archive American Libraries Collection.

Peerman, Ernest Leslie. Living Messages from Patmos. New York: Pyramid Press, 1941.

Pérez Márquez, Ricardo Antonio. L'Antico Testamento nell'Apocalisse: Storia della ricerca, bilancio e prospettive. Studi e ricerche, Sezione biblica. Assisi: Cittadella Editrice, 2010.

Perry, Peter Soren. The Rhetoric of Digressions: Revelation 7:1-17 and 10:1-11:13 and Ancient Communication. Wissenschaftliche Untersuchungen zum Neuen Testament, 2nd ser., 268. Tübingen: Mohr Siebeck, 2009.

Peschek, Joseph. Geheime Offenbarung und Tempeldienst: Eine Darstellung des Aufbaues der Apokalypse des heiligen Apostels Johannes samt Text und Erklärung. Paderborn, Germany: Verlag Ferdinand Schöningh, 1929.

Peters, Olutola K. The Mandate of the Church in the Apocalypse of John. Studies in Biblical Literature 77. New York: Peter Lang, 2005.

Petersen, Johann Wilhelm. Der veste Grund Des In der siebenden Posaunen annoch zukünfftigen Reiches Christi . . gründlich gezeiget Und Aus Gottes Wort bestättiget. 2 vols. Frankfurt am Main, 1692-1694. Accessed August 17, 2015. Google Books. 
Petersen, Rodney Lawrence. Preaching in the Last Days: The Theme of 'Two Witnesses' in the Sixteenth and Seventeenth Centuries. New York: Oxford University Press, 1993.

Phillips, John. Exploring Revelation. Chicago: Moody Press, 1974.

Pieters, Albertus. Studies in the Revelation of St. John. Grand Rapids, MI: William B. Eerdmans, 1943.

Pirie, Alexander. The French Revolution Exhibited, In The Light Of The Sacred Oracles: Or, A Series Of Lectures On The Prophecies Now Fulfilling. Perth, United Kingdom: R. Morison \& Son, 1795. Accessed September 30, 2015. Google Books.

Plummer, Alfred, Thomas Randell, Arthur Thomas Bott, Clement Clemance, Samuel Conway, Richard Green, and David Thomas. Revelation. Pulpit Commentary. New York: Funk \& Wagnalls, [1880?]. Accessed August 18, 2015. Internet Archive American Libraries Collection.

Poirot, Éliane. Les prophètes Élie et Élisée dans la littérature chrétienne ancienne. Collection Monastica. [Turnhout, Belgium?]: Brepols; [Bégrolles-en-Mauges, France?]: Abbaye de Bellefontaine, 1997.

Pollard, Leslie N. "The Function of Loipos in Contexts of Judgment and Salvation in the Book of Revelation." PhD dissertation, Andrews University, 2007. Accessed November 11, 2015. ProQuest Dissertations \& Theses Global.

Pond, Enoch. "The Day-Year Interpretation." Methodist Quarterly Review 26, Fourth Series (January 1874): 116-124. Accessed October 23, 2015. Google Books.

Porter, Stanley E., and Kent D. Clarke. "What Is Exegesis? An Analysis of Various Definitions." In Handbook to Exegesis of the New Testament, edited by Stanley E. Porter, 3-21. Boston: Brill Academic, 2002.

Postilla, sive Commentarius in Sancti Joannis Apostol. Apocalypsin universam. Sancti Bonaventuræ ... operum omnium . . supplementum. . . . , vol. 2, cols. 1-1037. Trent: Giambattista Monauni, 1773. Accessed August 16, 2015. Google Books.

Potestà, Gian Luca. Il tempo dell'Apocalisse: Vita di Gioacchino da Fiore. Collezione storica. Rome: Editori Laterza, 2004.

Poythress, Vern S. The Returning King: A Guide to the Book of Revelation. Phillipsburg, NJ: P\&R, 2000.

Prager, Ludwig. Die Offenbarung Johannis auf Grund der heiligen Schrift eingehend erklärt. 2 vols. Leipzig: Kommissionsverlag der A. Deichert'schen Verlagsbuchhandlung Nachfolger (Georg Böhme), 1901. Accessed July 15, 2015. Google Books. 
"Presidents of the Royal Irish Academy: 1785 to 1985." In The Royal Irish Academy: A Bicentennial History, 1785-1985, edited by T. Ó Raifeartaigh, 337. Dublin: Royal Irish Academy, 1985.

Preston, Ronald Hadyn, and Anthony Tyrrell Hanson. The Revelation of Saint John the Divine: Introduction and Commentary. Torch Bible Commentaries. London: SCM Press, 1949.

Preuß, Hans. Der Antichrist. Biblische Zeit- und Streitfragen zur Aufklärung der Gebildeten, 5th ser., 4. Gr. Lichterfelde-Berlin: Edwin Runge, 1909.

Priestley, Joseph. Notes on All the Books of Scripture, for the Use of the Pulpit and Private Families. Vol. 4. Northumberland, PA: by the author, 1804. Accessed November 3, 2015. Google Books.

Prigent, Pierre. Apocalypse 12: Histoire de l'exégèse. Beiträge zur Geschichte der biblischen Exegese 2. Tübingen: J. C. B. Mohr (Paul Siebeck), 1959.

. Commentary on the Apocalypse of St. John. Translated by Wendy Pradels. Tübingen: Mohr Siebeck, 2001. . L'Apocalypse de Saint Jean. Rev. ed. Commentaire du Nouveau Testament, 2nd ser., 14. Geneva: Labor et Fides, 2000.

Primasius of Hadrumetum Commentarius in Apocalypsin. Edited by Arthur White Adams. Corpus Christianorum, Series latina, 92. Turnhout, Belgium: Typographi Brepols Editores Pontificii, 1985.

Puthussery, Johnson. Days of Man and God's Day: An Exegetico-Theological Study of $\dot{\eta} \mu \varepsilon \dot{\rho} \alpha$ in the Book of Revelation. Tesi Gregoriana, Serie Teologia, 82. Rome: Editrice Pontificia Università Gregoriana, 2002.

Pyle, Thomas. A Paraphrase on the Acts of the Holy Apostles, upon All the Epistles of the New Testament, and upon the Revelations. .. Vol. 3. New ed. Oxford: J. Parker; London: Law and Whittaker, 1817. Accessed October 20, 2015. Internet Archive American Libraries Collection.

Quin, E. G. "Irish Studies." In The Royal Irish Academy: A Bicentennial History, 17851985, edited by T. Ó Raifeartaigh, 166-187. Dublin: Royal Irish Academy, 1985.

Quispel, Gilles. The Secret Book of Revelation: The Last Book of the Bible. New York: McGraw-Hill, 1979.

Quodvultdeus Liber promissionum et pradictorum Dei. Translated by René Braun. Sources Chrétiennes 101-102. Paris: Les Éditions du Cerf, 1964. 
Ralston, Samuel. A Brief Explication of the Principal Prophecies of Daniel and John, As They Regard the Church of God. . . . Pittsburgh, PA: Luke Loomis, 1842.

Accessed September 20, 2015. Internet Archive American Libraries Collection.

Ramsay, Alexander. The Revelation and the Johannine Epistles: With Introduction and

Notes. Westminster New Testament. New York: Fleming H. Revell; London: Andrew Melrose, [1910?]. Accessed July 13, 2015. EBSCOhost American Theological Library Association (ATLA) Historical Monographs Collection, Series 2.

Ranisavljević, Daniel. "Le témoignage de Jésus et celui des fidèles dans l'Apocalypse de Jean." ThD thesis, Institut Catholique de Paris, 1991.

Ratton, James Joseph Louis. The Apocalypse of St. John: A Commentary on the Greek Text. 2nd ed. London: R. \& T. Washbourne; New York: Benziger Brothers, 1915. Accessed July 23, 2015. Google Books.

Read, Charles Anderson. "James Henthorn Todd (1805-1869)." In The Cabinet of Irish Literature: Selections from the Works of the Chief Poets, Orators, and Prose Writers of Ireland, 4 vols., edited by Charles Anderson Read, Thomas Power O'Connor, and Katharine Tynan Hinkson, New ed., 3:57-58. London: Gresham, 1902-1903. Accessed August 16, 2015. Internet Archive American Libraries Collection.

Read, Hollis. The Coming Crisis of the World: or, The Great Battle and the Golden Age. The Signs of the Times Indicating the Approach of the Great Crisis, and the Duty of the Church. Columbus, OH: Follett, Foster, 1861. Accessed November 3, 2015. Google Books.

Reddish, Mitchell Glenn. Revelation. Smyth \& Helwys Bible Commentary. Macon, GA: Smyth \& Helwys, 2001.

. "The Theme of Martyrdom in the Book of Revelation." PhD dissertation, The Southern Baptist Theological Seminary, 1982. Accessed November 12, 2015. ProQuest Dissertations \& Theses Global.

Reeves, Marjorie Ethel. The Influence of Prophecy in the Later Middle Ages: A Study in Joachimism. Oxford: Clarendon Press, 1969. Reprint, Notre Dame, IN: University of Notre Dame Press, 1993.

Reid, William James. Lectures on the Revelation. Pittsburgh: Stevenson, Foster, 1878. Accessed August 30, 2015. Google Books.

Reisner, Erwin. Das Buch mit den sieben Siegeln. Göttingen: Vandenhoeck \& Ruprecht, 1949. 
Renan, Joseph Ernest. Antichrist, Including the Period from the Arrival of Paul in Rome to the End of the Jewish Revolution. Translated and edited by Joseph Henry Allen. Boston: Roberts Brothers, 1897. Accessed September 27, 2010. Google Books.

. L'Antéchrist. 3rd ed. Histoire des origines du christianisme. Paris: Michel Lévy frères; Paris: Librairie nouvelle, 1873. Accessed November 10, 2015. Google Books.

Resseguie, James Lynn. The Revelation of John: A Narrative Commentary. Grand Rapids, MI: Baker Academic, 2009.

Reuss, Édouard Guillaume Eugène. L'Apocalypse. Vol. 4 of La Bible: traduction nouvelle avec introductions et commentaires, Nouveau Testament. Paris: Librairie Sandoz et Fischbacher, 1878. Accessed October 20, 2015. Google Books.

"Revelation." In A Commentary on the Holy Bible, edited by John Roberts Dummelow, 1065-1092. New York: Macmillan, 1957.

"The Revelation of St. John the Divine." In The Seventh-day Adventist Bible Commentary, edited by Francis D. Nichol, Raymond F. Cottrell, Don F. Neufeld, and Julia Neuffer, 7:715-899. Washington, DC: Review and Herald, 1953-1957.

"The Revelation of St. John the Divine." In The Seventh-day Adventist Bible Commentary, edited by Francis D. Nichol, Raymond F. Cottrell, Don F. Neufeld, and Julia Neuffer, rev. ed., 7:715-899. Washington, DC: Review and Herald, 1976-1980.

Reynolds, Edwin Earl. "The Sodom/Egypt/Babylon Motif in the Book of Revelation." PhD dissertation, Andrews University, 1994. Accessed September 23, 2015. ProQuest Dissertations and Theses Global.

Richards, Hubert J. What the Spirit Says to the Churches: A Key to the Apocalypse of John. New York: P. J. Kenedy and Sons, 1967.

Riemer, Ulrike. Das Tier auf dem Kaiserthron? Eine Untersuchung zur Offenbarung des Johannes als historischer Quelle. Beiträge zur Altertumskunde 114. Stuttgart: B. G. Teubner, 1998.

Rigaux, Béda. L'Antéchrist et l'opposition au royaume messianique dans l'Ancien et le Nouveau Testament. Universitas Catholica Lovaniensis, Dissertationes ad gradum magistri in Facultate Theologica consequendum conscriptae, 2nd ser., 24. Gembloux, Belgium: J. Duculot; Paris: J. Gabalda et Fils, 1932.

Rissi, Mathias. Time and History: A Study on the Revelation. Translated by Gordon C. Winsor. Richmond, VA: John Knox Press, 1966. 
. Was ist und was geschehen soll danach. Die Zeit- und Geschichtsauffassung der Offenbarung des Johannes. 2nd ed. Abhandlungen zur Theologie des Alten und Neuen Testaments 46. Zürich: Zwingli Verlag, 1965.

Rist, Martin. "Exegesis of the Revelation of St. John the Divine." In The Interpreter's Bible, 12:345-551. New York: Abingdon-Cokesbury Press, 1951-1957.

. The Modern Reader's Guide to the Book of Revelation. Association Press Reflection Book 546. New York: Association Press, 1961.

Robbins, Ray Frank. The Revelation of Jesus Christ. Nashville, TN: Broadman Press, 1975.

Roberts, J. W. The Revelation to John (The Apocalypse). Living Word Commentary 19. Austin, TX: Sweet, 1974.

Robertson, David. Discourses Showing the Structure and Unity of the Apocalypse. . . 3 vols. Glasgow, 1833. Accessed November 4, 2015. Internet Archive American Libraries Collection.

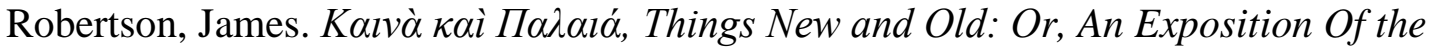
Book of the Revelation of John the Apostle. . . Edinburgh: by the author, 1730. Accessed August 27, 2015. Gale Eighteenth Century Collections Online.

Robinson, Bernhard P. "The Two Persecuted Prophet-Witnesses of Rev 11." Scripture Bulletin 19, no. 1 (1988): 14-19.

Robinson, David Charles. "The Mystic Rules of Scripture: Tyconius of Carthage's Keys and Windows to the Apocalypse." PhD thesis, University of St. Michael's College, 2010. Accessed August 17, 2015. ProQuest Dissertations \& Theses Global.

Rogers, Randolph R. "An Exegetical Analysis of John's Use of Zechariah in the Book of Revelation: The Impact and Transformation of Zechariah's Text and Themes in the Apocalypse." PhD dissertation, Southwestern Baptist Theological Seminary, 2002. Accessed November 11, 2015. ProQuest Dissertations \& Theses Global.

Rohr, Ignaz. Der Hebräerbrief und die geheime Offenbarung des heiligen Johannes. 4th ed. Die Heilige Schrift des Neuen Testaments übersetzt und erklärt in Verbindung mit Fachgelehrten. Bonn: Peter Hanstein, Verlagsbuchhandlung, 1932.

Roloff, Jürgen. The Revelation of John: A Continental Commentary. Translated by John E. Alsup. Continental Commentary. Minneapolis: Fortress Press, 1993.

Rondet, Laurent-Étienne. Dissertation sur le rappel des Juifs, et sur le chapitre onzième de l'Apocalypse. . . Paris: Lottin l'aîné, 1778. Accessed July 1, 2015. Google Books. 
. Supplément à "La dissertation sur le rappel des Juifs, et sur le chapitre onzième de l'Apocalypse," ou Lettre à Eusèbe, pour servir de dernière réponse aux contradicteurs. Paris: A. M. Lottin l'aîné, 1780. Accessed July 1, 2015. Google Books.

Roose, Hanna. »Das Zeugnis Jesu«: Seine Bedeutung für die Christologie, Eschatologie und Prophetie in der Offenbarung des Johannes. Texte und Arbeiten zum neutestamentlichen Zeitalter 32. Tübingen: Francke Verlag, 2000.

Rougemont, Frédéric de. La Révélation de Saint Jean expliquée par les Écritures et expliquant l'histoire: Précédée d'une brève interprétation des prophéties de Daniel. Neuchâtel, Switzerland: Delachaux et Sandoz; Geneva: E. Béroud; Lausanne, Switzerland: L. Meyer, 1866. Accessed November 2, 2015. Google Books.

Rowland, Christopher. "The Apocalypse: Hope, Resistance and the Revelation of Reality." Ex Auditu 6 (1990): 129-144. Accessed November 10, 2015. EBSCOhost ATLA Religion Database with ATLASerials.

Rowland, Christopher Charles. "The Book of Revelation." In The New Interpreter's Bible, 12:501-743. Nashville, TN: Abingdon Press, 1994-2002.

The Open Heaven: A Study of Apocalyptic in Judaism and Early Christianity. New York: Crossroad, 1982.

. Revelation. Epworth Commentaries. London: Epworth Press, 1993.

Roy, William L. A New and Original Exposition of the Book of Revelation. . . . New York: D. Fanshaw, 1848. Accessed October 14, 2015. Google Books.

Royse, Pleasant E. The Predictions of the Prophets, Which Have Been Most Wonderfully Fulfilled Since the Commencement of the Christian Era, and Especially Those Predictions concerning the United States of America. Cincinnati, OH: by the author, 1864. Accessed November 2, 2015. Internet Archive American Libraries Collection.

Rudolph, Stefanus Hermanus. "There Will Be No Death: Exegetical Evaluation of the Concepts of Life and Death in the Book of Revelation." PhD dissertation, University of Pretoria, 2005. Accessed October 22, 2015. UPSpace Institutional Repository Research Output, Theses and Dissertations (University of Pretoria).

Rushdoony, Rousas John. Thy Kingdom Come: Studies in Daniel and Revelation. Fairfax, VA: Thoburn Press, 1978.

Russell, James Stuart. The Parousia: A Critical Inquiry into the New Testament Doctrine of Our Lord's Second Coming. New ed. London: T. Fisher Unwin, 1887. Reprint, The Parousia: The New Testament Doctrine of Our Lord's Second Coming, Grand Rapids, MI: Baker Books, 1999. 
Rust, Ella Arjenette. An Exposition of the Revelation of Jesus Christ. [Worthington, MN?], 1939.

Rusten, Elmer Michael. "A Critical Evaluation of Dispensational Interpretations of the Book of Revelation." PhD dissertation, New York University, 1977. Accessed July 22, 2015. ProQuest Dissertations \& Theses Global.

Ryrie, Charles Caldwell. Dispensationalism. Rev. ed. Chicago: Moody Press, 1995. . Revelation. Everyman's Bible Commentary. Chicago: Moody Press, 1968. . "Update on Dispensationalism." In Issues in Dispensationalism, edited by Wesley R. Willis, John R. Master, and Charles Caldwell Ryrie, 15-27. Chicago: Moody Press, 1994.

Sadler, Michael Ferrebee. The Revelation of St. John the Divine. With Notes Critical and Practical. 2nd ed. Church Commentary on the New Testament, with Notes, Critical and Practical. London: George Bell and Sons, 1894. Accessed July 12, 2015. Internet Archive American Libraries Collection.

Sale-Harrison, Leonard. The Wonders of the Great Unveiling: The Remarkable Book of the Revelation. 4th ed. New York: Sale-Harrison Publications, 1930. Accessed November 4, 2015. HathiTrust Digital Library.

Satake, Akira. Die Gemeindeordnung in der Johannesapokalypse. Wissenschaftliche Monographien zum Alten und Neuen Testament 21. Neukirchen-Vluyn, Germany: Neukirchener Verlag, 1966.

. Die Offenbarung des Johannes. Edited by Thomas Witulski. Kritischexegetischer Kommentar über das Neue Testament 16. Göttingen: Vandenhoeck \& Ruprecht, 2008.

Schaumburg, John Jay. The Two Witnesses of Revelation Eleven, and Their "Sackcloth" Testimony. Oakland, CA: Messiah's Advocate, [1922?].

Schick, Eduard. The Revelation of St. John. Translated by Werner Kruppa. 2 vols. New Testament for Spiritual Reading 24-25. New York: Herder and Herder, 1971.

Schmidt, Josef. "NOY $\Sigma$ und $\Sigma$ OФIA in Offb 17." Novum Testamentum 46, no. 2 (January 2004): 164-189. Accessed November 11, 2015. EBSCOhost ATLA Religion Database with ATLASerials.

Schnabel, Eckhard J. "John and the Future of the Nations." Bulletin for Biblical Research 12, no. 2 (2002): 243-271. Accessed November 12, 2015. EBSCOhost ATLA Religion Database with ATLASerials.

Schor, Samuel. The Apocalypse. A Simple Exposition. 3rd ed. London: Barbican Mission to the Jews, n.d. 
Schreiner, Thomas R. Interpreting the Pauline Epistles. 2nd ed. Grand Rapids, MI: Baker Academic, 2011.

Schröder, Ingo. "Die staatlichen philosophisch-theologischen Hochschulen in Bayern von 1923 bis 1978." PhD dissertation, Ludwig Maximilian University of Munich, 2004. Accessed August 16, 2015. Universitätsbibliothek der LMU München Elektronische Dissertationen.

Schroten, Hendrik. Openbaring van Johannes voor de gemeente verklaard: Klassiek reformatorisch commentaar op het laatste bijbelboek. 's-Gravenhage, Netherlands: Boekencentrum, 1988.

Schüssler Fiorenza, Elisabeth. The Book of Revelation: Justice and Judgment. Philadelphia: Fortress Press, 1985.

. Revelation: Vision of a Just World. Proclamation Commentaries. Minneapolis: Fortress Press, 1991.

Schwarz, Ottilie J. R. A. "Die Zwei Zeugen: 'Kirche' und 'Israel'." Una Sancta: Zeitschrift für ökumenische Begegnung 15 (1960): 145-153.

Schwemer, Anna Maria. "Prophet, Zeuge und Märtyrer: Zur Entstehung des Märtyrerbegriffs im frühesten Christentum." Zeitschrift für Theologie und Kirche 96, no. 3 (1999): 320-350. Accessed November 12, 2015. EBSCOhost ATLA Religion Database with ATLASerials.

SCM R. Brockhaus. "Maier, Gerhard." Autoren. Accessed August 16, 2015. http://www.scm-brockhaus.de/autoren/autor.html ?tx_scmauthors_pi1\%5Buid\%5D=6943 \&tx_scmauthors_pi1\%5Bletter\%5D=M\&cHash=d263ffb823.

Scott, Charles Archibald Anderson. The Book of the Revelation. Practical Commentary on the New Testament. New York: A. C. Armstrong \& Son, 1906. Accessed December 1, 2015. Internet Archive American Libraries Collection. . Revelation: Introduction; Authorized Version; Revised Version with Notes; Index and Map. The New-Century Bible. New York: Henry Frowde; Edinburgh: T. C. \& E. C. Jack, n.d. Accessed July 22, 2015. Internet Archive American Libraries Collection.

Scott, Ernest Findlay. The Book of Revelation. New York: Charles Scribner's Sons, 1940.

Scott, Thomas. The Holy Bible: Containing the Old and New Testaments, According to the Authorized Version; with Explanatory Notes, Practical Observations, and Copious Marginal References. Vol. 6. Stereotype ed. Boston: Samuel T. Armstrong; Crocker and Brewster; New York: J. P. Haven, 1824. Accessed August 30, 2015. Google Books. 
Scott, Thomas Lucas. The Visions of the Apocalypse and Their Lessons. . . London: Skeffington \& Son, 1893. Accessed October 19, 2015. Google Books.

Scott, Walter. Exposition of the Revelation of Jesus Christ. 4th ed. London: Pickering \& Inglis, [1948?].

Scullion, John J. "Revelation (the Apocalypse)." In A New Catholic Commentary on Holy Scripture, edited by Reginald Cuthbert Fuller, Leonard Johnston, and Conleth Kearns, new ed., 1266-1283. London: Thomas Nelson \& Sons, 1969.

Seder Olam: or, The Order, Series, or Succession of All the Ages, Periods, and Times of the Whole World Is Theologically, Philosophically, and Chronologically Explicated and Stated. . . . Translated by John Clarke. London: Sarah Howkins, 1694. Accessed August 17, 2015. ProQuest Early English Books Online.

Seder Olam sive Ordo Seculorum, historica enarratio doctrinae. [Leiden?], 1693. Accessed August 17, 2015. Bayerische StaatsBibliothek.

Seiss, Joseph Augustus. The Apocalypse. A Series of Special Lectures on the Revelation of Jesus Christ. With Revised Text. 3 vols. 11th ed. New York: Charles C. Cook, 1913. Accessed July 9, 2015. Internet Archive American Libraries Collection.

Seng, Helmut. "Apk 11,1-14 im Zusammenhang der Johannesapokalypse. Aufschluss aus Lactantius und Hippolytus." Vetera Christianorum 27 (1990): 111-121.

[Shand, Alexander?]. An Explanation of the Interesting Prophecy Respecting the Two Apocalyptic Witnesses. . . London: by the author, 1817. Accessed September 19, 2015. Google Books.

Shea, William Henry. Selected Studies on Prophetic Interpretation. Edited by Frank B. Holbrook. Rev. ed. Daniel and Revelation Committee Series 1. Silver Spring, MD: Biblical Research Institute, General Conference of Seventh-Day Adventists, 1992.

Sheets, Dwight David. "The Sitz im Leben of the Apocalypse: Realized Eschatology and Apocalyptic Expression." PhD dissertation, Fuller Theological Seminary, 2000. Accessed November 11, 2015. ProQuest Dissertations \& Theses Global.

Shin, Eun-Chul. "More Than Conquerors: The Conqueror (Nıкá $\omega)$ Motif in the Book of Revelation." PhD dissertation, University of Pretoria, 2007. Accessed November 12, 2015. UPSpace Institutional Repository Research Output, Theses and Dissertations (University of Pretoria).

Sickenberger, Joseph. Erklärung der Johannesapokalypse. 2nd ed. Bonn: Peter Hanstein Verlagsbuchhandlung, 1942. 
Siew, Antoninus King Wai. The War between the Two Beasts and the Two Witnesses: A Chiastic Reading of Revelation 11.1-14.5. Library of New Testament Studies 283. London: T \& T Clark, 2005.

Simcox, William Henry. The Revelation of S. John the Divine: With Notes and Introduction. Edited by George Augustus Simcox. Cambridge Greek Testament for Schools and Colleges. Cambridge: Cambridge University Press, 1893. Reprint, 1909.

Simms, George Otto. "James Henthorn Todd." Hermathena, no. 109 (Autumn 1969): 523. Accessed August 17, 2015. JSTOR.

Simpson, David. A Key to the Prophecies; or, A Concise View of the Predictions Contained in the Old and New Testaments, Which Have Been Fulfilled, Are Now Fulfilling, or Are Yet to Be Fulfilled in the Latter Ages of the World. Newcastle upon Tyne, United Kingdom: Hutton Watson, 1812. Accessed May 23, 2012. Google Books.

Simpson, Douglas J. The Apocalypse: A Premillennial Interpretation of the Book of Revelation. Nashville, TN: Randall House Publications, 1975.

Skaggs, Bebe Rebecca, and Priscilla Carla Benham. Revelation: Pentecostal Commentary. Pentecostal Commentary Series. Blandford Forum, UK: Deo, 2009.

Smalley, Stephen Stewart. The Revelation to John: A Commentary on the Greek Text of the Apocalypse. Downers Grove, IL: InterVarsity Press, 2005.

Smith, Charles Edward. The World Lighted, a Study of the Apocalypse. New York: Funk \& Wagnalls, 1890. Accessed November 2, 2015. Google Books.

Smith, Ethan. Key to the Revelation. In Thirty-Eight Lectures, Taking the Whole Book in Course. 2nd ed. Boston: Whipple \& Damrell, 1837. Accessed August 31, 2015. Google Books.

Smith, Frederick George. The Revelation Explained: An Exposition, Text by Text, of the Apocalypse of St. John. . . 6th ed. Anderson, IN: Gospel Trumpet, 1908.

Smith, Jacob Brubaker. A Revelation of Jesus Christ: A Commentary on the Book of Revelation. Edited by J. Otis Yoder. Scottdale, PA: Herald Press, 1961.

Smith, Justin Almerin, and James Robinson Boise. Commentary on the Revelation. American Commentary on the New Testament. Philadelphia: American Baptist Publication Society, 1884. Accessed August 30, 2015. Internet Archive American Libraries Collection.

Smith, Uriah. Thoughts, Critical and Practical, on the Book of Revelation. Battle Creek, MI: Steam Press of the Seventh-day Adventist Pub. Association, 1865. Accessed September 24, 2015. Internet Archive Community Texts Collection. 
Smith, Wilbur Moorehead. "Revelation." In The Wycliffe Bible commentary, edited by Charles F. Pfeiffer and Everett F. Harrison, 1491-1525. Chicago: Moody Press, 1962.

Snell, Jeff. "Living Out Loud: The Witnessing Church in Revelation 11:1-14." In Dragons, John, and Every Grain of Sand: Essays on the Book of Revelation in Honor of Dr. Robert Lowery, edited by Shane J. Wood, 109-119. Joplin, MO: College Press, 2011.

Snodgrass, John. A Commentary, with Notes, on Part of the Book of the Revelation of John. Paisley, United Kingdom, 1799. Accessed November 8, 2015. Google Books.

Snow, Samuel Sheffield. The Voice of Elias: or, Prophecy Restored. Being a Complete and Truthful Exposition of the Visions of the Prophet Daniel and the Book of the Revelation. New York: Baker \& Godwin, 1863. Accessed August 17, 2015. Google Books.

Spicer, William Ambrose. Beacon Lights of Prophecy. Washington, DC: Review and Herald, 1935.

Spitta, Friedrich. Die Offenbarung des Johannes untersucht. Halle an der Saale, Germany: Verlag der Buchhandlung des Waisenhauses, 1889. Accessed November 12, 2015. Google Books.

Spurgeon, William Albertus. The Conquering Christ: An Interpretation of the Revelation. Muncie, IN, 1936.

St. Clair, John. Observations On Certain Passages in Daniel And The Apocalypse of John. . . London: S. Crowder and H. Woodgate, 1755. Accessed August 27, 2015. Gale Eighteenth Century Collections Online.

Stanford, W. B. "Polite Literature." In The Royal Irish Academy: A Bicentennial History, 1785-1985, edited by T. Ó Raifeartaigh, 188-200. Dublin: Royal Irish Academy, 1985.

Stanhope, Philip Henry. "Address of the President, April 26, 1870." Proceedings of the Society of Antiquaries of London 2nd ser., 4 (November 21, 1867-June 16, 1870): 471-480. Accessed August 16, 2015. Google Books.

Stanley, John E. "Revelation." In Asbury Bible Commentary, edited by Eugene E. Carpenter and Wayne McCown, 1225-1246. Grand Rapids, MI: Zondervan Publishing House, 1992.

Staten, Walter E. "Identity of the Two Witnesses in Revelation." MTh thesis, Dallas Theological Seminary, 1955. 
Stefanović, Ranko. Revelation of Jesus Christ: Commentary on the Book of Revelation. 2nd ed. Berrien Springs, MI: Andrews University Press, 2009.

Stern, Carl. Commentar über die Offenbarung des Apostel Johannes. Schaffhausen, Switzerland: Hurter'schen Buchhandlung, 1854. Accessed July 8, 2015. Google Books.

Stevens, Gerald L. Revelation: The Past and Future of John's Apocalypse. Eugene, OR: Pickwick Publications, 2014.

Stevens, William Coit. The Book of Revelation. Vol. 2 of Revelation, the Crown-Jewel of Biblical Prophecy. [Harrisburg, PA?]: Christian Alliance, 1928. Reprint, Revelation, the Crown Jewel of Biblical Prophecy: The Book of Revelation, Harrisburg, PA: Christian Publications, [1973?].

Stevenson, Gregory. A Slaughtered Lamb: Revelation and the Apocalyptic Response to Evil and Suffering. Abilene, TX: Abilene Christian University Press, 2013.

Stewart, Basil. Revelation Fulfilled in History: The Visions of St. John in Patmos a Pictorial Foreview of European History. . . . London: John Bale, Sons \& Danielsson, 1934.

Storrs, George. The Bible Examiner: Containing Various Prophetic Expositions. Second Advent Library 33. Boston: Joshua V. Himes, 1843. Accessed August 17, 2015. Google Books.

Strand, Kenneth Albert. "The Two Olive Trees of Zechariah 4 and Revelation 11." Andrews University Seminary Studies 20, no. 3 (Autumn 1982): 257-261.

. "The Two Witnesses of Rev 11:3-12." Andrews University Seminary Studies 19, no. 2 (Summer 1981): 127-135.

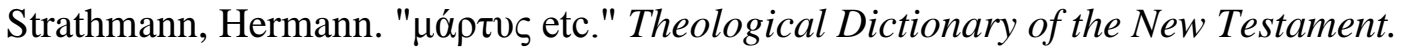
Edited by Gerhard Kittel. Translated and edited by Geoffrey W. Bromiley. Grand Rapids, MI: William B. Eerdmans, 1964-1976. 4:474-541.

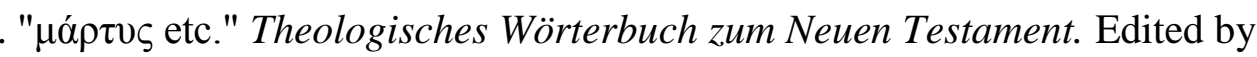
Gerhard Kittel. Stuttgart: W. Kohlhammer, 1933-1979. 4:477, line 6,-520, line 42.

Strauss, James Dean. The Seer, the Saviour, and the Saved; the Lord of the Future. Rev. ed. Bible Study Textbook Series. Joplin, MO: College Press, 1979.

Streett, Matthew J. Here Comes the Judge: Violent Pacifism in the Book of Revelation. Library of New Testament Studies 462. New York: T \& T Clark, 2012.

Stuart, Moses. A Commentary on the Apocalypse. 2 vols. Andover, MA: Allen, Morrill and Wardwell; New York: M. H. Newman, 1845. Accessed July 3, 2015. Internet Archive American Libraries Collection. 
Stubblefield, Benjamin Steen. "The Function of the Church in Warfare in the Book of Revelation." PhD Dissertation, Southern Baptist Theological Seminary, 2012. Accessed October 22, 2015. ProQuest Dissertations \& Theses Global.

Summers, Ray. Worthy is the Lamb: An Interpretation of Revelation. Nashville, TN: Broadman Press, 1951.

Sweet, John Philip McMurdo. "Maintaining the Testimony of Jesus: The Suffering of Christians in the Revelation of John." In Suffering and martyrdom in the New Testament: Studies Presented to G.M. Styler by the Cambridge New Testament Seminar, edited by William Horbury and Brian McNeil, 101-117. Cambridge: Cambridge University Press, 1981.

. Revelation. SCM Pelican Commentaries. London: SCM Press, 1979.

. Revelation. Westminster Pelican Commentaries. Philadelphia: Westminster Press, 1979.

Swete, Henry Barclay. The Apocalypse of St. John: The Greek Text with Introduction, Notes and Indices. 3rd ed. London: Macmillan, 1911. Accessed August 9, 2015. Internet Archive Canadian Libraries Collection.

Swetnam, James Hubbard. "Apocalypse 11,1-14: A Suggested Interpretation." In «Cieux nouveaux et terre nouvelle » (Ap 21,1): Pertinence du livre de l'Apocalypse pour l'Église d'Afrique ..., edited by Jean-Bosco Matand Bulembat, 85-101. Kinshasa, Democratic Republic of the Congo: Association panafricaine des exégètes catholiques, 2004.

Talbot, Louis Thompson. The Revelation of Jesus Christ: An Exposition on the Book of Revelation. Rev. ed. Grand Rapids, MI: William B. Eerdmans, 1937.

Tan, Christine Joy. "College Choice in the Phillipines." PhD dissertation, University of North Texas, 2009. Accessed August 17, 2015. ProQuest Dissertations \& Theses Global.

. "A Critique of Idealist and Historicist Views of the Two Witnesses in Revelation 11." Bibliotheca Sacra 171, no. 683 (July-September 2014): 328-351.

. "A Critique of Preterist Views of the Two Witnesses in Revelation 11."

Bibliotheca Sacra 171, no. 682 (April-June 2014): 210-225.

. "A Defense of a Futurist View of the Two Witnesses in Revelation 11:3-13." PhD dissertation, Dallas Theological Seminary, 2010. Accessed June 12, 2015. ProQuest Dissertations and Theses Global.

"A Futurist View of the Two Witnesses in Revelation 11." Bibliotheca Sacra 171, no. 684 (October-December 2014): 452-471. 
. "The Identity of the Two Witnesses in Revelation 11." ThM thesis, Dallas Theological Seminary, 2002. Accessed June 12, 2015. Theological Research Exchange Network (TREN).

. "Preterist Views on the Two Witnesses in Revelation 11." Bibliotheca Sacra 171, no. 681 (January-March 2014): 72-95.

Tan, Paul Lee. The Interpretation of Prophecy. Winona Lake, IN: BMH Books, 1974.

. A Pictorial Guide to Bible Prophecy. Garland, TX: Bible Communications, 1991.

Tanner, Cullen. "Climbing the Lampstand-Witness-Trees: Revelation's Use of Zechariah 4 in Light of Speech Act Theory." Journal of Pentecostal Theology 20, no. 1 (April 2011): 81-92. Accessed November 10, 2015. EBSCOhost Academic Search Complete.

Tanner, Joseph. Daniel and the Revelation: The Chart of Prophecy, and Our Place in It. A Study of the Historical and Fururist Interpretation. London: Hodder and Stoughton, 1898.

Tatford, Frederick Albert. The Final Encounter: An Exposition of the Book of Revelation. Newtown, Australia: Christian Outreach Book Service, 1983.

Tavo, Felise. "The Ecclesial Notions of the Apocalypse in Recent Studies." Currents in Biblical Research 1, no. 1 (October 2002): 112-136. Accessed July 3, 2015. EBSCOhost ATLA Religion Database with ATLASerials.

. Woman, Mother and Bride: An Exegetical Investigation into the "Ecclesial" Notions of the Apocalypse. Biblical Tools and Studies 3. Leuven: Peeters, 2007.

Taylor, Burchel K. "A Examination of the Book of Revelation from a Liberation Theology Perspective." PhD thesis, University of Leeds, 1990. Accessed November 11, 2015. British Library E-Theses Online Service (EThOS).

Taylor, Lauchlan. An Essay On some Important Passages Of The Revelation Of The Apostle John; Compared with correspondent Passages of the Book Of Daniel. 2nd ed. Edinburgh: by the author, 1770. Accessed September 7, 2015. Google Books.

Taylor, Michael. "Vortex." Script prepared for The Dead Zone, USA Network, August 2005. Accessed July 2, 2015. http://www2.usanetwork.com/series /thedeadzone/theshow/episodeguide/episodes/s5_vortex/script.pdf.

Tenney, Merrill Chapin. Interpreting Revelation. Grand Rapids, MI: William B. Eerdmans, 1957. Reprint, 1988.

Tertullian Adversus Marcionem. Translated by René Braun. Sources Chrétiennes 365, 368, 399, 456, 483. Paris: Les Éditions du Cerf, 1990-2004. 
De anima. Translated by Edwin A. Quain. Fathers of the Church, 10:163-309. New York: Fathers of the Church, 1950.

Thomas, Robert Lewis. Revelation 8-22: An Exegetical Commentary. Chicago: Moody Press, 1995.

Thompson, James Edmond. The History of the Fall and Dissolution of Christendom. Nashville, TN: McQuiddy Printing, 1917.

Thruston, Frederic. England Safe and Triumphant: or, Researches into the Apocalyptic Little Book, and Prophecies, Connected and Synchronical. 2 vols. Coventry, United Kingdom: F. C. and J. Rivington, 1812. Accessed October 27, 2015. West Bengal Public Library Network DSpace.

Todd, Elizabeth Marion, and Sinéad Agnew. "Todd, James Henthorn (1805-1869)." Oxford Dictionary of National Biography: In Association with the British Academy; from the Earliest Times to the Year 2000. Edited by Henry Colin Gray Matthew and Brian Howard Harrison. Oxford: Oxford University Press, 2004. 54:883-884.

Todd, James Henthorn. A Catalogue of Graduates Who Have Proceeded to Degrees in the University of Dublin, from the Earliest Recorded Commencements to July, 1866: With Supplement to December 16, 1868. Dublin: Hodges, Smith, and Foster; London: Longmans, Green, Reader, and Dyer, 1869. Accessed August 17, 2015. Google Books.

. Discourses on the Prophecies Relating to Antichrist in the Writings of Daniel and St. Paul. . . . Dublin: Hodges and Smith; London: J. G. F. and J. Rivington, 1840. Accessed August 17, 2015. Dallas Theological Seminary Turpin Library Rare Books Collection.

. Six Discourses on the Prophecies Relating to Antichrist in the Apocalypse of St. John. . . . Dublin: Hodges and Smith; London: F. and J. Rivington, 1846. Accessed June 12, 2015. Google Books.

Tolzien, Gerhard Wilhelm Helmut Adolf Theodor. Die Offenbarung des Johannes für bibellesende Gemeindeglieder erklärt. Hamburg: Agentur des Rauhen Hauses, 1947.

Torrey, Charles Cutler. The Apocalypse of John. New Haven, CT: Yale University Press, 1958.

[Towers, Joseph Lomas?]. Illustrations Of Prophecy: In The Course Of Which Are Elucidated Many Predictions, Which Occur In Isaiah, Or Daniel, In The Writings Of The Evangelists, Or The Book Of Revelation. . . . 2 vols. London, 1796. Accessed November 9, 2015. Google Books. 
Trafton, Joseph L. Reading Revelation: A Literary and Theological Commentary. Rev. ed. Reading the New Testament. Macon, GA: Smyth \& Helwys, 2005.

Tripp, John. A Discourse on the Character and Work, and the Death and Resurrection of the Two Witnesses. Portland, ME: A. Shirley, 1824. Accessed September 20, 2016. Google Books.

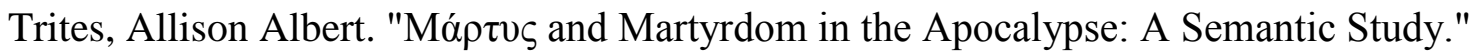
Novum Testamentum 15, no. 1 (January 1973): 72-80.

. The New Testament Concept of Witness. Society for New Testament Studies, Monograph Series, 31. Cambridge: Cambridge University Press, 1977.

Tucker, Walter Leon. Studies in Revelation: An Expositional Commentary. Binghamton, NY: J. Young, 1935. Reprint, Kregel Bible Study Classics, Grand Rapids, MI: Kregel Publications, 1980.

Turner, Charles William Merrill. Outline Studies in the Book of the Revelation and Key to the Chart of the Ages. 2nd ed. Plain City, Ohio: by the author, 1916.

Turner, Cuthbert Hamilton. "St. John in Asia Minor: The Apocalypse." In Studies in Early Church History: Collected Papers, 189-219. Oxford: Clarendon Press, 1912. Accessed July 6, 2015. Google Books.

Turner, Nigel. "Revelation." In Peake's Commentary on the Bible, edited by Matthew Black and Harold Henry Rowley, 1043-1061. London: Thomas Nelson and Sons, 1964.

Turner, Seth. "Revelation 11:1-13: History of Interpretation." DPhil thesis, University of Oxford, 2005. Accessed July 7, 2015. Oxford University Research Archive (ORA).

Tyconius Expositio Apocalypseos. Edited by Roger Gryson. Corpus Christianorum, Series latina, 107A. Turnhout, Belgium: Brepols, 2011.

Expositio Apocalypseos. Translated by Roger Gryson. Corpus Christianorum in Translation 10. Turnhout, Belgium: Brepols, 2011.

Fragmenta commentarii in Apocalypsim. ... Edited by Ambrogio Maria Amelli. Spicilegium Casinense. . . , vol. 3, pt. 1, 261-331. [Cassino, Italy?]: Typis Archiocoenobii Montis Casini, 1897.

Fragmenta Taurinensia. Edited by Roger Gryson. Corpus Christianorum, Series latina, 107A:347-386. Turnhout, Belgium: Brepols, 2011.

Tyso, Joseph. An Elucidation of the Prophecies, Being an Exposition of the Books of Daniel and the Revelation. . . . London: Jackson and Walford, 1838. 
Uitgeverij Kok. "Dr. H. R. van de Kamp." De reeks Commentaar op het Nieuwe Testament. Accessed August 16, 2015. http://www.cnt-serie.nl/h-r-van-de-kamp/.

Ulrichsen, Jarl Henning. "Das eschatologische Zeitschema der Offenbarung des Johannes." PhD dissertation, University of Trondheim, 1988.

Van Amringe, Henry Hamlin. Nature and Revelation, Showing the Present Condition of the Churches, and the Change Now to Come upon the World, by the Second Advent, in Spirit, of the Messiah, with Interpretations of Prophecies in Daniel, and the Book of Revelation. New York: R. P. Bixby, 1843. Accessed November 3, 2015. Google Books.

Van Daalen, David Hendrik. A Guide to the Revelation. Theological Education Fund Study Guide 20. London: SPCK, 1986.

VanderKam, James Claire. "1 Enoch, Enochic Motifs, and Enoch in Early Christian Literature." In Jewish Apocalyptic Heritage in Early Christianity, edited by James C. VanderKam and William Adler, 33-101. Compendia Rerum Iudaicarum ad Novum Testamentum, Sec. 3, Jewish Traditions in Early Christian Literature, 4. Assen, Netherlands: Van Gorcum; Minneapolis: Fortress Press, 1996.

. Enoch, A Man for All Generations. Studies on Personalities of the Old Testament. Columbia: University of South Carolina Press, 1995.

Vanni, Ugo. Apocalisse: Una assemblea liturgica interpreta la storia. 11th ed. Leggere oggi la Bibbia 2.15. Brescia: Editrice Queriniana, 2000.

. L'Apocalisse: Ermeneutica, esegesi, teologia. Associazione Biblica Italiana, Supplementi alla Rivista Biblica, 17. Bologna: Edizioni Dehoniane Bologna, 1988.

"La persecuzione nell'Apocalisse: L'atteggiamento del cristiano di fronte a un mondo eterogeneo." Strumento internazionale per un lavoro teologico: Communio 12, 2, no. 92 (March-April 1987): 32-40.

. "Le combat contre un monde étranger: la persécution dans L'Apocalypse." Revue Catholique Internationale: Communio 12, 2, no. 70 (March-April 1987): 32-40.

Vaughan, Charles John. Lectures on the Revelation of St. John. 5th ed. London: Macmillan, 1882. Accessed October 20, 2015. Google Books.

Venema, Herman. Pralectiones de methodo prophetica. ... Leeuwarden, Netherlands: Abraham Ferwerda, 1775. Accessed July 13, 2015. Google Books.

Victorinus of Poetovio Commentarii in Apocalypsin. Translated by Martine Dulaey. Sources Chrétiennes 423. Paris: Les Éditions du Cerf, 1997. 
Vischer, Eberhard. Die Offenbarung Johannis: Eine jüdische Apokalypse in christlicher Bearbeitung. Texte und Untersuchungen zur Geschichte der altchristlichen Literatur 2, issue 3. Leipzig: J. C. Hinrichs'sche Buchhandlung, 1886. Accessed July 10, 2015. Google Books.

Vivian, Thomas. The Book of the Revelation of Saint John the Divine Explained. . . Plymouth, United Kingdom: M. Haydon and Son, 1785. Accessed October 29, 2015. Gale Eighteenth Century Collections Online.

Vögtle, Anton. Das Buch mit den sieben Siegeln: Die Offenbarung des Johannes in Auswahl gedeutet. Freiburg im Breisgau, Germany: Herder, 1981.

Volkmar, Gustav Hermann Joseph Philipp. Commentar zur Offenbarung Johannes. Zurich: Orell, Füßli, und Comp., 1862. Accessed November 11, 2015. Google Books.

Völter, Daniel Erhard Johannes. Die Offenbarung Johannis neu untersucht und erläutert. 2nd ed. Strasbourg: J .H. Ed. Heitz (Heitz \& Mündel), 1911. Accessed June 25, 2015. HathiTrust Digital Library.

Vuilleumier, Jean. L'Apocalypse: Hier, aujourd'hui, demain. 4th ed. Dammarie-les-Lys, France: Les Signes des Temps, 1949.

Vuyst, Jacobus de. De Openbaring van Johannes: Het laatste bijbelboek ingeleid en, voorzien van aantekeningen, vertaald. Kampen, Netherlands: Kok, 1987.

Vyhmeister, Nancy Jean. Quality Research Papers: For Students of Religion and Theology. 2nd ed. Grand Rapids, MI: Zondervan, 2008.

Waddell, Robby. The Spirit of the Book of Revelation. Journal of Pentecostal Theology Supplement Series 30. Blandford Forum, United Kingdom: Deo, 2006.

Wagner, Manfred. "Evangelische Landeskirche in Württemberg Beziehungen zu orthodoxen Kirchen." Dienst für Mission, Ökumene und Entwicklung (DiMOE). Accessed August 16, 2015. http://www.dimoe.de/fileadmin/mediapool /einrichtungen/E_dimoe/Beziehungen_der_Landeskirche_zu_orth_Kirchen-3 .pdf.

Waid, Mark, Alex Ross, and Todd Klein. Kingdom Come. New York: DC Comics, 1997.

Wainwright, Arthur William. Mysterious Apocalypse: Interpreting the Book of Revelation. Nashville, TN: Abingdon Press, 1993.

Walhout, Edwin. Revelation Down to Earth: Making Sense of the Apocalypse of John. Grand Rapids, MI: William B. Eerdmans, 2000.

Wall, Robert Walter. Revelation. New International Biblical Commentary 18. Peabody, MA: Hendrickson Publishers, 1991. 
Wallis, Wilber B. The Coming of the Kingdom: A Survey of the Book of Revelation. N.p.: Biblical Studies Minsitries International, 2000. Accessed July 14, 2015. http://www.bsmi.org/wallis\%5Fkingdom.htm.

Walmesley, Charles [Pastorini, pseud.]. The General History of the Christian Church, from Her Birth to Her Final Triumphant State in Heaven: Chiefly Deduced from the Apocalypse of St. John, the Apostle and Evangelist. 5th American ed. New York: D. \& J. Sadlier, 1851. Accessed July 7, 2015. Google Books.

Walvoord, John Flipse. The Revelation of Jesus Christ: A Commentary. Chicago: Moody Press, 1966.

Warren, Israel Perkins. The Book of Revelation: A Exposition. . . . New York: Funk \& Wagnalls, 1886. Accessed August 28, 2011. Google Books.

Waugh, John S. Dissertations on the Prophecies of Sacred Scripture Which Relate to the Antichristian Powers. Annan, United Kingdom: by the author, 1833. Accessed November 2, 2015. Google Books.

Weaver, Joel Arthur. Theodoret of Cyrus on Romans 11:26: Recovering an Early Christian Elijah Redivivus Tradition. American University Studies, Ser. 7, Theology and Religion, 249. New York: Peter Lang, 2007.

Webber, Randall C. An Idealistic Reading of the Apocalypse. San Francisco: International Scholars Publications, 1999.

Weidner, Revere Franklin. Annotations on the Revelation of St. John the Divine. Lutheran Commentary 12. New York: Christian Literature, 1898. Accessed July 3, 2015. Google Books.

Weinrich, William Carl, ed. Revelation. Ancient Christian Commentary on Scripture, New Testament, 12. Downers Grove, IL: InterVarsity Press, 2005.

Weiss, Bernhard. Apostolische Briefe, Offenbarung Johannis. Vol. 2 of Das Neue Testament nach D. Martin Luthers berichtigter Übersetzung mit fortlaufender Erläuterung versehen. 2nd ed. Leipzig: J. C. Hinrichs'sche Buchhandlung, 1907. . A Commentary on the New Testament. Vol. 4. Translated by George Henry Schodde and Epiphanius Wilson. New York: Funk \& Wagnalls, 1906. Accessed November 10, 2015. Google Books.

. Die Apostelgeschichte, katholischen Briefe, Apokalypse im berichtigten Text: Mit kurzer Erläuterung zum Handgebrauch bei der Schriftlektüre. Vol. 3 of Das Neue Testament: Handausgabe. 2nd ed. Leipzig: J. C. Hinrichs'sche Buchhandlung, 1902. Accessed November 10, 2015. Google Books. 
Die Johannes-Apokalypse. Textkritische Untersuchungen und Textherstellung. Texte und Untersuchungen zur Geschichte der altchristlichen Literatur 7, issue 1. Leipzig: J. C. Hinrichs'sche Buchhandlung, 1891. Accessed November 12, 2015. Google Books.

Weiss, Johannes. Die Offenbarung des Johannes. Ein Beitrag zur Literatur- und Religionsgeschichte. Forschungen zur Religion und Literatur des Alten und Neuen Testaments 3. Göttingen: Vandenhoeck \& Ruprecht, 1904. Accessed July 10, 2015. Google Books.

Weiss, Johannes, and Wilhelm Heitmüller. "Die Offenbarung des Johannes." In Das Johannes-Evangelium, die Johannes-Briefe und die Offenbarung des Johannes. Sachregister zum ganzen Werke. Vol. 4 of Die Schriften des Neuen Testaments neu übersetzt und für die Gegenwart erklärt, edited by Wilhelm Bousset and Wilhelm Heitmüller, 3rd ed., 229-319. Göttingen: Vandenhoeck \& Ruprecht 1918.

Wesseling, Klaus-Gunther. "Sickenberger, Joseph." Biographisch-Bibliographisches Kirchenlexikon. Edited by Friedrich-Wilhelm Bautz and Traugott Bautz. Herzberg, Germany: Verlag Traugott Bautz, 1995. Vol. 10, columns 16-18. Accessed August 16, 2015. http://www.bbkl.de/lexikon/bbkl-artikel.php?art= ./S/Si/sickenberger_j.art.

Westminster Theological Seminary. "Articles and Publications: Works and Projects of Gregory K. Beale." Faculty. Accessed August 16, 2015. http://www.wts.edu /faculty/profiles/gbeale/gkbaandp.html.

. "Gregory K. Beale." Faculty. Accessed August 16, 2015. http://www.wts.edu /faculty/profiles/gbeale.html.


receptae. .. . Vol. 2. Amsterdam: Officina Dommeriana, 1752. Reprint, Novum Testamentum Graecum, vol. 2, Graz, Austria: Akademische Druck- und Verlagsanstalt, 1962.

Whealon, John F. "New Patches on an Old Garment: The Book of Revelation." Biblical Theology Bulletin 11, no. 2 (April 1981): 54-59. Accessed November 10, 2015. EBSCOhost ATLA Religion Database with ATLASerials.

Whedon, Daniel Denison. Titus-Revelation. Vol. 5 of Commentary on the New Testament: Intended for Popular Use. New York: Eaton \& Mains; Cincinnatti: Jennings \& Graham, 1908. Accessed August 31, 2015. Google Books.

Whiston, William. An Essay on the Revelation of St. John, So far as concerns the Past and Present Times. 2nd ed. London: by the author, 1744. Accessed November 2, 2015. Gale Eighteenth Century Collections Online. 
Whitaker, Edward William. A General And Connected View Of The Prophecies Relating To The Times Of The Gentiles, Delivered by our Blessed Saviour, the Prophet Daniel, and the Apostles Paul and John. . . Egham, United Kingdom: C. Boult, 1795. Accessed October 28, 2015. Google Books.

Whitcomb, John Clement. "The Two Witnesses." In Dispensationalism Tomorrow \& Beyond: A Theological Collection in Honor of Charles C. Ryrie, edited by David E. Olander and Christopher Cone, 359-373. Ft. Worth, TX: Tyndale Seminary Press, 2008.

White, Ellen Gould. The Great Controversy between Christ and Satan During the Christian Dispensation. Oakland, CA: Pacific Press, 1888. Accessed August 17, 2015. Internet Archive American Libraries Collection. . The Great Controversy between Christ and Satan from the Destruction of Jerusalem to the End of the Controversy. Vol. 4 of The Spirit of Prophecy. Oakland, CA: Pacific Press; Battle Creek, MI: Review and Herald, 1884. Accessed August 17, 2015. Internet Archive Community Texts Collection.

. The Great Controversy between Christ and Satan: The Conflict of the Ages in the Christian Dispensation. Mountain View, CA: Pacific Press, 1911. Accessed August 17, 2015. Internet Archive American Libraries Collection.

White, Josiah. The Two Witnesses. Rev. XI. Enfield, MA: by the author, 1823.

Whitley, John. The Scheme and Completion of Prophecy. ... London: C. J. G. \& F. Rivington, 1830. Accessed October 28, 2015. Google Books.

Whitman, John. Kingdom Come. Based on a story by Mark Waid and Alex Ross and the novelization by Elliot S. Maggin. Produced and directed by Maja Thomas. New York: Time Warner Audiobooks, 1998. 2 audiocassettes.

Whittemore, Thomas. A Commentary on the Revelation of St. John, the Divine. Boston: James M. Usher, 1848. Accessed November 2, 2015. Google Books.

Whitwell, Richard. The Apocalypse: An Inquiry into the Mystical and Prophetic Meaning of the Revelation Granted to St. John the Divine. London: "The Rally", 1940.

Who Was Who in America: A Companion Biographical Reference Work to Who's Who in America. Vol. 2. Chicago: A. N. Marquis, 1950.

Wickes, Thomas. An Exposition of the Apocalypse, in a Series of Discourses. New York: M. W. Dodd, 1851. Accessed August 31, 2015. Google Books.

Wikenhauser, Alfred. Die Offenbarung des Johannes übersetzt und erklärt. 3rd ed. Regensburger Neues Testament 9. Regensburg, Germany: Verlag Friedrich Pustet, 1959. 
Wikipedia [German ed.]. "Gerhard Maier." Accessed August 16, 2015. http://de.wikipedia.org/wiki/Gerhard_Maier.

Wilcock, Michael Jarvis. I Saw Heaven Opened: The Message of Revelation. The Bible Speaks Today. Downers Grove, IL: InterVarsity Press, 1975.

Williams, George. The Student's Commentary on the Holy Scriptures: Analytical, Synoptical, and Synthetical. New ed. Grand Rapids, MI: Kregel Publications, 1971.

Williams, Isaac. The Apocalypse: With Notes and Reflections. New ed. London: Rivingtons, 1889. Accessed October 19, 2015. Google Books.

Williams, Thomas. The Cottage Bible and Family Expositor; Containing the Authorized Translation of the Old and New Testaments, with Practical Reflections, and Short Explanatory Notes, Calculated to Elucidate Difficult and Obscure Passages. Vol. 3. London: W. Simpkin and R. Marshall, [1828?]. Accessed October 19, 2015. Google Books.

Wilson, M. M. [Kalamos, pseud.]. Prophetical Suggestions: Being Expository of the Books of Revelation and Daniel. 2nd ed. London: Digby, Long, 1909.

Wintermute, Orval Stewart. "Apocalypse of Elijah (First to Fourth Century A.D.): A New Translation and Introduction." In Apocalyptic Literature and Testaments, edited by James H. Charlesworth. Vol. 1 of The Old Testament Pseudepigrapha, 721753. Garden City, NY: Doubleday, 1983.

Witham, Robert. Annotations on the New Testament of Jesus Christ. . . Vol. 2. [Douai, France?], 1730. Accessed July 7, 2015. Gale Eighteenth Century Collections Online.

Witherington, Ben, III. Revelation. New Cambridge Bible Commentary. Cambridge: Cambridge University Press, 2003.

Witulski, Thomas. Apk 11 und der Bar Kokhba-Aufstand: Eine zeitgeschichtliche Interpretation. Wissenschaftliche Untersuchungen zum Neuen Testament, 2nd ser., 337. Tübingen: Mohr Siebeck, 2012.

Wolff, Christian. "Die Gemeinde des Christus in der Apokalypse des Johannes." New Testament Studies 27, no. 2 (January 1981): 186-197.

Wong, Daniel Kei Kwong. "The Two Witnesses in Revelation 11." Bibliotheca Sacra 154, no. 615 (July-September 1997): 344-354. Accessed November 11, 2015. EBSCOhost ATLA Religion Database with ATLASerials.

Wood, Hans [John M-D, pseud.]. The Revelation of St. John, Considered As Alluding to Certain Services of the Jewish Temple. . . L London: by the author, 1787. Accessed May 20, 2012. Google Books. 
Woodcock, Francis. The Two Witnesses: Discovered in severall Sermons Upon the eleventh Chapter of the Revelation. . . . London: Luke Fawne, 1643. Accessed August 17, 2015. ProQuest Early English Books Online.

Woodhouse, John Chappel. Annotations on the Apocalypse. . . London: J. Hatchard and Son, 1828. Accessed September 9, 2015. Google Books.

. The Apocalypse, or, Revelation of Saint John, Translated; with Notes, Critical and Explanatory. . . . London: J. Hatchard, 1805. Accessed October 26, 2015. Google Books.

Woolston, Thomas. A Fourth Free-Gift To The Clergy; Being A Discourse On The Two Apocalyptical Witnesses. .. . London: by the author, 1724. Accessed August 17, 2015. Gale Eighteenth Century Collections Online.

Wordsworth, Christopher. Lectures on the Apocalypse; Critical, Expository, and Practical, Delivered before the University of Cambridge. 3rd ed. London: Francis \& John Rivington, 1852. Accessed October 6, 2015. Google Books.

. St. Paul's Epistles; the General Epistles; the Book of Revelation, and Indexes. Vol. 2 of The New Testament of Our Lord and Saviour Jesus Christ, in the Original Greek: With Introductions and Notes. New ed. London: Rivingtons, 1872. Accessed November 2, 2015. Internet Archive American Libraries Collection.

Wright, Henry Parks, ed. History of the Class of 1868, Yale College, 1864-1914. New Haven, CT: Tuttle, Morehouse \& Taylor Press, 1914. Accessed August 17, 2015. Internet Archive American Libraries Collection.

Wurtz, Jean Wendel. Les précurseurs de l'Antechrist; . . . ou, La révolution française prédite par S. Jean l'évangéliste. . . . 6th ed. Lyon, France: Rusand, 1817. Accessed October 20, 2015. Google Books.

Wylie, James Aitken. The Seventh Vial; or, The Past and Present of Papal Europe as Shown in the Apocalypse. New ed. London: Hamilton, Adams; Edinburgh: Andrew Elliot, 1868.

Yeatts, John R. Revelation. Believers Church Bible Commentary. Scottdale, PA: Herald Press, 2003.

Zahn, Theodor. Die Offenbarung des Johannes. 2 vols. 1st-3rd ed. Kommentar zum Neuen Testament 18. Leipzig: A. Deichertsche Verlagsbuchhandlung Dr. Werner Scholl, 1924-1926. Reprint, in one volume, Wuppertal, Germany: R. Brockhaus Verlag, 1986.

Zeller, Benjamin Ethan. "Scaling Heaven's Gate: Individualism and Salvation in a New Religious Movement." Nova Religio 10, no. 2 (November 2006): 75-102. Accessed July 3, 2015. EBSCOhost ATLA Religion Database with ATLASerials. 
Züllig, Friedrich Jakob. Johannes des Gottbesprachten, eschatologische Gesichte, genannt: die Apokalypse; übersetzt, auf ihre Kunstform zurückgeführt, und zum Erstenmal erklärt, auch für Nicht-Gelehrte. 2 vols. Stuttgart: E. Schweizerbart's Verlagshandlung, 1834-1840. 


\section{CURRICULUM VITAE}

Name: Ian Robertson Brown

Born: December 23, 1970

\section{Education}

1999-2016 PhD in New Testament, Andrews University

1993-1999 MA in New Testament, Andrews University

1989-1993 BS in Economics, University of Iowa

1989-1993 Certificate in the Philosophy and Ethics of Politics, Law, and Economics (PEOPLE) Program, University of Iowa

\section{Work Experience}

1998-2002 Instructor, Intermediate Greek, Andrews University

2000 Research assistant for Dr. J. B. Doukhan, Andrews University

1998-2000 Research assistant for Dr. P. R. Choi, Andrews University

1997-1999 Instructor, Beginning Greek, Andrews University

1996-1997 Greek tutor, Andrews University

\section{Unpublished Graduate Papers}

A Critical Examination of the Traditional Arguments for Symbolic Interpretations of the

Temple Language of Rev 11:1-2

An Exegesis of Rev 22:8-9

An Exegesis of the Sixth Seal (Rev 6:12-17)

Hebrews 1:1-4: An Exegesis

Isaiah 53:12 and Vicarious Suffering

The MT and the LXX of Zech 4: A Partial Comparison

Reading Matt 7:21-23 in Light of Other Matthean Passages

Salvation and Revelation 5

Some Explorations concerning the Term Suneidessis in 1 Corinthians

A Study of Ephesians 5:1-2

A Study of the First Part of Romans 3:25

The Two Witnesses (Rev 11:3-13) as Two Individuals Appearing near the End of the Age: A Selective Literature Review and Issues of Interpretation (MA thesis)

Understanding the Vision of Zech 4: A Literary-Critical Perspective

\section{Publications}

Review of Bruce Winter's After Paul Left Corinth: The Influence of Secular Ethics and Social Change in Andrews University Seminary Studies 40, no. 2 (Autumn 2002): 346-348 